

MARYLAND E RARE RODX ROOM

UNIVERSTTY OF MARYLAND LIBRARY

COLlegE PARK. MD. 



\section{Digitized by the Internet Archive in 2010 with funding from \\ Lyrasis Members and Sloan Foundation}





\section{Wetlands in Maryland}

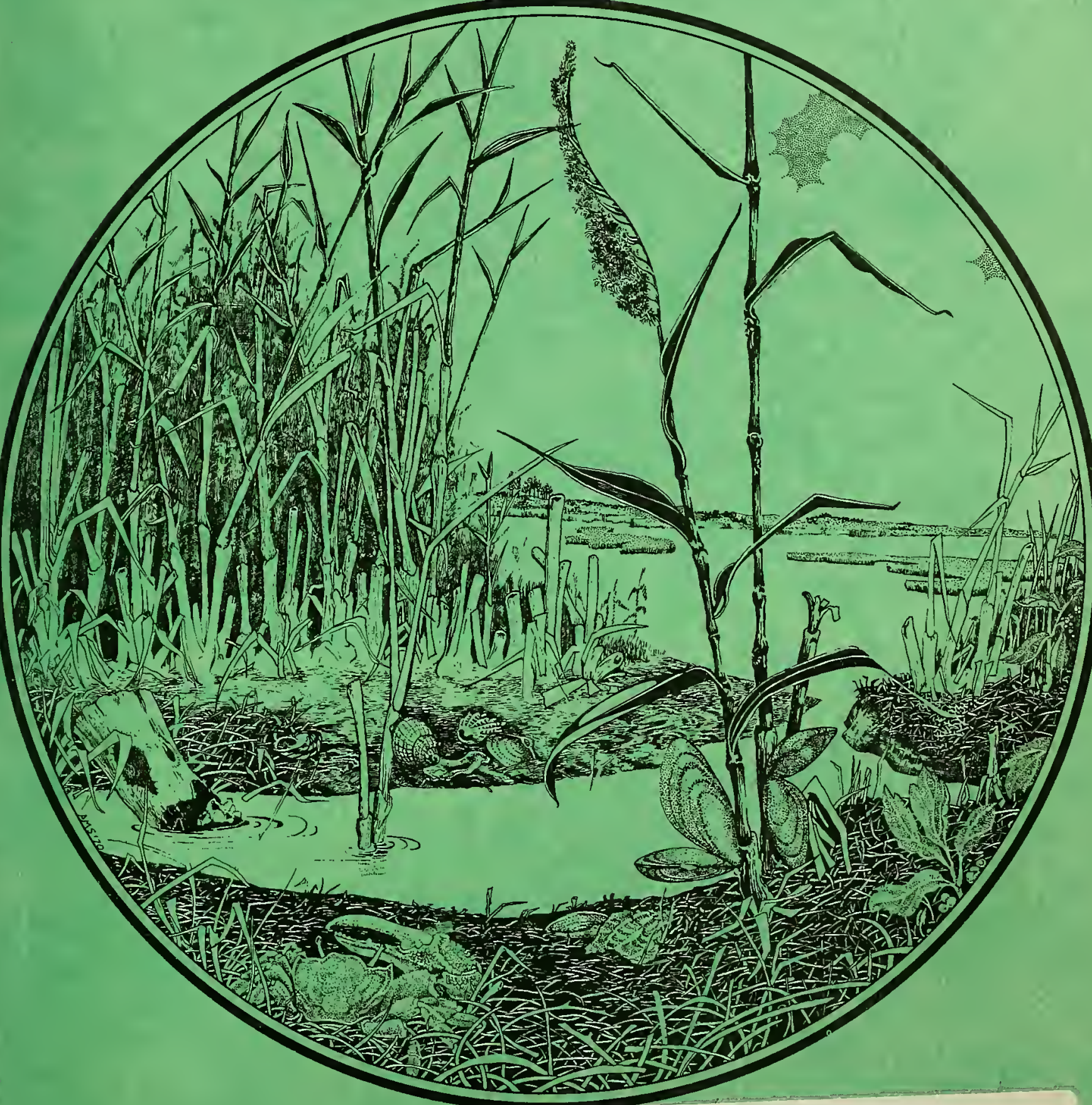

Map is in map collection with map no.:

Ches. Bay 21

DEPARTMENT OF STATE PLANNING

DEPARTMENT OF NATURAL RESOURCES 


\section{ACKNOWLEDGEMENTS}

Sincere appreciation is expressed to the members of the Wetlands Technical Advisory Committee for their unfailing interest, support and contributions to the study which made the production of this report possible. During the course of this study other persons too numerous to mention were contacted for information, publication requests, etc. Their cooperation and contributions are acknowledged and appreciated greatly.

Credit for major supportive efforts in the actual production of this report is due to George T. Evans for illustrative work and the clerical and editorial assistance of Mmes. Frances Marchlinus, Pat Russell and Sue Schildwachter. Also, the supervision and assistance of Dr. Albert R. Miller, Jr. was a most valuable contribution.

Finally, appreciation is due to Miss Ann Szymkowicz for the fine illustration of wetlands and associated biological life which graces the cover of this report, and to Dr. L. Eugene Cronin, Director, Natural Resources Institute, for permission to use it. 


\title{
STATE OF MARYLAND
}

Marvin Mandel, Governor

Department of Natural Resources James B. Coulter, Secretary
Department of Community and Economic Development Edmund F. Rovner, Secretary

Department of State Planning

Vladimir Wahbe, Secretary

\section{W ETLANDS IN M A R Y A ND}

\author{
by \\ Roy G. Metzgar \\ Natural Resources Planner \\ Department of State Planning
}

Prepared in cooperation with the member agencies of the Maryland Department of Natural Resources, the Department of Community and Economic Development, and the other members of the Wetlands Technical Advisory Committee.

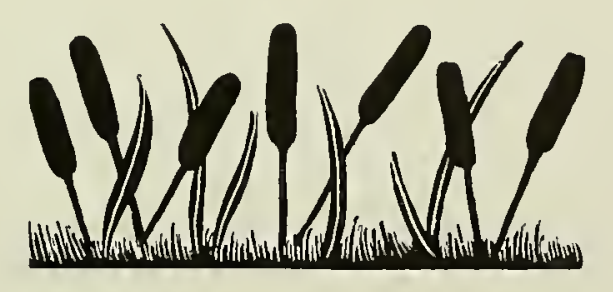

FOR FURTHER INFORMATION CONTACT:

Department of State Planning

(301) $383-2455$ 
Maryland

$\mathrm{HC}$

107

.$M 32$

no. 157

folio 

I. INTRODUCTION $\ldots \ldots \ldots \ldots \ldots \ldots \ldots \ldots \ldots \ldots \ldots \ldots \ldots \ldots \ldots \ldots \ldots$

II. SUMMARY ............................... II-1

III. FINDINGS AND RECOMMENDATIONS $\ldots \ldots \ldots \ldots \ldots \ldots \ldots \ldots \ldots \ldots \ldots \ldots$

IV. WHAT ARE WETLANDS?
Definition $\ldots \ldots \ldots \ldots \ldots \ldots \ldots \ldots \ldots \ldots \ldots \ldots \ldots \ldots \ldots \ldots \ldots \ldots \ldots \ldots \ldots$
IV 1 . $\ldots \ldots \ldots \ldots \ldots \ldots$

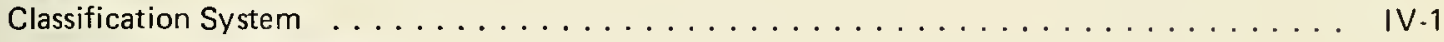

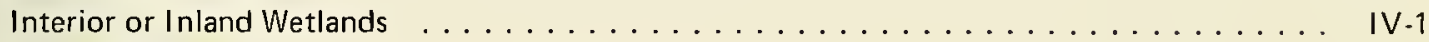

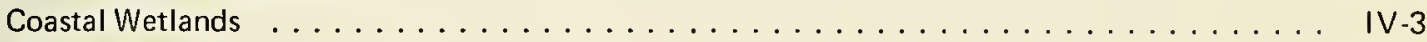

Fresh areas $\ldots \ldots \ldots \ldots \ldots \ldots \ldots \ldots \ldots \ldots \ldots \ldots \ldots \ldots \ldots \ldots \ldots \ldots$ IV 4

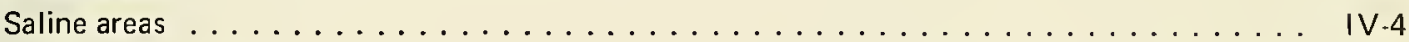

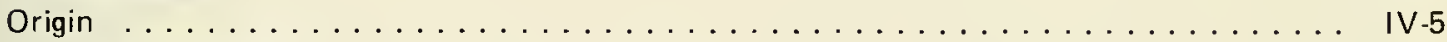

Natural Succession . . . . . . . . . . . . . . . . . . . . . . IV -5

Coastal Submergence $\ldots \ldots \ldots \ldots \ldots \ldots \ldots \ldots \ldots \ldots \ldots \ldots \ldots$. . . . . . . . . . . . . . .

V. WETLANDS ECOLOGY

Definitions ...................................

General Principles and Concepts of Wetland Ecosystems $\ldots \ldots \ldots \ldots \ldots \ldots \ldots \ldots \ldots$

The Role of Wetlands in Estuarine Productivity . . . . . . . . . . . . . . V V-3

Wetlands Dependent Production - Species Ecology $\ldots \ldots \ldots \ldots \ldots \ldots \ldots \ldots \ldots \ldots \ldots$. $\ldots \ldots$

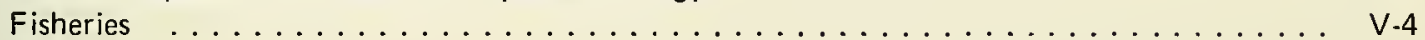

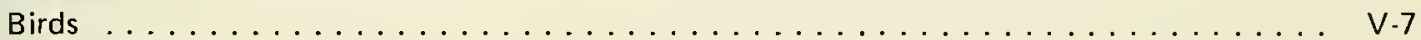

Other Wildife $\ldots \ldots \ldots \ldots \ldots \ldots \ldots \ldots \ldots \ldots \ldots \ldots \ldots \ldots \ldots \ldots \ldots$

Discussion $\ldots \ldots \ldots \ldots \ldots \ldots \ldots \ldots \ldots \ldots \ldots \ldots \ldots \ldots \ldots$

VI. WETLANDS HABITAT INVENTORY

Previous Wetland Studies in Maryland $\ldots \ldots \ldots \ldots \ldots \ldots \ldots \ldots \ldots \ldots \ldots \ldots \ldots \ldots$

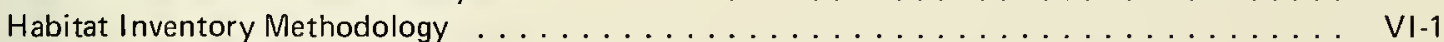

Wetlands Vulnerability Characteristics $\ldots \ldots \ldots \ldots \ldots \ldots \ldots \ldots \ldots \ldots \ldots \ldots$. . . . . . . . . .

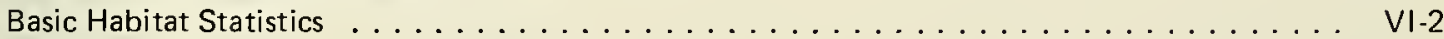

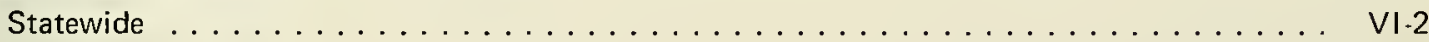

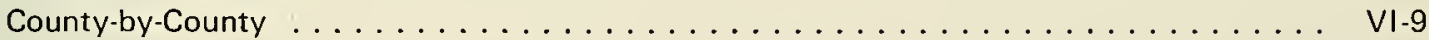

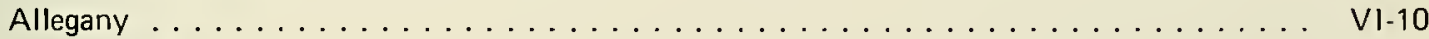

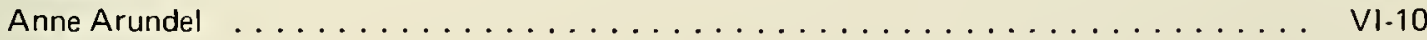

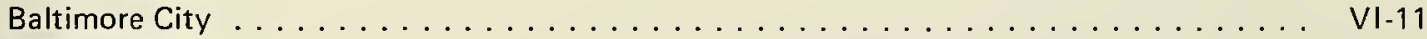

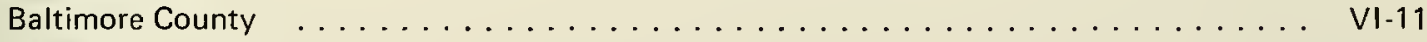

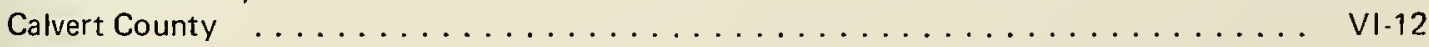

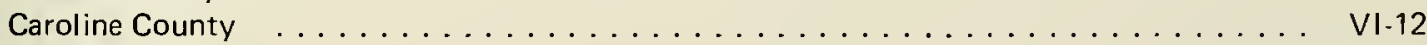

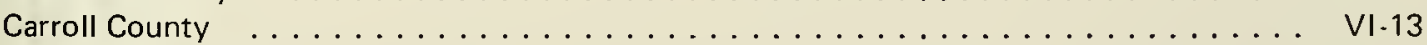

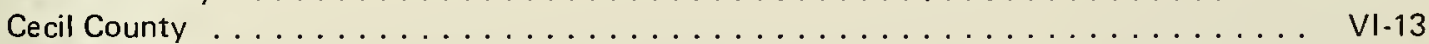

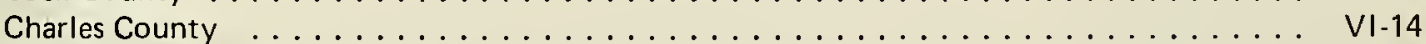

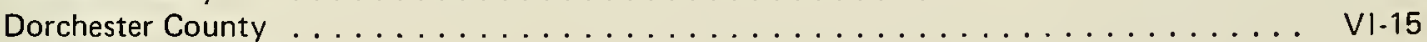

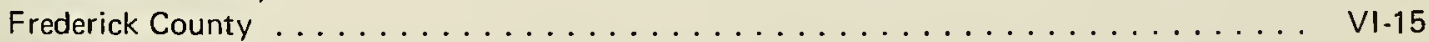

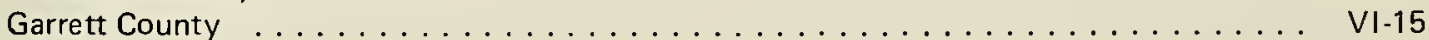

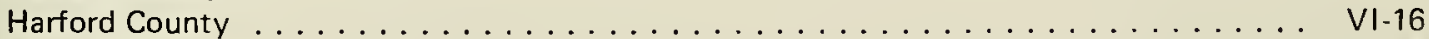

Howard County ............................. VI-16

Kent County ............................ $\ldots \ldots$ 


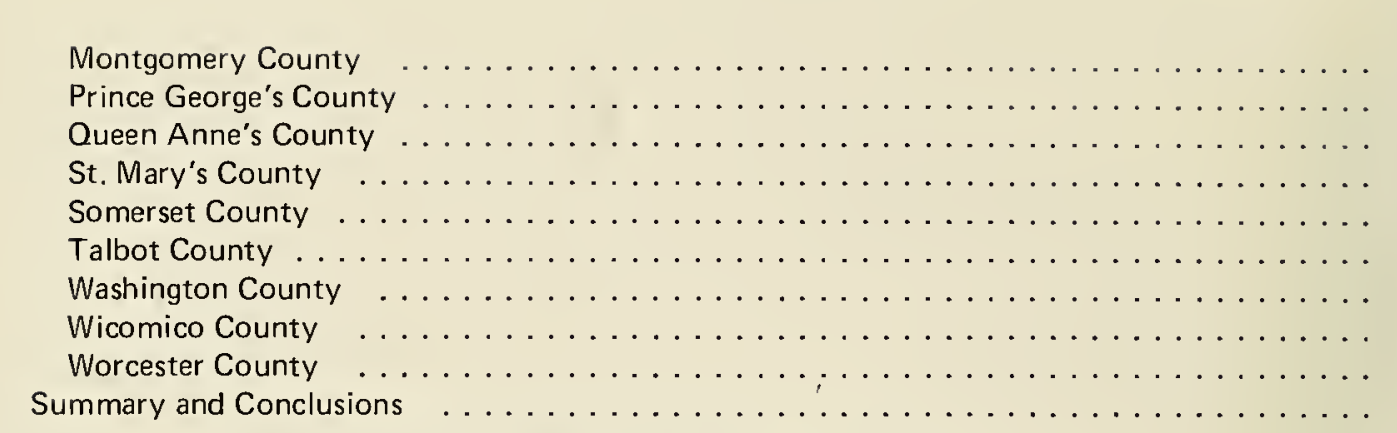

VII. SURVEY OF WETLANDS ASSOCIATED ECONOMIC VALUES

Fishing.

Commercial Seafood Industry

Sport or Recreational Fishing . . . . . . . . . . . . . . . . . . . . . VII-2

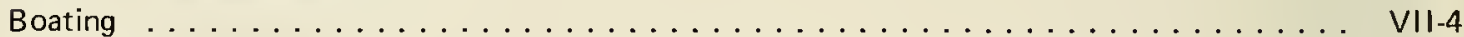

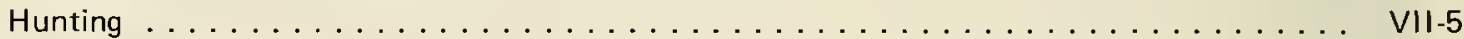

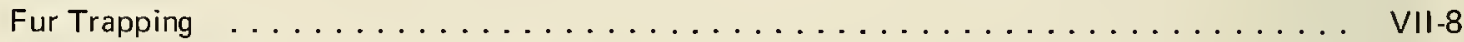

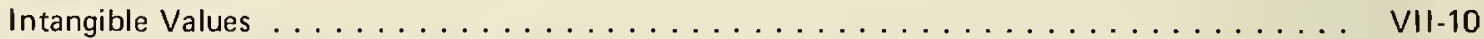

Summary of Economic and Other Values . . . . . . . . . . . . . . . VII-12

VIII. WETLANDS - AS REAL ESTATE, RESULTANT PROPERTY TAX CONTRIBUTIONS, SPECULATION AND PROPERTY OWNERSHIP ISSUES

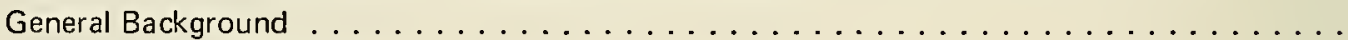

Real Estate Market Values . . . . . . . . . . . . . . . . . . . . . . .

Speculation ............................... VIII-3

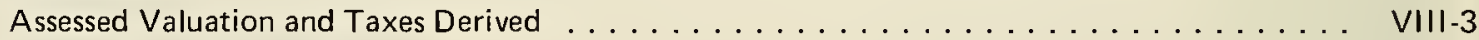

Property Ownership Issues $\ldots \ldots \ldots \ldots \ldots \ldots \ldots \ldots \ldots \ldots \ldots \ldots \ldots$. . . . . . . . . . . . . . . .

Summary and Conclusions $\ldots \ldots \ldots \ldots \ldots \ldots \ldots \ldots \ldots \ldots$ VIII-9

IX. SURVEY OF USES CHANGING THE NATURAL HABITAT CHARACTERISTICS OF WETLANDS

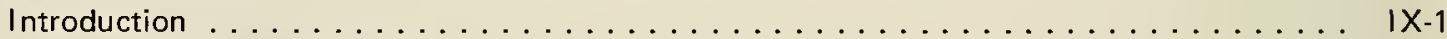

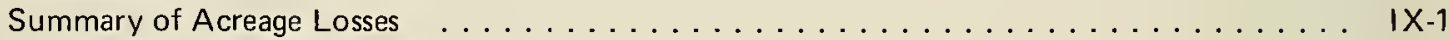

Housing Development $\ldots \ldots \ldots \ldots \ldots \ldots \ldots \ldots \ldots \ldots \ldots \ldots \ldots$ IX-1

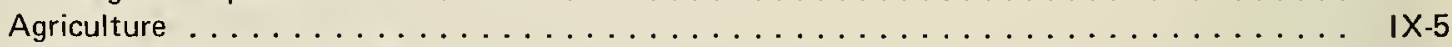

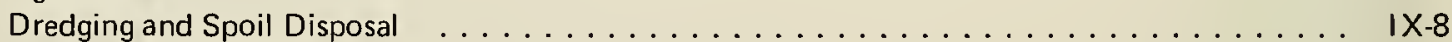

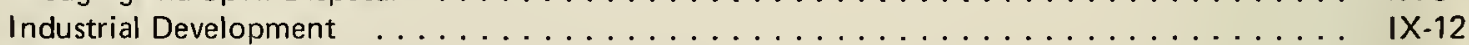

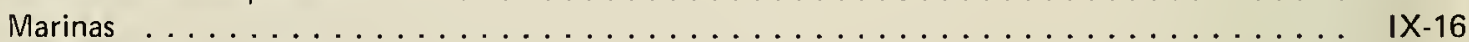

Other Uses $\ldots \ldots \ldots \ldots \ldots \ldots \ldots \ldots \ldots \ldots \ldots \ldots \ldots \ldots \ldots \ldots \ldots \ldots \ldots \ldots \ldots \ldots$ IX-18

Natural Succession . . . . . . . . . . . . . . . . . . . . . . . . . IX-20

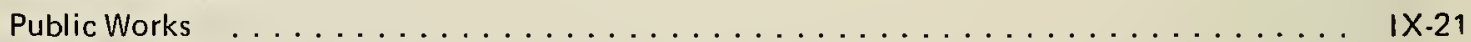

Shoreline Erosion $\ldots \ldots \ldots \ldots \ldots \ldots \ldots \ldots \ldots \ldots \ldots \ldots \ldots \ldots \ldots$. . . . . . . . . . . . . . .

Summary on Competing Uses and Implications to Wetlands $\ldots \ldots \ldots \ldots \ldots \ldots$ IX-23

X. SURVEY OF WETLANDS AND GROUND WATER HYDROLOGIC RELATIONSHIPS

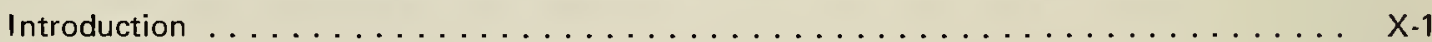

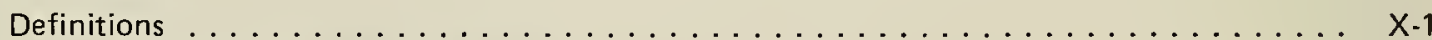

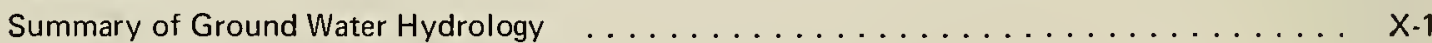

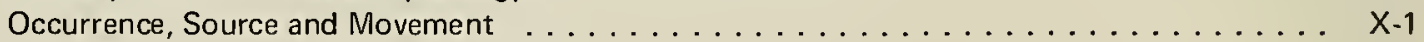




\section{TABLE OF CONTENTS (Cont'd.)}

\begin{tabular}{|c|c|}
\hline & Page \\
\hline Wetlands and Ground Water Hydrology in the Physiographic Provinces & $X-1$ \\
\hline Piedmont-Appalachian $\ldots \ldots \ldots \ldots \ldots \ldots \ldots \ldots$ & $X-2$ \\
\hline Coastal Plain ..... & $x-2$ \\
\hline${ }_{\ldots \ldots \ldots \ldots \ldots \ldots \ldots \ldots \ldots \ldots \ldots}$ & $x-3$ \\
\hline
\end{tabular}

XI. WETLANDS AND ESTUARINE POLLUTION

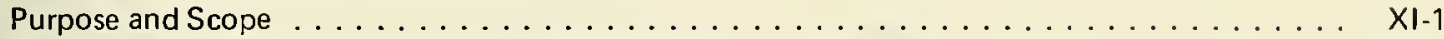

Pollution - A Definition Problem and Relative Term in Estuaries . . . . . . . . . . XI-1

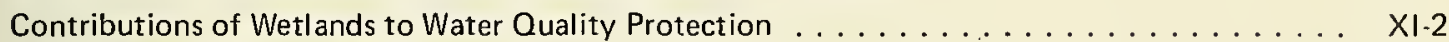

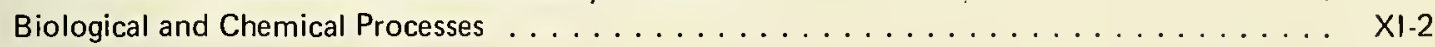

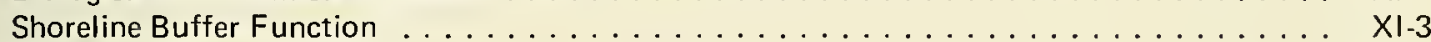

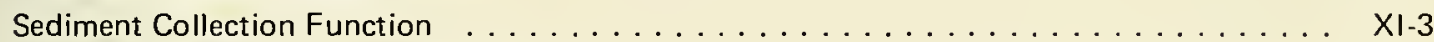

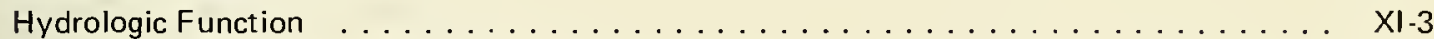

Threats to Natural Anti-Pollution Functions $\ldots \ldots \ldots \ldots \ldots \ldots \ldots \ldots \ldots \ldots \ldots \ldots$

Examples of Man's Impact on Estuarine Water Quality in Maryland . . . . . . . . . . . XI-4

The Upper Potomac Estuary . . . . . . . . . . . . . . . . . . . . XI-4

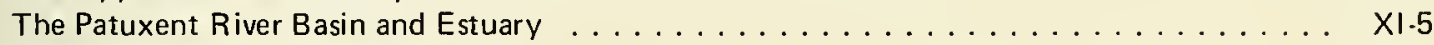

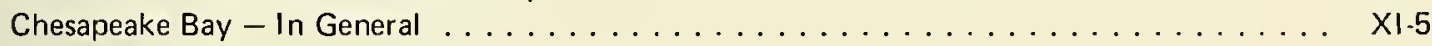

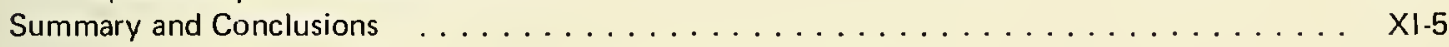

XII. SURVEY OF WETLANDS' ROLE IN ESTUARINE HYDRAULICS

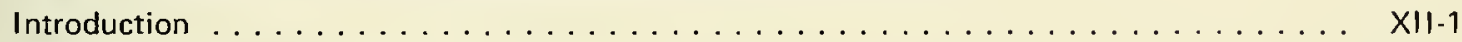

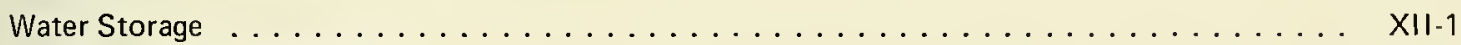

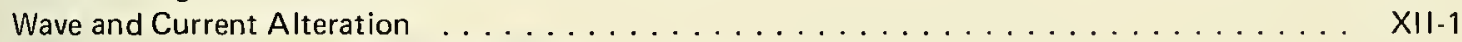

Stabilization of Coastal Land Inundation $\ldots \ldots \ldots \ldots \ldots \ldots \ldots \ldots \ldots \ldots$

XIII. CONVERSION OF LOW (NORMALLY DRY) LANDS TO WETLANDS
Introduction $\ldots \ldots \ldots \ldots \ldots \ldots \ldots \ldots \ldots \ldots \ldots \ldots \ldots \ldots \ldots \ldots \ldots \ldots \ldots \ldots \ldots \ldots \ldots \ldots \ldots$

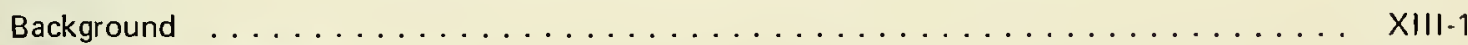

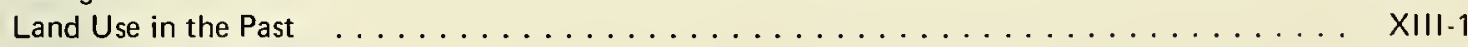

Present Land Conditions . . . . . . . . . . . . . . . . . . . . . . XIII-1

Areas Affected by Tidal Encroachment $\ldots \ldots \ldots \ldots \ldots \ldots \ldots \ldots \ldots \ldots \ldots \ldots \ldots$ XIII

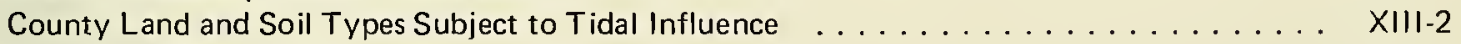

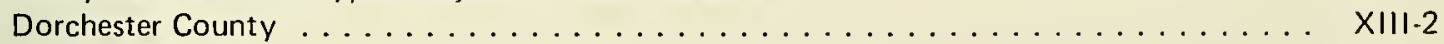

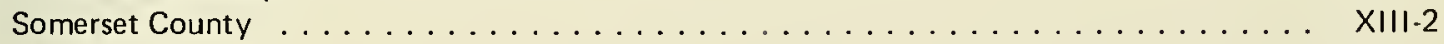

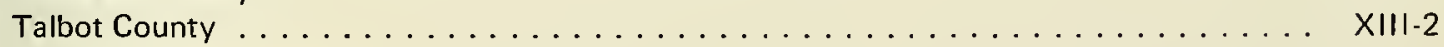

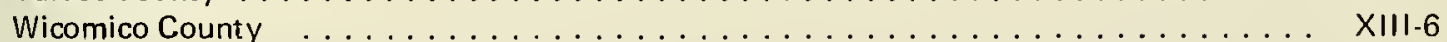

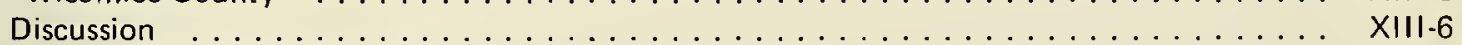

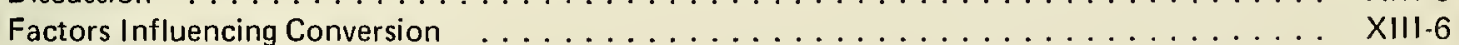

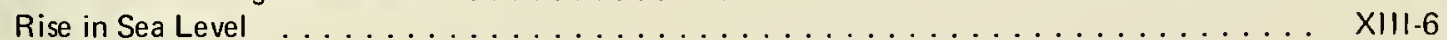

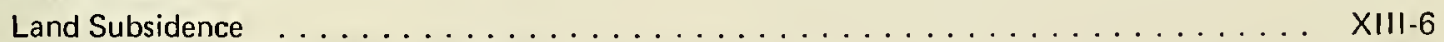

Drainage Ditches, Dikes and Tide Gates $\ldots \ldots \ldots \ldots \ldots \ldots \ldots \ldots \ldots \ldots \ldots$ XIII-8

Alteration of Lands Fringing Estuaries and Tidal Marshes $\ldots \ldots \ldots \ldots \ldots \ldots \ldots$. . . . . . XIII-8

Discussion and Conclusions . . . . . . . . . . . . . . . . . . XIII-9

XIV. WETLANDS - THE LEGAL CONTEXT

Wetlands and Flood Plain Statutes in Other States . . . . . . . . . . . . . . . XIV-1

Rights of Riparian Landowners in Waters Owned by the State of Maryland . . . . . . . . XIV-9

Extent of the Power of Eminent Domain . . . . . . . . . . . . . . . . . . . XIV-10

State's Power to Regulate the Use of Land Through the Police Power . . . . . . . . . . XIV-11

Legal Approaches Available to Maryland for the Protection of the State's Wetlands . . . . . . XIV-14 
TABLE OF CONTENTS (Cont'd.)

Page

BIBLIOGRAPHY

APPENDICES

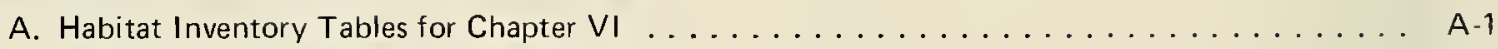

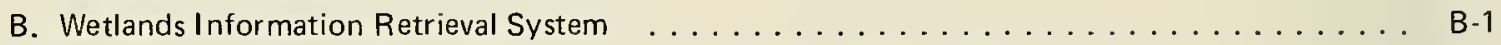

C. House Joint Resolution No. 2 (1967) $\ldots \ldots \ldots \ldots \ldots \ldots \ldots \ldots \ldots \ldots \ldots \ldots$ C-1

D. State Planning Department Advisory Letter on Wetlands to Local Governments and List of Addressees . . . . . . . . . . . . . . . . . . . . . . . . D 1

E. Maryland Wetlands Act(s) of $1970 \ldots \ldots \ldots \ldots \ldots \ldots \ldots \ldots \ldots \ldots \ldots \ldots \ldots \ldots$

F. Proposed Order Establishing Private Wetland Boundaries in Calvert County, Maryland, and

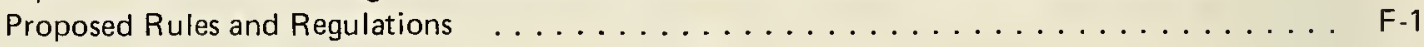

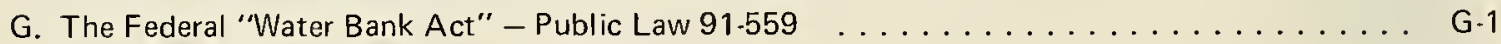




\section{LIST OF FIGURES}

PAGE

I-1 Wetland's Technical Advisory Committee I-1

IV-1 Adkins Mill Pond in Wicomico County an example of Type 5 Wetlands $\ldots \ldots \ldots \ldots \ldots$ IV-2

IV-2 An example of Type 7 Wetlands (Dorchester County) $\ldots \ldots \ldots \ldots \ldots \ldots \ldots \ldots$

IV-3 An example of Type 8 Wetlands (Garrett County) $\ldots \ldots \ldots \ldots \ldots \ldots \ldots \ldots \ldots$

IV-4 An example of Type 12 Wetlands (Kent County) $\ldots \ldots \ldots \ldots \ldots \ldots \ldots \ldots \ldots$

IV-5 An example of Type 12 Wetlands (Dorchester County) $\ldots \ldots \ldots \ldots \ldots \ldots \ldots \ldots$

V-1 Ultimate utilization of Smooth Cordgrass (partial food web energized by plants) representative of Lower Eastern Shore Wetlands

VI-1 Wetlands habitat inventory data sheet for specific Maryland Wetland areas (side 1) . . . . .

V1-2 Wetlands habitat inventory data sheet for specific Maryland Wetland areas (side 2) . . . . .

VI-3 Wetlands survey regions - Maryland $\ldots \ldots \ldots \ldots \ldots \ldots \ldots \ldots \ldots$

1X-1 Filling of Wetlands with dredge spoil near George's Creek, St. Mary's County . . . . . . .

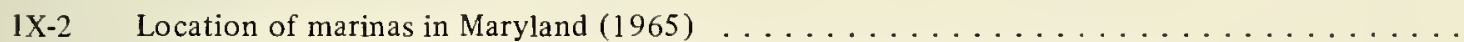

1X-3 Destruction of Type 16 Wetlands of Kent Narrows for marina development $\ldots \ldots \ldots \ldots$

1X-4 Solid waste disposal into wetlands $\ldots \ldots \ldots \ldots \ldots \ldots \ldots \ldots \ldots \ldots \ldots$

$\mathrm{X}-1 \quad$ General schematic of the hydrologic cycle $\ldots \ldots \ldots \ldots \ldots \ldots \ldots \ldots$

X-2 Location of the Fall Line and physiographic regions utilized in this report for discussion on ground water hydrology and wetland relationships in Maryland.

X-3 ldealized block diagram illustrating various geologic features related to transmitting water laterally from an aquifer intake (recharge) area in the uplands of the western shore to the eastern shore via formations which lie under Chesapeake Bay.

X-4 Geologic cross-section illustrating the underlying structure of the coastal plain region in Maryland and the southeast dip of formations which encompass the major artesian aquifers in the State.

X-5 Approximate surface outcrop (recharge) areas of the principal aquifers of the western shore and the general locations of certain wetlands in Anne Arundal County.

X-6 Approximate location of wetlands in Prince George's County with the potential for saltwater intrusion into underlying ground water aquifers.

X-7 Approximate location of wetlands in Calvert County along the Patuxent River with the potential for saltwater intrusion or contamination into underlying ground water aquifers.

X-8 Approximate extent of the buried recharge belt of the Manokin aquifer, including the general locations of overlying wetlands in southern Dorchester County. 


\section{LIST OF FIGURES (continued)}

PAGE

X-9 Approximate extent of the buried recharge belt of the Pocomoke aquifer, including the general locations of overlying wetlands in Somerset County. . . . . . . . . . . . .

X-10 Approximate extent of the buried recharge belt of the Manokin and Pocomoke aquifers, including the general locations of overlying wetlands in Wicomico County. . . . . . . . .

X-11 Approximate extent of the buried recharge belt of the Pocomoke aquifer, including the general

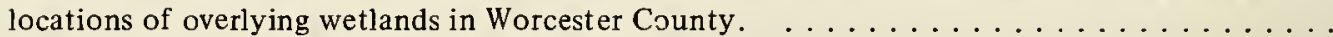

XII-1 A hypothetical illustration of a combination of climatological factors and physical features which have the potential for serious coastal flooding problems.

XIII-1 General locations in Dorchester County, Maryland of soil associations either actually or potentially influenced by tidal action and subject to marsh conversion. . . . . . . . . . .

XIII-2 General locations in Somerset County, Maryland of tidal marsh soil associations either actually

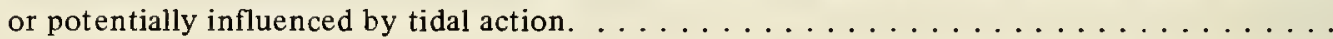

XIII-3 General locations in Talbot County, Maryland of tidal marsh soil associations, including Othello silt Ioam (low), which is subject to conversion to tidal marsh. . . . . . . . . .

XIII-4 General locations in Wicomico County, Maryland of tidal marsh soil associations, including Othello silt loam (low), which are subject to conversion to tidal marsh. 


\section{LIST OF TABLES}

PAGE

V-1 General orders of magnitude of gross primary productivity in terms of dry weight of organic matter produced annually $\ldots \ldots \ldots \ldots \ldots \ldots \ldots \ldots \ldots \ldots \ldots \ldots \ldots \ldots$

V-2 Sample evaluation of wetlands and dependent fishery resources by selected Maryland counties . V-4

V-3 Survey sample of fishery resources usage and abundance in irregularly flooded salt marshes (type 17) or nearby waters of Dorchester County, Maryland ............. V-5

VI-1 Summary of wetlands habitat inventory by survey regions $\ldots \ldots \ldots \ldots \ldots \ldots \ldots$

VI-2 Depth versus acreage computed for the open surface waters of Chesapeake Bay and tributaries . V1-7

VI-3 Summary of wetlands habitat inventory by vulnerability category and type of wetlands . . . . VI-8

VI-4 Wetlands in public ownership in Maryland in $1969 \ldots \ldots \ldots \ldots \ldots \ldots \ldots$ A $\ldots \ldots \ldots$

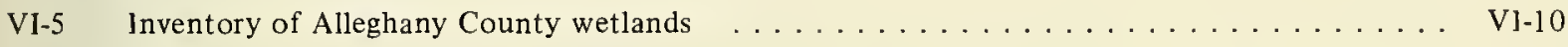

VI-6 Inventory of wetlands in Anne Arundel County including evaluation of present and future

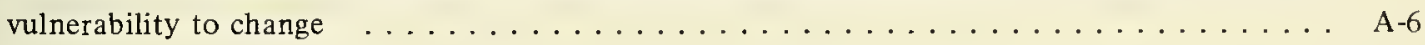

VI-7 Inventory of uses competing for wetlands in Anne Arundel County showing acerage losses and

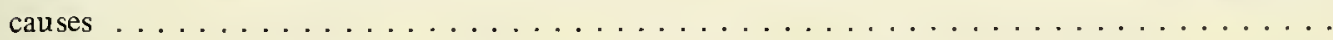

VI-8 Inventory of wetlands in Baltimore County including evaluation of present and future vulner-

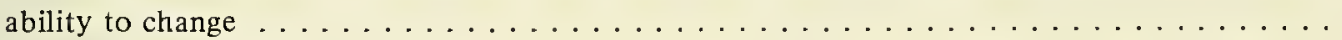

VI-9 Inventory of uses competing for wetlands in Baltimore County showing acreage losses and

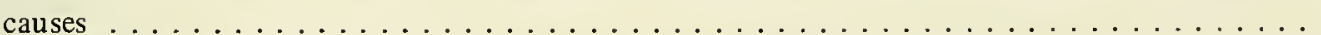

VI-10 Inventory of wetlands in Calvert County including evaluation of present and future vulner-

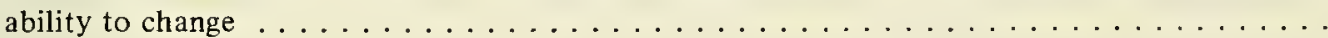

VI-11 Inventory of uses competing for wetlands in Calvert County showing acreage losses and causes .

V1-12 Inventory of wetlands in Caroline County including evaluation of present and future vulner-

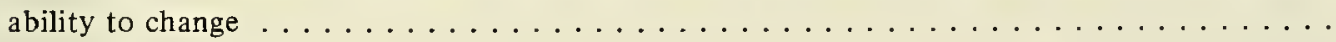

VI-13 Inventory of uses competing for wetlands in Caroline County showing acreage losses and causes

VI-14 Inventory of Carroll County wetlands $\ldots \ldots \ldots \ldots \ldots \ldots \ldots \ldots \ldots \ldots \ldots \ldots \ldots$

VI-15 Inventory of wetlands in Cecil County including evaluation of present and future vulnerability to change

VI-16 Inventory of uses competing for wetlands in Cecil County showing acreage losses and causes

VI-17 Inventory of wetlands in Charles County including evaluation of present and future vulnerability to change

VI-18 Inventory of uses competing for wetlands in Charles County showing acreage losses and causes .

VI-19 Inventory of wetlands in Dorchester County including evaluation of present and future vulnerability to change 


\section{LIST OF TABLES (continued)}

PAGE

VI-20 Inventory of competing uses for wetlands in Dorchester County showing acreage losses with causes

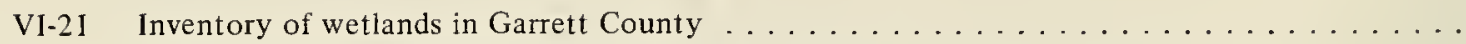

VI-22 Inventory of wetlands in Harford County including evaluation of present and future vulner-

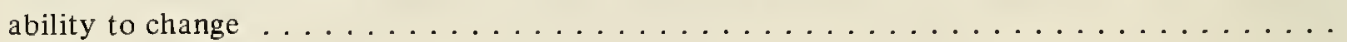

VI-23 Inventory of uses for wetlands in Harford County showing acreage losses and causes .......

VI-24 Inventory of wetlands in Kent County including evaluation of present and future vulnerability to change

VI-25 Inventory of uses competing for wetlands in Kent County showing acreage losses and causes ..

VI-26 Inventory of wetlands in Montgomery County

V1-27 Inventory of wetlands in Prince George's inc'uding evaluation of present and future vulner-

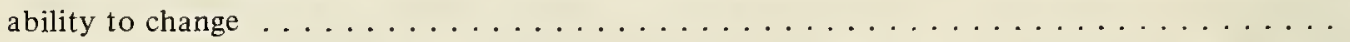

VI-28 Inventory of uses competing for wetlands in Prince George's County showing acreage losses

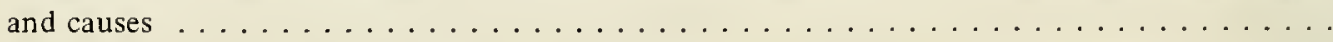

VI-29 Inventory of wetlands in Queen Anne's County including evaluation of present and future

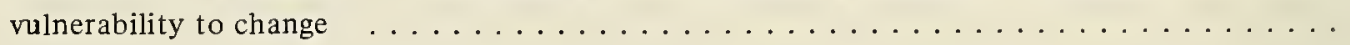

VI-30 Inventory of uses competing for wetlands in Queen Anne's County showing acreage losses and

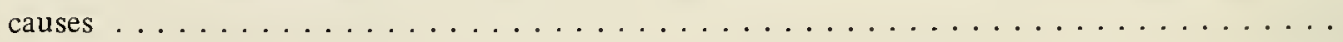

VI-31 Inventory of wetlands in St. Mary's County including evaluation of present and future

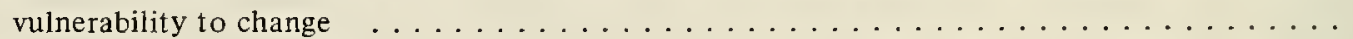

VJ-32 Inventory of uses competing for wetlands in St. Mary's County showing acreage losses and

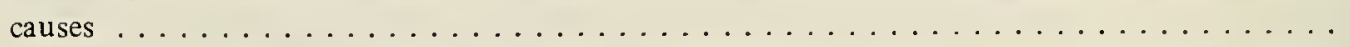

VI-33 Inventory of wetlands in Somerset County including evaluation of present and future vulner-

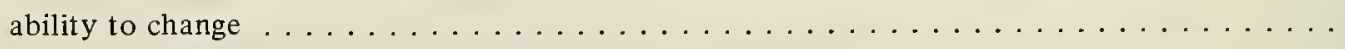

VI-34 Inventory of uses competing for wetlands in Somerset County showing acreage losses and

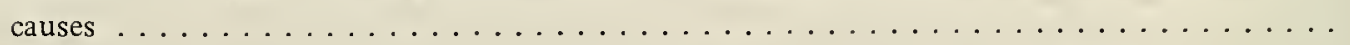

VI-35 Inventory of wetlands in Talbot County including evaluation of present and past vulnerability

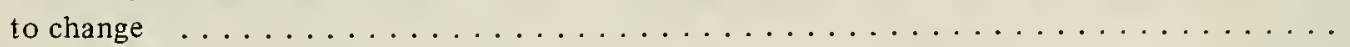

VI-36 Inventory of uses competing for wetlands in Talbot County showing acreage losses and causes .

VI-37 Inventory of Washington County wetlands

VI-38 Inventory of wetlands in Wicomico County including evaluation of present and future vainer-

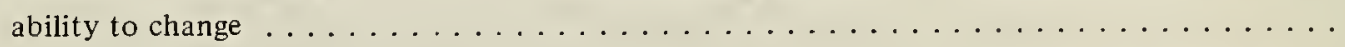

VI-39 Inventory of uses competing for wetlands in Wicomico County showing acreage losses and causes 


\section{LIST OF TABLES (continued)}

PAGE

VI-40 Inventory of wetlands in Worcester County including evaluation of present and future vulner-

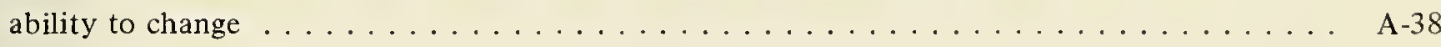

VI-41 Inventory of uses competing for wetlands in Worcester County showing acreage losses and

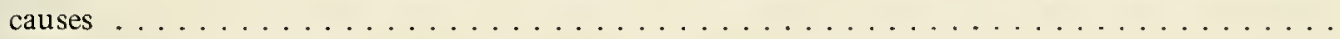

VII-1 Principal kinds of fish and shellfish in Maryland landings in 1967

VII-2 Output of the Maryland seafood processing industry, 1957-1965

VII-2

VII-3 Percentage of Maryland catch handled by the BaItimore wholesale fish market, 1959-1966

VI1-3

VI1-4 Estimated total expenditures of sportsmen fishing in the Maryland tidewaters during 1952, and amounts spent in Maryland, by type of expense $\ldots \ldots \ldots \ldots$

VII-5 Current capital investment of marinas by size, $1965 \ldots \ldots \ldots$

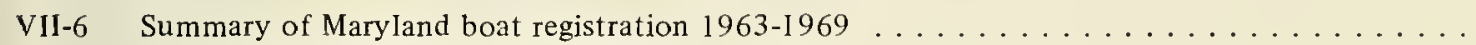

VII-4

VII-5

VII-6

VII-7 Numbers of hunting licenses issued in Maryland (summary) $\ldots \ldots \ldots$

VII-7

VII-8 Number and value of duck blind licenses issued in Maryland $(1963-1971) \ldots \ldots$

VII-9

VI1-9 List of the furbearer harvest in 1968-1969 by species and total dollar value of pelts

VII-IO

VII-10 Partial listing of conservation and outdoor recreation organizations and groups in Maryland (with approximate membership)

VII-I 1

VII-I I List of numbers of wetland areas, acreage and vulnerability included in the Catalog of Natural Areas in Maryland

VII-13

VII-12 List of numbers of wetland areas, acreage and vulnerability by county in Maryland that are or have been utilized for natural science research and education

VII-I 4

VII-I 3 Estimated current dollar product associated with wetlands in Maryland

VII-15

VIII-1 Approximate range of market values per acre of wetlands versus tillable Iand in curtain Maryland counties for the ten-year period I958-I968

VI1I-2

VIII-2 Assessed 1968-1969 valuations in dollar per acre of land categories containing wetlands by

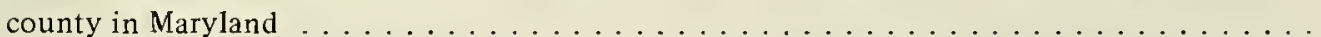

VIII-3 Assessed 1968-69 valuations in dollars per acre of marshland versus lands in agricultural production by Maryland county

VIII-5

VIl1-4 The five leading Maryland counties in terms of largest total tax revenues derived from, wetlands assessments (estimated)

VIII-7

VIII-5 Estimated assessed values and consequent tax revenues from wooded and shrub swamps and marshes by county in Maryland (1968-69)

VIII-8

IX-I Statewide summary of the uses changing the natural characteristics of wetlands in Maryland showing acreage losses for each type of wetland 


\section{LIST OF TABLES (continued)}

PAGE

IX-2 Statewide summary of the inventory of uses changing the natural characteristics of wetlands in Maryland showing acreage losses by use and by county

1X-3 Statewide summary of planned, proposed or potential industrial sites coinciding with wetland

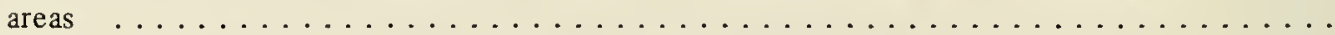

IX-4 Wetland areas being used as public or municipal solid waste disposal sites in Maryland . . . .

IX-5 Approximate wetland acres ditched for mosquito control as part of the permanent works

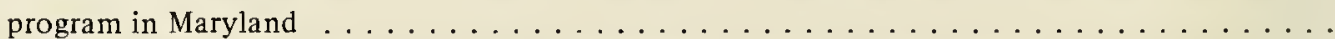

IX-6 Wetlands undergoing active erosion processes as determined by the wetland habitat inventory

IX-7 Summary of field inventory data on incidents and acreages of wetlands in a buffer role for uplands, including wetlands that are undergoing erosion $\ldots \ldots \ldots \ldots \ldots \ldots \ldots$

XI-1 General summary of survey information on wetlands and estuarine pollution . . . . . . . XI-6

XI-2 Surveillance sampling results, May and June, 1968, Statewide water quality investigation ... X XI-7

XIll-1 Composite summary of soil types and associations with potential for conversion to tidal marsh. XIII-8 

Wetlands management problems are in large measure attributable to our pluralistic society. While some look to natural resources mainly as sources of future income, maintenance of standards of living and tax dollars, others regard the manner in which most developmental activity takes place as being destructive to all life's essential support systcms as well as the amenity values frequently associated with undisturbed natural environments. It comes as no surprise, therefore, that the issue as regards wetlands reflects the same division of opinion, namely, wetlands reclamation via drainage and/or filling versus preservation. Fundamentally, agreement must be established as to what is a "wetland" and what are the economic, biological, and social consequences of all potential wetlands management policy alternatives ranging from complete development of substantial wetlands acreage through minimal disruption of wetlands' ecological systems.

The political process often attempts to mediate differing viewpoints and objectives through the traditional device of compromise. What may not be properly understood, however, is that at some point in perhaps the not too distant luture the opportunities for compromise will have run out. This is so because wetlands are by no means an inexhaustable resource nor are the processes and amenities inextricably linked to them. Thus, the principal thrust of this report is the compilation of essential background information and the formulation of carefully devised strategies to guide the future management of this valuable resource.

This approach is consistent with the intent of House Joint Resolution Two of 1967 (Appendix C). The Resolution requested "the Department of State Planning, with the cooperation of the Board of Natural Resources and the Department of Economic Development, to prepare a detailed long-term plan for the optimum use of wetlands in the State of Maryland".

To insure broad coverage of all problem areas relating to wetlands suggested by the Resolution and to coordinate all potential study inputs, a technical advisory committee was established by the Department of State Planning. Representatives from various State and federal agencies and other organizations concerned with wetlands management planning were included on the committee (Figure I-1).

The information prepared by the Wetlands Technical Advisory Committee in accordance with a study plan outlined initially by the Department of Game and Inland Fish' was utilized in drafting variously proposed wetlands conservation bills. Many of the findings, conclusions, and recommendations of this study have been incorporated already into new State laws or agency programs.
Figure I-1

MEMBERS OF WETLANDS STUDY TECHNICAL ADVISORY COMMITTEE

\section{Department of State Planning - Chairman Agency}

Robert M. August*

Roy G. Metzgar

Department of Chesapeake Bay Affairs

John Capper*

Nick Carter

Thomas Kloster

Edgar Hollis

Fred Sieling

Chesapeake Bay Institute of

Johns Hopkins University

Richard C. Whaley

Department of Forests and Parks

Edward 1. Heath*

William O. Johnson

Maryland Geological Survey

Harry Hansen

Chris Slaughter

Department of Natural Resources

Anthony Abar

Fish and Wildlife Administration

James R. Goldsberry

Vernon Stotts

David Wharton

Department of Economic and Community Development James McComas

Dr. Robert M. Sparks

University of Maryland - Institute of

Natural Resources

Dr. Richard R. Anderson

Department of Water Resources

Albert E. Sanderson

University of Maryland - Department of Entomology

Dr. George S. Langford*

\section{Other Contributors}

U. S. Soil Conservation Service

Edward R. Keil*

David Bowen

Eugene Whitaker

U. S. Fish and Wildlife Service - Patuxent Wildlife

Research Center

Dr. Ralph Andrews

Dr. James Kerwin

University of Maryland - Department of Agriculture

Dr. Gordon M. Cairns

Dr. R. Lamar Green

* Affiliations shown are those during the investigatory phase of the study. 
However, much of the information contained herein has not been available to the public. Because of the inherent short-term and long-range values derivable from improving widespread public comprehension and appreciation of the many facets and features as regards wetlands this report is being published.

In the time elapsed since the wetlands inventory was completed along with accompanying analytical work and writing, several significant events have occurred regarding Maryland wetlands which should be acknowledged in introducing this report. Among them are the news media coverage of wetland development procedures at Ocean City in Worcester County. This resulted in accelerating public concern about wetlands as well as demands for corrective legislative action. Another result of the Worcester County wetlands controversy was a much greater public familiarity with the term "wetlands" and economic and ecologic issues associated with Maryland's valuable shoreline areas. That episode culminated in the passage of two wetlands laws, Chapters 241 and 242, 1970 Acts of the Maryland General Assembly (Appendix E).

New legislation and subsequent implementation based upon statutory guidelines are often subject to legal challenges' through the court system. Maryland's wetlands laws have been no exception. The State's right to exert control over any modification to State-owned wetlands (those under navigable waters - meaning subject to ebb and flow of tide) as well as the right to require compensation to alter such areas was upheld recently by the Maryland Court of Appeals. ${ }^{2}$ Prior to that a careful examination of the new wetlands laws was presented in the Maryland Law Review. ${ }^{3}$

The initial operational document produced by the State agency assigned the administrative responsibility for the new wetlands laws is also noteworthy. The "Implementation Plan" is the first cut at spelling out the mechanics of the bills and outlines a process by which the Department of Natural Resources might fulfill its responsibilities under them. Also, the first set of county rules and regulations for controlling future wetlands management was drafted and distributed by that Department for Calvert County preliminary to a public hearing (Appendix F).

From this chronicle of recent events, it should be clear that the complete story of wetlands management in Maryland cannot be reported at this time since it is changing constantly. Instead, future events to be encountered by Maryland citizenry, responsible public officials, and State agency personnel will fashion and shape the ultimate patterns of our natural environment consistent with what reflects "optimum" choices, especially with regard to wetlands. In that context, the contents of this report should be viewed as a benchmark against which the results of present and future public policies and programs can be measured in terms of protecting and managing the environmental amenities as well as those economic values implicitly associated with or attributable to wetlands.

I The former Department of Game and Inland Fish is now subdivided into Fisheries Administration and Wildlife Administration. That agency undertook the study tasks of the former Board of Natural Resources which was abolished with the creation of the Department of Natural Resources in 1969.

2 Board of Public Works v. Lamar, 277 A. 2 d 427 (Md. 1971).

3 Salsbury, Stuart M., "Maryland's wetlands: The legal quagmire," Maryland Law Review. v. XXX, n. 3, University of Maryland School of Law, Baltimore. Summer 1970.

4 Capper, John R., "Maryland wetlands bills (House Bills 285 and 286): An implementation plan for the Department of Natural Resources," Annapolis. June 24, 1970 (mimeo). 
II

SUMMARY 

Wetlands are land-water edge areas which in Maryland are primarily associated with the estuarine and immediate tributary waters of Chesapeake Bay (Figure 11-1).* There are also wetlands of significant importance bordering the State's inland fresh waterways and its shallow saltwater estuaries on the Atlantic Coast. An abundance of aquatic vegetation species typically characterizes wetlands. Moisture supplied by either permanent, temporary or intermittent submersion or inundation of land by surface runoff, tidal cycles or permanent standing water is supportive of such vegetation.

There are two major groups of wetlands in Maryland, namely, inland and coastal, although the demarcation line between them is frequently indistinct, thus actually establishing a third intermediate group. Within these groups there are fourteen different types based upon carefully selected physical and biological features. In natural systems, vegetation occupies a basic position in the inter-connected food webs that eventually reach man. Wetlands, as locales for aquatic vegetation, constitute a habitat that is essential to varied and desirable species of aquatic and terrestrial animals.

Wetlands comprise a significant portion of the more important vestiges of Maryland's natural land and seascapes. Because of their shoreline location, wetlands have an important place in the State Scenic Rivers System under Chapter 749, Laws of Maryland 1971. In addition to esthetic values, wetlands have beneficial effects on the physical and chemical characteristics of river and estuarine systems. Through biological and chemical processes, sediment collection, and physical influences on hydrology, wetlands provide several functions important to water quality. Certain aquatic plants have the ability to take up and store inorganic materials that, in excessive amounts, cause conditions of aquatic overfertilization. Aquatic plants are also important sources of dissolved oxygen essential to natural processes that assimilate waste discharged in water bodies.

Because of their shoaling characteristics and usually abundant vegetation, wetlands function as settling or filtering basins which collect sediment as well as other suspended material. The water absorption and storage capabilities of wetlands temporarily retain water from overland runoff or tidal inundation. Delayed flows that are released at gradual rates by inland freshwater wetlands flush pollutants downstream, dilute them into harmless concentrations or provide additional volumes of water to augment natural assimilative abilities.

Besides the above-mentioned intangible values, important quantifiable benefits are also associated with *See inside back cover.
Maryland wetlands. These benefits are derived from fishing (commercial and sport), boating, hunting, and fur trapping. In Maryland, the commercial fishing and seafood processing industry as related to wetlands has an annual dollar product of $\$ 30.3$ million. This industry employs 6,000 fishermen full-time, 3,000 part-time, and 4,300 people in the food processing sector. Additionally between 200,000 and to 300,000 Marylanders annually spend an estimated $\$ 20$ million on goods and services for saltwater sport angling, exclusive of expenditures on boats and boating equipment. In the boating sector, 42 percent of marina-kept boats are used primarily for fishing. The value of boats and boating equipment used for saltwater angling is presently inestimable due to inadequate information. Since a very high percentage (60\%-90\%) of our important commercial and sport fish and shellfish are dependent on estuarine environments, the fundamental role of wetlands in aquatic ecology establishes their significance to the maintenance of desired fishery resources and values associated with their harvest.

The mixture of open surface waters and wetlands in Maryland is one of the most important in North America to migrating and wintering waterfowl. Waterfowl hunting provides outdoor recreation to 35,000 hunters annually in Maryland. It is estimated that these hunters spend between $\$ 10.5$ and $\$ 17.5$ annually. To this may be added estimated annual expenditures of $\$ 60,000$ for rail and snipe hunting and $\$ 250,000$ for the purchase of furbearer pelts. Altogether, the major quantifiable economic benefits associated with Maryland's wetlands are most conservatively estimated at approximately $\$ 65$ million annually.

Additionally, there are uses of wetlands that alter and destroy their ecologic and amenity values including: agriculture, housing, industry, marinas, dredging and spoil disposal, public works, solid waste disposal, and mosquito control. Generally, each specific instance of wetland destruction has not been too significant in terms of areal extent. The individual proposing wetlands destruction or alteration views his proposal as an isolated incident which will occur only once to a particular wetland. Consequently, wetland losses in that frame of reference are not often impressive nor important. However, when viewed from a Statewide perspective, the accumulation of acreage losses from all incidents of destruction becomes quite meaningful to natural resources management planning.

For the 25-year period 1942-67, wetland losses in Maryland due to the above-mentioned activities exceeded 23,000 acres. When historical reports on wetlands are taken into account, however, total wetland destruction for a 60 -year period may approach 200,000 acres. This es- 
timate is based on a 500,000 acre total reported to exist in $1908^{\prime}$ as compared with approximately 307,400 acres remaining in Maryland in 1968. The apparent abundance of remaining wetlands is grossly misleading when viewed against historical and present day-to-day destruction. It is difficult, indeed, to comprehend and assess the economic and ecologic implications reflected by such a large-scale alteration of the natural environment. On the other hand, it is not difficult to project the environmentally delterious results which will occur from persistent disturbances and destruction to functioning ecosystems. Once certain limiting thresholds are exceeded, correcting or compensating natural forces cease to exist. Consequently, the rich biological variety, productivity, and high amenity values derived from the State's existing terrestrial-aquatic ecosystems are apt to diminish substantially.

The apparent abundance of remaining wetlands is also an illusion when evaluating wetlands' vulnerability to future man-initiated destruction. This evaluation is based on known development proposals and plans, current zoning regulations, and other factors such as local attitudes toward wetlands. The results disclose that approximately 80 percent of the remaining wetlands are vulnerable to varying degrees of biologically destructive alteration.

The decisions affecting wetlands vulnerability are complicated by a regional dichotomy between the more populated and economically developed urban/metropolitan areas of the western shore region and the wetland, high environmental amenity "laden" but economically depressed eastern shore region of Chesapeake Bay. Approximately 58 percent of the State's remaining wetlands are located in two lower eastern shore counties, Dorchester and Somerset, while the entire eastern shore is the geographic locale of 83 percent of the inventoried wetlands. While Dorchester and Somerset counties have extensive wetland tracts they also exhibit numerous indicators of an unsatisfactory economic situation. Consequently, local sentiment sometimes tends to favor the exploitation of shoreline areas (including wetlands) attractive to industry, housing, and other development. This sentiment runs counter to that of many western shore residents who favor restriction of such development.

There is also an important competitive situation between farming and wetlands preservation. Agriculture is the leading industry on the eastern shore. However, soil conditions, low topographic relief, and consequent poorly defined natural drainage systems when combined with high average rainfall mean excessive amounts of surface water and delayed runoff which interferes with optimum agricultural productivity in that region. Consequently, installing corrective agricultural drainage measures has had a significant impact on inland fresh water wetlands which are inextricably associated with typical eastern shore watersheds.

Drainage is an attractive and viable solution to farmers because of State and federal government programs which provide technical and financial assistance (grants plus low interest rates) to defray much of the capital cost of draining land. Finally, governmental price support programs increase the revenues from crops grown on improved or reclaimed land above normal market demand price levels.

Man's alteration of wetlands is also encouraged by the low tax revenues that are derived from them. Of all real property, wetlands are assessed at the lowest rates for taxation purposes. While wetlands represent about 4.8 percent, of Maryland's total land area, they contribute only 0.2 percent to the State's total assessed land valuation. Wetlands property tax assessments produce an estimated revenue of $\$ 121,000$ on a total assessed valuation of $\$ 4.8$ million (1968-69). Consequently, extensive wetland holdings are viewed by some as a tax augmentation opportunity through development of areas contributing relatively little to the present taxable base. However, this tax situation is actually inconsistent with well-established real estate value patterns in which waterfronting property (including encompassed but lowervalued wetlands) has substantially higher market value than any other kind of land.

The real estate market, speculative land investment, and local government financial problems are powerful forces for change in land use, especially wetlands. Unfortunately, short-term solutions and consequent gains are more obvious and immediate, and therefore, they are more persuasively attractive than countering long-range gains and losses.

Safeguarding wetlands against excessive destruction is not a resource management problem unique to Maryland. Several other states have enacted wetlands protective legislation including Maine, New Hampshire, Massachusetts, Rhode Island, Connecticut, New Jersey, Delaware, North Carolina, Georgia, and recently Virginia. As compared to the other thirteen Atlantic Coast states Maryland's coastal wetland/estuarine complex has been rated seventh in percentage of "important" coastal wetlands; third in percentage of "important" open shoal habitat; and sixth overall.

A major problem facing future wetlands management planning rests on the efficiency and equity questions attendant with the distribution of economic and environmental benefits and costs by developing and/or 
preserving wetlands and associated resources. A contradiction exists between private and social values and goals attendant in wetlands since many benefits accrue to the public at large while the burden of habitat maintenance falls to private landowners. Because of this contradiction the market place fails to function as an effective mechanism for allocating wetlands between development (reclamation) and preservation. Consequently too few wetlands are likely to be preserved (with their public or social benefits) in the private sector without governmental intervention in the allocating processes. The free enterprise initiated market system has been further deflected from an effective allocation process through the impact of governmental programs which reduce capital costs for draining wetlands to increase agricultural productivity, dredging navigable channels for commerce and recreation, etc.

To date, much of the shoreline development that has occurred in Maryland has been of a random, opportunistic nature. Important features in the decisions concerning development have been based primarily upon the availability of suitable land and an interest in immediate return on investment capital. The pattern of previous developmental activity reflects these features. The questions that should be raised and evaluated are: Can Maryland afford this type of activity to continue in the future? Or, should such events and consequences be permitted to continue? Without careful forethought and weighing of all factors, the unfortunate consequence of unplanned and uncontrolled development can easily cost far more than the anticipated benefits. However, if the State, with the support and cooperation of local governmental units, develops, adopts, and enforces shoreline development policies consistent with carefully considered plans that reflect all of the inherent values and uses in wetlands, the best interests of all citizens will be served and protected.

The changing character of our natural environment due to the impact of increasing human populations is becoming increasingly apparent. Development of the State's coastal zone because of economic advantages and environmental amenities has produced frequent encroachments on wetlands. The economic imperfections regarding the goods and services, both private and public, that are related to wetlands, the real estate market for shoreline property, and local government revenue problems and attitudes toward the environment indicate that a scientifically and economically sound management program must be developed and implemented to assure an optimum combination of protection and utilization of wetlands. The strategies recommended in the next chapter have been devised with that objective in mind.
1 Report of the Conservation Commission of Maryland - for 1908-1909. p. 139.

2 Spinner, George P. A plan for the marine resources of the Atlantic coastal zone. Am. Geographical Society. 1969. 


The central finding of this investigation is that wetlands, as wetlands, are an exceedingly valuable resource asset to the State of Maryland. However, due to the population growth the State and surrounding areas are experiencing, increasing demands are being placed on the resource base. While the foreseeable extent and impact of increasing encroachment upon wetlands are not yet clearly discernible, they certainly will be greater than anything previously experienced.

The probable demands upon wetlands will focus heavily on the State's tidewater and land interface area, the coastal zone, where this valuable resource abounds. The significance of the attendant resource management problem is brought all the more sharply into view when it is realized that Maryland's most pronounced physical characteristic is the large proportion of the State in "tidewater" areas. The Chesapeake Bay comprises about onefifth of the State's surface area. To this must be added other important estuaries such as lsle of Wight, Assawoman, Sinepuxent, and Chincoteague bays on the Atlantic Coast. The existence of these large estuarine bodies of water, especially in the heart of the State, shoud be noted with emphasis because of: 1) inherent biotic and environmental amenity values; 2) growing population; 3) important commercial and industrial marine enterprises; and 4) the very important recreation potential. This territorial concentration in the midst of Maryland is unique among the fifty states. The urgent need for timely planning of the coastal zone, including wetlands, on a multiple-purpose basis within the context of a Statewide generalized land use plan need not, therefore, be labored.

Based upon current levels of scientific knowledge and technical information, the following major recommendations constitute a program which will develop a strategy for "optimum" management of wetland resources in Maryland. In examining these recommendations it is stressed that recent executive actions by the Governor. laws enacted by the Maryland General Assembly, and programs initiated by the Maryland Department of Natural Resources as well as other State agencies are predicated, in part, upon working papers and draft report documents of this study. Consequenlly, there are instances where State programs consistent with and based on these recommendations are already underway.

1. Maryland must develop a firm and consistent posture with respect to wetlands in both State and private ownership.

Carrying out this recommendation depends upon the adoption of a State policy restricting the sale of wetlands in State ownership, as well as developing regulatory control regarding privately owned wetlands. Retention of State wetlands in public ownership would be supportive of ongoing programs for the acquisition of wetlands by the Department of Natural Resources. Incontestible demonstration of the public interest should attend the sale of any State-owned wetlands.

2. The Department of Natural Resources should develop at once an overall plan and implementing program for the acquisition of wetlands including easements and development rights, based upon recently updated inventory and other data availabilities.

This recommendation is made all the more urgent by reason of the fact that market prices for waterfront property with conservation or outdoor recreation values and the riparian rights inherent in wetlands are rising more rapidly than other real property values.?

3. The State should assume leadership in formulating a management program for all natural resources, including wetlands, that would coordinate the objectives, plans and programs of all levels of government.

Part of the State's management problem with regard to wetlands lies in the proliferation of legal, political, and institutional arrangements concerned with natural resources. A multiplicity of governmental agencies at all levels are involved in resource management planning. Many of these agencies were established for special purposes

I See Chapters 241 and 242, Laws of Maryland 1970 and also "Proposed Order Establishing Private Wetland Boundaries in Calvert County, Maryland, and Proposed Rules and Regulations" in Appendices E and F, respectively.

2 Wetlands are being acquired or are planned for acquisition in conjunction with land purchases for State parks, natural environment, and wildlife management areas. They are being purchased with funds made available by the Outdoor Recreation Land Loan of 1969 (Ch. ). Some recently acquired or intended acquisitions which encompass wetlands are certain areas along the Gunpowder River (Baltimore and Harford Counties); Patuxent River (Howard, Montgomery and Prince George's Counties); Severn Run (Anne Arundel County); Mattawoman Creek (Charles and Prince George's Counties); Fishing Bay and Taylor's Island (Dorchester County); and Deal Island (Somerset County) to mention a few. 
and to accomplish single-purpose goals. Too frequently, inadequate recognition and attention has been given to the ecological impact of various publicly funded programs. e. g., land drainage, river and harbor, flood control projects.

4. More effective use should be made of existing statutory authority and agency regulations affecting wetlands

Abundant opportunities for the more effective application of State laws and regulations as related to wetlands management are to be found, particularly in the provisions of Article 96A (Water Resources) dealing with the disposal of solid matter into State waters and obstructing the 50-year flood plain; in the provisions of Article 43 (Health) dealing with county plans for public water supply and sewerage systems; and in the provisions of Article $88 \mathrm{C}$ (State Planning) dealing with land-use plannirg.

To carry out this recommendation, adequate funding of State planning and resource management programs is necessary.

5. Maintain an up-to-date resource inventory and information system as a necessary adjunct to resource management.

The data processing information retireval system as developed during the course of this investigation should be maintained and up-dated as needed. A very important element of the periodic updating of the resource inventory would be the proper identification of State and private wetlands. ${ }^{4}$

6. Stimulate and maintain high quality research on wetlands and related biotic resources.

Very broadly, this recommendation envisages a carefully coordinated program of both basic and applied research directed towards a vastly improved knowledge of the State's various ecological systems, including wetlands. Such research is a necessary adjunct of sound resource management plans and programs. ${ }^{5}$

7. The State should encourage and support demonstration projects where useful in providing for future resource management.

In addition to providing guidelines for resource management, the knowledge and experience derived from demonstration projects, such as the Rookery Bay Area Project in Florida described elsewhere in this report, could

3 The Chesapeake Bay Interagency Planning Committee was created in 1969 by Governor Marvin Mandel and charged to undertake a comprehensive resources planning effort for Chesapeake Bay and its related resources. The Committee is composed of the Departments of Planning, Natural Resources, Health and Mental Hygiene, Economic and Community Development, and Transportation. Major coordinative duties are being performed by the Department of State Planning. See: Integrity of the Chesapeake Bay, Pub. No. 184, Md. Dept. of State Planning. August, 1972.

4 See Section 724, Chapter 241 - Laws of Maryland 1970. Also, "Coastal Wetlands Inventory in Maryland" by Lester E. Garvin and Richard H. Wheeler. Conf. Am. Soc. Photogrammetry. Washington, D. C. June 7, 1972.

5 See Chapter 31 - Laws of Maryland 1971, especially Section 764, "Power Plant Environmental Research Program".

At St. Michaels, Maryland, The Center for Applied Research in Environmental Sciences affiliated with The Nature Conservancy is embarked on a Conservancy funded project entitled, "Exploration of the Ways and Means of Creating Tidal Marshlands in the Chesapeake Bay."

The Chesapeake Research Consortium, Inc., composed of the Johns Hopkins University, the University of Maryland, the Virginia Institute of Marine Science, and the Smithsonian Institution, received a grant in June, 1972, from the National Science Foundation to carry out one of the Consortium's major programs entitled, "Wetlands, Shorelines, and Shallows." This program along with another received one-year funding of $\$ 1.5$ million as a part of the Consortium research entitled, "THE CHESAPEAKE BAY: A Proposal for Research Applied to National Needs."

Additionally, Maryland Fish and Wildlife Administration biologists have completed research projects entitled, "Ecological Study of the Susquehanna River and Tributaries below Conowingo Dam," and "Stream Improvement Program for Anadromous Fish Management." These projects were assisted financially by the Federal government (50\%) under the Anadromous Fish Act (P. L. 89-304). 
be directed also towards improved strategies for interagency and intergovernmental coordination with all that this implies for the future management of the State's wetlands and shoreline areas. ${ }^{\circ}$

8. Action should be initiated by the Department of Natural Resources and cognizant federal agencies to assure widespread public familiarity with opportunities for financial support for wetlands conservation under the "Water Bank Act" (Public Law' 91-559).

The provisions of this Act apply specifically to fresh water wetland areas of Types 1 through 5. (See Chapter IV and Appendix G.) This is a most important point since Maryland's wetlands laws focus on coastal wetland types only. However, there are approximately 25,000 acres of Types 6, 7 and 8 wetlands which are neither regulated by Maryland wetland laws nor eligible for coverage under the Water Bank Act. Corrective actions at the State and federal levels should be contemplated and initiated to extend some form of protective and/or regulatory mechanisms to shrub swamps (Type 7), wooded swamps (Type 8), and bogs (Type 8).

6 Under the "Stream Improvement Program for Anadromous Fish Management" conducted by the Fish and Wildlife Administration numerous stream blockages were removed. Also, mitigating measures were devised and installed at road crossings over certain streams with the cooperation and assistance of the State Highway Administration. Planning procedures to either protect or enhance anadromous fisheries during the design and development of U. S. Soil Conservation Service watershed projects were developed also. 




\section{DEFINITION}

Wetland (s) is a collective term for land-water edge areas and submerged bottoms which occur in certain areas of the State. These areas usually support extensive growths of either submerged or emergent aquatic plants because of permanent, temporary or intermittent submersion or inundation. Sources of essential moisture include: natural surface runoff resulting from rainfall, groundwater, diurnal lunar tidal cycles, unusual tidal conditions due to wind and storms, or seasonal overflows on floodplains.

Wetlands often occur as a bordering fringe along shorelines interposed between permanent dry land and open surface water expanses of rivers, sounds, bays, and other estuarine waters in the State. Wetlands also occur as extensive tracts of several hundred acres extent and several miles wide as well as submerged bottom at depths where sunlight penetrates to permit photosynthetic processes. At higher elevations than the predominant coastal plain, wetiands are found in natural topographic depressions and along flowing waters.

Wetlands may be known locally as salt marsh, tidal marsh, marshland, tideland, submerged land, swamp, swampland, gut, slough, pothole, bog, mud flats, wet meadow, overflow land or flood plain. Shallow lakes and ponds (mainly having depths less than six feet and supporting emergent vegetation as a conspicuous feature) are included in the definition. Artificial reservoirs and the permanently submerged deep bottoms under broad reaches of certain streams, rivers, and estuaries are not included in the term "wetlands" as used herein because of greater depth of water.

The above definition of wetlands is presented only for purposes of information, education and for refining the description of the areas studied in response to House Joint Resolution No. 2 (1967). This definition should not be construed to affect title to any land, submerged land, or other area or to prescribe boundaries for any specific purpose other than use in public discussion.

\section{CLASSIFICATION SYSTEM}

Natural plant communities which are the fundamental basis for most wetlands' classifications do not fit neatly into any distinctive, man-devised system. Wetlands are infinitely varied, complexly integrated areas of plant and animal communities. Each wetland area is unique, but retains some degree of similarity with its neighbor whether the latter is downstream, upstream, across an estuary, or hundreds of miles away.

The classification system presented in this study is the product of combining selected features from sev- eral different sources. ${ }^{1}$ The system describes briefly each type of wetland inventoried in Maryland and outlines in general the more important physical and ecological characteristics of each. Some gaps in the numerical designations will be detected. This reflects the lack of a particular type of wetland in Maryland although it occurs somewhere else and therefore was incorporated into preceding classification systems. By retaining a widely used system, the results produced here may be more readily understood and compatible with past and future work on the subject

There are two major, distinct wetlands groupings in Maryland: interior (or inland) and coastal. Wetlands in the first group may occur, however, within the second, especially on the landward side of coastal marshes and in the upper reaches of waterways remote from tidal influence. So there is also somewhat of a third, intermediate or transition grouping which is neither distinctly interior nor coastal in character.

\section{Interior or Inland Wetlands}

There are seven types of wetlands in this category which is characterized by non-tidal, fresh water. They are:

Type 1-Seasonally flooded basins and flats

Type 2-Inland fresh meadows

Type 3-Inland shallow fresh marsh

Type 5-Inland open freshwater

Type 6-Shrub swamp

Type 7-Wooded swamp

Type 8-Bogs

\section{Type I-Seasonally Flooded Basin, Flats}

\section{And Type 2-Meadows}

Basins and flats (Type 1) are found in upland depressions and along edges of streams in overflow bottom land (flood plain). Meadows (Type 2) occupy shallow upland basins, sags or border deeper marshes on their landward side. Both of these ty pes of wetlands are quite similar and are often created artifically from drained and cleared shrub and wooded swamp and maintained by intensive grazing and mowing when drainage and water table conditions permit.

The soil is usually without standing water throughout the year but is waterlogged within at least a few inches of its surface. There may be a few inches of standing surface water after a heavy rainfall or spring snow melts. Along river courses, flooding occurs in late fall, winter or spring. Water depth can vary from a few inches in uplands to a few feet along rivers during seasonal flooding.

Vegetation varies greatly according to the season and the duration of the flooding. Lands that are 
inundated only very temporarily usually develop little or no wetland vegetation. Vegetation includes hardwoods, herbaceous growths, native and cultivated grasses, ironweed, goldenrod, sweetflag, common rush, spikerush, chufa, smartweed, sedges, tearthumb, joepyeweed, arrowhead, many-leaved rush, wool-grass, jewelweed and various broad-leaved annual and perennial plants.

These plant communities provide resting, feeding and shelter to numerous species of resident and migratory songbirds, and are frequented by large numbers of upland game birds, small game animals and furbearers, such as squirrels, rabbits, raccoons, foxes and deer.

\section{Type 3-Inland Shallow Fresh Marsh}

Wetlands of this type are found at the upper reaches of rivers and streams in shallow basins or bordering other types of wetlands on their landward side. This wetland type is also common as seep areas on irrigated land.

The soil is usually waterlogged during the growing season. Often the ground is covered with as much as six inches of water.

Vegetation includes grasses, bulrushes, spikerushes, and marsh plants such as arrowhead, pickerelweed, smartweed, wild millet, wild rice, and cattail in varying amounts, sometimes forming thick extensive beds.

These wetlands are capable of supporting high per acre populations of muskrats. They are used by black and wood ducks for nesting and rearing ducklings. The high quality foods produced by the many different plants attract migrating and wintering waterfowl and rails. These areas support opossum, nutria, otter, muskrat, raccoon and rabbit populations.

\section{Type 5-Inland Open Freshwater}

Shallow water in artificial ponds, lakes and open areas interspersed in inland fresh marsh types categorize this wetland type. Water depth is variable and this type is usually fringed by a border of emergent vegetation that grades into another type of wetland.

Vegetation (mainly at depths under six feet, but scarce or absent in stained or turbid waters) consists of sago pondweed, naiad, spatterdock, water-lily, smartweed, elodea, water-willow, water cress, coontail, water milfoil, duckweed, arrowhead, burreed, spikerush, native and introduced grasses and sedges, and various algal species (Figure IV-1).

This type functions as resting and feeding areas for migrating waterfowl and other waterbirds and also as nesting and brooding grounds for wood ducks, black ducks and mallards. This habitat provides sustenance

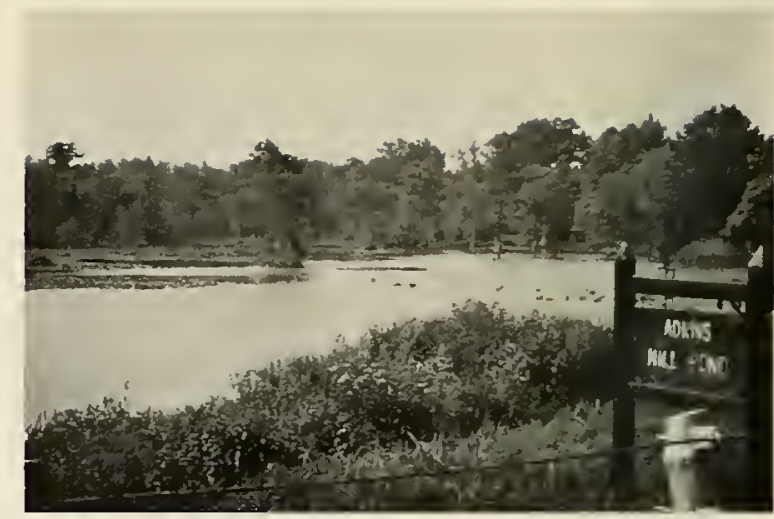

Figure IV-1. Adkins Mill Pond in Wicomico County an example of Type 5 wetlands.

for fish, muskrats, turtles, frogs, salamanders and the animals that use the shoreline to prey on these inhabitants.

\section{Type 6-Shrub Swamp}

Shrub swamps can be found often along sluggish streams and occassionally on river flood plains. They are common on the landward side (higher elevations) of coastal type wetlands. The soil is normally waterlogged during the growing season, and is covered with up to six or more inches of water.

Vegetation consists of alder, but tonbush, willows, small maples and sweetgums, tearthumb, swamp rose, beggar-ticks, beggar-lice, jewelweed, joe-pye-weed, looset rife, native grasses and sedges.

This type is moderately used by mallard, black and other puddle ducks during migration and is most important to wood ducks for nesting and nightly roosting. Rabbit, raccoon, opossum, fox, squirrel, otter, muskrat and deer find these areas to be valuable habitat as well as numerous reptiles, anphibians and resident and migratory songbirds.

\section{Type 7-Wooded Swamp}

Wooded swamps often occur in association with shrub swamps and along sluggish streams, on flood plains, on flat, poorly drained uplands, and in very shallow basins.

The soil is waterlogged to within a few inches of its surface during the growing season, and is of ten covered with a few inches in uplands to one foot of water near streams and rivers.

Vegetation consists mainly of trees (Figure IV-2). Principal ones are red maple, river birch, sweetgum, pinoak and cypress. Other trees occurring in variable numbers are sycamore, oaks, elms, ash, aspen, poplar, black gum, and maples. Forest floor growth includes nettle, lizard's tail, spicebush, magnolia, paw-paw, 
winterberry, greenbrier, holly, honeysuckle, blackberry, grapes, beggar-ticks, jewelweed, various grasses, sedges and broad-leaved plants.

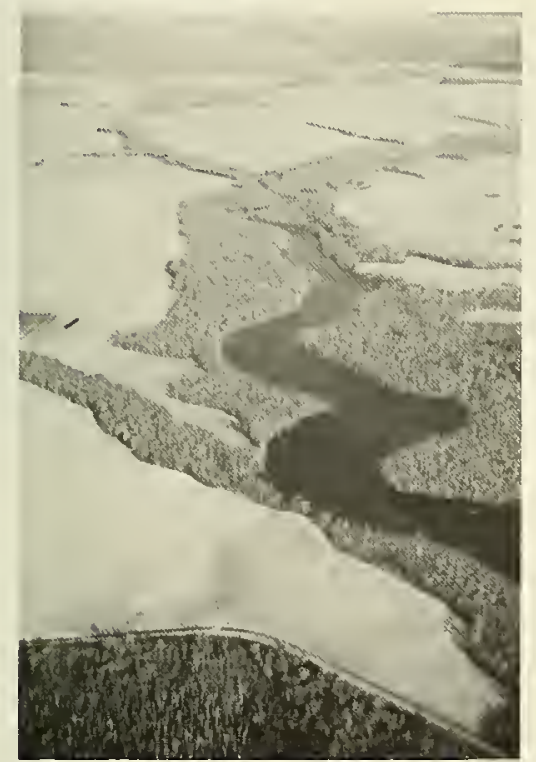

Figure IV-2 An example of Type 7 wetlands (Dorchester County).

This we tland habitat provides for numerous waterfowl, wildlife, and fishery species. A few examples of each include usage by puddle ducks for resting and feeding, but most importantly for black and wood duck nesting, brood production and nightly roosting. Other birds include migratory stops by mourning doves and woodcock, complete life cycle usage by great blue herons, egrets, ibis, killdeer, sandpipers, and large numbers of resident and migratory songbirds. Also, the bald eagle and osprey utilize this type for nesting sites. Deer, rabbit, squirrel, muskrat, otter, opossum, and fox also utilize this type. In permanently watered areas, there are several resident game fishes such as large mouth bass, pickerel, catfish, white perch, and yellow perch.

\section{Type $8-B o g$}

Bogs occur mostly in shallow basins, on flat, poorly drained uplands and along sluggish streams. Maryland's bogs, also known as "glades" are found exclusively in Garrett County.

The soil is usually waterlogged and supports a spongy covering of mosses. Other Type 8 wetland vegetation is either woody, herbaceous or both. Typical plants are heath shrubs, sphagnum moss, ferns and sedges. In more northern latitude climates and at higher elevations in Maryland such plants as leather-leaf, Labrador-tea, cranberries, sweet bay pond pine, pitcher plants, carex and cotton grass are often present. Also, scattered, often stunted black spruce and tamarack may occur as well as hemlock, alder, maple and aspen (Figure IV-3). The most important vegetative feature of Maryland bogs is the occurrence of plants that are dominant in the typical bogs of the glaciated portions of northern United States and Canada. Consequently, bogs represent distinctive ecological areas as isolated, extreme southern ranges for certain plant and animal species.

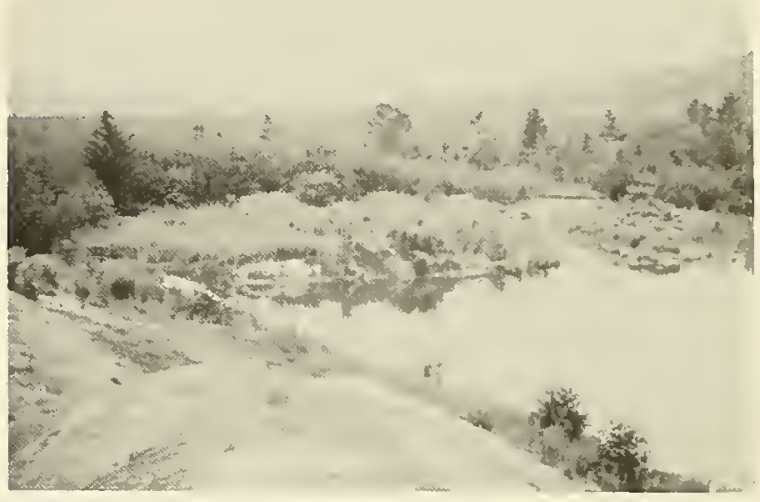

Figure IV-3. An example of Type 8 wetlands - Garrett County.

Animal inhabitants in this wetland type are cottontail rabbit, gray squirrel, red squirrel, raccoon, red and gray fox and bobcat, among numerous others. There are also extraordinary lists of reptiles and birds reported by naturalists familiar with these areas in Western Maryland. For example, Mansueti listed 23 different reptiles, 76 different birds and 19 different mammals as inhabitants or visitors of the Cranesville Pine Swamp, a montane bog that straddles the Garrett County, Maryland-Preston County, West Virginia line. ${ }^{2}$

\section{Coastal Wetlands}

Nine types of wetlands are encompassed within the coastal wetlands grouping-five fresh and four saline. Each type is characterized by special differences in shoreline elevation, geographical location, water quality or tidal influence. Because of their close association with coastal wetlands in many instances, shrub and wooded swamps are often very difficult to delineate from more extensive and dominant coastal wetlands. Types 6 and 7 wetlands from the inland grouping are also included, therefore, in the fresh water areas subdivision of the coastal grouping.

Soil survey reports by the U. S. Soil Conservation Service have variously described the soils underlying coastal wetlands as dark-gray, black, dark brown, drab, blue-tinted, bluish gray silt, silty-clay, clayey-loam material which is mixed with varying quantities of vegetable matter and plant roots in all stages of decay 
and decomposition, or choked with a mass of peaty fibrous material (the partly decayed remains of preceding generations of plants).

\section{Fresh Water Coastal Wetlands}

Type 6-Shrub swamp

Type 7-Wooded swamp

Type 12-Coastal shallow fresh marsh

Type 13-Coastal deep fresh marsh

Type 14-Coastal open fresh marsh

\section{Saline Areas}

Type 16-Coastal salt meadow

Type 17-Coastal irregularly flooded salt marsh

Type 18-Coastal regularly flooded salt marsh

Type 19-Mud flats

\section{Type 12-Coastal Shallow Fresh Marsh}

These marshes are found on the landward side of coastal deep fresh marsh (Type 13) along tidal rivers, sounds, and estuaries. Type 12 wetlands are tidal and may be covered at average mean high tide by as much as six inches of water. The soil is always waterlogged during the growing season.

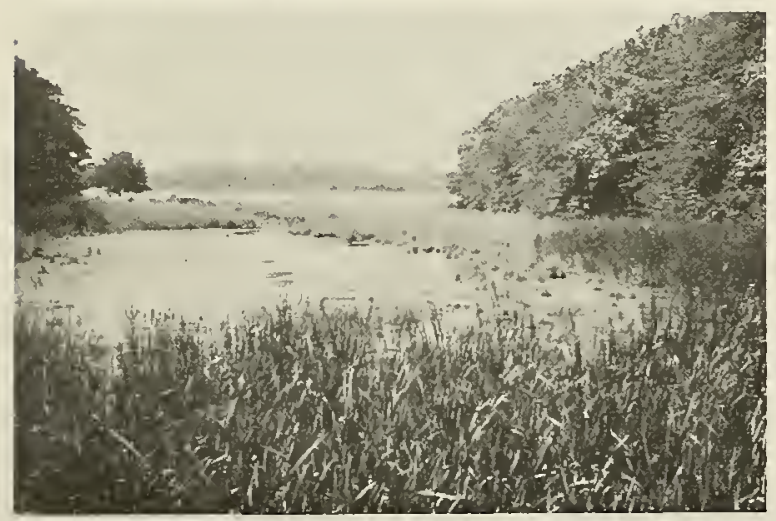

Figure IV-4. An example of Type I2 wetlands with cattail in the foreground and saltmarsh cordgrass beyond the exposed mudflats in the background - Kent County.

Vegetation consists mostly of cattail, reed, big cordgrass, arrow-arum, pickerel-weed, golden club, three square, panic grass, and rose mallow. Other plants are millet, swamp rose, rice cut-grass, water-parsnip, waterhemp, saltmeadow cordgrass, saltmarsh cordgrass, myrtle, hightide bush, and groundsel bush (Figure $1 \mathrm{~V}-4$ and IV-5).

These areas are heavily used for feeding by waterfowl, shorebirds and waders and receive some feeding usage by muskrats, raccoons and nutria. De-

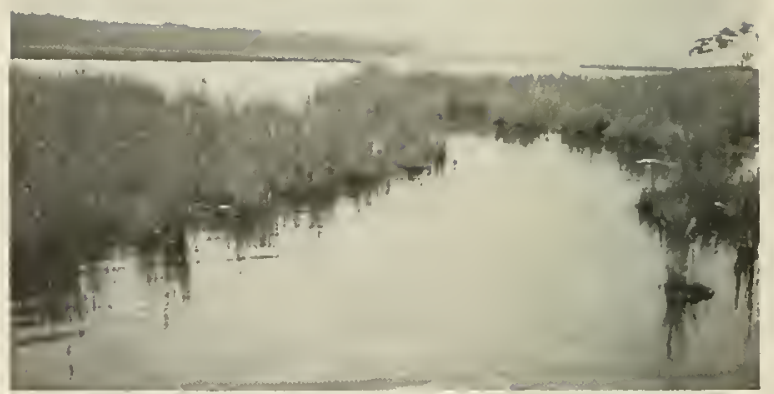

Figure IV-5. An example of Type 12 wetlands with 3 square the dominant aquatic vegetation near Blackwater National Wildlife Refuge, Dorchester County.

tailed wildlife and tisheries production related to this wetland type and the other coastal wetlands will be discussed in Chapter V-Wetlands Ecology.

\section{Type 13-Coastal Deep Fresh Marsh}

This type of wetland occurs along tidal tributaries and wetland meanders leading to bays, sounds and other estuarial areas of Chesapeake Bay. The soil is covered at average mean high tide with one-half to three feet of water.

Vegetation consists of wildrice, pickerel-weed, spatterdock, water-lily, arrow-arum, golden club, cattail, smartweed, tearthumb, coontail, pondweed, wild celery and other grow ths that occur in marsh openings.

\section{Type 14-Coastal Open Fresh Water}

This type includes shallow but variable depth portions of open water along fresh tidal rivers and sounds. This type is sometimes more or less enclosed tidal ponds or pondlike areas. Tidal cycles and natural currents keep sediment and detrital materials in suspension.

Vegetation may be scarce or absent because of turbid waters. However, pondweed, naiad, wild celery, coontail, muskgrass, and widgeon-grass are common at depths less than six feet. Border areas are often surrounded by cattail, saltmeadow cordgrass, reed, salt marsh cordgrass, myrtle, hightide bush, groundsel bush, and three-square.

Type 14 wetlands are heavily used by feeding and resting waterfowl and other water birds and fish species.

\section{Type 16-Coastal Salt Meadow}

This type is found along the landward side of salt marshes (Types 17 and 18) or bordering open water. 
The soil is always waterlogged during the growing season but its elevation is such that it is rarely covered by tide waters. However, there may be a few inches of water over the soil at spring or high wind tides.

Vegetation consists mainly of saltmeadow cordgrass, saltgrass and blackrush in combination with patches or borders of saltmarsh cordgrass. Type 16 wetland is lightly used by various wildlife, waterfowl and fisheries.

\section{Type 17-Irregularly Flooded Salt Marsh}

This type is found along the shores of tidal rivers and nearly enclosed bays, sounds and other estuarine waters. The soil is covered by a few inches of water by wind and spring tides at irregular intervals during the growing season.

The dominant vegetation is needlerush. Widgeongrass occurs in ponds and channels within the marsh. Other plants in border areas associated with this type are saltmarsh cordgrass, saltmeadow cordgrass, and hightide bush.

This type is used very little ordinarily by wildlife and waterfowl, but where broken by ponds, creeks, and meanders it is sometimes moderately used by feeding waterfowl and nesting clapper rails.

\section{Type 18-Regularly Flooded Salt Marshes}

These marshes are located almost exclusively in estuaries in Worcester County where the tidal range is influenced by the Atlantic Ocean. The soil is covered at mean high tide with one-half foot or more of water during the growing season.

Vegetation is dominantly saltmarsh cordgrass. Permanent open water in these marshes may support wigeon-grass, eelgrass, sago pondweed, elodea and coontail. Other closely associated plants are saltmeadow cordgrass, saltgrass, hightide bush, myrtles and glasswort.

Locally this type is heavily used by feeding waterfowl, especially where vegetation-filled ponds are present. It is important as nesting areas for gulls and rails, as feeding areas for herons, as habitat for mussels, snails, crabs and use by fish and some shorebirds.

\section{Type 19-Submerged Lands}

This type consists of the submerged lands under the open waters of Chesapeake Bay proper and the wide expanses of its sounds, bays, tidal rivers and mud flats from mean low tide seaward. Also included are the submerged lands under the waters of the bays behind the barrier beach islands on the ocean side of Worchester County.
Submerged and suspended (floating) aquatic vegetation may be abundant or scarce due to prevailing water depth, quality and turbidity. These factors determine environmental conditions and the amount and depth of sunlight penetration with consequent photosynthetic activity.

Submerged bottom areas are of great importance to waterfowl during migrating and wintering seasons. In addition to supply essential plant food, submerged bottom areas are also the substrata for oysters, clams, blue crabs and a myriad of other organisms which are ultimately responsible for Chesapeake Bay's renowned seafood production. While Type 19 wetlands are the largest in terms of inventoried acreage, the focus of this report is on wetland Types $1-18$ because of the definition and direction provided by House Joint Resolution No. 2 (1967). Since these wetlands are quite vulnerable to destruction while being relatively scarcer, consideration of management problems for Types 1-1 8 is all the more urgent

\section{ORIGIN}

Wetlands are formed by natural processes in two ways-natural succession and coastal submergence (or inundation). Both processes are continuously at work.

\section{Natural Succession}

Natural succession is a process whereby wetlands gradually change to fast (dry) land. This process amounts to a filling of open surface waters through a combination of sedimentation and vegetation advancement on the sediment deposits. The description presented here is on the origin of coastal wetlands for illustrative purposes, although the process is essentially the same for interior wetlands too.

Coastal wetlands develop under three different physiographic conditions: 1) in estuaries, 2) in the shelter of spits, off-shore bars or islands, and 3 ) in protected bays.

Estuaries and protected bays are particularly suited for wetland establishment and development. Tributary waters carry large loads of sedinent essential to building shallow areas by deposition. When a river reaches the estuary the rate of flow is substantially slowed down by the decreased stream gradient and by tidal influence. Additionally, upstream moving flood tides tend to "back-up" river flows at the head of tide. Salinity causes suspended material to "salt out" and settle to the bottom. Under these conditions of reduced flow rates and in increased salinities mucli of a river's sediment load will be deposited on the bottom. Ultimately through time, with the accumulation of 
enough layers of sediment and conducive environmental conditions aquatic vegetation will be established on the bottom. As vegetation grows, dies and multiplies, the decaying plant material adds to the growing depths of sediment. Eventually, the filling in process proceeds to where different kinds of plants start to replace the original aquatic species since the wetlands become more and more infrequently wet.

\section{Coastal Submergence}

Coastal submergence refers to gradually rising ocean levels (a rate of six to twelve inches per century) inundating low coastal lands. There is abundant botanical, physiographical and historical evidence to support this contention.' Also, certain man-initiated practices have been reported to be locally significant in Maryland in encouraging tidal encroachments ( $\mathrm{Ch}$. XIll).

During the early stages of submergence or inundation in coastal areas, shoreline erosion may produce an offshore bar which builds above sea level and forms a barrier beach or island given favorable time, tidal and ocean currents. Such islands parallel the shore, separating it and an enclosed bay from the waters of the open ocean or estuary. Along the shores of enclosed bays and estuaries formed by drowned river valleys, such as Chesapeake Bay, certain plant species take root, grow and reproduce themselves in increasing numbers. Each successive generation of grass, sedges, and other aquatic plants inches further into adjacent shallow, open water, growing upon the accumulated root stocks and deposited sediments. Eventually, an intertidal plateau is built of mixed layers of organic material and accumulated sediments from the region of the former shoreline into open water areas. The advancing vegetation ultimately fixes the tidal water courses meandering through the wetlands. The plant progression halts, however, at the edge of these channels because the force and volume of tidal and stream flows maintains its marsh delineated water course. Behind the channels build-up processes continue until the upper reaches or landward side of some marshes are flooded only by high or storm tide waters. Thus different types of wetlands evolve in the same area as some "build-up" while others submerge or extend into open waters.

The edges of marshland, the banks of the tidal stream meanders and extremely shallow mud flats are alternately flooded and exposed on twice daily tidal cycles. Some of these marshes receive the discharge of fresh water streams in addition to the overall salinity changes which occur in adjacent estuarine waters. Hence each marsh may have a changing saline environment.
The areal extent of flooding that a wetland receives depends upon elevation above mean sea level and the distance and slope from water's edge to the bordering upland or fast land. Consequently, some marshes may be flooded only during high or storm tides.

In some coastal areas submergence occurs while at others seaward transport and deposition of inland sediments by rivers may start the formation of new land through natural succession. Also, wetlands in some coastal areas are being eroded away and literally pushed back by the relative local rise in sea level. Two opposing lorces such as deposition versus rising sea level might possibly neutralize or cancel each other's independent result with the net effect of creating an apparently stable or stationary coastline. When shoreline shaping forces such as submergence and erosion coincide, such reinforcing action results in the net loss of land in a rapid and dramatic fashion. The net effect to a particular segment of coastline, either upbuilding or erosion, depends on the combination of alternatives that are in operation.

Differences in wetland plant species, abundance, size, and distribution are determined by environmental factors such as air and water temperatures, water salinities and other dissolved chemicals, duration of inundation, regimen of fresh water flows, level of ground water table, tidal range and relative land and sea level elevations. Thus the vegetation patterns which develop on any specific wetland result from natural selection by environmental conditions.

I Nicholson, W. R., and R. D. Van Deusen. Marshes of Maryland. Dept. of Research and Education, Resource Study Rept. No. 6, Solomons, Md. December, 1954.

Nicholson, W. R., and R. D. Van Deusen. Wetlands of Maryland. Md. Game and Inland Fish Commission. Baltinore. 1956.

Shaw, Samuel P., and C. Gordon Fredine. Wetlands of the United States. U. S. Dept. Interior. Fish and Wildlife Service, Circular 39. U.S.G.P.O: Washington, D. C. 1956.

Uhler, Francis M., and Neil Hotchkiss. Vegetation and its succession in marshes and estuaries along the South Atlantic and Gulf Coasts. In, Proceedings, Marsh and Estuary Management Symposium. LSU, Baton Rouge, La. 1968.

Office of River Basin Studies. Inventory of permanent water of major significance to waterfowl in the State of Maryland. U. S. Dept. of Interior, Fish and Wildlife Service, Atlanta, Georgia. July, 1956. 
2 Mansueti, Romeo. "The Cranesville Pine Swamp." Atlantic Naturalist, v. 13, n. 2. Audubon Naturalist Society of the Central Atlantic States, Inc. Washington, D. C. April-June 1958.

3 Chapman, V. J. Salt marshes and salt deserts of the world. Interscience Publishers, Inc. New York. 1960. 




\section{DEFINITIONS}

Ecology may be defined as the study of relationships between organisms and their environment or habitat. The term ecosystem is used to describe a particular habitat type and the intricately interdependent relationship between the living and non-living components of the habitat. It is formed by combining two words, ecological-system. Recently, ecologists have preferred to separate the study of ecosystems into two distinct units: (1) the structure of the ecosystem, including quantity and distribution of plants and animals and physical characteristics such as temperature, light and salinity and (2) the function of the ecosystem, including the rate and amount of biomass production and the cycling of nutrients within the biotic community. Complete understanding of fundamental ecological principles coupled with adequate supporting information are essential to formulating sound natural resource management policies.

\section{GENERAL PRINCIPLES AND CONCEPTS OF WETLAND ECOSYSTEMS}

Wetland ecosystems vary in character, ranging from western Maryland bogs to Eastern Shore salt marshes. Each has its own characteristic plants and animals. When viewed as a general habitat type, wetlands present an astounding array of biotic communities which are limited to, and survive only when the peculiar nature of the wetland habitat is maintained.

The existence of any ecosystem depends upon energy transfers. This is part of a pattern in nature whereby soil, water, air, plants and animals exist together in a system of interdependencies called a food web which is actually a series of interacting food chains commencing with the lowest single-celled organism up to man. (Food chains are the pathways by which energy is transferred from one user to another in a cycle energized by plants (Figure V1).

Sunlight is the ultimate source of energy for all living things and, therefore, for all ecosystems. Plants possess the unique capability of utilizing solar energy along with carbon dioxide and water to produce food. Because of this unique capability, plants occupy a fundamental position in food chains and are referred to as primary producers.

All animal life is bound together by dependency on plants for nourishment. The nutrients produced by plants are stored in them and thus made available for eventual consumption by plant eaters (herbivores), or else upon death, released for re-use by decay and decomposition of the organic detritus.
Since wetland organisms form an integral part of the aquatic and terrestial ecosystem food chains, a generalized description of their important biological functions follows.

1. Algae and bacteria growing on the nutrient-rich wetland muds are capable of fixing atmospheric nitrogen into proteins and also producing sugars and vitamins. Marsh grasses and other plant species do produce several tons of organic material per acre per year. Also, oxygen, another absolute for animal life, is produced as a by-product of the plant food-making process.

2. Marsh algae and higher plants die and through the process of decay important nutrients and vitamins are released from the plants and washed into the water by tides and rainfall (up to $50 \%$ of organic material produced). Examples of important compounds contributed to aquatic ecosystems are vitamins such as biotin, cobalanin, niacin and thiamin; sugars; organic acids; amino acids; and polypeptides. The latter three are important in forming complexes with micro-nutrients such as manganese, zinc, copper, iron and phosphate and making them available for use by phytoplankton.

3. Much of the organic matter is washed from a marsh in a partially decayed form and settles to the bottom of rivers and estuaries, where it is available for use by bottom dwelling organisms. Highly diverse, rich bottom communities are found in estuarine muds. It is not uncommon to find densities of between 11 and 12 million invertebrate animals per square meter concentrated in the top one centimeter of mud where they are readily available for use by higher aquatic animals.

4. The bottom communities, as well as detritus from the marshes, provide food for transient as well as permanent dwelling freshwater and estuarine shellfish and finfish.

5. Man is at the top of the food chain and of course depends on shellfish and finfish for a portion of his food.

Submersed rooted aquatic plants also play an important role in an aquatic ecosystem. Besides supplying organic material to bottom animal communities they contribute to oxygen balance in the water. Plant roots and stems or stalks stabilize the bottom. This reduces turbidity; encourages sedimentation; and provides a place of attachment for smaller plants and animals and 


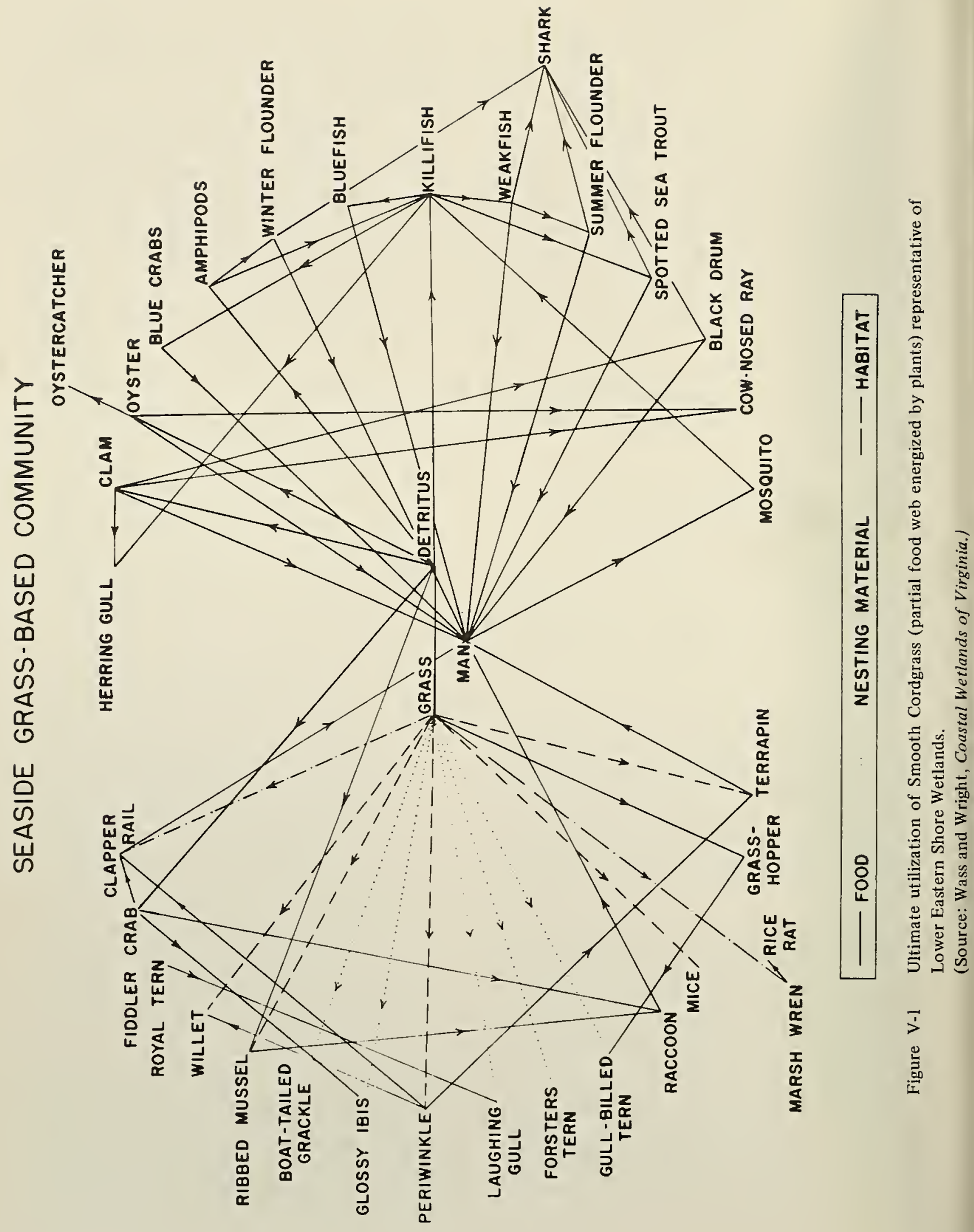


hiding places for young sport and commercial fishes. Aquatic plants are also an important source of food for many fishes, wildfowl and mammals.

Organisms which grow on rooted aquatic plants include algae, bacteria and protozoans. Aquatic plants are also coated with a diatomaceous ooze consisting of attached zooplankton and phytoplankton. All of these organisms serve as food for crustaceans, molluscs, worms and insect larvae on which carnivorous fishes in turn depend. Up to 7.5 percent of the biomass of a rooted aquatic community may be consumed directly, each day. The fruits and seeds of many rooted aquatics constitute the most important food for many types of waterfowl (coots, ducks, geese, and swans) and are eaten also by game birds (grouse, quail and pheasant).

\section{THE ROLE OF WETLANDS IN ESTUARINE PRODUCTIVITY}

The essential function of wetlands in the biological processes of either interior or coastal aquatic environments is basically the same. However, two important fundamental differences exist: 1) the presence or absence of sea water (salinity); and 2) the presence or absence of tidal or non-tidal currents. A distinctive feature of sea water is that all basic chemical substances necessary for life are present, although proportions vary somewhat from place to place. Fresh water, on the other hand, shows wide diversity in chemical constitution. No two lakes, ponds or rivers are precisely alike in their content of chemicals in solution.

Estuaries are among the most productive ecosystems known.' Table V-I provides a cursory comparison of gross primary productivity between estuaries and other ecosystems.*

The primary production contribution of wetlands to estuarine fertility occurs within three different community types. These three community types with distinct animal and plant species are marshland, mudflat (algae and submerged rooted vegetation) and aquatic (phytoplankton). Research on these three distinct production units shows that their order or importance as food makers for estuarine ecosystems is: (1) vast areas of marsh grasses, especially Spartina species; (2) benthic (bottom) "mud algae" and rooted aquatic vegetation which grow throughout intertidal sediments to a depth of

* Rather than present somewhat similar material by discussing the role of wetlands in both types of aquatic ecosystems, one aquatic environment, estuarine, was selected. In doing so, however, this action should not be interpreted as signifying relative differences of importance between interior and coastal wetlands ecosystems.
Table V-1. General orders of magnitude of gross primary productivity in terms of dry weight of organic matter produced annually.

Production

Land, deserts, deep oceans $\frac{\text { Ecosystems }}{\text { (lbs./acre/year) }}$

Grassland, forests, eutrophic lakes, ordinary agriculture

1,000 's

Estuaries, river deltas, coral reefs,

intensive agriculture (sugar cane, rice) 10,000's

Source: "The Role of Tidal Marshes in Estuarine Production," Eugene P. Odum, N. Y. State Conservation Dept. Info. leaflet (undated).

approximately six feet; and (3) phytoplankton (microscopic floating plants which live in water). ${ }^{4}$

Most of the primary production from wetlands, especially marsh grasses, is used in the form of organic detritus-finely sized, partly decomposed plant and animal material. As the grasses die and fall onto wetlands they are flushed by tides or other currents into an estuary. The abundant decomposer micro-organisms convert the plant material into particles rich in protein, carbohydrates and other nutrients essential to higher forms of life in the aquatic environment. The organically originating detritus is then distributed throughout the estuarine ecosystem as determined by the patterns of "nutrient traps."

A nutrient trap refers to a situation wherein vertical currents are created in an estuary by fresh water inflows meeting tidal waters. One result of this circulation pattern is the temporary retention and suspension of valuable nutrient materials carried into an estuary by fresh water inflows or produced in marshes and flushed bayward by tidal action. In addition to circulating nutrients and oxygen, cyclical water motion also serves to remove waste products from producers and distribute them to consumers of such products (decomposers).

"The beauty of an estuary is that the rhythmic water movement and mixing create a self-fertilizing and selfadjusting system." ${ }^{5}$ However, changes to the inflow of fresh water from tributary rivers can have serious consequence to cycles essential to estuarine ecology. ${ }^{6}$

The annual production of a marsh, or an estuary as a whole, may be double or triple that of ordinary agricultural land simply because it produces two or three times as long. Also, an estuary fertilizes itself, plants, harvests and stores several different crops derived from wetlands without human labor or investment which is needed to produce a crop on agricultural land.' 
Another important aspect of wetland ecology is the relatively large ratio of marshland and mudflat acreage to water surface area. The greater the interface between land and water-the entire shoreline of Chesapeake Bay is a prime example-the greater the potential or actual biological productivity.

\section{WETLANDS DEPENDENT PRODUCTION-SPECIES ECOLOGY}

The wide variety of habitat provided by wetlands is essential to complex life histories of dependant plant and animal species. For example, inherent variety provides protection for free-floating eggs, substratum for adhesive eggs, protection for delicate larval forms, refuge from strong currents, shade from intensive sunlight, and tolerable ranges of environmental conditions required by hundreds of plant and animal species. Their number and variety inhabiting Maryland's aquatic environment vary at any one time due to natural and man-caused phenomena.

It has been reported that at least 1991 flora and fauna species (combined) inhabit Maryland's tidewaters. ${ }^{\text {? }}$ Included within this total are many species on which virtually no information on taxonomy or life histories exist. While not everything is or need be known about each and every species, considerable information has been collected on some that are highly prized and immediately valuable to man. The following discussion touches very briefly on the role of wetlands in the ecology of some species of finfish, shellfish, waterfowl and other wildlife resources.

\section{Fisheries}

About 200 species of fish have been reported to visit or inhabit Chespeake Bay at some season of the year, and at least 60 of them are taken commercially. ${ }^{10}$ Although all interactions between Maryland's fisheries resources and wetlands are not known, considerable evidence indicates the dependency of a healthy fishery to wetlands.

Several Maryland counties were selected to compare various fish species with different types of wetlands. In addition, species usage and abundance were also indicated for a specific type of wetland in the county sampled. Table V-2 shows the counties selected and the number of fish species estimated to be in the various types of wetlands or in nearby waters. For example, 44 species were identified for Type 17 wetlands in Dorchester County, 47 species with Type 12 wetlands in Harford County, and 90 species with Type 18 wetlands in Worcester County.

Different fish species utilize wetlands for different purposes at various stages during their life cycles. Usage could be for spawning, or as nursery grounds where juvenile fish reside and feed while avoiding predators or unfavorable water conditions. Adults feed on the abundant and variable forage. Also usage may be seasonal depending upon the species, as is the abundance or numbers frequenting specific wetland areas. Table V-3 presents a sample survey of fishery resources in irregularly flooded saltmarshes (Type 17) of Dorchester County. Studies show that 20 species use this type for spawning, 31 species use them as nursery grounds, and 32 adult species utilize irregularly flooded saltmarshes for feeding. Seasonal usage varies from a summer high of 34 species to a winter low of 18 species. Irregularly flooded saltmarsh is a high valued habitat for fishery resources, based on 21 species including prized commercial and sportish such as bluefish, striped bass and white perch.

Brief case histories of selected fisheries will be cited

Table V-2. Sample evaluation of wetlands and dependent fishery resources, showing the number of fish species estimated or known to be present in the area or in nearby waters by wetland type sampled in certain, selected Maryland counties. Note, the blank spaces do not indicate either lack of this type of wetland or no fishery usage. Rather, numbers indicated are the only sample work conducted for this illustration.

\begin{tabular}{|l|c|c|c|c|c|c|c|c|}
\hline \multirow{2}{*}{\multicolumn{1}{|c|}{ County }} & \multicolumn{8}{|c|}{ Type of Wetland } \\
\cline { 2 - 9 } & 5 & 6 & 7 & 12 & 14 & 16 & 17 & 18 \\
\hline Anne Arundel & 35 & 25 & 51 & 38 & 29 & 42 & - & - \\
Baltimore & 40 & 20 & 29 & 39 & - & - & - & - \\
Charles & - & - & 23 & 38 & - & - & - & - \\
Dorchester & - & - & - & - & - & - & 44 & - \\
Harford & - & - & - & 47 & - & - & - & - \\
Worcester & - & - & - & - & - & - & - & 90 \\
\hline
\end{tabular}


Table V-3. Survey sample of fishery resource usage and abundance in irregularly flooded saltmarshes (Type 17) or nearby waters of Dorchester County, Maryland.

\begin{tabular}{|c|c|c|c|c|c|c|c|c|c|c|c|}
\hline \multirow[b]{2}{*}{$\begin{array}{l}\text { Fish species present } \\
\text { Scientific name }\end{array}$} & \multirow[b]{2}{*}{ Common name } & \multicolumn{3}{|c|}{ Useage } & \multicolumn{4}{|c|}{ Season of Useage } & \multicolumn{3}{|c|}{ Abundance } \\
\hline & & 胥 & 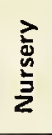 & 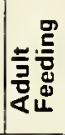 & 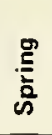 & 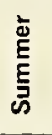 & $\frac{\overline{\bar{\pi}}}{\stackrel{\bar{L}}{ }}$ & 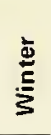 & 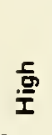 & 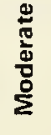 & J \\
\hline *Petromyzon marinus & sea lamprey & $x$ & & & & & & & & & \\
\hline Carcharhinus leucas & bull shark & & & $x$ & & $x$ & & & & & \\
\hline Carcharhinus milberti & sandbar shark & & & $x$ & & $x$ & & & & & \\
\hline Sphyrna zygaena & hammerhead shark & & & $x$ & & $x$ & & & & & \\
\hline Raja eglanteria & clearnose skate & & & $x$ & & $x$ & & & & & \\
\hline Rhinoptera bonasus & cownose rav & & & $x$ & & $x$ & & & & & \\
\hline "Acipenser oxyrhynchus & Atlantic sturgeon & $x$ & & & $x$ & & & & $x$ & & \\
\hline${ }^{*}$ Alo sa aestivalis & bluaback herring & $x$ & & & $x$ & & & & $x$ & & \\
\hline *Alosa mediocris & hickory shad & $x$ & & & $x$ & & & & $x$ & & \\
\hline${ }^{*}$ Alo sa pseudoharengus & alewife & $x$ & & & $x$ & & & & $x$ & & \\
\hline *Alosa sapidissima & American (white) shad & $x$ & & & $x$ & & & & $x$ & & \\
\hline Brevoortia tyrannus & Atlantic menhaden & & $x$ & $x$ & $x$ & $x$ & $x$ & & $x$ & & \\
\hline Dorosoma cepedianum & gizzard shad & & $x$ & $x$ & & $x$ & $x$ & & & & $x$ \\
\hline Anchoa mitchilli & bay anchovy & $x$ & $x$ & $x$ & $x$ & $\mathrm{x}$ & $x$ & $x$ & $x$ & & \\
\hline Cyprinus carpio & Carp & & & $x$ & & & $x$ & $x$ & & & $x$ \\
\hline Notropis hudsonius & spottail shiner & & & $x$ & & & $x$ & $x$ & & & $x$ \\
\hline Ictalurus catus & white catfish & & $x$ & & $x$ & & & & & & $x$ \\
\hline Anguilla rostrata & American eel & & $x$ & $x$ & $x$ & $\mathrm{x}$ & $x$ & $x$ & $x$ & & \\
\hline Strongvlura marina & Atlantic needlefish & $x$ & $x$ & $x$ & $x$ & $x$ & $x$ & $\mathrm{x}$ & $x$ & & \\
\hline Hyporhamphus unifasciatus & halfbeak & & $x$ & $x$ & & $x$ & $x$ & & $x$ & & \\
\hline Cyprinodon variegatus & sheepshead minnow & $x$ & $x$ & $x$ & $x$ & $x$ & $x$ & $x$ & $x$ & & \\
\hline Fundulus heteroclitus & mummichog & $x$ & $x$ & $x$ & $\mathrm{x}$ & $x$ & $x$ & $x$ & $x$ & & \\
\hline Fundulus majalis & striped killifish & $x$ & $x$ & $x$ & $x$ & $\mathrm{x}$ & $\mathrm{x}$ & $x$ & $x$ & & \\
\hline Lucania parva & rainwater killifish & $x$ & $x$ & $x$ & $x$ & $x$ & $x$ & $x$ & $x$ & & \\
\hline Syngnathus fuscus & northern pipefish & $x$ & $x$ & $x$ & $x$ & $\mathrm{x}$ & $\mathrm{x}$ & $\mathrm{x}$ & $\mathrm{x}$ & & \\
\hline${ }^{*}$ Roccus americanus & white perch & $x$ & $x$ & $x$ & $x$ & $x$ & $x$ & $x$ & $x$ & & \\
\hline${ }^{*}$ Roccus saxatilis & striped bass & $x$ & $x$ & $\mathrm{x}$ & $x$ & $x$ & $x$ & $x$ & $x$ & & \\
\hline Bairdiella chrysura & mademoiselle & & $x$ & $x$ & & $x$ & $x$ & & & $x$ & \\
\hline Cynoscion regalis & grevtrout (weakfish) & & $x$ & $x$ & & $x$ & $x$ & & & & $x$ \\
\hline Cynoscion nebulosus & spotted seatrout & & $x$ & $x$ & & $x$ & $x$ & & & & $x$ \\
\hline Pomatomus saltatrix & bluefish & & $x$ & $x$ & & $x$ & $x$ & & $x$ & & \\
\hline Leiostomus xanthurus & spot & & $x$ & $x$ & & $x$ & $x$ & & $x$ & & \\
\hline Micropogon undulatus & Atlantic croaker & & $x$ & $x$ & & $x$ & $x$ & & & & $x$ \\
\hline Pogonias cromis & black drum & & $x$ & $\mathrm{x}$ & & $x$ & $x$ & & & $x$ & \\
\hline Sciaenops ocellata & channel bass (red drum) & & $x$ & $x$ & & $x$ & $\mathrm{x}$ & & & & $x$ \\
\hline Chasmodes bosquianus & striped błenny & $x$ & $x$ & $x$ & $x$ & $x$ & $x$ & $x$ & & & $x$ \\
\hline Peprilus alepidotus & butterfish (Southern harvestfish) & & $x$ & & $x$ & $x$ & $x$ & & & & $x$ \\
\hline Menidia menidia & Atiantic silverside & $x$ & $x$ & $x$ & $x$ & $x$ & $x$ & $x$ & $x$ & & \\
\hline Paralichthys dentatus & summer flounder & & $x$ & & & $x$ & & & & & $x$ \\
\hline Pseudopleuronectes americanus & winter flounder & & $x$ & & $x$ & & & $x$ & & $x$ & \\
\hline Trinectes maculatus & hog choker & $x$ & $x$ & $x$ & $x$ & $x$ & $x$ & $x$ & $x$ & & \\
\hline Gobiesox strumosus & clingfish (skilletfish) & $x$ & $x$ & $\mathrm{x}$ & $x$ & $\mathrm{x}$ & $x$ & $x$ & & & $\mathrm{x}$ \\
\hline Opsanus tau & oyster toadfish & $x$ & $x$ & $x$ & $x$ & $x$ & $x$ & $x$ & & $x$ & \\
\hline \multirow[t]{2}{*}{ Spharoides maculatus } & northern puffer & & $x$ & & & $x$ & & & & & \\
\hline & Total & 20 & 31 & 32 & 24 & 34 & 30 & 18 & 21 & 4 & 12 \\
\hline
\end{tabular}

* Adults present during spawning migration, but not used as a spawning ground per se. 
next to illustrate the significance of wetlands to their survival and productivity.

Striped bass. Striped bass spawn in at least eleven different tidal water areas of the State at points where fresh and saltwater meet. These areas have large volumes of moving water with low salt content. The eggs are carried and agitated by tidal currents, which benefit their survival. After the newly hatched fry finish absorbing the attached egg yolk sac, they are on their own as nearly helpless members of the Bay's plankton (floating) community.

The striped bass fry by their own feeble movement, and with the assistance of tides and currents find their way to shoal areas and wetlands which provide food and shelter. The wetlands synthesize the nutrients which produce algae and other plant materials required by the microscopic animals fed upon by striped bass fry. Although many factors operating in the marine environment are critical, finding of the right food, of the right size, and in sufficient quantity limits survival in the early days and weeks for striped bass fry. Limited food or starvation-for even a short period of time-can be lethal in itself, or weakening, allowing the subjected animal to fall prey to disease, to another of its kind, or to another species.

The growing young striped bass move into estuarine nursery areas to prey and feed on a multitude of invertebrates and smaller fishes. At fingerling size (3 to 6 inches) they begin feeding on small schooling forage fish and the more abundant crustaceans. Adults eat many kinds of living fish, crabs and other numerous invertebrates. In Chesapeake Bay adult striped bass feed extensively on menhaden, anchovies (shiners), spot, white perch, small blue crabs, and less so on mollusks. During winter they feed actively on young croakers, different kinds of young herring, shrimp, and other organisms found close to the bottom.

Menhaden. Menhaden begin life with oceanic spawning. The spawning occurs off the Capes of Virginia during December, January, and February. Here the eggs float near the surface and hatch in about 2 days. The larval fish find their way to the bottom where northward moving, highly saline ocean currents transport the tiny fish into the Bay and disburse them shoreward. By early spring, they are being nurtured in the sluices and muskrat runs of tidal marshes.

Menhaden convert planktonic plant and animal organisms produced and found in wetlands into oil rich protein that is a principal food of juvenile striped bass. In terms of poundage, menhaden provide the largest commercial catch on the Atlantic Coast.

Shellfish. Commercial and non-commercial shellfish species are highly dependent upon the one-celled algal forms that derive their principal nutrients from material produced in marine (coastal) wetlands. This is particularly true for the shellfish that are filter feeders. During their adult life, they remain stationary, or nearly so, and capture food organisms by creating currents so that they can engulf particulate matter that passes in their near vicinity.

Coastal wetlands bordering large expanses of shoreline are highly important to the establishment and maintenance of many natural and seeded oyster bars, particularly those that are in tributaries and small bays. Natural grounds are critical for perpetuation of the oyster, soft clam and hard clam fisheries. Wide natural dispersal and protection facilitated by numerous adjacent wetlands ensure that some oyster grounds are protected from damaging natural acts and promote reproduction and harvesting. Maintenance of these shellfish populations provides the brood stocks whose free floating microscopic larvae repopulate harvested or naturally devastated areas.

Nearness of oyster and other shellfish grounds to wetlands may provide protection from the summer encroachment of oxygen poor bottom layers of water that limit the life of sedentary animals in deeper waters. Wetlands also provide some measure of protection to shellfish and other bottom life against burial from sedimentation, if shoreline areas were otherwise devoid of vegetative cover.

Many shellfish such as mussels, barnacles and limpets are not of direct economic importance, but they convert planktonic algae into proteinaceous material which, when consumed by fish and birds, may eventually be consumed by man.

Stationary shellfish have a highly important role in the food chain of a great many animals and perhaps have a critical position in the food web of certain communities, because individually they can amass relatively large volumes of proteins directly from unicellular algae. Some shellfish have adaptive mechanisms to protect them from environmental hazards for protracted periods, in some instances for more than two weeks. Consequently, they become sources of food for higher animals at times when other food is not readily available.

Blue crabs begin life near the Virginia Capes of Chesapeake Bay. Most spawning occurs in the saltier waters near the mouth of the Bay. Female crabs migrate to this area to deposit their eggs. The eggs hatch in 12 to 15 days and the larval crabs are set free into the water. The early stages are exceedingly small, require salty water, and depend on water currents for movement. With the aid of northward moving, highly saline bottom ocean 
waters, small crabs migrate up the Bay and are disbursed into tributary and inland waters. They feed on various materials, grow, and periodically shed their shells from late spring to early fall. The environment of grassy flats, sand bars, oyster bars, and mud flats found within the Bay and its tributaries supports high crab populations.

\section{Birds}

Waterfowl. Wetlands provide ideal habitat for waterfowl reproduction and brood raising purposes. Black duck, blue-winged teal, mallard, wood duck, godwit and hooded merganser are the principal breeding species in Maryland. Black duck nesting sites are good indicators of wetlands' important role in waterfowl reproduction because this species is widely distributed throughout the Chesapeake Bay region, is a year-around State resident, and utilizes a greater variety of habitats within this region than any other waterfowl."

Reported locations in Maryland of largest black duck breeding populations are along the margins of shallow brackish open estuaries and estuarine bay marshes. Fairly large breeding populations were also reported for salt estuarine bay marshes, and scattered pairs in coastal salt marshes, fresh estuarine bay marsh, and various areas of estuarine river marsh. ${ }^{13}$

Black ducks construct their nests in a variety of locational situations. For instance, nests were found in cordgrass bordering tidal creeks, salt meadows, coastal embayed marshes, salt estuarine bay marshes and along the margins of estuaries. ${ }^{13}$

The food habits of ducks, geese and swans vary greatly between species and from one habitat to another. The majority of waterfowl species are grazers. Aquatic vegetation comprises a large portion of the diet-up to nearly half of the food consumed by waterfowl as a whole. ${ }^{4}$ Aquatic vegetation is important to all waterfowl diets with the possible exception of sea ducks, (scoter, eider and old squaw) and mergansers. Ducks, geese and swans commonly feed on the seeds, tubers, rootstocks and foliage of water plants. Widgeongrass probabiy is the most important single waterfowl food and claspingleaf pondweed probably is second most important for the majority of waterfowl in Maryland. ${ }^{15}$

Other food plants important locally are wild celery, eelgrass, Olney threesquare, and dotted smartweed. The more important animal foods are the bivalve clam (Balthica macoma), the little surf clam, the salt marsh snail, various tiny gastropod mollusks, amphipod crustaceans, mud crabs, midge larvae, and insetcs. ${ }^{16}$ All of these animals are common in wetlands.

Further important evidence on the critical role of wetlands in waterfowl ecology is provided by the refuge system established by the Federal government. This action was based on the knowledge that if annual crops of waterfowl and other migratory birds were to be maintained, then areas ideal for breeding, resting, feeding and refuge must be preserved."

Birds Other Than Waterfowl. This arbitrary grouping comprises all of the bird species other than waterfowl. Within this category there are two basic groups of birds that utilize wetlands."

1) More characteristic species are birds that breed in wetlands.

2) Less characteristic species are birds that visit wetlands for feeding and resting purposes only.

Certain rails such as the clapper (Rallus longirostris), king ( $R$. elegans), Virginia ( $R$. limicola), sora (Porzana carolina), yellow (Coturnicops noveboracensis), and the black (Cresiscus jamaicensis) are more chracteristic birds. The food habits of rails depend on the season and the availability of food. Certain plants and a variety of insects, snails, and small crustaceans form the bulk of their diet. While rails abound in salt marshes, a casual observer might spend considerable time in these areas and never see a rail since they are retiring and elusive birds.

Sparrows such as the sharp-tailed (Ammospiza candacuta), seaside (A. maritima), and close relatives, the Savannah and grasshapper sparrows are also more characteristic wetland bird species. These sparrows feed on insects, spiders, snails, and sand fleas which make up about four-fifths of their diet; the seeds of grasses and other plants constitute the other fifth.

Other bird species that breed in the wetlands include the marsh hawk, short-eared owl, red-winged blackbird, meadowlark, boat-tailed grackle, marsh wrens and certain shore birds such as snipes, sandpipers, willets and plovers.

Most of the common birds of the eastern United States may be seen from time to time in or about wetlands. The group treated here is the "less characteristic species" although they are perhaps most conspicuous. Many of the wading birds such as the great blue heron. little blue heron, Louisiana heron, green heron, black-crowned night heron, common egret and snowy egret frequent wetlands. These birds feed on numerous types of larger aquatic life commonly inhabiting wetlands, such as frogs, snakes and fish.

Gulls and terns breed in wetlands and along beaches, and also feed heavily in wetland areas. Species include herring gull, the ring-billed gull, Bonaparte's gull, the laughing gull, least tern, common tern, Forster's tern, Caspian tern, royal tern, black tern and black skimmer. While many of the birds mentioned here may not be 
recognized or familiar to most people, they deserve protection because of their beneficial feeding habits. Depending upon local habitat conditions, shorebird species are highly insectivorous, feeding on grasshoppers, caterpillar pests such as the armyworm and cutworm, and beetles. They also feed on adults and larvae of horseflies and mosquitoes; marine worms which attack oysters; ticks which carry livestock diseases and numerous other insect pests.

Other birds that frequent wetlands include vultures, crows, belted kingfishers, and numerous species of songbirds, especially during migration. Most significantly, endangered species such as the bald eagle and osprey (fish hawk) utilize and are tied closely to numerous wetlands throughout the State for nesting and feeding purposes.

\section{Other Wildlife}

Permanent residence in a wetland habitat requires specific adaptation. Many of the conspicuous wildlife species are only visitors to wetlands. They are attracted there by the abundant supply of food produced in wetlands, protected or sheltered areas in which to hunt and feed, and an indisturbed environment remote from man.

Big game. White tail deer are frequent visitors and inhabitants of wetlands, especially shrub and wooded swamps. Populations vary depending upon habitat conditions in surrounding areas.

Upland game. The cottontail rabbit, bobwhite quail and the Eastern gray squirrel frequent most wetlands. Populations are generally estimated as moderate. In addition, several Eastern Shore wetland areas are inhabited by the endangered Bryant fox squirrel.

Fur animals. Common fur bears such as the raceoon, striped skunk, red and gray fox, and opossum are abundant throughout the State and are frequent wetland visitors. The river otter, nutria, muskrat and mink provide trapping in wetland areas. The beaver is making a comeback in Maryland. This valuable fur bearer is found in ever-increasing numbers in 17 counties, and is a valuable asset to many other wildlife species associated with wetland areas.

Reptiles and amphibians. Little information was obtained on reptiles and amphibians except that water snakes, black snakes, diamond-backed terrapin (rare and protected), and snapping, mud and painted turtles are common to wetlands. Amphibians such as bullfrogs, leopard frogs and salamanders are commonly found because their life cycles are tied to wetlands.

\section{DISCUSSION}

The role of wetlands as habitat and contributors to aquatic productivity is many faceted. Wetlands provide food and shelter not only for organisms naturally inhabiting the wetlands, but also for many organisms which spend all or part of their lives in Maryland's uplands, lakes, rivers, estuaries or shallow ocean. With specific reference to estuaries, "salt marshes are vitally necessary to the maintenance of population of virtually all our major shallow salt water fish and shellfish. Inasmuch as a very high percentage $(60-90 \%)$ of our important commercial and sports fish and shellfish can be found in these adjacent waters at some time during their lives, it is clear why salt marshes are so important to the total productivity of associated estuarine water."

Wetlands are also important to terrestial animals. Maryland enjoys an abundance of waterfowl, upland and big game, fur animals, shorebirds, songbirds and wading birds due to extensive wetlands habitat. For example, the Chesapeake Bay region is one of the more important areas in North America for migrating and wintering waterfowl. Wintering waterfowl populations in recent years have averaged more than one million birds. This figure represents about four percent of the continental wintering population and about 23 percent of the entire Atlantic Coast waterfowl population. ${ }^{20}$ Thus the wetland habitat conditions in Maryland affect the welfare of waterfowl in the Atlantic Flyway, and for some species such as the canvasback duck, the welfare of an entire species."

To a wild creature, habitat means a specific kind of area in which to live, to find food, or to reproduce. It is a place with the right temperature, the right amount and kind of water, and the right kind of plants and other animals. Wildlife are self-sustaining as long as they have a proper place to live and are not so disturbed or so reduced in numbers that they cannot maintain sufficient reproduction. The key is "a proper place to live."

Change in habitat is inevitable and a tenet of biology. Man cannot stop all natural changes completely, but can alter its direction, hasten or slow the pace. Most habitat alteration is, for all intents and purposes, irreversible for coastal wetlands and the loss of habitat is a final one for most dependent animals. Any suitable similar area will almost always be already filled to capacity with populations of those species whose habitat was destroyed. In fact, many types of organisms cannot move into another nearby, exactly similar environment. The ecological principle of carrying capacity states that for a given unit of habitat, all available niches will be filled at all times, and that the density of any given 
species is at the maximum supportable by the habitat under normal conditions. This is further reinforced by animal behavior and intra-species competition. An animal resident on a given habitat site has an almost unbeatable superiority over a competitor of the same species newly entering the area. An interloper or transient is harassed at every meeting with the effect of decreasing its health, its ability to compete and reproduce, and ultimately its survival. An animal in poor condition is, according to one Darwinian theory (survival of the fittest [natural selection]), not likely to survive. Thus there is no substitute habitat available for creatures displaced by destroyed habitat. "The destruction of habitat almost inevitably means the proportional destruction of the animals in it." 22

For maintenance of existing wildlife populations dependent on or related to wetlands, adequate wetland habitat in terms of both quality and quantity must be available. If the state of Maryland is to assert and sustain a positive role in wetlands management, the objectives of management policy must be to protect as much of the State's remaining wetlands as possible. However, the future scale of needed natural area protection will probably exceed governmental capabilities for acquisition. The state, therefore, must restrict its sales of publicly owned land, especially wetlands.

Besides being counter to positive resource management policy, the sale of publicly owned wetlands has several other undesirable consequences, namely:

1) encourages additional plans for non-ecologically conscious development on public property;

2) discourages local and municipal governments from undertaking or initiating protective activities such as conservation zoning ordinances, acquisition of wetlands for open space, conservation and recreation purposes; and

3) undermines public confidence in the ability of State government to handle its responsibility of protecting and managing natural resources placed in its trust for the common good of all citizens.

1 Wass, Marvin L., and Thomas D. Wright. Coastal wetlands of Virginia (Interim Report). Va. Inst. Marine Sci. Gloucester, Va. December 1969.

2 Coker, Robert E. Streams, lakes, ponds. Univ. of North Carolina Press. Chapel Hill. 1954.

3 Odum, Eugene P. Fundamentals of ecology. 2d. ed., W. R. Saunders Co., Philadelphia, Pa. 1959.

4 Odum, Eugene P. The role of tidal marshes in estuarine production. Information leaflet, N. Y. State Conservation Dept., Div. Cons. Ed., from N. Y. State Conservationist, (reprint).
5 Odum, Eugene P. The urgent need for landscape zoning of the estuarine region according to ecosystem principles. Address presented at Symposium of Estuarine Ecology of Coastal Waters of North Carolina. Raleigh, N. C., May 12, 1966.

6 Copeland, B. J. Effects of decreased river flow on estuarine ecology. J. Water Pollution Control Fed. November, 1966.

7 Odum, Eugene P. The role of tidal marshes in estuarine production. supra at 4.

8 Schuster, Carl N. The nature of a tidal marsh. Information leaflet, N. Y. State Conservation Dept., Div. Conservation Ed., from The N. Y. State Conservationist, Aug.-Sept., 1966.

9 Information provided by staff of the Department of Chesapeake Bay Affairs.

10 Jackson, Charles E. Chesapeake fisheries, history and outlook. In Symposium, Maryland Conservation Forum, April 12, 1944. Md. Dept. Research and Education, Educational series, no. 4, Solomons, Md. June, 1944.

11 Stewart, Robert E. Waterfowl populations in the upper Chesapeake region. U.S.D.I., BSF\&W Spec. Sci. Rept.-Wildlife No. 65. U.S.G.P.O: Washington. July, 1962.

12 Ibid.

13 Op. cit.

14 Martin, A. C., and F. M. Uhler. Food of game ducks in the United States and Canada. U.S.D.A. Tech. Bull. No. 634. 1939.

15 Stewart, Robert E., supra.

16 Ibid.

17 Special Committee on Conservation of Wildlife Resources. Wildlife and the land: a story of regeneration. Committee print. U.S. Senate, 75 th Congr., 1st Sess. U.S.G.P.O: Washington. 1937.

18 McAlee, W. L. Wildlife of the Atlantic Coast salt marshes. U.S.D.1., Fish and Wildlife Service, Wildlife Circ. 11, U.S.G.P.O: Washington. 1941.

19 Cooper, Arthur W. Salt marsh vegetation of the South Atlantic Coast. Paper presented in symposium on Current Research on Vegetation of the Southeastern States at AAAS meetings, Washington, D. C., December 29, 1966.

20 Stewart, Robert E., supra.

21 Stotts, Vernon D. Personal communication (Md. Fish \& Wildlife Administration.) May 14, 1970.

22 Conway, William G. "The consumption of wildlife by man." Parks \& Recreation, Vol. IV, no. 2, February, 1969. 



\section{VI}

\section{WETLANDS HABITAT INVENTORY}





\section{PREVIOUS WETLAND STUDIES IN MARYLAND}

Initiation of activities in response to House Resolution No. 2 (1967) commenced with an examination of previous wetland studies conducted in the United States. The reports of studies conducted in Maryland prior to 1967 include: Wetlands of the United States, Maryland Marshes. Wetlands of Maryland, Permanent Water Inventory-Maryland, Waterfowl Populations in the Upper Chesapeake Region, and Classification and Inventory of Habitats in Maryland.

These studies were essentially inventorial in nature and their contents were limited mostly to habitat data. None of them examined other issues or facets of management problems and none were prepared in response to a legislative request. However, each study recommended that wetlands should be preserved.

Review of these documents in light of the objectives outlined by the 1967 legislative directive suggested that another inventory should be undertaken, but of much greater extent. Also, the inventory should be accompanied by detailed studies of other collected data and information. Accordingly, the Director and staff of the Department of Game and Inland Fish* in cooperation with the U.S. Bureau of Sport Fisheries and Wildlife proposed and outlined a group of wetland study projects on behalf of the Maryland Board of Natural Resources.** The inventory and study began in July, 1967. The following discussion describes habitat inventory methods and provides a background for interpreting and understanding data and discussion presented in this chapter and throughout the entire report.

\section{HABITAT INVENTORY METHODOLOGY}

1) Two sets of U.S. Geological Survey topographic quadrangle maps $($ Scale $=1: 24,000)$ were assembled which covered the entire State.

2) All areas classified as wetlands (in Chapter IV) were identified and outlined on these maps and assigned a specific identification number unique to the particular county in which the wetland is located. For practical purposes an acreage limitation of at least five contiguous acres per wetland was imposed for inventorial con-

*Not known as the Maryland Fish and Wildlife Administration.

**Abolished with the creation of the Department of Natural Resources by Chapter 154, Laws of Maryland 1969 (Article 66C, 1957 Annotated Code of Maryland - 1970 Repl. Vol.) sideration. Individual data sheets were prepared for each wetland area identified. These sheets cover a wide variety of data and information (Figures VI-I and VI-2). Thus far, 1,557 wetland areas of five acres or larger in size have been identified.

It is stressed that there is nothing magical about the five acre limitation chosen for inventorial purposes. Areal extent is not a paramount criterion in evaluating or indicating the importance of a wetland. Therefore, wetlands smaller than five acres should not be downgraded or their values disregarded.

3) Two sets of U.S. Coast and Geodetic Survey marine charts were obtained and the acreage of marine depths at 0-6 ft., 6-12 ft., 12-36 ft., and over $36 \mathrm{ft}$. was computed within each tidewater county. Mud flat acreages were also computed.

4) Acreage measurements were made manually with either a grid (dot system) or a planimeter. Conversion factors of 1.43 acres per grid dot or 91.8 acres per planimetered square inch were utilized for the USGS maps.

5) Wetland acreage losses were obtained by a Statewide aerial reconnaissance which also authenticated cartographically identified wetlands and augmented the inventory with a visual assessment of the wetlands' present physical situation.

6) Habitat inventory information was obtained on each wetland by field surveys and by interviews with natural resource management and enforcement personnel. The information was recorded on wetlands habitat inventory data sheets originated for each specific unit identified during the course of the study (Figures VI$\mathrm{I}$ and $\mathrm{VI}-2$ ).

Additionally, a data processing system was designed and developed to conveniently store and rapidly retrieve this information. (See Appendix B-Wetlands Information and Retrieval System.)

Inventory information was also provided by the University of Maryland's Institute of Natural Resources during 1968. Every wetland was again visited. Each wetland's ecological values were described, including present condition due to natural or unnatural changes, and other factors listed on the habitat inventory sheets.

7) A determination was made of each wetland's vulnerability to changes initiated by natural or manmade activities. Wetland vulnerability was subdivided Into three categories representing potential, probable, or imminent change to the present and future natural environmental conditions of that particular wetland. As such, these values represent both the objective and subjective value judgements of observers based on present and future activities affecting each wetland. 


\section{WETLANDS VULNERABILITY CATEGORIES}

Category I-(highly vulnerable)-classifies wetlands experiencing destructive changes or assessed as having that possibility within the next five years.

Category II-(moderately vulnerable)- classifies wetlands where destructive changes can be anticipated within the next ten years.

Category III-(safe) - classifies wetlands that are highly inaccessible or isolated from societal activities, are in the ownership of wealthy landowners (assumes property ownership stability), are owned and managed for conservation purposes, or are owned by the State or Federal Government.

8) Each wetland identified on a USGS quadrangle map was also plotted on an appropriate Maryland State Roads Commission county highway map (Scale: 1 inch $=1$ mile). These county wetlands maps are utilized for resource planning activities and field work.

9) The field inventory data and sets of topographic maps, marine charts and county wetlands work maps are maintained by the Departments of Natural Resources and State Planning. These maps are available for reference by interested persons and use by the State and local agencies for resource planning and management activities.

10) By combining selected information generated by Steps (2), (6), and (7) with the county wetlands maps produced in Step (8), it was possible to establish an effective base for communication within the Wetlands Technical Advisory Committee. This achievement permitted a comprehensive collection and exchange of information linked to specific wetlands and facilitated the coordination of study activities.

It should be noted that the habitat inventory and methodology described here do not represent a survey of wetlands of the detail, accuracy, extent or intent of that required by recently enacted legislation. Section 718 in Article $66 \mathrm{C}$ of the Annotated Code of Maryland (Ch. 241, Laws of Md. 1970) requires a survey in order to background the establishment of wetlands management rules and regulations. (See Appendix E.) This legal requirement is now being implemented and fulfilled by the Wetlands Division in the Water Resources Administration, an agency of the Maryland Department of Natural Resources.

\section{BASIC HABITAT STATISTICS}

For purposes of stastical convenience only, the counties of the State were grouped into survey regions based strictly on the coincidence of geographical location and political boundaires. The survey regions devised to assist assembly and discussion on habitat statistical data include Central and Western, Western Shore, Upper Chesapeake Bay, Eastern Shore, and Lower Eastern Shore regions (Figure VI-3).

These survey regions as well as county boundaries reflect few, if any, values meaningful to ecosystems that would in turn be useful to most phases of resource management planning based upon sound ecological principles. In terms of a Statewide perspective, the entire wetlands habitat is important and should be considered and treated as one unit. However, from a local perspective what's happening within local political boundaries is naturally of foremost interest. Therefore, statistical data, analysis and discussion on basic habitat (acreage) statistics are presented in two ways.

First, data is presented on a survey region basis to provide a convenient form for Statewide presentation and discussion. Second, data is presented on a countyby-county basis for local interest and land-use planning decisions.

\section{Statewide}

Table VI-1 records the wetland habitat inventory by type and survey region. A total of 332,000 acres were inventoried. About 308,000 acres of wetlands (Types 1-19) still remain as of mid-1968. In addition, 1.6 million acres were computed for variable depth open surface water areas (and bottom) of Chesapeake Bay, its tributaries and the coastal embayments (Table Vl-2). Since survey emphasis was on wetlanids as defined by House Joint Resolution No. 2 (Appendix C), open surface water areas do not receive any attention beyond basic inventorial work although they comprise a major portion of the State's aquatic habitat.

From a regional perspective, $A$ Plan for the Marine Resources of the Atlantic Coast ${ }^{2}$ evaluates Maryland's combined coastal wetlands and estuarine habitat as follows:

a) seventh in percentage of "important" coastal wetlands $(8.4 \%)$;

b) third in percentage of "important" open shoal water habitat (12.3\%);

c) sixth overall ranking out of the 14 Atlantic Coast states.

Wetlands in Maryland (Types 1-19) consist largely of coastal salt meadow (25\%), coastal shallow fresh marsh $(22 \%)$, wooded swamp (22\%), and irregularly flooded salt marsh $(21 \%)$. These wetlands also experienced the largest share of acreage losses, a combined 19,956 acres or 84 percent of the total acreage loss. Other notable acreage losses in terms of percentage of total acreage inventoried by wetland type include: 
HABITAT INVENTORY DATA SHEET FOR

Figure VI-1

SPECIFIC MARYLAND WETLAND

AREAS-Side 1

WETLAND HABITAT INVENTORY DATA SHEET FOR SPECIFIC UNIT FOR MARYLAND

\begin{tabular}{|l|l|}
\hline 1. STATE & 3. COUNTY WETLAND UNIT NO. \\
\hline 4. ELEC. DIST.(S) & 5. OUUARANGLE (S) \\
\hline 6. PHYSIOGRAPHIC REGION & 7. NAME OF WETLAND \\
\hline
\end{tabular}

8. DESCRIP.

TION

ACREAGE

\begin{tabular}{|c|c|}
\hline TYPES & ACRES \\
\hline & \\
\hline & \\
\hline & \\
\hline & \\
\hline & \\
\hline
\end{tabular}

10. REL ATIONSHIP TO OTHER WETLANO UNITS

I1. LANO USE ON WETLANO

12. ON SURROUNDING AREA

13. OWNERSHIP

DOMINANT VEGETATIVE SPECIES

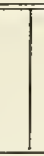

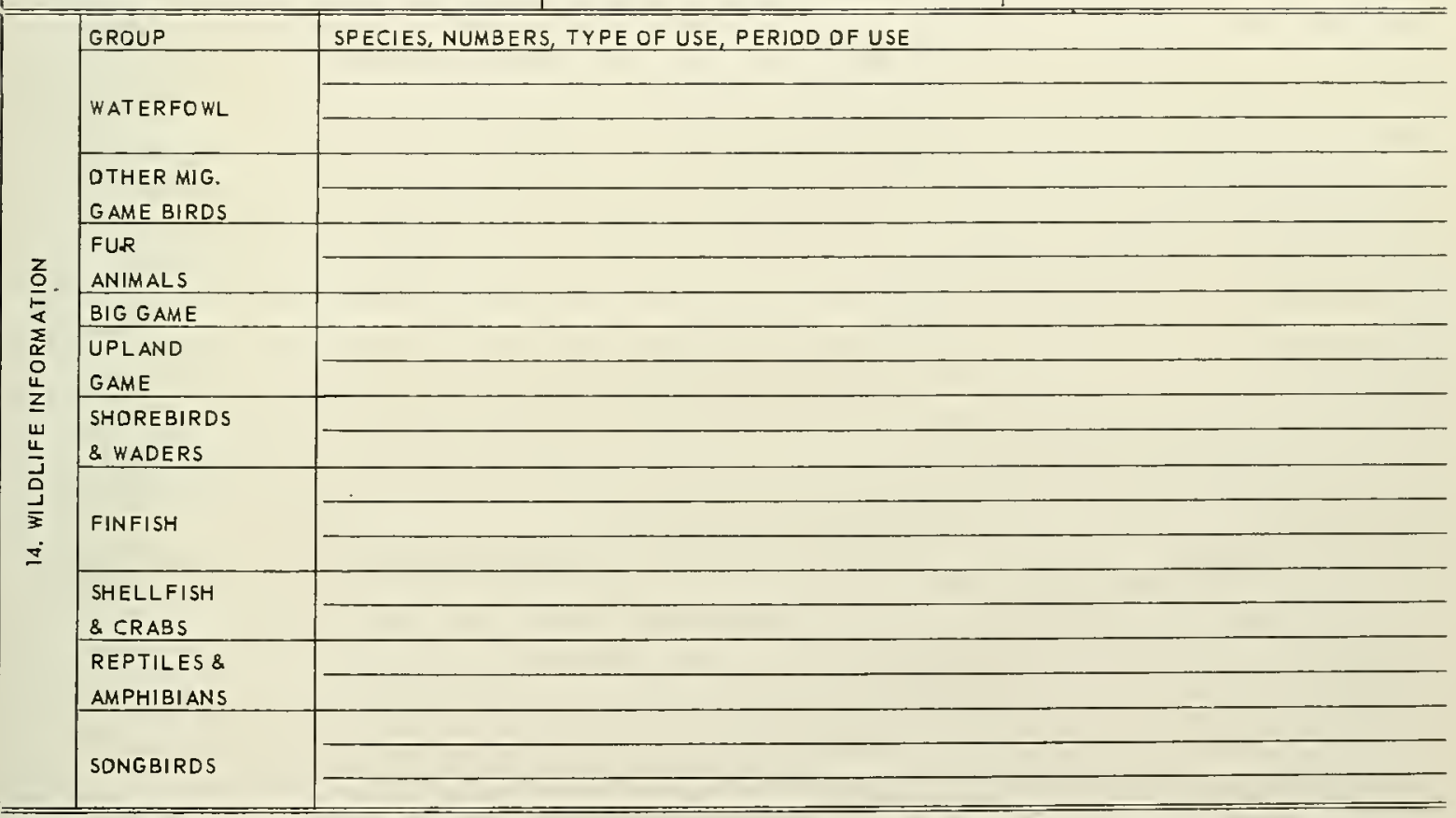

15. SOURCE OF DATA \& DATE

16. ADDITIONAL REMARKS: 
Figure- VI-2

HABITAT INVENTORY DATA SHEET FOR

SPECIFIC MARYLAND WETLAND

AREAS-Side 2

ASSESSMENT OF WETL AND VALUE

USE

HUNTING

FISHING (SPORT)

FISHING (COMM.)

TRAPPING (FURS)

BIRDWATCHING

OTHER RECREATION

F. \& W. REPROD.

UNIQUE HABITAT

UNIQUE WILOLIFE

IMPROV. CAPABILITIES

OTHER

OVERALL RESUME

ASSESSMENT OF VULNERABILITY

FACTOR

INDUSTRY

HOUSING

CHANNELIZING

PUBLIC WORKS

AGRICULTURE

MOSQUITO CONT.

POLLUTION

EROSION

SUCCESSION

OTHER

OVERALL RESUME

ACTION TAKEN FOR PRESERVATION

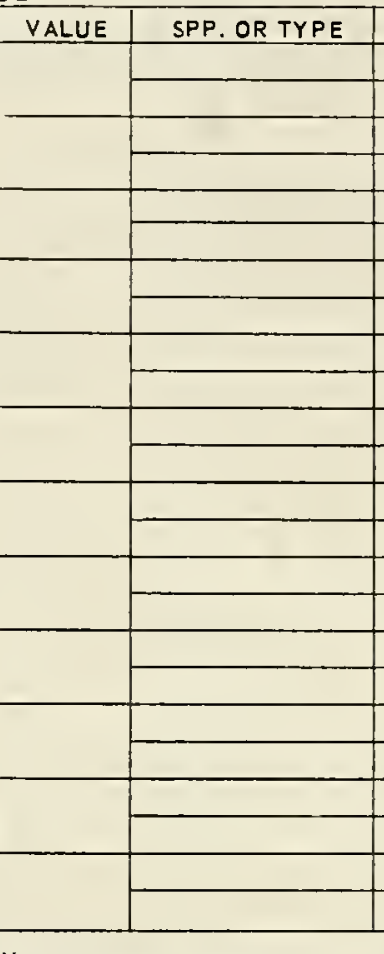

REMARKS

\begin{tabular}{|l|l|l}
\hline VALUE & TYPE & REMARKS \\
\hline
\end{tabular}




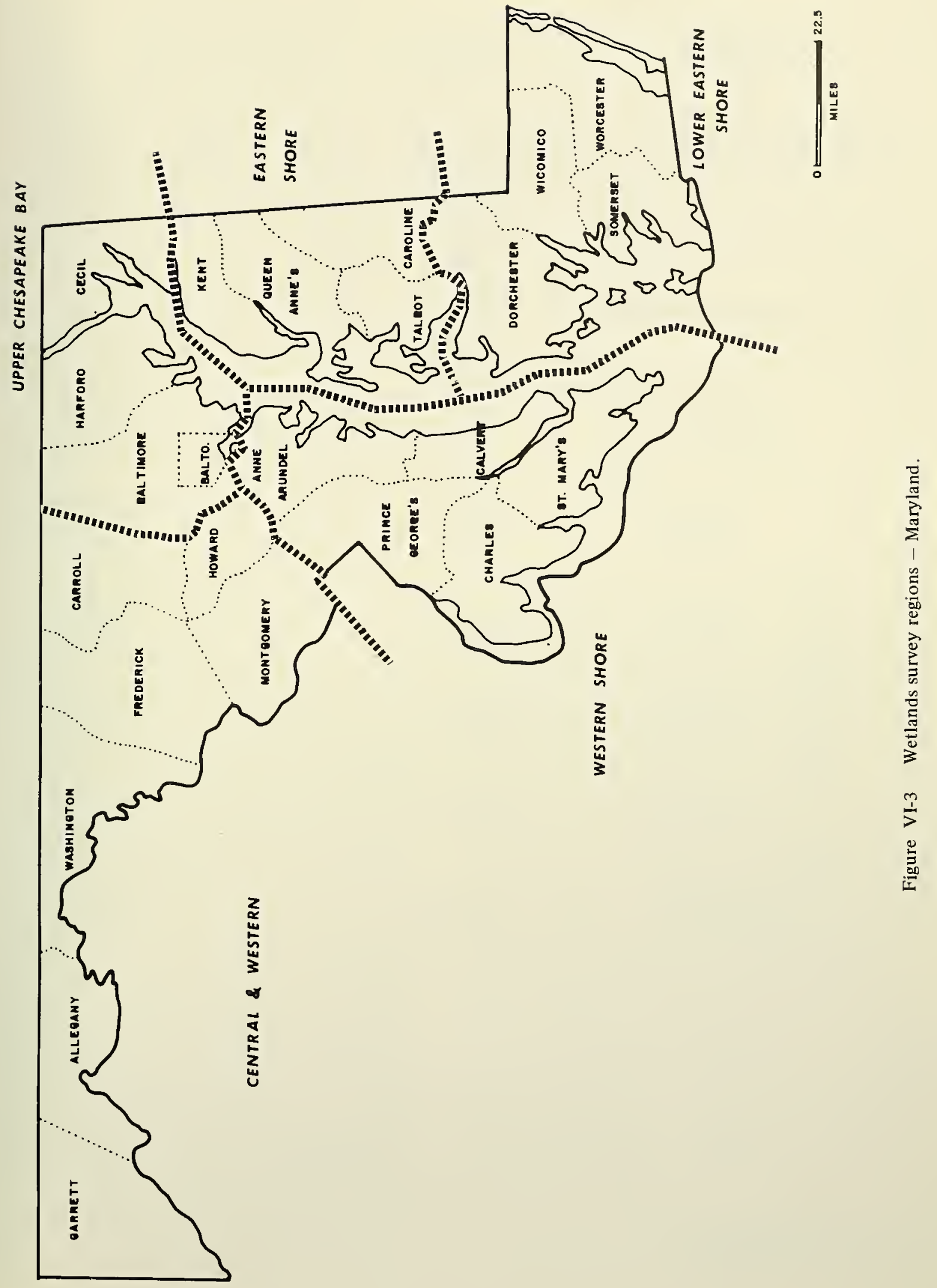




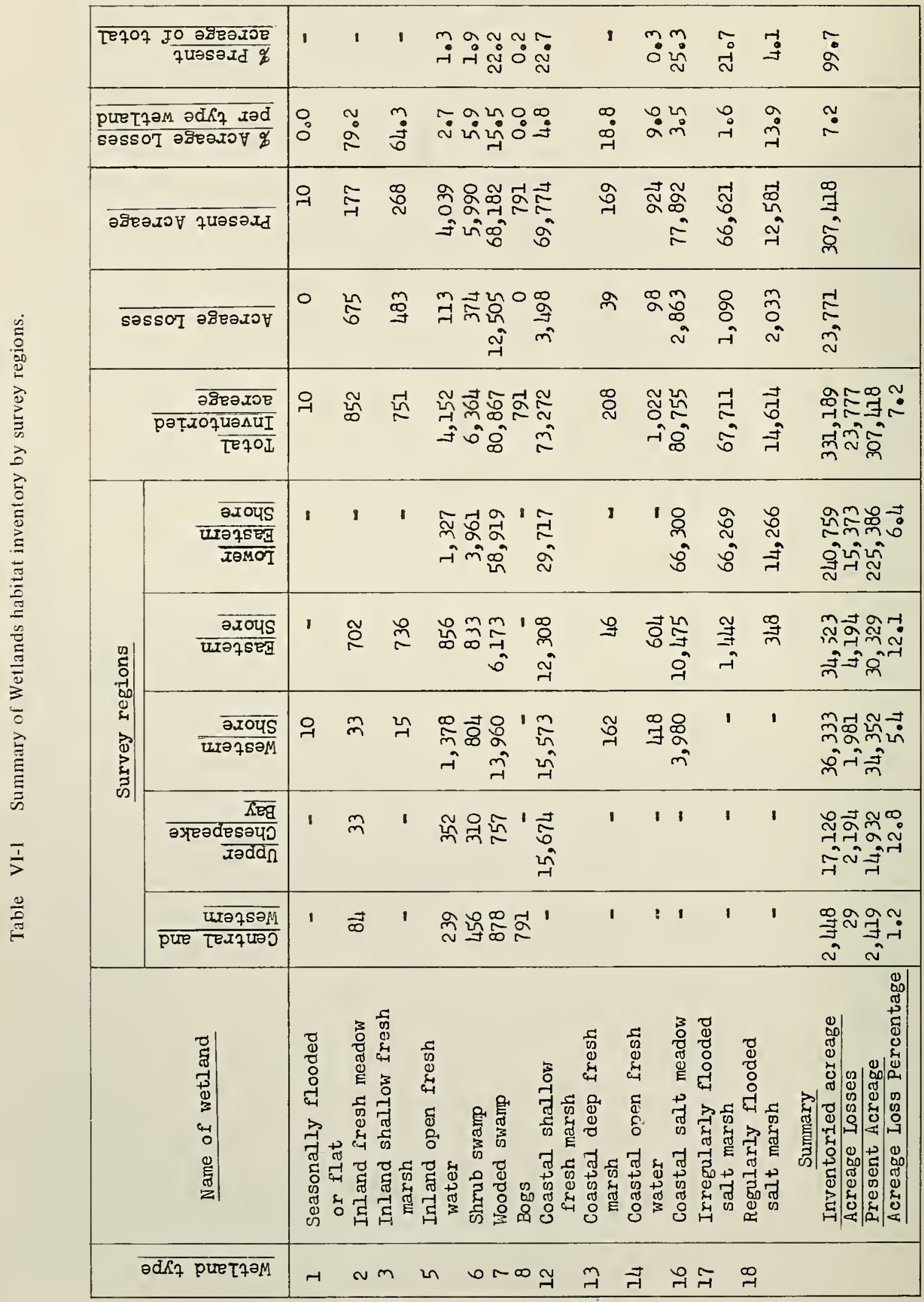


Table VI-2 Depth versus acreage computed for the open surface waters (Type 19P wetlands) of Chesapeake Bay and tributaries (1967-1968). Computations conducted by the Department of Game and Inland Fish on U.S. Coast and Geodetic Survey marine charts.

\begin{tabular}{|c|c|c|c|c|c|c|}
\hline \multirow[b]{2}{*}{ County } & \multirow{2}{*}{$\underline{\text { Nud }}$ flats } & \multicolumn{4}{|c|}{ Water Depths } & \multirow{2}{*}{$\begin{array}{l}\text { Total } \\
\text { Surface } \\
\text { Area } \\
\end{array}$} \\
\hline & & $0^{\prime}$ thru $6^{1}$ & 6! thru 121 & 121 thru 361 & $361+$ & \\
\hline $\begin{array}{l}\text { Anne Amudel } \\
\text { Baltimore } \\
\text { Calvert } \\
\text { Caroline } \\
\text { Cecil } \\
\text { Charles } \\
\text { Dorchester } \\
\text { Harford } \\
\text { Kent } \\
\text { Prince George's } \\
\text { Queen Anne's } \\
\text { Somerset } \\
\text { St. Mary's } \\
\text { Talbot } \\
\text { Wicomico } \\
\text { Torsester }\end{array}$ & $\begin{array}{r}28 \\
- \\
- \\
68 \overline{6} \\
- \\
89 \\
10 \\
- \\
- \\
\overline{8} \\
- \\
- \\
- \\
-\end{array}$ & $\begin{array}{r}20,719 \\
13,610 \\
11,945 \\
1,670 \\
23,663 \\
28,494 \\
97,140 \\
17,451 \\
31,232 \\
5,987 \\
4,739 \\
60,388 \\
34,678 \\
47,724 \\
6,298 \\
66,717\end{array}$ & $\begin{array}{r}15,104 \\
12,406 \\
6,782 \\
355 \\
34,469 \\
25,990 \\
56,521 \\
19,311 \\
19,731 \\
959 \\
3,167 \\
36,786 \\
21,337 \\
26,606 \\
2,523 \\
-\end{array}$ & $\begin{array}{r}67,269 \\
26,468 \\
47,782 \\
1,343 \\
10,207 \\
47,882 \\
109,032 \\
16,639 \\
53,375 \\
811 \\
5,770 \\
58,760 \\
120,249 \\
48,111 \\
1,846 \\
-\end{array}$ & $\begin{array}{r}39,267 \\
54,564 \\
- \\
- \\
6,932 \\
35,768 \\
8,644 \\
765 \\
1,149 \\
17,262 \\
117,537 \\
10,935 \\
- \\
-\end{array}$ & $\begin{array}{r}148,244 \\
56,640 \\
115,073 \\
3,368 \\
69,025 \\
109,298 \\
298,550 \\
53,417 \\
113,400 \\
8,522 \\
15,332 \\
173,214 \\
293,801 \\
127,376 \\
10,667 \\
66,716\end{array}$ \\
\hline Totals & 831 & 466,454 & 282,047 & 609,544 & 292,823 & $1,651,69$ \\
\hline
\end{tabular}

180 acres of inland fresh meadow (79\%), 270 acres of inland shallow fresh marsh (64\%), and 2,000 acres of regularly flooded salt marsh (14\%).

From an historical perspective, previous reporting on State wetlands suggested that there were considerably more along with a persistent developmental attitude. For instance, the Report of the Maryland Conservation Commission for 1908-1909 states that: "the eastern and southern counties of the State bordering Chesapeake Bay and the Atlantic Ocean have 323,326 acres, of which 118,912 acres are fresh-water swamps and 204,416 acres are salt-water marshes. The central and western counties have 5,440 acres of larger swamp tracts, all of which are fresh. In addition to the larger tracts here indicated smaller swamps and marshes scattered over the farm land raises the total to fully 500,000 acres, or about one-twelfth of the total area of the State. It requires little argument to show that this vast area of unproductive land, which might become the richest in the State, should be made available for agricultural purposes at the earliest opportunity."

From the field inventory undertaken for this study total wetlands acreage losses are calculated at 23,771 acres or 7.2 percent of the total acreage inventory for Types 1-19 (Table VI-1). This figure was based on the comparison with U.S. Geological Survey maps dating back to 1942. Most of the recorded acreage losses have occurred, however, in the past decade based on field inventory and aerial surveillance observations. Causes of the losses are housing development, industry, dredging and spoil disposal, public works, marinas, agricultural drainage, pollution, erosion and natural succession (natural filling and changing in vegetative types to non-wetlands). Detailed discussion on activities and competing uses responsible for inventoried acreage losses is presented in Chapter IX.

Calculations on the vulnerability of wetlands to change are presented in Table VI-3. Results show that approximately 47 percent of the State's wetlands (Types 1-19) were evaluated as highly vulnerable to changes destructive or substantially reducing existing natural habitat values. Additionally, 35 percent are moderately vulnerable and 17 percent are listed in the safe category. The latter is due primarily to wetlands in State and Federal ownership that are being managed as wildlife refuges, game management areas, and for outdoor recreation (Table VI-4).*

* Note, most Chapter VI tables (commencing with V1-4) are located in Appendix A in order to facilitate reading covenience. 


\begin{tabular}{|c|c|c|c|c|c|c|c|c|c|c|c|c|c|c|c|}
\hline & 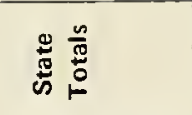 & $\stackrel{ }{\circ}$ & 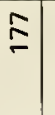 & $\underset{\sim}{\infty}$ & $\begin{array}{l}\mathscr{O} \\
0 \\
\sigma\end{array}$ & $\begin{array}{l}8 \\
8 \\
\circ \\
15\end{array}$ & 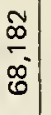 & $\bar{\Omega}$ & $\begin{array}{l}\frac{7}{5} \\
8 \\
8\end{array}$ & $\stackrel{8}{6}$ & নু & 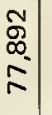 & $\begin{array}{l}\bar{\delta} \\
0 \\
8\end{array}$ & $\begin{array}{l}\bar{\infty} \\
\stackrel{5}{5} \\
\stackrel{-}{\longrightarrow}\end{array}$ & $\begin{array}{l}\frac{\infty}{\pi} \\
\frac{0}{0}\end{array}$ \\
\hline \multirow{6}{*}{ 产 } & $\begin{array}{l}\text { sletol-qns } \\
\text { ap!matels }\end{array}$ & 0 & 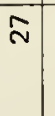 & $\infty$ & $\begin{array}{c}\infty \\
\stackrel{m}{m} \\
\stackrel{-}{-}\end{array}$ & {$\left[\begin{array}{c}0 \\
\stackrel{0}{n} \\
\sim \\
N \\
0\end{array}\right]$} & $\begin{array}{l}\hat{f} \\
m \\
\infty \\
\infty\end{array}$ & 0 & 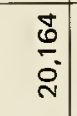 & ్ㅣำ & $\stackrel{g}{\mathcal{G}}$ & $\frac{\overline{6}}{\frac{5}{m}}$ & 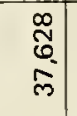 & $\begin{array}{c}\stackrel{L}{N} \\
\underset{N}{n} \\
\infty\end{array}$ & $\begin{array}{l}5 \\
\frac{9}{8} \\
\frac{8}{8}\end{array}$ \\
\hline & 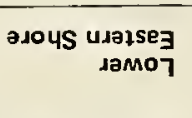 & & & & 总 & 胥 & $\begin{array}{c}\infty \\
\infty \\
\infty \\
\bar{m}\end{array}$ & & 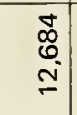 & & & $\begin{array}{l}\infty \\
6 \\
6 \\
\tilde{m} \\
\tilde{m}^{-}\end{array}$ & $\begin{array}{l}\frac{n}{5} \\
\tilde{m}\end{array}$ & $\begin{array}{l}\infty \\
\varnothing \\
\infty \\
\infty\end{array}$ & 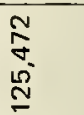 \\
\hline & 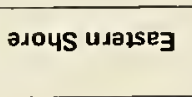 & & & \& & 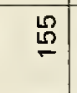 & $\bar{z}$ & 㔛 & & 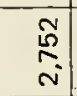 & $\sigma$ & స్ల & $\begin{array}{l}m \\
\text { m. } \\
\text { N }\end{array}$ & $\overline{5}$ & $\stackrel{5}{2}$ & $\underset{\infty}{\frac{g}{2}}$ \\
\hline & u & & $\hat{N}$ & & 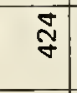 & $\vec{m}$ & $\frac{\infty}{m}$ & & $\begin{array}{l}\frac{\pi}{0} \\
\text { N. }\end{array}$ & $\stackrel{\mathcal{N}}{\stackrel{2}{\sim}}$ & N & $\begin{array}{l}\stackrel{\bigcirc}{\simeq} \\
- \\
-\end{array}$ & & & $\begin{array}{l}\text { N్ } \\
\text { L్ } \\
\infty\end{array}$ \\
\hline & $\begin{array}{r}\text { Aeg ayead } \\
\text {-esayo dadd }\end{array}$ & & & & $\bar{\varphi}$ & กิ & $\hat{\sigma}$ & & 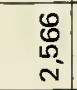 & & & & & & 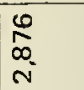 \\
\hline & $\begin{array}{r}\text { unaisam } \\
\text { pue jenuaj }\end{array}$ & & & & \% & $\infty$ & & & & & & & & & $\infty$ \\
\hline \multirow{6}{*}{$\begin{array}{l}\frac{g}{2} \\
\frac{0}{2} \\
\frac{0}{2} \\
\sum\end{array}$} & $\begin{array}{l}\text { s|elol-qns } \\
\text { əp!matels }\end{array}$ & 인 & g & $\bar{z}$ & $\begin{array}{l}\hat{\wp} \\
\dot{\sigma}\end{array}$ & \begin{tabular}{l|} 
\\
$\stackrel{2}{N}$ \\
$m$ \\
$m$
\end{tabular} & $\begin{array}{l}\mathbf{y} \\
\stackrel{6}{-} \\
=\end{array}$ & $\begin{array}{l} \\
6 \\
6 \\
0\end{array}$ & 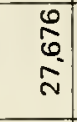 & 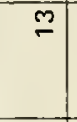 & 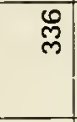 & $\begin{array}{l}\frac{10}{5} \\
\frac{1}{2} \\
-1\end{array}$ & 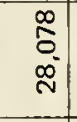 & 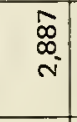 & 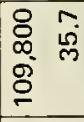 \\
\hline & 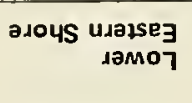 & & & & 量 & 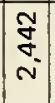 & $\begin{array}{c}\mathfrak{N} \\
\tilde{o}^{-} \\
\infty\end{array}$ & & $\begin{array}{l}\text { Nै } \\
\text { gे }\end{array}$ & & & $\begin{array}{l}5 \\
0 \\
0 \\
0 \\
0\end{array}$ & $\begin{array}{l}\tilde{N} \\
\text { Ñ } \\
\text { N. }\end{array}$ & $\begin{array}{l}\frac{N}{N} \\
\text { N }\end{array}$ & $\begin{array}{l}50 \\
\text { ల్ } \\
10 \\
10\end{array}$ \\
\hline & a & & & $\stackrel{\mathscr{N}}{=}$ & $\stackrel{\infty}{\stackrel{\infty}{N}}$ & 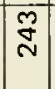 & $\begin{array}{l}\bar{N} \\
\bar{N} \\
\text { N }\end{array}$ & & $\begin{array}{l}\infty \\
0 \\
0 \\
\infty \\
\infty\end{array}$ & $\stackrel{m}{-}$ & $\stackrel{\mathscr{L}}{\stackrel{2}{\sim}}$ & \begin{tabular}{|l|} 
\\
5 \\
5 \\
10 \\
10
\end{tabular} & 号 & $\stackrel{0}{ }$ & $\begin{array}{l}\infty \\
\delta \\
\delta \\
0\end{array}$ \\
\hline & O.04S U גaมsaM & 음 & 0 & $\stackrel{12}{2}$ & $\stackrel{\mathscr{N}}{\curvearrowright}$ & 尺̊. & $\begin{array}{l}\infty \\
0 \\
0 \\
0\end{array}$ & & $\begin{array}{l}\mathscr{\Omega} \\
\stackrel{\Omega}{-} \\
=\end{array}$ & & $\bar{\Sigma}$ & 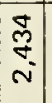 & & & $\frac{\tilde{\delta}}{\bar{~}}$ \\
\hline & $\begin{array}{r}\text { रеg ayead } \\
\text {-esayo dədd }\end{array}$ & & 官 & & $\stackrel{\mathscr{\infty}}{-}$ & m্লি & ชู & & $\begin{array}{l}0 \\
\text { O. } \\
\text { m. }\end{array}$ & & & & & & 导 \\
\hline & $\begin{array}{r}\text { usaisam } \\
\text { pue ןеличаว }\end{array}$ & & 8 & & 5 & $\overline{\widehat{N}}$ & $\overline{0}$ & $\begin{array}{ll}8 \\
80 \\
0\end{array}$ & & & & & & & $\bar{్}$ \\
\hline \multirow{6}{*}{$\frac{2}{\pi}$} & $\begin{array}{l}\text { letol-qns } \\
\text { әp!mąe1S }\end{array}$ & 0 & $\%$ & 8 & 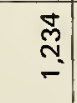 & 捊 & $\mid \begin{array}{c}\bar{\sigma} \\
\bar{\sim}\end{array}$ & $\bar{\sigma}$ & $\begin{array}{l}\overleftarrow{m} \\
\bar{N} \\
\bar{N}\end{array}$ & ম & $\stackrel{N}{N}$ & 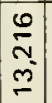 & $\frac{12}{\sigma}$ & $\begin{array}{l}8 \\
\dot{8} \\
\stackrel{+}{-}\end{array}$ & $\begin{array}{ll}\overline{\bar{\sigma}} & 0 \\
\bar{\sigma} & \stackrel{6}{\overline{5}}\end{array}$ \\
\hline & 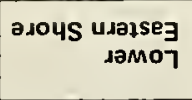 & & & & & กิ & 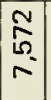 & & $\begin{array}{l}\hat{\mathfrak{\Omega}} \\
\stackrel{\sim}{\sim} \\
\end{array}$ & & & $\begin{array}{l}\tilde{m} \\
\tilde{\sigma} \\
=\end{array}$ & $\stackrel{\circ}{\infty}$ & $\begin{array}{l}8 \\
8 \\
8 \\
-\end{array}$ & $\begin{array}{l}\stackrel{9}{0} \\
\infty \\
0 \\
\mathbb{e}\end{array}$ \\
\hline & a & & $\Sigma$ & 于 & 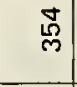 & is & $\begin{array}{c}0 \\
6 \\
-\end{array}$ & & 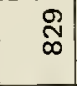 & ম & $\stackrel{\infty}{\infty}$ & $\stackrel{\stackrel{N}{N}}{\sim}$ & ㄱ & & ్ָర్ర్ర \\
\hline & 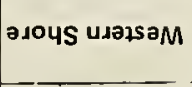 & & & & $\begin{array}{l}0 \\
0 \\
0\end{array}$ & 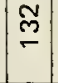 & $\begin{array}{l}8 \\
0 \\
\sim \\
\sim\end{array}$ & & $\stackrel{\infty}{\infty}$ & & $\underline{12}$ & $\begin{array}{l}\infty \\
\infty \\
\infty\end{array}$ & & & 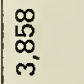 \\
\hline & $\begin{array}{l}\text { Neg ayead } \\
\text {-esayo daddn }\end{array}$ & & m & & 능 & $\bar{N}$ & $\bar{n}$ & & ్ָల్ల & & & & & & 㹂 \\
\hline & $\begin{array}{r}\text { usaisam } \\
\text { pue jestuas }\end{array}$ & & $\because$ & & $\stackrel{9}{=}$ & $\mid$ & $\frac{7}{10}$ & $\bar{\Phi}$ & & & & & & & $\begin{array}{l}0 \\
\infty \\
\infty\end{array}$ \\
\hline 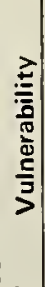 & 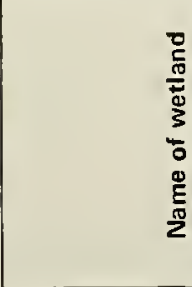 & 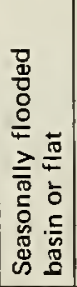 & 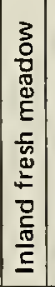 & 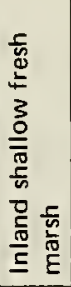 & 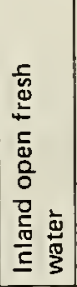 & 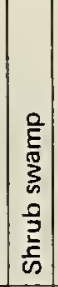 & 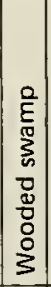 & 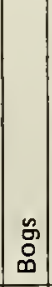 & 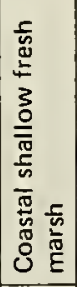 & 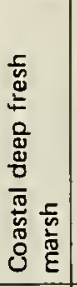 & 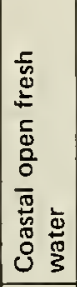 & 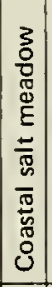 & 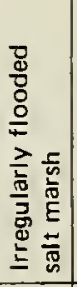 & 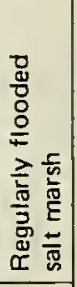 & 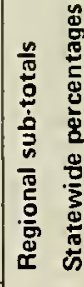 \\
\hline & adA 1 рuejzaM & - & $N$ & m & $\pi$ & 0 & $n$ & $\infty$ & 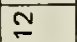 & $m$ & \pm & $\underline{0}$ & $=$ & $\stackrel{\infty}{=}$ & \\
\hline
\end{tabular}




\section{County-by-County}

To facilitate cohesiveness, discussion of county wetland inventory data and information generally follows a prescribed format. Points covered for each county include: 1) identification of general geographic areas that are the principal location of wetlands; 2 ) brief discussion on habitat invent ory statistics such as acreage, vulnerability, losses and causes, and ownership; and 3) survey the future of remaining wetlands by examining relevant sections of county land use policies and plans. Purposefully eliminated are such things as trend projections on acreage losses, acreage needs for wildlife, comparison of statistics between counties or survey regions, and evaluation of county zoning ordinances. In short, much of the traditional paraphernalia and methods of standard "master" plans have been deliberately omitted or ignored for the following reasons.

1. Planning of long-range wetlands management policies based solely on statistical extrapolations could be inaccurate and probably ineffective in the face of human and political equations that have emerged publicly in Maryland concerning Wetlands.

2. "Wetlands" is a new term to the public and a relatively recent 'problem' in the context of the larger 'quality of the environment' issue. Public recognition and interest in wetland issues has been notably lacking until quite recently. This situation was due in large measure to the relatively small, inconspicuous, isolated incidents of wetlands destruction. However, as largescale proposals to reclaim wetlands for more "valuable' purposes commenced to appear, there was improved public perception of what the overall impact might be due to the cumulative effects of lost acreage.

3. The diversity of wetlands in terms of their physical characteristics and the difficulty in perceiving their valuable contributions to society provide obstacles to firm, generally agreed to public concepts on the subject. In fact, there can be much difficulty in merely attempting to define the term "wetlands."

4. County governments exhibited a mixed reaction to the State study operations and had a varying degree of understanding and concern about wetlands. Besides calling for a detailed long-term plan for the optimum use of all wetlands in Maryland, House Joint Resolution No. 2 requested the Department of State Planning to "advise the planning and zoning agencies of the State's political subdivisions of the General Assembly's concern for proper wetlands management and the need for adequate provision for wetlands conservation in local zoning ordiances." (See Appendix C.)

Accordingly, appropriate correspondence was distributed to local governments (appendix D). Coopera- tive responses were received from all contacted county planning and zoning commissions. Responses were tempered by such factors as the extent of involvement as determined by amount of wetlands acreage in a particular county, size of local planning staff, extent of previous land use planning, extent of zoning ordinances adopted, comprehension of the term "wetlands" and how wetlands relate to other land and shoreline uses and adopted zoning ordinances, and other undetermined factors. Consequently, it was clear that an across the board or common understanding of wetlands and attendant issues was essential before proceeding on detailed or Statewide planning activities. Furthermore, land use zoning is the responsibility of local government through Article 66B of the Laws of Maryland.

5. Planning shoreline use for wetlands is too limited a purpose. It represents a single viewpoint and a single purpose for an area of the State that is multiplepurpose. Data presented here reflect a background of a larger volume of data and information that are now available to be applied in future shoreline and land use planning. Multiple-use planning on a larger and more enlightened scale is required to attain a satisfactory balance between uses that will satisfy the needs of contemporary society. Wetlands data now assembled reflects in a fragmented way increased knowledge about their natural functions which is based upon years of scientific study. The planning process must now proceed to assimilate it. However, to do so effectively other shoreline users must also enlarge their data and information inputs to reflect their current and future needs. A shoreline planning problem that must be resolved is the amount and location of shoreline segments essential to satisfy economic growth attendant with increasing human populations, rising expectations and higher standards of living while simultaneously protecting, and indeed, enhancing a high quality environment.

6. Past experience with comprehensive land use plans has shown that such plans are usually outdated before they are completed or adopted because conditions change so rapidly. Consequently, information, conditions or premises on which plans were based may no longer exist. Reality can change many important fundamental inputs and destroy the most orderly assumptions. Stated another way, the real world frequently differs from the assumptions made by planners. Therefore, the only functional purpose for wetlands' management planning derived from presenting both Statewide and county-by-county data is to provide a situation or status report on wetlands as of 1967-68. The county data as presented here represent a baseline level of understanding from which to proceed in plan formulation. 


\section{ALLEGANY COUNTY}

Natural wetlands areas are limited in Allegany County due to the topography and consequent drainage patterns. A total of only 12 acres of inland fresh meadow (Type 2) were identified at two different locations. However, water acreages and the shoreline of the Potomac River were not included in this inventory. Additionally, several man-made wetland type areas totaling 140 acres of inland open fresh water (Type 5) were inventoried. These wetlands are the result of construction for industrial, agricultural or commercial purposes such as waste settling ponds and remaining vestiges of the Chesapeake and Ohio Canal. The latter area with an adjoining inland fresh meadow is highly valued for the variety of wildlife found there, and is accessible to hikers using the tow path. All inventoried wetlands in Allegany County are in private ownership and believed to be in either safe or moderate vulnerability status with regard to potential future change. No wetlands losses were found.

Table V1-5. Inventory of Allegany County wetlands

\begin{tabular}{lccc}
$\begin{array}{l}\text { Vulnerability or } \\
\text { Status }\end{array}$ & \multicolumn{2}{c}{ Wetland Types } & Totals \\
\cline { 2 - 4 } & 2 & $5^{*}$ & \\
\hline Safe acreage & 5 & 35 & 40 \\
(No. occurences) & $(1)$ & $(1)$ & $(2)$ \\
Moderate acreage & 7 & 105 & 112 \\
(No. occurences) & $(1)$ & $(3)$ & $(4)$ \\
High acreage & 0 & 0 & 0
\end{tabular}

(No. occurences)

Summary totals

Acreage inventoried

$12 \quad 140 \quad 152$

(No. occurences) classed as "high" vulnerability to future destructive changes.

Additionally, 523 acres were destroyed or changed so as to be valueless for natural production purposes. The majority of the losses were attributed to industrial development $(48.9 \%)$ and housing development (35.4\%) with several different causes comprising the remainder (Table V1-7).

The present wetlands ownership pattern is 1,770 acres $(25 \%)$ owned publicly between Federal, State, county and municipal governments and 5,390 acres (75\%) owned privately. Most of the federally owned wetlands are located within the boundaries of Fort George Meade along the Patuxent and Little Patuxent Rivers (about 1,180 acres).

Another 130 acres (approximately) of wetlands are owned by the Smithsonian lnstitute on the Rhode River. More than ten miles of undeveloped shoreline within this holding are part of one of the largest remaining undeveloped expanses on the western shore of the Bay. The site is being utilized by the Smithsonian to provide facilities for education and research in field biology. Essential to this purpose is an expanse of natural environment suitable for controlled and uncontrolled observation and research on plants, animals and their communities. ${ }^{3}$

Concerning the future of the remaining 5,390 acres of wetlands in private ownership, reference was made to proposed or contemplated plans and policies for future land and shoreline development in the County. Results of background efforts ${ }^{4}$ on future County planning concluded that:

1. One of the County's most important existing and potential economic sectors is waterfront commerce and industry. Waterfront-related activities will include marinas, boatyards, restaurants, sales of fish and related products, some water-related manufacturing products, and of ten hotels and motels."

2. "Residential growth has occurred primarily near major urban centers and on the shoreline. Housing has been drawn to shoreline locations throughout the County-to the extent, in fact, that very little waterfront remains that is not occupied by or committed to some sort of development."

3. "Urban uses of land are expected to occupy half of the County's total area by year 2000."

The principle underlying the County's general development plan proposals is "that the waters of Chesapeake Bay must be available to the people of the Nation, the Region, and the whole County, as well as 
those who occupy its shores." 6 To fulfill this principle the following policies for waterfront land use were proposed. ${ }^{7}$

1. "Uses will be encouraged on the waterfront which benefit the largest possible number of people while protecting waterfront occupants from harmful effects."

2. "Uses will be encouraged on the waterfront only when they require or benefit by such location."

3. "Waterfront uses which conflict with residential and recreational waterfront uses will be encouraged in a limited number of locations, where their effects can be minimized."

While much of the consultant's effort on County planning deals with the development aspects of the remaining undeveloped shoreline, consideration was also given to open space, recreation and conservation uses. Among the goals and policies sought in providing land for these uses was "to preserve unique irreplaceable resources, stream valleys, and bay and river shorelines, and open space should be used to maintain ecological balance.",

Major areas recommended for protection for open space, recreation and conservation purposes include the Patuxent and Little Patuxent Rivers, Mill Creek Swamp, and the South, Severn and Rhode River strea m valleys. ${ }^{9}$ These areas encompass at least 14 different wetland areas having about 1,800 total acres.

Summing up, large and important wetland tracts exist where competition is heavy for undeveloped shoreline. Developmental pressure from competing uses can be expected to intensify. Some wetlands are in public ownership and in one specific instance are dedicated to biological research. An open space and recreational areas plan proposes acquisition of several shoreline areas encompassing significant wetland acreage, particularly in the Patuxent River watershed. Much depends upon the strategy adopted by the County in controlling future shoreline development. Based on results of marina zoning proposals, it will be challenged severely as development pressures mount. 10

\section{BALTIMORE CITY}

Very few wetlands remain in Baltimore City. One privately owned area of 60 acres and another of three acres of coastal shallow fresh marsh exist along the Patapsco River. Both wetlands are highly vulnerable due to a location adjacent to ongoing sanitary landfills. Suspected poor water quality also limits the present and future natural value of the remaining wetlands.
Five reservoirs (publicly owned) were noted within the City's limits which have a total fresh water surface area of 160 acres. These areas provide limited value for wildlife, waterfowl and fisheries, but are not included in the inventory.

While the total historical wetlands acreage losses due to shoreline development are not know, 150 acres have been destroyed in recent years for port and industrial development

\section{BALTIMORE COUNTY}

Wetlands are located principally along the shoreline of the Gunpowder, Middle and Back Rivers, and other estuarine areas of Baltimore County fronting on Chesapeake Bay. Approximately 3,700 acres were inventoried at 62 different locations of five acres in size or larger (Table V1-8). Wetlands represent about one percent of the total County land area. About 1,320 acres (35\%) inventoried as "safe," 1,220 acres (33\%) are classified as "moderately" vulnerable and about 500 acres (14\%) are in the "high" vulnerability category.

Additionally, 615 acres or 17 percent were destroyed. Shrub swamp (Type 6) and coastal shallow fresh marshes (Type 12) sustained the acreage losses, primarily due to filling to create waterfrontage property for marine-oriented commerce and industry of the Baltimore port complex (Table Vl-9).

The present wetlands ownership pattern is 1,200 acres publicly owned and 2,400 acres privately owned. The Maryland Department of Forests and Parks owns over 500 acres for recreation, open space and conservation purposes and the Federal Government owns over 600 acres within the boundaries of the Aberdeen Proving Grounds.

With regard to the future of the remaining wetlands, present County land use plans indicate that land along the Back River Neck and Patapsco Neck peninsulas, including 400 acres of wetlands (Type 12), has potential for deepwater marine transportation acess to serve water-oriented industry. ${ }^{11}$ The land parcels in these areas are stated to represent the largest tracts of vacant land with potential for industrial development in the Baltimore regional port area. This port-ind ustry is of national significance. ${ }^{12}$

Several studies conducted on the land needs for recreation and open space purposes in Baltimore County and the Baltimore metropolitan area advocated acquisition of water-fronting property for wateroriented recreational activities. ${ }^{13}$ Frequently, wetlands are located within the areas proposed for acquisition. These include shoreline areas on Saltpeter and 
Dundee Creeks and Middle and Bird Rivers having a total wetland acreage over 500 acres of mostly coastal shallow fresh marsh (Type 12).

Summing up, competition exists for remaining vacant waterfronting land. Previous appraisals of the growth needs of the Baltimore port-industrial complex, the need for public access to the shoreline for recreational purposes, and the conservation of wetlands essential to the ecology of surrounding estuarine waters suggests that careful planning, augmented by appropriate zoning, will be required to guide future development of the County's shoreline.

\section{CALVERT COUNTY}

Wetlands are located primarily along the shores of the Patuxent River and estuary. Approximately 4,400 acres were inventoried at 62 different locations of five acres in size or larger in Calvert County (Table VI-10). Wetlands represent about three percent of the total county land area. Only 25 acres (less than one percent) of the wetlands are classified in the "safe" category while 3,492 acres $(79.1 \%)$ are in the "moderate" category and 742 acres $(16.8 \%)$ are in the "high" vulnerability category.

In addition, 157 acres or 3.6 percent were inventoried as destroyed. Types 12 and 16 wetlands sustained the acreage losses due to a variety of reasons (Table VI-11). Marina development with attendant dredging, spoil disposal and landfill activities was identified as the principal cause. Natural erosion also accounted for some of the destruction.

The present wetlands ownership pattern is 59 acres publicly owned and 4,200 acres privately owned. Proposed future land use policies and plans with import to remaining wetlands and recommended in an adopted Comprehensive Master Plan ${ }^{14}$ include: encouraging cluster development around that which already exists, encouraging only complete, planned communities outside cluster areas, retaining land along the Patuxent River in its present agricultural use, and preserving the waterways and other areas of the County which because of either a uniqueness or other natural attribute, lend themselves to recreational usage and can serve as the basis for a future county recreation system.

Recreation and conservation areas are delineated by the land use plan. A number of sites in these categories have been selected and are either currently being reserved as conservation areas or are being considered. Based on a comparison between the Calvert County land use plan map and wetland work map, some of the most important and valuable wetlands, in terms of biological or ecological values, are within areas being contemplated or planned as recreation or conservation areas. However, many significant tracts of wetlands bordering the estuarial portions of the Patuxent River have not been recognized in present land use plans.

The significance of this situation with regard to the future for wetlands becomes readily apparent when past land development is reviewed and compared with the most likely trends of future development. In the past,

"the trend has been for more development to take place along the bay front than along river front. The economics of land development may bring about a change in this trend. At this time, the best land along the bay front is either developed or in the process of development. The cream has been skimmed off and the remaining land is rugged, relatively inaccessible, and has a limited amount of natural beach available. On the other hand, the land along the river (Patuxent) is relatively undeveloped in most cases, and topographically suited to extensive and economical development."15

Waterfront residential development has been responsible for the eventual establishment of many existing communities in the County. This development is usually the result of a planned and publicized land development project. Most of them start out aimed at the Washington metropolitan area market and people seeking a second (seasonal) home with water recreation near at hand. However, over the years such settlements have tended to become more and more permanent in character. As commuting to metropolitan employment becomes easier with each road improvement, this trend toward permanence can be expected to continue. Obviously, with increasing populations, more leisure time, greater incomes, and improved transportation systems from metropolitan areas, there will be an increasing demand for residential waterfront property. There will be more pressure to develop wetland to the fullest extent possible, consistent with the demand and county zoning ordinances.

\section{CAROLINE COUNTY}

Marshyhope Creek, the Choptank River, and Tuckahoe Creek are the locations of most of the wetlands. Approximately 6,900 acres were inventoried at 87 different locations of five acres in size or larger (Table VI-12). Wetlands represent about three percent of total county land area. About 800 acres (12\%) are classified "safe" while 3,200 (46\%) are "moderately" vulnerable and 2,000 acres $(29 \%)$ are believed to be "highly" vulnerable to future destructive change. 
Also, 819 acres were inventoried as destroyed or had experienced changes destructive to former natural habitat values. These losses represent about 12 percent of the total acreage inventoried in Caroline County. All of the wetland types experienced some acreage losses. The most significant was the destruction of inland shallow fresh marsh (Type 3). This loss represents 64.3 percent of the total Statewide inventory of Type 3 wetlands (Table Vl-1). The cause of this loss was agricultural drainage and flood prevention projects (Table V1-13).

The present wetland sownership pattern is 80 acres (1\%) publicly owned and 6,000 acres (99\%) owned privately. The wetlands in public ownership are within the Martinak and Tuckahoe State Parks owned and managed by the Maryland Department of Forests and Parks, and Smithville Community Lake and Idylwild Wildlife Demonstration Area owned and managed by the Maryland Fish and Wildlife Administration.

Concerning the future of privately owned wetlands, the recommended land use pattern is to continue or encourage future major development in clusters around already existing population centers. This has the advantage of providing a feasible base to support essential community services and facilities such as water supply and sewerage collection and treatment and also to prevent unwise consumption of valuable agricultural land. ${ }^{17}$

Two activities with potential impact on wetlands resources merit brief mention. One is that "lands along the lower Choptank River have prime development and reactional potential, but access to the waterfront is limited. 18 To rectify this situation "selected road improvements are aimed at opening up housing and local recreational development opportunities along the county's attractive riverfront a reas.",19

The other is the pending or contemplated improvement to the navigable waterways of the Choptank and Tuckahoe Rivers for commercial and pleasure craft. The improvement projects include dredging the Choptank River to provide a 12 foot depth channel from Pealiquor Shoals south of Denton to Denton, thereby making it navigable to all probable commercial traffic. North of Denton to Greensboro the river will be dredged to six feet, thus opening it to all pleasure boats. The County is also considering dredging a six feet deep channel in the Tuckahoe River to provide access to the landing in Hillsboro and to the Tuckahoe State Park. 20

River and harbor projects such as these are administered by the U.S. Army Corps of Engineers. Local cost-sharing responsibilities are an essential feature. Generally, the major local responsibility consists of providing spoil disposal areas, right-of-way permits, and provisions for liability arising from the project. From an economic standpoint wetlands are prime locations for spoil disposal sites, and they have been so used in the past. Consequently, any future channel maintenance or improvement project will probably utilize wetlands along the shoreline as spoil disposal sites.

Summing up, much of the wetland acreage in Caroline County is relatively inaccessible to human usage now. Recommended future land use patterns seem to indicate a policy favorable to wetlands management. However, two activities, road and navigable waterway improvements, may radically alter this situation. The ultimate impact of these proposed developmental activities on wetlands will be determined in large measure by local interest in wetlands.

\section{CARROLL COUNTY}

Very few wetland areas are located in Carroll County. Only two were recorded-one of approximately seven acres of inland fresh meadow (Type 2) and the other, six acres of inland open fresh water (Type 5). No wetland acreage losses were recorded for Carroll County and all acreage is evaluated as being either safe or moderately vulnerable to future change (Table V1-14). Both of the wetlands inventoried are in private ownership. In addition, two municipal water supply reservoirs, Liberty and Westminister, have created large open surface water areas where none previously existed.

Table VI-14. Inventory of Carroll County wetlands

\begin{tabular}{|c|c|c|c|}
\hline \multirow{2}{*}{$\begin{array}{l}\text { Vulnerability or } \\
\text { Stautus }\end{array}$} & \multicolumn{2}{|c|}{ Wetland Types } & \multirow[t]{2}{*}{ Totals } \\
\hline & 2 & 5 & \\
\hline Safe acreage & 0 & $3,125^{*}$ & $3,125^{*}$ \\
\hline (No. occurences) & & (2) & (2) \\
\hline Moderate acreage & 7 & 6 & 13 \\
\hline (No. occurences) & (1) & (1) & (2) \\
\hline $\begin{array}{l}\text { High acreage } \\
\text { (No. occurences) }\end{array}$ & 0 & 0 & 0 \\
\hline Summary totals & & & \\
\hline Acreage inventoried & 7 & 6 & 3,138 \\
\hline (No. occurences) & (1) & (1) & (4) \\
\hline
\end{tabular}

* Note: This acreage results from man-made water supply reservoirs, Liberty and Westminster, and is not included in State-wide totals.

\section{CECIL COUNTY}

Cecil County wetlands are located primarily in the southern part along the shores of the Elk, Bohemia and Sassafras Rivers, tributaries of Chesapeake Bay. 
Appproximately 3,900 acres were inventoried at 88 different locations of five acres in size or large (Table VI-15). Wetlands represent about two percent of the total County land area. Only 85 acres or two percent are in the "safe" category while 1,806 acres ( 46 percent) are "moderately" vulnerable and 1,431 acres (36 percent) are in the "high" vulnerability category. Also, 618 acres were destroyed or had experienced changes destructive to natural habitat values.

The coastal shallow fresh marshes (Type 12) sustained 94 percent of the wetlands losses inventoried in the County (Table VI-16). Most of the loss occurred along the Elk River and is related to dredging and spoil disposal attendant with maintaining navigable channels leading to the Chesapeake and Delaware Canal. The destructive incidents to Type 12 wetlands are attributed both to their predominance in terms of total County wetland acreage as well as their location, namely being immediately adjacent to navigable waterways. The latter factor facilitates convenient disposal of dredged materials.

Ther present wetlands ownership pattern is 650 acres owned publicly between the State and Federal Government and 2,660 acres owned privately. Much of the Federally owned wetlands (590 acres) have been used specifically as spoil disposal sites for channel dredging operations

Concerning the future of privately owned wetlands in Cecil County, the recommended land development pattern calls for preservation of large areas of shoreline and forest for recreation and open space uses. $^{21}$ This recommendation is predicated on the regional and roving character of boating, camping, hunting and fishing which are the predominant forms of recreational activity and require rather large areas relatively free of development. However, large sections of County waterfontage are now used for summer cottages and private residential purposes, and such usage will grow in the future. Consequently, future planning for Cecil County's remaining undeveloped shoreline presents a dilemma of contradicting purposes-how to preserve and enhance desired wateroriented outdoor recreation activities while simultaneously avoiding the destruction of the natural environmental amenities which attract and encourage over develop ment.

One plan suggests that the Elk and Sassafras River shorelines should be developed as summer and yearround residential areas, with marinas and other boating facilities where suitable. Not all of the shoreline should be developed for private year-round housing, since that would eliminate much of the potential market for visitors. ${ }^{22}$ These rivers are also where many wetlands are located. Only two areas encompassing wetlands were specifically designated as sites for development of park recreational facilities, Principio Furnace and the Pearce Creek area. ${ }^{23}$ The future of wetlands in Cecil County depends on the way that the plan is implemented and this will be determined largely by the public's understanding of the role wetlands play in the existing natural environment and in supporting wateroriented recreation. The implementation of effective plans for protection and careful utilization of shoreline resources will require appropriate zoning and subdivision regulations. ${ }^{24}$

\section{CHARLES COUNTY}

Wetlands are located along the shoreline of primary drainage systems such as the Wicomico River, Potomac River, Nanjemoy Creek, Mattawoman Creek, Gilbert Run and Zekiah Swamp. Approximately 11,500 acres were inventoried at 85 different locations of five acres in size or larger in Charles County (Table VI-17).

Wetlands represent about 3.9 percent of the total County land area. About 1,270 acres (10.9\%) are classified in the "safe" category while 8,600 acres $(75 \%)$ are in the "moderately" vulnerable category, and 1,200 acres $(10.7 \%)$ are "highly" vulnerable to future destructive changes.

In addition, over 380 acres were destroyed or about 3 percent of the total County wetlands acreage. Types 12 and 16 sustained most of the losses (Table VI-18). This is attributed to large Type 12 acreages as well as locations immediately adjacent to the open surface waters which are attractive for residential waterfront development. These factors increase the likelihood of destructive incidents.

The present ownership pattern is 170 acres in public ownership, located principally at the Federal Government's U.S. Naval Propellant Plant (Indianhead) and the Blossom Point Proving Grounds. Also, the Maryland Fish and Wildife Administration has acreage at the Myrtle Grove Wildlife Refuge. The remainder or about 11,000 acres of wetlands are privately ow ned in Charles County.

Concerning future growth and development in Charles County and the implications to wetlands resources several major factors exist.

Waterfrontage is one of the County's distinguishing assets which provides an opportunity or a base for attracting new economic development. Also, the proximity to the Washington metropolitan area will have an expanding impact as accessibility improves. Conse- 
quently, commuter-oriented homes, second or recreational homes and retirement housing will be a major development opportunity encouraged by attractive natural amenities such as abundant waterfontage property and rolling wooded landscapes. The density of development should be carefully controlled to encourage good quality construction. ${ }^{25}$ However, "recreation and the seafood industry are of such importance that any seriously conflicting waterfont uses should be avoided, however great their at tractiveness on other grounds."2 6

To properly handle growth the County has undertaken a comprehensive planning effort. Land use plan recommendations ${ }^{27}$ will have a major beneficial impact on the future of County wetlands resources, if fully implemented in a timely manner. Proposed parks and conservation areas encompass twenty-two wetlands of 7,427 acres total or about 67 percent of the wetlands in the County. Several of the most significant wetlands of the County and the State such as Mattawoman Creek, Nanjemoy Creek, Zekiah Swamp Run and Gilbert Swamp would be protected by the County's 1985 land use plan.

\section{DORCHESTER COUNTY}

There are extensive wetlands in this County due to combined features of geography, topography and climate. Dorchester County, largest in terms of combined total land and water area, extends into Chesapeake Bay as a broad peninsula almost surrounded by the combined waters of Chesapeake Bay and the broad Choptank and Nanticoke rivers. Additionally, an average annual rainfall of 45.5 inches sup plies enough water to continually inundate large tracts of low, flat poorly drained land besides those areas subject to tidal influence due to low elevation.

Approximately 122,370 acres were inventoried at ninety-four locations of five acres in size or larger (Table VI-19). This acreage represents about 32.7 percent of the total County land area and 39.5 percent of existing State wetland (Types 1-19) acreage. About 25,500 acres $(20.9 \%)$ are considered to be in the "safe" category, 13,100 acres (10.7\%) are "moderately" vulnerable and over 82,600 acres $(67.6 \%)$ are evaluated as "highly" vulnerable to change.

An additional 974 acres of wetlands were destroyed by natural causes (erosion) and man's activities (Table VI-20). Most of the losses were to bayshore (coastal) wetlands. Their location exposes them to erosion forces, makes them attractive for residential development, and convenient for spoil disposal. Also, because of the large acreages of Types 12,16 and 17 and since they comprise a significant percentage of the total area, there is greater opportunity for destructive incidents.

The present wetlands ownership pattern is 23,500 acres (19.4\%) owned publicly between the State and Federal governments and 97,900 acres $(80.6 \%$ owned privately. Public ownership includes the U.S. Fish and Wildlife Blackwater National Wildlife Refuge and the Maryland Fish and Wildlife Adiminstration management areas at Fishing Bay and Taylors Island.

Concerning the future of remaining privately owned wetlands, local land-use planning policy recommendations state that "a policy should be followed of minimum development in marsh areas and areas that should be preserved for agriculture. Agricultural areas also include the vast marsh areas in the lower part of the County. Although very little agriculture as such is found here, it should be maintained in its present state as much as possible. The economic value of the area should be preserved as a haven for wildlife and as an attraction for sportsmen.",28

\section{FREDERICK COUNTY}

Approximately 480 acres of inland open surface fresh water wetlands (Type 5) were identified and inventoried in Frederick County. This aquatic habitat is man-created for commercial enterprise or for water supply. The water acreage and shoreline of the Potomac River and other natural watercourses was not included in this inventory because of the five acre size limitation.

Most of the impounded water acreage is considered safe from any change although 35 acres have been reconverted to agricultural purposes such as pasturage. Ownership of the impoundments is 422 acres private and 24 acres public. One area, Tick Lake, is owned and managed by the Maryland Fish and Wildlife Administration for conservation purposes.

\section{GARRETT COUNTY}

Wetlands are located at the headwaters of many mountain streams, in open meadow areas or along the banks of the larger waterways. About 2,100 acres were inventoried at 46 different locations of five acres in size or larger (Table VI-21).

Wetlands represent one-half of one percent of the County's total land area. About 800 acres $(37 \%)$ are classed in the "safe" category, 1,200 acres $(60 \%)$ are "moderately" vulnerable, and 50 acres are "highly" vulnerable to destructive change. There were no iden- 
tified incidents of destruction or acreage losses. However, strip mining for coal and lumbering are potential threats to even the remotest of these areas.

An important feature of Garrett County wetlands is the uniqueness of the bogs (Type 8) which occur only in this part of the State. Plants common to these bogs are dominant in bogs typical of the glaciated portions of the northern United States. Consequently, from a natural science standpoint bogs or "glades" are among the more fascinating and unique natural areas in Maryland.

Approximately 500 acres of the wetlands are owned by the Maryland Department of Forest and Parks and the remainder (1,600 acres) is in private ownership.

\section{HARFORD COUNTY}

Wetlands occur primarily along the shoreline of upper Chesapeake Bay. Approximately 9,300 acres were inventoried at 39 different locations of five acres or larger in size (Table VI-22). In addition, 800 acres of Type 12 wetlands were destroyed (Table V1-23).

Wetlands represent about 2.2 percent of the County's total land area. Of this figure 6,100 acres $(66 \%)$ are classed as "safe," 1,465 acres (16\%) are "moderately" vulnerable, and 860 acres (9\%) are "highly" vulnerable. The latter evaluation is based upon the planned use of certain areas for industrial or housing development. Proposed industrial use totals 370 acres of which 80 acres have already been filled. Housing is planned for 880 acres of which 350 acres have already been developed by dredging and filling operations for waterfront residential property.

The present wetland ownership pattern is 6,100 acres $(73 \%)$ public and 2,300 acres $(27 \%)$ private. Most of the publicly owned wetlands are coastal shallow fresh marsh (Type 12) within the Federal Government's (Department of Defense) Edgewood Arsenal and Aberdeen Proving Ground. While all of the wetlands are classed as "safe" in these areas, 210 acres have been destroyed. This experience may continue from time to time due to the nature of operational activities associated with national defense within the governmental reservations. However, conservation and management of all natural resources within Edgewood Arsenal and the Aberdeen Proving Grounds is required by certain Department of Defense directives. ${ }^{29}$ The primary purpose of these directives is to establish and include plans for the management and conservation of fish and wildlife within military installation master plans. Furthermore, cooperative management plans with State and Federal fish and wildlife conservation agencies are required and have been formulated with the Maryland Fish and Wildlife Administration.

Concerning the future of the 2,300 acres in private ownership, proposed or contemplated plans and policies for future land development in the County include: "preservation of the County's most valuable natural features, particularly major stream valleys, for their contribution to the landscape generally and for possible public and private recreational use ..."30 Also, the Plan for Parks and Open Space ${ }^{31}$ proposes the acquisition and development of certain areas for public recreation uses. Many wetland acres are encompassed within the proposed public recreational areas. However, nearly every proposal for waterfrontage, including wetlands, contains the following remarks: "Mostly swamp reclamation on north and south sides"; "swamp reclamation at south end," "Forest conservation with swamp reclamation at estuary;" "Forest conservation, with landfill to reclaim flood plain;" and "Tidal flat reclaimed by sanitary landfill and dredging.",32

Summing up, a large part of County wetlands as well as the shoreline are in Federal ownership. This should insure protection although some destruction has occurred. Because of extensive public ownership, private ownership is restricted to a limited area and there is heavy pressure for development. County plans for parks and open space would acquire waterfrontage. However, plan development as envisioned would destroy encompassed wetlands.

\section{HOWARD COUNTY}

Only one wetland area has been identified and inventoried at the present time in Howard County. This is exclusive of the extensive inland open fresh water habitat (Type 5) associated with the water supply reservoirs constructed on the Patuxent River. There are probably other small wetlands which remain to be identified, primarily in and along the streams which drain the County.

The one area inventoried is an inland fresh meadow (Type 2) of approximately 27 acres in size along Deep Run. This privately owned wetland is evaluated as being moderately vulnerable to change within the foreseeable future.

\section{KENT COUNTY}

The hydrological boundaries of Kent County-the Sassafras River on the north, Chesapeake Bay on the west, Chester River on the South, and their tributary waters-are the principal locations of wetlands. Approximately 7,800 acres were inventoried at 90 
different locations of five acres in size or larger (Table VI-24). Wetlands represent about four percent of the County's total land area. About 1,600 acres (20\%) are classified "safe" while 3,900 acres $(50 \%)$ are "moderately" vulnerable and 1,800 acres $(23 \%)$ are "highly" vulnerable to future destructive change. Also, 433 acres were destroyed or had experienced changes destructive to former natural habitat values (Table VI-25). These losses represent about five percent of the total inventoried acreage.

The present wetlands ownership pattern is 880 acres public and 6,500 acres private. The publicly owned wetlands include the U.S. Fish and Wildlife Service's Eastern Neck Island National Wildlife Refuge and the Maryland Fish and Wildife Administration's Urieville Lake. In addition the Remington Arms Company maintains important wildlife and waterfowl management demonstration areas on the west fork of Langford Creek.

Concerning the future of privately owned wetlands, recommended land plans would protect 50 percent under a "Permanent Green Area" classification. Such areas include tracts of marshland, woodland and miles and miles of wooded stream valleys and shorelines. Since these areas "contribute so much to the over all desirability of the county environment they should remain essentially unchanged." 33

"As for the marshes, by and large they are undeveloped, and require little attention, but are an interesting part of the total scene and a necessary part of the habitat of waterfowl which are worthy of a great deal attention ... These marshes need not be purchased by a public agency except when threatened or except as part of a larger puchase. The public should, nevertheless, be interested in keeping them unpolluted and should encourage legitimate planning of food for wildlife." 34

However, development pressure may be generated by the recreational or commuter home market. Special impetus is provided by suggestions for an upper Bay bridge. Such as undertaking would have a tremendous impact on present development patterns. Summing up,

"With development pressures at present levels, there may seem little need for concern. Happily, past mistakes have been so small as to be barely noticeable. Yet development pressures will increase and crimes against the landscape are difficult to eradicate. However remote the urban examples of such crimes may seem, Kent County has too much at stake to postpone active consideration of the value of its natural features."35

\section{MONTGOMERY COUNTY}

Several wetlands are located in the southwestern part of Montgomery County on small tributary streams of the Potomac River. There are also some wetlands in the Patuxent River watershed. Eleven wetlands of five acres or larger in size and totaling about 180 acres were identified in Montgomery County (Table VI-26).

Wetlands represent a fraction of one percent of the County's total land area. About 150 acres (81\%) are considered "safe," 30 acres are "moderately" vulnerable and there are no wetlands either in the "high" or destroyed categories. This situation is due to public ownership of wetlands, proposed public ownership or protection, or appropriate local zoning laws and subdivision regulations.

Regarding the latter, Montgomery County Zoning Ordinance Sec. 101-14-“will prevent encroachments on the wetlands of Montgomery County."36 Also, there are proposals in The Nation's River ${ }^{37}$ to establish public parks and access along the Potomac River in Montgomery County as well as preserve and properly manage wetlands.

Present ownership of wetlands includes 63 acres (33\%) public, 39 acres (21\%) private, and 87 acres (46\%) are jointly owned by both.

\section{PRINCE GEORGE'S COUNTY}

Most of the wetlands in Prince George's County border the Patuxent River or occur along the major streams such as Western Branch, Charles Branch, Mataponi Branch, Piscataway Creek and Mattawoman Creek. Approximately 8,100 acres were inventoried at 71 different locations of five acres or larger in size.

Wetlands represent about two percent of the County's total land area. About 380 acres or four percent are classified in the "safe" category, 4,300 acres $(52.6 \%)$ are "moderately" vulnerable, and 2,800 acres $(35 \%)$ are "highly" vulnerable. (Table VI-27).

In addition, over 600 acres were destroyed or about seven percent of the County's total inventoried wetlands acreage (Table VI-28).

The present wetlands ownership pattern is 113 acres $(1.4 \%)$ by the Federal Government and 7,463 acres $(98.6 \%)$ owned privately. Concerning the future of remaining wetlands, large numbers are still in a relatively natural state with most of the developmental activity occurring in the densely populated portions of the County. Rezoning petitions were mainly concentrated along major highways and railroads. Most of them will have no impact on wetlands. "The overall picture of pending rezoning areas reveals that the 
present development does not impede the work on preservation of the wetlands." 38

In fact, wetlands have severe limitations for community development. They were unsuitable for disposal of sewage effluent from septic tanks, sewage lagoons, foundations for houses, landscaping and earth movement, streets and parking lots, sanitary landfill, cemeteries or gardens. ${ }^{39}$ However, one study proposed five wetland areas within the County for use as waste disposal sites for the Washington metropolitan region. 40

There are certain ongoing activities of a conservation nature in the County. Proposed outdoor recreation programs would require the acquisition of lands along the Patuxent River and several other major streams that encompass large portions of County wetlands. Large portions of the acquired acreage will be devoted to conservation and preservation of existing natural environment. Where recreational uses are developed, they will be of the type which are compatible with this environment. ${ }^{4} 1$

A review of local laws and zoning or dinances showed that there are no statements referring directly to wetlands, but sections of the Ordinance pertaining to site plan approval in certain zones are applicable. Briefly, various existing local laws with potential use for wetlands problems include:

1. The Prince George's County Zoning OrdinanceSections 15A.O R-T Zone (Town House), 15A.9 Site Plan Approval; 17A.O R-H Zone (Multi-family and High-Rise Residential), 17A.73 Site Plan Approval 19.0 R-P-C Zone (Development Community), 19.5 Commission Consideration.

Under these existing zoning ordinances, site development plans must show the location and site of all buildings and structures and the topography and major vegetation features now existing on the land, etc. In reviewing the applications the Planning Board should consider the standards and all other factors of such zone to achieve a maximum of safety, convenience and amenity for the residents within the development.

If the Planning Board finds that a proposed plan of development does not meet the purpose of the regulations or will have an adverse effect on the use of the area for development, it has the power to disapprove the plan in order to prevent such undesirable development.

2. Prince George's County Subdivision RegulationsSection 13-Subdivision Control of Flood Plan Areas and Unsafe Land.

A proposed amendment to the Subdivision Regulations has been made by the Planning Board to add the new section 13 authorizing the Planning Board to exercise subdivision control over flood plain areas and unsafe land. It empowers the Planning Board to restrict subdivision for development of any property which lies within the 50-year flood plain of any stream or drainage course and also to restrict subdivision of any land which is found to be unsafe for development.

The regulation requires that in the case of a subdivision of property which includes such a flood plain area along a stream which is to be left open in its natural state, unless such area is to become a public park or a recreation area maintained by a designated responsible authority, the area shall be denoted upon the plat as a flood plain easement across the lots in this portion of the subdivision. The plat shall denote that the flood plain easement may be used by public agencies if necessary for utility lines, etc., but is restricted from any use which would interfere with the purpose of such easement to preserve the flood plain areas from encroachment by any structures and to prevent filling and grading within the easement area.

As to unsafe land, restriction may be due to natural conditions, such as flooding, erosive stream action, unstable soil conditons or man-made conditions such as unstable fills or slopes. The regulation authorizes the Planning Board to have a broad power to restrict subdivision of any unsafe land for the health, safety, comfort and welfare of the county.

Since all of the wetlands are in either the flood plain areas or unsafe land category, the provisions of the Subdivision Regulations could be used by the Planning Board to protect wetlands from encroachment.

3. Prince George's County Ordinance Providing Tax Credits for Scenic Easements

The county is authorized to grant special tax credit to encourage the landowner to carry out a program to assist the preservation of open space through the use of scenic easement. By creating or imposing a servitude upon land, a scenic easement provides the control to maintain scenic views, open space, green area, animal refuges or natural habitat or flora and fauna. Said tax credit could be computed up to $50 \%$ of the taxes levied upon the value of the land assessment excluding improvements.

Through the use of scenic easement, public agencies should have the means to deal effectively with matters involved in the wetland areas if not publically owned, to preserve open space or to develop the land for a compatible use. (However, it must be noted that we have not had one applicant since the law went into effect on January 11, 1966.) $)^{42}$

4. Prince George's County Building Code-Sections 2100.0, Section 2101.0, subsections 2101.1, 2101.2 and 2101.3 .

Although the Building Code does not directly limit the use of land, it does set up restrictions 
governing the construction of buildings and structures within flood plain and storm drainage areas, which may be applied to wetlands to prevent encroachment from development. The provisions of the Building Code can be used to prohibit spot offenses on wetlands.

Summing up, large tracts of wetlands still exist near a growing metropolitan area. A very limited acreage is considered to be in a "safe" category and very little is in public ownership. A proposed recreation and park program would acquire considerable acreage encompassing a substantial portion of County wetlands. For the remainder there are several possible local zoning ordinances that have direct bearing on wetlands, depending on how they are implemented at crucial times. The timeliness of the recreational land acquisition program and the actions of local government in carrying out its zoning ordinances will determine to a large extent the intensity of development on wetlands in Prince George's County.

\section{QUEEN ANNE'S COUNTY}

The Chester River on the north, Chesapeake Bay to the west, Eastern Bay and the Wye River on the southern boundary are the principal locations of county wetlands. Approximately 10,000 acres were invent oried at 178 different locations of five acres or larger in size (Table VI-29). Wetlands represent about three percent of the County's total land area. About 1,670 acres $(16 \%)$ are classified "safe" while 3,550 acres $(35 \%)$ are "moderately" vulnerable and 3,030 acres $(30 \%)$ are believed to be "highly" vulnerable to future destructive change.

In addition, 1,770 acres were destroyed or had experienced changes destructive to former natural habitat values. These losses represent 18 percent of the acreage inventoried in Queen Anne's County, and are distributed among several different types of wetlands. Losses were attributed to a variety of causes or uses such as flood prevention and drainage projects (43\%), housing (18\%), and marinas (13\%) (Table VJ-30).

The present wetlands ownership pattern is 250 acres $(3 \%)$ public and 8,000 acres $(97 \%)$ private. The publicly owned areas include the Unicorn and Wye Mills Community Lakes that are managed by the Maryland Fish and Wildlife Administration for conservation and recreation purposes.

Concerning the future of remaining privately owned wetlands, recommended land use policies and plans recognize the importance of wetlands and the appropriate development of all land.

"More than 95\% of the County is still in farms, forests, marshlands and the like. There is space, indeed, in which to grow without over- crowding or the need to fill in marshes or create more land.

"Both sides of Kent Narrows, extending eastward to Grasonville, are mostly tidal marshes which cannot be utilized satisfactorily without extensive filling and the installation of central sewer systems. Marshes of this type have great importance, however, in the production and conservation of fish and bird life and for some of the smaller animals. They provide an essential habitat for the reproduction, nursing, feeding and preservation of game and commercial fishes, migratory waterfowl, and small marsh animals, the significances of which is hardly ever realized or appreciated. Preservaiton of the wetlands in Queen Anne's County from the mistaken inroads of "reclamation" through drainage, filling, bulkheading, dredging, and the like, should be a prime objective of the county plan." 43

Recommendations have been made to acquire and develop certain areas for public use over a period of years to meet the County's present and future recreational needs. Sixteen wetland areas having a total acreage of about 2,000 acres are encompassed within the recommended areas. ${ }^{44}$ This acreage figure represents about $24 \%$ of the total existing wetland acreage inventoried in the County. However, two of these areas are already in State ownership, Unicorn and Wye Mills Lakes, and one has been destroyed (at Crumpton). Also a zoning classification of "A-2", Agriculture-Conservation is stated to include "tidal marshlands around Kent Narrows and the larger concentrations of poorly drained or otherwise unsuitable upland soils." 45

Interestingly, before the construction of the Chesapeake Bay Bridge in 1952, there was very little subdivision activity in Queen Anne's County other than in and around the older towns. The completion of the bridge set off a major splurge, however, which continues to the present time.

"The greatest amount of subdivision activity has been on Kent Island. Nearly $80 \%$ of all the lots created since 1947, have been in this area, while the remainder have been mostly along the Chester River in the stretch between Kings Town and Millington. All but about six of the subdivisions have been along the shoreline, and most of the actual building development in these subdivisions has been on the actual waterfront lots even though the subdivisions were platted in depth. In most cases the interior lots have been popular and have lagged in development.

"Much of the subdivision activity, especially on Kent Island, has been aimed at seasonal or weekend use by non-resident owners who may live in the nearby metropolitan areas of Baltimore and Washington. Sales have been intensively promoted through newspaper ads or by mail for a few dollars down, sight unseen in many cases, and small monthly payments. Many lots have been as narrow as 40 or 50 feet, without water systems or sewers, 
and there have been only a few paved streets or other improvements. In one case a water tank was built to serve a subdivision but no water lines were installed and the tank is still unused. Only one small subdivision has actually installed a water system. Individual wells and septic tanks have created some health problems and the authorities have had to restrict further development in some cases where it was getting too dense. The smaller lots now have to be used in multiples to meet the minimum health requirements.

"Despite these difficulties, there are many good subdivision developments in the county and there should be more in the future. Past inadequacies and abuses cannot be repeated so long as the county's present subdivision regulations are in force . . . The regulations are intended to promote good subdivision design and a more substantial kind of development in the future. " th

Summing up, the construction of the first Chespeake Bay Bridge had a significant impact on developmental activity, particularly of subdivisions along the shoreline. Recommended County acquisitions and development for recreational purposes encompass several wetland areas. However, with rising real estate prices, increasing land speculation, and completion of the second bridge, a significant surge in pressure for development seems certain. The cumulative effect of these forces may determine the pattern of future land use and development in the County. The future of County wetlands is wrapped up in the results of local government decisions on land use plans and development and in supporting local interest and understanding of wetlands' values.

\section{ST, MARY'S COUNTY}

The Patuxent River on the north, Chesapeake Bay on the east, the Potomac River, and waters tributary to each of these water bodies are the principal location of wetlands in St. Mary's County. Approximately 4,500 acres were inventoried at 132 different locations of five acres or larger in size. (Table VI-31).

Wetlands represent about two percent of the County"s total land area. About 500 acres $(11 \%)$ are classified in the "sufe" category, another 2,300 acres $(51 \%)$ are "moderately" vulnerable and about 1,400 acres $(31 \%)$ ure "highly" vulnerable. In addition, 286 acres or six percent were destroyed. Type 12 and Type 16 wetlands sustained the heaviest losses (Table V1-32).
The present wetlands ownership pattern is 180 acres public and 4,000 acres private. The Patuxent Naval Air Test Center is the principal location of the publicly owned wetlands with 130 acres enclosed within its boundaries.

Concerning the future of County wetlands, much depends on how the County's Land Use Plan is implemented. In it, waterfront residential development is proposed for specific areas along the Patuxent Riverfront, the Chesapeake Bay, and the upper stretches of the Potomac and Wicomico Rivers. Certain other areas are proposed for waterfront park and recreational land use, such as Medleys Neck and Si. Ignoes Neck. ${ }^{47}$ Many acres of wetlands are within the areas designated for residential, park and recreational land use.

General guidelines stating how the plan should be implemented include-

"In so far as possible new growth needs to be encouraged within and adjacent to communities where services already exist and can be expanded without prohibitive costs. In turn, areas remote from existing service centers should remain undeveloped.

"The allocation of land for future growth must be structured so as to take advantage of existing and potential assets and avoid development which will have a destructive impact on the economy and fiscal resources.

"The danger of increasing water pollution and the possible collapse of the seafood industry is another major development drawback. Many soils in the county are unsuited to septic installations as a means of sewage disposal. Central sewerage systems will be required; but attendant high costs will tend to limit the amount of development. ${ }^{.48}$

Summing up, County land use plans recommend waterfrontage development while at the same time recognizing potential hazards of doing so. The proximity to the Washington metropolitan area may have an expanding influence as accessibility improves. Residential housing encouraged by abundant waterfrontage property and scenic landscapes will be a major development opportunity. The challenge will be to develop in a manner that doesn't degrade the environment attracting and supporting the economic opportunity. The manner in which County land use policies and plans are implemented will determine the impact of development on the existing environment. This rests largely with the local citizen's interest in the way the County's natural environment assets are protected during future developmental activity. 


\section{SOMERSET COUNTY}

Approximately 45 percent of Somerset County's 600 square miles lie below the tidal wash of Chesapeake Bay and its tributaries. ${ }^{44}$ Consequently, there are vast expanses of wetlands dominating the County's peninsular shoreline jutting into Tangier Sound. Extensive wetlands are also found on South Marsh Island, Smith Island and along the shores of Pocomoke Sound and the Pocomoke River.

About 58,600 acres of wetlands were inventoried at 37 different locations of five acres or larger in size (Table VI-33). Wetlands comprise about 27 percent of Somerset County's total land area. This ranks the County second in terms of total land area in wetlands. About 4,100 acres $(7 \%)$ are classified in the "safe" category while 39,000 acres $(66 \%)$ are "moderately" vulnerable and 14,800 acres $(25 \%)$ are "highly" vulnerable.

In addition, 709 acres were destroyed or had experienced changes destructive to natural habitat values. The majority of the losses were attributed to dredging and spoil disposal operations (32\%), housing developments (24\%), erosion (19\%), and a combination of causes for the remainder (Table V1-34).

The present wetlands ownership pattern is 17,000 acres public and 40,900 acres private. Most of the publicly owned land is managed for preservation and maintenance of wildlife at Deal Island, Fairmount, Cedar lsland, Pocomoke Sound, and Wellington Wildlife Management Areas by the Maryland Fish and Wildlife Administration. The Maryland Department of Forests and Parks owns Janes Island for conservation and recreational purposes and the Federal Government has established the Martin National Wildlife Refuge on Smith Island.

Concerning the future of privately owned wetlands, a brief review was made of County land use planning activities and reports. With specific reference to land use and wetlands the following comments and recommended policies were noted.

"The most desirable and economical form of land use in the County would be that which encourages the expansion of the existing built-up areas with provisions for adequate and desirable waterfront development. A policy should also be followed for a minimum of development in marsh areas .. Every effort should be made to concentrate residential, commercial and industrial development in areas that are now or can in the future be served by public sewer and water. In this way, property values and the health of the community will be preserved.

"The agricultural area also includes vast marsh areas along the western and southern fringes of the County. Although very little agriculture as such is found here, it should be maintained in its present state as much as possible. The economic value of the area should be preserved as a haven for wildlife and as an attraction for sportsmen."

The future development and/or preservation of privately owned wetlands in Somerset County is linked to the economic needs of the local residents, the public revenues needed for essential governmental services, the local attitude toward the role that wetlands play in the total environmental system, and the potential impacts of State and regional developmental activities and programs. While Somerset County is wetlands blessed, it is a mixed blessing. Too much of one commodity may mean low net incomes to local residents. Consequently, local government cannot be expected to hold a paternal attitude toward wetlands. For future economic growth to occur, it may have to be based on the opportunities presented by developing the natural resource base, including wetlands.

\section{TALBOT COUNTY}

Talbot County is surrounded entirely by water except for $7 \frac{1}{2}$ miles on its northern boundary. Eastern Bay, Chesapeake Bay and the Choptank River on the west, Tuckahoe Creek on the northeast, and the Choptank River on the southeast and south form the County's borders. These waters and smaller bays and tributary inlets provide numerous sites for wetlands. About 9,700 acres were inventoried at 145 different locations of five acres in size or larger (Table V1-35).

Wetlands comprise about five percent of Talbot County's land area. About 500 acres (5\%) are classified in the "safe" category while 6,200 acres $(64 \%)$ are "moderately" vulnerable and 1,800 acres (18\%) are "highly" vulnerable.

In addition, I,169 acres were destroyed or had experienced changes destructive to former natural habitat values. These losses were attributed to a variety of causes, the most important being housing development $(28.7 \%)$. However, erosion is also an important agent of wetlands destruction (24.8\%) (Table V1-36).

The present wetlands ownership pattern is 150 acres (1.7\%) public and 8,450 acres $(98.3 \%)$ private. The majority of the publicly owned wetlands are at a U.S. Coast Guard facility on the shoreline of Chesapeake Bay.

Concerning the future of wetlands in Talbot County, a survey of wetlands inventory data shows that 54 wetland areas have experienced some degree of mancaused destruction and 23 areas have experienced acreage losses due to erosion. There is pressure for 
waterfrontage development to create residential real estate and provide recreational and marina facilities due to several factors (Ch. IX). Also, the previous pattern of shoreline erosion will continue. Therefore, wetland acreage losses will continue in Talbot County unless plans are developed to direct and control the pattern of present and future land development in the County. Without plans, the present high quality environmental conditions may not be protected from ill-considered future land use and shoreline development activities.

\section{WASHINGTON COUNTY}

There are very few instances of naturally occurring wetlands in Washington County. Three wetlands were inventoried with a total of 23 acres (Table V1-37). Also, several man-made impoundments provide over 200 acres of open surface freshwater habitat.

No wetland losses were found and nearly every acre both natural and artifically produced is considered to be safe. This is due to public ownership both by Federal and State (Chesapeake and Ohio National Park and State Forest) and by private sportsmans clubs for conservation and outdoor recreation purposes.

\section{Table V1-37. Inventory of wetlands in Washington County}

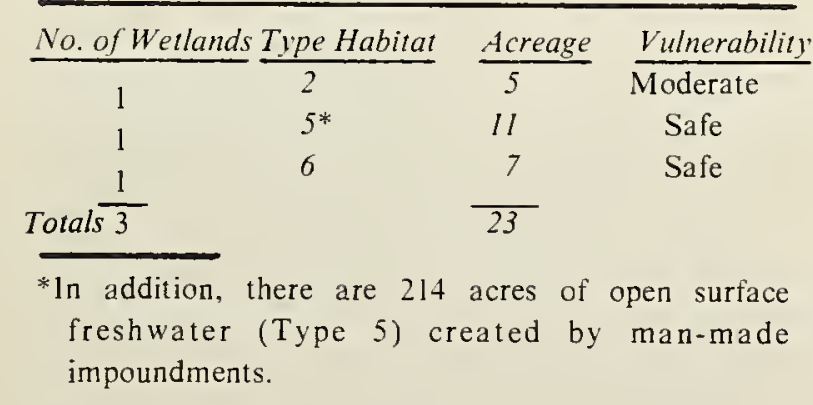

\section{WICOMICO COUNTY}

Wetlands in Wicomico County are located primarily along the shores of the Nanticoke, Wicomico and Pocomoke Rivers. There are also important interior wetlands on watercourses tributary to these major rivers. Approximately 22,000 acres of wetlands were inventoried at 57 different locations of five acres or larger in size (Table VI-38).

Wetlands comprise about eight percent of the County's total land area. The County ranks fourth in terms of Statewide total wetlands acreage. About 1,900 acres $(9 \%)$ are classified "safe" while 420 acres $(2 \%)$ are "moderately" vulnerable and 16,600 acres (75\%) are believed to be "highly" vulnerable to future destructive changes.

In addition, 3,051 acres were destroyed or had experienced changes destructive to natural habitat values. The losses represent 14 percent of the total County inventoried acreage and were due to housing and industrial development and agricultural use (Table V1-39). Most of the losses occurred near or within Salisbury and its urbanizing fringes.

The present wetlands ownership pattern is 2,070 acres public and 16,850 acres private. Most of the publicly owned land ( 1,900 acres) is at Ellis Bay Wildlife Management Area. The remainder is owned by the City of Salisbury for park and recreational use.

Municipal ownership and implementation of plans for using stream valleys for outdoor recreation purposes $^{51}$ has resulted in wetland alteration to provide recreational facilities because they were unsuitable for such use in their natural state. In other stream valley areas, wetlands have been filled for housing. Consequently, most wetlands within the city environs have been changed to meeting housing and park facility or recreation needs.

Two other activities with potential impact on Wicomico County wetlands merit brief discussion. One is the U.S. Army Corps of Engineers navigation project activity on the Wicomico River channel. Salisbury is about 20 miles upstream from the mouth of the river. Maintenance of a navigable channel that permits merchant shipping to reach Salisbury is of great economic interest to the local and regional community. ${ }^{52}$ This interest is reflected by an appropriate constructional response by the Corps. Since 1950 dredging for new channels and maintenance has produced about 925,650 cubic yards of spoil at a total Federal cost of $\$ 269,278 .{ }^{53}$ Part of the local share of project responsibility includes providing spoil disposal areas. Previous spoil disposal has been overboard into stream areas adjacent to the dredged channel and behind low dikes. From an economic standpoint wetlands have been utilized as spoil disposal areas in the past and will be so used in the future. Consequently, present and future channel maintenance projects on the Wicomico River will probably utilize wetlands along the shoreline as spoil disposal sites whenever dictated by engineering or economic limitations.

Another Federal program with potential impact on wetlands is the Small Watershed Program (Public Law 83-566) administered by the U.S. Soil Conservation Service for flood control and agricultural land drainage. This program has been utilized on several tributaries of the Pocomoke River and is more extensive than former Civilian Conservation Corps, conscien- 
tious objector or private entrepreneurial drainage projects of a similar nature. Consequently, the majority of Wicomico County wetlands inventoried as destroyed were Type 7 (wooded swamp) along the Pocomoke River and its tributaries. There are several more potential flood control and agricultural land drainage projects eligible for PL 566 financial assitance in the Pocomoke River watershed.

\section{WORCESTER COUNTY}

As Maryland's only county on the Atlantic Coast, Worcester County has an unusual mixture of wetlands. Expansive areas of coastal salt meadows and marshes border the Isle of Wight-Assawoman Bay estuarine complex from the Delaware boundary line to the Ocean City Inlet, and south from the Inlet in Sinepuxent and Chincoteague Bays to the Virginia line. Inland the Pocomoke River and its tributaries such as Nassawango Creek and Pusey Branch are the locales for large areas of fresh water swamps.

Wetlands comprise about eight percent of the land area in Worcester County. In terms of total wetlands acreage Worcester County ranks third Statewide. Significantly, 64 percent of Maryland's regularly flooded salt marshes (Type 18) occurs in the estuarine areas behind the coastal barrier beaches.

About 37,700 acres were inventoried at 80 different locations of five acres or larger in size (Table VI-40). About 3,300 acres $(9 \%)$ are classified in the "safe" category while 12,400 acres $(33 \%)$ are "moderately" vulnerable and 11,300 acres $(30 \%)$ are "highly" vulnerable. Of the latter figure, 8,000 acres of regularly flooded salt marsh (Type 18) are in the high vulnerability status. This situation is attributed to the geographical location of these wetlands coinciding with the State's limited oceanic shoreline. These areas are very attractive for recreation home-marina complex development to meet the high demand for such facilities.

Additionally, 10,639 wetland acres were recorded as destroyed or experienced changes destructive to wetland habitat values. Wooded swamp (Type 7) sustained 81 percent of the County's total wetlands acreage losses (VI-41). Most of this reported loss was due to agricultural drainage and flood prevention projects assisted by Federally financed programs. A series of these projects were completed on watercourses tributary to the upper reaches of the Pocomoke River, and have altered most of the wetlands above Whiton Crossing.

Regularly flooded salt marsh losses were due primarily to natural succession. The marshes were filled by a combination of blown sand siltation from beach dunes and an accumulation of decayed vegetation. However, housing and marina development are also significant destructive factors (Table VJ-41).

The present wetlands ownership pattern is 4,580 acres $(17 \%)$ public and 22,500 acres $(83 \%)$ private. The wetlands in public ownership are located within the Pocomoke State Forest and Assateague Island State Park (Maryland Department of Forests and Parks), Assateague Island National Seashore (Federal Government) and the Ernest A. Vaughn Wildlife Management Area (Maryland Fish and Wildlife Administration). The publicly owned areas are primarily managed for conservation purposes although some destruction of wetlands has occurred in providing recreational facilities for visitors and tourists.

Concerning the future status of privately owned wetlands, reference was made to both County-wide and local planning studies. The following comments merit especial attention.

"The open waters must not be filled in, and the tidal marshes that are so vital to the survival and constant replenishment of our fish and game resources must be preserved in their natural state. $^{54}$

"A few residential developments have occurred in the West Ocean City area and along the St. Martin River or elsewhere, but sanitation problems have arisen because of over-intensive development and lack of modern sewers. The danger is that the natural charm of these wooded shores will be lost, and the irreplaceable breeding and feeding grounds for valuable fish and waterfowl will be destroyed unnecessarily, by irresponsible and over-zealous types of real estate 'developers. ${ }^{55}$

"As custodian of Maryland's entire ocean shore, only 3] miles long, this county bears a certain obligation to the whole State. Its resources are coming into greater and greater demand but the supply is limited and must be used judiciously. 56

"The problems of the future clearly include making best use of limited land area (at Ocean City). While conditions are suitable for expansion on the bay side, this expansion must be carefully planned and limited to preserve the assets of these protected waters. ${ }^{57}$

"Of Ocean City's developable land, that is excluding the beach, 61.5 percent is vacant. 58

"Adding land by filling on the bay side may be expected to increase the total land area of the town by about 20 percent. The potential growth by filling to the bulkhead line, as of the summer of 1967 , is about 970 acres. However, it is probable that only one-half of this area (485 acres) will actually be filled. 59 
"The bay front will soon be far more important to Ocean City than it has been in the past. Its present value for building sites is demonstrated by the filling of the bay in some places and the dredging and piling to create boat slips in other places. The question of how much fill is permissable should be studied. This would relate to the inland waterway channel location among other considerations. As the cost of land rises in Ocean City, the incentive to fill the bay will grow. Presently filled land is used for town houses and apartments, but soon it will be economically justified by the value of single-dwelling sites.

"In relatively recent years there have been extensive undertakings in bulkheading, digging new channels, and filling of new land on the bay side. Much more of this lies in store since the bay side offers the only possibilities for substantia! enlargment of the town's land area ... Judged by the bad examples of most of the past works, establishment of standards and careful supervision of design and construction of land fills and channels on the bay side will form an important objective of the Comprehensive Plans. So far, the "designs" have been based mainly on long, narrow, dead-end channels with little thought to a circulation system necessary to avoid stagnant water. ${ }^{61}$

"The general land use plan (for Ocean City) illustrates the principle that filling of new land should be encouraged, but that extension should be limited by a bulkhead line which maintains the integrity of the bay, its channels and currents, its views, purity of water and its pleasures of fishing and boating. There appears to be little need for change in the present bulkhead line unless a substantial public purpose can be demonstrated. 62

"A sizeable portion of land on the bay side would be reclaimed by land fills such as previously undertaken for the existing amusement center, and as planned for the new sewage treatment plant site. Bay land south of the (new) bridge ramps should likewise be reclaimed and committed to use as parkland with a public landing dock and related parking facilities." 63

From the above, it is clear that much of the future development in Worcester County, particularly at Ocean City, is predicated on filling or reclaiming wetlands to provide additional land needed to support envisioned growth. At the same time some pre-cautionary statements were also made regarding policy guidance of such activity and possible results if ignored.

Besides development, planning guidance was also provided for future activity concerning conservation of important natural resource assets, particularly natural conservation areas. These areas are defined as including: "coastal marshes, cypress swamps and certain upland swamps and forests, that should be left primar- ily in their natural state for such uses as fish and wildlife management, hunting, boating, fishing, camping, exploring, forest management, and the like.",64

One plan recommended that as a goal, over 13,000 acres of forests and natural areas in combination with other existing parks and recreational facilities be obtained or set aside by the County. ${ }^{65}$ Many significant wetland areas are included in this recommendation such as certain segments of the shoreline on Chincoteague and Sine puxent Bays and tributaries and reaches of the Pocomoke River.

Considerable State and Federal acitivity on preserving, managing and developing Assateague lsland for outdoor recreation and conservation have set aside large areas for these purposes. Consequently, neither Ocean City or Worcester County is under pressure to acquire or preserve natural areas and hence the local thrust is logically on development to take advantage of a special resource (unique location) situation. Quite likely this pattern will continue in response to the pressures dictated by the recreation-based real estate market.

\section{SUMMARY AND CONCLUSIONS}

Maryland has significant wetlands in terms of remaining acreage and stature among other states of the Atlantic Coast. Loss of this important habitat has not been nearly as severe as experienced by some other states. However, acreage losses, as well as changes considered degrading to about seven percent of the inventoried acreage during the past decade or more indicate that man's presence is starting to become apparent in these areas of the coastal zone.

Also to be considered but not inventoried or documented are losses of small wetland areas (less than five acres) as well as the natural bottom destroyed under open surface waters. The latter destruction or modification occurs through dredging and overboard spoil disposal and by fill such that the former bottom is no longer sub-aqueous. Furthermore, areal extent is not a paramount criteria in evaluating or indicating the ecological significance of an area. In fact, many of the small wetlands are the only such areas within the immediate vicinity of large open surface water acreage and miles of shoreline.

The net impact of wetlands' losses is undoubtedly buffered due to the large remaining acreages. Quite likely, if future encroachments significantly reduce the habitat base, the net impacts will be more dramatically discernible. This will be seen in reduced populations of fish and wildlife, shifts in natural population composition and degraded conditions in the acquatic environment. 
The fact that Maryland has a healthy wetlands resource situation poses a challenging opportunity to future shoreline land-use and estuarine management planning. Maryland's present wetlands complex as is should assure a continual, rich and abundant production of fisheries, waterfowl and wildlife. However, a favorable inventorial situation may not reduce the vulnerability of wetlands to continued destructive activities. Large existing acreages, vast intact wetland tracts, and small losses (percentagewise) may suggest to decision-makers and the political process that there is either no need for protective management or concern over restriction on the allocation of wetlands to other uses. The apparant abundance of wetlands Statewide may lead to false impressions, unrealistic appraisals and inappropriate actions or inaction.

In man's systems devised to govern himself and his surroundings it was necessary to establish, orga nize and superimpose artificial boundaries on the natural environment. In this process the major responsibility for establishing and enforcing controls over land uses was vested with local government. However, wetlands and their related values do not correspond to political boundaries. The contributions derived from wetlands are local, regional, Statewide, national and even at times international in character.

A survey of Maryland county land use policies and plans reveals a varying awareness of important aspects of the wetlands situation. However, there are no mechanisms in the local decision-making processes to reflect or consider the regional significance of certain land use decisions.

Political and economic reality (Ch. VIII) suggests that it may be nearly impossible for local decision makers to resolve any conflict in favor of interests other than local. The burden for decisions of greater than local magnitude should not be borne alone by local governments. Neither should local citizens and their governments be deprived of their right to participate in matters concerning their destiny and their local environment.

With problems that are of more than local concern, there should be, in the interest of uniformity and recognizing the integrity of the entire region as a single unit, a device to reflect larger interests than simply local zoning laws. The device in the zoning sphere at the State level could serve as a guideline or umbrella to local shoreline zoning. It could be developed to reflect an overall, statewide perspective within which local zoning can spell out the details. "A device such as this may in some sense indicate a duplicate posture for such zoning, but it is felt that the totality of the Bay picture would dictate some uniformity and consistency with acceptance taking place at the local level. ${ }^{266}$ Clearly, what is needed are new forms of regional zoning or zoning review to resolve local-regional resource development conflicts. ${ }^{67}$

Part of the State's management problem with regard to coastal zone resources lies in the proliferation of legal, political and socio-economic institutions concerned with resource use and protection. There is a multiplicity of State, Federal and local governmental and non-government agencies-at all levels involved in the processes of planning and decision making-directly related to utilization of resources. Many of these agencies promote single-purpose goals and were established for specialized purposes. Some coordination exists between conflicting agencies, but this coordination needs imporvement. However, before there can be more meaningful and effective State inter-agency cooperation and coordination there has to be a prior mutually conceived and agreed to strategy. Because of the many legitimate but competing uses of the shoreline, a need exists for plans outlining management policies and plans for the land-water interface environment comprising the State's coastal zone. ${ }^{68}$

I. Shaw, Samuel P., and C. Gordon Fredine. Wetlands of the United States. USD1, Fish \& Wildlife Service, Circular 39. USGPO: Washington, 1956. Nicholson, W. R., and R. D. Van Duesen. Maryland marshes. Resource Study Report No. 6, Md. Dept. Research and Educ. Solomons, Md. 1954.

Shaw, Samuel P., and C. Gordon Fredine. Wetlands of Maryland. PittmanRobertson 1nvestigation Project No. W-30-R. 1956.

Shaw, Samuel P., and C. Gordon Fredine. Permanent water inventory - Maryland. ORBS, Fish and Wildlife Service, U.S.D.I., Atlanta, Georgia. 1956.

Stewart, Robert E. Waterfowl populations in the upper Chesapeake region. Special Sci. Rept. Wildlife No. 65. Fish and Wildlife Service, U.S.D.I., Washington, 1962.

Maryland State Planning Dept. Classification and inventory of habitats of Maryland. Baltimore. 1965.

2. Spinner, George P. A plan for the marine resources of the Atlantic coastal zone. American Geographical Society. 1969.

3. Farragut, Paul R. Chesapeake Bay: Shoreline utilization in the Baltimore Region. Regional Planning Council. Baltimore, Maryland. April, 1969. Taken from Smithsonian Institution. Proposal to the Old Dominion Foundation. Washington, D. C. March 20, 1967. 
4. Marcou, O'Leary and Associates. Land use plan, 1980. Anne Arundel County General Development Plan. Tech. Report. No. 4.. Washington. D. C. July, 1967.

5. Marcou, O'Leary and Associated. Long-range development guideline. Anne Arundel County General Development Plan. Tech. Report. No. 3., Washington, D. C. March, 1967.

6. Op. cit.

7. Marcou, O'Leary and Associated. Land use plan. Supra.

8. Marcou, O'Leary and Associated. Plan for open space and recreation areas. Anne Arundel County General Development Plan. Tech. Rept. No. 5. Washington, D. C. August, 1967.

9. Ibid.

10. Graves, Aubrey. "Rigid Restrictions on Marinas in Anne Arundel Proposed." The Washington Post. July 11, 1969; and "Marina Operations, Zoning Officer Clash." The Washington Post. July 18. 1969.

11. Baltimore County Office of Planning and Zoning. Preliminary 1980 guideplan. 1969.

12. Muncy, Dorothy A. Inventory of port-oriented land: Baltimore region. Maryland Department of Economic Development. 1963.

13. Baltimore County Department of Recreation and Parks and Office of Planning and Zoning. Baltimore County waterfront recreation survey. November, 1959; and

Baltimore County Department of Recreation and Parks. Recreation and parks in Baltimore County: A plan of action. 1966; and

Farragut, Paul R. Chesapeake Bay: Shoreline utilization in the Baltimore region. Regional Planning Council, Baltimore, Maryland. April, 1969.

14. Maryland State Planning Department. Comprehensive master plan, Calvert County, Maryland. Baltimore. 1967.

15. Werner-Dyer and Associates. Calvert County, Maryland - planning research. December, 1964.

16. Ibid.

17. Harland Bartholomew and Associates. Comprehensive plan, Caroline County, Maryland. April. 1968.

18. Ibid.

19. Op. cit.

20. Op. cit.

21. Blair and Stein Associates. Proposed master development plan for Cecil County, Maryland. Washington. D. C. October, 1962.

22. Ibid.
23. Marcou, O'Leary and Associates. Community facilities plan for Cecil County, Maryland. Washington, D. C. November, 1964.

24. Op. cit.

25. Harland Bartholomew and Associates. Comprehensive plan - Charles County, Maryland. Prepared for Charles County Planning Commission. Washington, D. C. August, 1966. rev. February, 1967.

26. Harland Bartholomew and Associates. Comprehensive plan - Charles County, Maryland, preliminary report - background for planning. Washington, D. C. May, 1965.

27. Op. cit.

28. Werner-Dyer \& Associates. Dorchester County, Maryland - plans and policies. July, 1963.

29. D.O.D. Directive No. 5500.5, May 24, 1965, and D.O.D. Instruction No. 4170.6. June 21. 1965.

30. Harland Bartholomew and Associates. General land use plan, part of the comprehensive plan, Harford County, Maryland. Washington. D. C. June, 1967.

31. Harland Bartholomew and Associates. Community facilities plan, part of the comprehensive plan, Harford County, Maryland. Washington, D. C. March, 1968.

32. Ibid.

33. Harland Bartholomew and Associates. The comprehensive plan for Kent County, Maryland. August, 1968.

34. Ibid.

35. Op. cit.

36. Maryland-National Capital Park and Planning Commission. Wetlands in the bi-county area. Research Dept. No. 8. October, 1967.

37. U. S. Department of Interior. The Nation's river. U.S.G.P.O.: Washington. 1968.

38. Maryland-National Capital Park and Planning Commission. Wetlands in the Bi-County Area. Research Rept. No. 8. October, 1967. From U.S.D.A., Soil Conservation Service, Soil Survey, Prince George's County, Maryland. U.S.G.P.O: Washington. 1967.

39. Ibid.

40. Black and Veatch. Solid waste disposal study for Washington metropolitan region. October, 1967.

41. Op. cit.

42. Maryland-National Capital Park and Planning Commission, supra.

43. Tarrant, Julian. Comprehensive master plan, Queen Anne's County, Maryland. 1965.

44. Ibid.

45. Op. cir. 
46. Op. cil.

47. Harland Bartholomew and Associates. Comprehensive plan, St. Mary's County. Washington, D. C. September, 1966.

48. Ibid.

49. Werner-Dyer and Associates. Background for planning, Somerset County, Maryland. March, 1963.

50. Werner-Dyer and Associates. Plan and policies, Somerset County, Maryland. Preliminary Report No. 7 (undated).

51. Salisbury Planning Commission and Wicomico County Planning and Zoning Commission. The Salisbury-Wicomico region: comprehensive plan. Tech. Rept. No. 3, July, 1961; and

The Salisbury-Wicomico region: existing land use and physical conditions. Tech. Rept. No. 1. May, 1960.

52. Report submitted to the United States Army Corps of Engineers on the savings and benefits accrued to the Salisbury-Wicomico community and the Eastern Shore resulting from an improved river channel up the Wicomico River to the City of Salisbury. Prepared by the Salisbury Chamber of Commerce, Salisbury Planning Commission and Wicomico County Planning and Zoning Commission. March 24, 1960.

53. Corps of Engineers. Baltimore district river and harbor project maps, 1968. December 31, 1968.

54. Tarrant, Julian. The Worcester County plan. Richmond, Va. 1966.

55. Ibid. Note: Emphasis is by the consultant.

56. Op. cit.

57. Harland Bartholomew and Associates. The comprehensive plan, Ocean City, Maryland. Prepared for athe Ocean City Planning and Zoning Commission. March, 1969.

58. Ibid.

59, 60, 61. Op. cit.

62. Op. cil. Nole: Emphasis is by the consultant.

63. Op. cit.

64. Tarrant, Julian, Op. cit. at 54.

65. Ibid.

66. O'Connell, James $J$. The role of state government in bay management. In Proceedings, Governor's Conference on Chesapeake Bay Wye Institute, September 12-13, 1968.

67. A useful document for this purpose has been produced by the Southeastern Wisconsin Regional Planning Commission entitled, Floodland and Shoreland Development Guide, Planning Guide No. 5, Waukesha, Wisc. November, 1968.
68. This is precisely the strategy thrust suggested in legislation introduced before Congress. The Coastal Zone Management Act (S. 582), as proposed, would initiate a comprehensive planning approach in order to develop a long-range master plan for the coastal zone. Development would be based on Federally approved master plans produced by a local coastal authority. 



\section{SURVEY OF WETLANDS ASSOCIATED ECONOMIC VALUES}





\section{FISHING}

\section{Commercial Seafood Industry}

The Maryland commercial seafood industry can be subdivided into several different sectors including: 1) harvesting; 2) processing and manufacturing; and 3) marketing.

Harvesting. About 9,000 fishermen, of whom some 6,000 have no other employment, harvest Maryland's fisheries resources. Approximately 6.500 boats and vessels are used in harvesting and transporting the catch.' The landed value of Maryland's commercial catch produced by these fishermen reached an all-time high of $\$ 16,913,000$ in 1967 , a recent year of completed fishery statistics. The total value of the 1967 catch was distributed among oysters $(66 \%)$, crabs (14\%), soft clams $(9 \%)$, fish $(9 \%)$, hard clams ( $1 \%)$, and other $(1 \%){ }^{2}$

Mollusks and crustaceans dominate the commercial lisheries of Maryland. Crabs, oysters and clams made up nearly 61 percent by weight and 91 percent by value of the 1967 harvest (Table VII-I).

A variety of fishes is landed in Maryland, but only a few species are of any great importance. In order of importance by weight, the principal species are menhaden, striped bass, puffer, alewife, white perch, shad, and flounders. By value, the order of importance is striped bass, white perch, flounders, shad, menhaden, puffer, and alewives. ${ }^{3}$
Oysters. Maryland leads the United States in oyster production. The landed value of the Maryland harvest in 1967 was over $\$ 11,000,000$ or more than one-third of the total value of the national harvest in that year. ${ }^{+}$Maryland enjoys oyster production advantages unequalled in any other state, including relative freedom from diseases, parasites, predators, pollution, and hurricanes. With an environment favorable to producing high quality oysters in a three to four year period there is one distinct disadvantage-the reproduction rate is very low in most State waters. "In only a few areas of very limited size is spatfall consistently heavy enough to produce seed oysters of "commercial" quality."

Blue crabs. Maryland is second only to Virginia in the harvest of blue crabs. Over 26 million pounds were landed in Maryland during 1967. The total Chesapeake Bay catch (Maryland \& Virginia combined) comprises about 50 percent of the total U.S. production of this species.

Soft shell clams. Maryland leads the nation in the production of soft shell clams. About 400,000 bushels were harvested in 1967. This figure is considerably lower than several preceding years due to unstable market conditions and extensive late summer mortality in 1966. Chesapeake Bay north of the Little Choptank River on the Eastern Shore and from the Potomac River north on the Western Shore is an almost ideal habitat for the soft

Table VII-1. Principal kinds of fish and shellfish in Maryland landings in 1967. By weight and estimated value, and their rankings.

\begin{tabular}{|c|c|c|c|c|}
\hline $\begin{array}{c}\text { Rank by } \\
\text { Weight }\end{array}$ & $\begin{array}{l}\text { Kind of Fish } \\
\text { or Shellfish }\end{array}$ & $\begin{array}{l}\text { Weight in } \\
\text { Millions } \\
\text { of Pounds }\end{array}$ & $\begin{array}{c}\text { Estimated Landed } \\
\text { Value in } \\
\text { Millions of Dollars }\end{array}$ & $\begin{array}{c}\text { Rank by } \\
\text { Value }\end{array}$ \\
\hline I & Blue Crabs & $26.79 \mathrm{I}$ & $\$ 2.448$ & 2 \\
\hline 2 & Oysters & 16.568 & 11.191 & I \\
\hline 3 & Clams & 5.394 & 1.770 & 3 \\
\hline 4 & Menhaden & 4. 134 & 0.077 & 8 \\
\hline 5 & Striped Bass & 4.072 & 0.665 & 4 \\
\hline 6 & Alewives & 2.327 & 0.039 & 9 \\
\hline 7 & Swellfish & 1.727 & 0.034 & 10 \\
\hline 8 & White Perch & I. 199 & 0.168 & 5 \\
\hline 9 & Shad & 0.884 & 0.091 & 7 \\
\hline \multirow[t]{2}{*}{10} & Flounders & 0.619 & 0.142 & 6 \\
\hline & Totals & 79.946 & $\$ 16.913$ & \\
\hline
\end{tabular}

Source: Dr. J. L. McHugh, Fisheries of Chesapeake Bay. In Proceedings, Governor's Conference on Chesapeake Bay, Wye Institute, September 12-13, 1968. 
shell clam. Growth is extremely rapid and reproduction almost invariably adequate.

Finfish. From available but perhaps inadequate statistical information, the volume of the finfish catch has increased during the past five years, but it has not been accompanied by an increase in value. Rather large increases in catch of several low value species such as alewives and menhaden have been offset by decreases in commercial catch of valuable species such as bluefish, flounder, croaker and shad. These decreases are attributed to reduced availability, changes in fishing methods, declines in oceanic fishing, and loss of markets due to restrictive legislation.

Maryland leads the United States in striped bass production. The striped bass catch usually accounts for about one-third of the total value of Maryland's finfish catch. The catch of this species has averaged 3,500,000 pounds since 1961, an increase of 11 percent over the annual average catch of $3,100,000$ pounds during the fiveyear period preceding 1961.)

Baltimore wholesale fish market. In 1964 some 30 wholesale seafood dealers in Baltimore sold about $\$ 19.2$ million worth of products and employed approximately 300 people. The typical wholesale dealer purchased about 20 to 25 percent of his products from the Chesapeake Bay area."

Striped bass is the leading finfish species, while the leading shellfish is blue crab which provides the largest portion of the total value moving through the Baltimore wholesale fish market.

Five percent of the total Maryland catch moved through the Baltimore wholesale fish market in 1966 (Table V11-2). This represents a decreasing trend from the 10 percent levels of $1961-62$, and probably reflects the growth of the Eastern Shore seafood processing and manufacturing industry as well as the growth of chain food stores. The remaining major portion of Maryland's fisheries harvest is either shipped directly to other market areas or processed and consumed locally.?

Processing and Manufacturing. Since only a small percentage of the total Maryland catch moves through the Baltimore market, dealership marketing, distributing, processing and manufacturing must be confined largely to tidewater areas of production. For example, nearly all of the clam processing plants are located in Talbot and Queen Anne's counties; crab processing plants are concentrated in Dorchester and Somerset counties; and the oyster processing plants are distributed fairly evenly between six Eastern Shore and three Southern Maryland counties. ${ }^{8}$

The output of Maryland's seafood processors has increased steadily over the last decade to a high of
Table V1I-2. Percentage of Maryland catch handled by the Baltimore wholesale fish market 1959-1966.

\begin{tabular}{lccr}
\hline Year & Finfish & Shell Fish & Total \\
\hline 1959 & $\ldots \ldots$ & $\ldots$ & percent........... \\
1960 & 19 & 4 & 9 \\
1961 & 20 & 4 & 9 \\
1962 & 22 & 4 & 10 \\
1963 & 21 & 5 & 10 \\
1964 & 17 & 4 & 9 \\
1965 & 10 & 4 & 6 \\
1966 & 8 & 4 & 5 \\
\hline
\end{tabular}

Source: Based on data from U. S. Department of Interior, Bureau of Commercial Fisheries, selected years.

$\$ 36.6$ million in 1965 (Table VII-3). ${ }^{9}$ The total output is composed of a large and varied group of highly processed items such as canned soups and chowders and frozen specialty products. At least $\$ 13.4$ million of the total value (in 1965) is derived from Maryland fishery resources production (oysters, clams and crabs) while the rest is based upon species imported for processing only.

The seafood processing industry provides employment to many residents of Maryland's tidewater counties. Employment during the past few years has fluctuated about a mean of $4,355 .^{10}$ It should here be noted that the seafood production and processing industry is most heavily concentrated in areas with the largest wetlands acreage. Since wetlands are essential to estuarine fishery resources, they must be considered a fundamental feature of the economy of both the Eastern Shore and Southern Maryland.

\section{SPORT OR RECREATIONAL FISHING}

Sport fisheries species. Striped bass is probably the most popular sport species. Spot, white perch, bluefish, shad, cobia, sea bass, flounders, gray and spotted sea trout, and several other species are popular also and contribute significantly to the sport fishing catch.

Accurate records on sport fishing have not been maintained. Estimates range from 10 to 40 percent of the corresponding commercial harvest of the same fishes. ${ }^{11}$ ln the case of the striped bass, however, it has been estimated that sports fishermen probably catch more than twice those taken by commercial fishermen. ${ }^{12}$

It is not always recognized that blue crabs and clams also support recreational fisheries. While no estimates have been made of the sport catch of these 
Table VI1-3. Output of the Maryland seafood processing industry, 1957-1965.

\begin{tabular}{|c|c|c|c|c|c|}
\hline Year & $\begin{array}{c}\text { Shucked } \\
\text { Oysters }\end{array}$ & $\begin{array}{c}\text { Shucked } \\
\text { Clams }\end{array}$ & $\begin{array}{l}\text { Cooked } \\
\text { Crab Meat }\end{array}$ & $\begin{array}{c}\text { Other } \\
\text { Products }\end{array}$ & Total \\
\hline \multicolumn{6}{|c|}{ (Thousand Dollars) } \\
\hline 1957 & $\$ 9,913$ & $\$ 896$ & $\$ 5,672$ & $\$ 9,005$ & $\$ 25,486$ \\
\hline 1958 & 7,963 & 1,123 & 4,568 & 11,266 & 24,920 \\
\hline 1959 & 8,316 & 1,323 & 4,332 & 11,490 & 25,461 \\
\hline 1960 & 8,086 & 1,587 & 3,867 & 17,399 & 30,939 \\
\hline 1961 & 7,203 & 1,777 & 4,412 & 21,488 & 34,880 \\
\hline 1962 & 7,664 & 1,964 & 4,794 & 21,454 & 35,876 \\
\hline 1963 & 6,544 & 2,439 & 4,502 & 22,574 & 36,059 \\
\hline 1964 & 5,803 & 2,653 & 4,426 & 22,340 & 35,222 \\
\hline 1965 & 5,681 & 2,737 & 4,963 & 23,222 & 36,603 \\
\hline
\end{tabular}

Source: U. S. Department of the Interior, Bureau of Commercial Fisheries.

Fishery Statistics of the United States.

species in Chesapeake Bay, it is believed to be considerable. ${ }^{13}$ This is indicated clearly by the results of a survey of the sport crab fishery in the Galveston Bay (Texas) estuarine system which disclosed that the total weight of a summer's month sport catch of crabs was equivalent to 15 percent of the reported commercial catch for the same period. ${ }^{14}$

Economic Significance of Sport Fishing. One survey conducted on the Patuxent estuary showed that more than 71,000 sport fishing trips were made to that estuary during 1963 . Expenditures associated with this activity approached $\$ 500,000$, not counting the investment in boats, permanent tackle and similar appertenances. ${ }^{15}$ These figures indicate an average per day expenditure of $\$ 7.00$ for sport fishing.

Another study concentrated on sport fishing activity in an area 20 miles above to 20 miles below the Bay Bridge ( 340 square miles of open Bay surface water). A preliminary estimate of angling expenditures in this area (based on 231,000 fisherman-days multiplied by resident and non-resident average daily expenditures) totalled $\$ 1,790,000$ for the June through September, 1962 or approximately $\$ 7.00$ per fisherman-day. ${ }^{16}$

Current estimates on tidal or saltwater angling participation in Maryland suggest a range of 200,000 to 300,000 fishermen annually. ${ }^{17}$ The exact number is unknown since no license is required for fishing in the tidal waters of the State. However, these numbers coincide with 30 year old records on sport fishing participation, ${ }^{18}$ suggesting that present activity is conservatively estimated.

Based on past estimates, the present total annual expenditure by each sport fisherman is at least $\$ 100$, which sum does not include boat and boat equipment costs. ${ }^{1920}$ Taking into account the participation rate, the potential expenditure of Maryland saltwater anglers is at least $\$ 20$ million annually, excluding major equipment purchase.

Earlier studies on sport fishing economics indicate that the $\$ 20$ million annual estimate may be appropriate, at least as a minimum figure. For example, total 1952 expenditures were estimated to be $\$ 9.6$ million of which $\$ 7$ million was spent exclusively in Maryland by 100,500 different tidewater fishermen each making 10 fishing trips per year (Table VII 4$)^{2}{ }^{1}$ These figures exclude the Atlantic Ocean sport fishery expenditures. By doubling the number of tidewater sport fishermen from 100,500 to 201,000 over the 17-year period 1952-69 and applying a per capita annual expenditure of $\$ 100$, the product is $\$ 20.1$ million. This estimated growth coincides with the reported five to seven percent annual increases in saltwater angling participation. 2223

Businesses that are the recipients of sport fishing expenditures are the boat industry, marinas, sporting goods, bait dealers, and a miscellaneous grouping of manufacturers, distributors, retailers and employees of numerous small miscellaneous items purchased by sport fishermen. There are also secondary businesses that receive expenditures related to sport fishing for foods and beverages, lodging, transportation, and miscellaneous items. Finally, it should be noted with emphasis that it is exceedingly difficult to evaluate the total economic value of sport fishing derived from Maryland's tidewaters because of the numerous and diverse businesses which benefit from expenditures associated with this activity and the lack of accurate recent data on sport fishing participation. 
Table VII-4. Estimated total expenditures of sportsmen fishing in the Maryland tidewaters during 1952, and amounts spent in Maryland, by type of expense.*

\begin{tabular}{|c|c|c|c|}
\hline \multirow[b]{2}{*}{ Expense category' } & \multirow{2}{*}{$\begin{array}{c}\text { Total } \\
\text { expenditure }\end{array}$} & \multicolumn{2}{|c|}{ Spent in Maryland } \\
\hline & & $\%$ of Total & Amount \\
\hline$\overline{\text { Boat rental fees }}$ & $\overline{\$ 445,000}$ & 100 & $\$ 445,000$ \\
\hline Bait purchases & $1,219,000$ & 90 & $1,097,000$ \\
\hline Food and beverages & $1,705,000$ & 80 & $1,364,000$ \\
\hline Lodgings & 258,000 & 100 & 258,000 \\
\hline Transportation & $1,855,000$ & 60 & $1,113,000$ \\
\hline Fishing Tackle & $1,055,000$ & 50 & 527,000 \\
\hline $\begin{array}{l}\text { Special clothing } \\
\text { and equipment }\end{array}$ & 639,000 & 50 & 319,500 \\
\hline Miscellaneous & $2,430,000$ & 80 & $1,944,000$ \\
\hline Total & $\$ 9,606,000$ & $73.6 \%$ & $\$ 7,068,100$ \\
\hline
\end{tabular}

*Source: Tidewater Sport Fishery by R. D. Buzzel] and E. T. Walker, Maryland Department Research and Education, Resource Study Report No. 4, Solomons, Md. March, 1954.

The conservatively estimated monetary values presented do not, of course, include the values that accrue to sportsmen from days spent just being outdoors

"There is no way to appraise values that go with angling, such as painstaking preparation, patience, application of cunning, knowledge of fish life and habits, adjustment to meteorology conditions, recreation, sportsmanship and, last but not least, the 'proper frame of mind,' and similar points that characterize fishing and fisherman. Even fish stories have their place and value." 24

\section{BOATING}

This section deals with certain aspects of boating that are associated either directly or indirectly with wetlands. The most tangible of these are boating use for sport and commercial fishing. A 1965 study, Marinas in Maryland, ${ }^{25}$ showed that 93 percent of berthed boats were used for pleasure while seven percent were used for commercial purposes. Of the marina-kept pleasure boats, 51 percent were used primarily for cruising, 36 percent for fishing, and the remaining 13 percent for water skiing, racing and other purposes. Marina-kept commercial boats were used almost exclusively for fishing, either commercial or sport.

\section{Service Facilities-Marinas}

In 1965, total investment in Maryland's 308 marinas was $\$ 35$ million. The amount invested in a single marina ranged from $\$ 1,000$ to $\$ 2.5$ million, while the average investment for all marinas was $\$ 104,000$ (Table VIl-5). ${ }^{\text {2h }}$

A sampling of the average annual revenue per marina was approximately $\$ 22,500$. Principal revenue sources were slip rentals and fuel and oil sales which averaged $\$ 18.400$ and $\$ 4.300$, respectively. ${ }^{27}$ The average net revenues are not properly representative, however, because of the disparity in size, operation and ownership characteristics among marinas.

Small marinas are organized usually as sole proprietorships and are frequently owner-operated, with the owner living on the property and employing family labor and/or neighbors. They are a part-time business for many small marina owners who work full-time away from home and operate the marina as a source of extra income. Since peak business occurs on weekends and holidays, the owner is able to utilize his free time to tend the marina business. Also, there are many retired or semi-retired proprietors who operate small marinas, in which instance marina revenues provide a supplementary source of income.

At the opposite end of the spectrum are the larger marinas which are usually corporations and multienterprise complexes. A variety of services and extra attractions are offered on a large volume basis. Such marinas employ about 2,200 persons both full and parttime during the month of maximum employment. Of these, approximately 1,700 are employed full-time with the remaining 500 employed part-time. ${ }^{28}$ Many of the full-time employees are skilled or semi-skilled, e. g., boat engine mechanics, boat carpenters, painters and finishers, lift operators, dockmasters and dredge operators. Most of the part-time employees are unskilled, e. g., dock personnel who pump gasoline and provide other minor boat care and food services. 
Table VII-5. Current capital investment to marinas by size, 1965.

\begin{tabular}{|c|c|c|c|c|}
\hline $\begin{array}{l}\text { Number of slips } \\
\text { and moorings }\end{array}$ & $\begin{array}{l}\text { Number } \\
\text { reporting }\end{array}$ & $\begin{array}{c}\text { Current } \\
\text { investment } \\
\text { of reporling } \\
\text { marinas }\end{array}$ & $\begin{array}{l}\text { Imvestment } \\
\text { pere marina }\end{array}$ & $\begin{array}{c}\text { Estimated } \\
\text { current } \\
\text { total } \\
\text { investment }\end{array}$ \\
\hline $10-89$ & 162 & $\$ 11,615,700$ & $\$ 71,702$ & $\$ 16,204,628$ \\
\hline $90-139$ & 34 & $5,860,000$ & 172,353 & $7,755,883$ \\
\hline $140-189$ & 10 & $2,700,000$ & 270,000 & $5,400,000$ \\
\hline $190-229$ & 6 & $1,930,000$ & 321,667 & $3,216,668$ \\
\hline 230 and over & $\mathrm{b}$ & $\mathrm{b}$ & $\mathrm{b}$ & $2,251,669$ \\
\hline Tolat and average & 212 & $\$ 22,105,700$ & $\$ 104,272$ & $\$ 34,828,848$ \\
\hline
\end{tabular}

a Estimated investment is the arithmetic mean of responding firms in each size group multiplied by the total number of marinas in each group.

h lesss than three firms responding, and the estinate is based on the mean of the next smaller sise group.

Source: Lyon, Gale H., et al. Economic analysis of marinas in Maryland. Agric. Expt. Sta., Dept. of Agric. Econ. Contribution No. 4100, Univ. Md. College Park, April, 1969.

\section{Economic Relationship of Boating and Wetlands}

The total number of boats, both registered and unregistered, used primarily for fishing in Maryland is unknown due to a lack of data. Therefore, reliable documentation of the economic values of boating which could legitimately be att ached to wetlands either directly or indirectly is a formidable task. However, based upon certain assumptions regarding boating statistics a very tenative evaluation may be made.

For example, application of the marina study's boating use percentages to the 1969 boat registration (Table VII-6) produces a figure of 25,100 boats that are used primarily for fishing (pleasure and commercial combined). Since all registered boats are not berthed at marinas, the estimate probably understates actual usage figures for fishing for the following reasons:

1) Low minimum horsepower limitation requiring registration $(7.5 \mathrm{hp})$ would seem to insure that nearly every motor-powered boat used for fishing is registered. However, many privately owner motor-powered boat are trailer-stored, thus they would not be marina kept boats.

2) Regarding non-motor powered boats, sailboats over 25 feet long must be registered. A sailboat, particularly of larger size, is apt to be very awkward to handle for trailer stowage. Consequently, a higher percentage of marina kept boats are probably registered and non-registered sailboats than motor-powered boats.

It is clearly conceivable that if appropriate values could be calculated and allocated properly to boats and boat accessories there would be another multi-million dollar value attributable to wetlands. Well planned research regarding the economics of recreational boating in Maryland should be accorded a high priority by interested researchers and academicians.

\section{HUNTING}

The Chesapeake Bay Region is an important area to the migratory waterfowl of the Atlantic Flyway. Detailed documentation of the total value of waterfowl hunting in Maryland has never been successfully compiled. Statistics on licenses, numbers of duck blinds, and user-days present in a preliminary fashion some of the economic value of waterfowl hunting in Maryland. However, intangible, non-market values associated with all outdoor recreation are not easily quantifiable.

\section{Hunter Participation}

Hunter participation values include number of hunters, amount of use (user-days), hunter expenditures, and the size of the waterfowl and wildlife harvest. For example, about 35,000 waterf owl hunters (7,000 non-resident) expended 302,000 user-days in the Bay area in 1967. This number of hunters represents about 20 percent of the total licenses issued and about 25 percent (over $\$ 200,000$ ) of the total value of licenses issued in 1966-67 (Table VII-7). ${ }^{29}$ In addition, these hunters purchased over 2,600 duck blind licenses which produced a revenue exceeding $\$ 13,000$ (Table VII-8). From the increase in the number of duck blind 
Table VII-6 Summary of Maryland boat registration 1963-1969.

\begin{tabular}{|c|c|c|c|c|}
\hline \multirow{2}{*}{$\frac{\text { Year and }}{\text { Owmer's residence }}$} & \multicolumn{3}{|c|}{ Type of boat } & \multirow{2}{*}{$\begin{array}{l}\text { Summary } \\
\text { Totals }\end{array}$} \\
\hline & Pleasure & Commercial & other & \\
\hline June 30,1963 & & & & \\
\hline $\begin{array}{l}\text { Maryland } \\
\text { Out of State }\end{array}$ & $\begin{array}{r}33,468 \\
8,353\end{array}$ & $\begin{array}{r}2,803 \\
181\end{array}$ & 347 & $\begin{array}{r}36,612 \\
8,538\end{array}$ \\
\hline Total & 41,821 & 2,984 & 345 & 45,150 \\
\hline June 30,1964 & & & & \\
\hline $\begin{array}{l}\text { Maryland } \\
\text { Out of State }\end{array}$ & $\begin{array}{l}43,820 \\
10,487\end{array}$ & $\begin{array}{r}3,609 \\
239\end{array}$ & $\begin{array}{r}344 \\
4\end{array}$ & $\begin{array}{l}47,773 \\
10,730\end{array}$ \\
\hline Tota? & 54,307 & 3,848 & 348 & 58,503 \\
\hline June 30,1965 & & & & \\
\hline $\begin{array}{l}\text { Maryland } \\
\text { Out of State }\end{array}$ & $\begin{array}{l}49,528 \\
12,111\end{array}$ & $\begin{array}{r}3,948 \\
273\end{array}$ & $\begin{array}{r}343 \\
3\end{array}$ & $\begin{array}{l}53,819 \\
12,337\end{array}$ \\
\hline Total & 62,206 & 4,221 & 346 & 66,773 \\
\hline December 31,1965 & & & & \\
\hline $\begin{array}{l}\text { Maryland } \\
\text { Out of state }\end{array}$ & $\begin{array}{l}57,944 \\
13,917\end{array}$ & $\begin{array}{r}4,728 \\
316\end{array}$ & $\begin{array}{r}458 \\
5\end{array}$ & $\begin{array}{l}63,130 \\
14,230\end{array}$ \\
\hline Total & $\overline{71,861}$ & $\overline{5,044}$ & $\overline{463}$ & 77,368 \\
\hline December 31, 1966 & & & & \\
\hline $\begin{array}{l}\text { Maryland } \\
\text { Out of State }\end{array}$ & $\begin{array}{l}47,662 \\
10,257\end{array}$ & $\begin{array}{r}3,593 \\
210\end{array}$ & $\begin{array}{r}245 \\
0\end{array}$ & $\begin{array}{l}51,500 \\
10,467\end{array}$ \\
\hline Total & 57,919 & $\overline{3,803}$ & $\overline{245}$ & $\overline{61,967}$ \\
\hline December 31,1967 & & & & \\
\hline $\begin{array}{l}\text { Maryland } \\
\text { Out of State } \\
\text { Total }\end{array}$ & $\begin{array}{l}51,034 \\
10,157 \\
\frac{62,091}{10}\end{array}$ & $\begin{array}{r}3,718 \\
195 \\
3,913\end{array}$ & $\begin{array}{r}317 \\
\frac{3}{320}\end{array}$ & $\begin{array}{l}55,969 \\
10,355 \\
66.321\end{array}$ \\
\hline December 31,1968 & & & & \\
\hline $\begin{array}{l}\text { Maryland } \\
\text { Out of State }\end{array}$ & $\begin{array}{r}52,916 \\
9,570\end{array}$ & $\begin{array}{l}3,633 \\
174\end{array}$ & $\begin{array}{r}313 \\
4\end{array}$ & $\begin{array}{r}56,907 \\
9,748 \\
\end{array}$ \\
\hline Total & $\overline{62,531}$ & 3,807 & 317 & $\overline{66,655}$ \\
\hline $\begin{array}{l}\text { December } 31,1969 \\
\text { Maryland } \\
\text { Out of State } \\
\text { Total }\end{array}$ & $\begin{array}{r}51,001 \\
9,011 \\
60,012\end{array}$ & $\begin{array}{r}3,354 \\
181 \\
3,535\end{array}$ & $\begin{array}{r}1,547 \\
86 \\
1,633\end{array}$ & $\begin{array}{r}55,902 \\
9,278 \\
65,180\end{array}$ \\
\hline
\end{tabular}




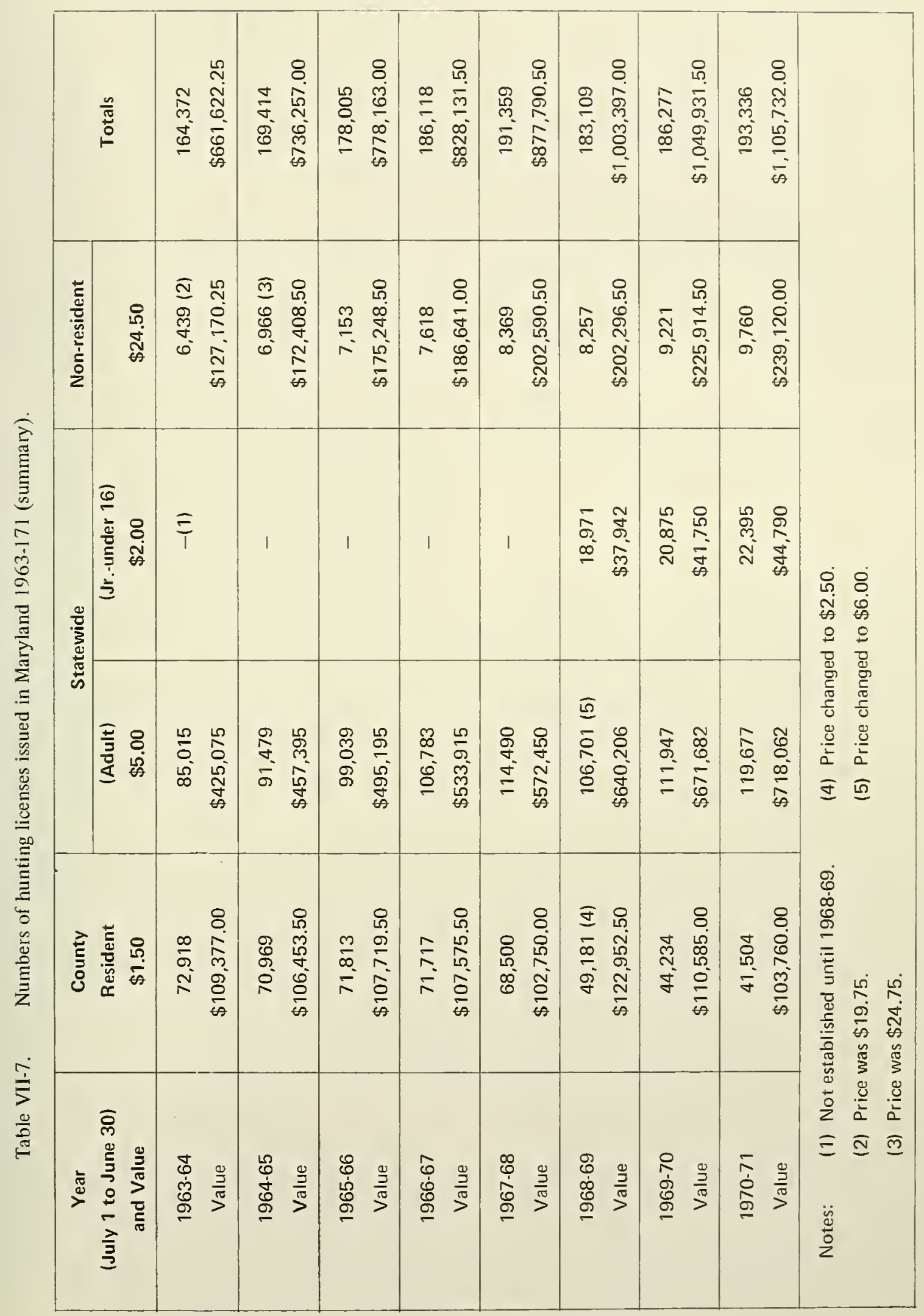


licenses issued from 1966 to 1970 , it is clear that there is significant, continuing interest and participation in waterfowl hunting in Maryland (Table VlI-8).

The 1965 National Survey of Fishing and Hunting reported that a hunter's expenditures for food, lodging, transportation, equipment, licenses, etc., averaged $\$ 82.54$ annually. ${ }^{30}$ Applying that average expenditure to the 35,000 licensed waterfowl hunters (Md.-1967) will produce a total expenditure exceeding \$2.2 million annually. However, much of Maryland waterfowl hunting is done under a club membership or leasing arrangement. This increases expenditures considerably. For example, estimates of the total cost to the average Maryland hunter are in a range of $\$ 300$ to $\$ 500$ annually. This cost indicates an annual economic value of $\$ 10.5$ million to $\$ 17.5$ million associated with waterfowl hunting. ${ }^{31}$

In addition to waterfowl hunting, rail and jacksnipe hunting totaled about 2,000 user-days, which at approximately $\$ 30$ per user-day, provides an additional annual economic value totalling $\$ 60,000 .^{32}$

\section{Hunting Leases}

Much of the Maryland waterfowl hunting is based upon a lease system due to property and riparian rights and extensive "No Trespassing" land closures backed by vigorous enforcement and prosecution by land owners. The tenure of lease varies. A National Recreation Survey conducted in 1962 as a part of the ORRRC studies reported that most leases for small game and waterfowl (34\%) are for periods of less than one month. However, a large proportion $(26 \%)$ are for periods of 1 to 5 years. ${ }^{33}$

The precise extent of hunting on property obtained through a purchase or lease arrangement is unknown. However, it has been reported that "the Chesapeake and Delaware Bay regions (Delaware, Maryland, Virginia) are the most intensly hunted part of the Atlantic Flyway. "At times it seems that every spot of water and field of grain is a site for duck or goose hunting. "Very few water areas are managed, but upland areas are often managed with goose hunting in view. "Control of shoreline is a key to evaluating duck-hunting sites more than the marsh that may be associated. "Owner-guest and membership hunting on leased lands dominate the area hunting." 34

A 1965 survey on about five percent of Maryland's shoreline indicated a minimum of about 2,500 private waterfowl clubs. ${ }^{35}$ These clubs operate with fixed memberships, include guest arrangements or are independent businesses that solicit lease hunter customers.
There are no estimates available on the expenditures and revenues derived or the extent of wetland related rents developed by this type of enterprise. One recent local advertising brochure on lease hunting quoted rates of $\$ 50.00 / \mathrm{d}$ ay for one person, $\$ 45.00 /$ day each for parties of two, $\$ 40.00 /$ day each for parties of three, and $\$ 35.00 /$ day each for parties of four, including guide, for duck and goose blind leases on the Eastern Shore. Leases were available by day, week or season.

\section{Hunter's Harvest}

Data from a Maryland Hunter Survey conducted by the Maryland Fish and Wildlife Administration indicate that hunters bag about 150,000 ducks and coot, 110,000 geese, and 2,000 rails and jacksnipes annually. The total value derived from this harvest is probably inestimable.

The present and future overall economic value of waterfowl is probably greater than imagined by most interested and disinterested persons. For example, an economic study conducted in Missouri calculated that the net benefits derived from a hunting a Canada goose population of 120,000 concentrated by one refuge on the Mississippi Flyway was over $\$ 20$ million. ${ }^{36}$ When this asset was capitalized at only 2.5 percent it became $\$ 120,497,500$ ! Using a six percent interest rate, the value of future returns was calculated to be $\$ 341,873$,$908 .^{37}$ Interestingly, the Atlantic Flyway Canada goose population of migrating and wintering birds in Maryland during the past few years has been averaging about 500,000 birds as compared with the 120,000 figured cited above. In 1969, about 135,000 Canada geese were harvested in Maryland or several thousand more than the population reported in the Missouri study. ${ }^{38}$

Besides attracting these birds into Maryland for hunters to bag, the State's water and wetlands complex also provides essential food and shelter for wintering and migrating waterfowl and wildlife. Without maintenance of brood stocks wildlife would become nonrenewable resources, no longer available for hunting and sustaining this sector of outdoor recreation. In addition, there are direct but not easily measurable values that accrue to sportsman from days spent outdoors pursuing waterfowl.

\section{FUR TRAPPING}

Trappers and hunters took a total of over 224,000 furbearer animals during the 1968-69 season, mostly from lower Eastern Shore wetlands. The pelts had a combined value of $\$ 431,665$ (Table Vll-9). Since much of the furbearer harvest is done for sport rather than as a full-time business venture, it is difficult to evaluate completely the economic values derived from this 


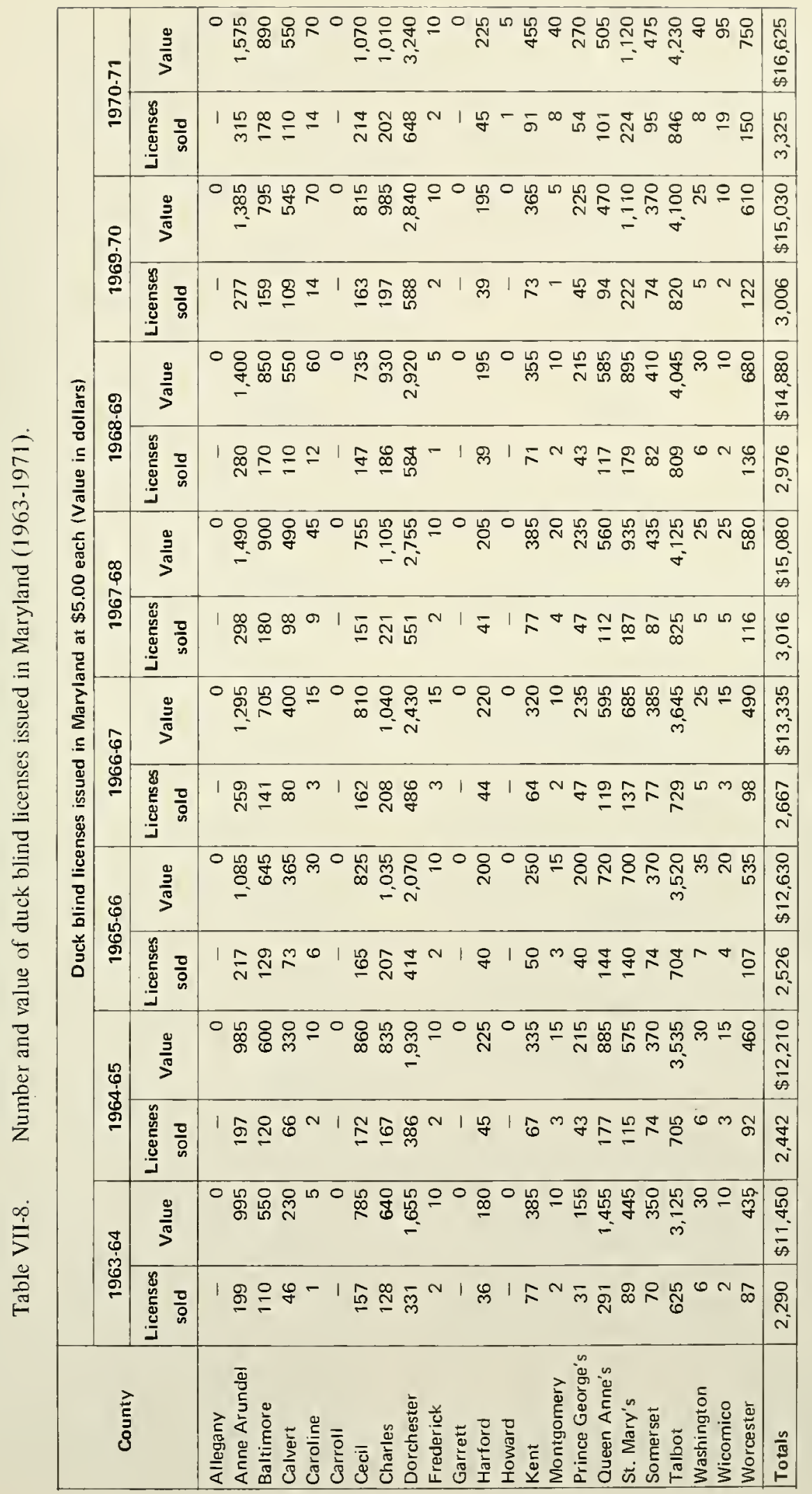


activity. The reported income from sale of furbearers pelts by an estimated 1,000 trappers averages $\$ 250,000$ annually.

\begin{tabular}{lrc}
\hline $\begin{array}{r}\text { Table V11-9. List of the furbearer harvest in } \\
\text { species and total dollar value of pelts. }\end{array}$ \\
\hline Species & $\begin{array}{r}\text { Vumber } \\
\text { of pelts }\end{array}$ & $\begin{array}{c}\text { Dollar } \\
\text { value* }\end{array}$ \\
\hline Beaver & 245 & - \\
Fox & 738 & - \\
Mink & 143 & - \\
Muskrat & 212,227 & - \\
Nutria & 269 & - \\
Opossum & 1,098 & - \\
Raccoon & 10,158 & - \\
Skunk & 75 & - \\
Weasel & 42 & - \\
\hline Totals & 224,990 & $\$ 431,665.44$ \\
\hline
\end{tabular}

* Data not available on a species basis.

Source: Maryland Fish and Wildlife Administration.

\section{INTANGIBLE VALUES}

There are significant uses of wetlands by humans and animal communities that have important nonpecuniary value. These uses are non-consumptive in the sense that essentially nothing in the resource base is either captured, removed or disturbed.

Wetlands are a specific type of area within all other natural communities. There are highly relevant values and uses of natural areas for resource management, scientific study and science education in general. Because of their transitional location between land and water, wetlands have an important esthetic function and serve as an open-space buffer zone between land and water. As such, these areas contain much of the remaining undeveloped, natural shoreline areas in the State.

\section{Nature Appreciation}

This human use of wildlife resources is steadily increasing. Observation, nature walks and photography are among the non-consumptive recreational uses of wildlife and their habitats that provide great enjoyment. Substantial numbers of people participate in these activities. A brief survey of conservation and outdoor recreation organizations in Maryland suggests a membership of at least 94,000 members (Table VII-10).

\section{Natural Areas}

Many State wetlands have been classified as unique natural areas. These are "areas where at present natural processes predominate and are not significantly in- fluenced by either deliverate manipulation or accidental interference by man." 39 The varying types of wetlands described in the classification system (Ch. IV) are based on differing vegetation types, typical plant species, levels of tidal inundation and water quality which determine the type of plant community. These differences provide the primary basis for distinction or characterization of each area and their value to resource management, scientific study and education.

Resource Management. Natural areas contribute to resource management by providing a basis for a better understanding of the effects on plants and animals when man influences the natural forces within the environment. Undisturbed (natural) areas serve as monitors (contrasting areas) for measuring the build-up and effects of pesticides, herbicides and other pollutants. Thus, natural areas serve as important control sites in providing basic standards against which resource development programs can be evaluated. Natural areas also serve as research sites for projects which lead to development of managerial alternatives in land and water resources use planning.

A protected natural area may ensure the preservation of unusual and valuable natural phenomena, enhance genetic diversity of flora and fauna by protecting gene pools, ${ }^{40}$ and also may serve in providing valuable foresight into the processes of natural change and development through time.

Scientific research and education. The great importance of natural areas for fundamental biological research and education has been documented and emphasized elsewhere (as well as in this study). ${ }^{41}$ Natural areas are needed not only for research in biologic disciplines such as taxonomy, ecology, and biogeography, but for many physical sciences like meteorology, geology, paleontology, hydrology and soil science. An extensive bibliography compiled by a committee of the American Association for the Advancement of Science indicates that natural areas are being widely used for studies in these sciences. ${ }^{42}$

Natural areas can also serve an especially valuable function as focal points for interdisciplinary research by specialists. When scientific specialists and other technical experts blend their efforts in the study of a given natural area with respect to both similar and dissimilar problems, they are likely to produce significant new understandings of natural and maninfluenced systems.

Natural areas are often utilized for science education because of their natural exhibitions of plants and animals. Such environmental displays are useful for demonstrating the ecological roles of different species 
Table V11-10. Partial listing of conservation and outdoor recreation organizations and groups in Maryland (with approximate membership).

\section{Organization}

Audubon Naturalist Society (Cen. Atlantic Sts.)

Baltimore Campers Association

Canoe Cruisers Association

Casual Garden Club

Chesapeake Bay Foundation

Chesapeake Environmental Protection Association

Chesapeake Rifle and Pistol Association

Chesapeake Rock Fish Association

Citizens Committee for Soldiers Delight Park

Committee for Maryland Trail Riding

Committee to Preserve Assateague

Cylburn Wildflower Preserve and Garden Center

Approximate

Deer Creek Watershed Association

$\frac{\text { membership }}{*}$

Ecology Action

Evergreen Garden Club of Harford County

Federated Garden Clubs of Maryland

Frederick County Sportsman's Council

Garrison Rifle and Revolver Club

Izaak Walton League of America (Md. State Div.)

League of Maryland Horsemen

Maryland Fly Anglers

Maryland Ornithological Society

Maryland Recreation and Parks Society

Maryland Wetlands Committee

Maryland Wilderness Association

Maryland State and D. C. Rifle and Pistol Assn.

Mountain Club of Maryland

Monocacy Canoe Club

Moyaone Association

National Rifle Association

National Wildlife Federation (Maryland)

Natural Area Council

Nature Conservancy

Naval Ordnance Laboratory Fishing Club

Potomac Appalachian Trail Club

Potomac River Association of St. Mary's County

Severn River Watershed Association

Sierra Club, Southeast Chapter

Soldiers Delight Conservation

Western Maryland Wildlife Federation

Wilderness Society

Wildlands Committee

Wildlife Management Institute
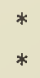

*

*

*

*No data obtained 
in diverse habitats. These biotic communities afford students the opportunity to learn about natural cycles and the interactions between living organisms.

While it is indeed difficult to calculate or impute the economic value(s) of education in general and natural science research, education and field studies in particular, one recent attempt was made in Georgia. The future educational value was estimated at over one million dollars annually for one specific Georgia river swamp ecosystem. ${ }^{43}$ Such benefits will, of course, vary depending upon the character of the wetland and the size of the student population it serves. The potential educational values attaching to wetlands are by no means inconsequential.

Scenic and esthetic values. The natural characteristics of wetlands determine that they occur in a transitional location between uplands and open surface water areas. The land-water interface has always had a magnetic, fasinating attraction for man. ln earlier colonial and pioneering days, waterfront locales initially constituted civilized sites because of their convenience to water transportation and ready availability of water both for consumptive use and waste discharge.

While living at the water's edge may not be essential to man's survival today, land and water together have one undiminishing value to our society an especially pleasing environment deriving from open space and exceptional natural beauty. It is thus significant that seventy-five percent of the Nation's population lives in the coastal zone area-"the margin where land and water meet and interact." 44

The State of Maryland recognized the scenic and esthetic aspects of shorelines with passage of the Scenic Rivers Act, Chapter 85, Laws of Maryland, 1968. The purpose of this Act, stated generally, is to establish a management program that will preserve scenic quality, protect water quality and fulfill vital conservation of land resources adjacent to many of the rivers and estuarine areas of the State. Wetlands are mentioned specifically in Section 761 (a) of Article 66C (Natural Resources), Annotated Code of Maryland for possible incorporation in the State's scenic rivers system. In follow-up directives, the Scenic Rivers Review Board reported on the initial rivers to be considered for such designation. The report, Scenic Rivers in Maryland, ${ }^{45}$ Summarizes the findings of the Board and outlines recommended policies pertaining to the Patuxent, Pocomoke, Youghiogheny, Wicomico (Charles County), and Severn Rivers and their related land resources, including wetlands. As a consequence, Chapter 749 (H. B. 1303) of the 1971 Laws of Maryland was enacted by the Maryland General Assembly. This Act added new sections to the existing law and designated those rivers and their tributaries as the initial components of the State Scenic Rivers System. It should be further noted that the new law specifically states that "(I)n the exercise of their responsibilities as may be related to a designated scenic river, all State agencies shall recognize the intent of the scenic rivers program and shall take whatever action is necessary to protect and enhance the scenic qualities of the river so designated" (Sec. 765).

Suminary on Intangible Values. The major purpose of the Catalog of Natural Areas in Maryland ${ }^{46}$ was to present basic information on certain natura! areas in the State. The areas presented were selected because of their existing natural or unaltered condition, scienic or esthetic value, ecological communities or their uniqueness compared to the remaining or surrounding environment. Of areas that qualified, many encompassed the coastal zone land and water interface because of natural scenic values. Two hundred and forty-five (245) wetlands totalling approximately 159,700 acres were selected as an essential part of the State's important remaining vestiges of natural landscape. These areas are distributed throughout the entire State, although most of them are in the tidewater region (Table VII-11).

Additionally, 98 wetlands are or have been utilized for natural science research and education. Many of these areas are coincident with designated natural areas. The greatest concentration is on the Patuxent River where extensive estuarine research and educational programs are conducted by the staff of the University of Maryland's Chesapeake Biological Laboratory at Solomons, Maryland (Table VII-12).

\section{SUMMARY OF ECONOMIC AND OTHER VALUES}

Significant benefits in terms of both monetary and intangible values are derived from wetlands. The relationship between some benefits and wetlands is not readily discernible, as in the case of marinas. Many boats are used primarily for fishing, but the contribution of wetlands to fisheries resources probably is not fully appreciated by marina owners and boat fishermen because of the complex life histories and intricate food chains of many species.

Waterfowl hunting is more obvious since this activity frequently occurs on wetlands and hunters naturally associate waterfowl with wetlands. Thus, wetlands and their importance as a supportive habitat to waterfowl is more readily perceived.

Any attempt to quantify the economic contributions of wetlands is severely limited by a lack of data 
Table V11-11. List of numbers of wetland areas, acreage and vulnerability included in the Catalog of Natural Areas in Maryland.

\begin{tabular}{|c|c|c|c|c|c|}
\hline \multirow[t]{2}{*}{ County } & \multirow{2}{*}{$\begin{array}{l}\text { No. of } \\
\text { areas }\end{array}$} & \multicolumn{3}{|c|}{ Acreage and vulnerability } & \multirow{2}{*}{$\begin{array}{l}\text { Total } \\
\text { acres }\end{array}$} \\
\hline & & $T$ & II & $I I I$ & \\
\hline Allegany & 0 & - & - & - & 0 \\
\hline Anne Arundel & 19 & 679 & 1,395 & 794 & 2,868 \\
\hline Baltimore City & 0 & - & - & - & 0 \\
\hline Baltimore & 6 & 101 & 151 & 512 & 764 \\
\hline Calvert & 27 & 123 & 1,868 & - & 1,991 \\
\hline Caroline & 18 & 256 & 1,394 & 49 & 1,699 \\
\hline Carroll & 0 & - & - & - & 0 \\
\hline Cecil & 3 & 21 & 85 & - & 106 \\
\hline Charles & 9 & - & 5,212 & 642 & 5,854 \\
\hline Dorchester & 20 & 50,351 & 8,846 & 25,565 & 84,762 \\
\hline Frederick & 0 & - & - & - & 0 \\
\hline Garrett & 6 & 620 & 262 & - & 882 \\
\hline Harford & 22 & 189 & 1,425 & 6,099 & 7,713 \\
\hline Howard & 0 & - & - & - & 0 \\
\hline Kent & 8 & 166 & 378 & 816 & 1,360 \\
\hline Montgomery & 0 & - & & 98 & 0 \\
\hline Prince George's & 17 & 74 & 3,201 & - & 3,373 \\
\hline Queen Anne's & 25 & 1,276 & 228 & 248 & 1,752 \\
\hline St. Mary's & 3 & 148 & - & 10 & 158 \\
\hline Somerset & 13 & 4,179 & 22,186 & 2,067 & 28,432 \\
\hline Talbot & 25 & 336 & 2,506 & 526 & 3,368 \\
\hline Washington & 0 & - & - & - & 0 \\
\hline Wicomico & 6 & 4,246 & 104 & & 4,350 \\
\hline Worcester & 18 & 5,723 & 3,042 & 1,522 & 10,287 \\
\hline Tolals & 245 & 68,488 & 52,283 & 38,948 & 159,719 \\
\hline
\end{tabular}

and must, therefore depend upon "best" estimates. However, the total of estimated values associated with or related to wetlands is impressive. The total for all of the major identifiable economic benefits associated with Maryland's wetland-estuarine complex is estimated conservatively at $\$ 64.5$ million annually (Table VII-13). This figure does not take into account the indirect benefits which accrue from multiplier effects.

Previous attempts at establishing the economic contributions of estuarine areas and wetlands have produced a wide range of values. The following range of estuary and wetland economic values are here cited in order to provide some 'yardstick' against which can be measured the above assessment or estimate of economic values associated with Maryland's estuaries and wetlands.

1. Maine estuaries. A scientifically managed estuarine area produced a per acre harvest of shellfish and bait worms worth $\$ 33,563$ annually. Where the stocks were unmanaged, however, the annual crop value per acre amounted to only $\$ 15,750 .^{47}$

2. Massachusetts estuaries. The 1964 minimum net economic value of commercial fisheries and boat rentals and launching fees for sport fishing was $\$ 450,145$ for the Merrimack River estuary $(4,000$ acres), or an average contribution of $\$ 112$ per acre. Additional expenditures by sport fishermen were estimated to be about one million dollars annually. For the North River the estimated total annual income from marine fishery resources was about $\$ 60,000$ plus another $\$ 70,000$ spent annually by sport fishermen. Thus this 533-acre estuary averaged a contribution of about $\$ 111$ per acre in 1965. The minimum economic values estimated for Quincy Bay $(7,780$ acre estuary) include commercial fisheries and boat rentals and launching fees for sport fishing $(\$ 93,910)$ and other expenditures by sport fishermen $(\$ 170,190)$ in 1964 or an average contribution of about $\$ 34$ per acre. ${ }^{48}$

3. New York marshland. Summing up all elements 
Table VII-12 List of numbers of wetland areas, acreage and vulnerability by county in Maryland that are or have been utilized for natural science research and education.

\begin{tabular}{|c|c|c|c|c|c|}
\hline \multirow{2}{*}{ County } & \multirow{2}{*}{$\begin{array}{l}\text { No. of } \\
\text { areas }\end{array}$} & \multicolumn{3}{|c|}{ Acreage and vulnerabulity } & \multirow{2}{*}{$\begin{array}{l}\text { Total } \\
\text { acres }\end{array}$} \\
\hline & & $I$ & II & III & \\
\hline Allegany & 0 & - & - & - & 0 \\
\hline Anne Arundel & 11 & 469 & 874 & 768 & 2,111 \\
\hline Baltimore City & 0 & - & - & - & 0 \\
\hline Baltimore & 3 & - & 313 & 124 & 437 \\
\hline Calvert & 25 & 169 & 1,683 & - & 1,852 \\
\hline Caroline & 4 & 521 & - & - & 521 \\
\hline Carroll & 0 & - & - & - & 0 \\
\hline Cec1I & 0 & - & - & - & 0 \\
\hline Charles & 2 & 36 & 44 & - & 80 \\
\hline Dorchester & 0 & - & - & - & 0 \\
\hline Frederick & 0 & - & - & - & 0 \\
\hline Garrett & 5 & - & 148 & 228 & 376 \\
\hline Harford & 0 & - & - & - & 0 \\
\hline Howard & 0 & - & - & - & 0 \\
\hline Kent & 0 & - & - & - & 0 \\
\hline Montgomery & 8 & - & 36 & 125 & 161 \\
\hline Prince George's & 17 & 696 & 2,352 & 90 & 3,138 \\
\hline Queen Anne's & 0 & - & - & - & 0 \\
\hline St. Mary's & 21 & 292 & 404 & 57 & 753 \\
\hline Somerset & 0 & - & - & - & 0 \\
\hline Talbot & 0 & - & - & - & 0 \\
\hline Washington & 0 & - & - & - & 0 \\
\hline 酒comico & 0 & - & - & - & 0 \\
\hline Worcester & 2 & 1,122 & - & 336 & 1,458 \\
\hline Totals & 98 & 3,305 & 5,854 & 1,728 & 10,887 \\
\hline
\end{tabular}


Table VII-13. Estimated current dollar product associated with wetlands in Maryland.

\begin{tabular}{llc}
\hline \multicolumn{1}{c}{ Item } & $\begin{array}{c}\text { Annual dollar } \\
\text { Product }\end{array}$ & $\begin{array}{c}\text { Number of employed } \\
\text { or participants }\end{array}$ \\
\hline Commercial fishery landed catch & $\$ 16,900,000$ & $\begin{array}{l}6,000 \text { full-time } \\
3,000 \text { part-time }\end{array}$ \\
$\begin{array}{l}\text { Seafood processing and manufacturing } \\
\text { products }\end{array}$ & $\$ 13,4000,00$ & $\begin{array}{l}4,355 \text { (average) } \\
105 \text { plants } \\
200,000 \text { sport } \\
\text { fishermen }\end{array}$ \\
Saltwater angling expenditures & $\$ 20,000,000^{*}$ & $\begin{array}{l}35,000 \text { hunters } \\
1,000 \text { trappers }\end{array}$ \\
Waterfowl hunting expenditures & $\$ 14,000,000$ & \\
Fur trapping & $\$ 250,000$ & \\
\hline \multicolumn{1}{c}{ Total } & $\$ 64,550,000$ & \\
*Additionally, there are marina facilities, boats and boating equipment that relate to use of \\
wetlands dependent production.
\end{tabular}

and their values (very conservatively estimated) for an average acre of inland freshwater marsh in New York provided an annual net value of approximately $\$ 20 .^{49}$

4. Georgia river swamp. The combined values provided by 25 miles of continuously wooded river swamp and bottom hardwoods (about 4,000 acres) which fit the Types I and 7 classification was estimated to be at least $\$ 7.1$ million or an average benefit of $\$ 1775$ per acre..$"$

\section{Texas' Galveston-Trinity-East Bay Estuary.} "The anticipated total future annual value (conservative) that is reasonably derivable from various utilizations of the biological products, dependent in some critical way upon this important Bay-estuarine complex, would amount to an estimated \$110.4 million." This figure was composed of $\$ 38.4$ million annual value of then-available commercial fisheries production (requiring increased production) and future "net economic benefits" (at \$3 per angler-day for 24 million angler-days) "that are reasonably realizable from Bay-estuarine dependent sport fisheries of $\$ 72$ million annually."

Besides the expenditures and resultant economic impacts there are significant non-monetary aspects. The psychic value of pleasures derived from being outdoors in pursuit of fish and game is high. Included in this category also are the non-consumptive uses of natural resources such as nature study and appreciation, scientific research and natural science education and scenic and esthetic values inherent in wetlands. Other important intangible values should not be forgotten such as buffering effects on water pollution incidents and shoreline erosion which are mentioned elsewhere in this report.
Wetlands are thus one of Maryland's most valuable natural resources.

1 Manning, Joseph H. Bay fisheries resources. In Proceedings, Governor's Conference on Chesapeake Bay, Wye Institute, Maryland. September 12-13, 1968.

2 Ibid.

3 McHugh, J. L. Fisheries of Chesapeake Bay. In Proceedings, Governor's Conference on Chesapeake Bay, Wye Institute, Maryland. September 12-13, 1968.

4 Op. cit.

5 Manning, Joseph H. Supra.

6 Suttar, R. E., and J. L. Cain. The Maryland seafood industry. Maryland Agri-Economics. College of Agriculture. Univ. of Md., College Park. April, 1968.

7 lbid.

8 Op. cit.

9 Op. cit.

10 Manning, Joseph H. Supra.

II McHugh, J. L. Supra. Also, (no author), SFI

Bulletin. No. 199, October, 1968.

12 Manning, Joseph H. Supra.

13 Op. cit.

14 SFI Bulletin, No. 202, March, 1969. 
15 Hollis, Edgar H., Fishery resources of the Patuxent River system, In Appendices, The Patuxent River, Maryland's Asset, Maryland's Responsibility. Governor's Patuxent River Watershed Advisory Committee. Md. State Planning Dept. Pub. no. 149a. July, 1968.

16 The Upper Chesapeake Bay Sport Fishing Survey was conducted jointly by the Natural Resources Institute of the University of Maryland (Solomons, Maryland) and the Maryland Department of Tidewater Fisheries from June 1 to September 30, 1962. Information from Mansueti and Hollis at note 17

17 Mansueti, Romeo J., and Edgar H. Hollis. Striped bass in Maryland. Educ. Ser. No. 61, Nat. Resources Institute, Univ. of Md., Solomons Island. February, 1963.

Game and Inland Fish Commission, Report to the General Assembly of 1969, Five-Year Plan. January, 1969.

Crossley, S-D Surveys Inc. National survey of hunters and fishermen. Supplemental State Report (Maryland). September, 1956.

18 Truitt, R. V. Sport fishing in Maryland. The Conservation Department of Maryland. 1938.

19 Buzzell, R. D. and E. T. Walker. Tidewater sport fishery. Md. Dept. Research and Educ., Resource Study Report, No. 4, Solomons, Md. March, 1954.

20 Atlantic States Marine Fisheries Commission. Twentieth annual report. Tallahassee, Fla. June, 1962.

2) Op. cit.

22 SFI Bulletin, No. 199, October, 1968.

23 Hollis, Edgar H. Supra at 15.

24 Truitt, R. V. Supra.

25 Lyon, Gale H., et. al. Economic analysis of marinas in Maryland. Agric. Expt. Sta., Dept. Agric. Econ. Contribution no. 4100, Univ. of Md., College Park, April, 1969.

26 Ibid.

27 Op. cit.

28 Op. cit.

29 Personal communication received from the Maryland Fish and Wildlife Administration.

30 Bureau of Sport Fisheries and Wildlife. National survey of hunting and fishing. U.S.D.I. Fish \& Wildlife Service. Resource Pub. 27. 1965.

31 Stotts, Vernon D. Personal communication. Md. Fish and Wildlife Administration. December 12, 1969.

32 lbid.
33 Outdoor Recreation Resources Review Commission. National recreation survey. ORRRC Study Report 19. U.S.G.P.O: Washington, D. C. 1962.

34 Benson, Dirck. The Atlantic Flyway survey of private waterfowl hunting clubs. Conducted for the Wildlife Management Institute by the Atlantic Waterfowl Council (mimeo) June, 1966.

35 Data produced by Maryland Fish and Wildlife Administration personnel.

36 Vaught, Richard W. Problems and economics of Canada goose management in the Mississippi Flyway. In Canada goose management: current continental problems and programs (symposium). ed. Hine and Schoenfeld. Dembar Ed. Res. Services, Madison, Wisc. 1969.

37 Ibid.

38 Stotts, Vernon D. Personal communication. Md. Fish and Wildlife Administration. September 24, 1970.

39 Maryland State Planning Department. Catalog of natural areas in Maryland. Pub. no. 148, Baltimore. August, 1968.

40 Franklin, Jerry F., and James M. Trappe. "Natural areas: needs, concepts, and criteria." J. Forestry, V. 66 , no. 6, June, 1968.

41 Ibid

42 American Association for the Advancement of Science. Report by the study committee on natural areas as research facilities. Washington, D. C. 1963.

43 Wharton, Charles H. The Southern River swamp-a multiple-use environment. Bur. Business and Economic Research, School Business Administration, Ga. State Univ., Atlanta. May, 1970.

44 National Council on Marine Resources and Engineering Development. Marine science affairs-a year of plans and progress. U.S.G.P.O: Washington. March, 1968.

45 Maryland Department of State Planning. Scenic rivers in Maryland. Report of the Scenic Rivers Review Board. Pub. no. 161. March, 1970.

46 Maryland State Planning Department. Op. cit.

47 (No author). Estuary values. SFI Bulletin, No. 213, April, 1970.

48 Jerome, William C., Jr., et al. A study of the marine resources of the Merrimack River estuary. Div. Marine Fisheries, Mass. Dept. Natural Resources, Monograph Series No. 1. June, 1965.

Jerome, William C., Jr., et al. A study of the marine resources of Quincy Bay. Div. Marine 
Fisheries, Mass. Dept. Natural Resources, Monograph Series No. 2. March, 1966.

Fiske, John D., et al. A study of the marine resources of the North River. Div. Marine Fisheries, Mass. Dept. Natural Resources, Monograph Series No. 3, May, 1966.

49 Benson, Dirck, and Robert F. Perry. An acre of marsh is worth... Information Leaflet, Div. Conservation Ed., N. Y. Conservation Dept., Albany. The article appeared in the $N . Y$. State Conservationist, June-July, 1965.

50 Wharton, Charles H. Supra.

$5 I$ SFI Bulletin at 47. 



\section{VIII}

\section{WETLANDS - AS REAL ESTATE, RESULTANT PROPERTY TAX CONTRIBUTIONS,}

SPECULATION AND PROPERTY OWNERSHIP ISSUES 



\section{GENERAL BACKGROUND}

All private real property in Maryland is subject to both county and State taxes. Municipal or town taxes are also levied in some instances. Wetlands are no exception and are taxed as all other private real property.

Generally, wetlands in Maryland are incident to rural farm property, meaning they border or are contiguous to land in agricultural production. There are exceptions, notably the interior marshes and "guts" found on the lower Eastern Shore, especially in Dorchester County.

Farmland is assessed on the basis of its value for agricultural production. Farmland tracts are usually subdivided into distinct parcels based on patterns of current usage which in turn is greatly determined by topography and soil properties. The parcel subdivisions are buildings or homesite, tillable land, woodland, marshes (wetlands), and "waste or barren land." In this classification system wetlands and waste or barren land (e.g., steep rocky slopes) rank lowest and are assessed accordingly.' There are two exceptions to this rule: 1) interior wetlands of the lower Eastern Shore are usually assessed at lower rates than wetlands that are incident to the farm tract; and 2) wetlands that are a part of non-farm tracts or in urbanizing areas are usually assessed at slightly higher rates than farm or rural wetlands due to greater, overall land value.

Procedures for assessing real estate are standardized throughout the State. However, assessment ratios and tax rates vary between counties. Assessed valuations are based on location of the land, current market values, the amount of acreage in eacls land category, and prevailing assessment ratios. The actual acreage in each land category is the basis for taxes on a specific tract of land. The acreage in each tract of land and the category is determined from past land title transfer records, deeds and more recently, published results of the soil surveys conducted by the U. S. Soil Conservation Service. Each land category is assessed individually. Total taxation is derived by summing all assessments on the different parcels in each land category and then multiplying the total assessment times the tax rate per $\$ 100$ of assessed valuation for each type of land. Refinements based on unusual circumstances or land characteristics are often made on the assessment of specific land parcels.

\section{REAL ESTATE MARKET VALUES}

Certain helpful data is not available to assist in interpreting market value. For example, data is lacking on the numbers of land transactions involving wetlands, specifically separating fast (dry) land and wetlands in the same package so as to determine the actual sale price of the wetlands. The size of the land parcel or package in a transaction is important, because acreage has bearing on the economics of any development plan. Also important is the location of wetlands in relation to exogenous factors or future actions that will determine the value of a tract, such as new roads, new channelization projects, and water and sewerage lines. Thus, data in Table VIII-I represent approximate market values based upon the experience of land appraisers retained by the State for public land acquisition purposes.

The locational factor of nearness to densely populated areas and their spreading urban fringes plus ease of accessibility via automobile is generally reflected by higher average market values for wetlands on the western shore and Southern Maryland over those on the Eastern Shore (Table VIII-1). There are notable exceptions, however, in Cecil, Kent, Queen Anne's and Worcester counties. The high market prices for wetlands in these counties reflect good accessibility via improved highway systems from relatively close, large population centers. In Worcester County, there is heavy development pressure to supply vacation residences and tourist facilities generated by ocean beach, wateroriented recreation. This ocean frontage locational factor is unique in Maryland.

Land values were reported to be leveling out in certain parts of Maryland while advancing rapidly in other parts of the State. Land values are stable where there is tight control on land development due to county planning commission's, when costly demands are placed on developers, besides extra time required and the number of people to be seen in order to get development approved. ${ }^{2}$ However, there has been a steady upward trend in land values almost everywhere in the Nation and Maryland is no exception. For example, farm land in Maryland has risen from an average value of about $\$ 55$ per acre in 1935 to $\$ 550$ per acre in $1968 .{ }^{3}$ Generally, land values are rising at 5 to 10 percent annually under favorable conditions, although 1968 prices in Maryland were reported to be up 15 to 20 percent over the previous year and were predicted to go up again in 1969."

Prices for lands suited to outdoor recreation are rising at a considerably higher rate. "For waterfront property, 'the sky is the limit' and one 95 acre property with 'a very poor house on it' sold for $\$ 225,000$." W With these rising rates in prices speculation in land investment is inevitable. 
Table VIII-l Approximate range of market values per acre of wetlands versus tillable land in certain Maryland counties for the ten-year period 1958-68.

\begin{tabular}{|c|c|c|c|c|c|c|}
\hline & \multicolumn{3}{|c|}{ Wetlands Market Values } & \multicolumn{3}{|c|}{ Tillable Land Market Values } \\
\hline & 1958 & 1963 & 1968 & 1958 & 1,63 & 1968 \\
\hline Southern Maryland & $\$$ & $\$$ & $\$$ & $\$$ & $\$$ & $\$$ \\
\hline Anne Arundel & No data & obtained & - & - & - & - \\
\hline Calvert & $75-150$ & $100-250$ & $150-360$ & $200-300$ & $250-350$ & $300-450$ \\
\hline Charles & $150-300$ & $250-400$ & $300-500$ & $300-400$ & $350-450$ & $400-500$ \\
\hline Prince George's & No data & obtained & & & & $30 n$ \\
\hline St. Mary's & $65-125$ & $100-200$ & $150-250$ & $200-250$ & $225-325$ & $300-400$ \\
\hline Average Value & 144 & 216 & 293 & 275 & 358 & 392 \\
\hline \multicolumn{7}{|l|}{ Upper Eastern Shore } \\
\hline Cecil & $100-150$ & 200 & $250-300$ & $250-300$ & $300-400$ & $400-600$ \\
\hline Kent & $100-200$ & 250 & 300 & $250-300$ & 400 & $500-600$ \\
\hline Queen Anne's & $100-150$ & 200 & $200-300$ & $200-300$ & $300-400$ & $350-600$ \\
\hline Average Value & 133 & 217 & 275 & 267 & 367 & 508 \\
\hline \multicolumn{7}{|l|}{ Lower Eastern Shore } \\
\hline Caroline & $75-125$ & $100-200$ & $150-250$ & $150-275$ & $200-300$ & $250-400$ \\
\hline Dorchester & $25-60$ & $40-75$ & $60-100$ & $200-300$ & $250-350$ & $300-500$ \\
\hline Somerset & $20-50$ & $25-60$ & $40-80$ & $100-150$ & $150-250$ & $200-350$ \\
\hline Talbot & $100-150$ & 200 & $200-300$ & $200-300$ & $300-400$ & $350-600$ \\
\hline Wicomico & $25-60$ & $40-75$ & $40-90$ & $175-250$ & $225-300$ & $300-400$ \\
\hline Average Value & 55 & 77 & 101 & 200 & 228 & 338 \\
\hline Atlantic Coast & & & & & & \\
\hline Worcester & No data & obtained & & & & \\
\hline
\end{tabular}




\section{SPECULATION}

One of the difficulties in discussing and analyzing the impact of speculation is the lack of a clear-cut definition of what constitutes speculation. Speculation means different things to different people. There is no recognized legal or administrative definition of the term, and in real estate transactions it often connotes unethical practice.

The linkage between wetlands and land speculation is usually a series of circumstances or situations wherein there is no pre-determined pattern to the development that is encouraged by rising land prices and market values for waterfront homesites. The investment in wetlands which is categorized here as speculation is closely related to the randomness of its occurence. Such investment "speculation" is encouraged, abetted and controlled only by the market factors such as frequency and availability of land suitable for residential - recreational waterfront development. This activity occurs irrespective of land uses in surrounding or adjacent areas as well as the specific importance of the natural values inherent at that particular site. Furthermore, once purchased and developed by installing an acess road, water and sewerage services, lot subdivision, bulkheading, and dredge and filling, the sales promotion is baded on opportunism. Advertisements state that persons purchasing land now may expect to earn large profits between their initial purchase price and future resale prices.

"The meeting of land and water can offer the developer and investor a fascinating variety. From luxury shoreline homes to commercial boatyard, from marina to lakeshore development, the potential is enormous. Probably in no other field of real estate is there such an opportunity for satisfaction as well as financial reward. The variety is unlimited. The mature developer can become again the small boy with his sailboat and look back on his dry-land days as dull and uninteresting." 6

Land price escalation attracting speculation occurs most consistently on areas suited for recreation such as wetlands because of their waterfront location. Rising land prices encouraging speculation are primarily the result of: ${ }^{7}$

1) a rising trend in land values generally throughout the country;

2) keen competition between individuals, developers and public agencies for prime recreation lands, particularly those which are water-oriented;

3 ) the upgrading of lands as a result of change in land use or zoning, i.e., in many cases from agricultural land or wetlands to prime residential-recreation land with frontage on water or easy access thereto.
With fast growing population, higher income, more leisure time and increasing scarcity of land for all purposes, the steady and oftentimes spectacular increase in the value of land suitable for outdoor recreation can be expected to continue.

One more aspect of real estate speculation should be described briefly. That is the tendency speculation has towards self-fulfillment. If a speculative purchase or investment is made, the individual or organization doing so may be active in doing every thing possible and exerting as much influence as the public will tolerate to see that hoped for gains or expectations are realized. Such activity will usually take the form of re-zoning petitions, road construction locations or relocations, bridge construction, installation of public services such as water and sewer systems, etc. These actions are understandable and legitimate within our governmental processes: however, the net results may be undesirable for the short-run and long-term aspects of both local and regional economic growth patterns. The immediate net gain of speculation is often to a very narrow sector of the general public.

\section{ASSESSED VALUATION AND TAXES DERIVED}

A survey was made of assessment rates for landuse categories assumed to contain wetlands in order to generally ascertain the magnitude of public revenues derived from taxation of wetlands. Wooded and shrub swamps were assumed to be in either the wood and timberlands or the waste and brushland categories while the marshland category was obviously wetlands. Table Vll-2 summarizes the State-wide assessed values for these land uses comprising wetlands as assigned by county assessors and reported to the Maryland Department of Assessments and Taxation. Comparison of the range of assessed values on marshland with those of farmland or land in agricultural production (tillable, permanent pasture, orchard) shows that marshland assessments are usually less than any of the rates assigned to all grades of tillable land and other lands in some kind of agricultural land use (Table VIIJ-3).

Wetlands as real property represent a very small proportion of the State's total assessed land valuation (taxable base). The total assessed valuation of all land in Maryland (excluding Baltimore City) was $\$ 2,355,519,000$ in 1968 . This compares with an estimated wetland assessed valuation of $\$ 4,843,600$. Wetlands account for about 4.8 percent of the State's total land area while contributing approximately 0.2 percent of the State's total assessed land valuation. 
Table VIII-2 Assessed 1968-69 valuations in dollars per acre of land categories containing wetlands by county in Maryland. Data are based on county assessor's reports to the Maryland Department of Assessments and Taxation.

\begin{tabular}{|c|c|c|c|c|c|c|}
\hline \multirow[b]{2}{*}{ County } & \multicolumn{3}{|c|}{ Wood or Timberland } & \multirow[t]{2}{*}{ Waste Land } & \multirow[t]{2}{*}{ Brushland } & \multirow[t]{2}{*}{ Marshland } \\
\hline & Good & Poor & Cutover & & & \\
\hline & $(\$)$ & $(\$)$ & $(\$)$ & $(\$)$ & (\$) & $(\$)$ \\
\hline Allegany & $5-6$ & $4-5$ & 4. & 1 & 4 & - \\
\hline Anne Arundel & $40-60$ & $25-40$ & $25-40$ & 25 & 25 & $10-25$ \\
\hline Baltimore & $75-$ & $40-$ & 20 & 15 & 25 & $15-25$ \\
\hline Calvert & $15-25$ & - & - & 15 & - & 5 \\
\hline Caroline & - & $20-35$ & $10-15$ & 10 & 20 & 10 \\
\hline Carroll & $25-50$ & - & $20-$ & $\begin{array}{c}20 \\
\text { (minimum) }\end{array}$ & - & 20 \\
\hline Cecil & $30-$ & $20-$ & 10 & 10 & - & 10 \\
\hline Charles & 20 & 20 & 20 & 20 & - & 8 \\
\hline Dorchester & $40-100$ & $20-40$ & $10-20$ & 5 & 10 & $5-50$ \\
\hline Frederick & $50-100$ & $10-45$ & $10-25$ & 10 & 20 & $10-30$ \\
\hline Garrett & $10-20$ & $8-10$ & $8-15$ & 8 & 10 & $4-8$ \\
\hline Harford & $50-60$ & $30-40$ & $25-30$ & 25 & 30 & $10-60$ \\
\hline Howard & - & 25 & $25-50$ & 25 & - & 25 \\
\hline Kent & $20-$ & 5. & - & 5 & 15 & $10-20$ \\
\hline Montgomery & $25-45$ & - & $15-25$ & 15 & 25 & $15-25$ \\
\hline Prince George's & $35-60$ & - & - & 30 & 50 & $10-25$ \\
\hline Queen Anne's & $25-$ & 15 & $10 \cdot 15$ & 10 & - & $10-50$ \\
\hline St. Mary's & $25-30$ & $25-$ & 15 & 15 & 15 & 15 \\
\hline Somerset & $50-100$ & $10-25$ & $10-25$ & 10 & 25 & $3-30$ \\
\hline Talbot & $75-100$ & $15-25$ & $15-20$ & 15 & - & $15-25$ \\
\hline Washington & - & $10-40$ & $5-15$ & 5 & 20 & - \\
\hline Wicomico & $100-50$ & $25-40$ & $10-15$ & 10 & 5 & 5.12 \\
\hline Worcester & $50-75$ & $20-50$ & $10-125$ & 5 & 10 & 3-35 \\
\hline
\end{tabular}


Table VIIl-3. Assessed 1968-69 valuations in dollars per acre of marshland versus lands in agricultural production by Maryland county. (Data are based on county assessor's reports to the Maryland Department of Assessments and Taxation).

\begin{tabular}{|c|c|c|c|c|c|c|}
\hline \multirow{2}{*}{ County } & \multirow{2}{*}{ Marshland } & \multicolumn{3}{|c|}{ Tillable Land } & \multicolumn{2}{|c|}{ Permanent } \\
\hline & & Poor & Average & Good & Pasture & Orchard \\
\hline & (\$) & $(\$)$ & (\$) & (\$) & $(\$)$ & (\$) \\
\hline Allegany & - & $10-30$ & $40 \cdot 60$ & $60-100$ & $20-40$ & $50-100$ \\
\hline Anne Arundel & $10 \cdot 25$ & $40-50$ & $50-75$ & $75-100$ & $40-60$ & 100 \\
\hline Baltimore & $15-25$ & 75 & 140 & 180 & $75 \cdot 180$ & $75-180$ \\
\hline Calvert & 5 & - & 40 & 60 & 30 & - \\
\hline Caroline & 10 & $35-45$ & $50-60$ & $70-100$ & 70 & - \\
\hline Carroll & 20 & $60-70$ & $80-100$ & $115-125$ & $50-100$ & $250-350$ \\
\hline Cecil & 10 & 65 & $75-85$ & $95-100$ & $40-50$ & 120 \\
\hline Charles & 8 & 60 & 60 & 60 & 25 & - \\
\hline Dorchester & 5.50 & $60-70$ & $70-80$ & $80-125$ & $60-80$ & $80-100$ \\
\hline Frederick & $10-30$ & $35-55$ & $60 \cdot 85$ & $90-135$ & $60-100$ & 100 \\
\hline Garrett & $4-8$ & $10-25$ & $25-50$ & $25-250$ & $9-20$ & - \\
\hline Harford & $10-60$ & 75 & 85 & 100 & $50-75$ & - \\
\hline Howard & 25 & - & 75 & 100 & $75-100$ & $125-150$ \\
\hline Kent & $10-20$ & 30.50 & $50 \cdot 70$ & $85-100$ & $30-40$ & - \\
\hline Montgomery & 25 & $60-70$ & $75-95$ & $110 \cdot 125$ & $25-45$ & $60-125$ \\
\hline Prince George's & 50 & - & $60-65$ & $85-100$ & $85-100$ & $85-100$ \\
\hline Queen Anne's & $10-50$ & $25-50$ & $60-75$ & 65.90 & 40 & - \\
\hline St. Mary's & 15 & 35 & $40-45$ & 70 & 40 & 70 \\
\hline Somerset & $3-30$ & $20-40$ & $40-60$ & $50-100$ & $20-40$ & 100 \\
\hline Talbot & $15-25$ & $40-45$ & $65-80$ & $80-100$ & - & $60-100$ \\
\hline Washington & - & $30-50$ & $45-100$ & $70-175$ & $30-50$ & $70-100$ \\
\hline Wicomico & $5-12$ & $40-60$ & $75-90$ & $100-120$ & $50-60$ & $90-100$ \\
\hline Worcester & 3-35 & 25.40 & $40-65$ & 65.80 & $20-50$ & $45-60$ \\
\hline
\end{tabular}


Based upon the wetlands acreage inventory conducted by the Maryland Department of Game and Inland Fish and using an averaged assessment figure for wetlands in land categories, an attempt was made to approximate the public revenues derived from wetlands. There are several constraints inherent in this exercise. First, there is no absolute inventory on wetlands acreage. The wetlands acreage inventory is derived from an inventory of wetlands of five acres in size or larger only. Second, it is impossible to verify or correlate actual acreages of wooded and shrub swamp within the timberland, "waste", or brushland categories. Therefore, the calculations showing the taxes derived from wetlands must be considered as estimates only.

The total 1968-69 estimated tax contribution to the State and counties from wooded and shrub swamps and marshland is $\$ 121,200$ (Table VIll-4). Of this total, approximately $\$ 8,230$ is realized by the State (at a rate of $\$ 0.17$ per $\$ 100$ of assessed valuation) and $\$ 112,834$ by the counties. Regardless of the accuracy of these estimates, it is obvious that tax revenues derived from wetlands are not large. Based on these low tax revenue estimates, wetlands are either a bargain or a burden depending upon differing values and benefits derived or expected from the same nat ural resource.

The five leading counties of estimated wetlands tax revenues are: Dorchester $(\$ 49,000)$; Somerset $(\$ 20,000)$; Worcester $(\$ 9,000)$; Prince George's $(\$ 6,300)$; and Anne Arundel $(\$ 5,600)$. While the five leading counties based on total wetlands acreage are: Dorchester (1); Somerset (2); Worcester (3); Prince George's (9); and Anne Arundel (11). Higher tax rates per $\$ 100$ of assessed value $(\$ 3.05$ and $\$ 3.06$, respectively) account for the ranking of Prince George's and Anne Arundel ahead of several other counties with more wetlands in terms of total tax revenues derived from wetlands. The assessed valuation of wetlands as a percent of total county land assessments for the five counties deriving the largest wetlands based tax revenues is shown in Table VIII-5.

\section{PROPERTY OWNERSHIP ISSUES}

Read or implied changes in legislative or judicial orientation towards wetlands ownership could have an impact on the tax revenue structure of both the counties and State. The net impact at the local level of any changes would probably be directly proportional to the total tax base represented by wetland acreage, and the percentage of county waterfrontage in wetlands.

Ownership of the shoreline fringe area between mean low water (MLW) and mean high water (MHW) is an area of uncertain or disputed ownership. Assuming that private ownership extended to the MLW line from the MHW line, this distance encompasses an estimated 10 linear feet (based on average prevailing shoreline slopes) between MLW and MHW marks for about 4,500 miles of tidal shoreline in the State. This estimate produces about 545 acres of wetlands that would be removed from county tax roles if the State ownership to $\mathrm{MHW}$ concept were validated as based upon statutory law. The law states that: 1) the State owns all lands lying below the navigable waters of the State (with certain exceptions); and 2) navigable waters are defined as those subject to the ebb and flow of tides. (See Chapter XIV.) The 545 acre figure represents an insignificant part of the State's total inventoried wetland acreage but a very significant and important portion in terms of resource management and wetland configuration, e.g., it is the "shoreline." There are also other important implications such as riparian ownership claims and benefits derived therefrom.

The effect of stricter State control over wetlands ownership and property rights, including the right to make alterations to the shoreline, could have impacts on regular land values. However, the prevailing attitude behind present patterns of shoreline property ownership discounts the potential opportunity to alter the shoreline except as necessary to provide for a boating facility such as a mooring pier with adequate water depth for safe navigation, erection of a duck blind to exercise waterfowl hunting privileges, and protective or preventative action against loss of shoreline due to erosion forces. Much of the future shoreline use and orientation on Maryland's shores by riparian landowners will probably focus on esthetic or recreational features. Such usage does not imply any intention or need to radically alter the shoreline. This is supported by results of the field inventory where many landowners stated that they wanted the "status quo" as far as their shoreline (encompassing wetlands) was concerned, implying retention of the natural setting.

The assessment rates on shoreline acreage encompassing wetlands are low compared to other land use categories. Any downward shifts in land or property values resulting from stricter control over shoreline use and/or alteration of wetlands might have some temporary impact on the tax base and resultant tax revenues. This decrease, if any, would be minor because of prevailing low assessment rates. Any decreases in market value of land under stricter control would probably affect short-term real estate speculation only. With increasing demands for recreational or residential waterfrontage and a fixed resource base to meet the increasing demand, real estate prices will continue to rise for this type of property. In fact, recreational land values are rising in an increasing rate. ${ }^{8}$ Therefore, in- 
Table VIII-4. The five leading Maryland counties in terms of largest total tax revenues derived from wetlands assessments (estimated).

\begin{tabular}{|l|c|c|c|c|}
\hline \multicolumn{1}{|c|}{ County } & $\begin{array}{c}\text { Total Assessed } \\
\text { Valuation }\end{array}$ & $\begin{array}{c}\text { Wetland Assessed } \\
\text { Valuation }\end{array}$ & $\begin{array}{c}\text { Real } \\
\text { tax revenue }\end{array}$ & $\begin{array}{c}\text { Percentage of total } \\
\text { real tax revenues }\end{array}$ \\
\hline Dorchester & $\$ 23,612,000$ & $\$ 1,930,400$ & $\$ 49,000$ & 8.0 \\
Somerset & $11,033,000$ & 879,270 & $\$ 20,000$ & 8.0 \\
Worcester & $34,359,000$ & 421,360 & $\$ 9,000$ & 1.0 \\
Prince George's & $482,217,000$ & 206,800 & $\$ 6,300$ & 0.4 \\
Anne Arundel & $196,256,000$ & 185,500 & $\$ 5,600$ & 0.9 \\
\hline
\end{tabular}

creasing assessment values which follow increasing property values would negate a temporarily depressed taxable base. Consequently, the heaviest impact of stricter control on shoreline development need not be to the domiciled property owner but to the speculative land development operation where significant shoreline alterations are required to immediately achieve short-term economic gains. The adoption of such strategy to control short-term speculation does not intend to imply nor advocate a complete antidevelopment policy. Rather it can provide a pause for all interests to re-evaluate the cause and effects of such action and perhaps make necessary adjustments to the established policy. The development, adoption and enforcement of land use policies favoring long-run values over short-term gains would protect the values that are attracting speculative development, as well as providing high present and future real estate values to present shoreline residents and property owners. Local governmental units would also profit by eventually realizing larger tax revenues from a higher assessed tax base due to higher real estate values.

Wetlands' natural productivity has no reference or significance to property lines or man-made geo-political boundaries. Therefore, the benefits derived from wetlands are often difficult to capture by an individual property owner, and usually must be shared with others. In fact, all naturally produced wildlife, waterfowl and fisheries are in common or public ownership. Yet simultaneously the property owner provides revenues to the government via property taxes. Thus, an individual property owner's perspective is likely to be that he is supporting or subsidizing public benefits through tax payments on property providing public goods and services. This is not exactly the situation because there are many tangible benefits both economic and non-economic which accrue to property owners of waterfrontage or shoreline. If they do not, what explains the higher market prices of waterfront property versus inland or non-shore frontage property? Common sense dictates that no one is going to pay a considerable higher price for something possessing relatively lesser values. Therefore, waterfront property owners are compensated for property tax payments on lands contributing to the health, safety and welfare of the general public. While wetlands' property values are usually lower, the value of the encompassing dry land is compensatingly higher because of the valuable riparian rights attached to such property by wetlands. Also, due to lower assessed property values of wetlands, lower taxes are paid on a valuable asset - shoreline frontage, which further compensates a riparian property owner.

One pessible strategy dealing with the wetland ownership issue - private versus public - and the attendant problem of local tax revenues based on property taxes might be to reduce taxes on private lands or areas important to the natural resource base and which generate public goods and services. At the same time a compensating source of revenue and transfer mechanism would be developed, most likely between the State and cooperating local government units (counties) involved. The "reward" or incentive for lowering property taxes on wetlands would be to the private owner agreeing to maintain or manage wetlands in their present, "natural" state. At the same time additional 


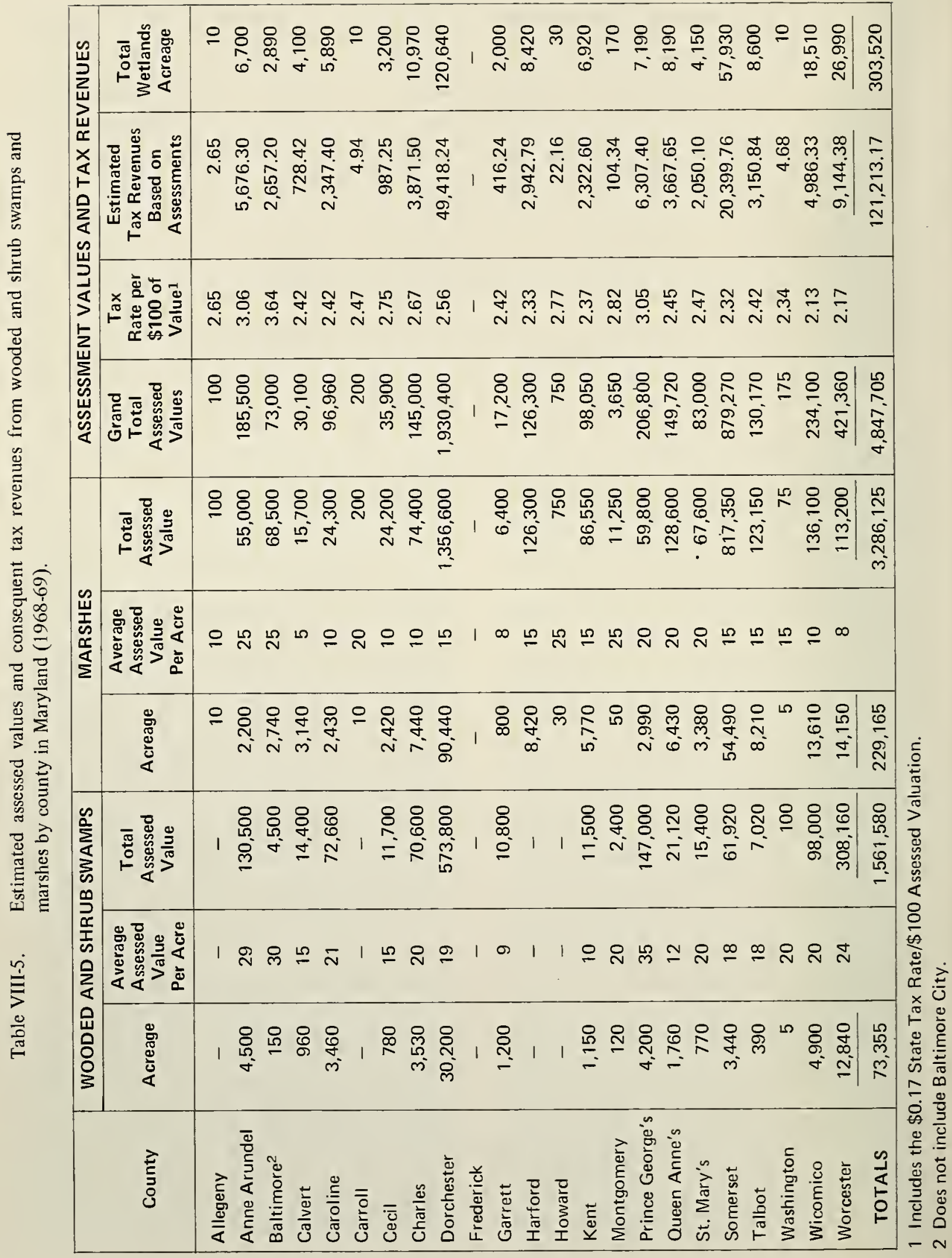


revenue would be provided to the local government from the State for revenues lost due to lower property tax revenues in wetlands in an agreed to preservation or custodial management status.

\section{SUMMARY AND CONCLUSIONS}

Wetlands are assessed at lower rates for property taxation purposes than several other land-use categories, including lands in agricultural production. Market values of wetlands also reflect this situation because tillable lands sell at higher prices.

Location is an important factor in the real estate market. Wetlands close to populated areas, near installed public services or facilities, or easily accessible have higher market value than others. However, the market or real estate value of wetlands is not based entirely on their in situ use but the opportunities or rights that shoreline (riparian) ownership grants to the owner of such property. Real estate interest in wetlands is generated by shoreline access for water-oriented uses such as boating facilities, hunting privileges, a recreational or vacation homesite, open space and an esthetically pleasing atmosphere.

Because more people are now interested and have the time to participate in these types of activities wetlands real estate prices are trending steadily upward. Prices for lands especially suited to outdoor recreation are rising at considerably higher than average rates with the "sky being the limit on certain waterfront property." Such rises in land value inevitably encourage speculative investment and development which disregard planned growth patterns for concerned local communities.

In Maryland, wetlands contribute only a small proportion of the total taxable base. However, in certain Eastern Shore counties with extensive wetlands acreage, wetlands derived tax revenues are considerably higher than for more urbanized counties. One method of estimating the total property tax revenues derived from wetlands in the State indicates about $\$ 121,200$ based on a total assessed valuation of $\$ 4.8$ million in 1968-69.

The smalt tax revenues derived from prevailing low assessment ratios suggest that validation of State ownership to all lands lying below navigable or stricter State control over shoreline development would not have a significant impact on current local government revenues. Local government's viewpoint tends to be exactly the opposite in counties with extensive tracts of wetlands.

Stricter State control or ownership of wetlands represents a threat to potential sources of future and larger tax revenues by preventing uncontrolled shoreline development that produces rapid augmentation to the assessible tax base. This situation presents a problem to local governments faced with a need for larger tax revenues from real estate taxes to finance increasing and costlier services. The local revenue/real estate tax squeeze is an aggravating problem to local governments because there is public resistance against substantial increases in other major taxes to supplement property taxes, and many counties are near or at the maximum authorized local piggy-back personal income tax of half the State's rates. Consequently, some local government's tend to view wetlands as an opportunity for tax relief through development. For instance, "in order to maintain the current level of [Somerset] County services without increasing the [real estate tax] rate, it will be necessary to increase the assessible base." A similar opinion is expressed by local officials in Worcester County to support development of wetlands. "To avoid raising local real property assessments on most lands, a change of land use by development moves formerly low revenue producing land (wetlands) into higher assessment brackets, thereby providing needed additional tax revenues.

Human desires are powerful forces for change in land use, especially wetlands. Land use changes are often hastened by the real estate market, speculative land investors, and pressures on local governments for increased tax revenues. Total gains and losses from developing wetlands are not easily quantifiable. Shortterm solutions and consequent gains are more obvious and, therefore, more persuasively attractive than countering long-term losses. Without careful forethought and weighing of all factors the net results of unplanned, uncontrolled development can easily cost more than anticipated benefits. However, if the State with the support and cooperation of local governmental units develop, adopt and enforce shoreline development policies consistent with carefully considered plans that reflect all of the inherent values and uses of land, including wetlands, the best interests of all citizens will be served and protected.

1 Walker, Wm. Paul. Improving farm property assessments. Agric. Expt. Sta. Bull. No. A36. University of Maryland, College Park. January, 1945.

2 Jones, Carlton. Land values slowed in county stalemate. The Sun, Baltimore, Maryland. October 13, 1969. 
3 Stevens, G. A. (ed.) "Land Resources," in Agriculture '76, Section I11, Resources and Services in Production. Agric. Div., Univ. Maryland, College Park. 1970.

4 Op. cit.

5 Jones, Carlton. Supra.

6 Rick, William B. Planning and developing waterfront property. Urban Land Institute, Tech. Bull. 49, Washington, D. C. June, 1964.

7 U. S. Bureau of Outdoor Recreation. A report on recreation land price escalation. U. S. Dept. Interior. U.S.G.P.O: Washington, D. C. 1967.

8 David, E. J. L. The exploding demand for recreational property. Land Economics, Vol. XLV, No. 2, May, 1969.

9 Werner-Dyer \& Associates. Background for planning, Somerset County. March, 1963.

10 Harrison, Joseph G. A letter "To Whom it May Concern" re: Wetlands development at Ocean City, Md. June 25, 1969. 


\section{IX}

SURVEY OF USES CHANGING THE NATURAL HABITAT CHARACTERISTICS OF WETLANDS 



\section{INTRODUCTION}

This chapter presents the results of the wetlands habitat inventory compiled by the Maryland Department ol Game and Inland Fish (now Maryland Fish and Wildlile Adnuinistration) on the impact of man's activities which have or are changing the natural character of many wetlands as a habitat or environment suitable for dependent biotil.

Several approaches were used in analyzing the inventory statistics in order to ascertain relationships between wetlands and man's uses. Those undertaken here include: 1) inspect acreage changes in terms of impact on the total wetlands habitat and on each particular type of wetland; 2) determine the relationships (if any) between specilic uses, specific types of wetlands and locale; and 3) determine the implications to wetlands planning and managing processes.

\section{SUMMARY OF ACREAGE LOSSES}

At least 23,700 wetland acres were reported as destroyed in Maryland for the 25-year period 1942-67. This loss figure represents the difference between the $\mathrm{U}$. S. Geological Survey 1942-1944 topographic map wetland acreages and the 1967-1968 inventory (Table IX1). The losses represent about 7.2 percent of the total 331,000 acres inventoried.

The losses occurred rather uniformily throughout the State except for counties in the central and western region (Figure VI-3) which had no recorded wetland acreage losses. This result was due to very limited wetland acreage and a high percentage of the few wetlands in the region are in public ownership. Highest reported losses were due to water resource management programs for agricultural land drainage and flood control (Table IX-2).

Major acreage losses were attributed to agricultural drainage $(52 \%)$, housing development $(13 \%)$, industrial development (6\%), marinas (4\%), and dredging and spoil disposal (5\%) (Table 1X-1). Natural processes such as erosion and natural succession also have an impact on wetlands, as well as mosquito control drainage activities. All of these factors are discussed in the following sections of this chapter.

\section{HOUSING DEVELOPMENT}

\section{Background}

Residential development near water bodies has strong historical roots. Colonial settlements started at the water's edge and pushed inland. Frontier settlements grew up next to streams to provide assured water supplies, convenient transportation routes into the unexplored interior, and waste disposal systems

Residential development is still attracted to the shores of any water body where shoreline remains open and unoccupied. The attractions now are recreational opportunities, an esthetically pleasing atmosphere, and real estate market factors (see $\mathrm{Ch}$. VIII). Consequently, housing development occurs more and more frequently on wetlands than in the past since they are some of the last remaining major undeveloped shoreline areas.

\section{Acreage Losses}

The construction of residential and vacation homes on waterfront property has resulted in the loss of 3,200 acres of wetlands (Table 1X-1). These losses occur throughout tidewater Maryland (Table 1X-2). Notable losses due to housing construction include Worcester (590 acres), Prince George's (390 acres), Harford (350 acres), Talbot (330 acres), Queen Anne's (320 acres), Cecil (230 acres), Wicomico (210 acres) and Anne Arundel (180 acres). Additionally, numerous, separate destructive incidents of less than five acres in size were noted, which if combined might approach the inventoried losses.

Wetlands lost to housing development result from bulkheading, dredging and filling. A bulkhead is constructed in desired configurations around the wetland or other shoreline area to be reclaimed. A dredge excavates bottom materials from the bay-side of the bulkhead and deposits the material in the fill area. Materials such as sand, gravel, and shell are used as fill. The bulkhead acts as a retainer and stilling basin, keeping the initially fluid fill material from flowing back into the waterway. As the heavier sedimentary materials settle out behind the bulkhead, the water (which was used as an entraining agent) runs off or is drained off through sluiceways going over the top of the bulkhead.

In some cases, the fill material is obtained from canals and boat access channels cut into the shoreline under development. The extent of dredging is determined by the size of the fill area, the height needed to obtain a desired elevation above sea level, and the design configuration of the waterways and canals associated with the development.

One popular shoreline development design is the "Venetian" or marina-housing complex. The bulkhead layout provides a system of waterways serving individual subdivision lots and connects with channels leading to the surrounding bodies of water. The homeowner can "park" his boat at his doorstep. This type of development produces more attractive lots because of water frontage 
Table IX-1. Statewide summary of the uses changing the natural characteristics of wetlands in Maryland. showing acreage losses for each type of wetland.

\begin{tabular}{|c|c|c|c|c|c|c|c|c|c|c|c|}
\hline Type of Wetland & 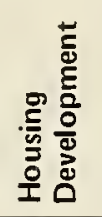 & 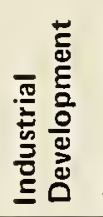 & 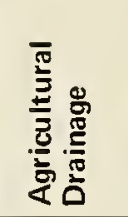 & 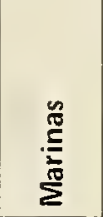 & 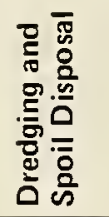 & $\begin{array}{l}\mathscr{2} \\
\vdots \\
\vdots \\
0 \\
\frac{0}{0} \\
0 \\
0\end{array}$ & 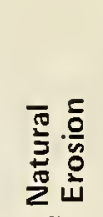 & 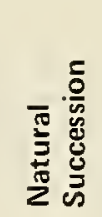 & $\frac{n}{\frac{a}{2}}$ & 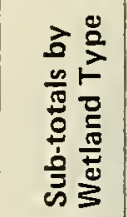 & 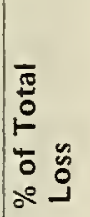 \\
\hline $\begin{array}{l}\text { 1-Seasonally } \\
\text { flooded basins } \\
\text { or flats }\end{array}$ & & & & & & & & & & 0 & 0.0 \\
\hline $\begin{array}{l}\text { 2-Inland Fresh } \\
\text { meadow }\end{array}$ & & & 675 & & & & & & & 675 & 2.8 \\
\hline $\begin{array}{l}\text { 3-Inland shallow } \\
\text { fresh meadow }\end{array}$ & & & 483 & & & & & & & 483 & 2.0 \\
\hline $\begin{array}{l}\text { 5-Inland open } \\
\text { fresh water }\end{array}$ & 20 & 15 & 26 & 3 & & & & & 49 & 113 & 0.5 \\
\hline 6-Shrub swamp & 103 & 204 & 9 & 6 & 13 & & 11 & & 28 & 374 & 1.6 \\
\hline 7-Wooded swamp & 591 & 759 & 10,958 & 33 & 51 & 65 & & & 48 & 12,505 & 52.6 \\
\hline 8-Bogs & & & & & & & & & & 0 & 0.0 \\
\hline $\begin{array}{l}\text { 12-Coastal shallow } \\
\text { fresh marsh }\end{array}$ & 1,032 & 341 & 88 & 361 & 495 & 453 & 310 & 14 & 404 & 3,498 & 14.7 \\
\hline $\begin{array}{l}\text { 13-Coastal deep } \\
\text { fresh marsh }\end{array}$ & 27 & & & & 1 & 11 & & & & 39 & - \\
\hline $\begin{array}{l}\text { 14-Coastal open } \\
\text { fresh water }\end{array}$ & 4 & & 10 & 31 & 13 & 37 & 3 & & & 98 & 0.4 \\
\hline $\begin{array}{c}\text { 16-Coastal salt } \\
\text { meadow }\end{array}$ & 673 & 267 & 226 & 363 & 443 & 263 & 461 & 22 & 145 & 2,863 & 12.0 \\
\hline $\begin{array}{l}\text { 17-I rregularly } \\
\text { flooded } \\
\text { salt marsh }\end{array}$ & 196 & 5 & 58 & 136 & 166 & 114 & 411 & & 4 & 1,090 & 4.6 \\
\hline $\begin{array}{l}\text { 18-Regularly } \\
\text { flooded } \\
\text { salt marsh }\end{array}$ & 570 & & 17 & 200 & 81 & 59 & 17 & 1,032 & 57 & 2,033 & 8.5 \\
\hline Totals & 3,216 & 1,591 & 12,550 & 1,133 & 1,263 & 1,002 & 1,213 & 1,068 & 735 & 23,777 & 99.7 \\
\hline Percent of total & 13.5 & 6.7 & 52.8 & 4.8 & 5.3 & 4.2 & 5.1 & 4.5 & 3.1 & 100.0 & \\
\hline
\end{tabular}


Table IX-2. Statewide summary of the inventory of uses changing the natural characteristics of wetlands in Maryland showing acreage losses by use and by county.

\begin{tabular}{|c|c|c|c|c|c|c|c|c|c|c|}
\hline County & 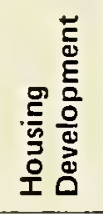 & 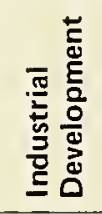 & 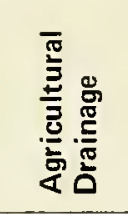 & 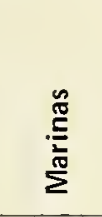 & 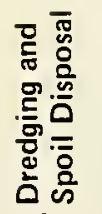 & $\begin{array}{l}\frac{0}{0} \\
\frac{3}{3} \\
\frac{3}{2} \\
\end{array}$ & 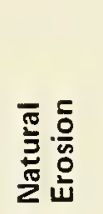 & 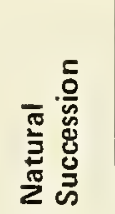 & 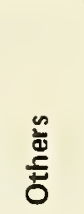 & 总㛸 \\
\hline Allegany & & & & & & & & & & 0 \\
\hline Anne Arundel & 185 & 256 & & 31 & 24 & 13 & & 14 & & 523 \\
\hline Baltimore & 48 & 220 & & 19 & 66 & 4 & 9 & & 249 & 615 \\
\hline Baltimore City & & 36 & & & & 118 & & & & 154 \\
\hline Calvert & 14 & 3 & & 42 & 32 & 7 & 38 & & 21 & 157 \\
\hline Caroline & 22 & 107 & 520 & 33 & 64 & 18 & 6 & & 49 & 819 \\
\hline Carroll & & & & & & & & & & 0 \\
\hline Cecil & 233 & 18 & & 36 & 250 & 34 & 44 & & 3 & 618 \\
\hline Charles & 55 & 66 & 20 & 138 & 55 & 27 & & & 21 & 382 \\
\hline Dorchester & 114 & 112 & 64 & 105 & 156 & 118 & 290 & 10 & 4 & 974 \\
\hline Frederick & 3 & & 26 & & & & & & & 29 \\
\hline Garrett & & & & & & & & & & 0 \\
\hline Harford & 359 & 20 & & 32 & 47 & 125 & 154 & & 70 & 807 \\
\hline Kent & 113 & 111 & 18 & 68 & 4 & 11 & 83 & & 25 & 433 \\
\hline Montgomery & & & & & & & & & & 0 \\
\hline Prince George's & 394 & 112 & 46 & & 1 & 64 & & & 16 & 633 \\
\hline Queen Anne's & 328 & 72 & 791 & 244 & 94 & 124 & 108 & 12 & & 1,773 \\
\hline St. Mary's & 37 & & 10 & 12 & 55 & 41 & 10 & & 121 & 286 \\
\hline Somerset & 171 & 18 & 3 & 45 & 230 & 40 & 136 & & 66 & 709 \\
\hline Talbot & 337 & 15 & 142 & 92 & 118 & 175 & 290 & & & 1,169 \\
\hline Washington & & & & & & & & & & 0 \\
\hline Wicomico & 213 & 408 & 2,351 & 39 & & 40 & & & & 3,051 \\
\hline Worcester & 590 & 17 & 8,559 & 197 & 67 & 83 & 4 & 1,032 & 90 & 10,639 \\
\hline Totals & 3,216 & 1,591 & 12,550 & 1,133 & 1,263 & 1,002 & 1,213 & 1,068 & 735 & 23,771 \\
\hline
\end{tabular}


which in turn brings higher prices on the real estate market.

\section{Interrelationships Between Shoreline Housing and Wetlands}

A large proportion of housing development on wetlands $(78 \%)$ occurs on coastal, estuarine-related wetlands. Ownership of such property provides several real and psychic values over non-waterfronting property.

Waterfront property provides esthetically appealing water landscapes, assured open space, riparian ownership assuring access to the Bay, hunting and fishing privileges, and social status, i.e., owning a piece of the "shore." Also, there is a finite limitation on actual shoreline available for any use. Consequently, waterfronting real estate values are expected to rise between purchase and resale

Waterfront housing development also fits highly successful sales promotion campaigns. Sales advertising suggests investment angles such as a "land bank" or "hedge" against inflation, as well as the opportunity to enjoy the "good life" or have a "world of fun." It is also olten suggested that there will soon be no more of this type of opportunity to further entice prospective buyers. However, many of the advantages and values stressed to lure the buyer will be consumed or diminished in developing such property. Open space is consumed. Continuing development will eventually present the same image as a city suburb. The wildlife and fishery resources which would have provided hunting and fishing require the natural habitat now lying buried under the foundations of waterfront homes resting on filled wetlands.

\section{Future Trends in Housing Development}

Present housing development on the tidewater shoreline has been governed largely by factors such as location in relation to population centers, accessibility, size of population, level of personal incomes, and the presence or absence of local zoning ordinances. These factors will continue to influence the demand for waterfront residential or recreational property. However, as more people desire to own part of the State's finite shoreline, pressure will increase to develop remaining and available undeveloped shoreline areas for housing.

Shoreline residential development was spurred by completion of the first Chesapeake Bay Bridge in 1952. Completion of the second parallel span could fulfill one predicted housing development pattern on the Eastern Shore. "The emergence of the 'Bay Bridge' counties
(Talbot, Kent, Queen Anne's and possibly parts of Dorchester) as a real factor in the Baltimore-Washington commuter picture." In addition, there is an upper Bay bridge authorized between Baltimore and Kent counties, as well as a proposal for a lower Bay crossing between Calvert and Dorchester counties.

Much of the future housing development in tidewater Maryland may occur on waterfront sites as indicated by the following collection of news items.

"A syndicate of Baltimore and Washington businessmen has initiated plans to develop an 800-acre residential community on St. Martin's Neck in Worcester County across the Assawoman Bay from Ocean City. The land including six miles of shoreline could be enlarged by nearly 200 acres if the adjacent saltwater marshland is dredged and filled according to the developers." The Baltimore Sun, 1/26/69.

"The undeveloped portion of Cape Isles of Wight will be sold at public auction. The sale will include . . . 55 acres of unfilled bay front and Herring Creek frontage." The Baltimore Sun, 6/29/69.

"Developers plan $\$ 4$ million dollar community on a 452-acre site on the Miles River two miles south of St. Michaels in Talbot County." The Baltimore Sun, 10/27/69.

"A similar project was proposed in nearby Queen Anne's County for the famous 1,700 acre Pioneer Estate between the Chester and Corsica rivers." The Baltimore Sun, 10/27/69.

"A developer proposes to build a 'Bay County Village' on the Great Marsh - 16 acre waterfront property along the Great Choptank River." The Baltimore Sun, 11/2/69.

The combined wetland acreage within these and other recently proposed, announced or planned shoreline housing developments already exceeds previously inventoried acreage losses for housing. In addition to potential wetland destruction, discussion on public works (Ch. IX) and water quality (Ch. Xl) indicates the scope of resource management problems that could result if accelerated, uncoordinated, and poorly planned housing development is permitted to occur along the shores of the Bay and elsewhere.

\section{Discussion on Housing Development}

Future extensive and intensive residential shoreline development in Maryland poses a resource management problem of a scale and scope not encountered before by State and local governments. Effective institutional arrangements are needed to properly guide such future 
development. In providing guidance, the capabilities of all levels ol government will be required. At the present time, government may not be structured to produce desired results or meet the criteria stated above. Mechanismis and experience demonstrating how the State can improve its management capabilities and exert better guidance of future shoreline development are needed.

One way to improve resource management systems might be through a demonstration model approach to one specific activity - residential shoreline development. This suggestion does not mean disregarding multiple-use concepts or advocating single-purpose resource planning and management. Rather the selection of shoreline housing as a sample problem area reflects the fact that this use requires variable management inputs and capabilities from several different State agencies, and it is and will be a major use competing for remaining undeveloped tidewater shoreline space. Something similar to the Rookery Bay Area Project produced by the Conservation Foundation is envisaged here. That project was a demonstration study in conservation and development at Naples, Florida to determine if profitoriented development surrounding a valuable wildlife, waterfowl and fishery sanctuary could be compatible with maintaining the resource values present. ${ }^{2}$

The purpose of initiating such a project in Maryland would be to achieve similar objectives and to develop a system of inter-agency and intergovernmental assistance and cooperation essential to future management of wetlands and other shoreline areas in the State. Another purpose would be to provide a visible example of how it might be possible to attain the objectives of development and conservation in a manner acceptable to both interests while using the same natural resource base.

\section{AGRICULTURE}

\section{General}

Agriculture is still an important Maryland industry. The fertility of the soil and the abundance of water make this one of the best agricultural areas of the eastern United States. According to the 1964 U. S. Census of Agriculture, the monetary value of farm products raised and sold in the nine counties lying east of Chesapeake Bay amounted to 51.5 percent of the State total. In fact, it has been reported that some Eastern Shore counties are of national stature in terms of their agricultural production. ${ }^{3}$

High agricultural productivity depends on good land use and adequate surface and sub-surface drainage.
Excessive water on some lands in agricultural production ciluses substantial losses of food, fiber and forest production. Economic losses from poor drainage result from temporary flooding or high ground water table levels and occur as direct damages and reduced productivity. Due to the low elevations of land on the Eastern Shore, natural draining capabilities of the soils and land are poorly developed. Consequently, projects designed to improve cropland drainage are an important facet of maintaining and increasing agricultural production on the Eastern Shore.

The purpose of this section is to examine and discuss brielly certain relationships between agricultural drainage and wetlands. There are three areas requiring attention. Two of them deal with agricultural land drainage programs under Maryland Drainage Laws. The other is the Watershed Protection and Flood Prevention Act of 1954 (Public Law 83-566) known as the Small Watershed Program. Projects under this act, sponsored by local governmental units and other organized groups. are financed in part with federal funds administered by the U. S. Soil Conservation Service.

\section{Maryland Agricultural Drainage Program and Laws}

The Maryland drainage program has been both active and effective on the Eastern Shore. The success of the program is attributed to excellent cooperation and support from local landowners and local, state and federal agencies. For more than thirty years the Maryland Agricultural Extension Service and State Department of Drainage have provided educational guidance for organization and operation of "tax ditches." County commissioners and soil conservation district supervisors have provided local leadership and support. The Soil Conservation Service of the U. S. Department of Agriculture has provided technical assistance to soil conservation districts for surveys, engineering design and supervision of construction. The State Roads Commission has cooperated where highway structures might have blocked channels."

Since 1941 a total of 105 public drainage associations have been organized which service 1,511 farms and 92,450 acres. When 28 associations now in process of organization are formed, totals will be 210,513 acres on 2,630 farms. The organizational process requires from one to two years depending upon the size of the project and availability of engineering services. Modern equipment and a successful program, together with some cost-sharing under Public Law 566, have led to larger associations in recent years. ${ }^{5}$ 
The Maryland drainage laws relevant to wetlands are Article 25, Public Drainage Associations (Sec. 5295), and Drainage Districts (Sec. 96-122). ${ }^{6}$ These laws were enacted to promote the ditching, draining, leveeing and reclamation of wet and overflowed lands which may be made available for agriculture, and to encourage the starting of such enterprises (Sec. 122). Furthermore, the draining of wet, swampy or overflowed lands or lands subject to overflow "shall be considered a public benefit and conducive to the public health, convenience and welfare" (Sec. 52). And also, "it is hereby declared that the drainage of swamps and the drainage of the surface water from agricultural lands and the reclamation of tidal marshes shall be considered a public benefit and conducive to the public health, convenience, utility and welfare" (Sec. 96).

\section{The Watershed Protection and Flood Prevention Act - Public Law 566}

The Watershed Protection and Flood Prevention Act of 1954, more commonly referred to as Public Law 566, established a national policy for Federal assistance to state and local agencies such as soil conservation districts, counties, public watershed associations and public drainage associations, for planning and constructing land and water resources development and conservation projects on a watershed basis.

Public Law 566 assisted projects are usually a combination of soil and water conservation measures on farm land, other rural land, and public land and consist of land treatment measures and structural measures (danis, levees, flood gates, drainage channels). The projects are planned and carried out jointly by local, state and federal agencies with the cooperation and support of a majority of landowners and citizens within the affected watershed. PL 566, as amended, authorizes the U. S. Secretary of Agriculture to administer the program, who in turn has designated the Administrator. Soil Conservation Service, to fulfill assigned responsibliities.

\section{Acreage Losses}

The total extent of wetlands altered by agricultural drainage projects was calculated by the Maryland Fish and Wildlife Administration to be 12,550 acres. This figure represents 53 percent of the total acreage losses compiled by the State survey. Major losses occurred to inland wetland types such as: fresh meadow (Type 2), 675 acres; shallow fresh meadow (Type 3), 483 acres; and wooded swamp (Type 7), 10,958 acres. Less than 400 acres of coastal wetland losses were attributed to agricultural drainage (Table IX-1).

The results of the wetlands survey are consistent with past and current U. S. Soil Conservation Service soil surveys and their appraisals of the potential agricultural value of coastal wetlands. "Tidal marsh and swamps in their present (natural) condition have no agricultural value," although tidal marsh may provide pasturage if conditions are favorable. "It is conceivable that some areas may be reclaimed for agriculture in the future, but such a time is not in sight at present. Extreme acidity and toxic sulphur compounds will always be a problem with reclaimed acreage, and may preclude their use (tidal marshes) for commercial plant production. For the foreseeable future tidal marshes will be limited in use to wildlife, some kinds of recreational purposes or for esthetic purposes."

Another Soil Conservation Service soil classification/land use, (wet) meadows, was frequently identified as suitable for reclamation by deepening stream channels, tiling and ditching. After installing these measures, such lands could be placed in agricultural production. The soil surveys' definition(s) of (wet) meadows describe wetland areas classified as inland fresh meadow (Type 2), inland shallow fresh meadow (Type 3), shrub swamp (Type 6), wooded swamp (Type 7), and coastal salt meadow (Type 16). Results of the wetlands habitat inventory indicate that these types of wetlands are highly susceptible to reclamation by agricultural land drainage projects.

\section{Future Trends of Agricultural Drainage}

Prior to passage of PL566, assistance to local governments and private landowners for agricultural drainage was primarily through Maryland Drainage Laws, Article 25, Sections 52-122, Annotated Code of Maryland (1957). Since 1958, however, the PL 566 progran has provided an important share of the financial support necessary to solve rural flooding and agricultural drainage problems.

The U. S. Soil Conservation Service has been surveying and evaluating local, regional and national watershed management problems for several years. Information collected and analyzed by the SCS covers various aspects of flood prevention, drainage, fish and wildlife, recreation, water supply and water quality control. The results of this work have been compiled as a "Conservation Needs lnventory." A "Summary of Conservation Needs Inventory of Maryland Watersheds" suggests that 69 watersheds or drainage areas on the entire Eastern Shore, encompassing 83 percent of the State's wetlands, have drainage conditions 
requiring some level of corrective action. ${ }^{8}$

It should be noted with emphasis that the new State wetlands laws do not apply to fresh water types such as those with already large acreage losses due to agricultural drainage measures (Table VI-I) and encompassed within the above projections. Also, "drainage systems designed exclusively for the purpose of collection, conveyance, or disposal of storm water" are excluded from the Department of Water Resources permit system required by Section 12(a) of Article 96A (Water Resources) of the Laws of Maryland.

To encourage and support the application of "conservation" measures the U. S. Department of Agriculture has the Agricultural Conservation Program to provide payments to farmers for carrying out such measures on farms. This program was intended originally to encourage farmers to maintain the productive capacity of their farms. However, preservation of capacity soon shades into building additional capacity. The practices for which payments are made include drainage. While soil-conserving, it is also an outputincreasing measure. "Public subsidy for such practices cannot be justified at a time when agriculture is trying to reduce excessive capacity.",

As a result of this situation the President's National Advisory Commission on Food and Fiber recommended that "public funds for agricultural reclamation, irrigation. drainage and development projects should be justified on the basis of whether they represent the cheapest methods of getting additional farm production - if needed." The Commission more succintly recommended also that "public subsidies for capacityincreasing farm practices should be disconinued."

If wetland resource misallocations induced by subsidies through certain agricultural programs are judged to be socially undesirable then some counter programs should be devised to protect remaining wetlands. Much of the reclamation would cease if subsidies were not provided to the agricultural sector and if competitive prices existed in the market for agricultural commodities. With price supports in effect, however, drainage becomes privately profitable despite the fact that it is socially inefficient.

\section{Discussion}

To date, the Soil Conservation Service has not been able to provide planning and technical assistance for all PL 566 project applications due to limited funds and stalf. These problems were somewhat alleviated through recent action by the Maryland General Assembly empowering the Department of Water Resources to apply technical services and public funds to various water resource development programs.

The Maryland Department of Water Resources cooperates in all water resource projects or programs alfecting the waters of the State. The Department also administers such financial assistance for PL 566 projects as may be made available to the Department. Recent State legislation establishes a State contribution up to filty percent of the non-Federal (local) share of approved projects under PL 566." Under this legislation, additional funding has been made available to the Soil Conservation Service for PL 566 project planning purposes.

In planning any PL 566 project, consideration must be given to fish and wildlife resource management problems related to any proposed developmental activity. Project features that would have detrimental impacts are resolved or compensated for during project planning belore final work plans are submitted for authorization and approval. In the past, wetlands have been dried up. Now, special steps or activities are incorporated within each project to provide compensating or "improved" habitat for wildlife wherever feasible. This policy when it is actually applied often results in destruction of certain types of existing habitat and established ecosystems while creating new or improving other types of habitat for other species.

The Soil Conservation Service is not insensitive to the implications of its PL 566 program to the alteration ol significant natural habitat and the implications to the ecology of affected natural communities and systems (ecosystems). Belore any project is finalized, approved, and developed, it must be reviewed and approved by all cognizant State resource management agencies, and obtain the final approval of the Governor. In addition. the Service believes that there is a large untapped potential under Public Law 566 for permanent protection and improvement of wetlands. Any development that enhances land for wildlife can be cost-shared under the program if a non-federal financial source is available too. On certain types of development PL 566 funding can also pay for hall the cost of acquiring the land for a public agency. ${ }^{12}$

The Maryland drainage laws, the small watershed program under PL-566 and the Agricultural Conservation Program all have major implications to future wetlands management planning. Certain measures under PL-566 and ACP coverage as well as Article 25 (Sections 52-122) of Maryland Laws support and encourage drainage of wetlands, particularly fresh water types. As policy matters now stand public funds - local, State and Federal - are being expended for draining wetlands of 
varying types and values. Simultaneously, growing public awareness and concern about the economic and ecologic signilicince of wetlands generate a demand for increased protection and preservation of such areas.

Much of the wetlands management problem in the agricultural sector (as well as all others) is due to a divergence between private and social values and goals attendant in wetlands with the benefits derivable accruing to the public at large while much of the burden of habitat maintenance being borne by private landowners. Because of this divergency the markel place fails to function as an effective mechanism for allocating wetlands between development (reclamation) and preservation, and consequently too few wetlands are likely to be preserved in the private sector without governmental intervention in the allocaling processes. The market system has been further dellected from an effective allocation process through the impact of federal technical and financial assistance in cerlain agricultural programs which reduce capital costs for draining wetlands to increase agricultural productivity while simultaneously insuring cash returns for production which exceeds demand and consequent market price levels.

Terminating price supports would correct much of the problem, but the price support program is well entrenched and has withstood more compelling attacks in the past. However, it might be possible to eliminate payments that encourage socially inefficient drainage with substitute payments to farmers for maintaining wetlands that are judged to be important wildlife habitat. The source of the habitat easements or maintenance payments could be the beneficiaries of protecting wetlands such as waterfowl hunters, fishermen, trappers, naturalists, etc., who obtain direct tangible and inlangible benefits from wetlands. Such a broad-based beneficiary taxing system is, however, likely to be full of adninistrative difficulties. Consequently, it is probably most equitable and socially efficient to finance an easements payment program (for wetlands maintenance or preservation) out of general revenue funds if the payments were viewed as income maintenance payments (in the same sense that price supports are) as well as a means of promoting allocative efficiency..$^{13}$

In recognition of the important contributions of wetlands and the apparent disproportionate incentive to drain them for agricultural purposes with federal financial subsidies, Congress enacted the Water Bank Act (Public Law 91-559) in 1970. The thrust of this Act is to pay landowners to retain natural wetlands by offering them contractual agreements for long-term (10 yr.) payments against drainage, filling and burning. Payments are to be at a rate to encourage owner participation in the program. The wetlands covered by the Water Bank Act include inland fresh areas (Types 1 through 5) as described in Wetlands of the United States, ${ }^{14}$ and artificially developed wetlands which meet the same descriptions. (See Appendix G.) Since the program initiated under that Act is so new, however, a time lapse of some significance must be anticipated until it becomes fully operational and its consequent balancing impact (versus drainage) can be observed and evaluated.

Under the above circumstances, the continied agricultural land drainage program in Maryland under the aegis of the U. S. Soil Conservation Service requires careful public examination and reconciliation of divergent resource management goals.

\section{DREDGING AND SPOIL DISPOSAL}

\section{Definitions}

Dredging is the physical act of excavating land or buttom materials. This is often done to create or enlarge a waterway for safe navigability. Dredging is also done to obtain fluvial deposits of sand, gravel and shells for use as construction materials or for fill in reclamational efforts

Spoil is bottom material removed by dredging operations that must be disposed of somewhere else. It usually consists of sand, clay, mud, muck (accumulated layers of decayed organic matter produced in wetlands) and other material produced by the dredging operations.

Spoil disposal can be accomplished in three ways: 1) pumping or dumping spoil back into the water (frequently adjacent to the excavation site); 2) depositing spoil on land or wetlands which may or may not have dikes installed to prevent the spoil from returning to the waterway: and 3) dumping into deep water sites at locations distant from the dredging site.

\section{A creage Losses}

The impact of dredging and spoil disposal on high natural environmental values results from the physical destruction of existing bottom materials or wetlands and/or their burial under dredged material (Figure IX1). Dredging and/or spoil disposal operations are reported to have destroyed 1,260 acres of wetlands. This figure. while not including the permanently submerged bottoms of estuaries, rivers, sounds or bays, represents 5.3 percent of the total inventoried acreage losses (Table IX-1). Most of the destruction occurred to coastal wetlands such as shallow fresh march (Type 12), 490 acres, coastal salt meadow (Type 16), 440 acres, and irregularly flooded salt marsh (Type 17), 160 acres. 


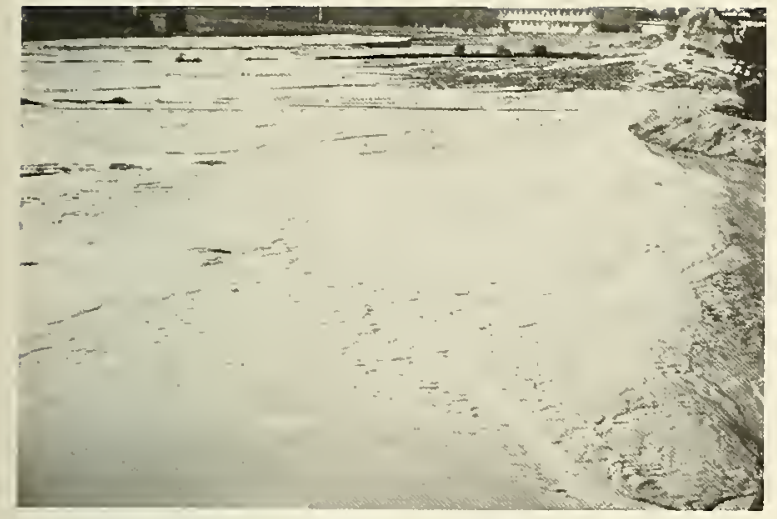

Figure IX-I Filling of wetlands with dredge spoil near George's Creek, St. Mary's County.

Losses were evenly distributed among several tidewater counties (Table 1X-2). Much of the acreage loss in Cecil County was due to construction and maintenance of marine shipping channels connecting the Bay with the Chesapeake and Delaware Canal. Wetlands were used there as spoil disposal sites.

An intelligent perspective on the extent of dredging and spoil disposal activity in Maryland waters is not readily apparent to casual observers. Also, records on the resultant economic and ecologic impacts of this activity are not easily obtainable. The following historical footnote is presented to demonstrate how easily the impacts of dredging and filling may be overlooked and unappreciated.

"In recent years large areas of marsh and shallow water have been filled with material dredged from the channels and converted into land. Extensive tidal marshes at the south end of Analostan Island (now officially named Theodore Roosevelt Island) were modified by the cutting of a channel to form the mouth of Little River and by the construction of Columbia Island, which separates Boundary Channel from Georgetown Channel. Potomac Park is based on tidal marshes that have been covered by artificial fill dredged from Georgetown and Washington Channels. Much of Anacostia Park, also is reclaimed marshland."

"A large part of the National Airport was built of dredgings from the river. Tiber Creek, which was formerly flowed past the site of the City Post Office and along Constitution Avenue to a wide mouth near the Lincoln Memorial, has been completely filled in." 15

Besides observable destruction to habitat some other disadvantages of dredging include segmentation of bays which promotes shoaling; increased saltwater intrusion; altered tidal exchange, mixing and circula- tion patterns. These effects are notable because the spatial and temporal distribution of salinity profoundly affects the activities of many estuarine species in tidal estuaries. Care must be exercised in the approval of engineering projects or industrial processes that will alter salinity regimes in tidal estuaries and lagoons and in their associated wetlands. ${ }^{16}$

If deep holes are left in the wake of extractive activity such as sand and gravel mining, the holes will tend to concentrate the normal bottom detritus produced or carried into the area by water movements. A lack of water circulation in the excavation area would result in anaerobic decomposition of the accumulated detrital material with the production of hydrogen sulfide. Under such conditions the area is uninhabitable for most life forms. Also, silt suspended during the dredging process increases the turbidity of surrounding waters and thus reduces photosynthetic activity. As the silt slowly settles it covers adjacent areas and becomes a new substrate which may not be conducive to rapid recolonization of benthic life smothered by accelerated sedimentation from nearby dredging. In cases where the bottom is actually removed or covered with spoil it has been reported that it frequently takes at least a year or two for benthic life to re-establish itself in destroyed or disrupted areas. 17 "None of these changes, however are as significant as the direct physical loss of habitat."18

Some advantages may be derived from dredging and spoil disposal depending upon the circumstances. These include: connection of isolated waters and marshes to make them available as fish nursery areas, provisions of routes of escape or refuge for fish during cold periods, improvement of water exchange and circulation, and release of nutrients trapped in bottom sediments. ${ }^{19}$ Additionally, it may be possible under proper conditions to create new marshes by innovative disposal of spoil. The natural circumstances and final altered conditions determine whether or not there are net advantages or disadvantages from dredging, disregarding the loss of previous habitat.

\section{Dredging Economics}

Dredging is an essential component of the marine shipping industry. In Maryland, extensive dredging activity is associated with Baltimore Harbor, the Chesapeake and Delaware Canal and certain other areas of the Chesapeake Bay. The spoil material generated by dredging Baltimore Harbor, its approach channels, and elsewhere in the Bay amounted to about 38 million cubic yards of material for the period 1957-1968.20 The total amount of material to be removed from 
Baltimore Harbor and its approach channels during the 20-year period 1969-1989 is estimated at 99 million cubic yards. ${ }^{21}$

Besides Baltimore Harbor, other navigation improvement projects are undertaken throughout the Chesapeake Bay tidewater area. These projects, administered by the U. S. Army Corps of Engineers, have been undertaken to provide channels for commercial shipping, commercial fishing boats and recreational boating within the Bay and between the Bay and tidewater communities located on tributary waters. Upwards of 16 million cubic yards of spoil material have had to be disposed of in constructing and maintaining these navigation improvements between 1939-1969. ${ }^{22}$ An estimated 41 percent of the spoil material (6.5 million cubic yards) was deposited on land, primarily wetlands.

Most navigation improvement projects require some assistance from local benefiting interests in order to obtain Federal financial assistance. Generally, the local assistance consists of providing all lands, easements and rights-of-way required for construction and subsequent maintenance of the project including areas suitable for initial and subsequent disposal of spoil.

Local responsibility for providing spoil disposal sites for navigation improvement projects may result in use of wetlands for two fundamental reasons.

First, a spoil disposal site may require land acquisition or an easement at local expense. (Some sites may be acquired by the Corps of Engineers, depending upon the project and assigned financial responsibilities.) Wetlands are consistently the lowest priced waterfront real estate (Chapter VIII). This economic situation when combined with the common social perception that wetlands are worthless, or useless in comparison to other land may strengthen the local tendency to provide wetlands for spoil disposal sites.

Second, local pre-occupation with increasing the taxable base and tax revenues encourages an attitude that wetlands as wetlands aren't worth as much as productive farmland or other types of land. If wetlands are not perceived to be valuable in a natural state, then there is logic in believing that reclaiming wetlands by draining or filling will create valuable land from worthless land. Also, wetlands may be volunteered freely to serve as disposal sites, so as to gain free fill and "im- . prove" the land for the owner at no personal private expense.

\section{Future Trends of Dredging and Implications to Wetlands}

Large dredging projects are planned for Baltimore Harbor and connecting waterways. However, because designated spoil disposal sites in the Bay are nearly filled, and due to the poor chemical quality and physical characteristics of the sediments to be dredged, special disposal sites are required. A tentative solution to this problem was provided by State legislative action which authorized $\$ 13,000,000$ for developing needed spoil disposal sites in certain open water areas of the Bay. 23

Future navigable waterway improvement projects in other areas of the Bay are of potentially greater importance and consequence to wetlands than Baltimore Harbor projects. Ever-increasing numbers of recreational boats will require improved channels and essential support facilities. Local economies tied to commercial fishing and marine shipments will require similar considerations. If past experiences with locally supported and cost-shared dredging and spoil disposal siting projects are reliable forecasters, wetlands will be used as spoil disposal sites.

\section{Discussion on Dredging and Spoil Disposal}

The Chesapeake Bay and tributarial waters have experienced considerable dredging, particularly Baltimore Harbor, Patapsco River, Elk River, the Chesapeake and Delaware Canal, Nanticoke River, Wicomico River (Wicomico Co.), Potomac River, and Assawoman, Isle of Wight and Sinepuxtent Bays. This disruption to the aquatic environment has resulted also in a large volume of spoil material requiring disposal sites. Wetlands have frequently been such sites.

Because of the importance of marine shipping, recreational boating, and commercial fishing to Maryland's economy, dredging projects in Baltimore Harbor, connecting waterways and other areas of the Bay are an indefinite fact of life. Since dredging is an indefinite reality in certain areas of the State's waters, the other component of dredging, spoil disposal, is the factor of this activity with potential flexibility concerning its impact on the aquatic environment.

The Bay is a multiple use resource of differing values to Maryland, surrounding regions and the Nation. It has been noted before, that far from being a limited matter, dredging and spoil disposal practices have direct and indirect effects upon most segments of our population. ${ }^{24}$

Mounting scientific evidence indicates the valuable contributions of wetlands and estuaries to our environment. In the future, it will be more undesirable to disrupt or destroy remaining key segments of a diminishing natural environment by dredging or spoil disposal. If so, problems will arise concerning socioeconomically and ecologically acceptable parameters for spoil disposal sites. 
Sites satisfying all parameters are becoming increasingly scarce. In fact, they are becoming almost non-existent except at both higher economic and environmental costs. For example, spoil disposal costs about $\$ 1.50 /$ cubic yard for spoil dredged in the Baltimore Harbor area and disposed of in the dumping ground near Kent Island. Ocean disposal of fut ure spoil from the same area necessitated by undesirable chemical quality and physical characteristics would raise the cost to about $\$ 6.00 /$ cubic yard. ${ }^{25}$ The solution, mentioned earlier, was passage of State legislation which authorized future State cost-shared dredging by financing the construction of suitable spoil disposal sites near the project area.

The selection of spoil disposal sites that satisfy all management policy parameters remains unresolved for other navigation improvement projects besides Baltimore Harbor. One solution, dumping spoil overboard into waters adjacent to the dredged area can have ecologically undesirable effects from the resulting turbidity and siltation. ${ }^{26}$ Wetlands are not satisfactory spoil disposal sites for several ecological reasons. If both overboard areas and wetlands should become unacceptable spoil disposal sites in the future because of damages to other Bay uses, alternative methods of spoil disposal or choices of site location will be necessary.

One such alternative site(s) might be abandoned sand and gravel borrow pits located in shoreline situations, if the spoil could be contained and prevented from encroaching on or despoiling surrounding waters and submerged bottom areas. Also, shoreline areas that are definitely planned and dedicated for development for housing or industrial use might be utilized for disposing of spoil materials suitable for supporting such construction purposes.

The Commission on Submerged Public Lands (1960) explored some of these problems. Concerning disposal of materials dredged for local cost-sharing navigation improvement projects-

"It is the responsibility of the U.S. Army Engineers to perform such channel development and maintenance works as are authorized by the Congress of the United States, for the benefit of local public interests, where the benefit-cost ratio of such works can be shown to be a favorable one. It is the local community, and not the Corps of Engineers, that initiates the request to Congress for the navigation works. It is actually the responsibility of the local community, and not the Corps of Engineers, to find suitable areas for spoil disposal. Since the State benefits from the development and maintenance of navigation projects in the tidal waters, it is the State responsibility to find suitable areas and methods for spoil disposal.
"Maryland has not, in general, found it necessary in the past to meet this responsibility. Over the years the Engineers generally have attempted to develop plans in cooperation with local interests which would facilitate channel development and maintenance, and designate marine areas where the dredged material could be deposited ....

The Commission also attempted to ascertain the scope of the disposal problem in tidewater Maryland and the anticipated disposal needs in the forseeable future. With regard to deep water disposal sites as an alternative, the Commission concluded that:

"[1]t has been increasingly apparent to all of us (Commission) that the State's interest can be served best by a comprehensive policy. Deep water disposal of dredged material appears to have been in the best interest of the State. In some instances such deep water disposal will remain in the best interests of the State in the future. However, it is evident that alternate disposal methods must be found for part of the spoil material which will result from future channel development and maintenance projects. The deep waters of the Bay remain an important ecological environment which should remain free from encroachment whenever possible."28

Effective long-term solutions must be found to reduce the adverse environmental impacts from disposal of dredged materials in the waters and on the wetlands of the State. Tentative steps have been taken by the Corps of Engineers in this direction by the initiation of studies on "the relationships of the engineering works of the Corps to the ecology of coastal waters. The primary objective is to develop criteria, standards and guidelines for including ecological effects in planning for water resource development.",29 Further suggestions as to how the Corps might take environmental considerations into account have been provided by the House Committee on Government Operations in "Our Waters and Wetlands: How the Corps of Engineers Can Help Prevent Their Destruction and Pollution." 30

With further regard to guidelines and criteria on dredging and spoil disposal practices which will serve to ameliorate adverse environmental impacts, the following ones are presented for information purposes.

1. Channels should not cross nor should spoil be placed on high-value natural habitat. Highvalue habitat in most estuaries includes, but is not limited to, brackish marshes, vegetated shoreline zones, beds of submerged aquatic vegetation, protected shallow waters near shore, oyster reefs, and small meandering tributaries (guts) in the tidal zone. Opportunities for enhancing or protecting natural habitat should be sought always with dredging and spoil disposal activities. 
2. To provide for maximum water exchange and circulation, spoil should be placed in mounds at least 1,000 feet apart on alternating sides of a channel. At places where feasible, the mounds should be developed to elevations above mean high water to create islands. Under certain circumstances and depending upon wildlife management goals, creation of a continuous spoil bank may be a more desirable method of spoil disposal.

3. Spoil should not be placed in the water closer than 500 feet from the shoreline of shallow, protected bays. However, opportunities to 'improve' or protect waterfront land areas should not be overlooked via "filling" with spoil depending upon the environmental impacts.

4. Natural drainage channels and waterways should not be blocked by spoil. Isolation of an area should be avoided. The weighing and application of this criteria is heavily dependent, however, upon the natural conditions of the specific area in question as well as management goals for it .

5. The integrity of natural waterways should be maintained. This principle is applicable especially to dead-end access channels and canals.

6. Spoil should be placed on uplands and not back into the water. Constructive uses should be sought for the spoil such as fertilizing agricultural land (if high in organic material). Otherwise it should be confined to as small an area as practical. When spoil is confined behind levees or other containment devices, care should be exercised in preventing the pooling of stagnant water which will promote mosquito breeding.

7. Spoil deposition sites should be retained for future maintenance spoil. The selection and creation of spoil disposal sites should be done with a look toward the eventual uses of potentialities of such sites once they are filled completely, and hence, no longer suitable for receiving additional spoil materials.

8. "For the protection of estuarine organisms, no changes in channels, in the basin geometry of the area, or in fresh water inflow should be made that would cause permanent changes in isohaline patterns of more than \pm 10 percent of the natural variation.",31

These guidelines and criteria are not all inclusive nor are they minimum or maximum standards that must be adhered to absolutely. Rather as presented originally ${ }^{32}$ (except for No. 8), they were intended to assist and be applied and modified by trained biologists familiar with areas for which dredging and spoil disposal activities are proposed.

\section{INDUSTRIAL DEVELOPMENT}

\section{General}

Industrial development includes port-industry complexes such as marine shipping terminals, docks and other support facilities, port-oriented manufacturing industries, electrical power generating plants, and sand and gravel extraction. Much of the shoreline industrial development has been governed by a need for access to water. Water is needed in large quantities for manufacturing processes, cooling, waste discharge and dispersal, and transportation. One result has been encroachment onto wetlands because of their location at the land-water interface.

\section{Acreage Losses}

The wetlands habitat inventory lists 1,590 acres destroyed by industrial development. This figure represents 6.7 percent of the total Statewide losses (Table IX-1). These losses were distributed among several counties with the largest being Wicomico (400 acres), Anne Arundel (250 acres), and Baltimore (220 acres) (Table IX-2).

\section{Future Trends in Industrial Development and Implications to Wetlands}

Industries requiring land fronting on navigable waters are important to the economy of Maryland. Consistent with the economic significance of waterfront industrial development, a survey was conducted during this study to identify future potential industrial land use sites which involved wetlands. Criteria used in that survey included: geographical location, availability of transportation services (railroad and highway network), deepwater access, waterfront access, surrounding land uses, and nearness to population centers. Results show that at least 41 wetlands with a total of 1,488 acres met the criteria established for the first cut of the survey (Table IX-3).

Most of the wetlands within potential industrial development sites are found in the following counties: Baltimore (540 acres); Somerset (275 acres); Harford (200 acres); Anne Arundel (130 acres); and Kent (120 acres). Development, if it does occur on the surveyed wetlands, will be primarily on coastal shallow fresh marsh (Type 12).

The potential future physical damage due or related to industrial development is small in terms of the residual inventoried wetland acreage. However, there are other important considerations that need to 
Table IX-3. Statewide summary of planned, proposed or potential industrial sites coinciding with wetland areas.

\begin{tabular}{|c|c|c|c|c|c|c|c|}
\hline \multirow{2}{*}{ County } & \multirow{2}{*}{$\begin{array}{c}\text { Total } \\
\text { No. of } \\
\text { Wetlands }\end{array}$} & \multicolumn{5}{|c|}{ Acreage total per number of wetlands by type } & \multirow{2}{*}{$\begin{array}{c}\text { County } \\
\text { Sub- } \\
\text { Totals }\end{array}$} \\
\hline & & 5 & 6 & 7 & 12 & 16 & \\
\hline \multirow[t]{3}{*}{ Anne Arundel } & 3 & & & 109 & \multirow{3}{*}{21} & & \multirow[b]{3}{*}{130} \\
\hline & 2 & & & & & & \\
\hline & 5 & & & & & & \\
\hline \multirow[t]{4}{*}{ Baltimore } & 1 & & 3 & & \multirow{4}{*}{479} & & \\
\hline & 2 & 61 & & & & & \\
\hline & $14^{*}$ & & & & & & \\
\hline & 17 & & & & & & 543 \\
\hline Baltimore City & $1^{*}$ & & & & 3 & & 3 \\
\hline Caroline & $1^{*}$ & & & 31 & & & 31 \\
\hline \multirow[t]{3}{*}{ Cecil } & 1 & & & 13 & \multirow{3}{*}{41} & & \\
\hline & 2 & & & & & & \\
\hline & 3 & & & & & & 54 \\
\hline Dorchester & 2 & & & 24 & & & 24 \\
\hline Harford & 3 & & & & 200 & & 200 \\
\hline Kent & 1 & & & & 127 & & 127 \\
\hline \multirow[t]{3}{*}{ Prince George's } & 1 & 17 & & & \multirow{3}{*}{39} & & \multirow[b]{3}{*}{56} \\
\hline & 3 & & & & & & \\
\hline & 4 & & & & & & \\
\hline Queen Anne's & 1 & & & & & 15 & 15 \\
\hline St. Mary's & 1 & & & & & 10 & 10 \\
\hline Somerset & $1^{*}$ & & & & & 275 & 275 \\
\hline Wicomico & 1 & 20 & & & & & 20 \\
\hline Totals & 41 & 98 & 3 & 177 & 910 & 300 & 1,488 \\
\hline
\end{tabular}

${ }^{*}$ More than one wetland type in the same area. 
be taken into account concerning such use of wetlands and other waterfront lands. In the past, the shoreline available and ideally-suited for industrial use was assumed to be plentiful enough to satisfy envisioned growth needs. That situation may not hold true much longer against increasing pressure and competition between all potential users for remaining areas of undeveloped shoreline. This is due in part to growing human populations and attendant shoreline development in certain favored locations or else vacant land is allocated to other uses through public programs and zoning.

It has been noted elsewhere that land with deepwater access for marine shipping and possessing potentials suitable for future port-oriented industrial growth is already scarce in the Baltimore regional port area. ${ }^{33} 34$ Consequently, long-range economic development based on waterfront industry may require locating in other than the Baltimore regional port area. Land that might be economically suitable and socially acceptable for waterfront industrial development outside the Baltimore region in the future could be in short supply. Since wetlands occur naturally at the land-water interface and because they represent sizeable tracts of undeveloped, low tax revenue generating lands to local governments ( $\mathrm{Ch}$. VIII), wetlands will be looked at and analyzed critically for industrial development in any shoreline development squeeze situation.

Sand and gravel extraction. Within the industrial development category there is one use of coastal zone resources that merits specific attention because of its interrelationship with wetlands - mineral extraction, especially sand and gravel. The reason for its significance is based upon the fact that onshore aggregate supplies for building and highway construction are reported to be approaching exhaustion in many urbanizing areas. This situation is due to depletion of available reserves, denial of deposits because of being built over or restrictive zoning regulations and environmental protection reasons.

The National Sand and Gravel Association predicts a generally critical supply situation near most urban areas within the decade. ${ }^{35}$ Locally in the Baltimore region, one comparison of future demand and projected availability (exclusive of zoning restrictions) indicates a "critical situation developing in 1985 or sooner with respect to sand and gravel,... However, zoning trends and current planning attitudes are likely to precipitate a regional natural resources availability problem even sooner." ${ }^{36}$ Also, the farther the source from demand the greater the need for very inexpensive bulk transportation, because a significant part of the cost of aggregate is in its transportation. In order to minimize this cost either supply must be located near demand or economic bulk movement must be feasible. These factors combined with findings of large deposits of sand and gravel in or near coastal waters have made the following two alternatives increasingly attractive.

1) For urban areas: dredging to barges and barge movement to demand centers. Sand and gravel movements are already second only to petroleum products in annual tonnage for most of the small ports near urban centers, such as those along the Chesapeake Bay. ${ }^{37}$

2) For beach nourishment: dredging and pumping directly on to beaches from either a backbay or ocean site.

Obviously, both of these alternatives for coastal sand and gravel deposits could have potentially adverse impacts on wetlands.

Many activities in the coastal zone are affected by the extraction of sand and gravel, both positively and negatively. Foremost among the beneficiaries of an extensive supply of aggregate is the construction industry which seeks to serve the demands for facilities by a diversity of interest. Via this route, all residents of the coastal are affected in one way or another. Many of the diverse interests which can benefit from an inexpensive and ready source of aggregate can also be adversely affected if the environmental abuses cited earlier (under dredging) are allowed.

Recent proposals to extract significant quantities of sand and gravel from Maryland's coastal waters and near shore land areas have become very controversial because of perceived damages to wetlands and other environmental values. These include the Potomac River, Piscataway Creek, and Stillpond Creek proposals to mention a few.

Since there is slight probability of developing economical substitutes or sources for aggregate in the metropolitan and urbanizing areas of Maryland, proposals for dredging extraction of subaqueous aggregate deposits can be expected to mount in the future. Resolution of coastal zone resource use conflicts, therefore, will have to be oriented toward mitigating or minimizing the adverse environmental impacts of extracting a vailable aggregate deposits.

Summary on industrial development trends. Eventually, development competition for remaining undeveloped shoreline and inappropriate, unplanned allocations of shoreline for different uses may produce chaotic and unmanageable coastal zone land use patterns. To insure optimum allocations among all users of shoreline areas and adjacent waters, establishment of a Statewide priority system may be required. 


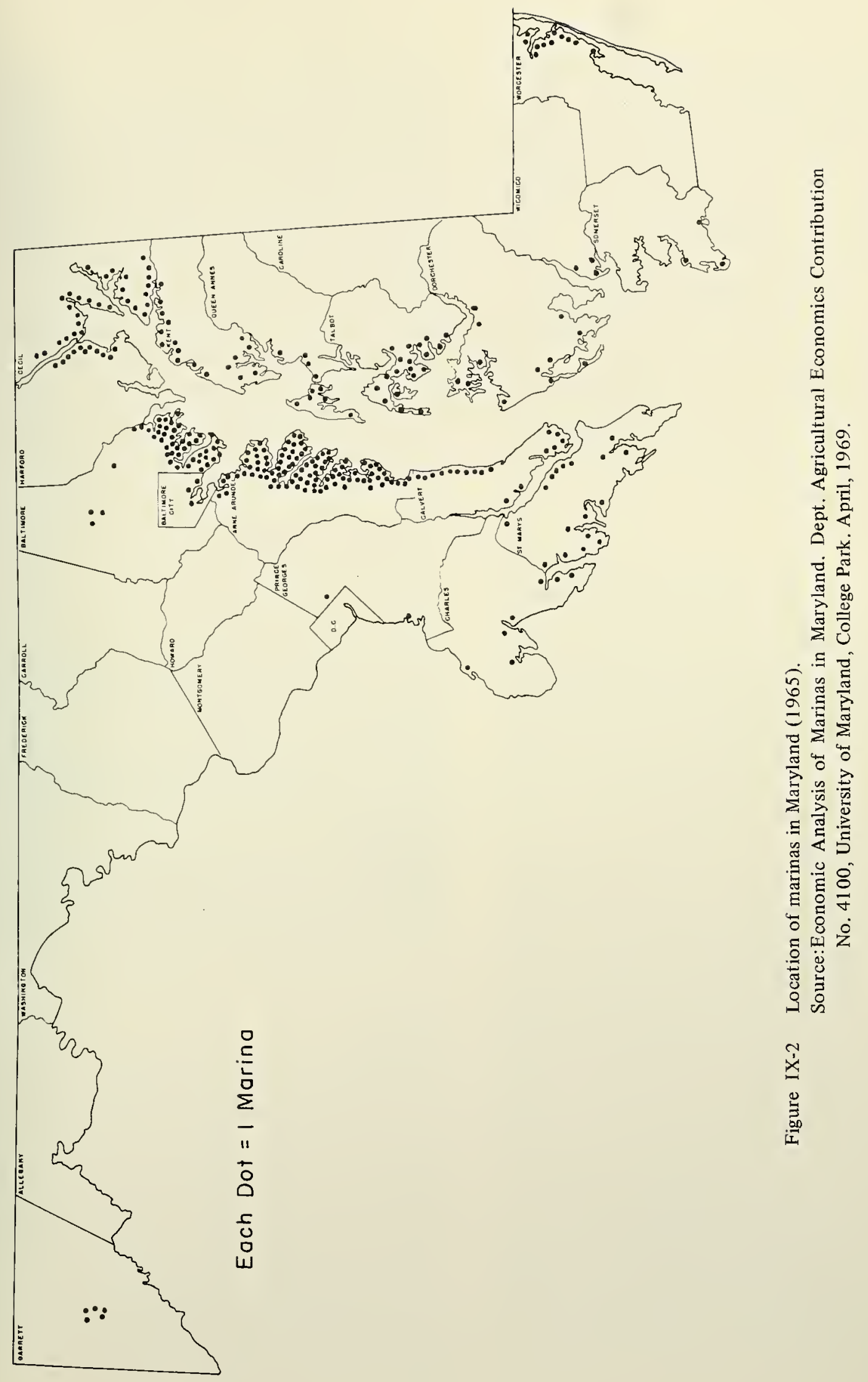


For example, there are several different shoreline needs categories that might be established within industrial development. These categories would aid evaluating site needs and the potential adequacy of certain locations to fulfill identified development requirements. Envisioned industrial waterfront categories might consist of the following:

1) deep-water sites for ports and industries requiring use of deep draft vessels;

2) shallow-draft sites for ports and industries requiring or able to use shallow-draft vessels, e.g., barges;

3) contiguous uplands for industries that are linked by process, by product, or critical service to basic shoreline industries; and

4) sites for industries requiring water for process purposes only. ${ }^{38} 39$

Without some determinations on land and water needs for future industries development, management plans and allocations for other uses of the shoreline and water resources of the State are incomplete. Matching or companion study and planning efforts on Statewide management plans for industrial development, even of a preliminary nature, are an essential input into shoreline land use planning activities.

\section{MARINAS}

\section{Background}

A marina is a place on waterfront property that provides launching, mooring, docking, repair and service facilities for pleasure and commercial boats. For a marina to be functional, it must be on or accessible to navigable waterways. It must also provide or be a safe place for boats from storms. All but a few of the 308 marinas in Maryland are on Chesapeake Bay or bodies of water with easy access to the Bay. The 308 marinas had 19,559 slips and 1,909 moorings for a total of 21,468 berths. The majority of the marinas, 173, were in Anne Arundel, Baltimore and Cecil Counties (Figure IX-2). ${ }^{40}$

Originally, the marina industry started as boatyards to support commercial fishermen. However, the majority of the marinas today cater to the pleasure boat owner, and only a few serve the commercial fishing industry. The industry's composition is that of relatively small business operating largely free of regulations in most areas.

\section{A creage Losses}

The growth and development of marinas has had an impact on wetlands. Results of the wetlands habitat survey show that 1,100 acres were destroyed or significantly altered for use as marinas. This loss figure represents 4.8 percent of the Statewide losses (Table IX-1). Most of the losses occurred to coastal types of wetlands (Figure IX-3). Their waterfront or shoreline locations, the economics of marina development, plus the ease with which they facilitate engineering alteration into land and water marina configurations explain the location and destructive use relationship. The marina facilities created by wetland reclamation include dredging of navigable channels, boat slips, moorings and berths, and filling to provide convenient parking lots, roadways and land for repair and service facilities, boat storage, and trash disposal. Much of this construction is by the bulkhead and dredge and fill methods. The material removed by dredging to provide channels and berthing spaces is often used to fill adjacent areas creating additional waterfront land.

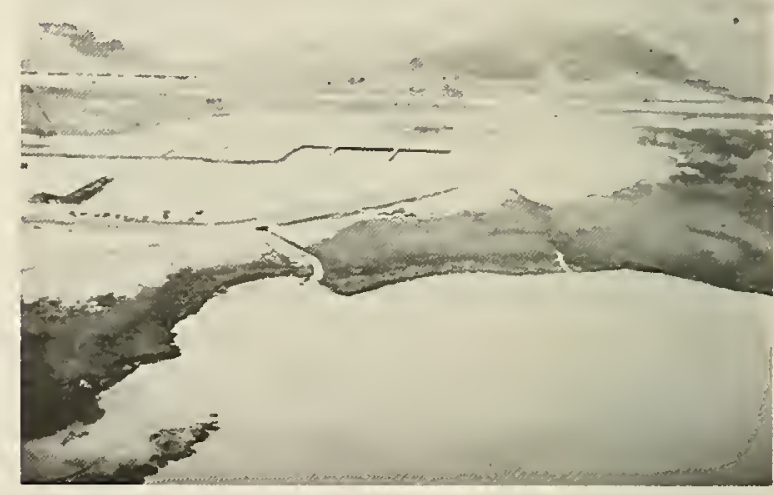

Figure IX-3 Destruction of Type 16 Wetlands of Kent Narrows for marina development.

\section{Future Marina Growth Trends}

Growth of marinas has been spurred by increasing numbers of recreational boaters. The growth of boating is due to more people with greater mobility, higher incomes and more leisure time to enjoy expenditures for outdoor recreational activities. Of the marinas in existence in 1965, about 65 percent were opened for business following World War II, and 38 percent began operating between 1956 and 1965 . Indications show an upward trend in boat buying and a consequent increased demand for boat facilities. Altogether, marina owners reported that they needed 30 percent more slips than they had in $1965 .{ }^{41}$ 
In addition to satisfying greater demand, other business reasons have dictated a trend toward larger marina facilities over original development stages. An important point is that the size of a marina determines land cost, and an increase in the size of physical holdings means higher total land costs. The investment in land for a marina varies because of at least three factors: 1) the size of the marina, 2) the location of the marina, and 3 ) the improvements to the land that will be needed.

Concerning size, one recommended land/water ratio for marinas is that land holdings should be 1.25 times the water area. ${ }^{42}$ When this requirement is coupled with the trend toward larger marinas for economic reasons, the initial development costs due to land value become an important criteria in site selection. Since wetlands generally have lower market value than other lands with water frontage and are easier to dredge (less development costs), it seens likely that they will continue to receive consideration as prime sites for marinas.

Location is a significant factor in marina development because it determines the value of the land in terms of investment costs and the desirability and utility of a site as a marina. Close proximity to population centers provides convenience to boat owners or renters. Marina clientele convenience translates into a desire to minimize travel and time costs between residence and marina. Consequently, marinas closer to population centers tend to have more use than outlying ones." However, shoreline available for marina development or any other purpose which meets the travel and time cost criteria is becoming scarce. As expected, land and shoreline located in or nearer populated areas sells for more than land in remoter areas (Table VIIJ-I)

There is intensive shoreline development on the Western Shore due 10 closer proximity to dense population centers. Large numbers of recreational boaters have prompted and supported a heavy concentration of marina development. Proposed expansions of marina facilities to satisfy needs have resulted in public zoning and re-zoning issues, particularly in Anne Arundel County. ${ }^{44}$ However, construction of the second Bay bridge will probably provide a solution and a shift of problems elsewhere. Improved and immediate access will be provided to miles of undeveloped shoreline with comparatively uncrowded waterways offering a lightly tapped supply to meet the recreation boating demand for marina facilities.

Improvement costs to sites selected for marina development often include bulkheading when wetlands are used. Where bulkheading was necessary it was often a major part of total marina investment. Bulkheading costs within total investment costs ranged from 10.4 percent for a 200 slip marina to 18 percent for a 50 slip marina."s

Considering past and anticipated growth in boating, there will be a continuing demand for marina facilities and services. To meet the demand, it is apparent that new or additional marina development will take place in the next few years. Wetlands are likely to be marina sites because:

1) greater inducement for marina development on the Eastern Shore due to improved accessibility;

2) lower market prices for waterfront property due to less intensive shoreline development competition;

3) greater incidence of wetlands as shoreline features of the Eastern Shore than on the Western Shore; and

4) more attractive recreation areas due to less boating congestion and developed shoreline.

\section{Discussion on the Interrelationship Between Marinas and Wetlands}

Three salient points should be considered concerning future marina development that utilizes wetlands.

1) While the economics of marina development may dictate selecting wetlands as prime sites, one of the net results is destruction of the ultimate source of a primary attraction for marina kept boats. Sport and commercial fishing boats constitute 42.4 percent of marina kept boats. ${ }^{\text {th }}$ Nearly one-half of marina business is tangibly linked to fishing. The fisheries resources supporting this business are in turn dependent on wetlands for part of their lile cycles.

2) Marina development may result in undesirable spill-over effects. For example, dredge and fill operations often create heavy water turbidity and silting to immediately adjacent wetlands and submerged bottoms. The result may be partial or total loss of more aquatic habitat than that at the development site.

3) Once encroachment on a wetland has occurred, development tends to encourage further destructive incidents to immediately adjacent wetlands by various activities. For example, wetlands are convenient trash and other solid waste disposal sites. Seepage from septic tanks or spilled petroleum products may filter into nearby wetlands. Gradually, unintentional destruction creeps over greater areas of wetlands fostered by the initial development activity.

Future development of the marina industry faces a paradoxical situation. Wetlands are attractive sites for marinas. However, such utilization of wetlands reduces a key element in the life cycle of many fish species, and 
fishing is the primary purpose of a significant portion of marina boating business.

\section{OTHER USES}

\section{General}

The other uses category includes public dumps and solid waste disposal sites, recreation (campgrounds and golf courses), and mosquito control work. Each specific use has not accounted for significant wetland acreage losses as yet. Each occurrence does, however, contribute to the net impact on wetlands and dependent biota. When viewed from a broader, Statewide perspective, the accumulation of acreage losses from all uses becomes meaningful to natural resources management planning.

\section{Acreage Losses}

Losses from other uses totaled 735 acres or 3.1 percent of all acreage losses (Table IX-1). Most of the losses were recorded for coastal wetlands such as coastal shallow fresh marsh (Type 12) and coastal salt meadow (Type 16). Losses are distributed uniformly throughout the State with the largest being Baltimore County sanitary land fill projects (240 acres), mosquito control work in St. Mary's County (120 acres), recreational use in Worcester County (90 acres) and Harford County public dumps or fills and construction on military reservations (70 acres) (Table IX-2). Thousands of additional acres have been worked on by the mosquito control program, but while altered, they are not considered to be destroyed biologically.

\section{Discussion}

Solid waste disposal. Disposal of solid wastes is a major problem. Traditionally, the most expedient and cheapest method is sought and adopted. Land fills and incineration are the principal refuse disposal methods currently available and utilized.

Wetlands have been and continue to be used as reluse disposal sites (Figure IX-4). Such use is encouraged by the fact that they are not of direct benefit to the owner, their convenience and adaptability for filling, their location in rural areas, and a tendency to regard wetlands as "waste" land until reclaimed."

A recent study of solid waste disposal problems in the Washington (D. C.) Metropolitan Region suggested several wetland areas in Maryland and Virginia as potentially satisfactory for solid waste disposal sites. Among those in Maryland were sites on Mattawoman

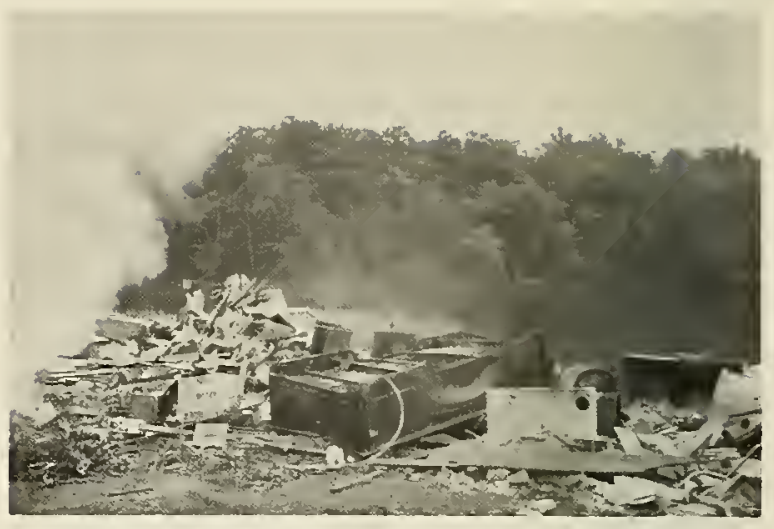

Figure IX-4 Solid waste disposal into wetlands.

Creek and White Marsh Branch in Prince George's County and Cedar Point Neck in Charles County. ${ }^{\mathrm{d}}$

Unfortunately, such use would not be inconsistent with on-going solid waste disposal activities elsewhere in Maryland. One Statewide study ${ }^{4 y}$ showed that 14 wetland areas were being used as public or municipal solid waste disposal sites (Table IX-4).

Improper solid waste disposal practices can also be the source of surface and ground water pollution if water enters a sanitary landlill in sufficient quantity to cause supersaturation of the refuse. Consequently, a highly polluted and inalodorous fluid may leach from the fill. This discharge can pollute ground water in the immediate vicinity or surface waters into which it flows. "The continuous leaching of an acre-foot of sanitary landfill will result in a minimum extraction of approximately 1.5 tons ol sodium plus potassium, 1.0 tons of calcium plus magnesium, 0.91 tons of chloride, 0.23 tons of sulfate and 3.9 uns of bicarbonate. Removals of these quantities would take place in less than one year. Removals would continue with subsequent years, but at a very slow rate. It is unlikely that all ions ever would be removed." erosion of soil from landfill sites can be a major source of sediment in nearby surface waters.

Land suitable for solid waste disposal through sanitary landfill methods near urban centers is limited. Al the same time growing populations and higher standards ol living are resulting in increasing volumes of solid waste. Consequently, solid waste disposal problems will intensily because some of the most logical disposal sites are planned for or already used by other uses.

Since refuse landfills are not aesthetically pleasing, reasonahle isolation is essential to minimize nuisance and public opposition. A site should be in a relatively undeveloped area with a minimum number of residences having a view of the operation or being affected by refuse 
Table IX-4. Wetland areas being used as public or municipal solid waste disposal sites in Maryland.

Source: Collection and Disposal of Solid Wastes - A Maryland Program, Maryland State Department of Health, August I, 1966.

\section{County $\quad$ Report location numbers and abbreviated remarks}

\begin{tabular}{|c|c|}
\hline Anne Arundel & Site No. 4 - Furnace Creek - pollution and solid fill \\
\hline Baltimore & Site No. 3 - Reliable sanitary landfill, 100 acres, swamp on the Patapsco Flats \\
\hline Cecil & Site No. 1 - Town of Elkton, 10 acres, swamp on Elk Creek \\
\hline Frederick & Site No. I - City of Frederick, 2 acres, pond \\
\hline St. Mary’s & Site No. 4 , in a marsh \\
\hline \multirow[t]{6}{*}{ Somerset } & Site No. 2 - Deal Island, marsh reclaiming operation \\
\hline & Site No. 3 - 5 acres, pond \\
\hline & Site No. 4 - 5 acres, pond \\
\hline & Site No. 5 - Crisfield, marshland on Jersey Island \\
\hline & Site No. 6 - marsh \\
\hline & Site No. 7 - Dames QuarterMarsh \\
\hline Talbot & Site No. 6 - Tilghman's Island \\
\hline Wicomico & Site No. 3 - swamp \\
\hline Worcester & Site No. 9 - swamp adjacent to Bunting Branch \\
\hline
\end{tabular}

Allegany, Baltimore City, Calvert,

Caroline Carroll, Charles, Dorchester,

Garretl, Harford, Howard, Kent, - None

Montgomery, Prince George's, Queen

Anne's, Washington

Sunımary 14 pond, swamp or marsh sites

truck trallic. Exposure to view from major highways is olten objectionable also.

The necessity for isolation and high land values in developing areas usually limits landfill sites to rural locations and marginal lands. Since many wetlands meet these criteria such areas are often considered logical refuse landlill sites."

Mosquito Control Program. The mosquito control program, administered by the Maryland State Board of Agriculture, is in its fourteenth year of operation. Currently, there are more than 800 communities in the State participating in mosquito control programs. Participation is entirely on a voluntary basis and predicated on community need and local financial assistance. The budgetary law underwriting the work provides for both temporary and permanent control, and requires the local taxing area requesting such work to cost share expenses. ${ }^{53}$

Tenporary measures include larviciding and spraying or fogging for adult insects. Mosquito control operations in Maryland follow the guidelines provided by the Conmunicable Disease Center of the U. S. Public Health Service and the Federal Committee on Pest Control. The three chemicals normally used in mosquito control in Maryland are malathion, naled and abate. These chemicals are among those recognized by cognizant authorities as most safe when appropriately used and have label approval under Federal law for mosquito control. ${ }^{\text {st }}$

The use of pesticides in temporary mosquito control work in Maryland is widespread. This program is of high value to many citizens, however, in some quarters cuncern has been expressed about possible detrimental ellects. Concerning this program, it was the opinion of the Commission on Pesticides that no additional regulatory legislation was required over the temporary program because of (1) apparent effective control of the public program by the State Entomologist; (2) the longlasting chlorinated hydrocarbons have been excluded and replaced completely by short-lived materials with 
minimal toxic residues; and (3) the acreage receiving treatment applications is "small" in relation to the total acreage of the State.

Permanent measures of mosquito population control include: marsh ditching, upland ditching and filling, tide gate installations and related operations to eliminate, change or regulate the water in a breeding area to make it unsuitable for mosquito development. ${ }^{56}$ The permanent works program is concentrated on the Eastern Shore due to the nature of the topography and the wellands acreages present.

The data in Table $1 X-5$ on wetlands acreage ditched for mosquito control is based on the ditch footage constructed and does not mean necessarily wetland destruction. However, significant alteration to wetland ecology has been reported previously under certain circumstances."?

Table IX-5. Approximate wetland acres ditched for mosquito control as part of the permanent works program in Maryland.

\begin{tabular}{|c|c|}
\hline Counti & Acres Ditched \\
\hline Dorchester & 425 \\
\hline St. Mary's & 981 \\
\hline Somerset & 10,563 \\
\hline Talbot & 128 \\
\hline Wicomico & 4,508 \\
\hline Worcester & 14,681 \\
\hline & $3 \mathrm{I}, 286$ \\
\hline
\end{tabular}

The policy governing both temporary and permanent measures in Maryland's mosquito control program is to provide or improve control but not to the detriment of fish and wildlife. The State Entomologist has stated that "mosquito control interests in Maryland are vitally concerned about Maryland wetlands and are attempting to follow procedures in the interest of their maintenance." $\$ x$ Accordingly, in the implementation of the temporary program the practice has been to avoid applying any pesticides to areas that are predominantly, wetland in character. Instead, ditching has been favored for at least two reasons.

1) Ditching permits the re-cycling of waters through tidal action, which allows rapid runolf of water accumulated following a high tide or heavy rain and prevents stagnate water conditions suitable for mosquito larvae development: and

2) Ditching permits the entrance and free movement of minnows which, as natural predators, eliminate the larvae.
The permanent control program which may involve water impoundment as well as ditching has impacts on wetlands ecology which are not completely understood by the scientilic community. The preference of State natural resource management agencies is to maintain the ecological base in as natural a condition as possible. However, the health and welfare of citizens affected by mosquitoes merits serious consideration and appropriate action by the mosquito control program whenever warranted. The problem is to attempt to balance the protection afforded by the mosquito control program against any unfavorable impacts on the ecology in areas where the program is applied.

To resolve problems that may arise from time to time between the policies of the Department of Natural Resources and those of the State Board of Agriculture and the State Entomologist, closest cooperation and coordination will be necessary between the interested parties.

\section{NATURAL SUCCESSION}

\section{Definition}

Natural succession is an orderly, sequential process of change in plant and animal communities. In essence, former wetlands are filled in by accumulated sediment and onsite deposited decaying organic material. As the wetlands fill in, they become less wetland-like in character and more like drier uplands. Gradually dilferent plant communities replace former aquatic plant residents and dilferent animal species inhabit the changed environment. "Sy (See also Ch. IV on the origin of wetlands).

\section{Acreage Losses}

Results of the wetlands habitat inventory show that about 1,060 acres were recorded as having naturally converted from wetland to upland or fast land. This natural process was responsible for about five percent of the rotal acreage losses (Table IX-I). All losses recorded were to coastal wetland types. Regularly flooded salt marsh (Type 18) experienced the heaviest losses (97\% of the total) due to wind blown sand filling in the marshes on the inland side of Assateague Island.

\section{Discussion on Natural Succession}

In some instances organisms which man most desires to perpetuate are members of earlier rather than later plant communities. Many of the most desired game and fisheries resources thrive best in what are actually 
transition communities. Since a particular organism cannot be maintained in nature without maintaining at least the essential parts of its community, in this case wetlands, the challenge is to learn how to halt succession and keep the desired community permanently in existence. An alternative would be to allow succession to proceed normally, but arrange sufficient numbers of areas to be continually coming int o the desired stage. ${ }^{60}$

\section{PUBLIC WORKS}

\section{General}

Public works include county roads, State highways, bridges, power lines, water and sewerage lines, bulkheading and other engineering works to prevent or control shoreline erosion, and public boat launching ramps and parking areas. Public and private solid waste disposal sites (dumps and fills) are discussed elsewhere in this chapter as are navigation improvement projects.

\section{Acreage Losses}

Public works were identified as the cause of destruction to 1,000 acres of wetlands (Table IX-1). This loss, constituting 4.2 percent of total recorded losses, was distributed rather evenly among all tidewater Maryland counties (Table 1X-2). The large amounts of sediment generated by many public works projects also had damaging (but difficult to detect) effects on wetlands and their ecology.

\section{Future Trends and Implications of Public Works Projects to Wetlands}

Of all activities listed under public works, road construction and the installation of water and sewerage lines may have the most significant future consequences to wetlands. The impact would not be large in terms of direct acreage losses from these activities, but indirect from other developmental activities encouraged by public works.

Road Construction. Roads are one of the most important factors leading to eventual man-induced ecological changes in any area. Much of the State's shoreline is inaccessible except by water transportation or is remote from heavily populated areas because of limited existing land transportation networks. However, road construction would alter this situation and make presently remote and inaccessible areas suitable and attractive for development.

For example in Caroline County, "lands along the lower Choptank River have prime development and recreational potential, but access to the waterfront is limited. However, selected road improvements are aimed at opening up housing and local recreational development opportunities along the county's attractive riverfront areas." 61

Construction of the first Chesapeake Bay bridge in 1952 was a major improvement in land transportation accessibility to the Eastern Shore. Among ot her results were notable increases in shoreline residential development in Queen Anne's County, particularly on Kent Island. ${ }^{62}$ Work on a second bridge, paralleling the first, commenced in 1969 and is due for completion 1973. In addition, proposals have been made for two other bridge crossings of the Bay in Maryland. One would be between Calvert and Dorchester counties and the other between Baltimore and Kent counties. If either or both bridges were constructed, much of the Eastern Shore would be within commuting distance to the BaltimoreWashington metropolitan area.

Water and sewerage system installation. Many of the Eastern Shore soil ty pes are unsuited for sept ic tank drainage field usage because of high water tables. These soil types often underlie wetlands or are in close to proximity to them. As a general rule, soils that are best for agricultural purposes are also suitable for building sites and other non-agricultural uses. Homesites planned for poorly drained soil areas will need a centralized sewage collection and treatment system or special means of waste disposal, if the quality of surface and ground water in the immediate vicinity is to be protected.

The installation of a central sewerage collection and disposal system will promote and permit the development of wetlands and other areas previously undevelopable because of soil conditions unsuitable for septic tank drainage. For instance, "the initiation of sewer facilities, coupled with the extension of the water system (run by the city) in 1963, opens North Ocean City to virtually unlimited development. Many of the system's new clients are new subdivisions, such as the controversial Caine Harbor Mile and Caine Keys II developments."63

A State program for county water supply and sewerage system planning ${ }^{64}$ may facilitate the development of previously undevelopable areas where soil conditions would not meet satisfactory percolation rate tests for sewage disposal via septic tanks. Certain regulations formulated by the Maryland Department of Health and Mental Hygiene for use in implementing the Statewide county water and sewerage planning program have special significance to future shoreline use allocations. For example, one such regulation is that which deals with the minimum requirements in the county planning program. 
"Show how existing and programmed water supply and sewerage facilities will conform to water quality criteria and stream classifications established by the State of Maryland."

"Study uses of water for purposes other than water supply and waste disposal and shall show how and where opportunities for such uses will be provided. These uses include recreation, commercial and sport fisheries, agriculture, navigation, and esthetic enjoyment."

"Take into consideration and coordinate the pertinent objectives and planning of other counties, the State of Maryland, and the Federal Government."65

"The Health Department shall assist in the required coordination. Section 0405 - Prior to approval by the Department, all county plans, revisions, or amendments shall be submitted to the Department of Water Resources by the Department of Health for advice and information on matters pertaining to water allocations, adequacy of industrial waste treatment and the effect of proposed withdrawals and waste discharges on waters of the State." 66

\section{Discussion on Water and Sewerage Systems' Implications to Wetlands}

Comprehensive land use planning undertaken for local governments in Maryland has pointed out that development should center at established communities and rural centers. The net effect of this action would produce urban clusters and avoid ribbon development, preserve open space, and conserve important cultural, esthetic and natural environmental values. Cluster development also facilitates optimal ultilization of community services at minimal ccosts. The potential impact of improved road networks and greater accessibility to the Eastern Shore threatens the recommended long-range development pattern.

The attractiveness of shoreline areas makes them prime for development and recreational use if accessibility were improved. This situation will create additional pressure for local and State road programs to improve accessibility to areas with development potential. There are, however, limitations on sound residential development without central sewerage collection and treatment systems due to unsuitability of soil for septic tank usage.

When new public policies on sewerage system planning, shoreline areas not previously suitable for septic tank installation could be susceptible to development. With this factor is combined with improved accessibility through better road systems, present development patterns and consequent implications to natural environmental values could be radically altered in a short time.

\section{SHORELINE EROSION}

\section{General}

Erosion of the shoreline on Chespeake Bay and tributary estuaries is a process which results from the combined action of waves, tides and stream flows acting upon reaches of the shoreline exposed to these forces. The erosion process results in the detachment and transportation of soil particles from the existing shoreline. Waves generated by wind blowing over large areas of open water (fetch) are the greatest erosion hazard. ${ }^{67}$ Although waves generated by passing ships are also a source of eroding wave action in certain locations.

An important consideration in assessing losses due to erosion is the rate at which it is taking place. The rate may be highly variable depending upon the configuration of the shoreline, the direction and force of wind and waves, the frequency and intensity of storms, the movement of sediment along the shore by currents, and the composition and structure of the coastal materials. In some Maryland shoreline areas several thousand feet of erosion has taken place in a period of approximately 100 years while in others the amount is perhaps 25 to 50 feet or less in the same period of time. ${ }^{68}$

The purpose of this section is to briefly survey and assess relationships between wetlands and shoreline erosion. Extensive study and work has already been done on the mechanics of shoreline erosion. Maryland's problems, and possible solutions, primarily by the Maryland Geological Survey. 697071

\section{Acreage Losses}

As a result of shoreline erosion activity 1,200 wetland acres have been lost. Coastal wetlands have experienced almost the entire loss (Table 1X-1). Highest acreage losses were in Dorchester and Talbot counties (Table IX-2). For a 25 year span based upon the difference between U.S. Geological Survey maps of 1942-44 and the year of the wetlands field inventory (1967-68), Maryland's average wetland loss rate due to erosion was 40 to 50 acres per year. The actual, eventual net result was the conversion of certain types of wetlands into another type - submerged bottom areas.

About 100 individual wetland areas are currently undergoing active erosion (Table $1 X-6$ ). Nearly all of these areas are on the Eastern Shore and coincide with reaches of the Bay shoreline noted for high shoreline erosion rates and acreage losses. 72 
Wetlands listed in Table IX-6 do not represent either an inclusive or exclusive group. The information gathered on this subject was incidental to habitat inventory work. Consequently, it is not certain that all wetlands experiencing erosion were identified because no specific request was made for such information during formulation of habitat inventory data sheets. Also, wetland erosion data does not mean that all of the indicated acreage is undergoing erosion. If it were true, then erosion losses would probably be much higher than shown.

\section{Wetlands Providing Protection To Upland Areas}

The physical characteristics of wetlands sometimes lend themselves to providing a natural form of protection against shoreline erosion. The low-lying profile of seaward wetlands are less susceptible to destructive wave action than shoreline uplands. Consequently, wetlands offer much less soil material compliant to wave action. Shallow waters common to wetlands cause a reduction in wave energy prior to reaching shore. Abundant wetland plant root growth serves to stabilize the soil by holding the bottom material in place. Submersed plant growths also reduce wave and current action which may cause deposition of suspended sediments thus adding to the growth and stability of the area.

Plant communities may establish themselves on shallow offshore shoal areas or bars built up of material eroded and carried from elsewhere by the currents until diminishing velocity causes deposition. Once wetlands are firmly established and stablized, a wetland's interposed position on the former shoreline may prevent or buffer erosive wave action on the former shoreline.

"One interesting change is on the north side of the Great Choptank River near its mouth, where there was once a pond or small lake which contained a vigorous growth of a water-grass common to many shores of the tributaries. When the land surrounding washed away, this vegetable growth not only remained intact but held the dirst and other material that swept upon it, until it became dry land entirely surrounded by water, and is now of ficially known as Nelson's Island.

The shore that is fortunate enough to have along its water's-edge a vigorous growth of the grass 1 have just mentioned has the assurance of remaining terra firma about as long as if set with a thick growth of deep-rooted forestry. In many of the estuaries the grass, combined with the sediment and flotsam, has defied the tides, and by a slow accumulating process has extended farther out into the water, instead of wasting away, as the earth, with greater specific gravity, would have done., 73

Results of the field survey show that 360 wetland units are buffering upland areas from active or potential erosion. Largest numbers of wetlands and acreage are located on the Eastern Shore (Table 1X-7).

\section{Discussion on Shoreline Erosion}

\section{and Wetlands}

Future shoreline development may create or impose different erosion forces on remaining areas of natural shoreline. This may or may not cause greater difficulty in protecting against or preventing erosion of natural shorelines. However, experience has shown that construction of man-made works must be closely related to the dynamics of the natural shoreline processes if such works are to be effective. ${ }^{74}$ Consequently, it is essential that any structure (protective or otherwise) must be designed specifically for the individual shore line environment on which it will be located..$^{75}$

Past experiences with the impact of erosion on shoreline development, the potential impacts of development on the forces of erosion, and examples of the results of man-induced alterations on the forces of erosion have perhaps not received enough public recognition. The State has recognized some of the problems of shoreline erosion and established programs for control and prevention. ${ }^{76}$ Certain erosion control activities are authorized to receive public financial assistance.

Since numerous expanses of the State's shoreline are subject to the forces of erosion, including wetlands, any developmental activity in this area may be subject to those forces. With a public policy commitment to financial assistance for erosion control and prevention, the State should have thorough beforehand knowledge of all proposed activities that may become eligible for those funds or which ones through their construction might alter the forces of erosion so as to create situations requiring the expenditure of public funds for corrective or preventive actions.

\section{SUMMARY ON COMPETING USES, THEIR TRENDS AND IMPLICATIONS TO WETLANDS}

Individually examining each use or activity responsible for wetland losses only illuminates small features of a larger picture. If every activity were to continue as an isolated demand competing with wetlands for space, 


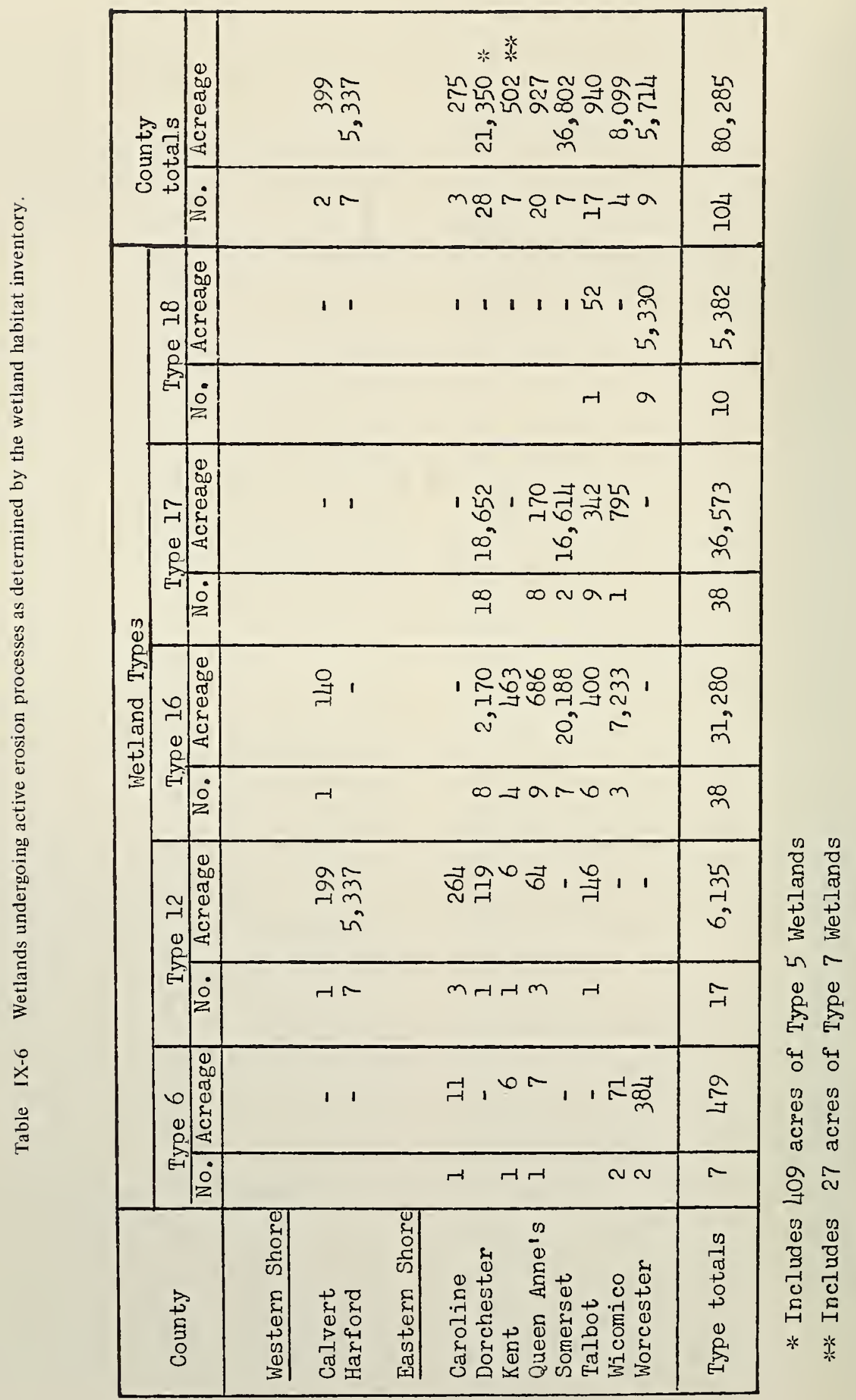




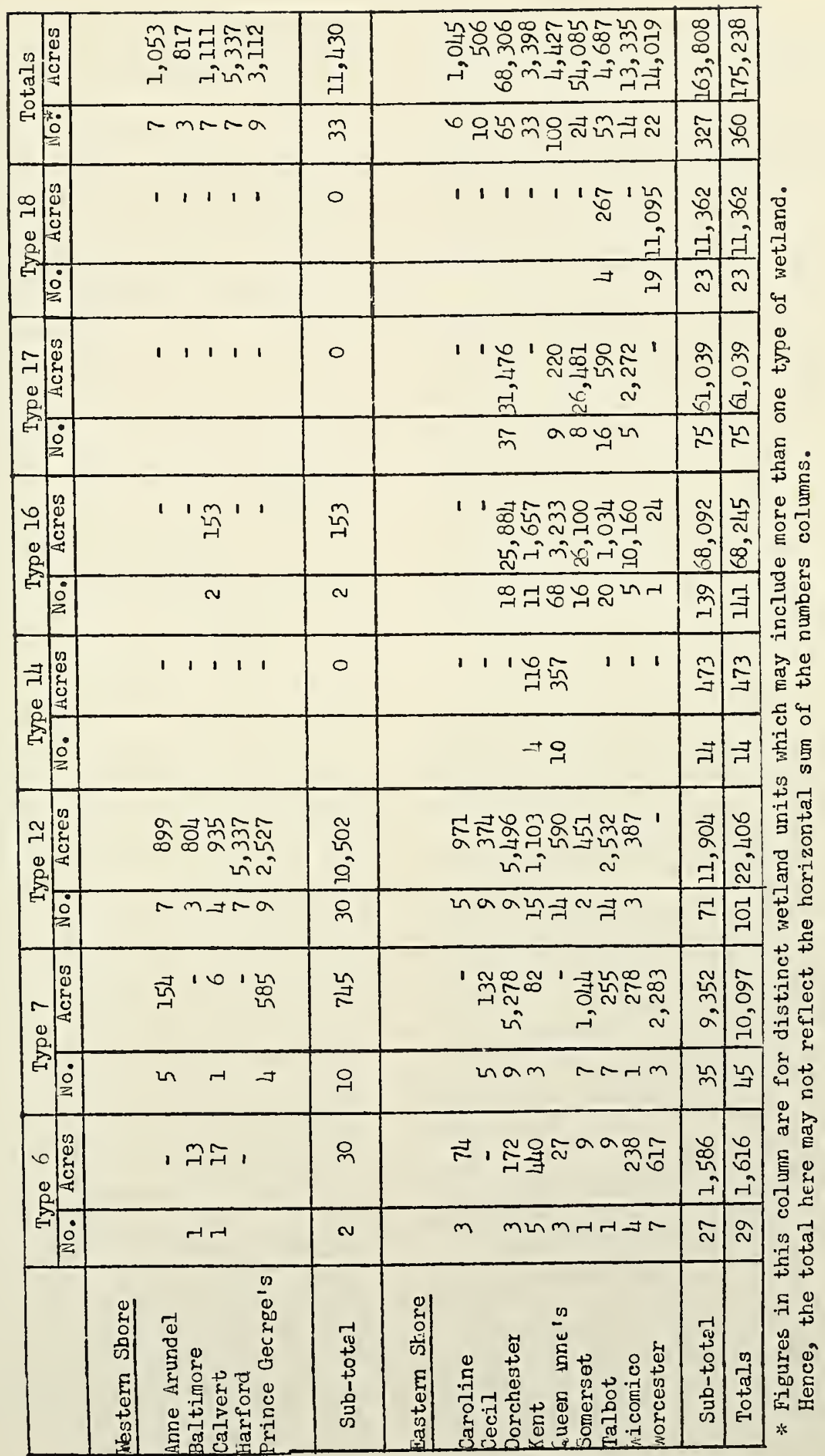


the destructive impact on wetlands might be absorbed without significant loss of environmental amenities and ecological values. Instead, several of the activities are interrelated and as they proceed apace there is the distinct possibility of magnifying their impact beyond small-scale localized incidents into regional problems.

As pointed out earlier, there are several undesirable cause and effect relationships between public works, industrial and residential development, dredging and wetlands. The future locations of roads and sewerage collection systems will determine the pattern of development along stream valleys and other important areas of the State's shoreline. Introduction and promotion of development through expenditure of public funds in previously remote or inaccessible areas represents a significant threat to wetlands.

Inadequate recognition and attention has been given to the influence of public fund expenditures on certain State resource management programs such as wetlands, water quality protection, open space and outdoor recreation. In fact, unperceptive public programs may counter other public programs and encourage private opportunism at public expense. For example,

"The capital investment necessary to make waterfront property usable ranges from high to very high ... The net result is that most recreational waterfont development is assisted or underwritten by government, and in large part by the federal government.

"River and harbor development is generally viewed from a broad benefit to cost ratio;... Fortunately, it is possible for joint use of federal, state, local and private money. The Corps of Engineers has control of navigable wat erways, and, where a favorable benefit/cost ratio is evident, can recommend federal funds for flood and river control, breakwater, and commercial waterways. The State and local agencies can, through bond issues and capital outlays, provide funds for recreational harbor and shoreline development. Private enterprise can then proceed to develop waterfront facilities.

"Private investment can, of course, run the gamut from leasing and operating on prepared public-owned waterfront to dredging and developing water and land communities."7

New roads and sewerage systems will have a profound impact on future patterns of land development in Maryland, and they will encourage the destruction of wetlands. Especially troublesome in the future to the goal of preserving coastal wetlands will be waterfront housing developments and aggregate extraction activities. Agricultural land drainage programs also threaten considerable inland (freshwater) wetland acreage for the following reasons.

1) According to Maryland law, the improvement of drainage on poorly drained cropland (some of it classed as wetlands) is considered a "public benefit and conducive to the public health, convenience and welfare." Consequently, there are organizations and activities legally authorized for land drainage purposes. Activities pursuant to this purpose may purposely or sometimes inadvertently drain private wetlands.

2) Because agricultural drainage is an activity with public benefits, public funds are available to support and sustain agricultural drainage work. Therefore, land drainage projects are not of a temporary nature.

3) On-going projects, planned projects, and potential projects for agricultural drainage are in watersheds containing most of the State's wetlands. A close surveillance must be kept on these projects by all concerned to prevent unnecessary damage to wetlands.

The problem posed by each activity proposing to utilize wetlands is that ecological questions are asked last, if at all. Rather they should be first, and since many answers remains to be obtained through further research, the planning (and management) decision should always be conservative.

Each new road, each new suburb, each new shoreline subdivision, and each sanitary system built in ignorance and neglect of the geology, hydrology and ecology will result in seemingly small localized disturbances to the natural environment. However, the sum of many small, local environmental disturbances may be a regional catastrophe.

The coastal zone of Maryland, the areas where land and water meet, of fers attractive opportunities for economic development and growth. Wetlands as a part of the coastal zone, are a fundamental feature of potential development opportunities.

Future management problems will not center on "whether development" but "what kind of development and how?" This is an important question in. tidewater counties traditionally oriented to an agriculture and seafood industry economy.

Gradually, much of Maryland's traditional agricultural-marine-rural character will shift to a non-farm and even suburban way of life. Such change is evident on Western Shore areas closest to the large and growing population centers of Baltimore and Washington and at Ocean City on the Eastern Shore. In future years the changes in land and shoreline use, such as already observed on the Western Shore and Maryland's Atlantic Coast may involved tidewater regions of Southern Maryland and the Eastern Shore. 
It is useful to identify the fundamental goals of regional development and the challenges posed to resource management to aid in understanding the issues at hand.

Regional development goals should be to stablize human population; genuinely stimulate the local economy; broaden the economic base; provide jobs for the resident labor force; reduce reliance on the existing dominant forms of employment; and provide an expanded and growing tax base to shoulder the burden of increasing costs for more essential community services attendant with development.

In attempting to achieve those goals, resource management problems will arise such as accommodating development in a manner that will maintain, enhance or be least destructive to the existing natural environment, and ensuring that economic development is an asset rather than a liability to the region in which it is to occur. Important efficiency and equity issues regarding the distribution of both economic and environmental benefits and costs by developing and/or preserving wetlands and associated resources must be satisfactorily resolved. These issues as regards wetlands and other coastal zone resources are becoming well recognized and documented. ${ }^{78}$ The divergency that exists between private and public values and goals and market system inefficiences must be resolved too if a truly balanced development program is to devised and implemented for coastal zone resources. The balancing act represented by and inherent in coastal zone resources planning and managing involves thorough consideration of the tradeoffs between economic growth and unavoidable destruction of environmental amenities on the one hand, while in the other devising those strategies which will best serve our society via the way we govern ourselves to achieve desired but frequently divergent, contradictory social goals.

I Jones, Carleton. Growth and problems continue (housing prospects for the 1970`s). The Sun, Baltimore, Md. November 9, 1969. p. 2, Section F.

2 The Conservation Foundation. Rookery Bay Area Project. Washington, D. C. 1968.

3 Maryland State Planning Dept. Counties of Maryland and Baltimore City: their origin, growth and development 1634-1967. Pub. no. 146. June, 1968.

4 Green, R. L., and C. P. Merrick. Drainage law of Maryland. Dept. of Drainage, Univ. of Md. Coop. Ext. Service, Extension Bull. 196, College Park. October, 1962.
5 thid.

6 The Michie Co. Annotated Code of the public general laws of Maryland. (1970 Supp.) Charlottesville, Va. 1966.

7 U. S. Soil Conservation Service. Written communication to the Md. Dept. State Planning from the Maryland State Conservationist (SCS). April 29, 1970.

8 U. S. Soil Conservation Service. Summary of conservation needs inventory of Maryland waltersheds. (nimeo). USDA, College Park, Md. rev. January, 1968.

9 National Advisory Commission on Food and Fiber. Food \& Fiber for the future. Report of the President's Commission. USGPO: Washington, July 1967

10 lbid.

11 Laws of Maryland, 1969, Ch. 692 (House Bill 801), repeal and re-enact with amendments, Sec. 52 of Article 96A of the Annotated Code of Maryland.

12. U. S. Soil Conservation Service. Supra at 7.

13 Resources for the Future, Inc. Resources, n. 38, September 1971. Adapted from Competition for Wetlands in the Midwest: An Economic Analysis by Jon H. Goldstein, published by RFF, Johns Hopkins Press, Baltimore. 1971.

14 Shaw, Samuel P., and C. Gordon Fredine. Wetlands of the United States. US Dept. Interior. Fish \& Wildife Service, Circular 39. USGPO: Washington. 1956.

15 Cooke, C. Wythe. Sedimentary deposits of Prince George's County and the District of Columbia. In, Geology and Water Resources of Prince George's County. Md. Dept. Geology, Mines and Water Resources. Bulletin 10, 1952.

16 Sherk, J. Albert, Jr. and L. Eugene Cronin. The effects of suspended and deposited sediments on estuarine organisms. An annotated bibliography of selected references. U. S. Army Corps of Engineers. Washington, D. C. April, 1970.

17 Ibid

18 Chapman, Charles. Channelization and spoiling in Gulf Coast \& South Atlantic estuaries. In, Proceedings, Marsh and Estuary Management Symposium. (Ed. John Newsom) LSU, Baton Rouge, La. 1968.

19 Ibid.

20 Corps ol Engineers. River and Harbor project maps, 1968. U. S. Dept. Army, Baltimore District. December, 1968.

21 Biggs, R. B. The magnitude of the spoil disposal problem. FWPCA public hearing, Annapolis, Md. 
October 30, 1968. Univ. of Md. Chespeake Biological Lab. Ref. No. 68-90.

22 Op. cil.

23 Chapter 468 (Senate Bill No. 623), Laws of Maryland passed by the General Assembly in 1969. The Act authorized the creation of a State debt in the aggregate amount of $\$ 13,000,000$ for the design and construction of one or more dike disposal areas and other appurtenant facilities to receive dredging spoil from the harbor and the approach channels in the water and adjacent areas known generally as the harbor of Baltimore City; and for acquiring lands, properties, facilities, structures, and options for these purposes and in connection therewith.

24 Maryland Board of Natural Resources. Report of the Commission on Submerged Public Lands. Appendix B, 18th Annual Report. Annapolis, 1961.

25 Statement by Walter C. Boyer, Deputy Director, Maryland Port Authority, at a public hearing on estuarine pollution, Annapolis, Md. October 30, 1968. Proceedings, Maryland-District of Columbia Public Meeting, Vol. II, National Estuarine Pollution Study, FWPCA, Charlottesville, Va.

26 Hollis, Edgar H. A critique of "A report to the District Engineer on the effects of the disposal of spoil from the inland waterway, Chesapeake and Delaware Canal, in upper Chesapeake Bay. (undated). (mimeo). And,

Hollis, Edgar H., et al. A literature review of the eflects of turbidity and siltation on aquatic life. Dept. of Chespeake Bay Affairs. Staff report. Annapolis, Md. December, 1964 (mimeo).

27 Maryland Board of Natural Resources, Supra at 24. 28 Ibid.

29 Cronin, L. Eugene, et al. Effects of engineering activities on coastal ecology (interim report). Corps of Engineers, Office of the Chief of Engineers, U. S. Army. September, 1969.

30 Committee on Government Operations. Our waters and wetlands: how the Corps of Engineers can help prevent their destruction and pollution. House Report 91-917.91 Congr. 2d Sess. USGPO: Washington, 1970.

31 National Technical Advisory Committee. Water quality criteria. FWPCA. Washington, D. C. April I, 1968.

32 Chapman, Charles. Supra at 18.

33 Baltimore County Office of Planning and Zoning. Preliminary 1980 Guideplan. 1969.

34 The Back River Neck and Patapsco Neck Peninsulas are rated nationally significant by one study. Muncy, Dorothy A. Inventory of port-oriented land: Baltimore region. Md. Dept. of Economic Development. 1963

35 Center for the Environment and Man, Inc. Coastal and estuarine areas: Appendix $\mathrm{U}$ - North Atlantic Regional Water Resources Study Coordinating Committee. U. S. Army Corps of Engineers. New York. (First draft). January, 1971.

36 McCarl, Henry N. The mineral aggregate industry in the vicinity of Baltimore, Maryland. Unpublished doctoral dissertation - Pennsylvania State University, State College. December, 1969.

37 Op. cit.

38 San Francisco Bay Conservation and Development Commission. Waterfront industry. San Francisco, California. February, 1968.

39 Muncy, Dorothy. Waterfront industry around San Francisco Bay. San Francisco Bay Conservation and Development Commission. San Francisco, Calif. February, 1968.

40 Lyon, Gale H., Dean F. Tuthill and Wm. B. Matthews. Economic analysis of marinas in Maryland. Md. Agric. Exp. Sta., Dept. Agric. Econ., Contribution No. 4100. Univ. of Md., College Park, April, 1969.

41 Ibid.

42 Chaney, Charles A. Marinas, 2d. ed. Nat'l. Ass'n. Engine and Boat Manufacturers, Inc., New York, N. Y. 1961.

43 Op.cit.

44 Graves, Aubrey. "Rigid Restrictions on Marinas in Anne Arundel County Proposed" The Washington Post. July II, 1969; and "Marina Operations, Zoning Officer Clash." The Washington Post. July 18, 1969.

45. Lyon, Gale H., et al. Supra at 40.

46 Ibid.

47 Black and Veatch Consulting Engineers. Solid waste disposal study for Washington metropolitan region. Northern Virginia Regional Planning Commission, Metropolitan Washington Council of Governments, and The Maryland-National Capital Park and Planning Commission. October 1, 1967. 48 Ibid.

49 Maryland State Department of Health. Collection and disposal of solid wastes - a Maryland program. August 1, 1966.

50 Black and Veatch, op. cit.

5 I Ibid.

52 Letter from the State Entomologist to Prince George's Board of County Commissioners, March 13, 1968, in Report of the Governor's Commission on Pesticides, September, 1968. 
53 Laws ol Maryland, Ch. 42, 1956; Ch. 454, 1957; Ch. 40, 1958, Ch. 585, 1959; Ch. 40, 1962; Ch. 598, 1961; Ch. 69, 1962; Ch. 845, 1963; Ch. 68, 1964; Ch. 298, 1965; Ch. 138, 1966; Ch. 199, 1967; and Ch. $418,1968$.

54 Letler of the State Entomologist, op. cit.

55 Report of the Governor's Commission on Pesticides, Septenuber, 1968.

56 Mallack, Jerry, et al. Mosquito control in Maryland. Md. State Board of Agriculture. Bull. No. I (revised), September, 1966.

57 Bourn, Warren S., and Clarence Cottam. Some biological eflects of ditching tidewater marshes. USDI, Fish and Wildlife Service, Research Report 19. USGPO: Washington. 1950.

58 Personal communication to the Department of State Planning from the State Entomologist, November 11, 1969.

59 Odum, Eugene P. Fundamentals of ecology. W. B. Saunders Co., Philadelphia. 1957.

60 Niering, William A. The life of the marsh. McGrawHill Book Company, New York. 1966.

61 Harland Bartholomew and Associates. Comprehensive plan, Caroline County, Maryland. April, 1968.

62 Tarrant, Julian. Comprehensive master plan, Queen Anne's County, Maryland. 1965.

63 Bashan, Thomas. "Ocean City sewer system hailed: \$5.6 million dollar project near completion." The News American. July 31, 1969. p. 4-C.

64 General Laws of Maryland, Article 43, Section 387C.

65 Maryland State Department of Health and Mental Hygiene. Departmental regulations formulated to implement Article 43, Section 387C, Laws of Maryland. (43L01 - Regulations for planning Water Supply and Sewerage Systems, Section 04

- Requirements Applicable to County Plans.). Adopted: September 23, 1966. Effective: October 15, 1966.

66 Ibid., but Subsection 0405.

67 Governor's Special Committee to Study Shore Erosion. Shore erosion policy for Maryland, A. Rept. December, 1961.

68 Wolman, M. Gordon. The Chesapeake Bay: geology and geography. In, Proceedings, Governor's Conlerence on Chesapeake Bay. September 12-13, 1968.

69 Singewald, J. T., Jr., and T. H. Slaughter. Shore erosion in tidewater Maryland. Md. Dept. Geology, Mines and Water Resources, Bull. No. 6. 1949.
70 Slaughter, T. H. Shore erosion control in tidewater Maryland. J. Washington Acad. Sci. 57, 1967.

71 Maryland Dept. Geology, Mines and Water Resources. Proposed shore erosion program. Educational Ser., (pamphlet 1) 1964.

72 Singewald and Slaughter, op. cit.

73 Wright, Charles W. Chesapeake Bay - "Mother of Waters." Address before The Eastern Shore Society of Baltimore City. March 25, 1919. (nimeo).

74 Slaughter, T. H., op.cit.

75 Maryland Dept. Geology, Mines and Water Resources, op. cit.

76 General Laws of Maryland, Article 25 (Sections 16I167E), Article 66C (Sections 756-758A) and Chapter 563 (House Bill 39 of 1969).

77 Rick, William B. Planning and developing waterfront property. Urban Land Institute, Tech. Bull. 49. Washington, D. C. June, 1964

78 Goldstein, Jon H. Competition for wetlands in the midwest: an economic analysis. Resources for the Future, Inc. Johns Hopkins Press, Baltimore. 1971. and

Craine, Lyle E. Institutions for managing lakes and bays. Nat. Res. J., v. II, n. 3, U. New Mexico School of Law. July 1971. 



\section{$X$}

\section{SURVEY OF WETLANDS AND GROUND WATER HYDROLOGIC RELATIONSHIPS}





\section{INTRODUCTION}

The purpose of this survey is to present results of a review of hydrologic relationships between wetlands and ground water resources in Maryland. The principal sources of information were previous studies undertaken by the U. S. and Maryland Geological Surveys.

\section{DEFINITIONS}

For discussion purposes, several of the commonly used terms are defined here:

Hydrology is a science that deals with the processes governing the depletion and replenishment of the water resources of the earth's land areas.

Hydrologic cycle refers to the system of continuous circulation of water from the land and sea to the atmosphere and from the atmosphere to the land and sea. Because the system (and its processes) has no beginning or ending, it is known as a cycle.

Ground water is water that is contained in the zone of saturation - saturated voids in the rocks of the earth"s crust and the saturated mantle rock and soil.

Water table is the upper surface of the zone of saturation. It is not a flat or constant level, but fluctuates according to amounts of water supplied and withdrawn as well as surface topography and geological structure.

Unconfined water occurs under water table conditions and only partially fills a permeable bed. The surface of the water is free to rise and fall since it is in direct contact with the atmosphere through soil and weathered rock.

Aquifer is a geologic formation, part of a formation, or group of formations in the zone of saturation that is permeable enough to transmit water in useable quantities to wells or springs.

Aquiclude is a bed or layer of soil or rock that is either semipervious or relatively impervious to water movement.

Confined water completely fills a permeable bed that is overlain by an aquiclude or occurs between aquicludes. Consequently, its surface is not free to rise or fall, and the water is said to be under artesian conditions.

Artesian conditions refer to confined water under sufficient hydraulic pressure to cause the water to rise above the top of the bed in which it occurs when tapped by a well, though not necessarily to the land surface above.

Recharge to aquifers means water replenishment by precipitation in the outcrop area of the aquifer, or by leakage from adjacent soils or rock.

\section{SUMMARY ON GROUND WATER HYDROLOGY}

\section{Occurrence, Source and Movement}

Ground water occurs in aquifers under unconfined (water table) or confined (artesian) conditions. Water table conditions occur where the top of the zone of saturation is in direct contact with the atmosphere through the porous soil and weathered mantle rock. Under artesian conditions the water in an aquifer occurs beneath a confining bed. When the aquifer is tapped by a well the water rises to a level determined by the hydraulic head in the recharge area less frictional losses resulting from transmission through the aquifer.

Ground water is replenished chiefly by precipitation that filters through the soil zone in the outcrop area of the water-bearing formation (aquifer). Only a small part of the total amount of rainfall becomes ground water. The majority of precipitation becomes part of other phases of the hydrologic cycle (Figure $X-1$ ).

Water stored in the ground is moving slowly from one place to another in response to differences in hydraulic head under confined and unconfined conditions. Movement of unconfined ground water in water table conditions is controlled in part by the configuration of the land surface (relief) and the permeability of the deposits the water is moving through. Unconfined water discharges occur or emerge in low places such as seeps, swamps, springs, and stream beds. During periods when there is no surface or overland runoff from precipitation, ground water seepage or discharge may maintain stream flows.

The movement of ground water in artesian aquifers is controlled by the regional geologic structure, the hydraulic gradients, and by differences in permeability. The direction of artesian ground water movement is from points of high elevation (or hydraulic head) to points of lower elevation (or hydraulic head).

\section{Wetlands and Ground Water Hydrology in the Physiographic Regions.}

For survey purposes, Maryland was divided into two physiographic regions along the Fall Line. The Fall Line is denoted by a series of falls and rapids in stream valleys between the Piedmont-Appalachian to the west, and the Coastal Plain to the east of this line (Figure X-2). These regions serve as subdivisions for discussion on ground water hydrology and wetlands relationships. It should be clearly understood, however, that specific instances concerning ground water anomalies can be expected to be 
at variance with the general overview discussion that follows.

Piedmont-Appalachian. Understanding of ground water occurrences, availability and movement in this region is governed by several complex factors such as the degree to which rocks are jointed, fractured, and faulted; the relationship between an aquifer and overlying topography; the amount of precipitation and evapotranspiration in a locality: regional geologic structure; and aquifer characteristics such as porosity, permeability and thickness.

In the Piedmont-Appalachian region ground water recharge is provided by precipitation. Because of a predominance of gently sloping to rugged terrain, rapid surface runoff is facilitated for most rainfall. Consequently, the net percentage of precipitation that becomes ground water is relatively low. Precipitation that does become ground water generally moves downward and laterally from upland to lowland areas. Natural discharges occur at springs or in stream beds where the land surface intersects the water table.

Examining the geographic and topographic locations of inventoried and mapped wetlands in this region shows that they occur along or coincide with surface drainage patterns in places of lowest relative elevation. Since wetlands are found along streams whose flows depend in part upon ground water discharges, wetlands are probably not recharge areas for aquifers in the Piedmont-Appalachian region.

Coastal Plain. The underlying geological structure of this region consists of a homocline dipping to the southeast which is comprised of a huge mass of unconsolidated sediments resting on a sloping surface of crystalline rocks (Figure X-3). The Coastal Plain aquifers occur as a series of irregularly shaped wedges that gently dip to the south and east in conformity with the regional geologic structure. The recharge areas for these formations outcrop as a series of concentric bands in upland areas near the Fall Line.' From west to east on the Western Shore (Fall Line toward the Bay) the Coastal Plain aquilers are the Paluxent Formation. Patapsco-Raritan (undivided) Formation, Magothy Formation. Aquia Greensand, and Piney Point Formation.

Except in their outcrop areas, all of these formations function as artesian aquifers. Water table conditions prevail at the outcrop areas. Under natural conditions the outcrop belts function as recharge areas in upland localities and discharge areas in lowland localities. ${ }^{2}$ Since all of the above-mentioned major confined aquifers outcrop on the Western Shore, they are several hundreds of feet beneath the surface when they reach the Eastern Shore (Figure X-4).
Few possibilities exist for interaction between wetlands and Coastal Plain confined (artesian) aquifer hydrology. The most probable occurs in the aquifer outcrop areas on the Western Shore when and where water table conditions prevail. Wetlands commonly occur in lowland (shoreline) localities which are aquifer discharge areas due to the hydraulic head resulting from recharge in inland outcrop areas of higher elevation.

There is some limited potential for brackish water intrusion into aquifers in certain wetland areas, but it is not believed to be of great significance. The following specific localities detail where this wetland-aquifer hydrological relationship might exist.

1) Anne Arundel County. "Well logs in the vicinity of the Patuxent River south of Laurel suggest that a hydrologic connection may exist between the river and the basal sand in the Patuxent Formation, in which case the river would function as a recharge source. "3 Wetland unit No. 4 of Anne Arundel County is in the immediate vicinity along the north bank of the Patuxent River.

Heavy pumping from the Aquia Greensand aquifer might induce salt water to move into it from numerous brackish water estuaries in the Shady Side-Deal vicinity (Anne Arundel County Wetland units nos. 18-31 and 35$41)$ shown in Figure $X-5$. The magnitude and immediacy of this hazard is governed partly by the thickness and uniformity of the silt or clay layer commonly present on the bottom of the estuaries. Where clays or silts form an extensive, impervious cover over the underlying aquifer the entrance rate of brackish water will be substantially retarded or reduced."

2) Southeastern Prince George's County. Aquifer contamination is reported to be a possibility by inducing water from adjacent saltwater bodies through heavy pumpage. This situation exists for 10 to 12 miles along the Patuxent River (Prince George's County Wetland unit nos. 13-21) shown in Figure X-6. "However, the silt on the bottom of the Patuxent River may form an effective seal to prevent leakage of brackish water into producing aquifers." "s

3) Eastern Calvert County: Overdraft of aquifers might induce brackish water contamination in certain areas along the Patuxent River. These areas are across the river from ones identified in Prince George's County. The area where this potential exists in Calvert County encompasses several wetlands (Calvert County Nos. 113) shown in Figure X-7. As noted previously, the silt bottom of the Patuxent River may form an effective seal to prevent the leakage of brackish water into producing aquifers if the potential does exist."

Easiern Shore. Two important Coastal Plain aquifers, the Manokin and Pocomoke, outcrop on the 
Eastern Shore. The Manokin aquifer receives recharge from overlying sands and gravels of the Pleistocene and Pliocene series.' Water table conditions prevail in this aquiler at depths ranging from 5 to 15 feet below land surlace. The recharge area or intake belt for this aquifer ranges from 2.5 to 6 miles wide and lies beneath many wetland areas along the Nanticoke River, at Elliott Island, Bishops Head, Bloodsworth Island, and South Marsh Island in various parts of Dorchester, Somerset, and Wicomico counties (Figures X-8, 9, and 10). Here the brackish waters of the Bay and marsh areas have access to the aquifer. However, so long as the fresh water potential from the inland area remains high and pumping rates from the aquifer do not become excessive, possible encroachment of brackish water is remote. ${ }^{*}$

The Pocomoke aquifer is an extensive water-bearing sand underlying certain parts. of Somerset, Wicomico and Worcester counties. The intake belt or recharge area of the aquifer is 1.5 to 4 miles wide and strikes northeasterly from the Crisfield area, through Marion, Westover, Nassawango forest and Willards to the southeastern corner of Delaware. The intake belt is buried beneath the Pleistocene and Pliocene mantle and receives recharge from it. ${ }^{9}$ Its location passes beneath a number of wetlands in Somerset, Wicomico and Worcester counties (Figures X-9, 10 and 11). However, there is believed to be little, if any, direct hydraulic connection between either the Manokin or Pocomoke aquifers and wetlands. In most instances, the soils of wetlands or soils underlying wetlands are poorly drained or impermeable, a prime reason for extensive wetlands on the Eastern Shore. Consequently, it is quite unlikely that these wetlands could be functioning as recharge areas to underlying aquifers, since their existence is due in part to the impermeability of their soils.

Another reason is that although there is slight topographic relief in many of theEastern Shore wetland areas, there are discrete drainage basins. Therefore, each basin functions as a semi-independent hydrologic unit. In ground water aquifers beneath the surface drainage area, there is lateral movement of water from the high points of the water table at almost imperceptible basin divides, to lowest points being creeks or marginal marshes. Thus, the wetlands are in areas of ground water discharge.

\section{CONCLUSIONS}

Ground water supplies to aquifers in the PiedmontAppalachian and Coastal Plain regions are replenished primarily by precipitation. Wetlands do not have a significant recharge function with the State's major confined (artesian) aquifers. These aquifers are overlain by aquicludes that prevent potential recharge from wetlands.

The most common wetland-aquifer hydrologic relationship is on the basis of aquifer discharge or rejected recharge because of the hydraulic head produced by recharge in upland (non-wetland) areas. The hydraulic head in the aquifer prevents any recharge from wetlands when they may coincide with an aquifer, which is generally in lowland (shoreline) localities where the land surface has intersected the unconfined water table and not the deeper lying confined aquifers.

The same situation exists for the extensive unconfined aquifers and near surface water table conditions on the Eastern Shore. As long as the fresh water potential from inland areas of slightly greater elevation than wetlands remains high, Coastal Plain wetlands will remain aquifer discharge or rejected recharge areas.

The only occasion when wetlands might function as aquifer recharge areas would be under conditions of reversed hydraulic head caused by heavy pumping of shallow aquifers adjacent to estuarine water. However, such conditions probably would not develop because in many wetland and shoreline areas shallow aquifers are olten already brackish. Where this potential does exist, the sediments deposited on the bottom (a process encouraged by wetlands) probably form effective seals to prevent intrusion of brackish water into the producing aquifer.

1 Maryland State Planning Dept. Ground-water aquifers and mineral commodities of Maryland. Pub. no. 152. Baltimore. May, 1969.

2 Ibid.

3 Mack, Frederick K. Ground-water supplies for industrial and urban development in Anne Arundel County. Dept. Geology, Mines and Water Resources, Bull. 26, 1962.

4 lbid.

5 Mack, Frederick K. Ground water resources in Prince George's County. Maryland Geological Survey, Bull. 29, Baltimore. 1966.

6 Ibid.

7 Rasmussen, William C., and T. H. Slaughter. The ground-water resources in Somerset, Wicomico and Worcester Counties. Dept. Geology, Mines and Water Resources, Bull. 16, 1955.

8 lbid.

9 Op.cit. 


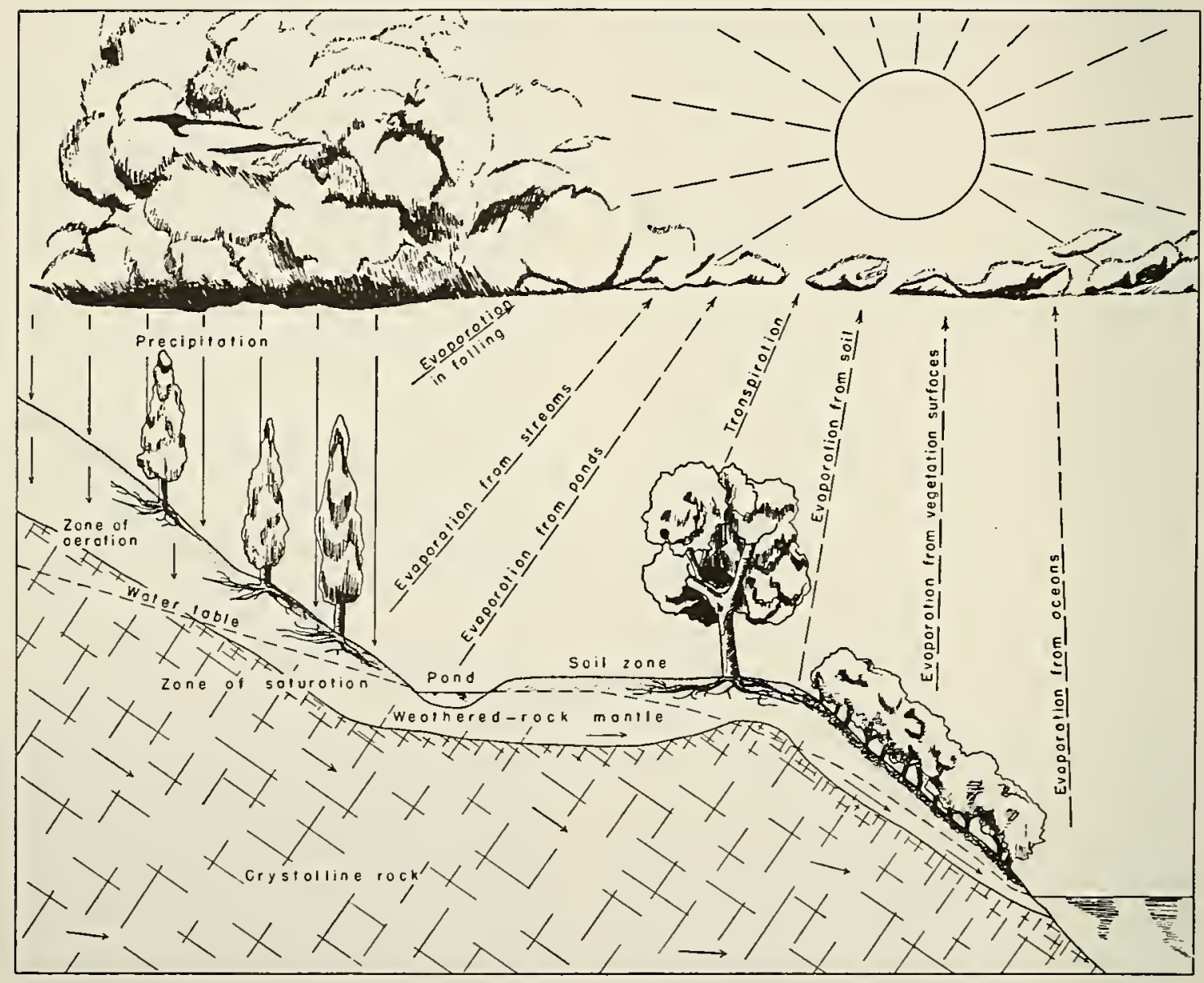

Figure X-1 General schematic of the hydrologic cycle. 


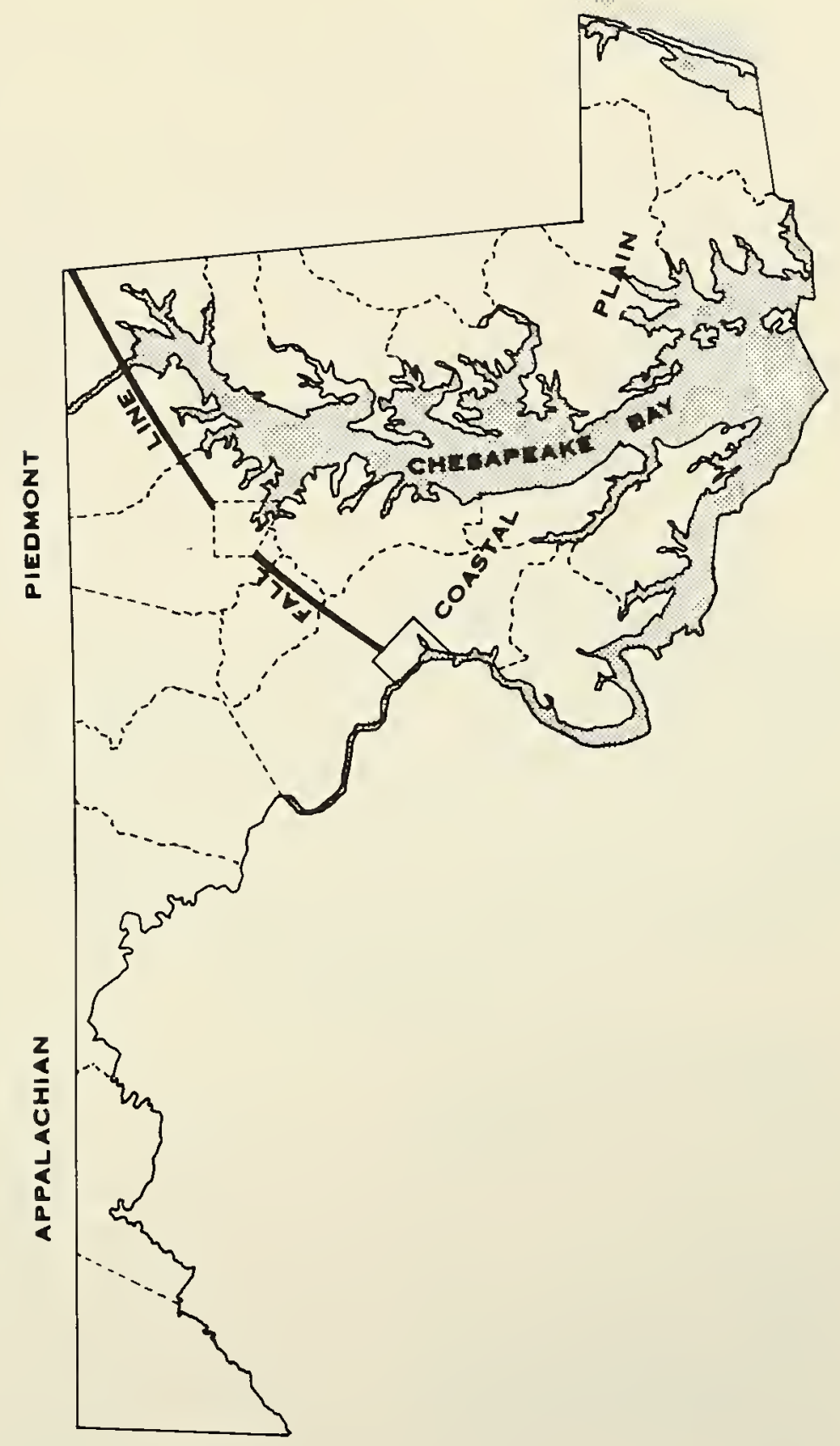

Figure X-2 Location of the Fall Line and physiographic regions utilized in this report for discussion on ground water hydrology and wetland relationships in Maryland. 


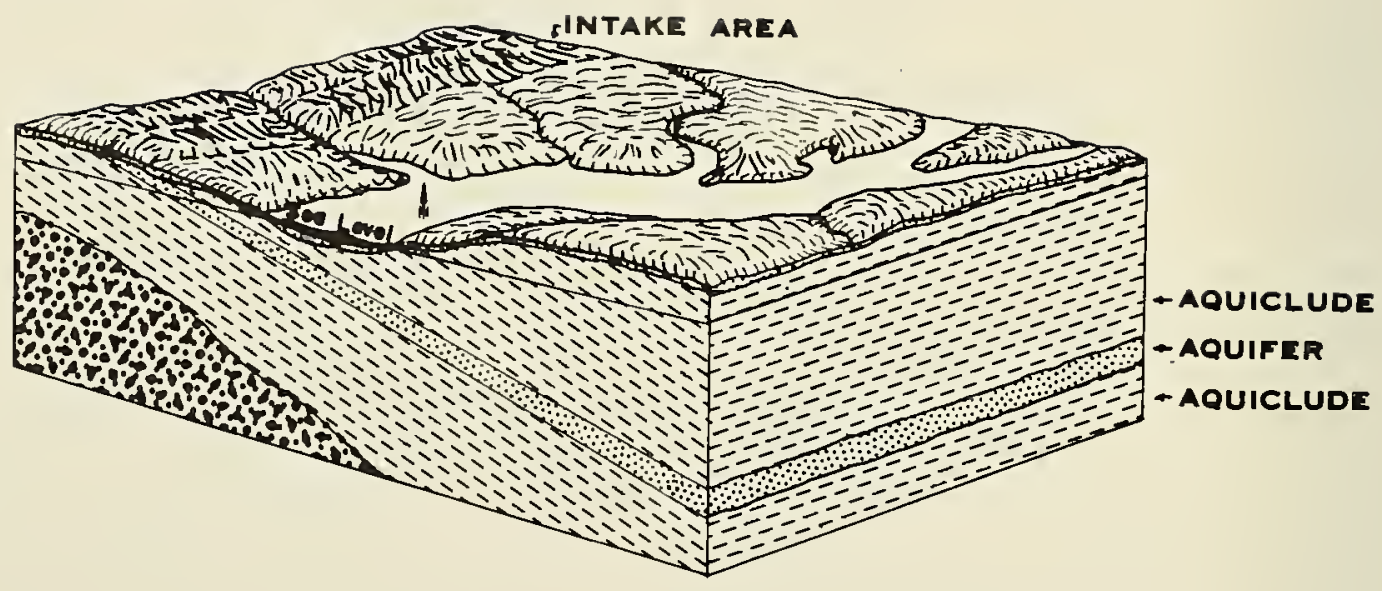

Figure X-3 Idealized block diagram illustrating various geologic features related to transmitting water laterally from an aquifer intake (recharge) area in the uplands of the western shore to the eastern shore via formations which lie under Chesapeake Bay. 


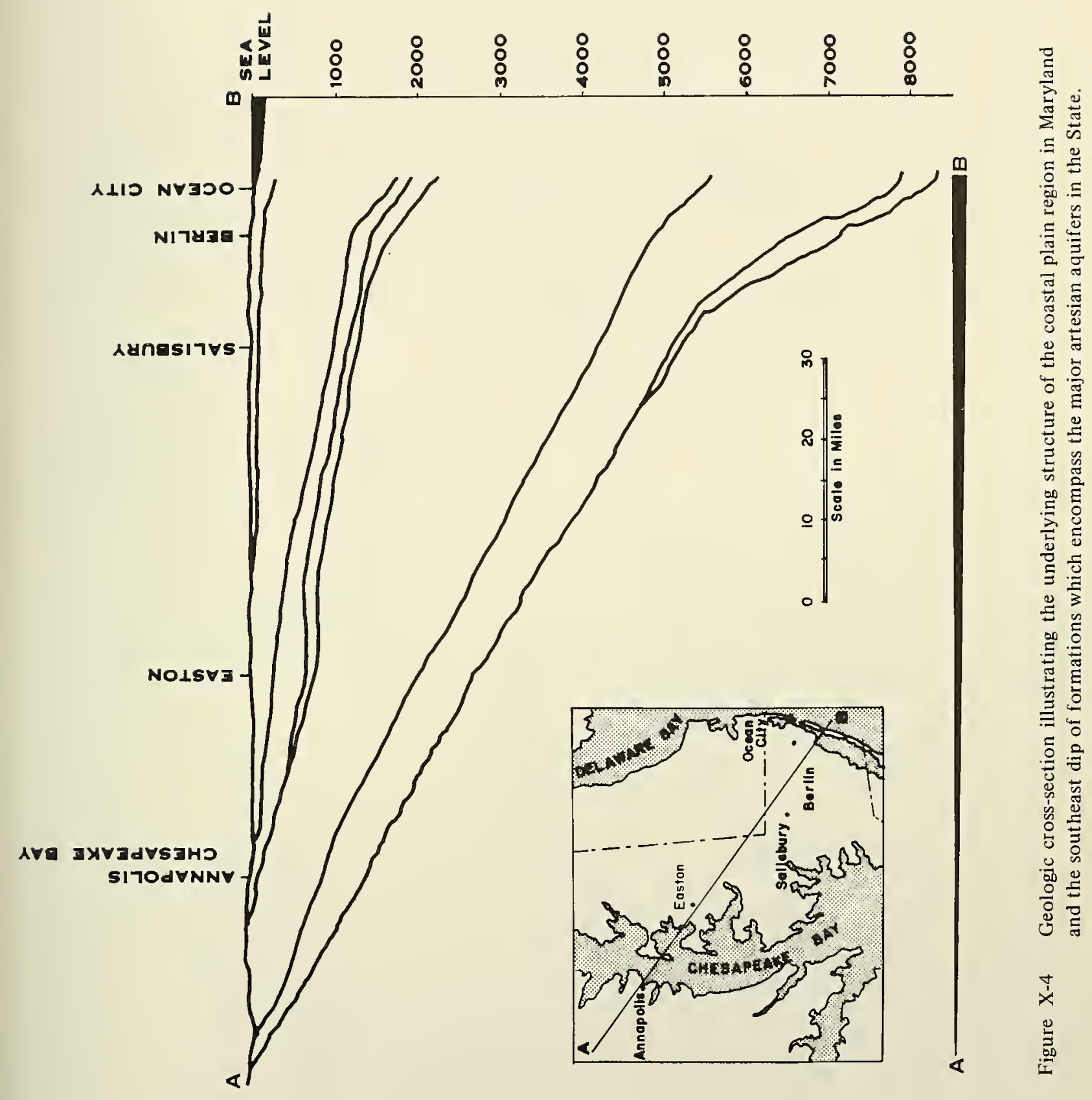




\section{ANNE ARUNDEL COUNTY}

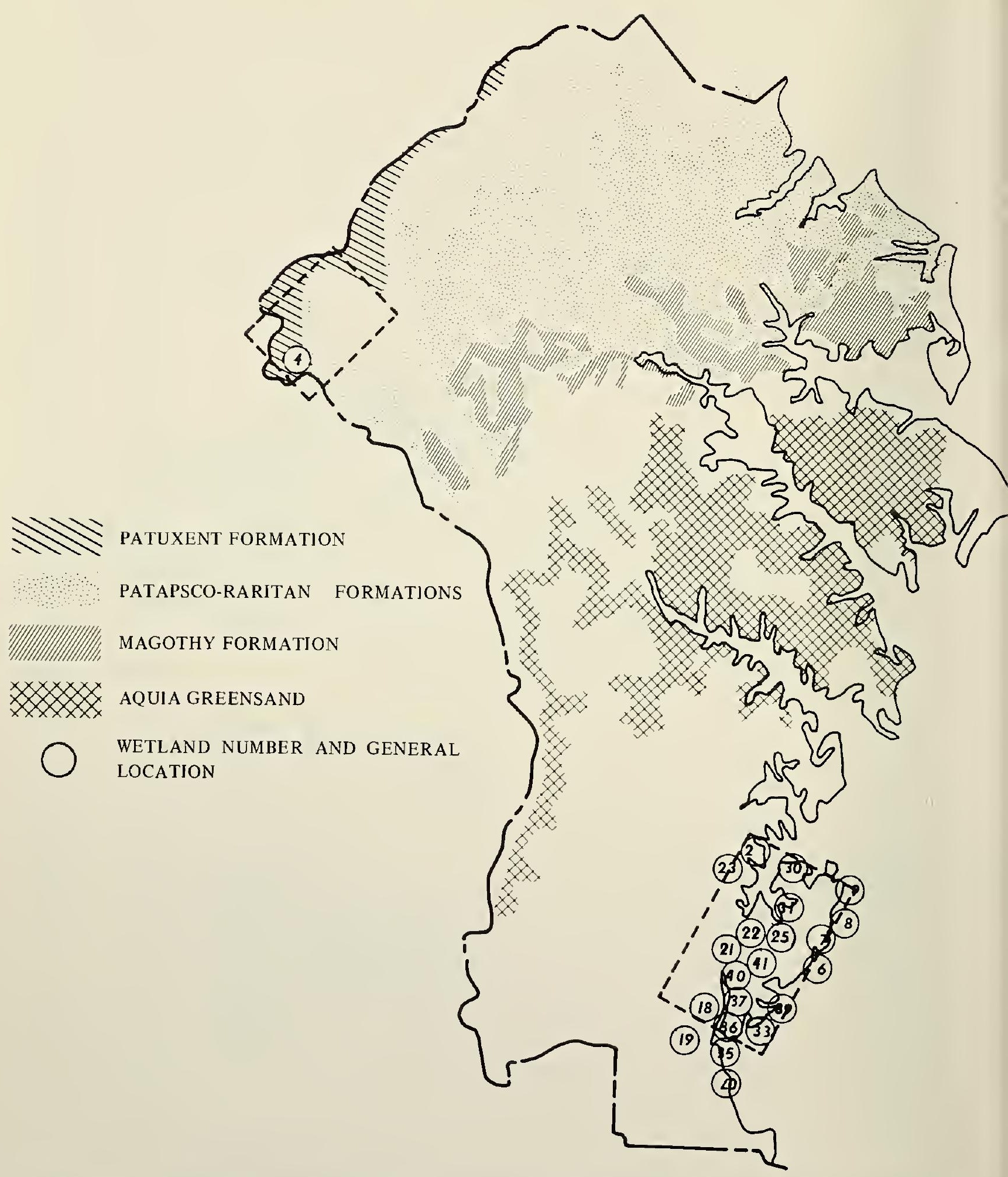

Figure X-5 Approximate surface outcrop (recharge) areas of the principal aquifers of the western shore and the general locations of certain wetlands in Anne Arundel County. 


\section{PRINCE GEORGE'S COUNTY}

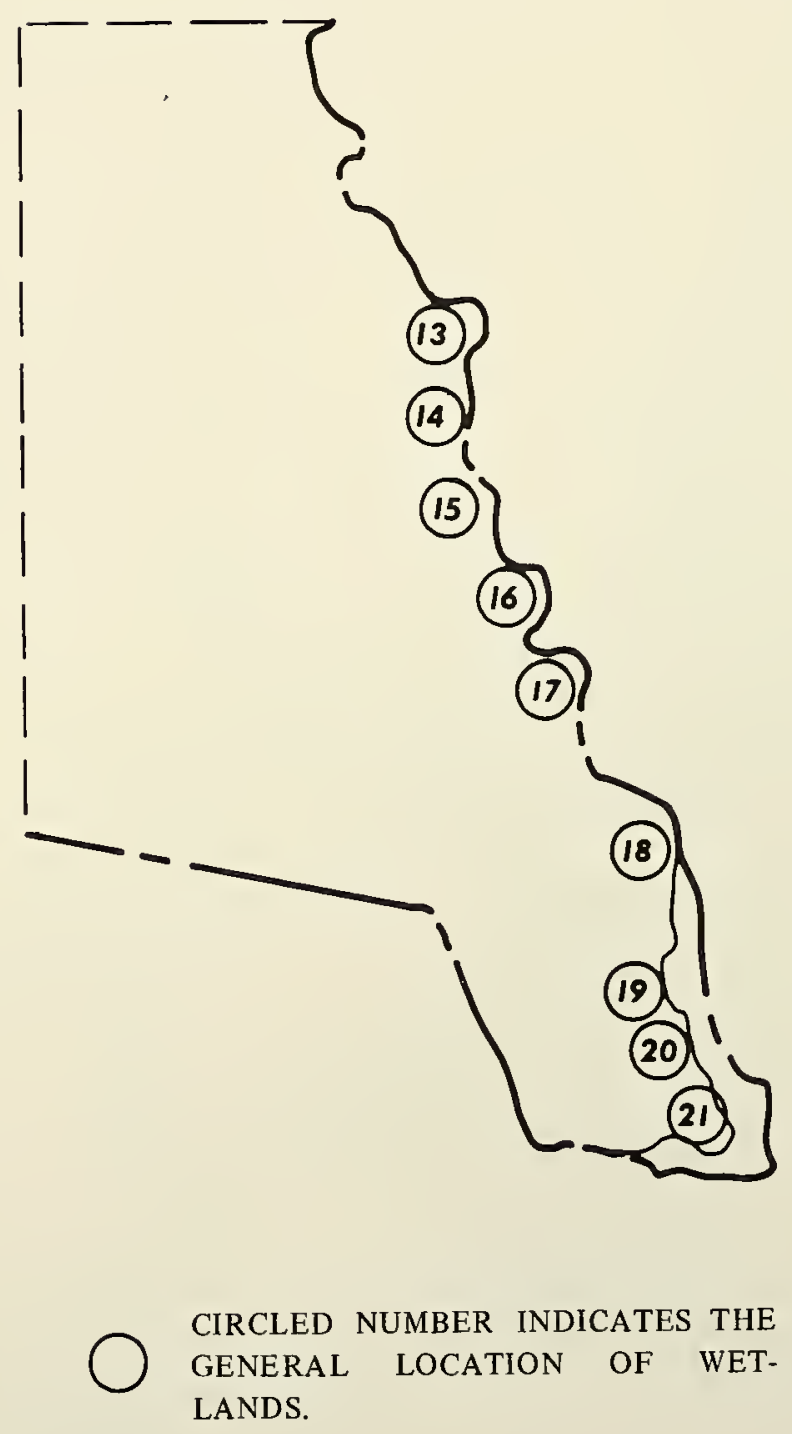

Figure X-6 Approximate location of wetlands in Prince George's County with the potential for saltwater intrusion into underlying ground water aquifers. 


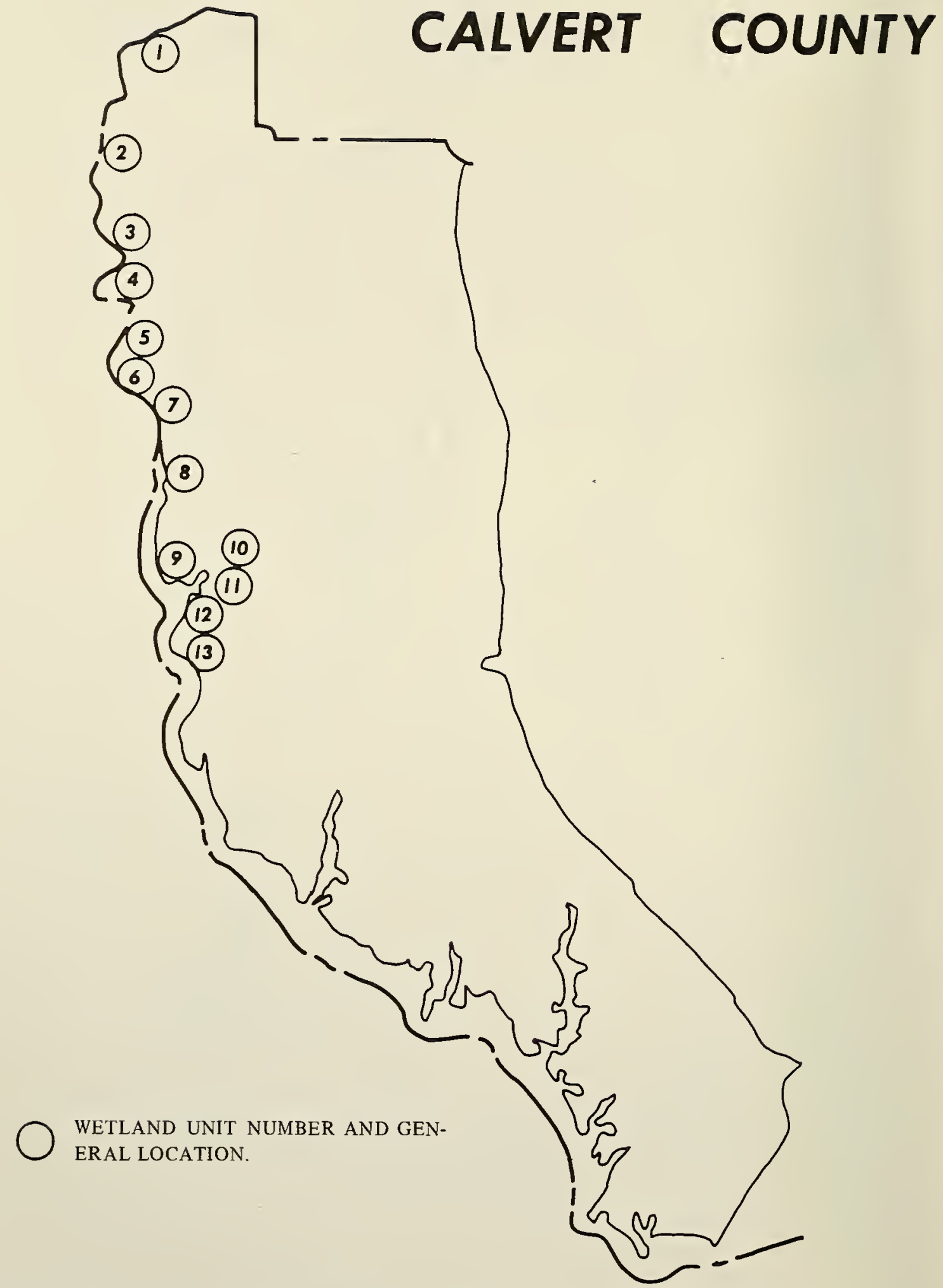

Figure X-7 Approximate location of wetlands in Calvert County along the Patuxent River with the potential for saltwater intrusion or contamination into underlying ground water aquifers. 


\section{DORCHESTER COUNTY}

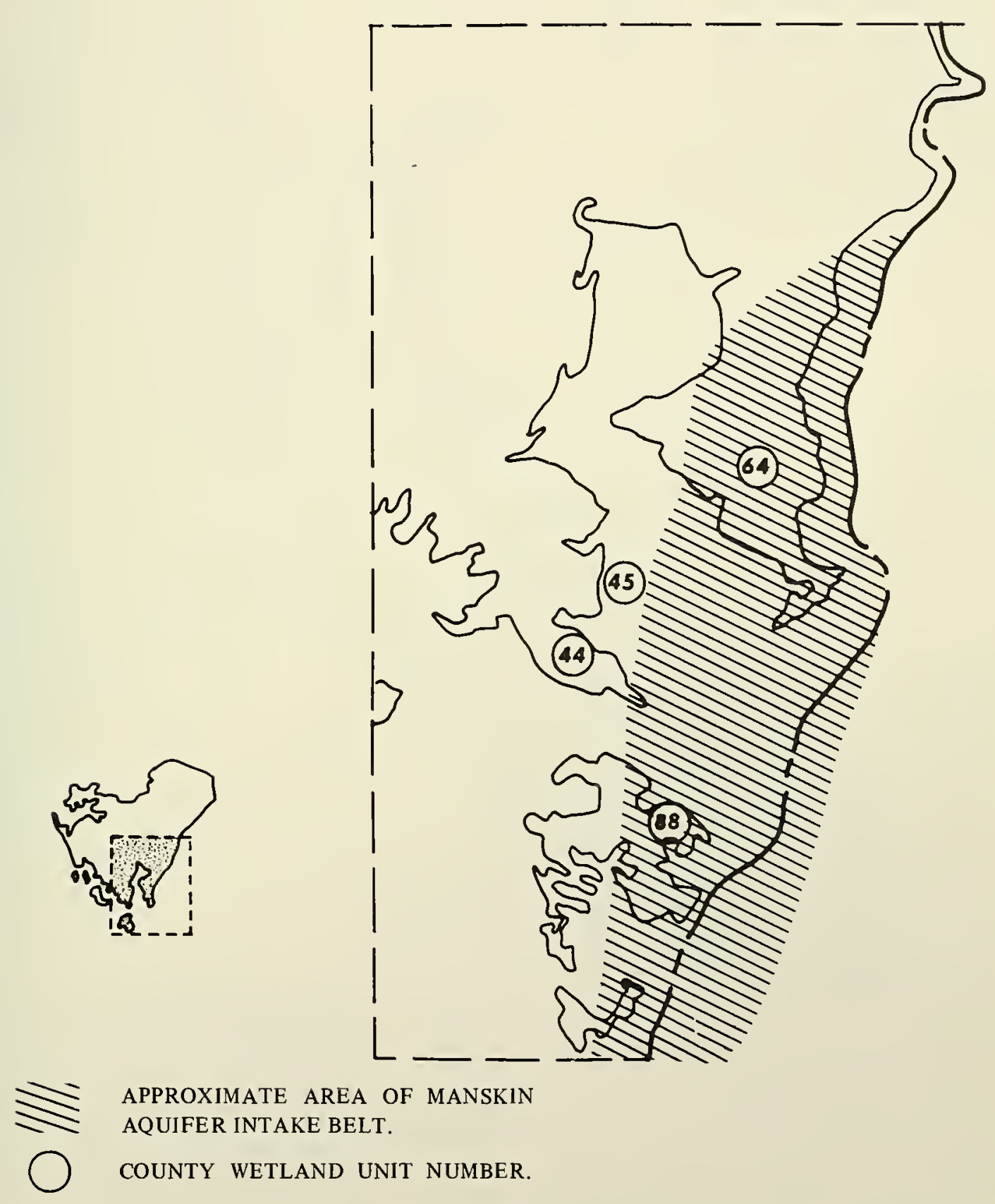

Figure X-8 Approximate extent of the buried recharge belt of the Manokin aquifer, including the general locations of overlying wetlands in southern Dorchester County. 


\section{SOMERSET COUNTY}
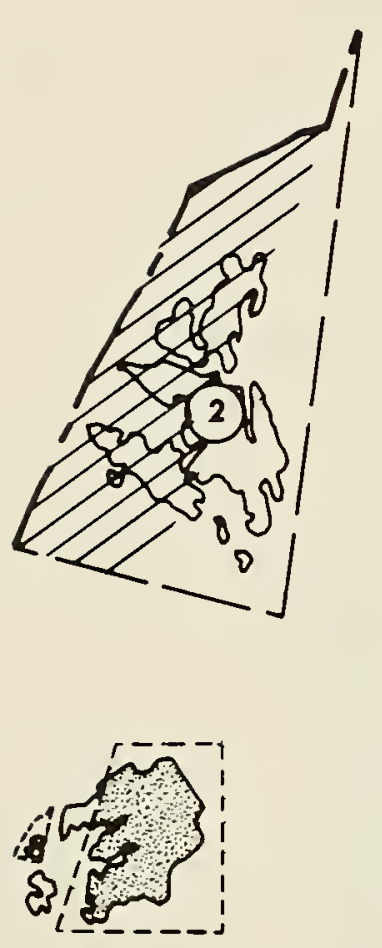


\section{WICOMICO COUNTY}

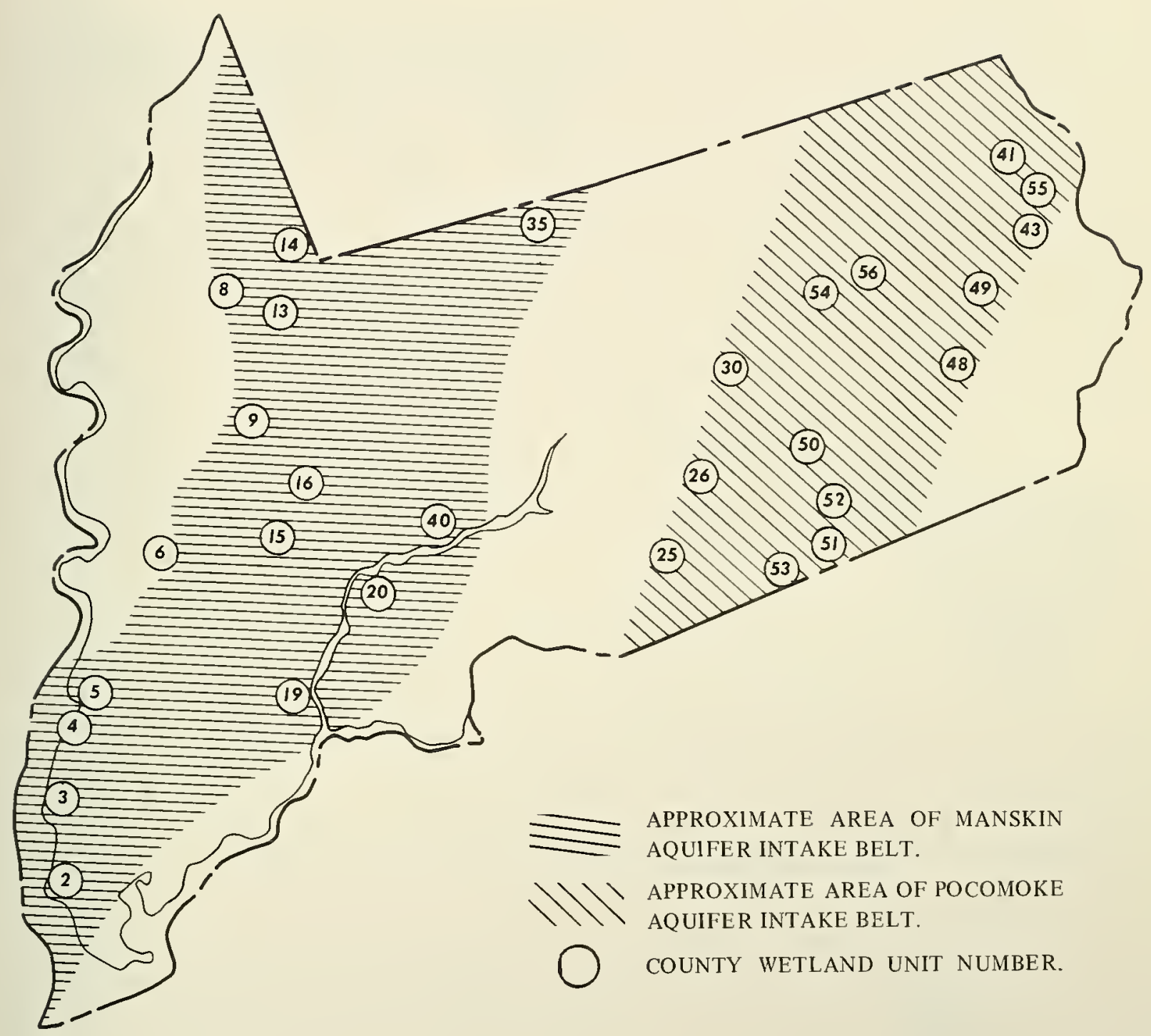

Figure X-10 Approximate extent of the buried recharge belt of the Manokin and Pocomoke aquifers, including the general locations of overlying wetlands in Wicomico County. 


\section{WORCESTER COUNTY}

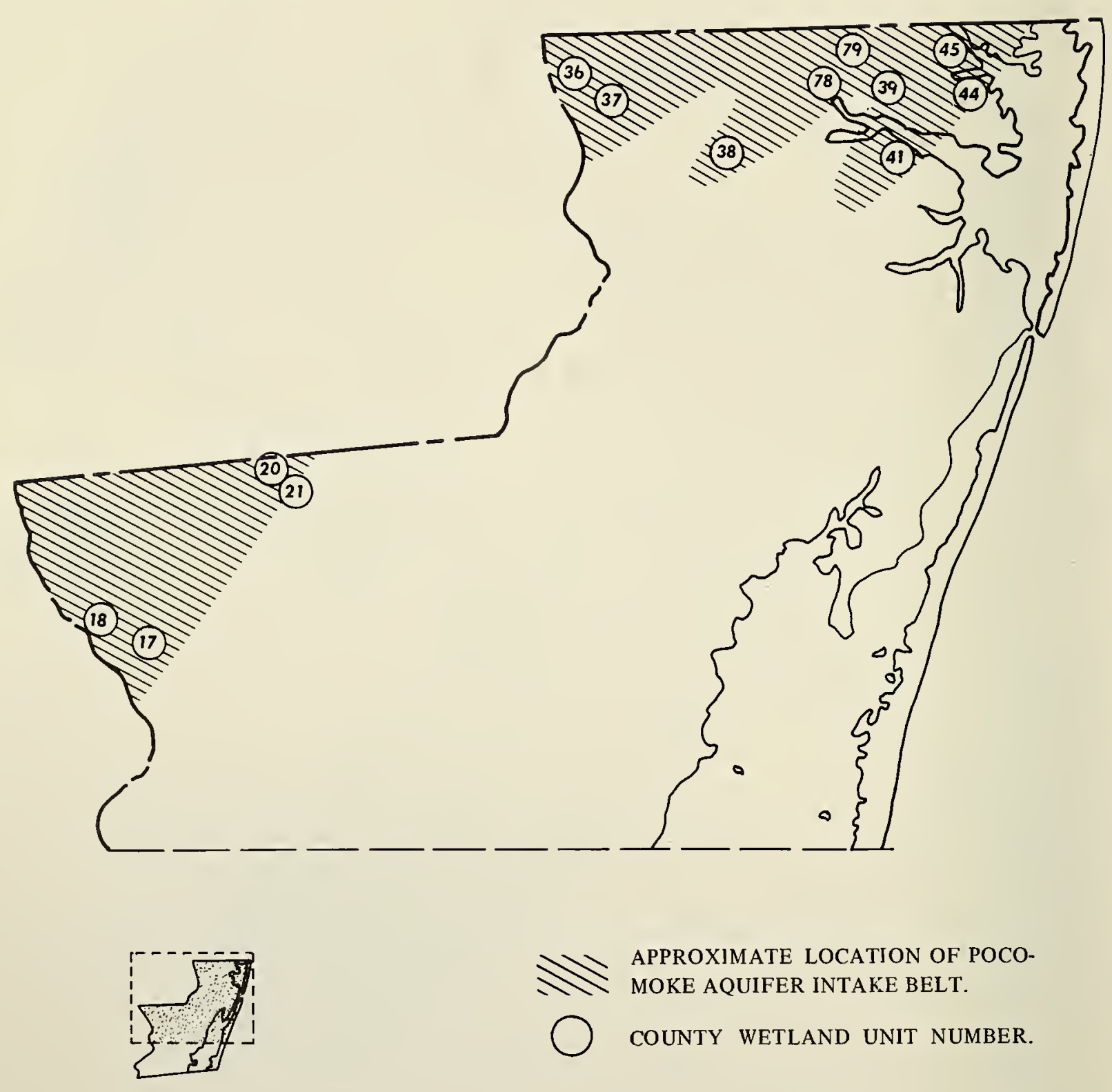

Figure X-11 Approximate extent of the buried recharge belt of the Pocomoke aquifer, including the general locations of overlying wetlands in Worcester County. 
XI

WETLANDS AND ESTUARINE POLLUTION 



\section{PURPOSE AND SCOPE}

The purpose of this chapter is to provide in a limited way general information about the complexities of water pollution and specific information on the role of wetlands in water quality protection and improvement. Additionally, insight is furnished on the impacts of certain potential pollutants orr wetlands ecology and their threat to the present and future well-being of State waters. (Considerable information on water quality management problems in estuaries is available in the National Estuarine Pollution Study.)'

Descriptive information on Maryland's wetlands and estuarine water quality problems used in this survey was available from several sources including the wetlands habitat field inventory conducted as a part of this effort, previous water quality studies and reports, and current state and Federal water quality field investigations, activities and analyses.

The selection of estuarine pollution should not be inferred as disregarding or minimizing the importance of water quality problems in strictly freshwater, non-tidal areas of the State. Rather this selection recognizes and emphasizes the fact that nearly all of Maryland's surface water drainage ultimately ends in estuarial waters. Therefore. many waste discharges and potential water degrading incidents and conditions in fresh water areas may eventually reach estuarine areas, where rivers meet ocean waters.

\section{POLLUTION - A DEFINITION PROBLEM AND RELATIVE TERM IN ESTUARIES}

Pollution is a relative term. What represents pollution to one user due to the introduction of a substance that acts as a pollutant and causes denial or decreased useability of water, on the other hand may represent a short-term benefit to another user by being the receptacle for wastes produced during desired processes.

Technically, any substance foreign, natural or any unnatural environmental condition that interferes with a specific desired use may be considered a pollutant. Generally, specific qualification and quantification is needed on a potential pollutant to determine whether there is pollution and/or the extent and degree of polluted conditions.

Wetlands pollution refers to man-originated deleterious alterations to the quality of waters that abut or are a part of the natural habitat defined as wetlands so that existing or future populations of dependent biota have been affected detrimentally. Therefore, physical destruction of wetlands for purposes such as housing, marinas, industry, "sanitary" landfills and other solid waste disposal activities, etc., also consitutue wetlands pollution. Additional discussion on the cause and effect relationships of wetlands losses due to competing uses is also handled as a matter of economic development rather than pollution in Chapter IX.

In a strict sense, nearly all bodies of water near man are polluted because they receive substances foreign to the water and thus are potential contaminants. In a relative sense, however, whether a water body is polluted or not depends on the degree of contamination.

It is important to note that there are buildups of waste that represent a latent threat of pollution, although no use of water might be presently affected. Thus, an area of water might be yielding full benefits in the form of seafood production and recreation, yet be close to a threshold concentration of some waste, beyond which these uses would be prohibited. For example, the singular and combined effects of agricultural materials such as fertilizers, insecticides, herbicides and animal wastes carried by water running off agricultural lands are difficult to detect due to their simultaneous, widespread entry into waters of the State, as well as their subtle synergistic effects upon aquatic life and wildlife.

The buildup of nutrients from discharged sewage and storm water runoff is another form of latent pollution. Nutrients, principally biologically available forms of nitrogen and phosphorous, are necessary for all forms of life. However, beyond certain limits or concentrations eutrophication (the process of enrichment with nutrients) ${ }^{2}$ will result in the undesirable overproduction of algae and phytoplankton. Under these conditions a general reduction or exclusion of more desirable forms of life result.

Because water pollution is a matter of degree, and because it can have hidden or latent components, positive and timely identification, documentation, evaluation, and implementation of appropriate corrective action may be delayed. Fundamentally, work on water quality problens commences with a determination of the concentration of a pollutant in water. This factor in turn depends primarily on two variables: (a) the amount of the polluting substance(s), and (b) the volume of diluting water. The concepts of waste dilution and assimilation by receiving waters are stated to be relatively simple, straightforward and calculable in rivers. ${ }^{3}$ However, the concepts are altered markedly in regions where river waters mix with saline waters, such as found in most estuaries.

The special characteristics of estuarine environments make assessing the impact of pollutants 
difficult. Detailed explanations such as those presented at the National Symposium on Estuarine Pollution ${ }^{4}$ illustrate the complexities. For example, the effects of municipal, industrial and agricultural wastes on estuaries depend not only on the characteristics of the discharged wastes and the location of the discharge points, but also on the nature or properties of the receiving water body. One of the most influential properties is the fluctuation, sometimes quite unexpected, in natural water quality daily, seasonally or geographically within a tidal estuary. Naturally occurring changes in salinity, $\mathrm{pH}$, turbidity, temperature, dissolved oxygen, tidal action, animal populations and other factors influence the distribution, critical concentration and ultimate impact of pollutants on estuarine environments. The composite effect of all of these variables must be considered before reaching conclusions on what constitutes estuarine pollution.

The most obvious effect of tidal action in an estuary is to change water depth. This indirectly changes current patterns, water temperature and density, and concentrations of mobile animal populations. Depending on the hydrology of an estuary and the amount of fresh water draining into it, salinity patterns may vary from relatively uniform conditions throughout a tidal cycle to situations in which the water is clearly stratified with a layer of relatively fresh water overlying bottom salt water, or to situations where the major portion of the water mass changes from fresh to salt and back to fresh again.

Tidal dynamics along with fresh water inputs from tributaries determine the distribution of salinity both vertically with depth and longitudinally along the channels carrying fresh water to the sea through the tidal reaches. "It has been established that the resulting density variations together with the turbulent mixing processes associated with the tidal flows are the principal factors governing the diffusion of pollutants and the distribution of sedimentation in the estuaries."

Estuaries produce differing ecosystems because of inherently different physical and chemical characteristics. All of the preceding discussion has dealt primarily with non-biological aspects of wetlands and estuarine pollution. In addition to understanding what constitutes water pollution and the variable character of estuaries, the variability of the impact of potential pollutants on natural communities poses a significant problem. There is considerable natural variation in biological populations, community composition, area occupied, critical tolerances, and life cycles.

A key factor concerning wetlands and estuarine pollution is that the maximum conversion of solar energy into aquatic plant life takes place in these areas. Without this vital event occurring, there would be no life at all in any body of water. Therefore, wetlands and estuaries are justly identified as "nurseries" since so many animals utilize them for feeding in their early life stages and many more depend upon the multitude of plant-eaters for their food (see Ch. VI). Very importantly, wetlands contribute significantly to the natural ability of an estuary to disperse and assimilate wastes introduced into it. However, when the natural ability to assimilate wastes is exceeded for only a short period of time or the affected area is quite limited in size (i. e. spawning beds in a tributary stream) the results can be far reaching. Severe biological mortalities can result and several year's production of desirable organisms may be lost.

\section{CONTRIBUTIONS OF WETLANDS TO WATER QUALITY PROTECTION}

Wetlands have an important role in the natural ability of water to purify and assimilate nutrient-rich waste discharges and other potential pollutants, thus aiding in preventing the deterioration of water quality. This is accomplished by chemical and biological processes, sediment collection, shoreline buffer effect and hydrologic functions all of which contribute in a cumulative fashion to the protection of high water quality.

\section{Biological and Chemical Processes}

Certain rooted aquatic plants through various natural processes have the ability to take up and store inorganic materials (nutrients) which otherwise would generate undesirable algal blooms interrupting the normal distribution and cycling of dissolved oxygen. In addition to absorbing nutrients such as phosphates in the growth process certain plants of the sedge family also take up toxic substances and pollutants such as phenols. These pollutants are broken down in part by the plants into amino acids.?

Aquatic plant removal and storage of nutrients makes them available to higher members of the food web. Consequently, tidal marsh storage of phosphorous has been noted as probably the best source of it to surrounding estuarine areas. ${ }^{8}$ It should be noted too, that tidal marshes regulate the time and spatial distribution of nutrients to an estuary. "The thin enormously extended water surface films on marsh plants is of significance. Loss of estuarine marshes as well as shallow, welloxygenaled waters of mudflats by filling, deprives an estuary of an important pollutant degrader." 


\section{Shoreline Buffer Function}

Soils frequently associated with or found underlying wetlands are unsuited for septic tank drainage fields. If development is prohibited in such areas which are not serviced by sewerage collection systems, wetlands can act as a natural buffer against water quality problems associated with shoreline development.

\section{Sediment Collection Function}

Stabilized, vegetated wetlands function as settling or filtering basins and collect sediment as well as other suspended material because of their shallow or shoaling characteristics. These characteristics serve to retard the velocity of river and tidal currents and thus reduce their silt transport capacity. Silt removal reduces turbidity, prevents deposition in other more undesirable areas such as oyster bars, marine shipping channels, and harbors, and reduces dredging activity necessary to maintain navigable waterways.

Once sediments and other materials are deposited, a complex structure of plant stems, leaves, roots, and accumulated decaying vegetation holds deposited sediment in place and prevents it from re-entering other parts of the aquatic environment. This is also one of the key processes that aids in building and maintaining wetlands.

\section{Hydrologic Function}

The natural characteristics of wetlands provide large water absorption and storage capability. Temporarily retained waters supplied by overland runoff or tidal inundation may be helpful in flushing pollutants downstream, diluting them into harmless concentrations, or providing additional volumes of water to augment natural assimilative abilities as the water is released at natural rates from the wetlands. One acre of marsh is reported to be capable of holding 300,000 gallons of water."

\section{THREATS TO NATURAL ANTI-POLLUTION FUNCTIONS}

Water's natural ability to purify and assimilate wastes can be impaired or destroyed by waste discharge rates that exceed or overwhelm natural capabilities, by the wastes' toxicity, or by the physical destruction of components of natural systems.

Most wastes responsible for polluted water conditions originate from three sources either separately or simultaneously; municipal (domestic) discharges, in- dustrial discharges, and overland runoff, including agricultural wastes. These wastes may be composed of organic matter, bacteria, suspended and floating solids, acids, alkalis, heavy metals, biocides, fertilizers, sediment, and heat among others.

One obvious impact of physically destroying wetlands through dredging and filling or other reclamation is that the many previously existing complex natural functions that maintained high quality conditions at that site are destroyed permanently.

"Uncontrolled fill or reclamation, for example. has three effects on pollution. It reduces the volume of water and thereby limits dilution of pollutants; reduced volume and water surface reduces oxygenation essential for water quality; and reduced volume reduces current velocities and so prevents the dispersion of pollutants."

Another facet of physical destruction is that the process in itself introduces additional pollutants into waterways and increases the possibility of future pollution from development on waterfronting sites. The closer the proximity of potential sources of pollutants to water the greater the hazard that pollutants will be introduced in quantities with deleterious effects.

Wherever maṇ's developmental activities occur; e.g. dredging and filling of wetlands in coastal areas; earthmoving for housing and industrial sites, road construction, or tilling agricultural fields in inland areas; these activities disrupt the natural functions of plants. Removing the natural protective cover furnished by plants exposes bare soils to rainfall, encourages soil erosion, and provides the sources of unwanted sediment in the aquatic environment. Disrupting aquatic bottoms removes plant growths stabilizing sediments and reintroduces the sediment into the aquatic environment. The new bottom environment consists of unstabilized, shifting sediments which usually prevent reestablishment of plants and other biological populations that previously inhabited the disturbed area.

Excessive silt or sediment in any body of water is a pollutant and has numerous undesirable effects. As a major water pollutant it adds to the cost of water treatment, interferes with natural purification in the river, smothers the bottom life essential to the biological cycle, reduces the enjoyment of water sports and other water-oriented recreation activities, and is aesthetically objectionable among other reasons.

Sediment, as a suspended solid, has a pronounced influence on turbidity and dissolved oxygen. Sediment pollution increases water turbidity which inhibits light transmission and limits photosynthesis. Consequently, the efliciency of microbiological waste decomposition 
ultimately declines because plant growths furnishing oxygen to the water are retarded. Due to this chain sequence, water's natural waste assimilative capacity is greatly reduced because of insufficient dissolved oxygen originating from sediment turbidity.

Waterfront housing development is a pollution threat because of frequent soil drainage problems in sea level areas. Since this type of development usually occurs in areas beyond installed sewerage collection and treatment systems and because the net cost of it very often makes the initial per unit development cost too expensive, septic tanks are used as the waste disposal system. However, many shoreline soils, including those of wetlands, are unsuited for septic tank drainage fields because of soil composition, poor drainage characteristics, high water tables, or hydraulic connection with the adjacent open surface waters. The installation and usage of septic tanks under these conditions often result in seepage from them and their drainage fields into adjacent waterways. Such a situation will cause closure of shellfish harvesting waters and bathing beaches by health authorities due to contamination by untreated domestic wastes.

If a housing development is sewered and the collected wastes do not leak from sewer piping or are treated to only a secondary level, the purifying or cleansing processes may result in the discharge of excessive nutrients into local waters at one concentrated point. Algal growths may then occur which can lead to serious water quality problems such as dissolved oxygen imbalance, toxic algal growths, and reduced light penetration.

The chemical and biological characteristics of many estuaries are being altered by an excess of nutrients derived from ever increasing volumes of sewage effluent. Nutrient-rich waters demand larger quantities of dissolved oxygen for the natural processes that disperse, break down, digest and assimilate wastes. Thus the algal growth cycles stimulated by nutrient-rich sewage wastes at times utilize the available dissolved oxygen essential to natural waste purifying and assimilating cycles. "Many parts of an estuarine system are normally operating at full capacity in regard to oxygen; since domestic and some types of industrial wastes have a high oxygen demand, a relatively small added input can cause the system to go anaerobic (without oxygen) which means that it becomes biologically speaking, useless."'2

Therelore, when wetlands are destroyed their contribution to certain aspects of natural waste assimilative abilities such as plant uptake of nutrients and production of dissolved oxygen is reduced. The scope of this contribution is not known. However, the following conclusion was reached concerning the role of wetlands in estuarine pollution and conservation.

"Conservation of the Bay (San Francisco), is heavily reliant on a minimum of change in the basic characteristics of the tides, on a minimum reduction in the water surface area, and on minimum elimination of mud flats and tidal marshes, to obtain the oxygen essential to the marine life of the Bay and to the assimilative capacity of reducing pollution from municipal, industrial and agricultural waste flows. Reduction in surface area by filling, reduction in volume by filling, .... will adversely affect oxygenating capacity."

\section{EXAMPLES OF MAN'S IMPACT ON ESTUARINE WATER QUALITY IN MARYLAND}

Man has great influence over the introduction and impact of pollutants in estuarine areas. Results may or may not be obvious. The following examples are presented to demonstrate some of man's impact on estuarine water quality in certain areas of the State.

\section{The Upper Potomac Estuary}

Water quality in the upper estuarine zone of the tidal ,Potomac River (Chain Bridge to Hallowing Point) is degraded when compared with established and accepted dissolve oxygen (DO), biochemical oxygen demand (BOD), and bacterial standards. Bacterial pollution is excessive in the Washington metropolitan area (by any standard), but decreases somewhat toward Fort Washington. The primary sources of this pollution are the partially treated effluents from several municipal sewage treatment plants in the area. Industrial wastes are not a significant part of the water quality problems in this estuary. ${ }^{1+}$

The upper tidal Potomac River is a conspicuous example of an estuary being altered by an excess of nitrates and phosphorous derived from increases in partially treated sewage effluents. Resultant algal turbidity and seasonal dissolved oxygen deficiencies adversely affect fishery resources, wildlife and recreation uses. . $^{\text {S }}$

Sediment is a serious pollutant in the Potomac Estuary. Annually, nearly 60 million cubic feet or 2.5 million tons of silt are washed into the estuary. ${ }^{16}$ Principal sources of the silt originating in Maryland are earth-moving operations for:

l) commercial, industrial and residential developments, 
2) highway and other public construction projects, and 3) dredging and filling operations, flood plain disturbances, and dredging for construction materials (sand and gravel).

\section{The Patuxent River Basin and Estuary}

Except for certain sections of the fresh water river and parts of the upper estuary, the water quality is relatively good. However, the Patuxent River basin is located between two rapidly expanding metropolitan centers, Baltimore and Washington. Rapid urban growth is not only changing the character of land in the basin, but is placing increasing demands upon the resources of the river both for water supply and waste disposal.

Projected increases in organic loads in the upper tidal reaches due to new development could cause dissolved oxygen reduction that would interfere with spawning activity and production of native as well as migratory species.

Discharges of partially treated sewage are causing higher concentrations of nutrients, particularly phosphates and nitrates, in the middle reaches of the basin and upper estuary. The continued discharge of wastes receiving only secondary treatment will result in accelerated eutrophication, with dissolved oxygen levels at times below the water quality standard and greatly increased phytoplankton productivity. Excessive algal blooms have been observed recently in the upper estuary." The lower portion of the estuary has experienced a slight increase in nutrients attributable to treated waste discharges into the waters of the upper basin. However, there have been no measured adverse effects to date from this condition. ${ }^{19}$

It has been estimated that 183,000 tons of sediment are deposited in the estuary per year. ${ }^{21}$ Sources of this sediment include the eight sand and gravel operations located in the basin and runoff from agricultural land and urban developments.

\section{Chespeake Bay - In General}

Sources of information were the wetlands habitat field inventory conducted by the Maryland Department of Game and Inland Fish (now Fish and Wildlife Administration) during 1967-68, Fish and Wildlife Resources as Related 10 Pollution ${ }^{21}$ and the Statewide Water Quality Surveillance Network 1968 Survey Results." Undoubtedly, there are additional areas where aquatic habitat has been adversely affected in some respects at some time and have gone undetected, or remedial measures have been initiated to correct the problems noted. It is emphasized that Table XII-I is based on general, non-technical information only, except for the oyster bar closures.

The general summary indicates several different types of wetlands identified with water quality problems throughout the State. Incidence is highest for coastal types of wetlands beciuse of their concentration along tidal estuaries and because these types were frequently coincident with the 27,800 acres of the Bay that have been closed to shellfishing for public health reasons (Table XII-1). The primary cause was degraded water quality due to domestic sewage contamination from untreated or partially treated wastes. Industrial wastes from food processing firms were noted to be the source of pollution in a few instances.

In May and June, 1968, the Water Quality Investigation Divison of the Maryland Depariment of Water Resources conducted an intensive, statewide water sampling study. Several water quality parameters were analyzed at over 1,000 sampling stations. Water quality deficiencies as listed in Table XII-2 do not necessarily mean pollution. More importantly, it should be recognized that deficiencies are not a local matter in the sense that only certain areas of the State's waters have experienced water quality problems. Instead, every county in the State had some sampling stations with deficient water quality values during the time of the surveillance elfort.* Therefore, water quality improvement requires the interest, support and cooperation of all citizens and all responsible governmental units in Maryland.

\section{SUMMARY AND CONCLUSIONS}

Maryland will continue to experience human population growth. This means not only increasing volumes of domestic waste but also more industrial and land runolf wastes will be generated by essential supporling economic development. While the area and volume of receiving waters into which these wastes are discharged remains constant, the sources, volumes and locations of waste discharges will increase continuously. At this time some deterioration has been recorded in the natural health and condition of certain State waters. This is happening because the waste discharges exceed the water's natural ability and capacity to disperse and assimilate them satisfactorily. In the future, the manner in which people demand to use their land and water resources will or will not result in additional incidents of water pollution.

One important aspect of past, present and future water quality problems is that partially treated effluent from sewage treatment plants, untreated domestic 
Table XI-1. General summary of survey information on wetlands identified with estuarine water quality problems (principally from domestic sewage).

\begin{tabular}{|c|c|c|c|c|c|c|c|c|c|c|c|}
\hline \multirow[b]{2}{*}{ County* } & \multicolumn{11}{|c|}{ Wetland Types (Acres) } \\
\hline & 5 & 6 & 7 & 8 & 12 & 13 & 16 & 17 & 18 & $19 \mathrm{P}$ & Totals \\
\hline Anne Arundel & 36 & & & & 40 & & & & & & 76 \\
\hline Calvert & & & & & 365 & & & & & & 365 \\
\hline Caroline & & & 16 & & 59 & & & & & & 75 \\
\hline Charles & & & 1,045 & & 2,814 & & & & & & 3,859 \\
\hline Dorchester & & & & & 382 & & & & & & 382 \\
\hline Garrett & & & & 41 & & & & & & & 41 \\
\hline Kent & & & 27 & & 338 & & 457 & & & & 822 \\
\hline Prince George`s & 6 & 23 & 801 & & & 115 & & & & & 945 \\
\hline Queen Anne's & & & & & 156 & & & & & & 156 \\
\hline St. Mary’s & & & 10 & & 291 & & 16 & & & & 317 \\
\hline Talbot & & & 9 & & 98 & & 111 & 112 & & & 330 \\
\hline Wicomico & & 26 & 590 & & & & & & & & 616 \\
\hline Worcester & & 30 & & & 54 & & & & 943 & & 1,027 \\
\hline Subtotals* & 42 & 79 & 2,498 & 41 & 4,597 & 115 & 584 & 112 & 943 & No data & 9,011 \\
\hline $\begin{array}{l}\text { Chesapeake Bay } \\
\text { Area*** }\end{array}$ & & & & & & & & & & 27,837 & 27,837 \\
\hline Total & & & & & & & & & & & 36,848 \\
\hline
\end{tabular}

* General information retrieved from habitat inventory sheets produced by field surveys during 1967-68. Majority of the causes was domestic sewage pollution.

** Information obtained from Table 34, page 167, Fish and Wildlife Resources as Related to Water Pollution Chesapeake Bay and Tributaries, U. S. Dept. Interior, Fish and Wildlife Service, October, 1968, also the Maryland Department of Chesapeake Bay Affairs. The pollution effects were through December, 1969, from domestic sewage for tidal salt water habitat areas only, and represent oyster bar acreage closed to commercial fishing.

wastes, and some industrial and agricultural wastes contain nutrients such as nitrates and phosphorous. Excessive quantities of such materials cause overfertilization of aquatic ecosystems (the consequences have been discussed earlier).

* The 1968 water quality sampling study has been updated by the Report on Status of Water Quality and Significant Sources of Wastewater Discharges in Maryland. Md. Dept. Water Resources and Dept. of Health and Mental Hygiene. November 1, 1970.

There is an important relationship between wetlands, certain land development patterns and water quality. Extensive land development in the past has been concentrated largely near metropolitan centers, their urbanizing fringes, and rural community centers. The resultant population concentrations generated wastes that were disposed of after varying amounts of treatment into nearby waterways at specific localized points. The impact on water quality in terms of the total area of estuarine waters was primarily small or local. Recently, however, large amounts of Maryland's shoreline have experienced developmental activity. More is contemplated, proposed or can be expected in the future. This means that unless effective waste disposal systems are installed concurrent with development and appropriate land use plans enforced, more of the State's waters will experience additional water quality problems as the customary means of disposal are overtaxed, thus aggravating pollution problems, reducing conveniently 


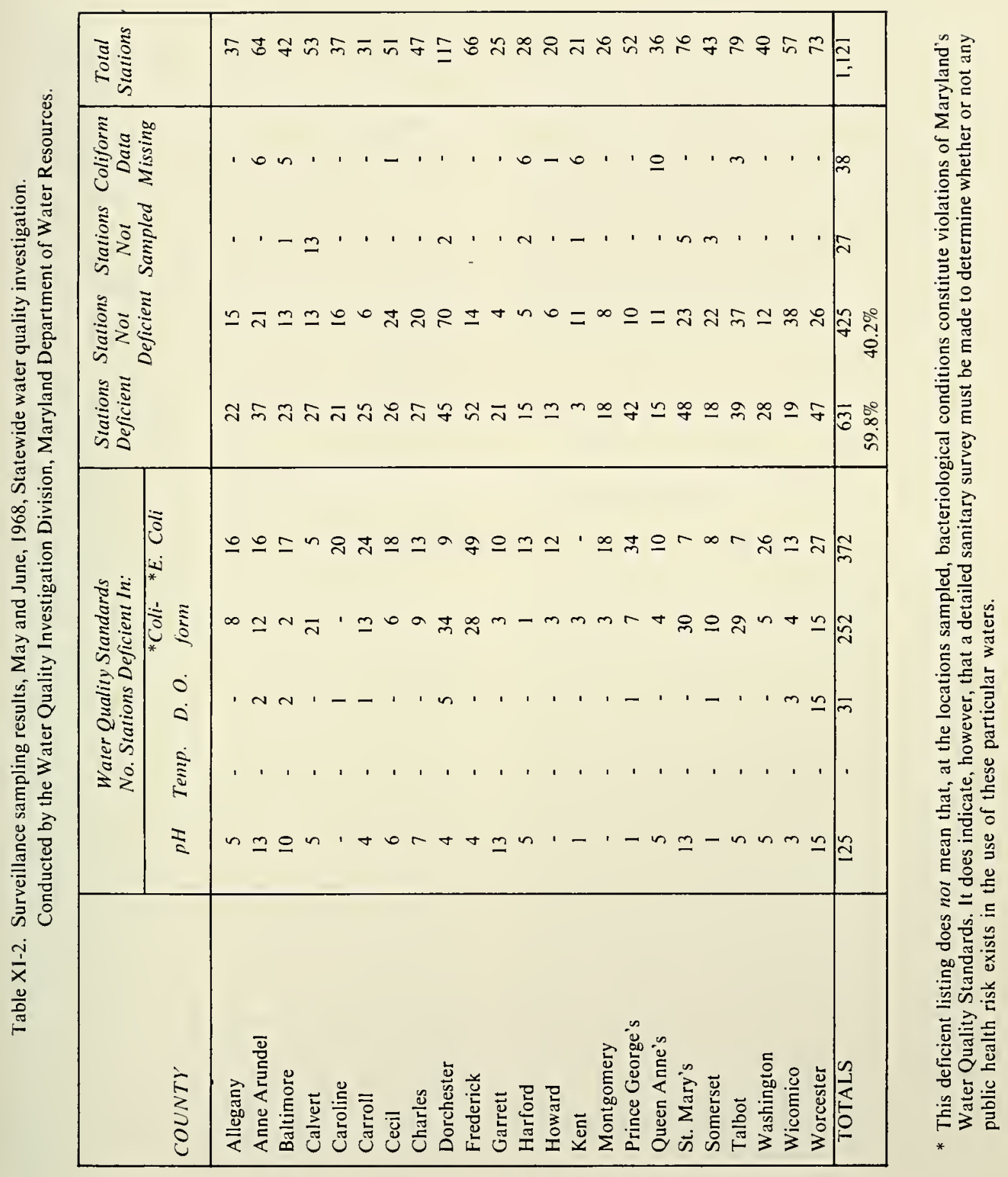


available potable water, and diminishing opportunities for recreation and other water uses. ${ }^{23}$

The deterioration process may not be necessarily traceable to a specific incident or event such as filling wetlands or excessive waste discharges. Rather, it is initiated by or due to a series of events that have a gradual, cumulative negative effect on the natural factors and functions essential to water's waste assimilative abilities and capacities. However, once crucial thresholds are crossed disastrous consequences are inevitable. The fish and crab kills experienced on the Miles River and in the harbor at St. Michaels in 1969 are believed to be specific examples of the combined effects of excessive waste discharges and decreases in natural waste assimilative capabilities due to cumulative tidewater shoreline development.

Water is a very pervasive element of Maryland's natural environment. Therefore, water quality is inherently one of the major factors affecting the overall quality of life in our environment. Any steps proposed to be taken that suggest even a remote threat to environmental degradation should be examined very carefully. Wetlands contribute important functions to natural protection and improvement of water quality. If the quality of Maryland's waters is to be protected, wetlands must be managed accordingly because they are an inseparable part of the total aquatic and terrestial environmental framework.

Incumbent with that objective, significant efforts should be undertaken and sustained on various research projects concerning different aspects of wetlands and estuarine systems. Apparently, not enough is known yet about certain biological, chemical and physical parameters of wetlands and estuaries to completely understand and accurately predict the behavior, dispersal and assimilation of wastes discharged into them so that management systems can ensure protection of high water quality. Also, when considering the major interdependencies between water quality protection, wetlands, and land development, especially that of the shoreline, special attention and careful thought must be given to ways and means of effectively guiding future development in the important shoreline interface area in order to protect high water quality and resultant natural productivity and utility of the State's waters.

I Federal Water Pollution Control Administration. National Estuarine Pollution Study. November, 1969. The study was authorized by Title II, Sec. 5 (g) (1) of the Clean Water Restoration Act of 1966 (Public Law 89-753) with the objectives to: 1) document and analyze the various aspects of estuarine pollution; 2) make recommendations for a comprehensive National program for the preservation. study, use and development of the estuarine zone; and 3) recognize the respective roles of Federal, State and local governments plus public and private interests.

2 Stewart, Kenton M., and Gerard A. Rohlich. Eutrophication - a review. State of California, State Water Quality Control Board. Pub. no. 34, Sacramento. 1967.

3 McKee, J. E., and H. W. Wolf. Water quality criteria. California. State Water Quality Control Board. 2d ed. Pub. No. 3-A. 1963.

4 Stanford University. Proceedings, National Symposium on Estuarine Pollution, Stanford, Calif. August 23-25, 1967.

5 Wastler, T. A. Municipal and industrial wastes and the estuaries of the South Atlantic and Gulf Coasts. In. Proceedings, Marsh and Estuary Management Symposium. LSU, Baton Rouge, La. 1968.

6 Ippen, Arthur T. Estuary hydrodynamics. In, Proceedings, Symposium on Hydrology of the Coastal Waters of North Carolina, May 12, 1967. Water Resources Research Institute, University of North Carolina, Raleigh, N. C.

7 American Water Resources Association. The Water Resources Newsletter. v. 6, n. I, February, 1971.

8 Daiber, Franklin C., R. J. Reimold, and D. Aurand. Tide marsh ecology and wildlife. PittmanRobertson Project W-22-R-2, Annual Report. Dept. Biological Science, Univ. of Delaware. 19661967.

9 Heath, James P., et. al., "A statement addressed to the Legislature of the United States of America," in The Nation's Estuaries: San Francisco Bay and Delta, Calif. Subcommittee hearing print, Committee on Government Operations, H.R. 9/st Congress, 1st Session, U.S.G.P.O: Washington, May 15, 1969.

10 Johnson, Peter L. Wetlands preservation. Open Space Institute. New York. 1969.

1 I Boerger, F. C., Col. District Engineer, U. S. Corps of Engineers, San Francisco District. Statement in The Nation's Estuaries: San Francisco Bay and Delta, Calif. Subcommittee hearing print, Committee on Government Operations. H. R. 91st Congress, Ist Session, U.S.G.P.O: Washington, May 15, 1969.

12 Odum. Eugene $P$. The theory of the estuarine ecosystem in relation to use, management and pollution. Statement made at field hearings at Jekyll Island, Georgia, in connection with the 
National Estuarine Pollution Study. February 29, 1968.

13 Smith, Bernard J. The tides of San Francisco Bay. San Francisco Bay Conservation and Development Commission. June, 1966.

14 Aalto, Johan A. Statistics and projections, in the Potomac estuary ... a changing environment. Proceedings 1968-1. Interstate Commission of the Potomac River Basin. June, 1968.

15 Uhler, Francis M., and Neil Hotchkiss. "Vegetation and its succession in marshes and estuaries along the South Atlantic and Gulf Coasts." In. Proceedings, Marsh and Estuary Management Symposium, L.S.U., Baton Rouge. 1968.

16 Tuthill, Dean F., D. Sobers and J. P. Marshall. The effects of sediment pollution on water recreation in the upper Potomac estuary. Dept. of Agric. Econ., Univ. of Md., Misc. Pub. 653, December, 1967.

17 Mihursky, Joseph A. Summary report on environmental conditions of the tidal Patuxent River. In, Appendices, The Patuxent River Maryland's Asset, Maryland's Responsibility. Governor's Patuxent River Watershed Advisory Committee. Md. State Planning Dept. Pub. No. 149a. Baltimore, Maryland. July, 1968.

18 Federal Water Pollution Control Administration. The Patuxent River water quality management technical evaluation. U.S.D.I. Charlottesville, Virginia. September, 1969.

19 Ibid.

20 Heidel, S. G. and W. W. Fremer. Chemical quality of water and trace elements in the Patuxent River Basin. Md. Geological Survey Report of Investigations, No. 1, 1965.

21 Bureau of Sport Fisheries and Wildlife. Fish and wildlife resources as related to water pollution, Chesapeake Bay and tributaries. U.S.D.I. Atlanta, Ga. October, 1968.

22 Longwell, John R., and Richard L. Sharpless. Statewide water quality surveillance network 1968 survey results. Water Quality Investigation Division, Maryland Department of Water Resources, Annapolis. 1968.

23 Craine, Lyle E. Maryland's role in water resources development. Water Resources Study Committee, Univ. of Mỏ., College Park. 1966. 

XII

\section{SURVEY OF WETLANDS' ROLE IN ESTUARINE HYDRAULICS}





\section{INTRODUCTION}

Wetlands may have certain beneficial effects on the hydraulics of river and estuary systems. These effects include delay and storage of surface runoff and tidal surges; alteration of river flows, waves and tidal currents; and buffering or stabilizing the inundation of coastal lands. The purpose of this chapter is to briefly discuss the relationship of wetlands to each of these effects.

\section{WATER STORAGE}

The composition of the upper layers of wetland soils have significant water absorption and retention capabilities. Accumulated vegetable materials ranging from live plants to peat have excellent water absorbent characteristics. One acre of marsh is reported to be capable of absorbing and holding 300,000 gallons of water.' This hydraulic feature of wetlands has implications to surface runoff from upland areas and tidal surges in estuaries.

All interior or inland wetlands are located adjacent to or are part of surface drainage patterns. Therefore, in many areas surface runoff must pass through wetlands. The capability of wetlands to absorb or temporarily retain large volumes of water can lessen potentially damaging effects of excessive surface runoff rates. Gradual release of water into adjacent waterways lowers potentially higher flood stages, reduces stream erosion, and prolongs higher stream flow rates. Additional water supplies during lower flow periods provide protection to aquatic ecosystems and promote improved water quality (see Ch. XI).

Decreases in depth and in surface and subsurface areas in the upper reaches of tributary rivers and estuaries mean a reduction of in-channel water storage capacity. Consequently, tidal surges may produce water levels that are several inches higher in areas lacking the storage capacity to handle extra volumes of water. Depending upon shoreline elevations, rising water levels may mean intermittent or temporary inundation of normally dry land. Wetlands, by definition, function as storage areas to temporarily assimilate additional volumes of water generated by tidal cycles.

When high tides coincide with other forces of nature such as high winds associated with coastal storms, they can magnify greatly the total effects of coastal high water situations. In particular, an especially disadvantageous situation could occur with "funnel-shaped" estuaries which have wide openings at their mouth and narrow necks at their head (Figure XII-1). A large mass of winddriven water can easily enter the estuary with great momentum. As the estuary narrows, the only direction that incoming tide or wind-driven waters can move is upward since the original volume of the estuary is already filled with water. If at the same time inland runoff should be seeking discharge into the estuary, there is no place for it to go except upward also. Most likely, the surface runoff carried by the river will be both backed up to higher elevations and added to the swelling volume in the headwaters area of the estuary. Naturally, all low land areas immediately adjacent to both the estuary and the river will be potential flooding sites as the rising water levels reach their elevation.

Supposing that in the above described situation "former" wetlands have been filled for developmental purposes. Consequently, the estuarial flood plain is no longer available to case the flooding pressure due to rising water levels. Therefore, the increasing water volume must continue to move to still higher levels since there is no other direction or space available to accept it. Any flooding that should occur as a consequence may be more serious and severe because of induced higher water levels.

\section{WAVE AND CURRENT ALTERATION}

The physical and biological characteristics of wetlands can have beneficial influences on wave action, river flows and tidal currents. The low elevation of wetlands offers a profile much less susceptible to destructive wave action than certain other shoreline areas. Shoal waters common to wetlands cause a reduction in wave energy prior to reaching the shore, and the sponge-like qualities of wetland vegetation are suited to intercept and absorb limited wave shock.

Abundant rooted plant growth also reduces river flows and tidal currents by acting as a baffle. ${ }^{2}$ Reduced water velocity will cause deposition of suspended sediments. Sedimentation adds to the growth and stability of wetlands. Eventually through natural processes, intertidal plateaus are built from mixed layers of deposited organic material and accumulated sedinents. These areas grow from the original shoals out into deeper open water. In doing so, this advancement produces tidal meanders of considerable length, increases the extent of the ecologically valuable land-water interface, and produces a barrier between shoreline areas formerly exposed to wave and tidal action.

\section{STABILIZATION OF COASTAL LAND INUNDATION}

Sea levels are rising gradually. Various reported rates for this natural event include three inches per 

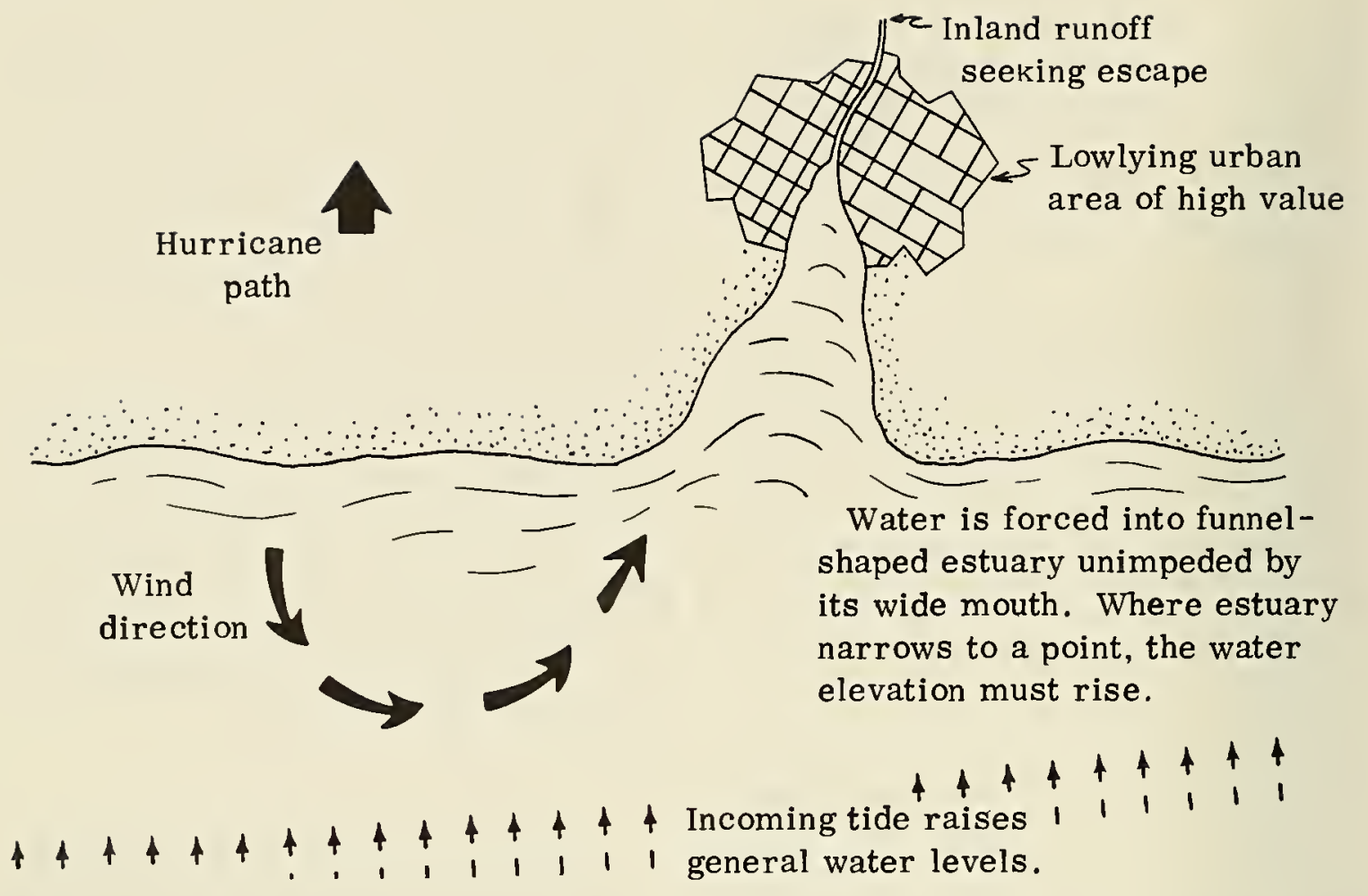

Figure XIJ-1. A hypothetical illustration of a combination of climatological factors and physical features which have the potential for serious coastal

century along the Atlantic Coast, ${ }^{3}$ six to twelve inches per century, ${ }^{4}$ and 10-15 inches per century. ${ }^{5}$ Whatever the actual rate is, there is abundant botanical, physiographical, and historical evidence to support this contention."

Rising sea levels threaten inundation of low elevation shoreline and coastal areas. In fact, coastal submergence is one of the natural processes that initiates the formation and growth of wetlands (Ch. IV). Certain land areas on the Eastern Shore, particularly in Dorchester and Somerset counties, have been and are being converted to tidal marshes due to encroachment by adjacent waters (Figures XIII-2 and 3, respectively). While this conversion is basically a natural process promoted by the gradual rise in sea level, man has augmented or accelerated coastal inundation by certain land management and water drainage practices ( $\mathrm{Ch}$. XIII).

For a marsh to keep pace with sea level rises, it would have to accumulate about three cubic yards/acre/year of sediment.' Reports on sedimentation rates in certain Virginia coastal marshes suggest that as flooding problems. (After Coastal and Estuarine Areas, App. U (draft), North Atlantic Regional Water Resources Study. New York. January, 1971.)

much as 5,000 cubic yards of soil were deposited on each acre of marsh during the past two centuries. ${ }^{8}$ While in another Virginia coastal marsh, over 25,000 acres were reported to have retained an estimated 76,000 tons of sediment each year. This amount represented about six percent of the total sediment load carried by the river in which the marsh was located. ${ }^{9}$ This rate of deposition translates to roughly three tons of sediment/acre/year or at a rate sufficient to build marshes equal to rising sea levels.

High sediment deposition rates depend upon supporting erosion rates in upland areas. While past agricultural land practices have been modified by soil conservation measures and improved land usage techniques, urban growth probably provides equally large if not larger volumes of sediment (Ch. XI). Road construction, residential, commercial and industrial development, as well as dredging and spoil disposal activities are current major sources of sediment found in every waterway.

In addition to the volume of accumulated sediments, the organic material generated in wetlands also contributes to total deposition rates. While sizeable quan- 
tities of organic material are utilized and re-cycled in aquatic and terrestial ecosystems, a substantial amount of the estimated $10,000 \mathrm{lbs}$. (dry weight)/acre/year ${ }^{10}$ is deposited in the immediate vicinity of the wetland on which it was produced.

Wetlands are constantly growing. The direction of growth is upward and outward. Their slow but steady growth is estimated to approximate the pace of a constantly rising sea level. One estimate is 75 years from initiation of wetland growth to the development of a mature coastal salt marsh." The growth and development of wetlands, when combined with their water storage capabilities can act as a buffer against inundation or conversion of non-tidal coastal lands into wetlands by periodic tidal flooding (discussed in detail in the next chapter).
I Johnson, Peter L. Wetlands preservation. Open Space Institute. New York. 1969.

2 Klein. George. Comparison of recent and ancient tidal flat and estuarine sediments. In Estuaries, AAAS, Pub. no. 83. Washington, D.C. 1967.

3 Op. cit.

4 Chapman, V. J. Salt marshes and salt deserts of the world. Interscience Publishers, Inc. New York. 1960.

5 Wass, Marvin L., and T. D. Wright. Coastal wetlands of Virginia: interim report. Spec. Rept. no. 10. Va. Inst. Marine Sciences, Gloucester Point, Va. December, 1969. From Hicks, S. D. Long-period variations in secular sea level trends. Shore and Beach. v. 36:32-36.

6 Op. cit.

7 Wass and Wright, op. cit.

8 lbid.

9 Op. cit.

10 Odum, Eugene. The role of tidal marshes in estuarine production. N. Y. State Conservation Dept., Div. Cons. Educ., Information leaflet. n.d.

11 Chapman, V. J.Supra. 



\section{XIII}

\section{CONVERSION OF LOW}





\section{INTRODUCTION}

During the wetlands legislation creation process, it was pointed out that the State was actually gaining wetlands in certain areas of the lower Eastern Shore due to the encroachments of tidal flooding. The purpose of this chapter is to examine and discuss the process of conversion whereby certain low elevation lands adjacent to tidal marshes or other estuarine areas are themselves becoming tidal marshes.

\section{BACKGROUND}

The Eastern Shore of Maryland is a low-lying, predominantly agricultural region of the state (figure VI1-3). Many acres of the peninsula's land area are directly influenced by the tidal waters of the Chesapeake Bay. In some localities a process of tidal encroachment is gradually changing wood, shrub, idle and crop lands to tidal marshes.

Tidal encroachment is related to several factors among them the low elevation of land on the Eastern Shore, gradually higher tides, and man's use of land. No data exist on total losses or conversion rates of land to regularly flooded tidal marsh. However, isolated instances have been documented. One such instance concerns the Marumsco Creek watershed in Somerset County in which 684 acres of crop land were converted to marsh land in 20 years (1938-58).'

Low elevation of land is a very important factor in tidal flooding. Much of the Lower Shore has an elevation of only one to five feet above mean high tide levels. The Upper Shore has an average elevation which is 5 to 10 feet greater than that of the Lower Shore. It is obvious that under these circumstances, unusual weather or tidal conditions or other factors modifying estuarine hydraulics will result in intermittent or temporary inundation of substantial coastal land areas. The problem of tidal flooding is, therefore, more widespread in Dorchester, Somerset, Talbot and Wicomico Counties than it is in the other Eastern Shore counties. An exception on the Lower Shore is Worcester County where no significant occurrence of land conversion to tidal marsh has been observed. In Worcester County, land adjoining tidal marsh is higher in elevation than in Dorchester and Somerset Counties particularly, and therefore, there is no extensive tidal flooding.

Tidal encroachment can be attributed in large part also to a gradual rise in sea and tide levels. For instance, tide levels at Fort McHenry in Baltimore Harbor are recorded as having risen six inches since the mid-1930's.

Man's use of the land has contributed in several ways to a process of land subsidence and also to tidal encroachment. Heavy agricultural equipment compacts the soil causing some reduction in land elevations which are already close to that of sea level. Increased tidal flooding is further encouraged by poorly maintained diking and tide gates, poorly located drainage ditches and "brushing" out of the protective fringe vegetation which provides a buffer for usually dry land.

\section{LAND USE IN THE PAST}

No evidence was found to suggest that tidal encroachment was considered an unusual problem on the Lower Shore during early settlement and through the 1860 's. Prior to 1863 , diking and dike maintenance were common practices, particularly in Somerset County. The availability of slave labor made protection of marginal crop lands and homesites possible. Some of this land was probably subject to occasional (historical) flooding before diking. With emancipation and increasing labor costs, however, marginal agricultural lands were abandoned and dikes fell into disrepair.

Early agricultural practices involved the use of light equipment and consequently, less soil disruption and compaction occurred. Because land was not scarce and sophisticated machines were not available for diking and draining, it seems reasonable to assume that only lands which were readily convertible to crop land were farmed intensively. Consequently, lands bordering on tidal marshes, as well as the marshes, were probably not cultivated.

\section{PRESENT LAND CONDITIONS}

\section{Areas Affected by Tidal Encroachment}

Areas along the Choptank River in Dorchester County, and the Deals Island - Dames Quarter, Crisfield, Fairmount and Marumsco Creek watershed areas in Somerset County are significant areas where tidal flooding and land conversion occur. It should be noted that this is not a comprehensive coverage of areas so affected. There are undoubtedly other areas of varying size, particularly on the Lower Eastern Shore, where conversion from agricultural and wooded land to tidal marsh is occurring.

At one time, the Deals Island - Dames Quarter area was farmed intensively and an extensive dike system existed. This area is currently undergoing conversion and much of the converted land is now providing habitat for wildlife. Crisfield, Fairmount and their surrounding areas have traditionally faced the problem of tidal 
encroachment. Dikes, which were maintained prior to the mid-1800's, are now nearly non-existent.

Quantitative studies have been conducted on the Marumsco Creek watershed east of Crisfield. ${ }^{2}$ This particular watershed contains approximately 14,000 acres of which approximately 8,200 acres (between Hudson's Corner and the Pocomoke Sound) have an elevation between two and five feet above sea level, while normal tidal range varies between 0.75 and 2.7 feet. Consequently, much of the watershed is subject to periodic tidal flooding now. Occasionally, extreme high tides may exceed five feet above mean sea level. Of the 8,200 acres subject to tidal influence in 1956,2,800 acres were crop land (divided among 56 farm units), 2,900 acres were idle and wood land, and 2,500 were tidal marsh. During a storm on March 6-7, 1962, 44 percent of land in the watershed subject to tidal influence was damaged by tidal flooding (3,590 of 8,200 acres). However, of the acreage experiencing damage only 1,700 acres were crop and wood land and of this figure only 45 acres were actually being cultivated at that time. Based on land use records, the U. S. Soil Conservation Service has estimated that 684 acres of land had re-converted to tidal marsh between 1938 and 1958 in the Marumsco Creek watershed. Similar conversion rates (34 acres per year) may exist for certain comparable areas of the Lower Eastern Shore lying within 2-5 feet of the mean high tide.

\section{County Land and Soil Types Subject to Tidal Influence}

Tidal flooding is the most significant factor or mechanism responsible for converting normally dry land to marsh land, although a very high ground water table also has significant influence on land use patterns and consequent vegetative regimes. Elkton and Othello low phase soil types are the ones most vulnerable to tidal encroachment. In addition, tidal marsh (high phase) i. e.,

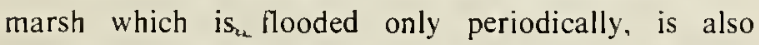
susceptible to conversion to tidal marsh (low phase) which is flooded daily.

Recent soil survey reports for Dorchester, Somerset, Talbot and Wicomico Counties suggest which lands and soils are vulnerable to conversion to tidal marsh.

\section{Dorchester County}

The Elkton silt loam and silty clay loam llow phases) are only slightly above the level of tidal marsh areas. Because of their low position or being very close to sea level, they are almost impossible to drain. At times these soils are flooded when tides are extremely high. The soils are not suitable for crops but will furnish some limited grazing for cattle and loblolly pine appears to be the climax vegetation in woodland areas. These soils occupy about 34,000 acres in the county. ${ }^{3}$

The Othello silt loam (low phase) is close to sea level. Occasionally it is flooded temporarily when the tide is unusually high, but tide gates have been provided in some places to control the level of water. This soil is difficult to almost impossible to drain and it is generally not suited for cultivated crops. Under good management it can be used for pasture or woodland. This soil occupies about 12,400 acres in the county, principally south of Cambridge (Figure XIII-1). ${ }^{+}$While this soil type is not generally suited for crops, it can in some instances be cultivated if protected with dikes and tide gates.

In addition, many of the islands of this county consist almost entirely of tidal marsh. Within the tidal marsh soil association about 4,000 acres (out of 81,600 acres) $)^{5}$ have the potential for conversion to tidal marsh.

\section{Somerset County}

Othello silt loam (low) soil lies so close to sea level that it is subject to occasional flooding by high tides, mostly in the Fairmount and Crisfield areas. This soil remains wet for long periods and is difficult to almost impossible to drain in some places. Because salt water is likely to flood this soil, it is not generally cultivated although under good management it will sustain limited grazing and timber growth. Othello silt loam (low) occupies about 1,600 acres or about 0.8 percent of county lands. ${ }^{6}$

Tidal marsh is extensive in the western and southern parts of Somerset County adjacent to estuarine areas (Figure XIII-2). This category of land and soil association consists of areas likely to be or that already are flooded by salt water. The tidal marsh category encompasses areas that range in size from small, disconnected units to large, extensive tracts. There are varying degrees of vulnerability to conversion within this category because much of the acreage is not under the direct influence of tidal action as it is effectively buffered by tidal marshes (low phase) and heavy wood and shrub growths on drier land.

\section{Talbot County}

Othello silt loam (low) occurs in the western part of the county in small areas that border the heads of tidal creeks and areas of tidal marsh (Figure XIII-3). Because this soil is near sea level it is flooded by salt water when 


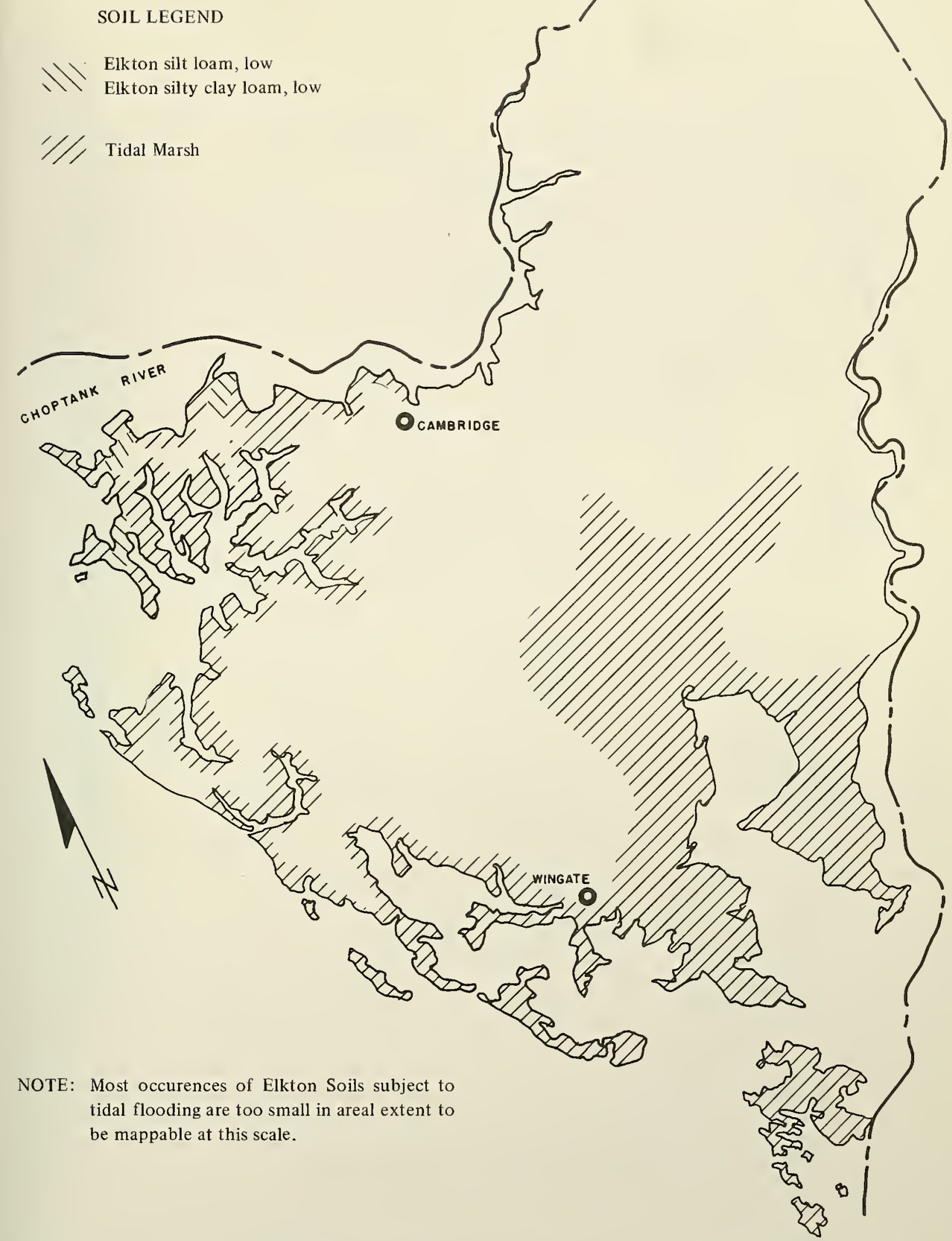

Figure XIII-1 General locations in Dorchester County, Maryland of soil associations either actually or potentially influenced by tidal action and subject to conversion. 
SOIL LEGEND

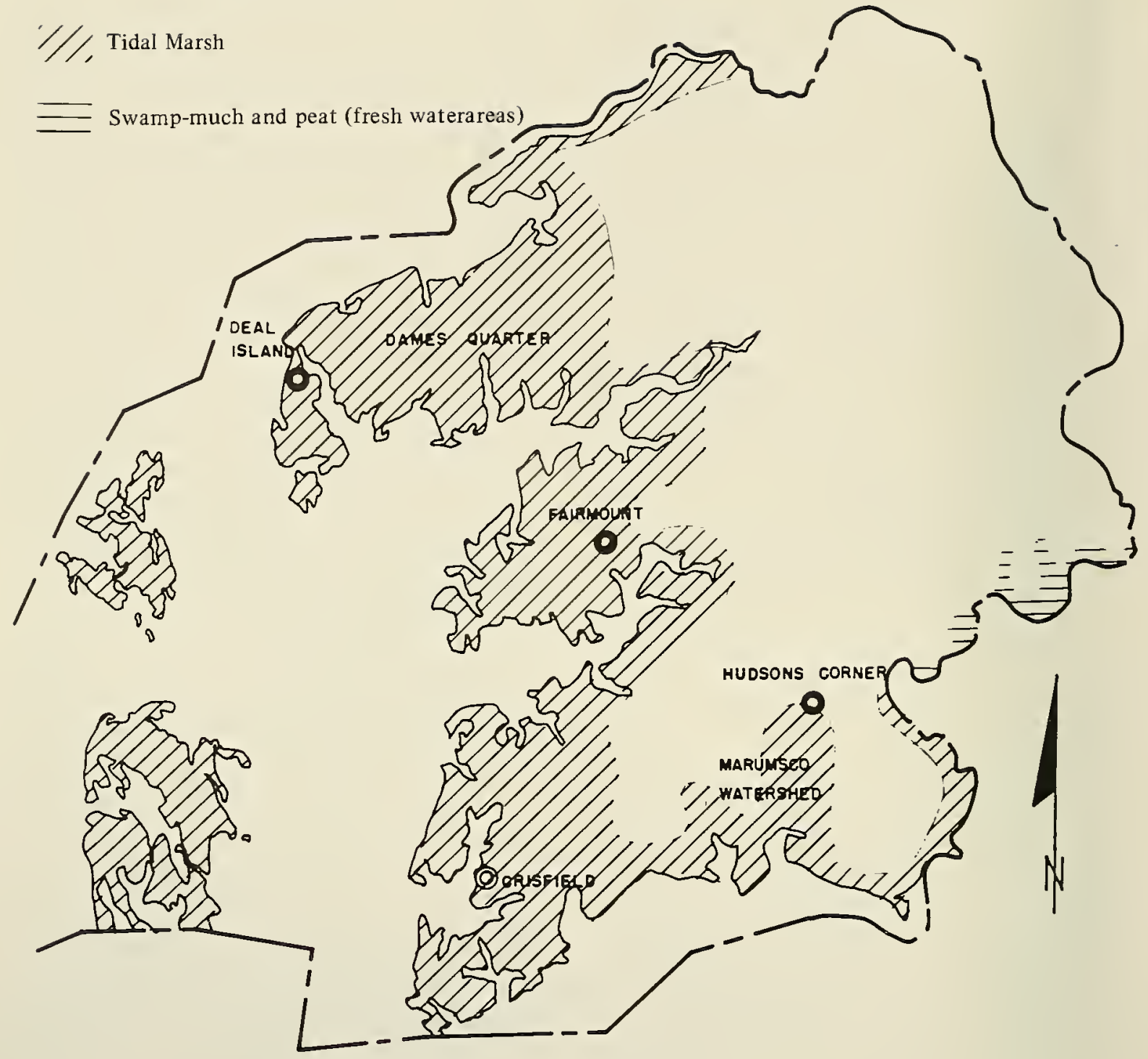

Figure XIII-2 General locations in Somerset County, Maryland of tidal marsh soil associations either actually or potentially influenced by tidal action. 


\section{SOIL LEGEND}

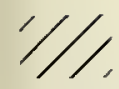

Otlello silt loam, low

II' Tiad Mash

Po

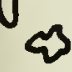

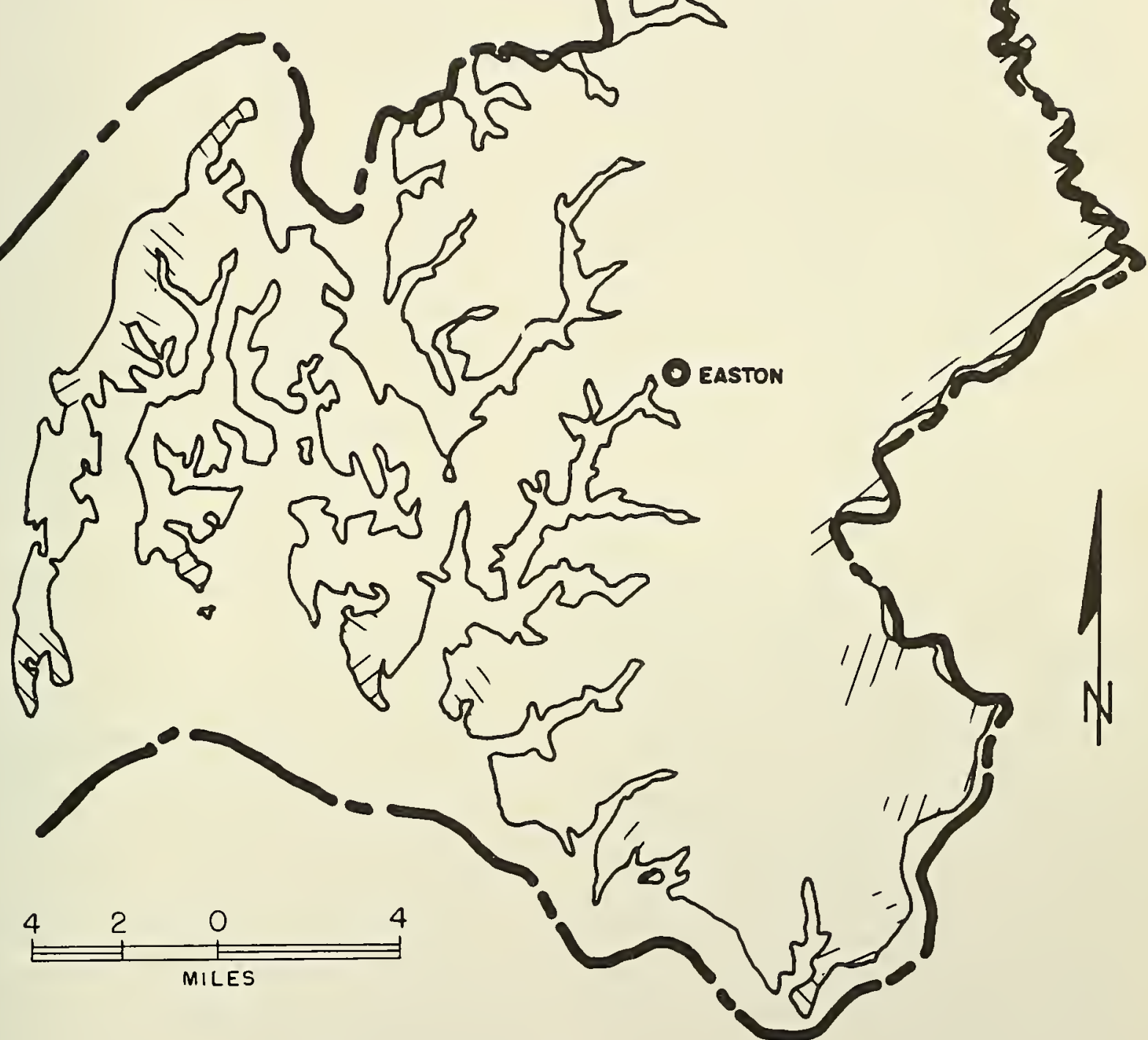

NOTE: Most occurences of Othello silt loam (LOW) soil are too small in areal extent to be mappable at this scale.

Figure XIII-3 General locations in Talbot County, Maryland of tidal marsh soil associations including Othello silt loam (low) which is subject to conversion to tidal marsh. 
tides are usually high. Consequently, it is intermittently salty and supports only salt tolerant vegetation, although the salt leaches out during periods of rainfall. In some places low dikes have been constructed to prevent flooding, but such construction is expensive and not economically feasible. Drainage is not feasible also because of the low elevation and removing excess water may require the building of tide gates to prevent salt water from backing into drainage ditches. Othello silt loam (low) is suitable for wildlife habitat but most other non-farm uses are limited. This soil occupies about 1,500 acres $(0.8$ percent $)$ in the county which are or might be subject to periodic flooding and conversion.?

Tidal marsh by definition consists of land that is covered with brackish or salt water on each flood tide. This soil contains varying amounts of decaying organic matter and occurs along the shoreline in areas of $I$ to 10 acres in tidal tributary creeks and in areas of a hundred acres or more along the Choptank River and Tuckahoe Creek in the eastern part of the county (Figure XIII-3). Within this soil association there are certain areas which are not yet tidal marsh due to slightly higher elevation or natural protective features. ${ }^{8}$ No estimates are available on the acreage that might be in this situation.

\section{Wicomico County}

Othello silt loam '(low) lies so close to sea level that occasionally it is flooded by exceptionally high tides. The soil remains wet for long periods and is almost impossible to drain because suitable outlets generally are lacking. Some areas have been seriously affected by salt water and in some way resemble tidal marsh. ${ }^{9}$

Wetness severely limits use of the Othello soils for building sites. Even if drainage and sewage disposal were provided, use of this soil for homesites would be severely limited by water that would flood excavations for basements in wet periods and would injure or kill many kinds of trees, shrubs, grasses and other plants used in landscaping." This soil occupies about 550 acres or 0.2 percent of the county land." Principal locations are in the upstream tidal areas of Broad and Shiles Creeks in the southwestern part of the county. (Figure XI1I-4).

Tidal marsh occupies large areas that border the estuaries of the Wicomico and Nanticoke Rivers, and it occurs also along the lower courses of streams flowing into those rivers. Usually it is too wet and brackish for farming because it is flooded regularly by salt water from estuaries. Within this soil association there are areas which are not yet fully tidal marsh. There is no estimate as to the acreage in this situation.

\section{Discussion}

Soil types similar to those discussed above appear in other Eastern Shore counties. However, conversion to tidal marsh is more infrequent because the land elevation is generally higher there.

With further regard to the selected soil types and acreages subject to tidal influence it should be noted that much of the acreage is already considered to be marsh land. It may be dry much of the time, but the low elevation and plant communities are more characteristic of land which is in transition between dry land and actual tidal marsh. Furthermore, only the inland fringe areas of tidal marsh are subject to rapid conversion and the rate of conversion depends on the protection - natural or manmade - which exists in any specific area. Reliable data does not exist concerning crop land and productive timber land which might be converted to marsh land. However, casual inspection of the Somerset and Dorchester counties soils maps shows that well over onehalf of the acreage of soils susceptible or vulnerable to conversion is not in a cultivated land use category. A composite tabular summary indicates that about 54,000 acres of low elevation land is clearly identifiable with a potential for conversion to tidal marsh depending upon the circumstances (Table XIII-1).

\section{FACTORS INFLUENCING CONVERSION}

\section{Rise in Sea Level}

It has been pointed out previously that the Lower Eastern Shore land areas subject to tidal influence have an elevation of merely 1-5 feet above mean high tide level. Large areas of Dorchester, Somerset, Talbot and Wicomico counties presently in agricultural production are within this range of elevation, consequently there is extensive periodic tidal flooding.

Tidal records and studies indicate that the overall trend in sea level is rising (Ch. Xl1). The implication of this gradual event to the low-lying lands of the Lower Eastern Shore is obvious. It is also obvious that this is a natural process over which man can exert little control. However, no evidence was found to support a conclusion that the trend will either continue or reverse itself.

\section{Land Subsidence}

The phenomenon of land subsidence is not uncommon. Several areas around the world are experiencing this problem, including Los Angeles and the San Joachin Valley in California, Houston, Tokyo, Lon- 


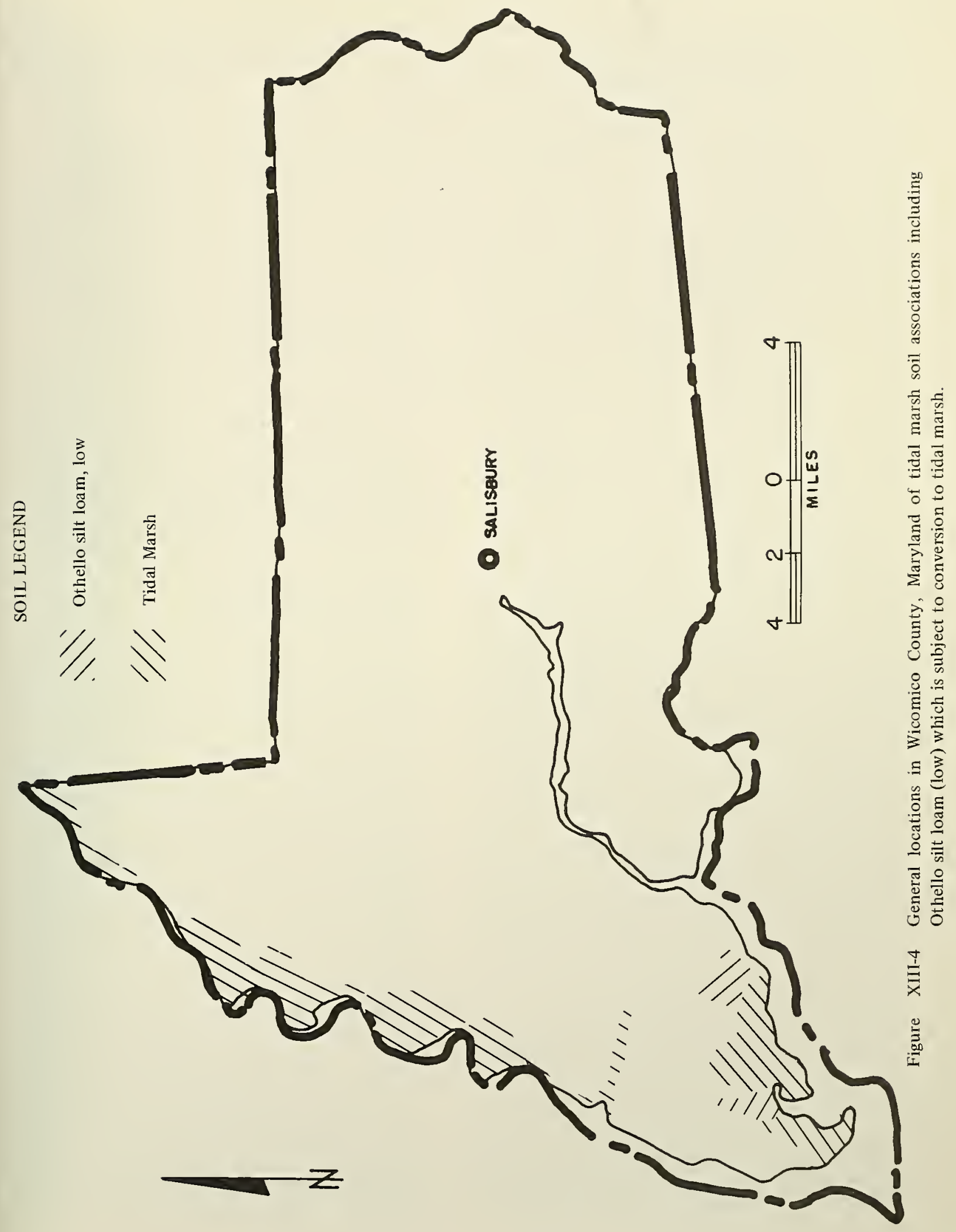


Table XII1-1. Composite summary of soil types and associations with potential for conversion to tidal march.

\begin{tabular}{lcccc}
\hline County & $\begin{array}{c}\text { Elkion Silt Loam } \\
\text { \& Silty Clay. Loam } \\
\text { (Low Phases) }\end{array}$ & $\begin{array}{c}\text { Othello Silt Loam } \\
\text { (Low Phase) }\end{array}$ & $\begin{array}{c}\text { Tidal } \\
\text { Marsh }\end{array}$ & $\begin{array}{c}\text { Approximate } \\
\text { Totals }\end{array}$ \\
\hline Dorchester & 34,000 & 12,400 & $4,000^{*}$ & 50,400 \\
Somerset & 0 & 1,600 & $?$ & 1,600 \\
Talbot & 0 & 1,500 & $?$ & 1,500 \\
Wicomico & 0 & 550 & $?$ & 550 \\
\hline \begin{tabular}{l} 
Approximate \\
\multicolumn{1}{c}{ Totals }
\end{tabular} & 34,000 & 16,050 & $4,000+$ & $54,050+$ \\
\hline
\end{tabular}

*This acreage figure within the overall soil association is considered subject to possible conversion.

don and Mexico City. In these documented cases, the subsidence has been induced by man's pumping either oil and/or water from underground areas. ${ }^{12}$ The surface topography sinks as the subsurface soil and rock structure is altered by withdrawal of fluids. It has been found that, as fluid is withdrawn, areas with claylike soils are more likely to undergo shrinkage and consolidation. In the case of Maryland's Lower Eastern Shore, land subsidence is occurring but the cause is probably somewhat different. Drainage and tillage of clayey and organic soils could be reducing the high ground water table and the fluid structure of certain soils. This "drying" out enchances easier compaction of the clayey soil and accelerates the natural process of oxidation (decomposition) of organic material. ${ }^{13}$ The effect of soil shrinkage could be an imperceptible, but real cause of subsidence in some marginal lands on the Eastern Shore.

Farming with heavy equipment may be further compacting the soil and contributing to the "sinking" phenomenon. Soil compaction, measurable in inches, when combined with rising tide levels may accentuate the areal extent of tidal flooding. In effect, the sea is rising while the land is sinking.

\section{Drainage Ditches, Dikes and Tide Gates}

Most land drainage occurs in areas somewhat above the range of tidal influence. Therefore, drainage ditching is not generally responsible for tidal flooding. However, isolated instances of attempts to drain low-lying soils suhject to flooding have been noted and in these instances drainage attempts have facilitated the process of conversion to tidal marsh by allowing tidal surges to flow into areas unencumbered by buffering marsh vegetation or shrub growth.
It should likewise be obvious that lands cultivated under the protection of dikes and tide gates are subject to conversion if dikes and tide gates are not kept in repair. Consequently, any breakdown in protection devices will invite a natural process such as tidal flooding to exert its influence on unprotected, low elevation lands.

\section{Alteration of Lands Fringing Estuaries and Tidal Marshes}

Inland fringe areas of tidal marshes with abundant vegetation and shrubby growth help to protect interior low-lying lands from flooding and possible conversion. It has been estimated that one acre of tidal marsh can "hold" the equivalent of a one foot rise in tide or about 300,000 gallons of water." Without the buffer and tidal flood plain inherent in a tidal marsh, water levels rise higher relative to the elevation of the existing tidal shore.

When salt water encroaches into fresh water plant communities, the fresh water vegetation dies off (depending upon the duration of inundation). The buffering effect of the fresh water vegetation is then lost and tidal action may then penetrate to (and erode) interior lands (soils), causing a gradual change from wood, shrub or cropped lind to marsh.

Bulldozing, burning and timber cutting are often used to destroy vegetation growing on lands bordering estuarine areas. New residents settling the Lower Shore have been responsible for much deliberate "brushing" out of shoreline buffer vegetation with bulldozers to increase their access to and view of the water. Burning of lands is done ostensibly to "improve" their aesthetic value, but, like "brushing" out, promotes the invasion of tidal surges and subsequent conversion to tidal marsh. Elimination of timber can also lead to a rise in the 
groundwater table. The permanent flooding of wet soils can bring on a conversion cycle which eventually leads to establishment of a tidal marsh.

\section{DISCUSSION AND CONCLUSIONS}

Conversion of former low-lying coastal lands into tidal marsh by inundation commencing with tidal flooding is a natural process. As long as sea level rises continue, and land elevations remain constant, there will be no natural reversal of the conversion process. The rate at which conversion takes place is not rapid, but consistent with rising sea level rates (Ch. XII).

Certain areas of the Eastern Shore, particularly Somerset and Dorchester counties are, in fact, experiencing shifts in soil and land types toward marsh lands. However, it is not known whether or not there is a net gain in tidal marsh when taking into account the cumulative wetland loss of 23,700 acres due to natural erosion, dredging, filling and drainage (Ch. IX). Examination of the incidents of wetlands destruction suggests that man and modern technology have the ability to radically alter or destroy wetlands at rates greatly exceeding nature's ability to manufacture replacements.

The remnants of old dikes and drainage works suggest that for those who attempted to cultivate land lying close to the tidal zone it was a constant battle against storms and tides. Rising costs of agricultural production probably outstripped the landowners ability to protect the land they were cultivating which lead to abandoning it to the forces of nature. Especially after the Civil War, an increasing number of families apparently abandoned their homesites.

Based on the limited data available, wood, shrub or idle land compose the largest portion of acreage which has become tidal marsh in recent years. Crop land and homesiles probably incurred smaller losses. However, in the Dames Quarter - Deal Island area of Somerset County, much of what is now tidal marsh was cultivated land with homesites 75-100 years ago.

There are several socio-economic aspects of coastal inundation and conversion of land into tidal marsh, most of which can not be determined easily. Of the soil types most likely to be affected by the conversion process, only a relatively small acreage is capable of supporting crops and recommended for farming or development under Soil Conservation Service land use standards. ${ }^{15}$ Most of the susceptible lands are good only for grazing livestock and harvesting of marsh hay under limited conditions. Combining soil survey reports of these areas produces an estimate of about 54,000 acres susceptible to conversion to tidal marshes. Whether or not this would occur depends on significant trends in natural phenomenon such as rising or falling sea levels.

A shift in land use from agricultural production to tidal marsh has implications to real estate value and derived property tax revenues. For instance, tax revenues are lowest in counties with the greatest potential for such conversion. Assessment policies in Maryland counties distinguish between tillable, wood or timberland, waste and marsh land. Tillable lands are assessed at higher rates than wooded lands, and marshes are assessed at the lowest rates (Ch. VI]I). Therefore, as certain lands in a formerly higher assessment category convert to marshland the property tax revenues will decrease due to a lower assessment ratio on the same land. It should be noted, however, that lower assessment ratios do not necessarily mean a net tax revenue loss to a county. Instead, such a situation, if it should occur, may be compensated for by a larger decrease in public expenditures. Farm abandonment may reduce relatively costlier public services for limited numbers of people dispersed in remote, sparsely settled rural areas.

Land conversion has an impact also on the individual or family that attempts to settle and farm lands subject to tidal flooding and conversion. It is a constant battle to protect such lands against storms and tidal surges. Adding the costs of protection against tidal flooding to those of agricultural production may exceed the landowner's financial abilities. The result will be inevitably the abandonment of the land and consequent economic, sociological and psychological losses to the landowner.

Soil types vulnerable to the conversion process (Elkton and Othello low phases) are not good choices for homesites because soil drainage is poor and septic systems will not function properly. In addition, these soils are not suited for construction of protective dikes, drainge ditches and highways. However, both the Elkton and Othello (low phases) soils are suitable for wildlife and shallow impoundments. While it is true that previously settled land has been and continues to be converted to tidal marsh, it appears that such conversion is toward the best use for this particular kind of soil and land-prime wildlife habitat."

The process by which conversion takes place is not likely to be altered on a broad scale. Throughout the Lower Eastern Shore, landowners will have to accept the fact that tidal flooding encroachments and potential attendant conversion will continue to occur. Homesites and prime crop land will, however, most likely justify selective, intensive protection against tidal flooding.

While the natural forces responsible for conversion 
are beyond man's control, he does have control over activities that are believed to augment or accelerate the process. These activities include the following:

1) withdrawal of fluids from subsurface soils and geological formations which results in land subsidence;

2) farming low-lying areas with heavy equipment that results in compacting formerly loose, underlying soils composed mainly of organic material;

3) brushing out shoreline fringe vegetation including shrubs and trees to facilitate access and improve esthetic values and visibility; and

4) installing surface drainage systems in such a way that they function in reverse, thereby facilitating tidal surges through coastal wetlands into dry but low-lying interior lands.

Adoption and application of certain land management and drainage practices which restrain the rate of tidal encroachment or at least refrain from encouraging it would seem to be advisable. In areas of low elevation relative to sea level, a careful examination should be made of the role of vegetation fringing the shoreline before brushing out operations are undertaken. The location of drainage channels should be evaluated relative to tidal action before installation. Perhaps they should be restricted to higher elevations and exit or discharge into the landward side of tidal marshes. Channeling which leads to or facilitates direct access to large open water should be discouraged if it has the potential to promote tidal flooding of low-lying inland areas.

Where intensive land uses prevail (homesites, businesses, prime agricultural tracts), appropriate dikes and tide gates can effectively hold back encroachment of tidal marsh. However, if continual maintenance is not provided in these areas, diking will not be effective. This is especially true where soils are unstable and where muskrats are common. These animals will burrow into dikes to construct homes and this will eventually destroy the integrity of the protection system.

Tidal encroachment on the Eastern Shore of Maryland presents a challenge to the landowners and public officials to develop an effective system of land use which recognizes the forces of nature, natural suitabilities of soils and pressures of land settlement. As the Lower Eastern Shore becomes more accessible, proper land-use control will become mandatory, if private and public costs due to tidal flooding and encroachment are to be kept to a minimum. A most effective tool for accomplishing this objective is already at hand - the appropriate county U. S. Soil Conservation Service soil survey. It is up to cognizant and responsible citizens and public oflicials to insure that future land use planning and management does not contradict the findings and implications of existent knowledge concerning certain Eastern Shore lands and soils and their interaction with historical natural forces.

I U. S. Soil Conservation Service. Watershed Protection PL-566 - Marumsco Creek Watershed Study. (Preliminary Analysis). U.S.D.A. College Park, Md. April, 1962

2 Ibid.

3 Matthews, Earle D. Soil survey of Dorchester County. Maryland. U.S.D.A. Soil Conservation Service. August, 1963. p. 11.

4 Ibid., p. 18.

5 Op. cit., p. 24.

6 Matthews, Earle D., and Hall, Richard L. Soil survey of Somerset County, Maryland. U.S.D.A. Soil Conservation Servicc. July, 1966. p. 9.

7 Raybold, III, William U. Soil survey of Talbot County, Maryland. U.S.D.A. Soil Conservation Service. December, 1970. p. 5.

8 Ibid.

9 Hall, Richard L. Soil survey of Wicomico County, Maryland. U.S.D.A. Soil Conservation Service. January, 1970. p. 26.

10 Ibid., p. 4.

11 Op. cit..p. 9

12 "Geologic Subsidence," Scientific American, Vol. 216. No. 6, June 1957, pp. 93-100.

$13 \mathrm{lbid}$. This process and consequent land subsidence has occurred in the northern San Joachin Valley, Californiá.

14 Johnson, Peter L. Wetlands preservation. Open Space Institute. New York. 1969.

15 Recent soil survey reports on Maryland Eastern Shore counties (see earlier footnotes).

16 lbid. 


\section{XIV}

\section{LANDS TO WETLANDS}

WETLANDS - THE LEGAL CONTEXT 



\section{WETLANDS AND FLOOD PLAIN STATUTES IN OTHER STATES}

\section{What have other state legislatures done to protect their wetlands?}

This part consists of synopses of the more significant state statutes aimed at protecting wetlands. ${ }^{2}$ Since most of these statutes have been enacted within the past several years, there are few court cases discussing them. A brief summary of those few cases which have arisen under these statutes is included. Comments from state agencies charged with administering a statute are provided in some instances.

\section{CALIFORNIA}

San Francisco Bay Conservation and Development Commission - Senate Bill No. 309, 1965 (McAteerPetris Act) as amended by $\mathrm{Ch} .713,1969$ Regular Sess.

In order to protect the public interest in San Francisco Bay a new regional planning and governmental approach was declared to be necessary. A commission was created consisting of 27 members representing federal and state governments, cities and counties in the San Francisco Bay area and the general public.

A detailed study was called for in order to formulate a comprehensive conservation and development plan to protect the present shoreline and the body of San Francisco Bay to the maximum extent possible. During such period the Commission was empowered to issue and deny permits, after public hearings, for any proposed project that involved placing fill in the bay or extracting submerged materials from the bay. The Commission submitted its final report and policy recommendations in 1969 in accordance with the original Act. ${ }^{3}$ The Act, as amended in 1969, authorizes the Commission to continue in existence and to regulate certain uses of the bay, diked saltponds adjacent to the bay, managed wetlands diked off from the bay, and a shoreline band 100 feet landward and parallel to the bay. Annual reports on Commission activities are due to the Governor and Legislature commencing in 1971.

\section{California Fish and Game Code: Ch. 6, Secs. 1600- 02 (Additional Supp. 1967)}

General plans sufficient to indicate the nature of a project for construction by a government agency or public utility of any project which will divert, obstruct or change the natural flow or bed of any river, stream or lake designated by the Department of Fish and Game, or which will use material from the stream beds designated by the Department, must be submitted to the Department. When an existing fish or game resource may be adversely affected by such construction, the Department will "propose," and the governmental agency or public utility will "consider," any reasonable modifications in the proposed construction for the protection and continuance of the fish or game resource.

Any person who substantially diverts or obstructs the natural flow or substantially changes the bed, channel or bank of any river, stream or lake, or uses any material from the stream beds, must notify the Department of such operations, except when the Department has been notified pursuant to the preceding paragraph. The Department must submit to the person its recommendations as to the measures necessary to protect fish and wildlife.

\section{CONNECTICUT}

Connecticut Generảl Statutes Annotated: Title 25, Ch. 473.

Sec. 25-4a. The Water Resources Commission is empowered to establish along any waterway or flood plain area lines beyond which no obstruction or encroachment may be placed. The Commission may issue or deny permits for establishing such encroachments based upon its findings.

Sec. 25-4e. After the Commission has established such lines on any waterway or flood plain, any obstruction placed within such lines, without the authorization of the Commission may be enjoined or abated as a public nuisance.

Sec. $25-7 d$. No one may place a structure or any obstruction within the tidal, coastal or navigable waters of the State without a permit from the Water Resources Commission. The Commission may impose conditions upon the work.

Sec. 25-7e. Any structure violating the above section may be enjoined or abated as a public nuisance.

Sec. 25-7f. Penalty: fine of \$15-\$50, and/or imprisonment from 10-30 days.

Sec. 25-10. No one may remove sand and gravel from lands under tidal and coastal waters without obtaining a permit from the Water Resources Commission.

\section{Public Act No. 536 - January Session 1967}

The State Board of Fisheries and Game is empowered to do the following: 
1. Acquire wetlands, or any easements, interests or rights therein, by purchase, exchange, condemnation, gift, devise, lease or otherwise.

2. Enter into agreements with owners of wetlands to conserve wetlands.

3. Enter into leases with an option to purchase wetlands, provided:

a. approval of the Commissioners of Agriculture and Natural Resources is obtained, and

b. the lease does not exceed 10 years.

4. Take wetlands by eminent domain.

5. Secure title to wetlands by paying to a municipality the amount of the municipality's tax liens on such wetlands, where the municipality's property tax on such wetlands is unpaid for 6 years.

Messrs. Theodore Bampton and Philip Barske of the Connecticut Board of Fisheries and Game commented on Public Act 536 - An Act concerning the acquisition of wetlands.

Mr. Bampton explained that the Act contains only two new features: first, the Board of Fisheries and Game was empowered to acquire tidal wetlands by exercising the power of eminent domain; second, the Board was authorized to take title to tidal wetlands on which the municipal property tax has been unpaid for six or more years. Plans for the exercise of both of the above options are now being made, but at this time the Board has not yet acquired title to wetlands under the Act. Mr. Bampton believes the act is a big step forward in the preservation of wetlands.

Mr. Barske was much less optimistic about the Act. He believes the Massachusetts wetland acts have a greater potential for saving wetlands. He noted that Connecticut is "pussy-footing" around the issue because of an emphasis on constitutional rights in that State.

\section{Public Act No. 695 of the 1969 General Assembly}

This Act deals with the preservation of wetlands and tidal marsh and estuarine systems. The purpose of the $\mathrm{Act}$ is to preserve the wetland resources of Connecticut by regulating indiscriminate dredging and filling of tidal wetlands. It gives the Commissioner of Agriculture and Natural Resources the power to issue or deny permits for regulated activities such as draining, dredging, excavation, or removal of soil, mud, sand, gravel, aggregate of any kind, or rubbish from any wetland. His authority also covers various kinds of depositional activities on wetlands as well as constructional activities whether or not they change the ebb and flow of tides. Several exceptions are allowed - as by mosquito control and agricultural activities.

The Act defines "wetlands" as those areas which border on or lie beneath tidal waters, such as, but not limited to, banks, bogs, salt marsh, swamps, meadows, flat, or other lowlands subject to tidal actions, including those areas now or formerly connected to tidal waters and whose surlace is at or below an elevation of one foot above local extreme high water and upon which may grow or be capable of growing specific species of plants. The act lists 18 species of vegetation in tidal areas.

The Commissioner is to make an inventory of all wetlands within the state. Following the inventory several procedural arrangements are outlined to carry out the policy intent of the act and ensure the rights of wetland owners.

\section{Public Act No. 138 of the 1971 General Assembly}

This is an act concerning tidal wetlands which amends the 1969 supplement to the general statutes. If, before the inventory maps can be prepared, the Commissioner of Agriculture and Natural Resources finds that an area is in immediate danger of being dispoiled by any activity which would require a permit if such area were designated as wetland and that such area shall probably be so designated when such maps are completed, the Commissioner may designate such area as wetland, provided if such map of such area is not completed within sixty days, such designation shall be void.

\section{DELAWARE}

\section{Delaware Code: Ch. 64, Secs. 6451-6459.}

The Water and Air Resources Commission and the Governor have exclusive jurisdiction to convey a fee simple or lesser interest, to lease or grant permits or easements in or over any parts of the public lands of the State lying beneath the waters of the State, and no use of such lands shall be undertaken except pursuant to a permit or grant.

Each applicant for a lease, permit or grant shall file with the Commission a request containing specifications for any proposed construction.

The Commission shall recommend to the Governor that the application be denied, or be granted on such terms and conditions as the Commission deems just. No lease, permit, deed or grant shall be executed by the Governor unless it conforms to the recommendations of the Commission but the Governor may refuse to 
execute any lease, permit, deed or grant in his sole discretion. The permit or grant shall be executed by the Governor if he so approves.

\section{Coastal Zone Act - Ch. 70 (H. Sub No. 2 for HB No. 300), 1971 General Assembly}

The protection of the environment, natural beauty and recreation potential of the State is of great concern as well as future industrial growth and development. In order to strike a correct balance between the two the Act prohibits entirely the construction of new heavy industry and establishes State level control over the location, extent and type of future industrial development in Delaware's coastal areas through a permit system.

The "coastal zone" is defined as all that area of the State ol Delavare, whether land, water or subaqueous land, between the territorial limits of Delaware in the Delaware River, Delaware Bay and Atlantic Ocean, and a line formed by certain Delaware highways and roads.

The Act will be administered by the State planning Office through a permit system. A State Coastal Zone Industrial Control Board consisting of ten voting members is empowered to hear appeals on decisions of the State Planner and affirm, reverse or modify his decisions on any permit request. Board membership consists of five regular members appointed by the Governor and confirmed by the Senate. The additional five members shall be the Secretary of Natural Resources, the Secretary of Community Affairs and Economic Development, and the Chairmen of the Planning Commissions of each county, who shall be ex-officio voting members. A majority of the total membership of the Board shall be necessary to make a final decision on a permit request.

\section{FLORIDA}

The organic act of greatest significance is the Florida Bulkhead Act of 1957 (Florida Statutes, Section 253.12 et seq.). That Act has been amended significantly in 1967, 1969 and 1970 and is so noted where appropriate in the following sections of the Act quoted or paraphrased here.

Sec. 253.02. The Board of Trustees of the Internal Improvement Trust Fund has the power of eminent domain over submerged lands. The Board shall be a party in eminent domain proceedings involving submerged lands under navigable waters. (Ch. 70-358, Fla. Laws - 1970.)

Sec. 253.12. Vests title in tidal lands in the trustees of the internal improvement trust fund. The trustees may sell such lands, provided that they determine the sale would not adversely affect public interests, including the preservation of fish and other natural resources. Notice of the sale must be published in the county newspaper. If objections are filed to the sale, a public hearing must be held. If it appears as a result of the hearing that the public interest would be adversely affected by the sale, then the trustees must withdraw the land from sale. A biological and an ecological survey of the land to be sold must be made in determining whether the sale of the land would adversely affect the public interest.

Sec. 253.12(1). The Trustees of the Internal Improvement Trust Fund are vested with title to all sovereignty submerged lands, including: (1) all islands, sand bars, shallow banks and small islands made by the dredging of any channel by the United States Government; (2) sand bars and shallow banks located in navigable waters: (3) all coastal and intracoastal waters of the state; and (4) all submerged lands owned by the state by right of its sovereignty in navigable freshwater lakes, rivers and streams, except submerged lands conveyed by prior deed or statute. Submerged land in navigable freshwater lakes, rivers and streams are hereby included within restrictions relating to bulkhead lines and filling and dredging of submerged lands. (Ch. 69-308, Fla. Laws - 1969.)

Sec. 253.122. The Board of County Commissioners ol each county or governing body of any municipality, alter obtaining a biological and an ecological survey, may locate and fix bulkhead lines. Any extension of land outward into the waters of the county is deemed an interlerence with navigation and the conservation of natural resources.

Sec. 253.123. The removal of sand, rock or earth from the navigable waters of the State and the submerged bottoms thereof either channelward or landward of bulkhead lines by dredging, pumping, digging or other means is specifically prohibited for the replenishment of eroded beaches or the prevention or reduction of beach erosion. (Ch. 70-167, Fla. Laws - 1970.)

Sec. 253.124. Anyone desiring to add to existing land bordering on the navigable waters of the State must apply for a permit to do so. A permit will be issued only if a biological and an ecological survey reveal that the public interest will not be adversely affected. The permit may be revoked for non-compliance with its terms. Anyone who violates this section is guilty of a misdemeanor and upon conviction shall be fined a maximum of $\$ 500$, imprisoned for not more than 6 months, or both. The trustees have the authority to require the person to remove the fill.

Also, riparian upland owners bordering navigable 
waters must obtain a permit before rebuilding, replacing, repairing or reconstructing certain coastal structures Coastal structures covered include: seawalls, retaining walls, revetments, bulkheads or similar structures. Permits shall be issued by the authorized local or county body. Permits are subject to the approval of the Board of Trustees of the Internal Improvement Trust Fund and are not valid without such approval. The Act outlines circumstances under which riparian owners may be exempt from submitting biological and ecological studies concerning the effects of their proposed work. (Ch. 70333, Fla. Laws - 1970.)

The Board of Trustees of the Florida Internal Improvement Trust Fund shall in no case issue after-thefact construction permits for the filling of land. Upon consideration of a report from the Department of Natural Resources, however, such a permit may be granted where the Board finds that any other remedy available to it would be more damaging to the environment or marine resources. The granting of such permits shall not absolve applicants from the other subsections herein. (Ch. 70-116, Fla. Laws - 1970.)

Sec. 253.124(1). Relating to the regulation of submerged lands and amending a prior act, this legislation requires that certain conservation reports shall be requested by the Trustees of the Internal Improvement Trust Fund. The Trustees shall request the studies and surveys from the State Board of Conservation within thirty days after the receipt of an application for sale of submerged land, setting of a bulkhead line or a dredge or fill permit. (Ch. 69-337, Fla. Laws - 1969.)

Sec. 253.124(4). Amending and clarifying an existing act, this legislation provides that a fill permit, which shall be issued by the Trustees of the Internal Improvement Fund only if the proposed work is to be completed within three years, shall expire three years after the issuance of the fill permit. Such time may be extended for additional periods of up to three years by the Trustees for good cause, upon a showing that all due elforts and diligence toward completion of the work have been made. Provision is made for revocation of permits for non-compliance or violation of their terms. Judicial review of such revocation is also provided. (Ch. 69-336, Fla. Laws - 1969.)

Zabel v. Pinellas County Water and Nav. Control Authority. 17/ So. 2 d 376 (1965), on remand 179 So. $2 d$ 370 . dealt with sections 253.122 and 253.124. In this case the local authority lost in its attempt to prevent owners of bottom land from filling approximately 11.5 acres of land to be used as a trailer park. The court held that denial of permission to fill the land amounted to a taking of property without just compensation, because it was not established that granting the permit would materially and adversely affect the public interest.

Note: subsequent judicial proceedings have, however, modified substantially, if not in fact reversed, these findings. SEE: Zabel v. Tabb, 430 F. 2d 199 (5th Cir. 1970).

\section{Florida Statutes Annotated: Ch. 375 (Additional Supp. 1966)}

This chapter, entitled "Outdoor Recreation and Conservation," empowers the trustees of the internal improvement trust fund to acquire wetlands and floodways by purchase, lease-purchase agreements, or otherwise, with funds from the land acquisition trust fund.

\section{GEORG1A}

Coastal Marshland Protection Act of 1970 - H. B. 212

The intent of this Act is to balance use of marshland between protection of the environment on the one hand and industrial and commercial development on the other. "Coastal marshlands" means any marshland or salt marsh in the State of Georgia within the estuarine area of the State, whether or not the tide waters reach the littoral areas through natural or artificial water courses. Several plant species common to these areas are listed as well as estuarine areas being defined as all tidally-influenced waters, marshes and marshlands lying within a tideelevation range from five and six-tenths (5.6) feet above mean tide level and below.

The Coastal Marshlands Protection Agency is created as an autonomous division of the State Game and Fish Commission to administer the provisions of this Act. The agency is composed of seven members: Director, State Game and Fish Commission; Executive Director, Ocean Science Center of the Atlantic; Executive Secretary, Water Quality Control Board; Director, Coastal Area Planning and Development Commission; Executive Director, Georgia Ports Authority; and, Director, Department Industry and Trade.

Statutory procedures to administer the Act include: providing public hearings; establishing a permit system; creating an appeals procedure on permit application decisions; providing an enforcement function; and establishing penalties for violations. Certain exceptions to the provisions of the Act are allowed such as maintaining navigable waterways and public highway systems, etc. 


\section{MAINE}

Maine Revised Statutes Annotated: Title 12, Ch. 421, Secs. 4701-4709 (Additional Supp. 1967)

No one may remove, fill, dredge or drain sanitary sewage into, or otherwise alter any swamp, marsh, bog, beach, flat or other wetland bordering coastal waters, or fill, dredge or drain sanitary sewage into such waters within such area, without filing written notice to do so, with plans, to the municipal officers and the Wetlands Control Board. A public hearing is held after receipt of such notice. After the hearing, a permit is issued if the Wetlands Control Board approves. Approval may be conditioned upon the applicant's amending his plans. Approval may be withheld by the municipality or the Board if either body finds the plans damaging to fish life. An appeal is provided for. Anyone violating any provision of this statute is subject to a maximum fine of $\$ 100$. A continuing violation of this statute may be enjoined.

Mr. Richard Parks of Maine's Department of Inland Fisheries and Game commented on Title 12, Chapter 421, of the Maine Revised Statutes Annotated.

He noted that the first individual who was denied a permit to fill a coastal wetland took his case to court, on the ground that the law amounts to a taking of his property without due process of law. Since this case has not yet been decided, Mr. Parks felt that any further comment on the law at this time would be superfluous. Subsequent proceedings in this case found that the denial of a permit to fill coastal wetlands represented a taking of property without constitutional due process and just compensation. The test used by the court in this case was whether compensation by sharing in the benefits which the restriction intended to secure is so disproportionate to their deprivation of reasonable use that such exercise of the State's police power is unreasonable. The ruling was, that, unfilled, the land was of no commercial value to the owners. Maine v. R. B. Johnson and Mabel F. Johnson, Supreme Judicial Court of Maine, No. 860883, May 21, 1970.

Maine Revised Statutes Annotated: Title 30, Ch. 229, Sec. 4001 (Additional Supp. 1967)

Wetlands may be "taken" by a municipality with the consent of the owner and payment of compensation.

Maine Revised Statutes Annotated: Title 30, Ch. 229. Sec. 3801 (Additional Supp. 1967) gifts.

Any municipality may receive wetlands as devises or

\section{MASSACHUSETTS}

Advance Legislative Service to the Annotated Laws of Massa chusetts, Number 10 (1967). 1967 G.L.C. 131, Sec. 40. Protection of Flood Plains.

No person shall remove, fill or dredge any bank, flat, marsh, meadow or swamp bordering on any inland waters without filing notice of his intention to do so, with plans of the proposed activity, with the local authority and with State Departments of Public Works and Natural Resources. A public hearing is provided for. The local authority may recommend protective measures in the public interest, which are submitted to the Commissioner of Natural Resources. If the area where the work is to be done is essential to proper flood control, the Commissioner may impose conditions necessary to protect the public interest, which must be complied with. A continuing violation of this section may be enjoined.

\section{Massachusetts General Laws: Ch. 130, Sec. 105 (Additional Supp. 1966)}

Because of the urgent necessity of protecting coastal wetlands, the Commissioner of Natural Resources was given the power to adopt, amend, modify or repeal orders regulating, restricting or prohibiting dredging, filling, removing or otherwise altering, or polluting coastal wetlands. Violation of the Commissioner's order is punishable by a fine of between $\$ 10$ and $\$ 50$ and/or maximum imprisonment ol one month.

However, if the Commissioner's order so restricts the use of the property as to deprive the owner of its practical use, a court may decree that the order does not apply to that owner's land. In such a case, the Department of Natural Resources may take the land for the State by eminent domain.

Massachusetts General Laws: Ch. 40, Sec. 8c (Additional Supp. 1968)

This section empowers a city or town to acquire by gift, purchase, grant, bequest, devise, lease or otherwise the fee or any lesser interest in wetlands and open spaces. It also empowers a city or town to take land by eminent domain for conservation purposes.

Massachusetts General Laws: Ch. 132A, Sec. 11 (Additional Supp. 1968)

The State may reimburse a city or town up to $50 \%$ of the cost of acquiring land for conservation purposes pursuant to Section $8 \mathrm{c}$ of Chapter 40 of the Massachusetts General Laws (supra). 
Massachusetts General Laws: Ch. 130, Sec. 27A (Additional Supp. 1966)

No person shall remove, fill or dredge any bank, flat, marsh, meadow or swamp bordering on coastal waters without filing written notice of his intention to do so with the local licensing authority, the State Department of Public Works, and the Director of Marine Fisheries. Restrictions may be placed on such work and such work must be done subject to these restrictions. Violation of this section is punishable by a maximum fine of $\$ 100$, imprisonment for not more than 6 months, or both. A continuing violation of this section may be enjoined.

Commissioner of Natural Resources v. S. Volpe \& Co., 206 N.E. 2d 666 (Mass. 1965) held that this section does not authorize an absolute prohibition against the filling in of a privately owned marshland if the result would be that the owner would be so deprived of the practical uses of his land as to amount to a taking of the land without compensation.

Whether there had been such a deprivation of the practical uses of the marshland as to be equivalent to a taking without compensation depended upon the uses to which the marshland could be put without violating the statutory prohibition against the marsh. Since the evidence at trial on this issue was lacking, the injunctive decree of the trial court was reversed and the case was remanded for additional findings on the above issue.

Section 27A of Chapter 130 of the Massachusetts General Laws was also reviewed by the Superior Court (a trial court of general jurisdiction) in the case of Perry v. Director of Marine Fisheries (October 23, 1967). The plaintiff in this case gave proper notice to the State of his intention to fill on the shorefront of his property to a depth of one foot. The defendant refused to allow the plaintiff to continue with his project because the area contained shellfish. The court found for the defendant, holding that the refusal did not amount to a taking by eminent domain. The court based its decision on the fact that the value of the plaintiff's property and its practical uses were not diminished by the defendant's order preventing the plaintiff from completing the work. The only effect of the order was to very slightly inconvenience the plaintiff by forcing him, for swimming, to walk a short distance to the public beach adjacent to his property. Plaintiff's right in his property was held to be subject to the right of the Commonwealth to preserve marine fisheries on such property.

Mr. Russell Cookingham of the Division of Fisheries and Game of Massachusetts commented on the Massachusetts wetlands acts. He was of the opinion that protective acts by themselves are not the entire answer to the problem, but that acquisition programs must also be implemented.

\section{MICHIGAN}

Michigan Compiled Laws Annotated: Sec. 3.651 (1967)

The Great Lakes Commission has the power to recommend policies relating to water resources including the institution and alteration of flood plain and other zoning laws, ordinances and regulations.

\section{Michigan Compiled Laws Annotated: Sec. 281.628}

Any city, township, etc., may acquire any interest in land necessary to any flood control, drainage or beach erosion control project, or to preserve flood plains, by purchase, gift, exchange, condemnation or otherwise. The legislative body of any such city, township, etc., may institute and prosecute proceedings under the power of eminent domain. The purposes of the Act are declared to be public purposes within the meaning of the constitution, relative to the power of eminent domain.

\section{NEW HAMPSH1RE}

New Hampshire Revised Statutes Annotated: Ch. 483-A, Sec. 1-5 (Additional Supp. 1967)

No person shall excavate, remove, fill or dredge any bank, flat, marsh, or swamp in and adjacent to tidal waters without notifying the New Hampshire Port Authority of the intention to do so, together with a detailed plan drawn to scale of the proposed project. A public hearing is provided for. The Port Authority may deny the petition or require conditions to protect fish life or to prevent subsequent fill runoff back into tidal waters.

Anyone violating any provision of the statute is liable for the removal of fill, spoil, or structure placed in violation of the statute and shall be fined not more than $\$ 1,000$. A continuing violation of the statute may be enjoined.

\section{NEW JERSEY}

\section{The Wetlands Act of 1970 - Assembly No. 505}

This is an Act concerning the protection of natural resources in coastal wetlands, providing for the designation by the Commissioner of Environmental Protection of certain coastal wetlands after public hearing, and requiring permits from the Commissioner prior to the 
dredging, removing, filling or otherwise altering or polluting coastal wetlands.

The Commissioner is directed to make an inventory of all tidal wetlands within the State. $\mathrm{He}$ is also empowered to regulate numerous activities affecting coastal wetlands. "Regulated activity" includes but is not limited to draining, dredging, excavation or removal of soil, mud, sand, gravel, aggregate of any kind or depositing or dumping therein any rubbish or similar material, or discharging therein liquid wastes either directly or otherwise, and the erection of structures, driving of pilings, or placing of obstructions, whether or not changing the tidal ebb and flow. "Regulated activity" does not include continuance of commercial production of salt hay or other agricultural crops or the exercise of duties and powers conferred or imposed by law on the State Department of Environmental Protection, the State Mosquito Control Commission, other authorized mosquito control activities, and the State Department of Health.

For the purposes of this Act "coastal wetlands" means any bank, marsh, swamp, meadow, flat or other low land subject to tidal action in numerous, variously described areas of the state. Several species of plants which may grow or are capable of growing on or in coastal wetlands are specified. The term "coastal wetlands" does not include any land or property subject to the jurisdiction of the Hackensack Meadowlands Development Commission granted by prior statutory authority.

Public hearing and appeal procedures on proposed regulations to carry out the intent of this Act are provided for.

\section{NEW YORK}

\section{New York Conservation Law: Sec. 394 (1967)}

This is the Long Island Wetlands Act. It permits the State to enter into cooperative agreements with towns, villages or counties for the purpose of preserving and maintaining wetlands on Long Island which have been dedicated for conservation purposes. The State is empowered to provide one-half of the cost of maintaining such areas.

\section{New York Conservation Law: Secs. 429 a-g (1967)}

These sections require the issuance of a permit by the Water Resources Commission before anyone may alter the waters of the State. The Commission may issue the permit subject to conditions upon which the work must be done. The following activities require a permit: altering the channel of a stream, removing materials from a stream, excavating or filling in navigable waters, erecting an impoundment structure, dock or wharf in or across a natural stream or watercourse. A violation of this statute constituted a misdemeanor, punishable by a maximum fine of $\$ 500$, maximum imprisonment of one year, or both.

New York Public Lands Law: Art. 2, Sec. 3.5 (Additional Supp. 1967)

The Commissioner of General Services may license and regulate the business of taking sand, gravel or other materials in or upon lands under water and may prescribe the terms and conditions under which the same may be taken. After adoption of regulations by the Commissioner, it shall be unlawful to take or remove from lands of the State under water any sand, gravel or other material without a license.

New York Public Lands Law: Art. 6, Secs. $75-78$ (Additional Supp. 1967)

Empowers the Commissioner of General Services to grant lands under water to a county, city, town or village for conservation and other purposes.

\section{OREGON}

\section{Oregon Laws of 1967: Ch. 421, Secs. 109-113}

A state official may not issue a permit for the removal of materials from the beds or banks of any body of water which may be utilized or made available to fish, without first notifying the Fish and Game Commissions of the plans of the operation. The Fish Commission or the Game Commission will advise the state official of possible damage to fish life and they should cooperate to develop a plan to minimize damage. But before giving such advice, the Fish or Game Commission must survey the removal site and determine that the removal will substantially affect fish life.

The state official cannot issue a permit within 15 days of his mailing notice to the commissions, unless either commission has notified him that it has no interest in the removal or that the materials should be removed subject to specified conditions. Fifteen days after the state official has notified the commissions, he may grant a permit, which "may" contain provisions for the preservation of fish life. 


\section{RHODE ISLAND}

General Laws of Rhode lsland: Secs. 2-1-13 to 2-117 (Additional Supp. 1967)

Wetland zoning. Wetland areas are designated and the uses of such areas are restricted to those compatible with fish preservation. Contrary uses may be enjoined.

\section{General Laws of Rhode 1sland: Sec. 11-46.1-1 (Additional Supp. 1967)}

Anyone who dumps or deposits mud, dirt or rubbish upon, or who excavates and disturbs the ecology of intertidal salt marshes, without first obtaining a permit therefor issued by the Department of Natural Resources shall be fined for each offense $\$ 100$ : $\$ 50$ to the State and $\$ 50$ to the complainant. The Director of Natural Resources shall refuse to issue such a permit if in his judgment the dumping or depositing of mud, dirt or rubbish or excavation would disturb the ecology of intertidal salt marshes.

\section{VIRGINIA}

Code of Virginia: Sec. 62-2.1 (Additional Supp. 1966)

With certain exceptions, it shall be unlawful and constitute a misdemeanor for anyone to build, dump, or otherwise trespass or encroach upon or take or use any materials from the beds of the bays, rivers, creeks and the shores of the sea, which are the property of the Commonwealth, without first obtaining authority from the Commission of Fisheries which shall approve or disapprove such request and il approved, shall specify such conditoins, terms and royalties as it deems appropriate.

\section{Code of Virginia: Sec. 15.1 - 486 (Additional Supp. 1966)}

The governing body of any county or municipality may, by ordinance, divide the territory into districts and it may regulate, restrict, permit, prohibit, and determine the use of land buildings, structures and other premises for flood plain (sic) uses.

\section{Wetlands Study - House Joint Resolution No. 60 - 1971 Session}

A commission is created and authorized to make a study and report upon the wetlands of the State. Such study shall include, among other matters, an inventory of the wetland resources, dangers threatening them, and steps the State and local governments can take to preserve the potential of wetlands for present and future generations.

The commission is composed of nine members: three appointed by the Speaker, House of Delegates; three appointed by the President of the Senate; and three appointed by the Governor from the State at large. The study results are to be reported to the Governor and General Assembly by December, 1971. All agencies of the State are directed to assist the commission upon its request.

\section{WASHINGTON}

Revised Code of Washington Annotated: Sec. 75.20.100 (Additional Supp. 1967)

Plans for a project which may divert the flow of water or use materials from beds of water and plans for the protection of fish must be submitted to the Department of Fisheries and the Department of Game. The written approval of both Commissions must be obtained before work is commenced.

The commencement of work prior to such approval, or the failure to comply with the approved plans for the protection of fish life, constitutes a gross misdemeanor.

If a person is convicted of violating this statute and continues the work without complying with its provisions, his work is declared a public nuisance and is subject to abatement as such.

\section{WISCONSIN}

\section{Wisconsin Statutes: Ch. 87, Sec. 87.30 (Additional Supp. 1967)}

If any county, city or village does not adopt a reasonable and effective flood plain zoning ordinance by January 1, 1968, the Department of Resource Development, upon petition or its own motion, may determine the limits of the flood plains within such county, city or village within which serjous damage may occur. The Department will adopt a flood plain zoning ordinance applicable to each county, city or village and such flood plain determination and zoning ordinance shall be of the same effect as if adopted by the county, city or village. The county, city or town may adopt a flood plain ordinance more restrictive than that adopted by the State.

Every structure, building, fill or development placed or maintained within any flood plain in violation of a 
zoning ordinance adopted under this section is a public nuisance which may be enjoined or abated as such. A person who places or maintains any structure, building, fill or development within any flood plain in violation of a zoning ordinance adopted under this section may be fined not more than $\$ 50$ for each offense. Each day during which such violation exists is a separate offense.

\section{Wisconsin Statutes: Sec. 59.971 (Additional Supp. 1967)}

Counties may, by ordinance, zone all shorelands within the following distances from a normal high-water elevation of navigable waters: 1,000 feet from a lake, pond or flowage; 300 feet from a river or stream or to the landward side of the flood plain, whichever distance is greater.

\section{RIGHTS OF RIPARIAN LANDOWNERS IN WATERS OWNED BY THE STATE OF MARYLAND}

The following questions deal with the rights of riparian landowners in waters owned by the State.

\section{A. What waters in Maryland are owned by the State?}

In Maryland, the general rule is that the State is the owner of the land below the high-water mark of navigable waters. Wagner $v$. City of Baltimore, $210 \mathrm{md}$. 615,622 (1955). There are two statutory provisions which modify the general rule.

The first is Section 48 of Article 54 (Chapter 129 of the Acts of 1862). This section provides ". . . no patent shall hereafter issue for land covered by navigable waters." [Note: A patent is any valid grant by the State of its interest in land. Article 54, Section 13.] In the case of Hess v. Muir, $65 \mathrm{Md}$. 586 (1886), the court stated that the only effect of this section was to restrict the powers of the Commissioner of the Land Office.

The second relevant statutory provision is Section 15 of Article 78A, which empowers the Board of Public Works to issue a patent for land under the waters of the State.

Since Section 48 of Article 54 only restricts the power of the Commissioner of the Land Office to issue patents for lands under navigable waters, it does not conflict with Section 15 of Article 78A, giving the Board of Public Works the power to issue patents for lands under navigable waters. Thus, the rule in Maryland is that the State is the owner of all land below the highwater mark of navigable waters, except for such lands for which the State has issued a valid patent.

There still remains the question of what is a navigable water. In most states, water is deemed navigable if it can be used for purposes of commerce or travel. In Maryland, however, navigable waters are defined as those waters which are subject to the ebb and flow of tides. Thus, in Maryland, those waters which are not subject to the ebb and flow of tides are non-navigable. even if they can be used for purposes of commerce or travel. Linthicum v. Shipley, 140 Md. 96, 98 (1922); Wagner v. City of Baltimore, supra.

B. To what extent may a riparian owner in Maryland dredge in waters owned by the State and extend his fastland into waters owned by the State?

Although the State is the owner of all lands below the high-water mark of tidal waters, the Legislature has granted tidewater riparians certain rights in these lands owned by the State.

Section 485 of Article 27 gives riparian owners of lands bordering on navigable rivers, creeks or branches the right to dig, dredge, take and carry away sand, gravel from the beds of such waters below the high-water mark. This section was strictly interpreted in 51 Opinions of the Attorney General 452. The terms "rivers, creeks or branches" were held not to encompass a bay. The words "or other materials" in the phrase "sand, gravel or other materials" were said to include only those grades of submersed soil specially suited for commercial use. Thus this section, as construed by the Attorney General, confers rights only upon riparian owners of lands bordering on navigable rivers, creeks or branches, and the rights conferred are limited to the right to dig, dredge, take and carry away only commercially valuable sand, gravel or similar matter, and not every quality of material in the bed which might be considered suitable fill.

Section 45 of Article 54 gives the proprietor of land bounding on any of the navigable waters of the State the right to all accretions to his land caused by the recession of the water formed or made "by natural causes or otherwise." [5I Opinions of the Attorney General 452] stated that this section does not confer upon a tidewater riparian proprietor a general right to fill in front of his property. The Attorney General pointed out that the doctrine of accretion rests upon an increase by imperceptible degrees through natural causes, and does not apply to land reclaimed by man through filling in land under water. 
Section 46 of Article 54 gives the proprietor of land bounding on any of the navigable waters of the State the right of making improvements into the waters in front of his land, provided such improvements do not interfere with the navigation of the stream of water into which the improvements are made. ${ }^{6} 51$ Opinions of the Attorney General 452 previously cited also construed this section of the Maryland Code. The Attorney General reviewed the legislative history of Section 46, as well as judicial decisions construing the section. He concluded that the right to make improvements into the water granted by this section does not confer upon a tidewater riparian proprietor a general right to fill in front of his property. Rather, Section 46 was interpreted as granting a tidewater riparian owner only the right to fill up small areas in connection with wharfing out for the purpose of improving the riparian's own commercial access to deep water.

Chapters 690 and 757 of the Laws of 1965 also effect the rights of riparian owners in land under navigable waters.

Chapter 690 affects only the shorelines of Worcester County. It allows a person, association, or corporation to construct or reconstruct a bulkhead, change a shoreline, or make a fill along the shorelines, but only with a permit from the Worcester County Shoreline Commission.

Chapter 757 concerns only the Isle of Wight Bay and Assawoman Bay in Worcester County. It allows any person, firm, or corporation to pump, dig, excavate, or remove sand or other solid fill materials within certain areas in the lsle of Wight and Assawoman Bays.

The Attorney General, in his letter of June 7, 1968 , to the Director of the State Planning Department, was of the opinion that no deed is required from the Board of Public Works to permit an owner of land contiguous to the existing shoreline of Assawoman Bay in Worcester County to bulkhead and dredge in compliance with the provisions of Chapters 690 and 757 of the Law's of 1965. The letter next addressed itself to the question of the extent of the owner's title after he has bulkheaded and filled over land which was formerly under the navigable waters of Assawoman Bay. In answer to this question, the Attorney General stated, "We are unwilling to say categorically that after such bulkheading and filling the title of the State is entirely divested in the land which was formerly under navigable waters, but we feel certain that there is no possibility that the State can be divested of its interest in the land under water in any event until the filling within the bulkhead line has been completed to the extent that the navigable waters have been caused to recede." In effect, the question was left unanswered.

\section{EXTENT OF THE POWER OF EMINENT DOMAIN}

The following questions deal with the power of eminent domain.

\section{A. What are the constitutional limitations on the exercise of the power of eminent domain?}

The Fifth Amendment of the United States Constitution provides in part: ". . . (N) or shall private property be taken for public use without just compensation." The Fifth Amendment restraint on the power of eminent domain is deemed incorporated by the due process clause of the Fourteenth Amendment of the United States Constitution, and is therefore a limitation on state action, as well as action by the federal government. See Chicago, $B \& O R$. R. Co. v. Chicago, 166 U.S. 226 (1897), in which it was held that the taking of private property by the state or its agency for a public use without the payment of compensation violates the due process clause of the Fourteenth Amendment.

The concept of public use is broad and includes moral, social. economic, physical, aesthetic, and political wellbeing of the community, Berman v. Parker, 348 U.S. 26 (1954).

A formal condemnation of property by the government is obviously a "taking" thereof. However, a taking may also occur when some governmental act causes such a direct and immediate interference with the use or value of the property as to constitute a "taking" thereof.

\section{B. May a state condemn land for aesthetic purposes?}

There are no Maryland cases on the question of whether the State may condemn lands for aesthetic purposes. However, courts in other states have answered this question affirmatively.

In Merced Dredging Co. v. Merced County, 67 F. Supp. 598 (D. C. Cal. 1946), the court stated at page 607: "If the public desires to preserve the scenic or historical features of privately-owned land, the power of eminent domain is available to satisfy the public desire, and the constitutional requirement of just compensation secures the private interests of the owner."

And in Kamrowskiv. State, 31 Wisc. 2d 256, 142 N. WV. 2d 793 (1966), landowners brought an action against the State of Wisconsin to contest the right of the State Highway Commission to condemn scenic easements on lands between a highway and the Mississippi River. The 
Supreme Court of Wisconsin held that scenic easements could constitutionally be taken from landowners by the state, where just compensation was determined and paid.

It should be noted that although the Maryland Court of Appeals has not passed upon the question of condemnation of land for aesthetic purposes, the Maryland Legislature has given its approval to such takings. Sections 236, 237 and 238 of Article 89B of the Maryland Code authorize the State Roads Commission to acquire by condemnation strips of land for the enhancement of the scenic beauty of the State. The State Roads Commission, pursuant to these sections, is now in the process of acquiring in excess of one million dollars worth of "scenic lands."

C. May a state condemn land for natural resource purposes?

Again, there are no Maryland cases on the question of whether the State may condemn lands for the purpose of protecting natural resources. However, courts in other states have answered this question affirmatively.

In Pearl River Valley Water Supply District v. Brown, 156 So. 2d 572 (Miss. Sup. Ct. 1963), the court stated that land was taken for a public purpose where it was condemned for pollution control and use as a wildlife sanctuary, as well as for other purposes.

And in State, Department of Water Resources $v$. Natomas Co., 49 Cal. Rptr. 64, 239 C. A. 2d 547 (1966) the trial court's statement that the taking of land for fish and wildlife enhancement was a public use which justified the State's condemnation of the land, was cited with approval on appeal.

D. What is the measure of damages where land is taken for a public purpose?

In Maryland, as in the other states, the general measure of damages in cases where land is taken for a public purpose is the fair market value of the land at the time of the taking. State Roads Commission v. Warriner, 211 Md. 480 (1957). With respect to the amount of the award, each condemnation proceeding must be judged by its own peculiar facts and circumstances. C. J. S. Eminent Domain, Sec. 156.

\section{STATE'S POWER TO REGULATE THE USE OF LAND THROUGH THE POLICE POWER}

A. Under what circumstances and to what extent may a state be held liable in damages for a restrictive land use policy?

A state's power to restrict the use of privately owned land is an aspect of its police power. Under its police power a state may reasonably restrict the use of an individual's property without payment of compensation to the owner only for the promotion of the health, safety, morals, or general welfare of the community. However, a restriction on the use of private land by a state may be unconstitutional even though the purpose of the restriction is to promote the health, safety, morals, or general welfare of the community. The reason for this is that a state's police power is limited by the constitutional provision that private property may be taken by a state only for a public purpose upon payment of just compensation to the property owner. Thus, if the regulation of the use of property is deemed too restrictive by the court, the regulation will be recognized as a "taking" for which the state must pay just compensation to the property owner. The problem is to determine when the regulations under the police power place such limitations on the use of the property that the enforcement of the regulation amounts, in effect, to a practical confiscation of the land. If the regulation is too restrictive, it will be declared unconstitutional because it authorizes the taking of private land for a public purpose without payment of just compensation to the property owner. If the state still desires to regulate the use of the land, it may take the land by eminent domain, paying just compensation, or it may enact less restrictive regulations.

Land use restrictions may take many forms. Whether valid exercise of the police power for which compensation need not be made often depends upon the facts of the particular case. The following cases are pertinent to the wetlands problem and shed some light on the question of how far a state may go in restricting the use of private land before it will be required to pay compensation to the owner.

The first case to be considered is Morris County Land Improvement Co. v. Township of Parsippany Troy Hills, 40 N. J. 539, 193 A. 2d 232 (1963). The plaintiff owned 66 acres of swampland which consisted of three layers of materials. The top two layers were very unstable. The bottom layer was composed of sand and gravel and was, on the average, seven or eight feet beneath the surface. The two top layers would not bear structures, were unsuitable for fill and would have to be removed and the land filled with proper material before it could be used for any active purpose, except possibly the raising of fish or the growing of aquatic plants.

In March 1960, the defendant-township enacted a "Meadows Development Zone" classification. The regulations permitted the following uses as agricultural uses: raising of woody or herbaceous plants, commercial greenhouses, raising of aquatic plants, fish and fish food (with a one-family dwelling as an adjunct to any of these 
uses, provided its lowest floor was a specified distance above flood level); outdoor recreational uses operated by a governmental division or agency; conservation uses "including drainage control, forestry, wildlife sanctuaries and facilities for making same available and useful to the public:" hunting and fishing preserves; public utility transmission lines and substations; radio or television transmitting stations and antenna towers; and township sewage treatment plants and water supply facilities.

The section went on to provide for uses which may be permitted as special exceptions. A special exception was required for any permitted use which involved a change in any drainage ditch, for the removal of earth products, such as gravel, sand, fill-dirt and peat, and for the diking, damming or filling of any land within the zone.

In August 1960, the plaintiff applied for a special exception in order to fill its lands, to excavate for an 18 acre reservoir, and to use the material taken therefrom to supply the fill. The application was denied in January 1961, and the plaintiff filed suit against the township.

The Supreme Court held that the township zoning ordinance constituted a taking of land for a public purpose without just compensation and was therefore unconstitutional.

The Court stated that the prime objective of the zone regulations was to retain the land substantially in its natural state. It pointed out that the character of the surface soil was such that it was unsuited for any of the permitted active uses, except possibly the raising of fish and aquatic plants. The Court found it significant that, apart from the matter of having to obtain permission subject to exceedingly difficult conditions, the regulations absolutely prohibitied not only removal of the usable top two layers of earth from the zone, but also forbid the importation from outside the zone of suitable fill material. In addition, the Court noted that many of the permitted uses in the zone were public or quasi-public in nature, rather than of the type available to the ordinary private landowner as a reasonable means of obtaining a return from his property.

In Dooley v. Town Plan and Zoning Commission. I51 Conn. 304, 197 A. 2d 770 (1964), the defendant, the Town Plan and Zoning Commission of the Town of Fairfield, changed the zonal classification of an area of about 400 acres from a residential to a flood plain district. The plaintiff owned land within the area covered by this change of zone.

In the new flood plain district only the following uses were permitted:

1. Parks, playgrounds, marinas, boat houses, landings and docks, clubhouses and accessory uses.
2. Wildlife sanctuaries operated by governmental units or non-profit organizations.

3. Farming, truck and nursery gardening.

4. Motor vehicle parking as an accessory to a permitted use in this district or an adjacent district.

The zoning regulations also forbade the excavation, filling and removal of soil, earth or gravel within the flood plain district except under a special exception.

The plaintiff brought suit, claiming that the application of the regulations to his property constituted the taking of property without compensation and without due process of law in violation of the fifth and fourteenth amendments of the Constitution of the United States and in violation of the Connecticut Constitution.

The court agreed with the plaintiff's contention and held that the zoning regulations were unreasonable and confiscatory. The court gave five main reasons for its decision.

First - To restrict the use of privately owned property to parks and playgrounds bars the development of the land for residential or business purposes. The practical effect of this limitation or use is to restrict potential buyers of the property to town or governmental uses, thus depreciating the value of the property.

Second - The plaintiffs property was about half a mile from Long Island Sound, and consequently could not be used for a marina, boathouse or landing and dock.

Third - The regulations permit the use of the property for wildlife sanctuaries operated by governmental units or non-profit organizations. Such a use does not provide the landowner with any reasonable or practical means of obtaining income or a return from his property.

Fourth - The regulations also permit farming, truck and nursery gardening. But a real estate expert testified that farming had long been ruled out of the area.

Fifth - The regulations also permit motor vehicle parking as an accessory to be a permitted use in the flood plain district or an adjacent district. However, the court pointed out that the land could not be filled or paved except by special exception granted by the defendant under stringent conditions, and then only for a limited time.

The court concluded that for all practical purposes the zoning regulation rendered the use of the plaintiff's land impossible.

The final case to be considered is Commissioner of Nalural Resources v. S. Volpe and Co., 206 N. E. 2d 666 (Mass. 1965). In this case the defendant purchased approximately 50 acres of marshland adjacent to the coastal waters of Wareham, Massachusetts, in 1960. In 
1963, sec. 27A of Chapter I30 of the Massachusetts General Laws was enacted. Sec. $27 \mathrm{~A}$ provided in part: "No person shall remove, fill or dredge any bank, flat, marsh, meadow or swamp bordering on coastal waters without written notice of his intention to so remove, fill or dredge to the board of selectment in a town ...., to the State Department of Public Works, and to the Director of Marine Fisheries... The selectmen .. shall hold a hearing on said proposal . . If the area on which the proposed work is to be done contains shellfish or is necessary to protect marine fisheries, the said Director may impose such conditions on said proposed work as he may determine necessary to protect such shellfish or marine fisheries, and work shall be done subject thereto... The Superior Court shall have jurisdiction in equity to restrain a continuing violation of this section . . .

In October 1963, the defendant notified the appropriate authorities of his intention to dredge a channel through the marsh as part of a project to fill the marsh for the construction of houses. After a hearing the Director of Marine Fisheries notified the defendant that "in the interest of protecting marine fisheries and maintaining the ecological components of this estuarine complex . . . no fill of any type (may) be placed on the area known as Broad Marsh."

When the defendant ignored the Director's order, the Commissioner of Natural Resources and the Director of Marine Fisheries successfully brought a bill in equity to enjoin violation of the Commissioner's order and to require the removal of all fill placed on the marsh in violation of the order.

The defendant appealed this decision to the Supreme Judicial Court of Massachusetts. The court pointed out that the question presented by this case is analogous to that which arises when the validity of a zoning ordinance is considered (as was the situation in the two cases previously discussed). The court stated that the protection of marine fisheries was clearly a public purpose for which the use of private property may be regulated by the State. The court phrased the issue as "whether, notwithstanding the meritorious character of the regulation, there has been such a deprivation of the practical uses of a landowner's property as to be the equivalent of a taking without compensition."

Since the trial judge had made insufficient findings on this issue, the case was remanded to the trial court for the taking of further evidence and for further findings on the issue. The court suggested that there be evidence and findings on the uses which can be made of the land in its natural state and the present fair market value of the land, subject to the limitations imposed by the
Commissioner and without such limitations, as well as other matters.

\section{B. May a state control the use of land for aesthetic purposes?}

Since 1926 when the United States Supreme Court first upheld a comprehensive zoning ordinance in Village of Euclid : Ambler Really Co., 272 U. S. 365 (1926), there has been no doubt that the police power of a State could consitutionally be utilized to restrict the use of an individual's property for the benefit of the community in general. There are four universally accepted purposes that justify any use of the police power: the promotion of the health, safety, morals, and general welfare of the community.

Subsequent to this decision zoning ordinances were enacted in many states which sought to regulate the use of private property for purely aesthetic reasons. The issue presented in these cases was whether zoning for purely aesthetic purposes constituted an exercise of the police power for the promotion of the "general welfare" of the community. The position taken in the earlier cases, which is still the view in the vast majority of states today, is that zoning for purely aesthetic purposes does not constitute a valid exercise of the police power. However, a zoning ordinance which tends to promote an aesthetic purpose will be upheld if the ordinance also serves to promote the public health, salety, or welfare.

States taking this position include: California, Delaware, Illinois, Iowa, Louisiana, Massachusetts, Michigan, Minnesota, Mississippi, Missouri, Nebraska, New Hampshire, New Jersey, North Carolina, Ohio, Pennsylvania, Tennessee, Texas, Virginia, Washington, and Wisconsin.

In many of these states, zoning ordinances which tend to promote aesthetic purposes are upheld where they have the effect of protecting property values in the community. The protection of property values in the community is considered to be a matter of public welfare. And in Florida, Louisiana, Massachusetts and New Hampshire zoning ordinances based on aesthetic considerations have been upheld where the ordinances have had the effect of promoting tourism.

To date, only two states have held that zoning for purely aesthetic purposes may constitute a valid exercise of the police power.

The first state to adopt this view was New York, in the case of People v. Stover, 12 N. Y. 2d 462, 19l N. E. 2d 272, 240 N. Y. S. 2d 734 (I963). This case concerned an ordinance prohibiting the maintenance of clotheslines in a front or a side yard abutting a street. The court did not base its decision on the protection of property values. 
The court stated: "Consequently, whether such a statute or ordinance should be voided should depend upon whether the restriction was an arbitrary and irrational method of achieving an attractive, efficiently functioning, prosperous community - and not upon whether the objectives were primarily aesthetic."

In 1965, the Oregon Supreme Court, in Oregon City v. Hartke, 400 P. 2d 255 (Ore. 1965) upheld an ordinance that totally excluded automobile wrecking yards from the city. The court stated: "It must be conceded that authority for the validity of zoning for aesthetic purposes only is scant. People v. Stover . . . is most directly in point with the instant case. We join in the view that aesthetic considerations alone may warrant an exercise of the police power."

The Maryland Court of Appeals has made no mention of the validity of zoning for aesthetic purposes. However, mention should be made of Sections 38 to 50 of Article 66 B of the Maryland Code. These sections are grouped under the heading of "Historic Area Zoning." These sections enable the counties of Maryland and Baltimore City, by ordinance or regulation, to regulate the construction, alteration, repair, moving, and demolition of structures of historic and architectural value within their respective limits. Each county and Baltimore City are allowed to establish districts which are deemed to be of historic or architectural value and may create "historic district commissions." Anyone desiring to alter the exterior appearance of a structure of historic or architectural value must file an application to do so with the commission. In reviewing the plans for any such change, the commission may give consideration to, among other things, "any other factors including aesthetic factors which the commission deems to be pertinent."

C. What legislative action have the counties of Maryland taken in order to protect their natural resources?

A survey of the codes of the counties of Maryland revealed that little is being done legislatively by the counties for the protection of their wetlands. Only three of the eighteen Maryland counties whose codes were surveyed (the Codes of Carroll, Queen Anne's, Somerset, Talbot and Worcester Counties were unavailable) contained provisions which seemed pertinent. Summaries of these provisions follow.

\section{Frederick County Code, Sections 40-57 to 40-63}

These sections establish a conservation district within the County zoning scheme. The uses of land are restricted to those consistent with conservation purposes. These sections provide in part that only those mines, quarries and pits which are worked in such a manner as not to impede the natural flow of any stream or pollute its waters are allowed in a conservation district.

\section{Howard County Code, Section 205}

This section creates a Board of Parks, which is empowered to acquire rights in real and personal property for watershed conservation and for the preservation of open spaces and areas for public recreation and enjoyment.

\section{Montgomery County Code - Section 79-31}

This section provides that no building permit shall be issued for any structure or alteration of an existing structure on land which lies within the fifty-year flood plain of any stream or drainage course, with the exception that a building permit may be issued for fences, public utilities, recreation and agricultural uses on such lands.

\section{Section 104-21}

This section permits the Montgomery County Planning Board to restrict subdivision for development of any property which lies within the fifty-year flood plain of any stream or drainage course, when it deems it necessary to do so for the health, safety, comfort or welfare of the present and future population of the regional district and necessary to the conservation of water, drainage and sanitary facilities.

\section{Prince George's County Code}

Refer to the discussion under Prince George's County in Chapter VI.

\section{LEGAL APPROACHES \\ AVAILABLE TO MARYLAND FOR THE PROTECTION OF THE STATE'S WETLANDS}

What are the legal approaches available to the Maryland Legislature for the protection of the State's wetlands?

A. Eminent Domain

Several states have enacted statutes which specifically enable municipalities or state agencies to 
acquire title to wetlands through the exercise of the power of eminent domain. Since just compensation must be paid to the owner whenever land is taken by eminent domain, this approach may be utilized only to the extent that funds may be provided for the reimbursement of those owners whose land is to be taken. A state's power to take land by eminent domain is a well-recognized legal right; authorizing the taking of wetlands by eminent domain is certainly one approach available to the Maryland Legislature.

\section{B. Acquisition}

A number of state statutes empower municipalities or state agencies to acquire the fee, or lesser interests, in wetlands. Acquisition by any legally recognized means is usually authorized. Again, unless the acquisition is accomplished by some form of gift, considerable problems of expense may arise.

Maryland has enacted a statute which may authorize the acquisition of wetlands. Section 357A of Article 66C of the Maryland Code empowers any city or county, the Maryland-National Capital Park and Planning Commission and the State Department of Forests and Parks to acquire the fee, or any lesser interest, in "open spaces." The definition of "open spaces" includes areas whose natural condition, if retained, would maintain or enhance the conservation of natural resources. It seems that this definition would include wetland areas.

\section{Police Power}

Under its police power, a state may regulate the use of its wetlands in any way it sees fit, as long as the means chosen are reasonably calculated to achieve the desired result (i. e., the preservation of wetlands) and as long as the regulation is not so restrictive as to deprive the owner of all reasonable use of his land. As long as the restriction does not amount to a practical confiscation of the land, the state will not be required to compensate the landowner for the limitations placed upon the use of his land.

Statutes regulating dredging and filling in wetland areas are the most common type of police power regulation of wetland uses. Such an approach would not conflict with existing Maryland law.

\section{Flood Plain Zoning Ordinances}

Wetlands situated in flood plains may be preserved by means of flood plain zoning ordinances. Wisconsin enacted a statute which provided that if any county, city or town did not enact a reasonable and effective flood plain zoning ordinance by January 1, 1968, a state agency would have the power to adopt such an ordinance applicable to the county, city or village. This approach could be used by the Maryland Legislature to ensure that each Maryland county has a flood plain zoning ordinance which would serve to preserve wetlands located in flood plains.

I In March of 1968, I was asked by the Maryland State Planning Department to provide answers to legal questions which had arisen in connection with a study of Maryland's wetlands in which the Department was engaged. My job was simply to report the law as it existed; I was not called upon to recommend any particular legislative approach to wetlands preservation.

This report represents the efforts of a third year student at the University of Maryland School of Law over a period of four and one-half months. The questions presented to me and my response thereto follow. Dennis J. Dimsey, July 31, 1968.

2 Since Mr. Dimsey completed his work several states have enacted significant legislation pertaining to wetlands and other coastal zone resources. As aviliable, summaries of these statutes are included by the writer in order to provide updated information.

3 San Francisco Bay Conservation and Development Commission. San Francisco Bay Plan. January, 1969.

4 Repealed by Chapter 241 Laws of Maryland 1970 , and the general context of said section incorporated into new Sections 718 through 731, inclusively, to Article 66C (Natural Resources) of the Annotated Code of Maryland (1970 Replacement Volume).

5 Ibid.

6 Op. cit 



\title{
BIBLIOGRAPHY
}

To facilitate identifying study reference sources and documents this bibliography is subdivided into the following classifications:

\author{
Bibliographies \\ Ecology and biology \\ Soil Surveys \\ Planning reports \\ General
}

Note: $\quad$ Reference items which were especially valuable to this report are prefaced with an asterisk (*).

\section{BIBLIOGRAPHIES}

Crook, Charles B. Drainage of agricultural land: an annotated bibliography of selected references $1956-1964$. Nat'1. Agricultural Library, U.S.D.A. Library List No. 91. Washington. 1968. 524 p.

Ditsworth, George R. Environmental factors in coastal and estuarine waters. Bibliography series - vol. 1. Coat of Oregon. FWPCA Pub. WP-20-2. 1966.61 p.

*Ecological Society of America. Ecology: thirty year index (Vols. 1-30, 1920-1949). Duke University Press, Durham, N.C. 1952.212 p.

Fisher, Leo J. An annotated bibliography of flushing and dispersion in tidal waters. U.S. Navy Hydrographic Office Spec. Pub. 33. Washington. 1960. 34 p.

Hull, C.H.J. Bibliography of Maryland water resources data. Maryland Department of State Planning. Baltimore. 1952. 25 p. (mimeo).

* Livingston, Robert Jr. A preliminary bibliography with KWIC index on the ecology of estuaries and coastal areas of the eastern United States. USD1, Fish and Wildlife Service, Spec. Sci. Rept. - Fisheries No. 507. USGPO: Washington. 1965. $352 \mathrm{p}$.

*Mansueti, Romeo. Maryland natural resources bibliography. Md. Dept. of Research \& Education, Resource Study Rept. No. 7., Chesapeake Biological Lab., Solomons, Md. 1955. 27 p.

*Sherk, J. Albert, Jr. and L. Eugene Cronin. The effects of suspended and deposited sediments on estuarine organisms. An annotated bibliography of selected references. U.S. Army Corps of Engineers. Washington, D.C. April, 1970.

Stewart, R. Keith, W.M. Ingram and K.M. Mackenthun. Water pollution control - waste treatment and water treatment: selected biological references on fresh and marine waters. USDI. FWPCA Rept. No. WP-23, 1966. $126 \mathrm{p}$.

*Virginia Institute of Marine Sciences. Bibliography of the physical, chemical, and geological oceanography of Chesapeake Bay. Special Sci. Rept. No. 34. Gloucester Point. 1962. 43 p.

*Water Resources Research, Office of. Selected water resources abstracts. Water Resources Scientific Information Center. USDI. Clearinghouse, Springfield, Va.

\section{ECOLOGY AND BIOLOGY}

Amos, W.H. The life of the seashore. McGraw-Hill, New York. 1966. 232 p.

Bourn, Warren S., and Clarence Cottam. Some biological effects of ditching tidewater marshes. USDl. Fish and Wildlife Service, Research Report 19. USGPO: Washington. 1950. 33 p. and maps.

*Chapman, V.J. Salt marshes and salt deserts of the world. Intersciences Publishers, 1nc. New York. 1960.392 p.

*Coker, Robert E. Streams, lakes, ponds. Univ. of North Carolina Press. Chapel Hill. 1954. 327 p.

Cooper, Arthur W. Productivity of salt marshes, (In). Salt marsh vegetation of the South Atlantic Coast. Paper presented in symposium on Current Research on Vegetation of the Southeastern States at AAAS meetings, Washington, D.C. December 29, 1966. pp. 13-21. 
Copeland, B.J. Effects of decreased river flow on estuarine ecology.J. Water Pollution Control Fed. November, 1966. pp. 1831-1839.

${ }^{*}$ Cronin, L. Eugene, et al. Effects of engineering activities on coastal ecology (interim report). Corps of Engineers, Office of the Chief of Engineers, U.S. Army September, 1969.40 p.

Daiber, Franklin C., R. J. Reimold, and D. Aurand. Tide marsh ecology and wildlife. Pittman-Robertson Project W-22-R-2, Annual Report. Dept. Biological Science, Univ. of Delaware, Newark. 1966-1967. 38 p.

Douglas, Philip A., and Richard H. Stroud. A symposium on the biological significance of estuaries. Sport Fishing lnstitute, Washington, D.C. Marsh, 1971.111 p.

Hollis, Edgar H., Fishery resources of the Patuxent River system, In Appendices, The Patuxent River, Maryland's asset, Maryland's responsibility. Governor's Patuxent River Watershed Advisory Committee. Md. Dept. of State Planning. Pub. no. 149a. July, 1968. Various paging.

*Hollis, Edgar H., et. al. A literature review of the effects of turbidity and siltation on aquatic life. Dept. of Chesapeake Bay Affairs. Staff report. Annapolis, Md. December, 1964 (mimeo). 20 p. and biblio.

*Kerwin, James A., and Robert A. Pedigo. Synecology of a Virginia salt marsh. VIMS Contribution no. 397 , Chesapeake Sci., v. 12 (3): 125-130. September, 1971.

Kurz, H., and K. Wagner. Tidal marshes of the Gulf and Atlantic Coasts of northern Florida and Charleston, South Carolina. Florida State Univ. Studies No. 24. 1957.

Mackenthun, Kenneth M. and W.M. Ingram. Biological associated problems in freshwater environments: their identification, investigation and control. USDI, FWPCA. USGPO: Washington. 1967.287 p.

Manning, Joseph H. Bay fisheries resources. (In) Proceedings: Governor's Conference on Chesapeake Bay, Wye Institute, Maryland. September 12-13, 1968. pp. 91-101.

Mansueti, Romeo. A brief natural history of the Pocomoke River, Maryland. Md. Dept. Research and Education. Ches. Biol. Lab., Solomons, 1953.9 p.

"The Cranesville Pine Swamp," Atlantic Naturalist, v. 13, n. 2. Audubon Naturalist Society of the Central Atlantic States, lnc., Washington, D.C. A pril-June, 1958.

Martin, A.C., and F.M. Uhler. Food of game ducks in the United States and Canada. USDA, Tech. Bull. No. 634. 1939.

Food of game ducks in the United States. Research Report 30. USGPO: Washington. 1951.

*McAlee, W.L. Wildlife of the Atlantic Coast salt marshes. USD1, Fish and Wildlife Service, Wildlife Circ. 11, USGPO: Washington. 1941. (Rev. of USDA Circ. no. 520, March, 1930). 32 p.

McHugh, J.L. Fisheries of Chesapeake Bay. (In) Proceedings: Governor's Conference on Chesapeake Bay, Wye Institute, Maryland. September 12-13, 1968. pp. 135-160.

Mihursky, Joseph A. Summary report on environmental conditions of the tidal Patuxent River. (In) Appendices,

The Patuxent River Maryland's Asset, Maryland's Responsibility. Governor's Patuxent River Watershed Advisory Committee. Md. State Planning Dept. Pub. No. 149a. Baltimore, Maryland. July, 1968.

*Nicholson, W.R., and R.D. Van Deusen. Marshes of Maryland. Dept. of Research and Education, Resource Study Rept. No. 6, Solomons, Md. December, 1954. 8 p. \& maps.

* W_. Wetlands of Maryland. Pittman-Robertson Project No. W-30-R. Md. Game and lnland Fish Commission. Baltimore, Md. 1956. 10 p. \& tables \& maps.

*Niering, William A. The life of the marsh. McGraw-Hill Book Company, New York. 1966. 232 p.

*Newsom, John D. (ed.). Proceedings: Marsh and estuary management symposium. July 19-20, 1967. LSU Div.

Continuing Educa., Baton Rouge, La. 1968.250 p.

North Carolina, University of. Proceedings: Symposium on estuarine ecology-coastal waters of North Carolina.

Water Resources Research Institute, Raleigh. 1966. 111 p.

*Odum, Eugene P. Fundamentals of ecology. 2d. ed., W.R. Saunders Co., Phila., Pa. 1959. 546 p.

*__. The role of tidal marshes in estuarine production. Information leaflet, N.Y. State Conservation

Dept., Div. Cons. Ed., from N.Y. State Conservationist, (reprint). n.d.

*

The theory of the estuarine ecosystem in relation to use, management and pollution. Statement

made at field hearings at Jekyll Island, Georgia, in connection with the National Estuarine Pollution Study.

February 29, 1968. 
Oosting, H.J. Ecological processes and vegetation of the maritime strand in the southeastern United States. Bot. Rev. 1954. 20:226-262.

Phillip, Charles C., and R.G. Brown. 1956. Ecological studies of transition zone vascular plants in South River, Maryland. Chesapeake Science. 1956 6(3): 73-81.

* Reid, George K. Ecology of inland waters and estuaries. Reinhold Publ. Corp. New York. 1961.375 p.

Reid, George K. Ecology of intertidal zones. Rand McNally. Chicago. 1967.85 p.

*Schuster, Carl N. The nature of a tidal marsh. Information leaflet, N.Y. State Conservation Dept., Div. Conservation Ed., from The N.Y. State Conservationist, Aug.-Sept., 1966. 8 p.

Segar, Martha B. An ecological s.rvey of the Potomac and Anacostia Rivers with special emphasis on pollution. Ph. D. dissertation. The Catholic University of America. Washington, D.C. June, 1959.

*Shaw, Samuel P., and C.G. Fredine. Wetlands of the United States, their extent and their value to waterfowl and other wildlife. USDI, ORBS, Fish and Wildlife Service, Circ. No. 39. USGPO: Washington. 1956.67 p.

Smith, Roland F. Competition for aquatic environment. Commerical Fisheries Review. v. 30, n. 5, May, 1968 : 27-29.

*Smith, Roland F. et. al. (eds.). Symposium on estuarine fisheries, Amer. Fish. Soc. Spec. Pub. no. 3. Allen Press, Inc. Lawrence, Kansas. 1966. 1954 p.

Stewart, Robert E. Waterfowl populations in the upper Chesapeake region. USDI. BSF\&W. Spec. Sci. Rept. Wildlife No. 65. USGPO: Washington, July, 1962. 208 p.

Stross, R.G., and J.R. Stottlemeyer. Primary production in the Patuxent River, Chesapeake Science, 6(3): 125-140.

Taylor, N. Salt tolerance of Long Island salt marsh plants. New York State Museum, N.Y. Circ. 23. Albany. 1939.

Teal, J.M. Energy flow in the salt marsh ecosystem of Georgia. Ecology. 1962. 43:614-624.

Uhler, Francis M., and Neil Hotchkiss. "Vegetation and its succession in marshes and estuaries along the South Atlantic and Gulf Coasts." (In) Proceedings, Marsh and Estuary Mangement Symposium, July 19-20, 1967. LSU. Baton Rouge. 1968. pp. 26-32.

*Wass, Marvin L., and T.D. Wright. Coastal wetlands of Virginia: interim report. Spec. Rept. no. 10. Va. Inst. Marine Sciences, Gloucester Point, Va. December, 1969. 154 p.

*Wharton, Charles H. The Southern River swamp - a multiple-use environment. Bur. Business and Economic Research, School Business Administration, Ga. State Univ., Atlanta. May, 1970. 48 p.

\section{SOIL SURVEYS}

Hall, Richard L. Soil survey of Wicomico County, Maryland. USDA, SCS, USGPO: Washington. January, 1970. 90 p. + maps.

Kirby, Robert M., Earle D. Matthews, and M.A. Bailey. Soil survey of Prince George's County, Maryland. USDA, SCS, USGPO: Washington. April, 1967. 170 p. + maps.

Mat thews, Earle D. Soil survey of Dorchester County, Maryland. USDA, SCS, USGPO: Washington. August, 1963,66 p. + maps.

maps. Soil survey of Calvert County, Maryland. USDA, SCS, USGPO: Washington. July, 1971. 76 p. + Soil survey of Caroline County, Maryland. USDA, SCS, USGPO: Washington. January, 1964. 53 p. + maps.

Matthews, Earle D., and Richard L. Hall. Soil survey of Somerset County, Maryland. USDA, SCS, USGPO: Washington. July, 1966. 90 p. + maps.

Matthews, Earle D., and William U. Reybold, III. Soil survey of Queen Anne's County, Maryland. USDA, SCS, USGPO: Washington. September, 1966. 117 p. + maps.

Perkins, S.O., and S.R. Bacon. Soil survey of Prince George's County, Maryland. USDA, Bur. Chemistry and Soils, Series 1925, no. 30, USGPO: Washington. 1930. 34 p. + map. 
Perkins, S.O., and S.R. Bacon. Soil survey of Worcester County, Maryland. USDA, Bur. Chemistry and Soils, Series 1924, no. 11, USGPO: Washington. 1928. 31 p. + map.

Perkins S.O., and Merle Hershberger. Soil survey of Calvert County, Maryland. USDA, Bur. Chemistry and Soils, Series 1928, no. 13, USGPO: Washington. 1931.22 p. + map.

Perkins, S.O., and H.B. Winant. Soil survey of Queen Anne's County, Maryland. USDA, Bur. Chemistry and Soils, Series 1931, no. 3, USGPO: Washington. 1934. 24 p. + map.

Phillips, S.W., S.O. Perkins and H.B. Winant. Soil survey of Anne Arundel County, Maryland. USDA. Bur. Chemistry and Soils, Series 1928, no. 18, USGPO: Washington. 1932.29 p. + map.

Reybold, William U., H1. Soil survey of Talbot County, Maryland. USDA, SCS, USGPO: Washington. December, 1970. 84 p. + maps.

Ruble, Ralph W. Physical land conditions in Kent County soil conservation district, Maryland. USDA, SCS, Physical land survey no. 37. USGPO: Washington. 1945. 28 p. + maps.

Snyder, J.M., and R.L. Gillett. Soil survey of Wicomico County, Maryland. USDA, Bur. of Soils. USGPO: Washington. 1925. 27 p. + map.

Snyder, J.M., W.C. Jester and O.C. Bruce. Soil survey of Dorchester County, Maryland. USDA, Bur. Soils, USGPO: Washington. 1926. 25 p. + map.

Winant, H.B., and S.R. Bacon. Soil survey of Caroline County, Maryland. USDA, Bur. Chemistry and Soils, Series 1929, no. 7, USGPO: Washington. 1932. 26 p. + map.

Winant, H.B., and J.P. Bewley. Soil survey of Kent County, Maryland. USDA, Bur. Chemistry and Soils, Series 1930, no. 3, USGPO: Washington. 1933. 24 p. + map.

\section{PLANNING REPORTS}

Black and Veatch Consulting Engineers. Solid waste disposal study for Washington metropolitan region. Northern Virginia Regional Planning Commission, Metropolitan Washington Council of Governments, and The Maryland-National Capital Park and Planning Commission. October 1, 1967.

Blair and Stein Associates. Proposed master development plan for Cecil County, Maryland. Washington, D.C. October, 1962.65 p.

Baltimore County. Baltimore County waterfront recreation survey. Department of Recreation and Parks and Office of Planning and Zoning. Baltimore, November, 1959. 45 p.

. Preliminary 1980 guideplan. Office of Planning and Zoning. 1969. 1966.

${ }^{*}$ Center for the Environment and Man, Inc. Coastal and estuarine areas. Appendix U - North Atlantic Regional Water Resources Study Coordinating Committee, U.S. Army Corps of Engineers. New York. (First draft). January, 1971. 294 p. (biblio.).

Delisle, Glenn. Preliminary fish and wildlife plan for San Francisco Bay - Estuary. California Department of Fish and Game. Prepared for San Francisco Bay Conservation and Development Commission. December, 1967. $118 \mathrm{p}$.

Farragut, Paul R. A reconnaissance study of thẻ Chesapeake Bay. Regional Planning Council. Baltimore. 1968. 90 p. (appendices).

Farragut, Paul R. Chesapeake Bay: Shoreline utilization in the Baltimore region. Regional Planning Council. Baltimore. April, $1969.91 \mathrm{p}$.

Governor's Patuxent River Watershed Advisory Committee. The Patuxent River: Maryland's asset, Maryland's responsibility. Md. State Planning Department. Baltimore. $1968.50 \mathrm{p}$.

Governor's Patuxent River Watershed Advisory Committee. The Patuxent River: Maryland's asset, Maryland's responsibility. Appendices. Md. State Planning Department. Baltimore. 1968. Various paging.

Harland, Bartholomew and Associates. Community facilities plan, part of the comprehensive plan, Harford County, Maryland. Washington, D.C. March, 1968. 48 p. 
Comprehensive plan, Carolina County, Maryland. April, 1968. 113 p.

Comprehensive plan, Charles County, Maryland. Prepared for Charles County Planning Commission. Washington, D.C. August, 1966. (rev. February, 1967). 191 p.

Comprehensive plan - Charles County, Maryland: Preliminary report - background for planning.

Washington, D.C. May, 1965.94 p.

. Comprehensive plan - Kent County, Maryland (The). August, 1968. 189 p.

Comprehensive plan - Ocean City, Maryland (The). Prepared for the Ocean City Planning and

Zoning Commission. March, 1969. 143 p.

Comprehensive plan, St. Mary’s County. Washington, D.C. September, 1966. 199 p.

General land use plan, part of the comprehensive plan, Harford County, Maryland. Washington,

D.C. June, $1967.18 \mathrm{p}$.

. Marcou, O'Leary and Associates. Community facilities plan for Cecil County, Maryland, (Draft).

Washington, D.C. November, 1964, 17 p.

Land use plan, 1980: Anne Arundel County general development plan. Tech. Rept. No. 4.

Washington, D.C. July, 1967. 89 p.

. Long-range development guidelines: Anne Arundel County general development plan. Tech. Rept.

No. 3. Washington, D.C. March, 1967. 13 p.

Plan for open space and recreation areas: Anne Arundel County general development plan. Tech.

Rept. No. 5. Washington, D.C. August, 1967. 42 p. (appendices).

Maryland Department of State Planning. Scenic rivers in Maryland. Report of the Scenic Rivers Review Board.

Pub. no. 161. March, 1970. 40 p.

Maryland Game and Inland Fish Commission. Report to the General Assembly of 1969, Five-Year Plan. January, 1969. $40 \mathrm{p}$.

Maryland-National Capital Park and Planning Commission. Wetlands in the bicounty area. Research Rept. No. 8. October, 1967. 32 p.

Maryland State Planning Commission. Conservation problems in Maryland. Subcommittee on Conservation.

Baltimore. 1936.62 p.

Maryland State Department of Planning. Catalog of natural areas in Maryland. Pub. no. 148, Baltimore. August, 1968. 108 p.

Classification and inventory of habitats of Maryland. Baltimore. 1965. $74 \mathrm{p}$.

Comprehensive master plan, Calvert County, Maryland. Baltimore. 1967. 43 p.

Ground-water aquifers and mineral commodities of Maryland. Pub. no. 152. Baltimore. May, 1969.

36 p. + maps.

*Muncy, Dorothy. Waterfront industry around San Francisco Bay. San Francisco Bay Conservation and Development Commission. San Francisco, California. February, 1968.115 p.

Rick, William B. Planning and developing waterfront property. Urban Land Institute, Tech. Bull. 49, Washington, D.C. June, 1964.

Salisbury Chamber of Commerce, Salisbury Planning Commission and Wicomico County Planning and Zoning Commission. Report submitted to the United States Army Corps of Engineers on the savings and benefits accrued to the Salisbury-Wicomico community and the Eastern Shore resulting from an improved river channel up the Wicomico River to the City of Salisbury. March 24, 1960. (mimeo). 27 p.

Salisbury Planning Commission and Wicomico County Planning and Zoning Commission. The SalisburyWicomico Region: Comprehensive plan. Tech. Report No. 3, July, 1961. 57 p. + map.

The Salisbury-Wicomico Region: Existing land use and physical conditions. Tech. Rept. No. 1. May, 1960. 64 p.

San Francisco Bay Conservation and Development Commission. San Francisco Bay Plan. January, 1969.

Smith, Bernard J. The tides of San Francisco Bay. San Francisco Bay Conservation and Development Commission. San Francisco, Calif. June, 1966.42 p.

*Southeastern Wisconsin Regional Planning Commission. Floodland and shoreland development guide. Planning Guide No. 5, Waukesha, Wisc. November, 1968. 199 p. 
Spinner, George P. A plan for the marine resources of the Atlantic coastal zone. American Geographical Society. 1969. 80 p.

Stokes, James D., et. al. Fish and wildlife resources planning guide. California Dept. of Fish and Game. Sacramento, Calif. 1967.96 p.

Tarrant, Julian. Comprehensive master plan, Queen Anne's County, Maryland. Richmond, Va. 1965. 73 p. Comprehensive master plan, Worcester County plan. Richmond, Va. 1965. 156 p.

U.S. Fish and Wildlife Service. Tinicum Marsh preservation: A proposal. USD1, BSF\&W. USGPO (pamphlet) n.d.

U.S. Soil Conservation Service. Watershed protection PL-566 - Marumsco Creek watershed study (preliminary analysis). USDA, College Park, Md. April, 1962.

Werner-Dyer and Associates. Background for planning, Somerset County, Maryland. March, 1963. 29 p.

Calvert County, Maryland - planning research. December, 1964. 38 p.

Dorchester County, Maryland - plans and policies. July, 1963. 26 p. + maps.

Plan and policies, Somerset County, Maryland. Preliminary Report No. 7 (undated). 25 p.

\section{GENERAL}

Anonymous. Fish and birds get voice in big fill job. Engineering News-Record. v. 180, May 23, 1968: 88-90.

Fishing in Maryland Magazine. Baltimore. 1969. 114 p.

Proceedings: Governor's conference on Chesapeake Bay. Westinghouse Ocean Research \& Engr.

Ctr., Annapolis. 1968. 213 p.

Aalto, Johan A. Statistics and projections, in the Potomac estuary ... a changing environment. Proceedings

1968-1. Interstate Commission of the Potomac River Basin. June, 1968. pp. 1-7.

Ahnert, F.O. Estuarine meanders in the Chesapeake Bay area, Geographical Review, 1960. 50(3): 390-401.

American Association for the Advancement of Science. Report by the study committee on natural areas as research facilities. Washington, D.C. 1963.

Atlantic States Marine Fisheries Commission. Developing and managing estuaries. Prepared by the Estuarine Committee, adopted at Portland, Me. 1966.8 p. (mjmeo).

Twentieth annual report. Tallahassee, Fla. June, $1962.80 \mathrm{p}$.

Auld, David V. 1964. Potomac estuary values, waste disposal and water supply. Address presented to the Winter

Meeting of the Interstate Commission on the Potomac River Basin, Arlington, Virginia. January 23, 1964.

Basham, Thomas. "Ocean City sewer system hailed: $\$ 5.6$ million dollar project near completion." The News American. July 31, 1969. p. 4-C.

*Baumann, Ruth. Cherokee Marsh: Win, draw, compromise? Inst. Gov. Affairs, Univ. Ext., Univ. Wisconsin, Madison. 1968. 93 p.

Benson, Dirck. The Atlantic Flyway survey of private waterfowl hunting clubs. Conducted for the Wildlife Mangement Institute by the Atlantic Waterfowl Council. June, 1966. (mimeo).

*Benson, Dirck, and Robert F. Perry. An acre of marsh is worth . . Information Leaflet, Div. Conservation Ed., N.Y. Conservation Dept., Albany. The article appeared in the N.Y. State Conservationist, June-July, 1965: 19(b): 30-33.

Besley, F.W. The forests of Maryland. Md. State Board of Industry. Baltimore. 1916.152 p.

Biggs, R.B. The magnitude of the spoil disposal problem. FWPCA public hearing, Annapolis, Md. October 30, 1968. Univ. of Md. Chesa peake Biological Lab. Ref. No. 68-90. Solomons, Md. 12 p.

Boerger, F.C., Col. District Engineer, U.S. Corps of Engineers, San Francisco District. Statement (in) The Nation's Estuaries: San Francisco Bay and Delta, Calif. Subcommittee hearing print, Committee on Government Operations, H.R. 91 st Congress, 1st Session, USGPO: Washington, May 15, 1969. pp. 110-136.

Boyer, Walter C., Deputy Director, Maryland Port Authority. Statement made at a public hearing on estuarine pollution, Annapolis, Md. October 30, 1968. Proceedings, Maryland-District of Columbia Public Meeting, Vol. 11, National Estuarine Pollution Study, FWPCA, Charlottesville, Va. pp. 422-436.

Buzzell, R.D. and E.T. Walker. Tidewater sport fishery. Md. Dept. of Resrarch and Educ., Resource Study Report No. 4, Solomons, Md. March, 1954.20 p. 
Canada, Department of Fisheries. Economic aspects of sport fishing. Canadian Fisheries Repts. No. 4. Ottawa. 1965. $147 \mathrm{p}$.

Carter, Luther J. Estuaries: will Congress save them from encroachments? Science, v. 156, June 30, 1967: 1717-1720.

Chaney, Charles A. Marinas. 2d. ed. Nat'l. Ass'n. Engine and Boat Manufactuers, lnc., New York, N.Y. 1961. 247 p.

Chapman, Charles. Channelization and spoiling in Gulf Coast \& South Atlantic estuaries. (In) Proceedings: marsh and estuary management symposium. (Ed. John Newsom) LSU, Baton Rouge, La. 1968. pp. 93-106.

Clark, John. Fish and man: conflict in the Atlantic estuaries. American Littoral Soc: Spec. Pub. No. 5. Highland, N.J. 1967.78 p. (biblio).

Commission on Conservation of Natural Resources. Report to the Governor of Maryland. 1948.91 p.

Commission on Marine Science, Engineering and Resources. Our nation and the sea. USGPO: Washington. 1969. $305 \mathrm{p}$.

Conservation Commission of Maryland, Report for 1908-1909. pp. 137-139.

Conservation Foundation, The. The Corps of Engineers has strengthened mandate to protect environmental values. CF Letter, August, 1970. 12 p.

Rookery Bay Area Project. Washington, D.C. 1968.61 p.

Conway, William G. "The consumption of wildlife by man," Parks \& Recreation, v. IV(2): 18-26 and 46-50, February, 1969

Cooke, C. Wythe. Sedimentary deposits of Prince George's County and the District of Columbia. (In) Geology and Water Resources of Prince George's County. Md. Dept. Geology, Mines and Water Resources. Bulletin 10, 1952. pp. 1-53.

Cooper, Edwin L. (ed.). A symposium on water quality criteria to protect aquatic life. American Fisheries Soc. Spec. Pub. No. 4. 1967. 37 p.

Craine, Lyle E. Maryland's role in water resources development. Water Resources Study Committee, Univ. of Md., College Park. 1966. 85 p.

Cronin, L. Eugene. The role of man in estuarine processes. ( $I n$ ) Estuaries, George Lauff (ed.), Washington, D.C. 1967. pp. 667-680.

Crossley, S-D Surveys, Inc. National survey of hunters and fishermen. Supplemental State Report (Maryland). September, 1956. 8 p. + tables (appendices).

Cueman, E.R. Conservation district zoning. J. Soil \& Water Conservation, 21(5): 179-180. 1966.

David, E.J.L. The exploding demand for recreational property. Land Economics, Vol. XLV, No. 2, May, 1969.

Davis, Chester. Waves of development threaten the tidewater. Wildlife in North Carolina, March, 1968: 4-7.

(Reprinted from Winston-Salem Journal-Sentinel.)

Deuel, David G., and John R. Clark. The 1965 salt-water angling survey. Bureau Sport Fisheries and Wildlife, USD1 Resource Pub. 67. Washington. 1968. 51 p.

Durum, W.H., and W.B. Langbein. Water quality of the Potomac River estuary at Washington, D.C. USDI Geological Survey Circ. 529-A. Washington. 1966. 9 p.

Federal Water Pollution Control Administration. National estuarine pollution study. USDI. Office Estuarine Studies. 1968. (pamphlet).

. National Estuarine Pollution Study. Authorized by Title II, Sec. 5 (g) (1) of the Clean Water Restoration Act of 1966, P.L. 89-753, 80 STAT. 1246, November 3, 1966. (3 Volumes). November, 1969. Various paging.

Patuxent River water quality management technical evaluation. USDI. Charlottesville, Virginia. September, 1969. Various paging and appendices.

Water quality criteria. Report of the National Technical Advisory Committee to the Secretary of the Interior. USGPO: Washington. April, 1968. 234 p. (biblio).

Fiske, John D., et. al. A study of the marines resources of the North River. Div. Marine Fisheries, Mass. Dept. Natural Resources, Monograph Series No. 3, May, 1966. 53 p.

*Franklin, Jerry F., and James M. Trappe. "Natural areas: needs, concepts, and criteria." J. Forestry, V. 66, no. 6, June, 1968. 
Frisbie, Charles M. and D.E. Ritchie, Jr. Sport fishing survey of the lower Potomac estuary, Chesapeake Science, December, 1963: 4:175-191.

Gaffney, Mason. Land planning and the property tax. J. Amer. Insti. of Planners. Vol. XXXV, No. 3, May, 1969.

Galbreath, Paul M. Maryland water law. Water Resources Study Committee, Univ. of Md., College Park. 1965. $87 \mathrm{p}$.

Georgia, University of. Report on the proposed leasing of State-owned lands for phosphate mining. Advisory Committee on Mineral Leasing. Athens. 1968. 21 p. and Appendices.

Geyer, John C. Groundwater in the Baltimore industrial area. Md. State Planning Commission. May, 1945. 299 p.

Geyer, John C., et. al. A research program for the Potomac River. Potomac Estuary Study Planning Committee, Baltimore, Maryland. 1965. 143 p. (biblio).

Gilliam, Harold. The fallacy of single-purpose planning. Daedalus. Fall, 1967. pp. 1142-1157.

Goldstein, Jon H. Competition for wetlands in the Midwest: an economic analysis. Resources for the Future, Inc. Johns Hopkins Press, Baltimore. 1971.

Gottschalk, L.C. Effects of soil erosion on navigation in upper Chesapeake Bay, Geographical Review. 1945. 35:219-238.

Governor's Special Committee to Study Shore Erosion. Shore erosion policy for Maryland, A. Rept. December, 1961.63 p.

Graves, Aubrey. "Rigid Restrictions on Marinas in Anne Arundel Proposed." The Washington Post. July 11, 1969: and "Marina Operations, Zoning Officer Clash." The Washington Post. July 18, 1969.

Green, R.L., and C.P. Merrick. Drainage law of Maryland. Dept. of Drainage, Univ. of Md. Coop. Ext. Service, Extension Bull. 196, College Park. October, 1962.13 p.

Griffith, Chuck. Effort made to halt wetland destruction. North Dakota Outdoors. v. XXXI(12): 6-9. June, 1969.

Harmon, Keith W. Prairie potholes. National Parks and Conservation Magazine, v. 45 (3): 25-28, March, 1970. (reprint).

Harrison, Joseph G. A letter "To Whom It May Concern" re: wetlands development at Ocean City, Md. June 25, 1969 (mimeo).

*Hawkes, Alfred L. Coastal wetlands - problems and opportunities. Audubon Soc. Rhode Island. March 14, 1966 (leaflet) 15 p. (biblio).

*Heath, Milton S., Jr. State programs for estuarine area conservation. Rept. to the N.C. Estuarine Study Committee. Inst. Gov’t. U.N.C. Chapel Hill. 1968. 25 p.

Heidel, S.G. and W.W. Fremer. Chemical quality of water and trace elements in the Patuxent River Basin. Md. Geological Survey Report of Investigations, No. 1, 1965.

Hite, J.C., aNd J.M. Stepp. Economic analysis of the development potential of the commerical fisheries of the coastal plains region. Clemson Univ. S.C. Agric. Expt. Sta. Econ. Marine Resources, No. 1., Clemson, S.C. 1969. $78 \mathrm{p}$.

*Hollis, Edgar H. A critique of "A report to the District Engineer on the effects of the disposal of spoil from the inland waterway, Chesapeake and Delaware Canal, in upper Chesapeake Bay. (undated). (mimeo). $10 \mathrm{p}$.

. Fishery resources of the Patuxent River system. In Appendices, The Patuxent River, Marylana's asset, Maryland's responsibility. Governor's Patuxent River Watershed Advisory Committee. Md. State Planning Dept. Pub. no. 149a. July, 1968. Various paging.

Interstate Commission on the Potomac River Basin. George Washington ... his river. Rept. for 1967. Washington. $28 \mathrm{p}$.

. Proceedings: The Potomac estuary .. a changing environment. Washington. 1968. 32 p.

Ippen, Arthur T. Estuary hydrodynamics, (In) Proceedings, Symposium on hydrology of the coastal waters of North Carolina, May 12, 1967. Water Resources Research Institute, University of North Carolina, Chapel Hill. pp. 84-94.

Jackson, Charles E. Chesapeake fisheries, history and outlook. (In) Symposium, Maryland conservation forum, April 12, 1944. Md. Dept. Research and Education, Educational series, no. 4, Solomons, Md. June, 1944. pp. $67-76$. 
Jerome, William C., Jr., et. al. A study of the marine resources of the Merrimack River estuary. Div. Marine Fisheries, Mass. Dept. Natural Resources, Monograph Series No. 1. June, 1965.90 p.

. A study of the marine resources of Quincy Bay. Div. Marine Fisheries, Mass. Dept. Natural Resources, Monograph Series No 2. March, 1966.62 p.

*Johnson, Peter L. Wetlands preservation. Open Space Institute, New York. 1969

Jones, Carleton. Land values slowed in county stalemate. The Sun, Baltimore, Maryland. October 13, 1969.

. Growth and problems continue (housing prospects for the 1970's). The Sun, Baltimore, Md.

November 9, 1969.p. 2, Section F.

Klein, George. Comparison of recent and ancient tidal flat and estuarine sediments. ( $I n$ ) Estuarines, AAAS, Pub. no. 83. Washington, D.C. 1967.

Klingel, Gilbert. 1951. The Bay: a naturalist discovers a universe of life above and below the Chesapeake. Dodd, Mead \& Co., New York.

Lauff, George H., (ed.). Estuaries. AAAS, Washington, D.C. 1967.757 p.

Linde, Arlyn F. Techniques for wetland management. Wisconsin Dept. Nat. Resources, Research Rept. 45. Madison. 1969. $156 \mathrm{p}$

Lindurka, Joseph P., (ed.). Waterfowl tomorrow. Bureau Sport Fisheries \& Wildlife, USGPO: Washington, D.C. 1964. $770 \mathrm{p}$.

Longwell, John R., and Richard L. Sharpless. Statewide water quality surveillance network 1968 survey results. Water Quality Investigation Division, Maryland Department of Water Resources, Annapolis. 1968.

Lyon, Gale H., Dean F. Tuthill and Wm. B. Matthews. Economic analysis of marinas in Maryland. Md. Agric. Exp. Sta., Dept. Agric. Econ., Contribution No. 4100. Univ. of Md., College Park, April, 1969. 68 p.

Mack, Frederick K. Groundwater resources in Prince George's County. Maryland Geological Survey, Bull. 29 ,

Baltimore. 1966. 101 p. + maps.

Mallack, Jerry, et. al. Mosquito control in Maryland. Md. State Board of Agriculture. Bull. \#1 (revised), September, $1966.8 \mathrm{p}$.

Mansuetti, Romeo J. Effects of civilization on striped bass and other estuarine biota in Chesapeake Bay and tributaries. Gulf and Caribbean Fisheries Institute. 14th Annual Session. November, 1961.

Mansuetti, Romeo J., and Edgar H. Hollis. Striped bass in Maryland tidewater Educ. Ser. No. 61, Nat. Resources Institute, Univ. of Md., Solomons lsland. February, 1963.28 p.

Maryland Board of Natural Resources. Annual reports. Annapolis.

Solomons. $1944.96 \mathrm{p}$.

Six-year conservation programs. 2d. ed. Anna polis. 1948. 44 p.

The commercial fisheries of Maryland. Md. Dept. Research and Ed. Educ. Series No. 30. Ches. Biol.

Lab. Solomons. 1953.45 p.

* R_ Report of the Commission on Submerged Public Lands. Appendix B, 18th Annual Report. Annapolis, 1961.pp. 151-160+ maps.

Maryland Dept. Geology, Mines and Water Resources. Proposed shore erosion program. Educational Ser., (pamphlet 1) 1964.10 p.

Maryland Department of Health and Mental Hygiene. Collection and disposal of solid wastes - a Maryland program. August 1, 1966.

Maryland Department of Health and Mental Hygiene. Departmental regulations formulated to implement Article 43, Section 387C, Laws of Maryland. (43L01 - Regulations for Planning Water Supply and Sewerage Systems, Section 04 - Requirements Applicable to County Plans). Adopted: September 23, 1966. Effective: October $15,1966$.

Maryland Department of State Planning. The counties of Maryland Baltimore City: their orgin, growth and development 1634-1967. Pub. No. 146. Baltimore. June,1968. 106 p.

Maryland, University of. Potomac River basin - research, planning and development. Bureau Business and Econ. Res. Studies. vol. 11. no. 3. College Park.

Maryland, University of. Tidewater Maryland development problems. Bur. Business and Econ. Res. Studies. vol. 15, no. 2. College Park. 23 p. 
Massmann, W.H. San Francisco Bay development vs. fish and wildlife conservation. Oral presentation, Atlantic Estuarine Research Society, College Park, Md. Meeting. November 4-5, 1966. 7 p.

Marx, Wesley. Suicide in the shallows. National Wildlife, v. 6, June-July, 1968: 4-9.

McAdams and Associates. States tidelands: states rights. Washington. 1952. 32 p.

McCarl, Henry N. The mineral aggregate industry in the vicinity of Baltimore, Maryland. Unpublished doctral dissertation - Pennsylvania State University, State College. December, 1969. 249 p.

McKee, J.E., and H.W. Wolf. Water quality criteria. California. State Water Quality Control Board. 2d ed. Pub. No. 3-A. 1963.

Michie Co., The. Annotated Code of the public general laws of Maryland. (1970 Supp.). Charlottesville, Va. 1966.

Muncy, Dorothy A. Inventory of port-oriented land: Baltimore region. Maryland Department of Economic Development. 1963.62 p. + maps.

Nash, C.B. Environmental characteristics of a river estuary. Chesapeake Biological Laboratory, Pub. no. 64. Solomons Island, Maryland. 1947.

National Academy Sciences. Alternatives in water management. A Report of the Committee on Water. Pub. 1408. Washington. $1966.52 \mathrm{p}$.

National Advisory Commission on Food and Fiber. Food \& fiber for the future. Report of the President's Commission. USGPO: Washington, July, 1967. $361 \mathrm{p}$.

National Council on Marine Resources and Engineering Development. Marine science affairs - a year of plans and progress. 2d. Rept. of the President to Congress. USGPO: Washington. March, 1968. $228 \mathrm{p}$.

. Marine science affairs - a year of broadened participation. 3d. Rept. of the President to Congress. USGPO: Washington. 1969.251 p.

National Park Service. Our vanishing shoreline. USDI. 1956. 36 p.

Newcombe, C.L., W.A. Horne, and B.B. Shepherd. Studies on the physics and chemistry of estuarine waters in Chesapeake Bay. Sears Foundation. Jour. Marine Research, 1939, 2:87-116.

North Carolina, University of. Proceedings: Symposium on hydrology of the coastal waters of North Carolina. Water Resources Research Institute, Rept. No. 5. Chapel Hill. 154 p.

O'Bryan, Deric, and R.L. McAvoy. Gunpowder Falls, Maryland. U.S. Geological Survey Water-Supply Paper 1815. 1966. $90 \mathrm{p}$.

O'Donnell, James J. The role of State government in Bay management. (In) Proceedings, Governor's Conference on Chesapeake Bay Wye Institute, September 12-13, 1968. pp. 187-196.

Odum, Eugene P. The urgent need for landscape zoning of the estuarine region according to ecosystem principles. Address presented at Symposium of Estuarine Ecology of Coastal Waters of North Carolina. Raleigh, N.C., May 12, 1966. 4 p.

Odum, Eugene P. Man and the landscape. Scientist and Citizen, v. 9(1): 12-15, January, 1967. Excerpted from Waste Mangement and Control, Pub. no. 1400, Natl'l. Aca. Sci., National Research Council, Washington, D.C. 1966. $257 \mathrm{p}$.

Odum, William E. Pesticide pollution in estuaries. Sea Frontiers, v. 14(4): 234-245. July-August, 1968.

Outdoor Recreation Resources Review Commission. National recreation survey. ORRRC Study Report 19. USGPO: Washington, D.C. 1962.394 p.

Pritchard, D.W. The physical structure, circulation and mixing in a coastal plain estuary. The Johns Hopkins University Technical Report III. The Chesapeake Bay Inst. Ref. 52-2. 1952.

Provenza, V.D. An investigation of the physiochemical characteristic of a river estuary. Ph. D. Thesis. Univ. of Md. College Park. 1952.

Rasmussen, William C., and T.H. Slaughter. The groundwater resources in Somerset, Wicomico and Worcester Counties. Dept. Geology, Mines and Water Resources, Bull. 16, 1955. 533 p. + maps.

Redford, Polly. Vanishing tidelands, Atlantic, June, 1967. 219:75-83.

Resources for the Future, Inc. Resources, n. 38, September, 1971.

Rice, David A. Estuarine lands of North Carolina: legal aspects of ownership, use and control. Inst. Gov't. U.N.C., Chapel Hill. 1968. 
Rorholm, Niels, et. al. Economic impact of marine-oriented activities - a study of the southern New England marine region. Univ. R.I., Agric. Exp. Sta. Bull. 396. Kingston, 1967. 132 p.

Ryan, J. Donald. The sediments of Chesapeake Bay. Md. Dept. Geol. Mines and Water Resources. Baltimore. 1953. $120 \mathrm{p}$.

Salsbury, Stuart Marshall. Maryland's wetlands: the legal quagmire. Maryland Law Review, v. XXX(3): 240-266, Summer, 1970.

Singewald, J.T., Jr., and T.H. Slaughter. Shore erosion in tidewater Maryland. Md. Dept. Geology, Mines and Water Resources, Bull. No. 6, 1949.

Slaughter, T.H. Shore erosion control in tidewater Maryland. J. Washington A cad. Sci. 57: 117-129 (1967).

Sobers, David G. The implications of sediment pollution on water recreation in the upper Potomac estuary, M.S.

Thesis. Univ. of Md., College Park, 1965.

Sport Fishing Institute. SFI Bulletin, Nos. 199, 202, 213.

Stanford, University of. Proceedings, The national symposium on estuarine pollution, August 23-25, 1967.

Dept. Civil Engr. Stanford, Calif. 1967.850 p.

Stevens, G.A. (ed.) "Land Resources," (In) Agriculture '76, Section 1I1, Resources and Services in Production. Agricultural Div., Univ. Md., College Park. 1970.

*Stewart, Kenton M., and Gerard A. Rohlich. Eutrophication - a review. State of California, State Water Quality Control Board, Pub. no. 34, Sacramento, 1967. 188 p.

*Suttar, R.E., and J.L. Cain. The Maryland seafood industry. Maryland Agri-Economics. College of Agriculture. Univ. of Md., College Park, April, 1968. (leaflet) 4 p.

Taormina, Anthony S. The natural values of marine wetlands. Conservationist, June-July, 1967, v. 21 : 6-9.

Texas Legislative Council. State-owned submerged lands and islands. Rept. to the 56th Legislature. No. 55-6. Austin. 1958.29 p.

Transgard, June. An environment fit for ducks. North Dakota Outdoors, vol. XXXIV(1): 12-15, July, 1971.

Truitt, R.V. Sport fishing in Maryland. The Conservation Department of Maryland. 1938. 16 p.

Tuthill, Dean F., D. Sobers and J.P. Marshall. The effects of sediment pollution on water recreation in the upper Potomac estuary. Dept. of Agric. Econ., Univ. of Md., Misc. Pub. 653. College Park. December, 1967.62 p.

U.S. Army Corps of Engineers. River and harbor project maps, 1968. Baltimore District. December 31, 1968 (revised 1970). Various paging.

U.S. Bureau of Outdoor Recreation. A report on recreation land price escalation. USDI, USGPO: Washington, D.C. 1967.

*U.S. Congress House. Committee on Government Operations. Our waters and wetlands: how the Corps of Engineers can help prevent their destruction and pollution. House Report 91-917.91 Congr. 2d Sess. USGPO: Washington, $1970.18 \mathrm{p}$.

U.S. Congress. House Committee on Government Operations. Protecting America's estuaries: The Potomac. Hearings ... 91 st Congr., 2d Sess. July 21-22, 1970. USGPO: Washington, 1970. 439 p.

*U.S. Congress. House. Committee on Government Operations. The nation's estuaries: San Francisco Bay and delta, Calif. Hearings ...91 st Congr., 1 st Session. May 15, 1969. USGPO: Washington, 1969. 251 p.

U.S. Congress. House. Committee on Merchant Marine and Fisheries. Coastal Zone Management Conference. Hearings before the Subcommittee on oceanography (Committee Print). 91st Congr., lst Sess., Ser. No. 91-14. USGPO: Washington, 1969. $198 \mathrm{p}$.

U.S. Congress. House. Committee on Merchant Marine and Fisheries. Estuarine areas: report to accompany H.R. 25, 90 th Cong., 1st sess., House Rept. no. 989, USGPO: Washington, 1967. 48 p.

U.S. Congress. House. Committee on Merchant Marine and Fisheries. Subcommittee on Fisheries and Wildlife Conservation. Estuarine areas. Hearings .. 90 90 th Cong., 1st sess. on H.R. 23, H.R. 1397, H.R. 4505, H.R. 4749, H.R. 4755, H.R. 4780 . . March 6, 8, 9, 1967. Serial No. 90-3, USGPO: Washington, 1967.486 p.

U.S. Congress. Senate. Committee on Commerce. Subcommittee on Merchant Marine and Fisheries. Estuarine areas and jellyfish control. Hearings ... 89th Cong., 2d sess. on S. 3528 and S. 3744. September 28, 1966. Serial No.89-90, USGPO: Washington, $1967.67 \mathrm{p}$.

*U.S. Congress. Senate. Special Committee on Conservation of Wildlife Resources. Wildlife and the land: A story of regeneration. Committee print. 75th Congr., lst Sess. USGPO: Washington. 1937.90 p. 
U.S. Department of Defense. D.O.D. Directive No. 5500.5, May 24, 1965, and D.O.D. Instruction No. 4170.6. June 21, 1965.

U.S. Department of Interior. The Nation's river. USGPO: Washington. 1968. 128 p.

U.S. Fish and Wildlife Service. Federal aid in fish and wildlife restoration. Wildlife Mgt. Inst. and Sport Fishing lnst. BSF\&W. Washington. 1967. 96 p.

* Fish and wildlife resources as related to water pollution, Chesapeake Bay and tributaries (except Susquehanna River Basin). BSF\&W. Atlanta, Georgia. October, 1968. 173 p. Inventory of permanent water of major significance to waterfowl in the State of Maryland. ORBS, BSF \&W, Atlanta, Georgia. July, 1956.7 p. National survey of hunting and fishing. BSF\&W, Resource Pub. 27. 1956.

What is happening to our estuaries and coastlines? USDI. Conservation Backgrounds. v. 2, n. w, January $15,1960.3$ p.

U.S. Soil Conservation Service. Summary of conservation needs inventory of Maryland watersheds. USDA, College Park, Md. rev. Ja nuary, 1968. (mimeo).

Vaught, Richard W. Problems and economics of Canada goose management in the Mississippi Flyway. In Canada goose management: current continental problems and programs (symposium). ed. Hine and Schoenfeld. Dembar Ed. Res. Services, Madison, Wisc. 1969. pp. 27-29.

Virginia Marine Resources Study Commission. Marine resources of Virginia - their use, conservation and development. Report to the Governor and the Gencral Assembly, House Document No. 19, Commonwealth Va. Dept. Purchases and Supply, Richmond, Va. 1967.

*Walker, Wm. Paul. Farm ownership valuation and taxation inrural-urban Maryland. Univ. Md. Dept. Agric. Econ., Agric. Expt. Sta., Misc. Pub. No. 639. College Park. 1967. 27 p.

Walker, Wm. Paul. Improving farm property assessments. Agric. Expt. Sta. Bull. No. A36. University of Maryland, College Park. January, 1945.

Wastler, T.A. Municipal and industrial wastes and the estuaries of the South Atlantic and Gulf Coasts. (In) Proceedings, Marsh and Estuary Management Symposium. LSU. Baton Rouge, La, 1968. pp. 114-1 19.

Wengert, Norman. Natural resources and the political struggle. Random House. New York. 1955.71 p.

Wolman, M. Gordon. The Chesapeake Bay: geology and geography. (In) Proceedings: Governor's Conference on Chesapeake Bay. September 12-13, 1968. pp. 7-48.

Wright, Charles W. Chesapeake Bay - "Mother of Waters." Address before The Eastern Shore Society of Baltimore City. March 25, 1919. (mimeo). 16 p. 
APPENDIX A

Habitat Inventory Tables for Chapter VI 



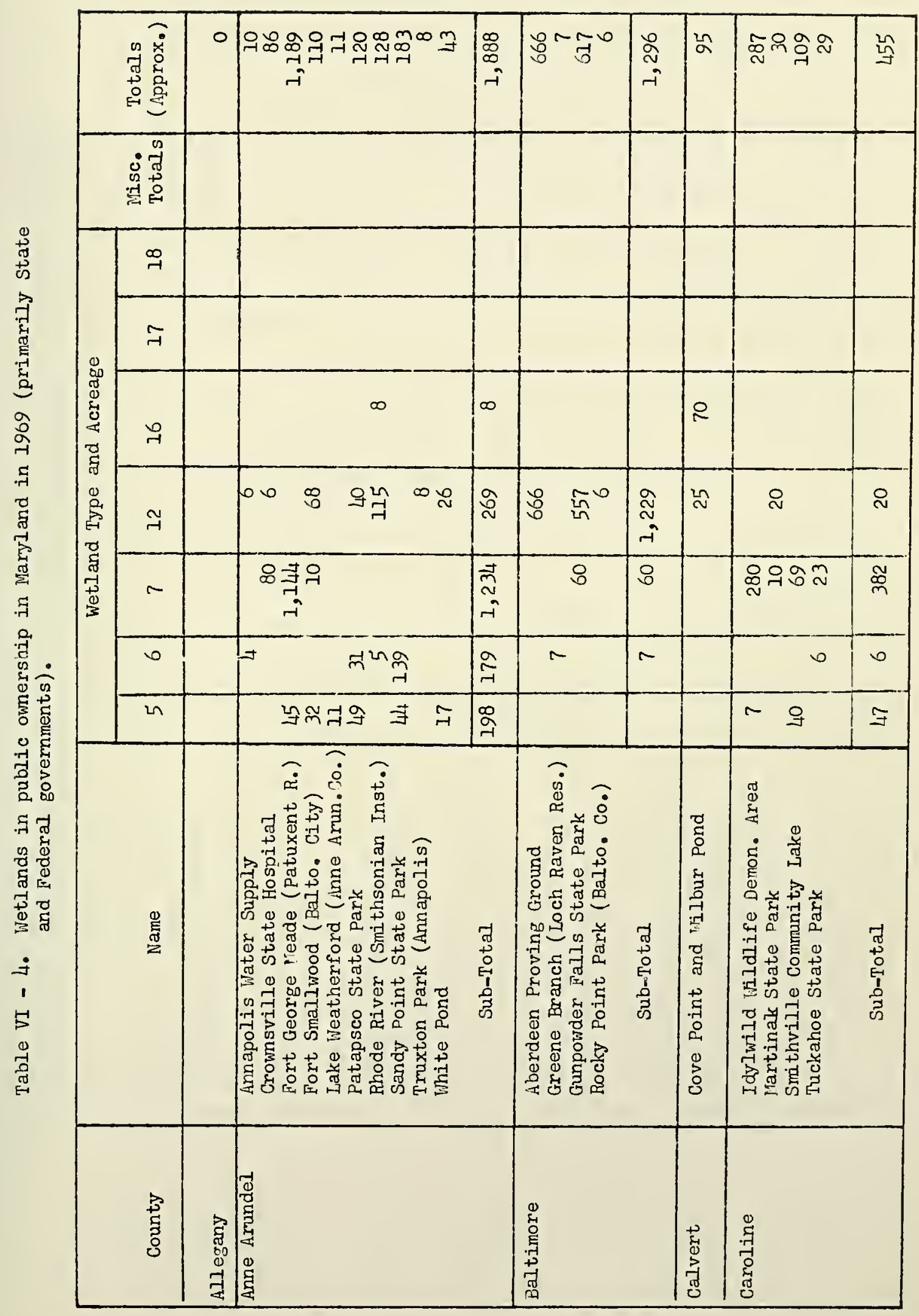




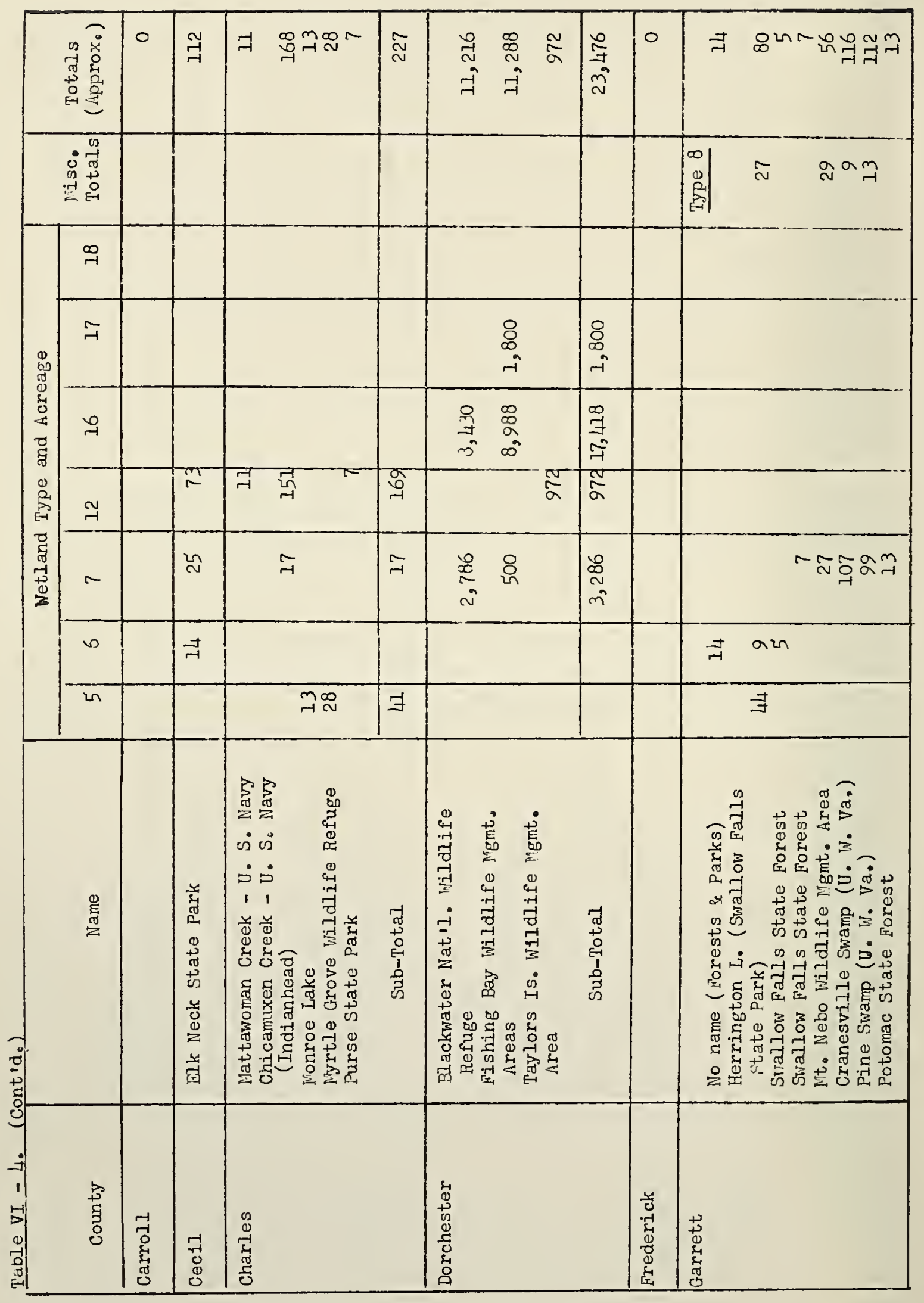




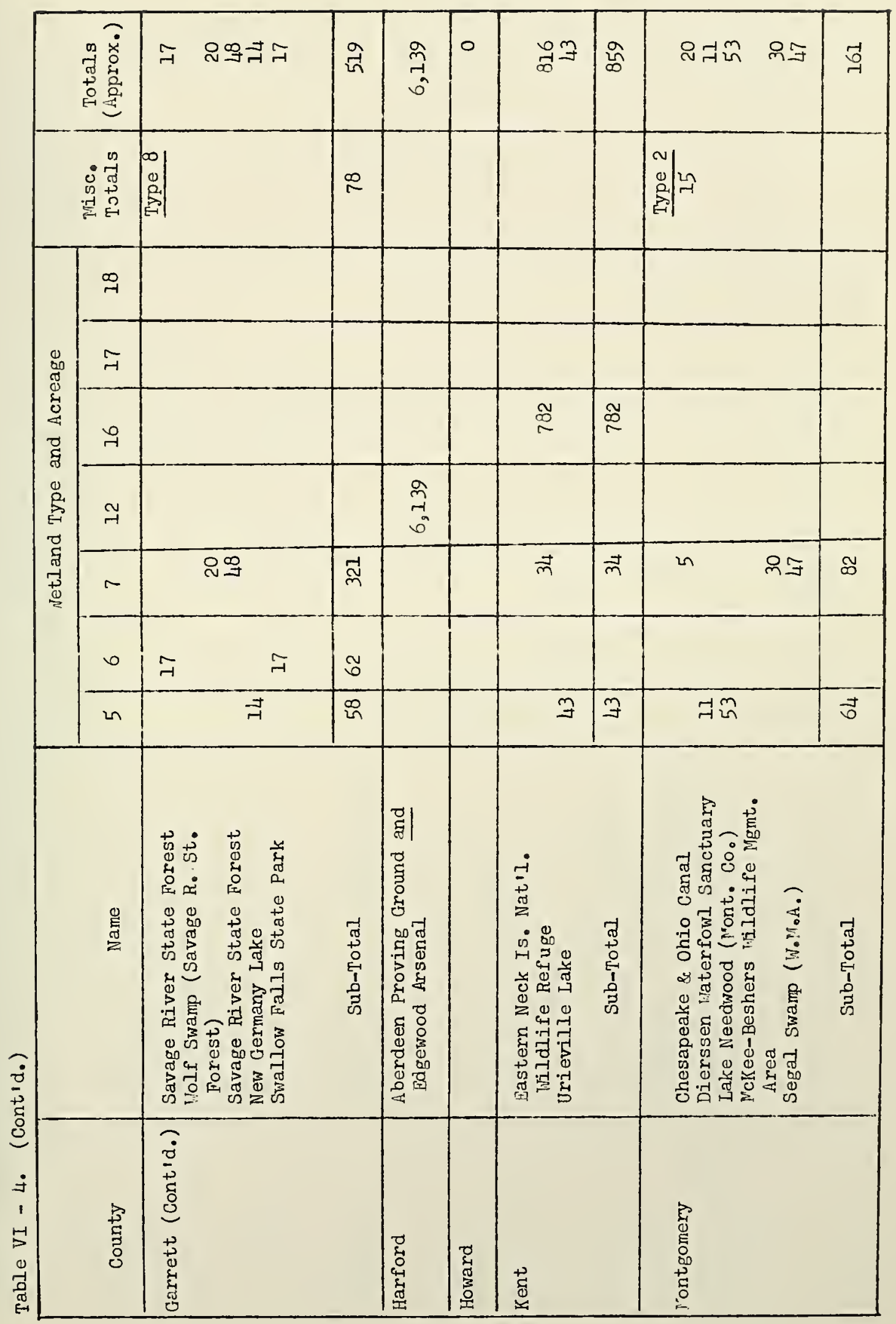




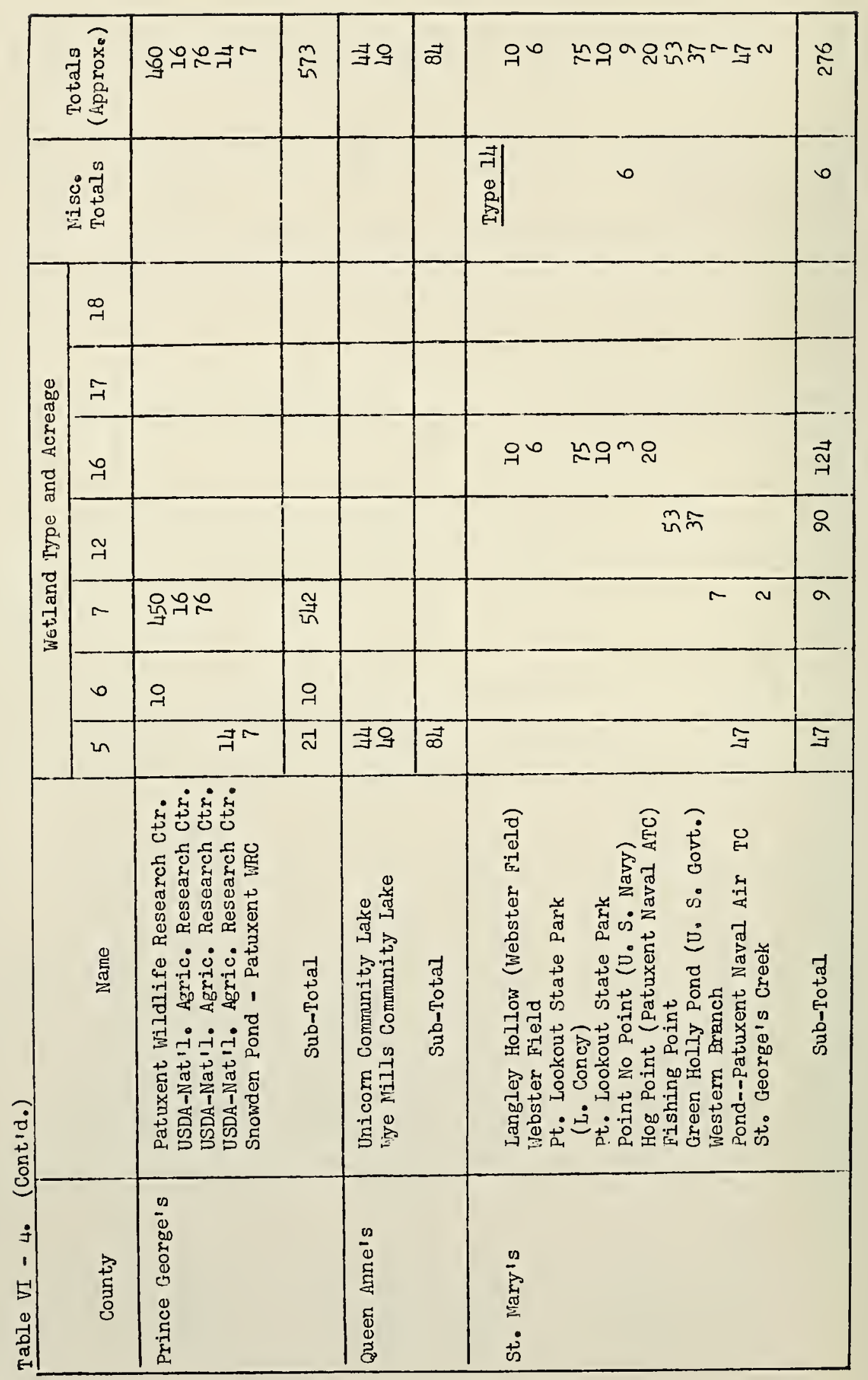




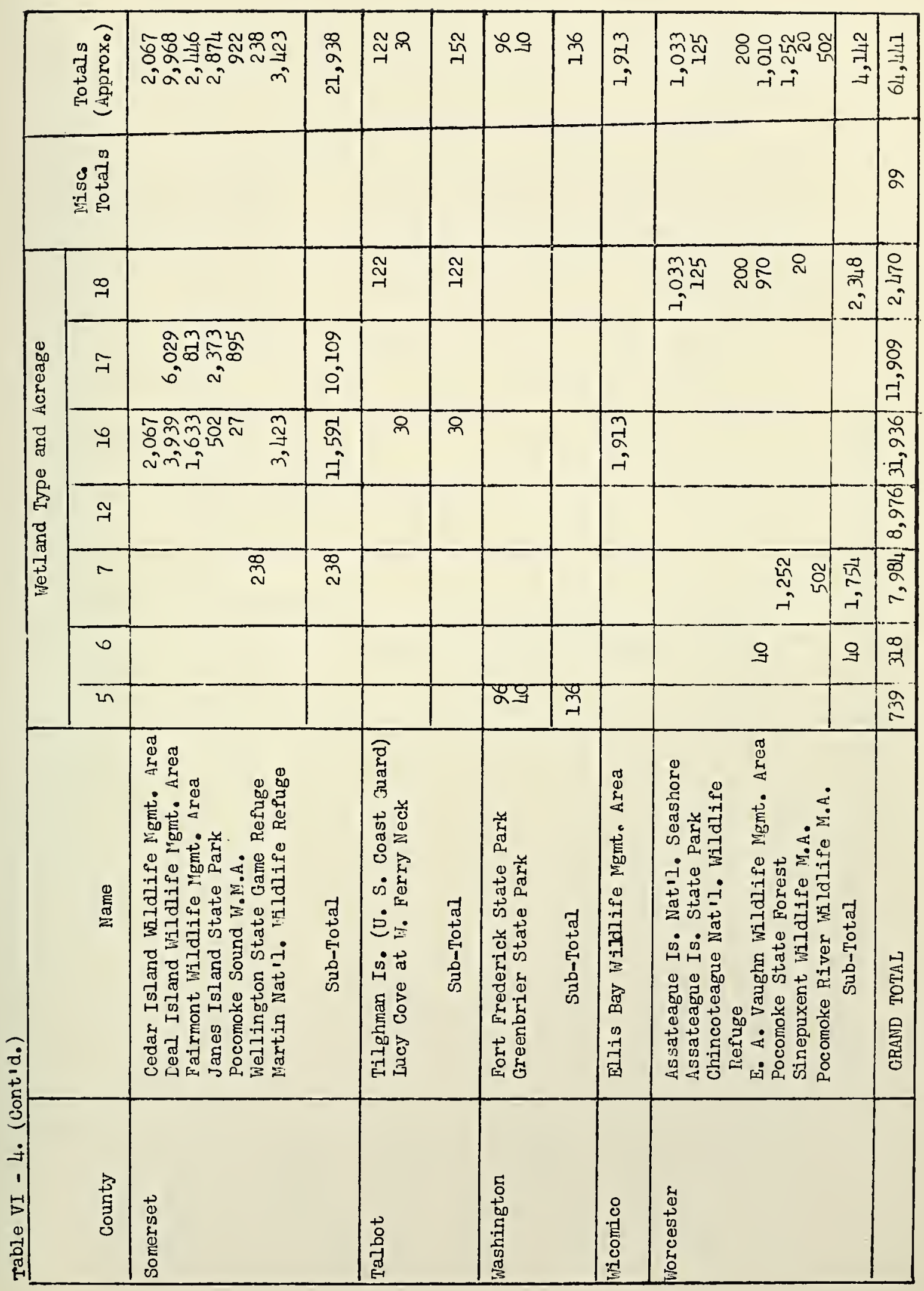




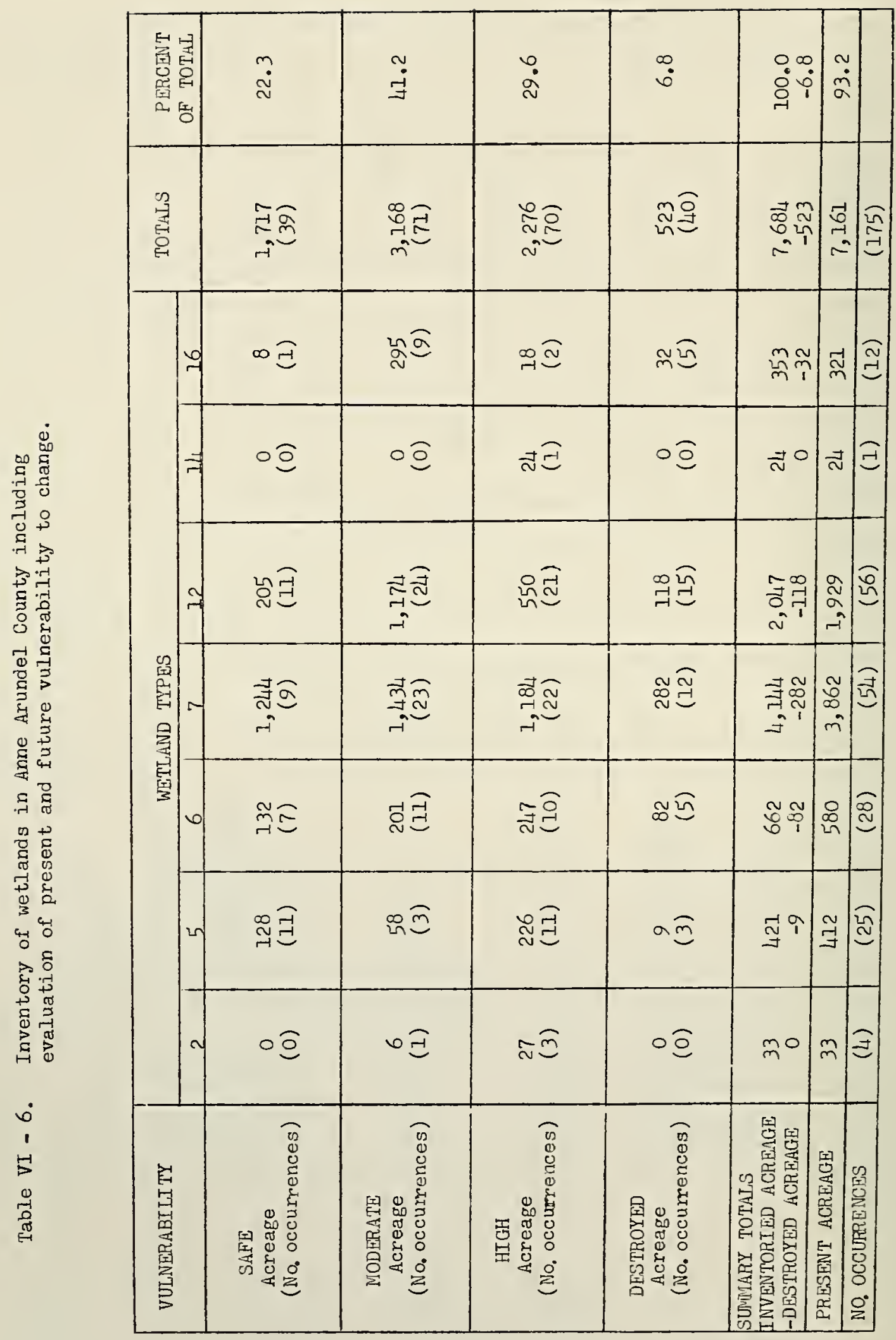




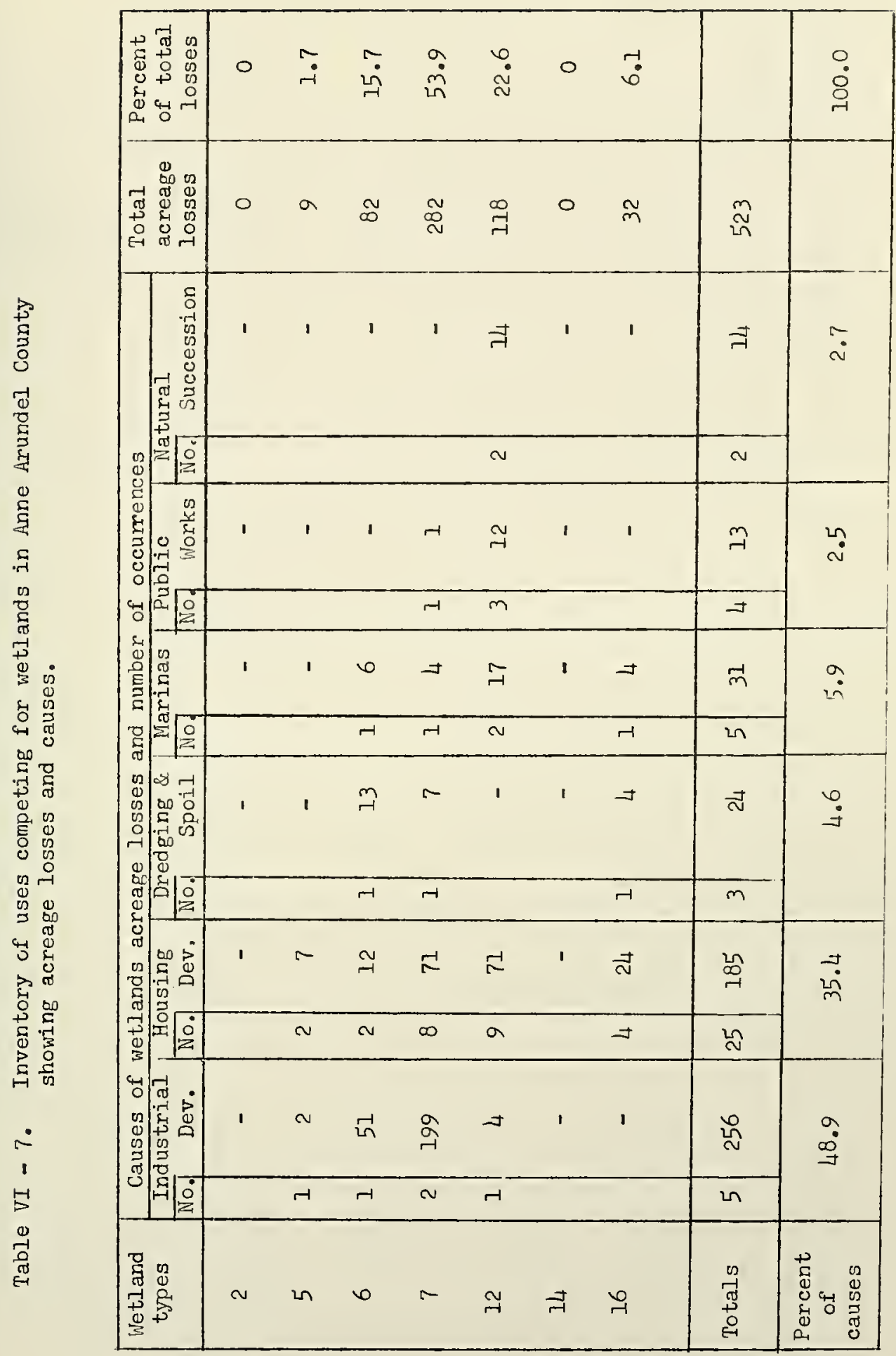




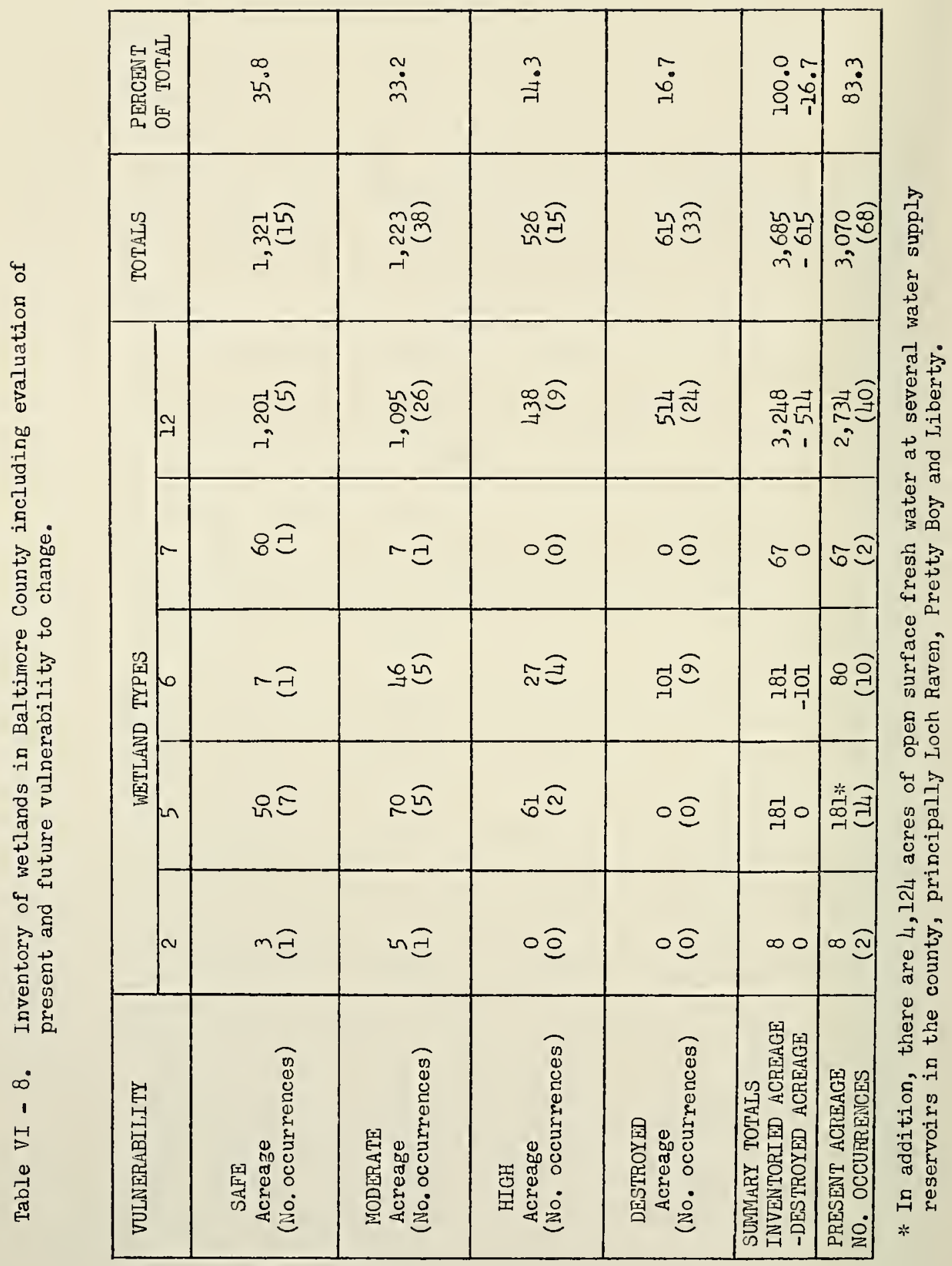




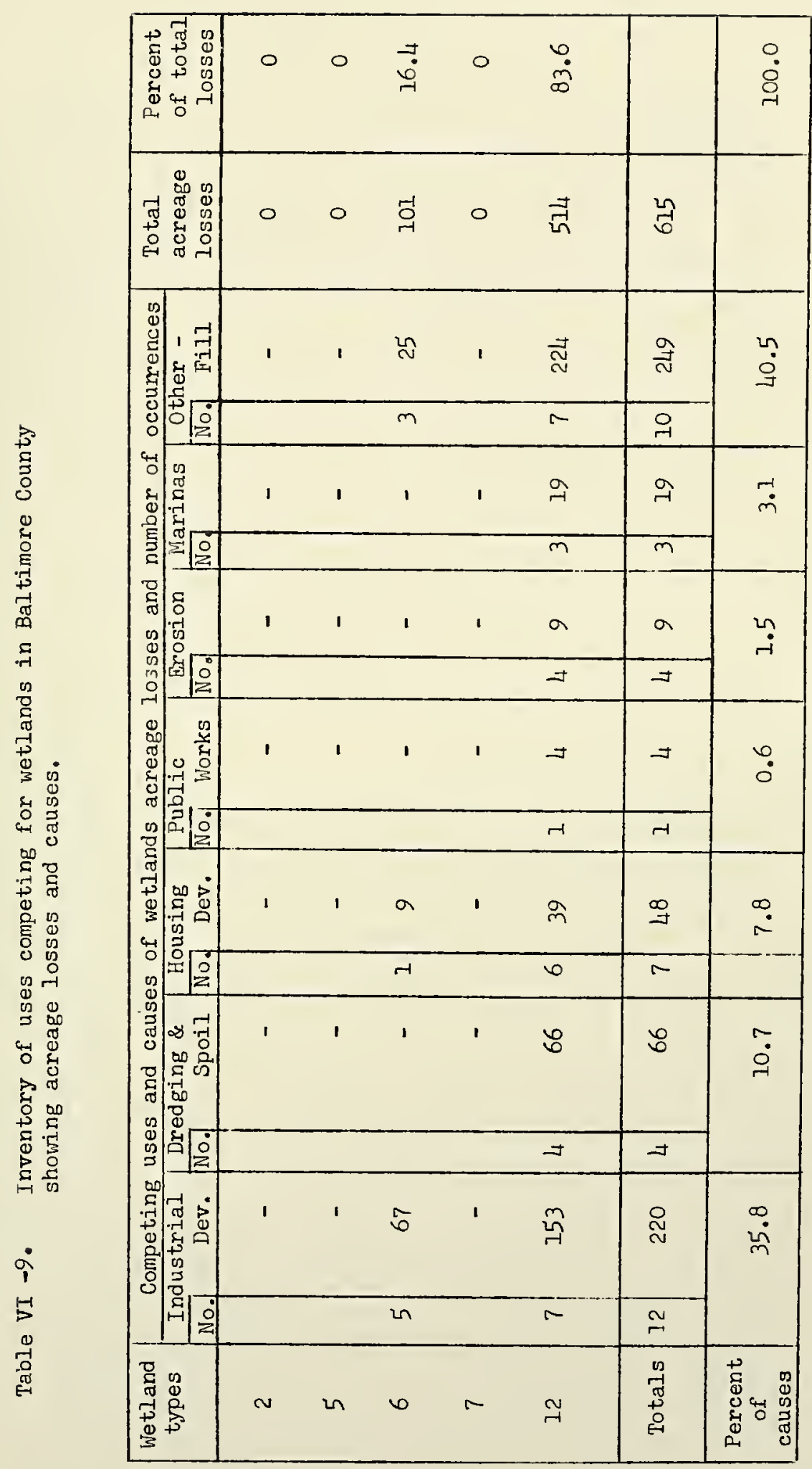




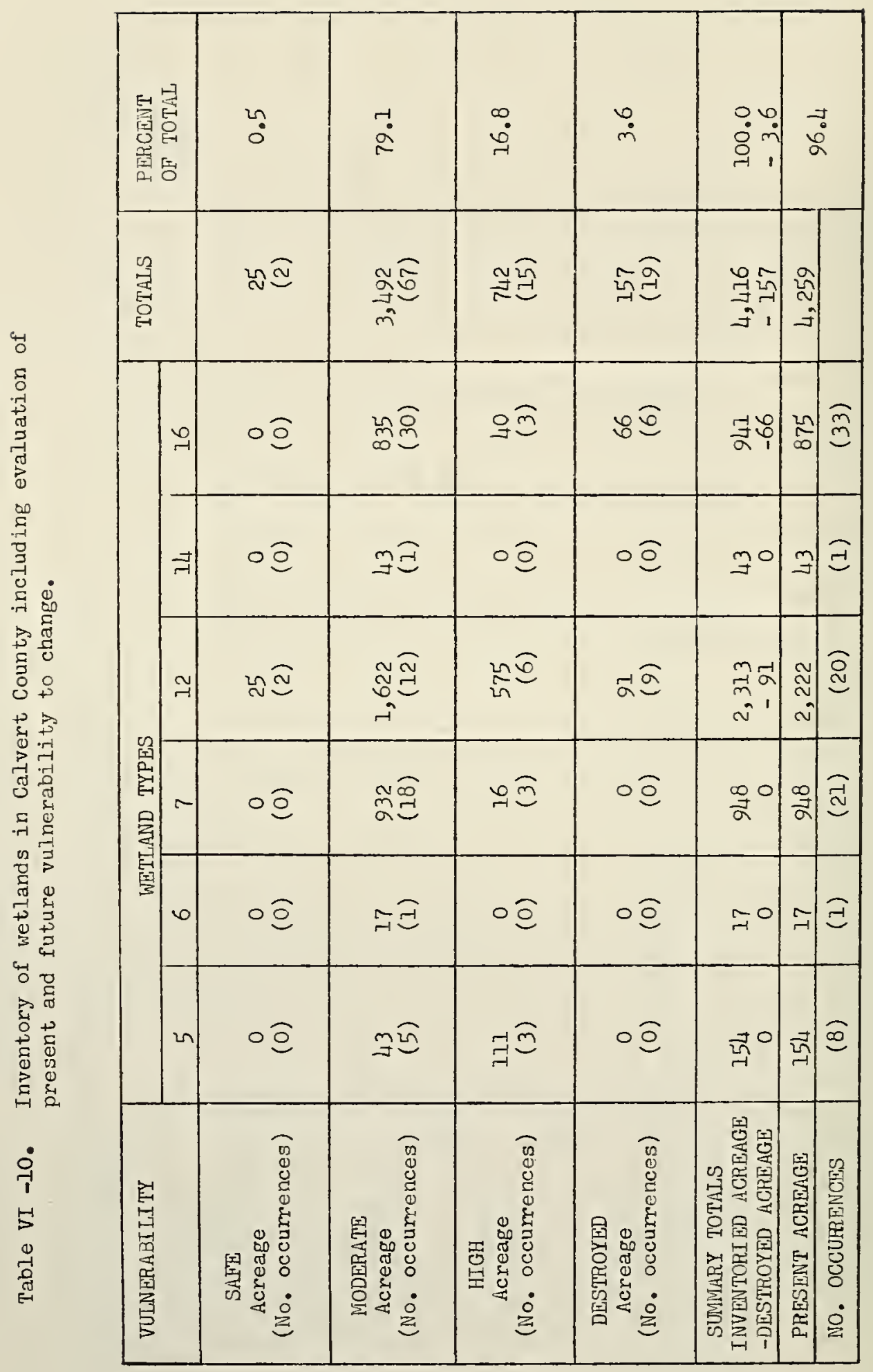




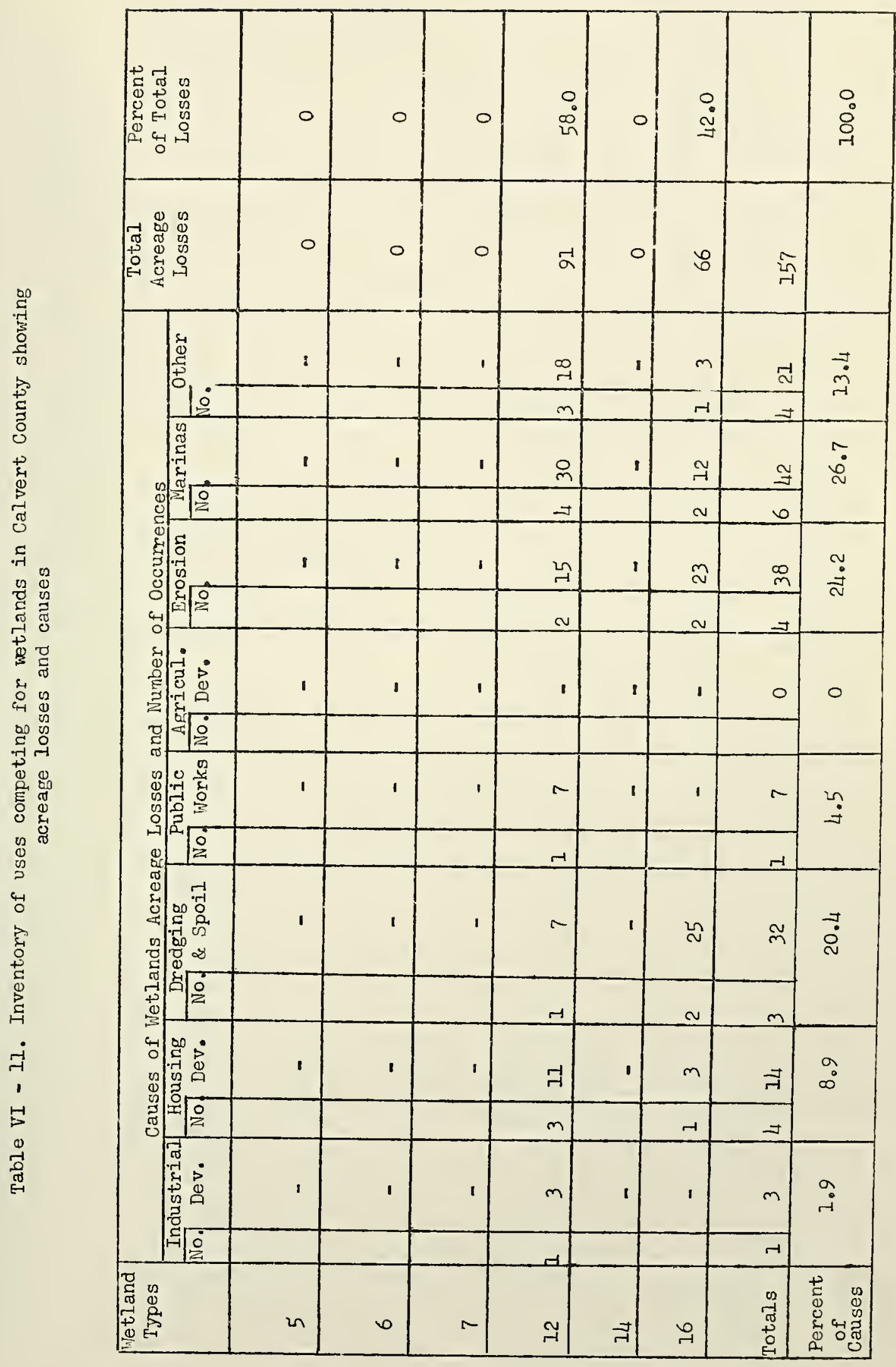




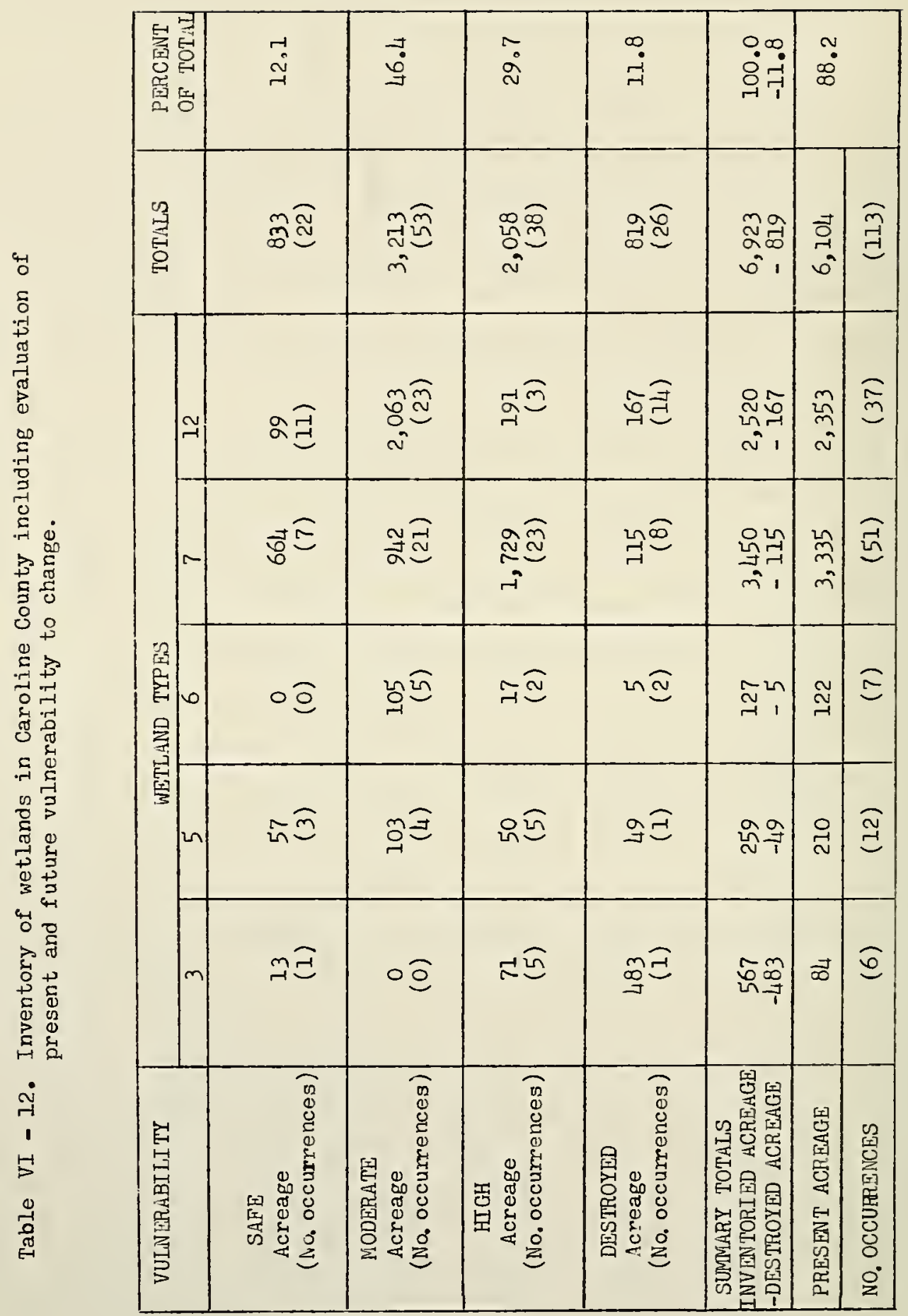




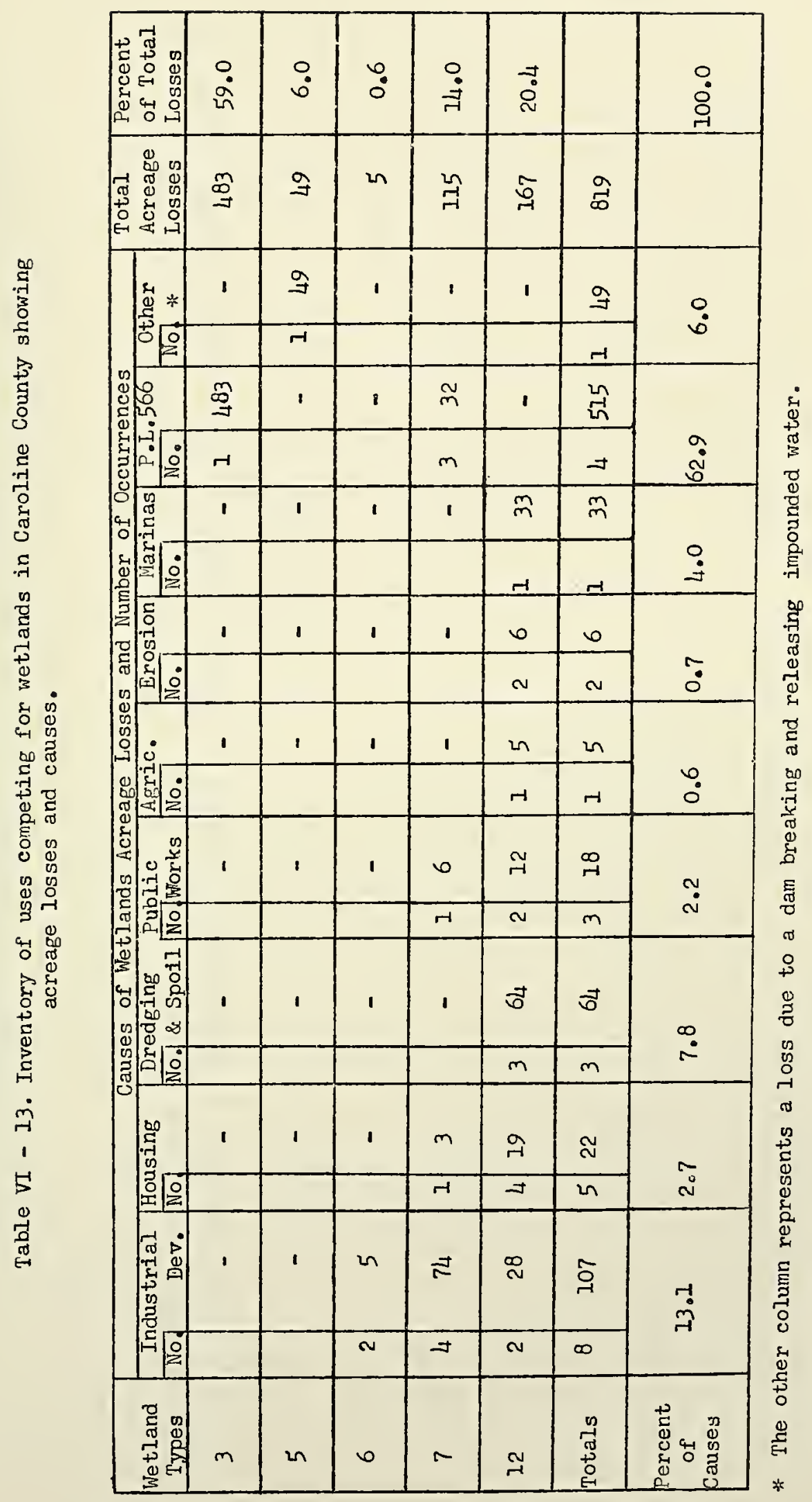




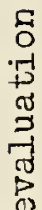

\begin{tabular}{|c|c|c|c|c|c|}
\hline 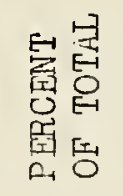 & $\dot{\sim}$ & $\begin{array}{l}\infty \\
\stackrel{\infty}{\vartheta}\end{array}$ & 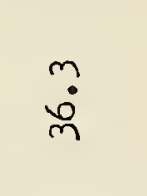 & 象 & 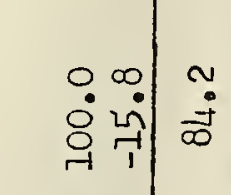 \\
\hline 視 & nم & 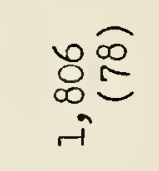 & 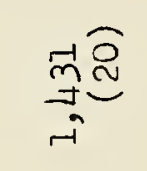 & 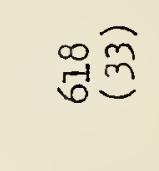 & 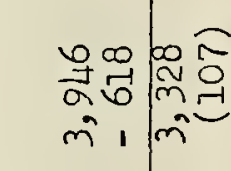 \\
\hline \multirow{4}{*}{$\begin{array}{l}\text { 㽞 } \\
\text { 离 } \\
\text { 最 } \\
\text { 舅 }\end{array}$} & $m \widehat{\Xi}$ & 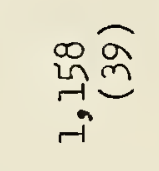 & 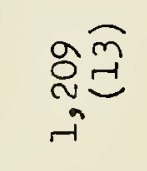 & 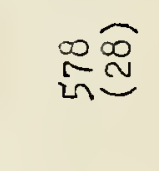 & 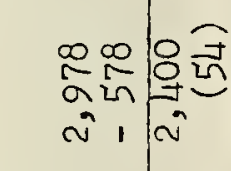 \\
\hline & $F \widehat{\Xi}$ & 绿 & बूल & 的害 & Soñ \\
\hline & 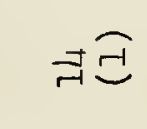 & $\widehat{\infty} \bar{a}$ & $\stackrel{\sim}{\infty} \widehat{\Xi}$ & $m \widehat{\Xi}$ & 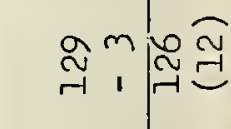 \\
\hline & $\approx \sqrt{n}$ & 궁 & $0 \widehat{0}$ & $\circ \widehat{Q}$ & 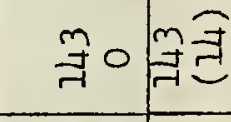 \\
\hline 舅 & 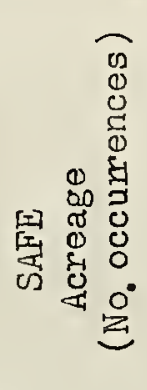 & 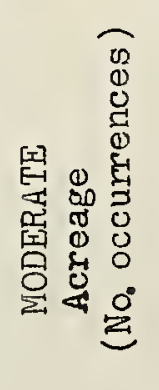 & 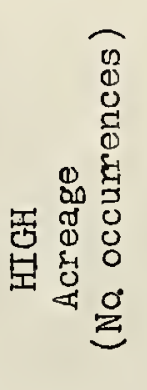 & 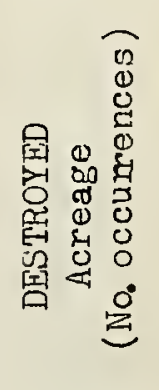 & 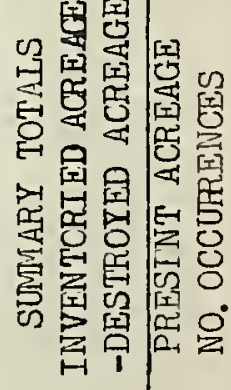 \\
\hline
\end{tabular}




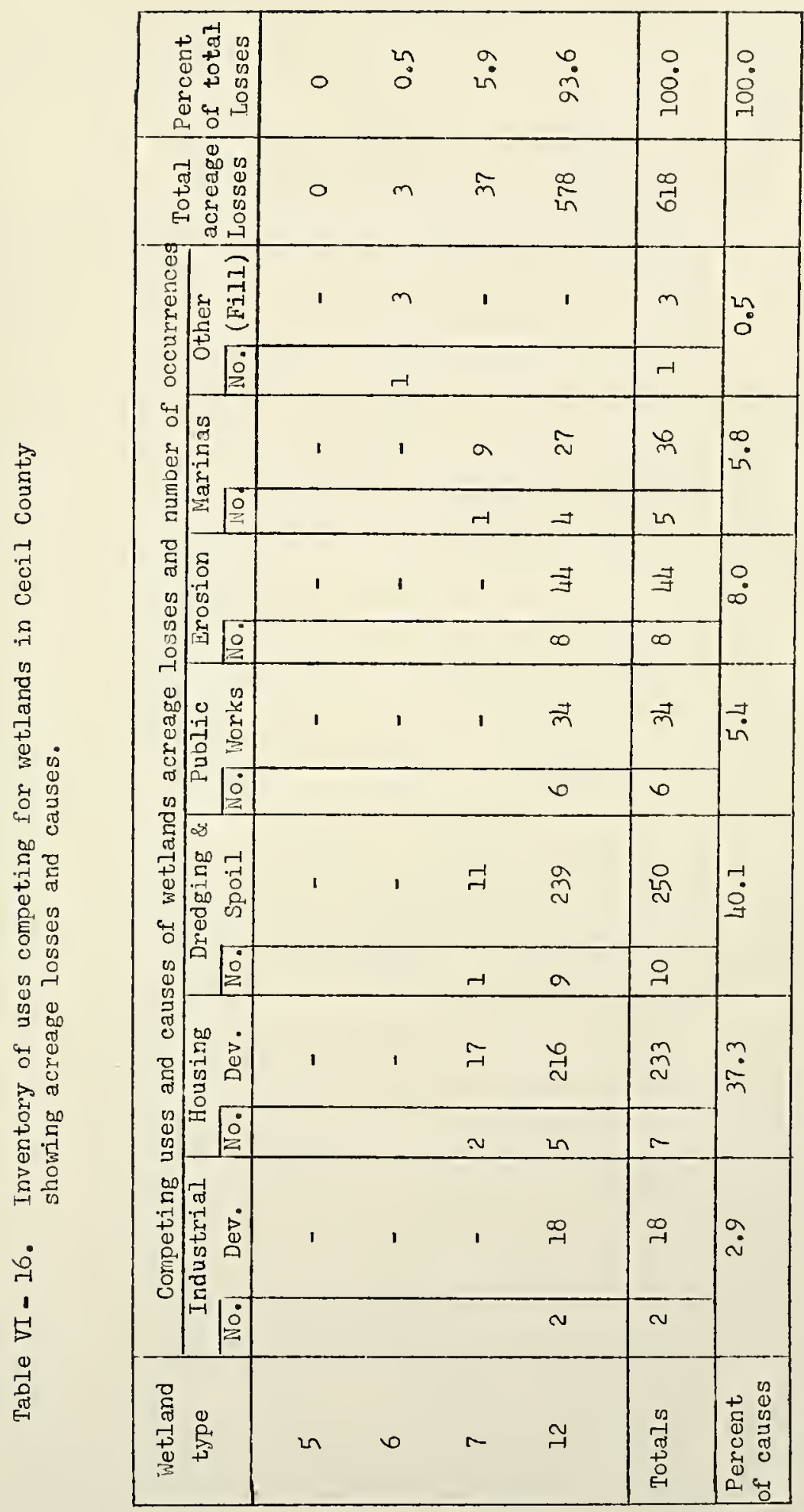


4

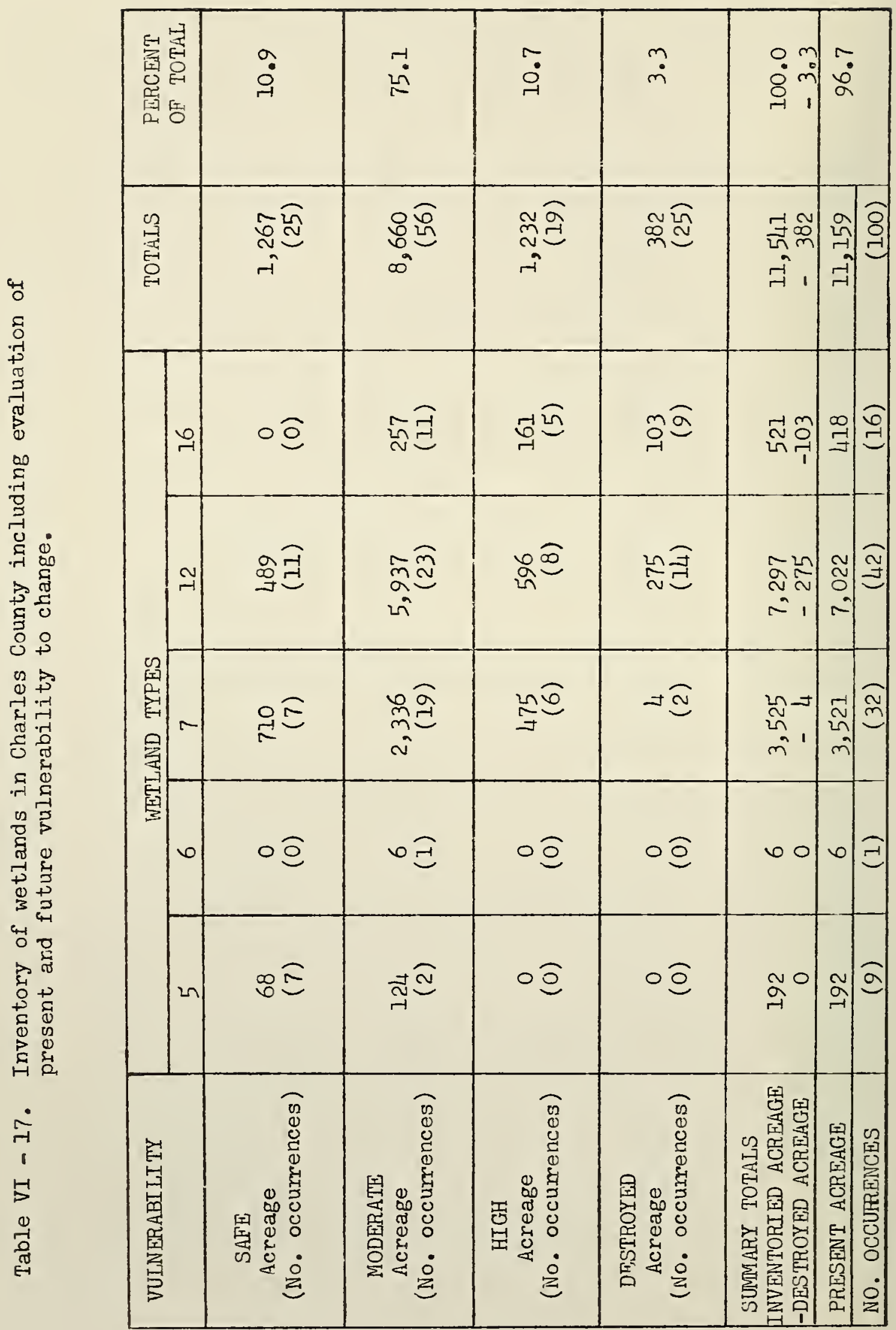




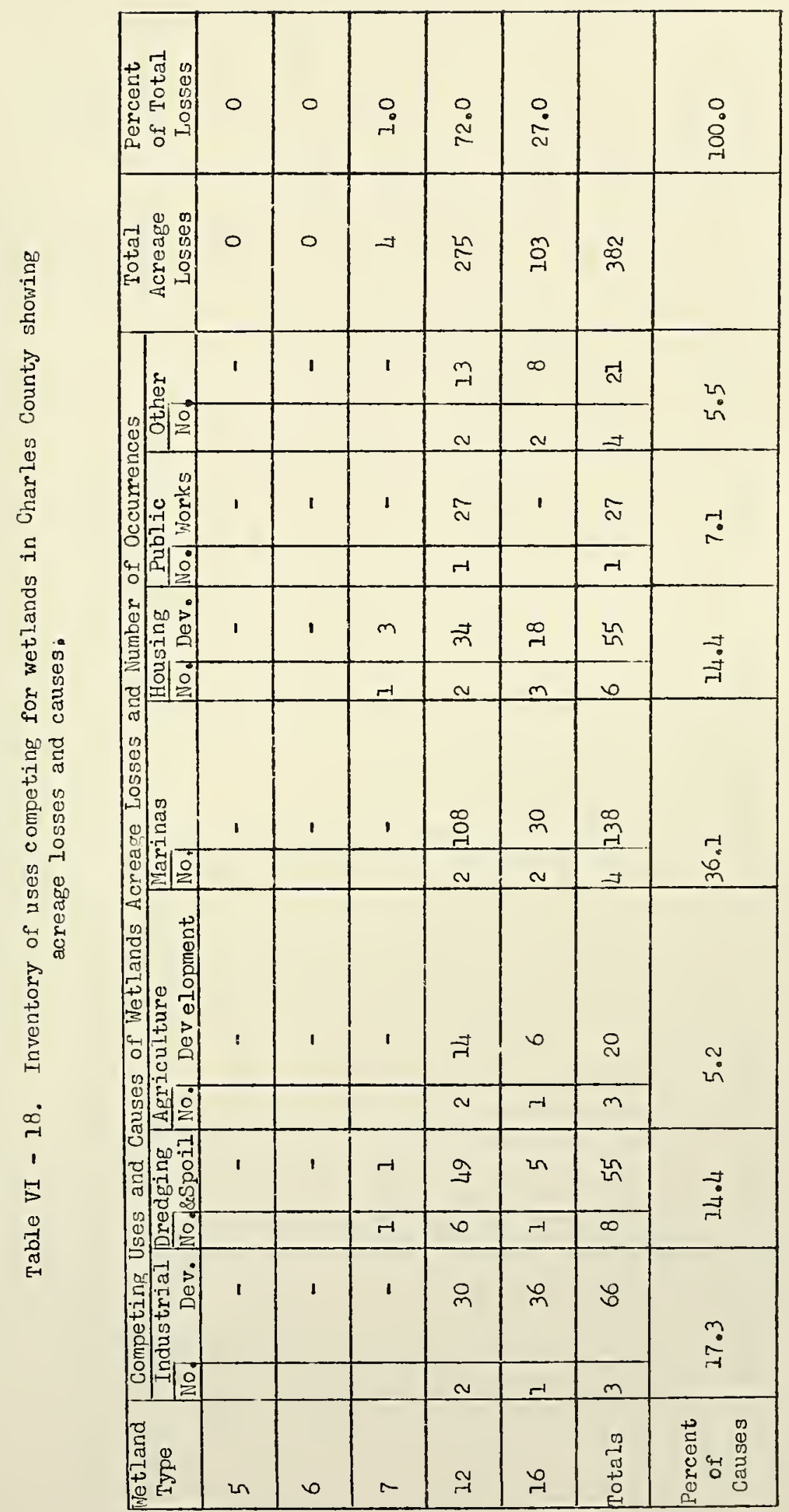




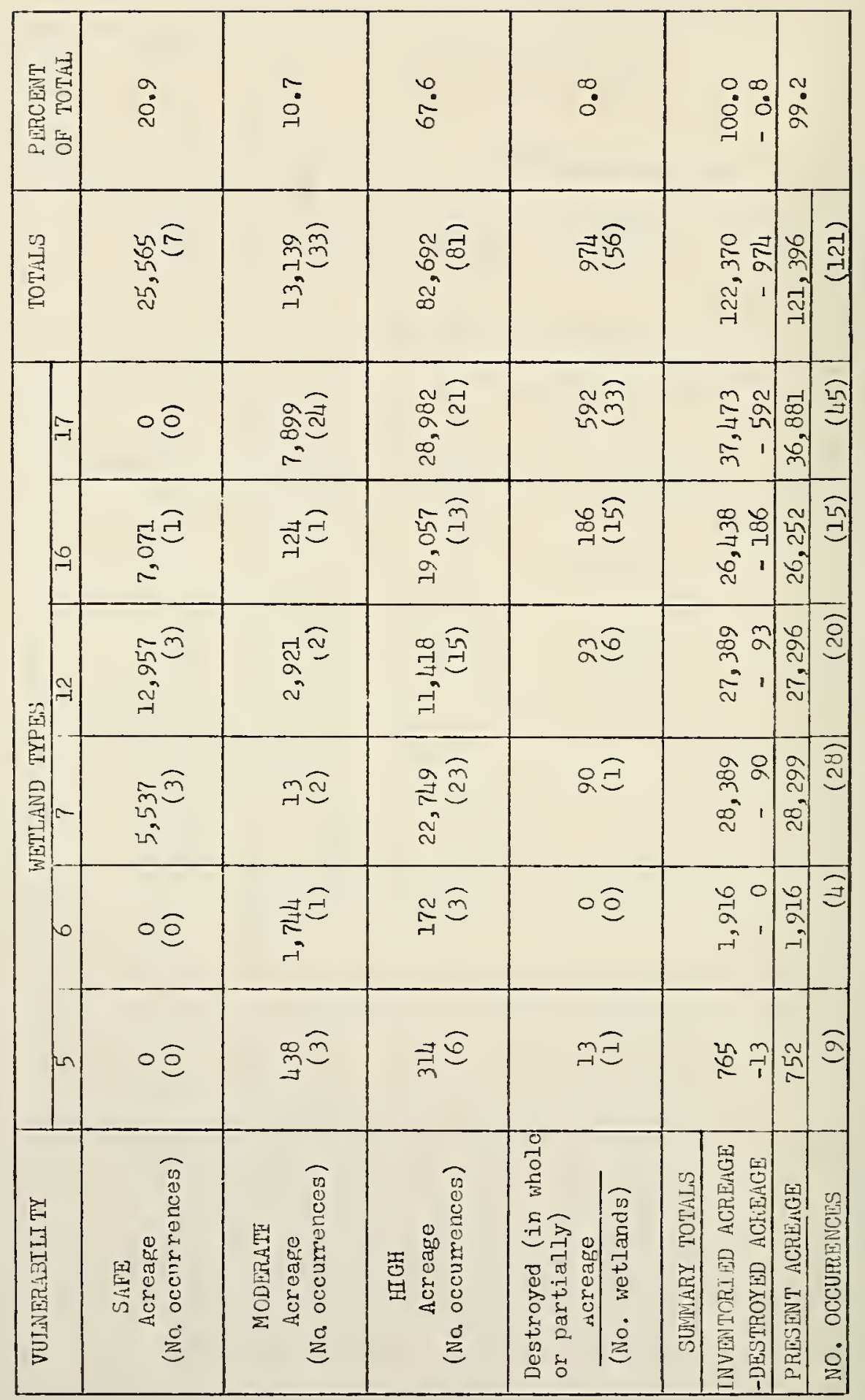




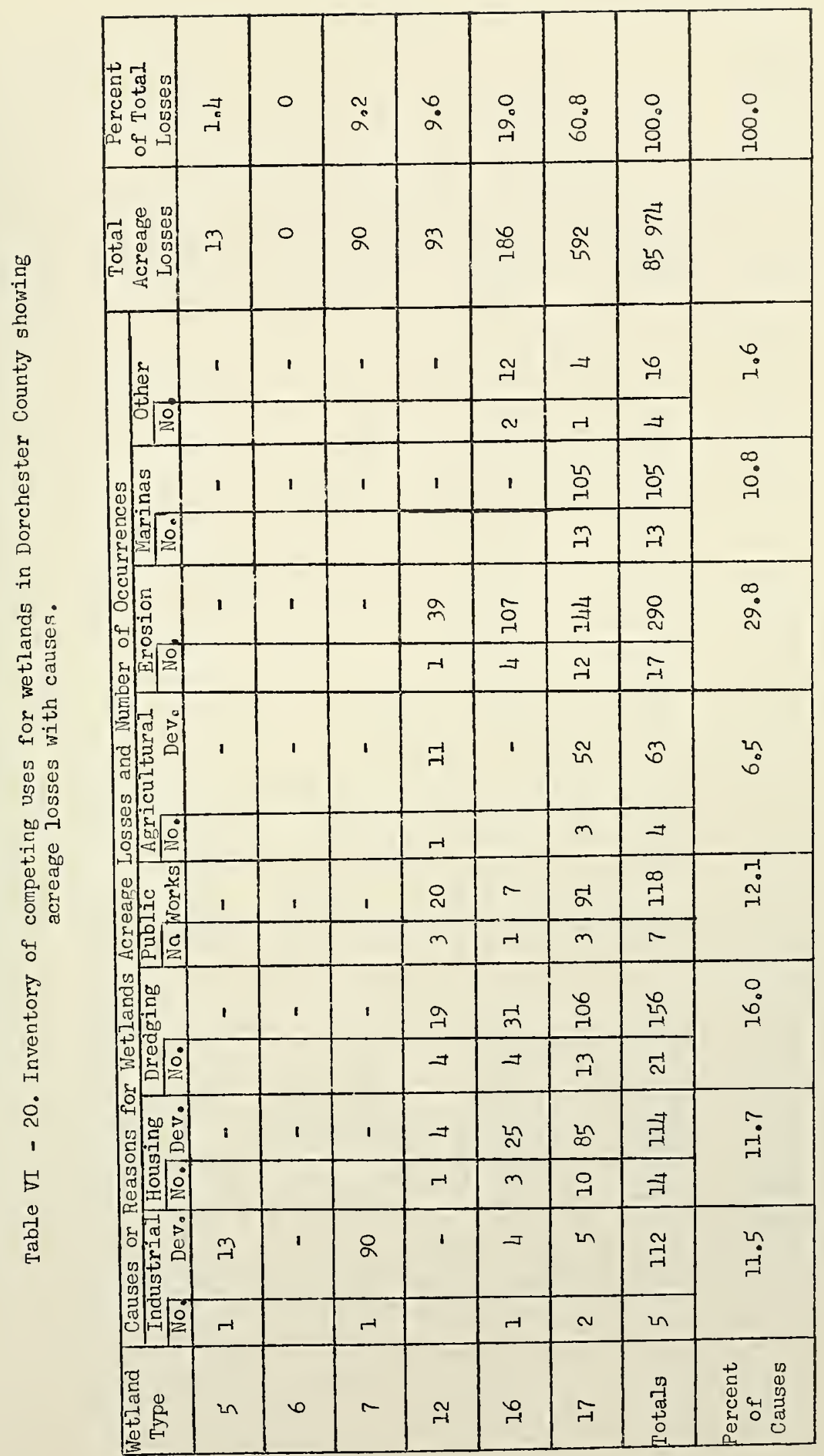




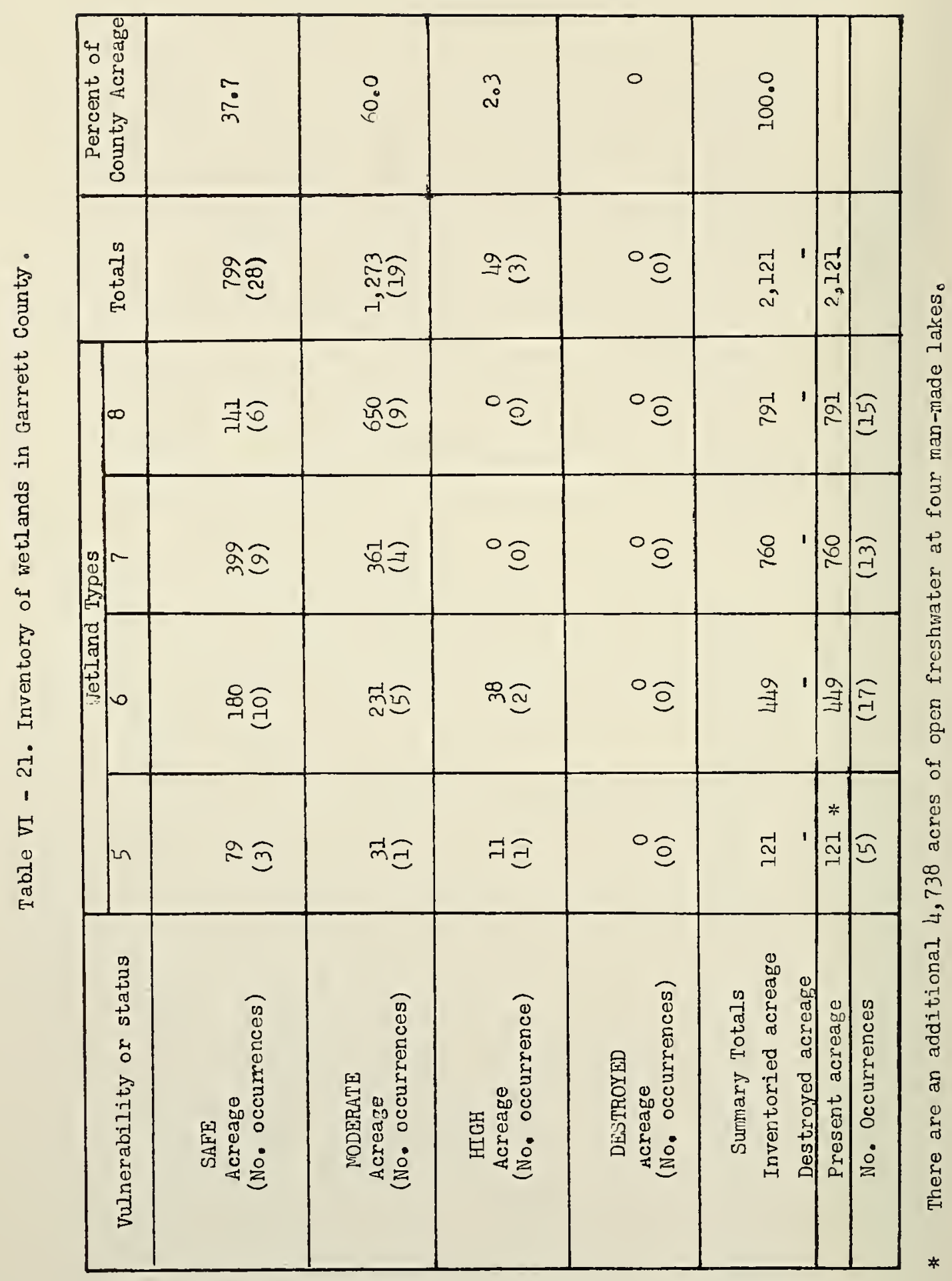




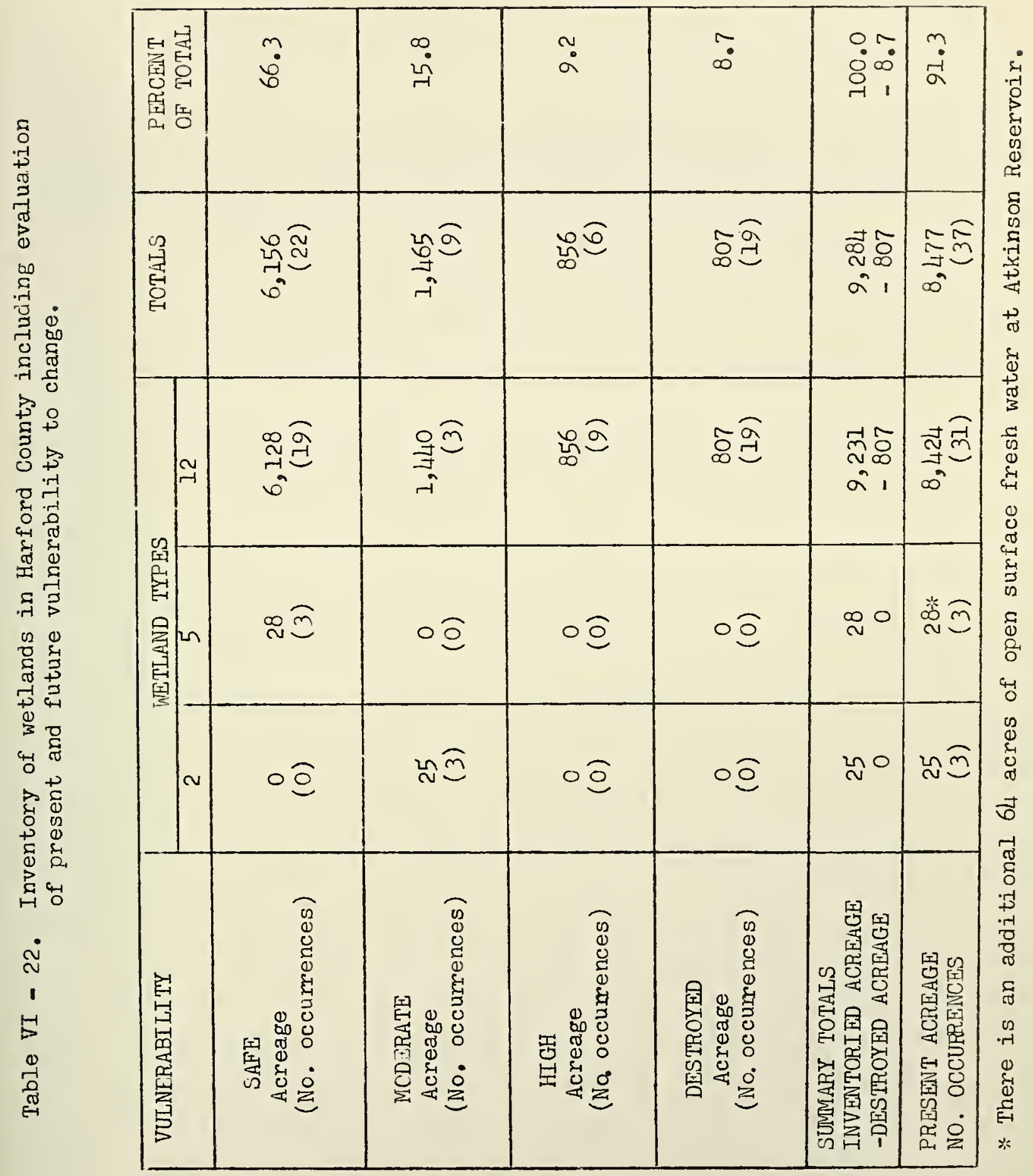


Table VI - 23. Inventory of uses competing for wetlands in Harford County showing acreage losses and causes.

\begin{tabular}{|c|c|c|c|c|c|}
\hline \multirow{2}{*}{$\begin{array}{l}\text { Competing use or } \\
\text { cause of change }\end{array}$} & \multicolumn{3}{|c|}{ Wetland Types } & \multirow{2}{*}{$\begin{array}{l}\text { Total/ } \\
\text { use or cause }\end{array}$} & \multirow{2}{*}{$\begin{array}{l}\text { Percent of } \\
\text { total losses }\end{array}$} \\
\hline & 2 & 5 & 12 & & \\
\hline Industrial develop. & - & - & 20 & 20 & 2.5 \\
\hline Housing development & - & - & 359 & 359 & 44.4 \\
\hline $\begin{array}{l}\text { Dredging \& spoil } \\
\text { disposal }\end{array}$ & - & - & 47 & 47 & 5.8 \\
\hline Public Works & - & - & 125 & 125 & 15.5 \\
\hline Erosion & - & - & 154 & 154 & 19.1 \\
\hline Dumps \& Fills & - & - & 23 & 23 & 2.9 \\
\hline Marinas & - & - & 32 & 32 & 4.0 \\
\hline Other-military & - & - & 47 & 47 & 5.8 \\
\hline Total Iosses/Type & 0 & 0 & 807 & 807 & 100.0 \\
\hline
\end{tabular}




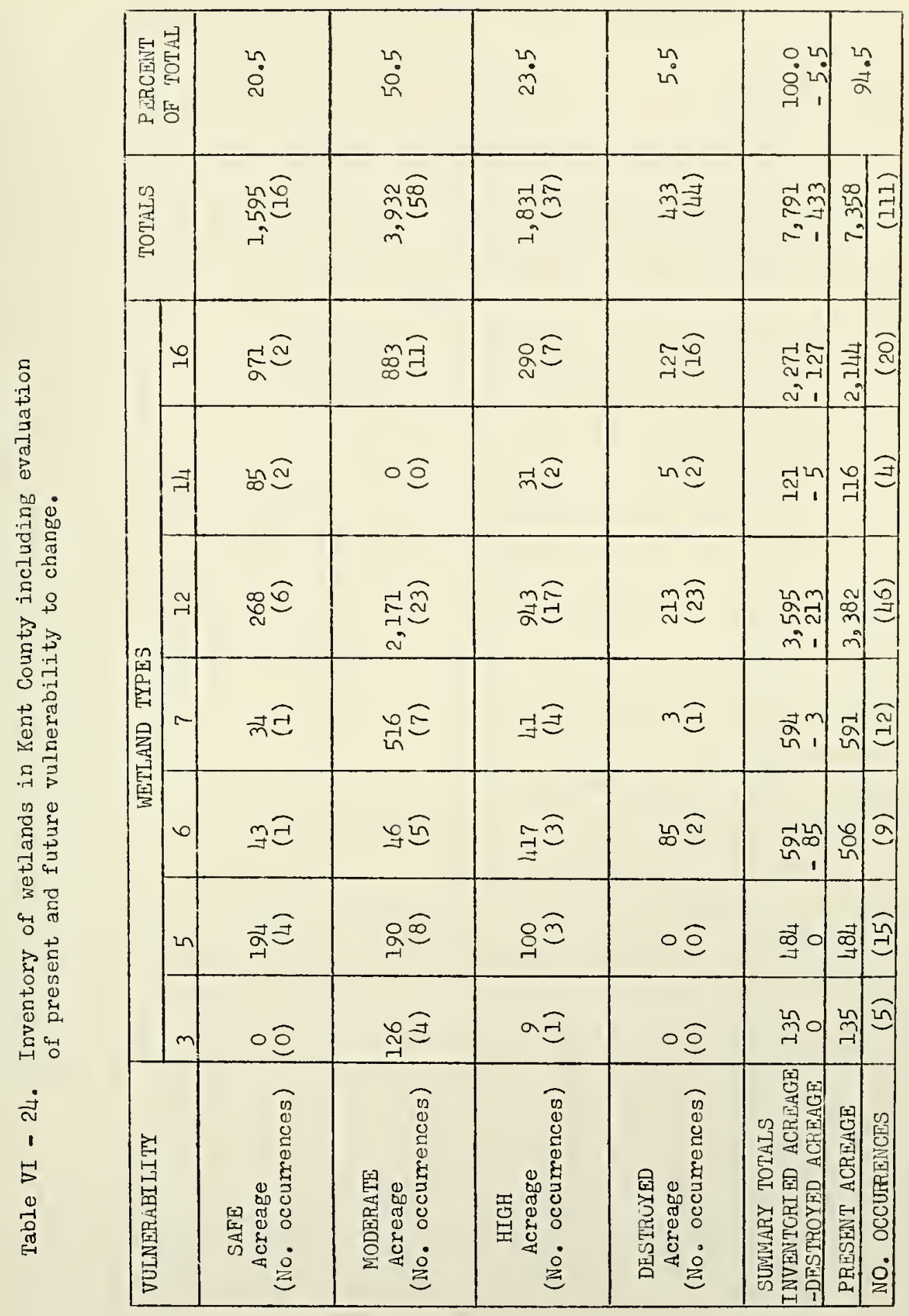




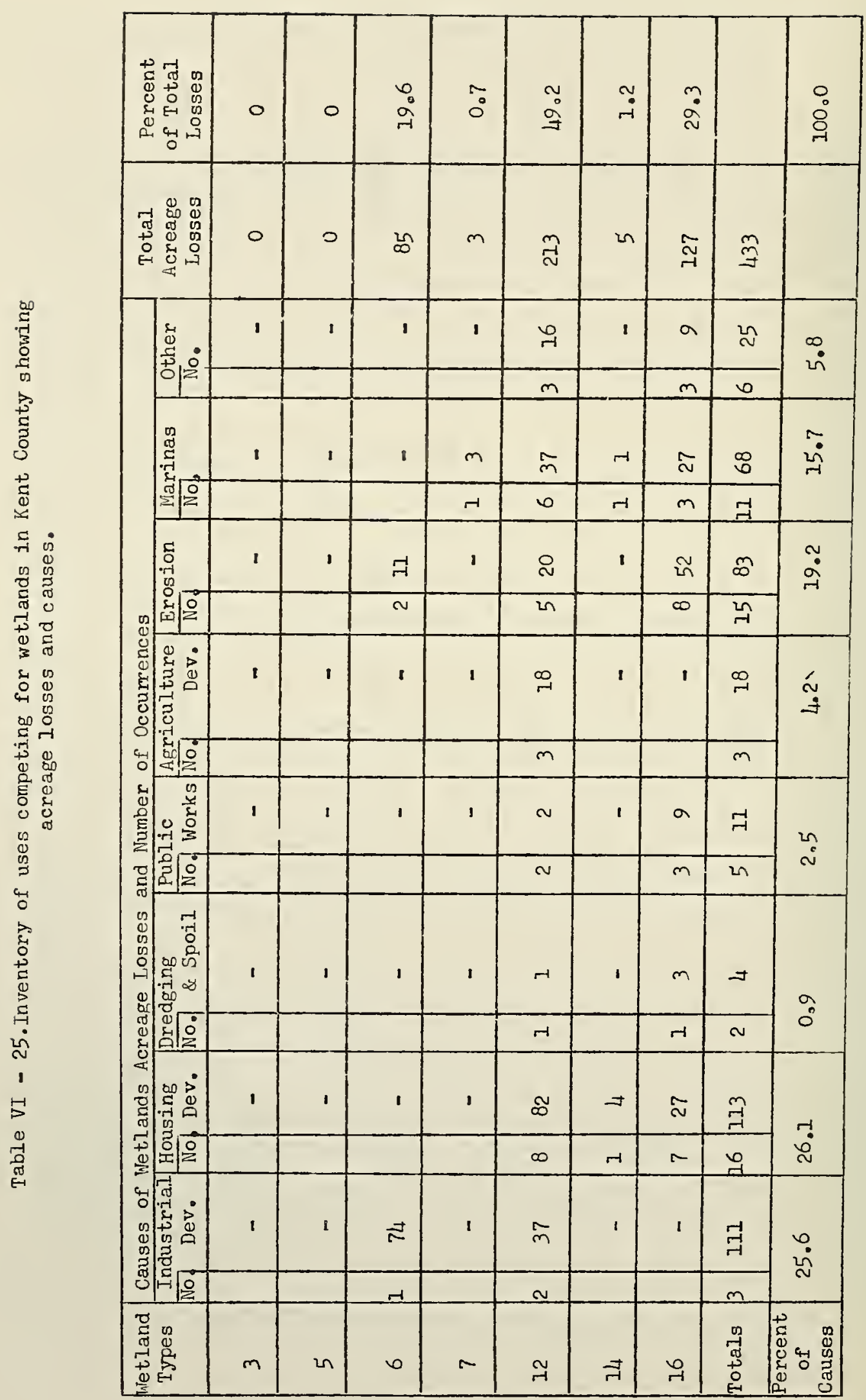




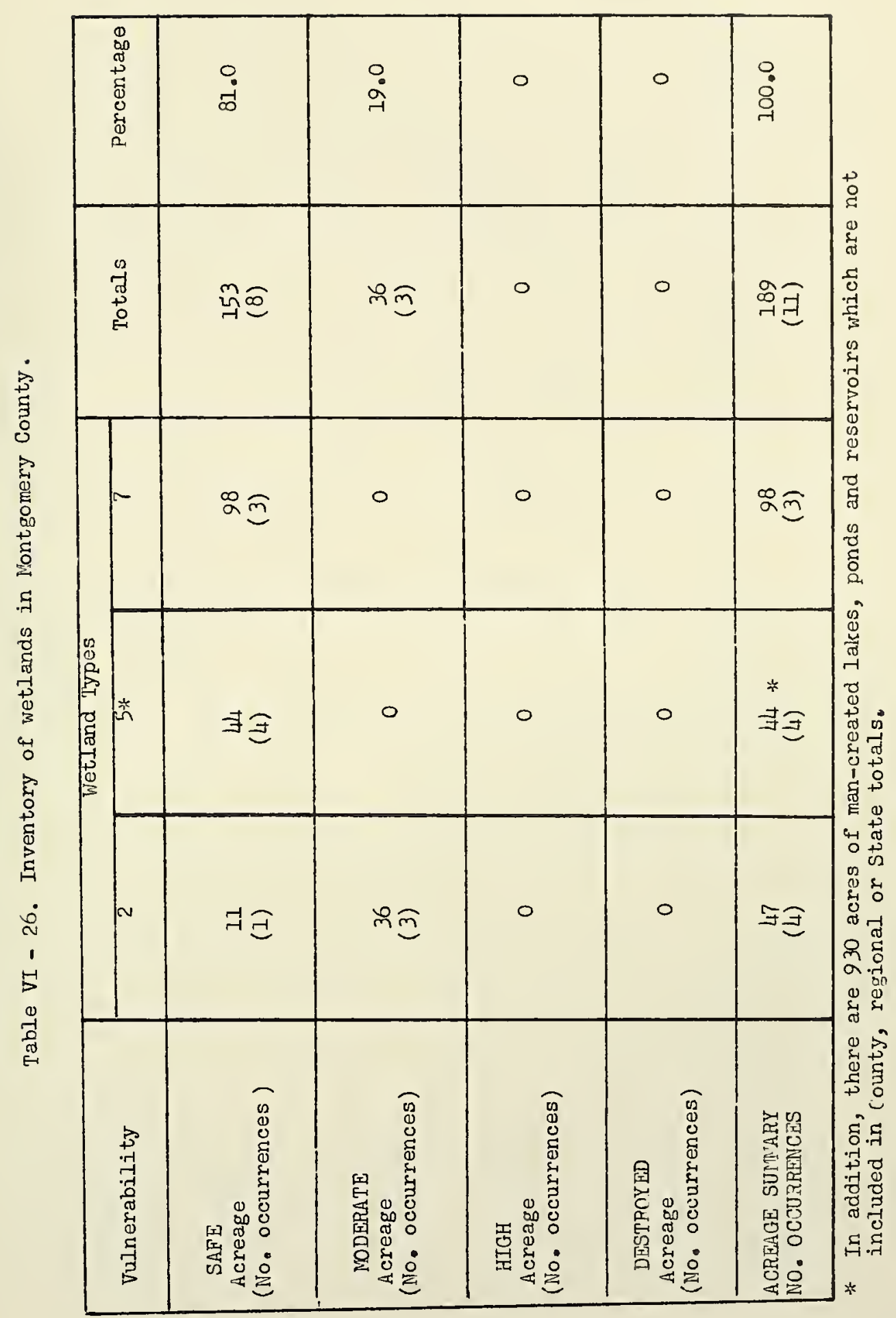




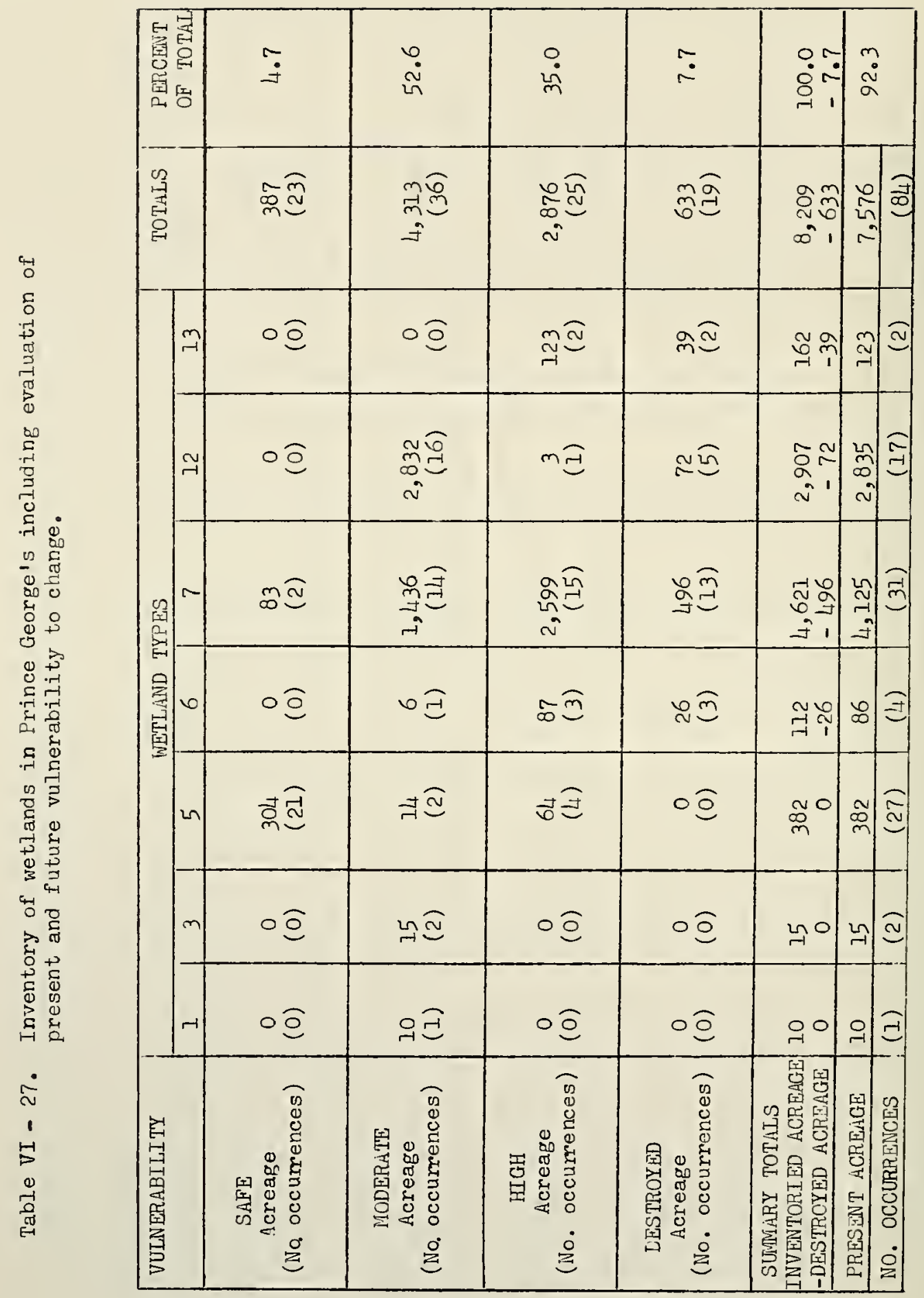




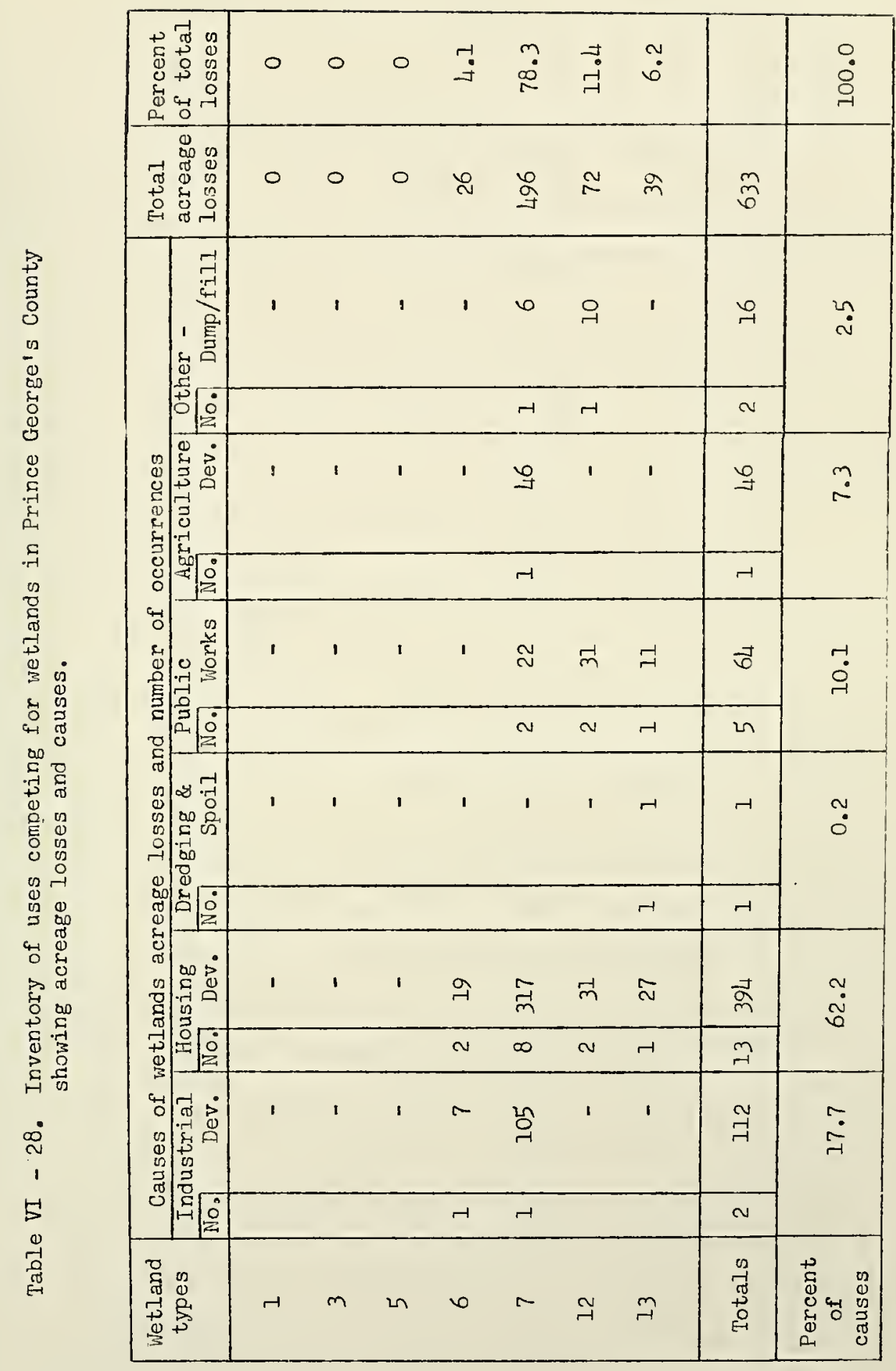




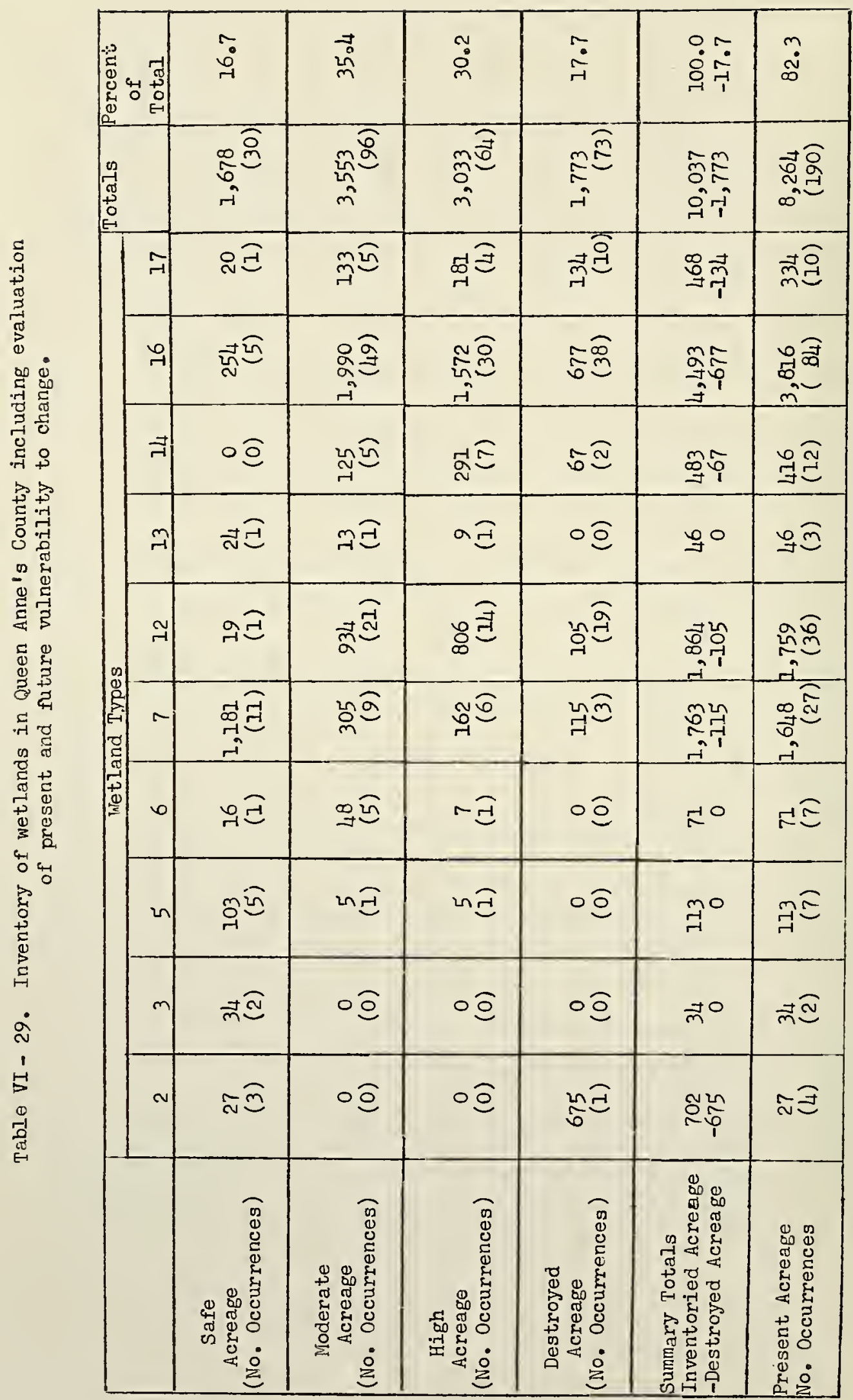




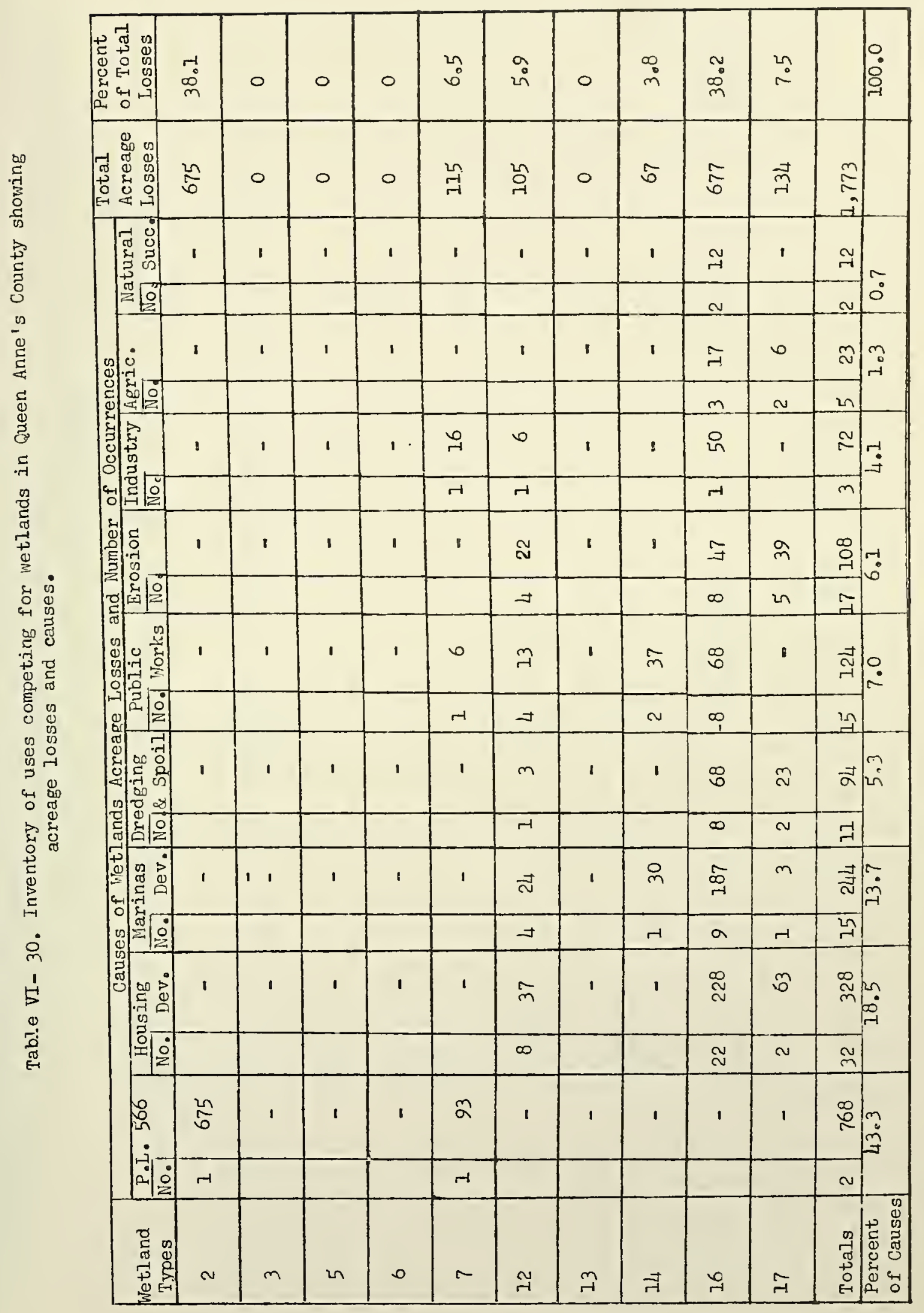




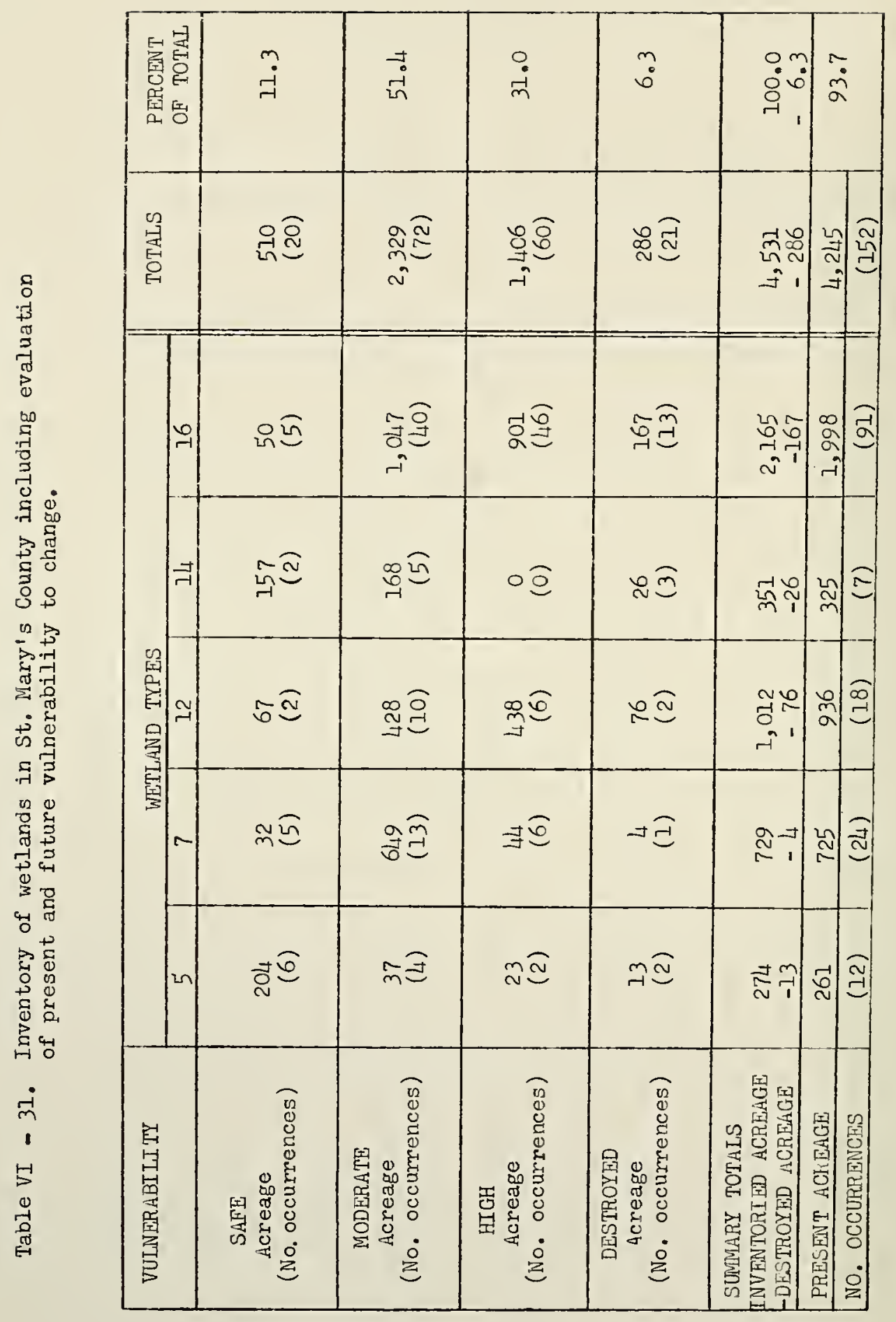




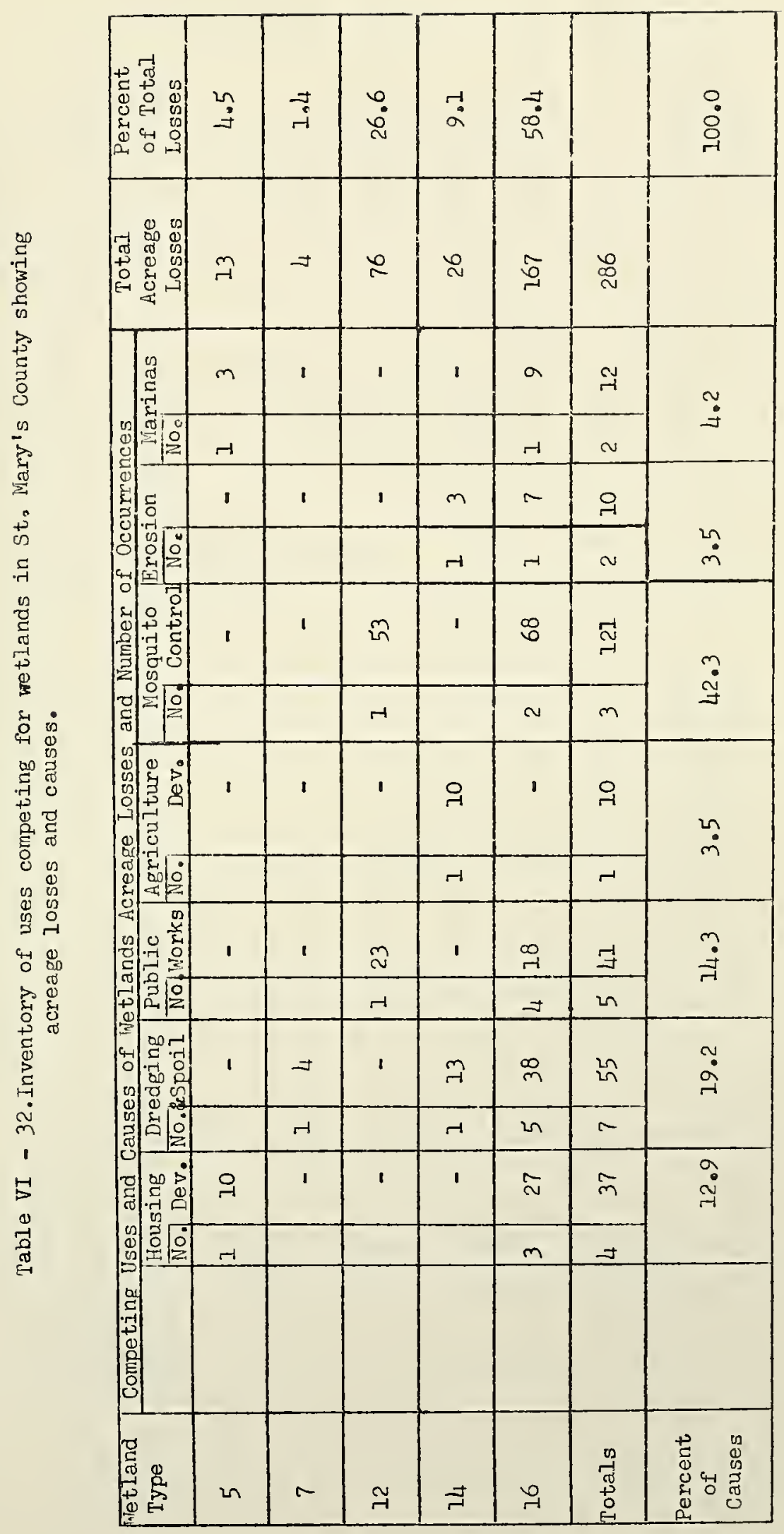




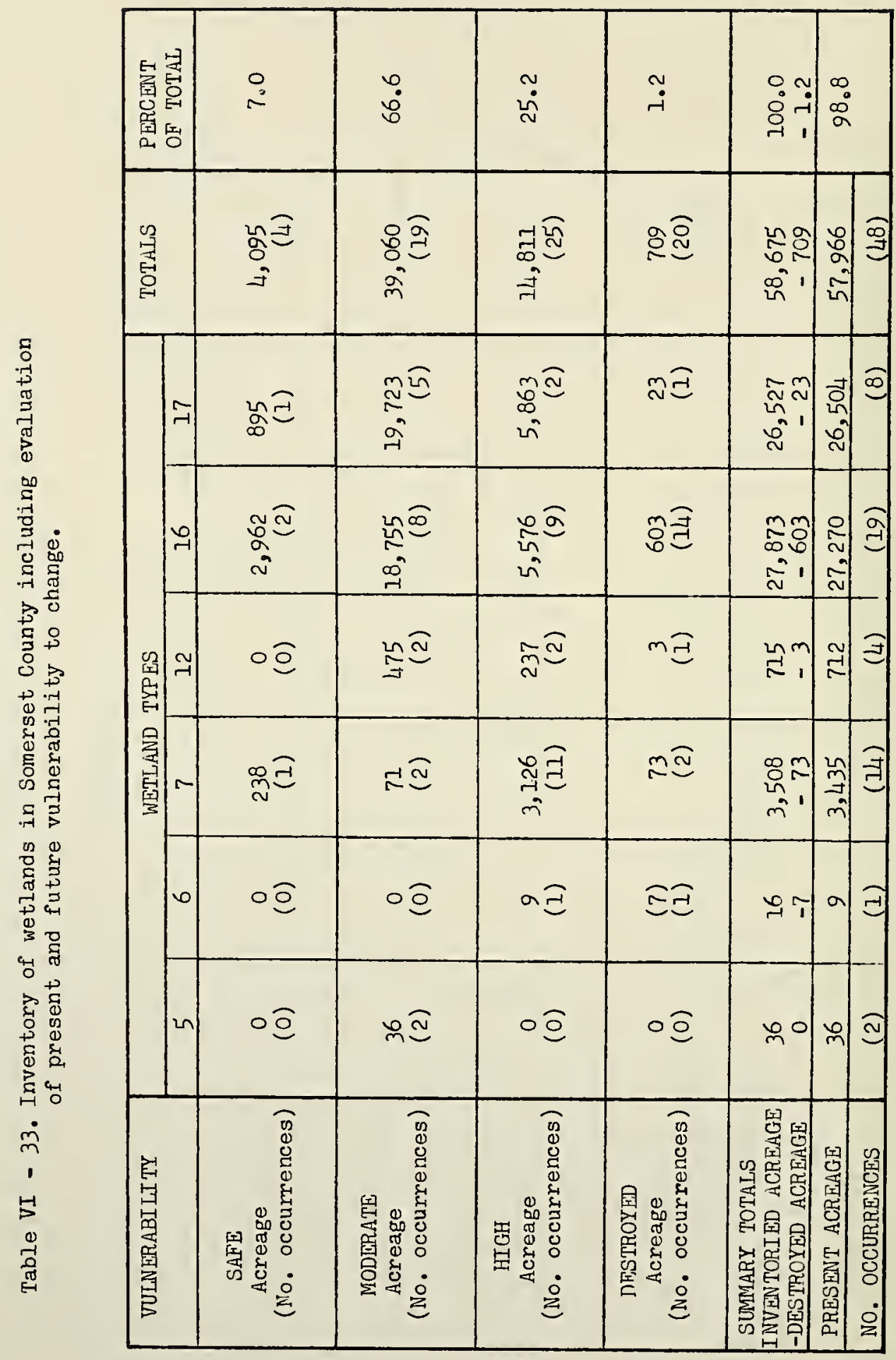




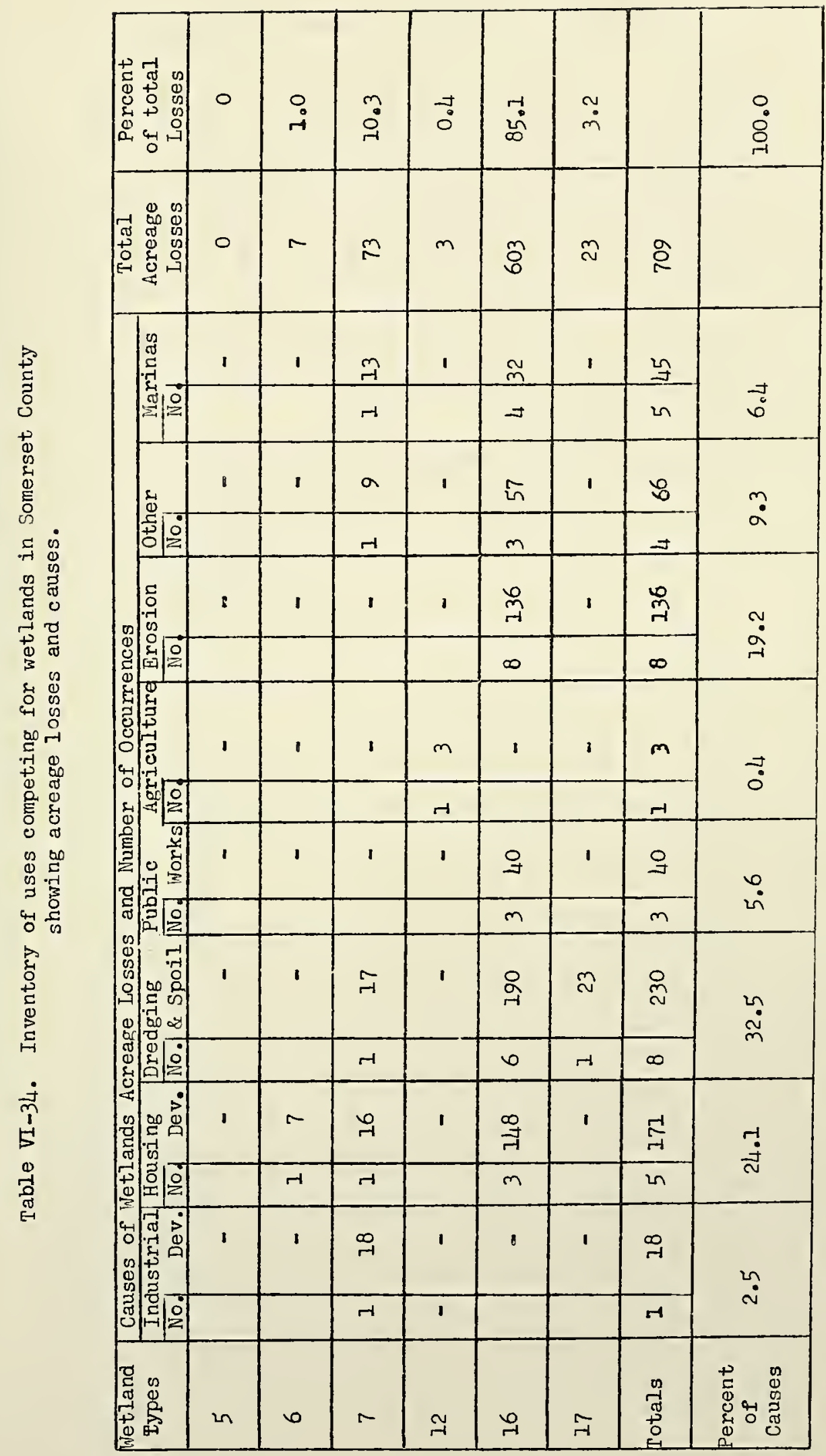




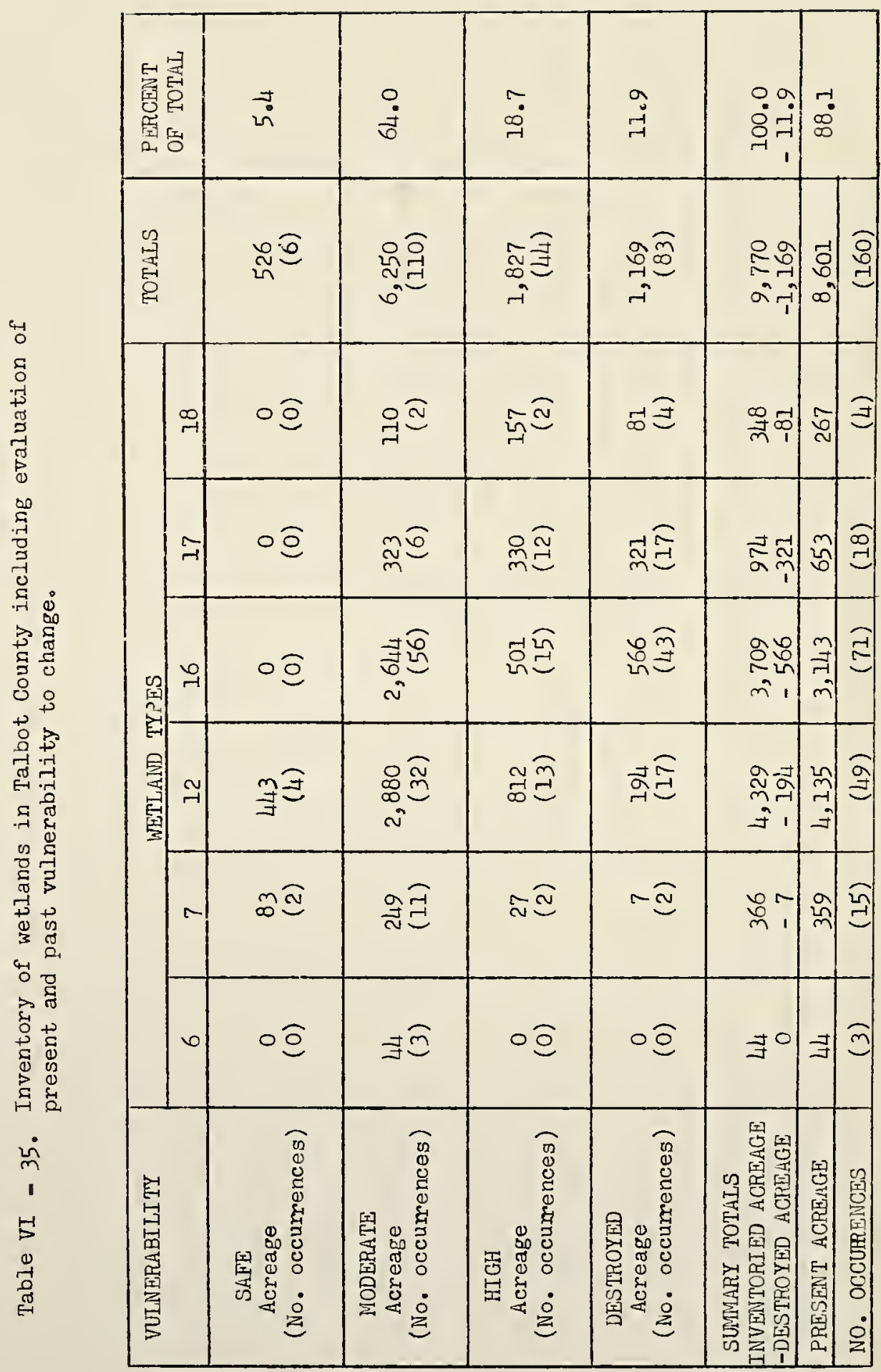




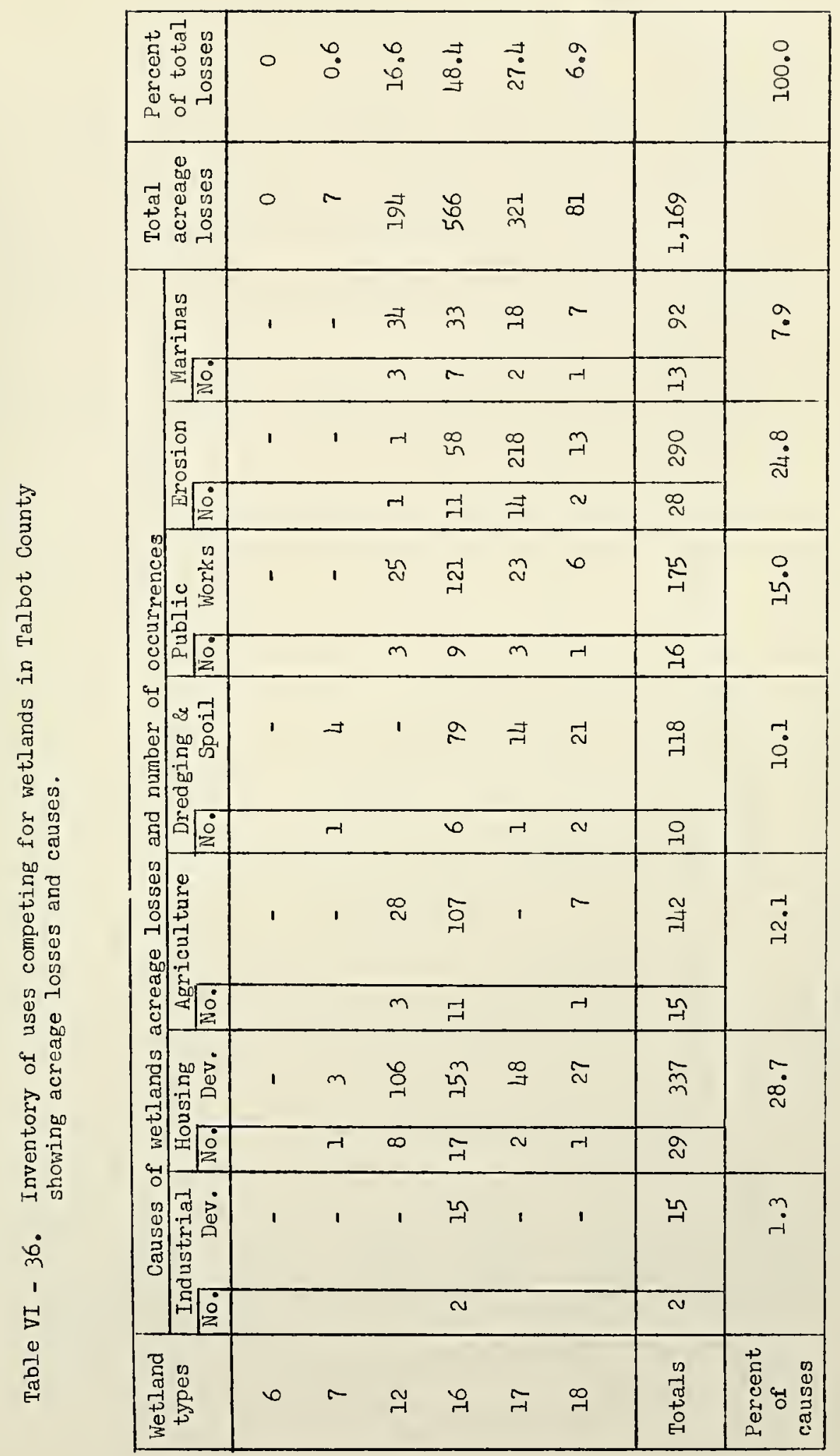




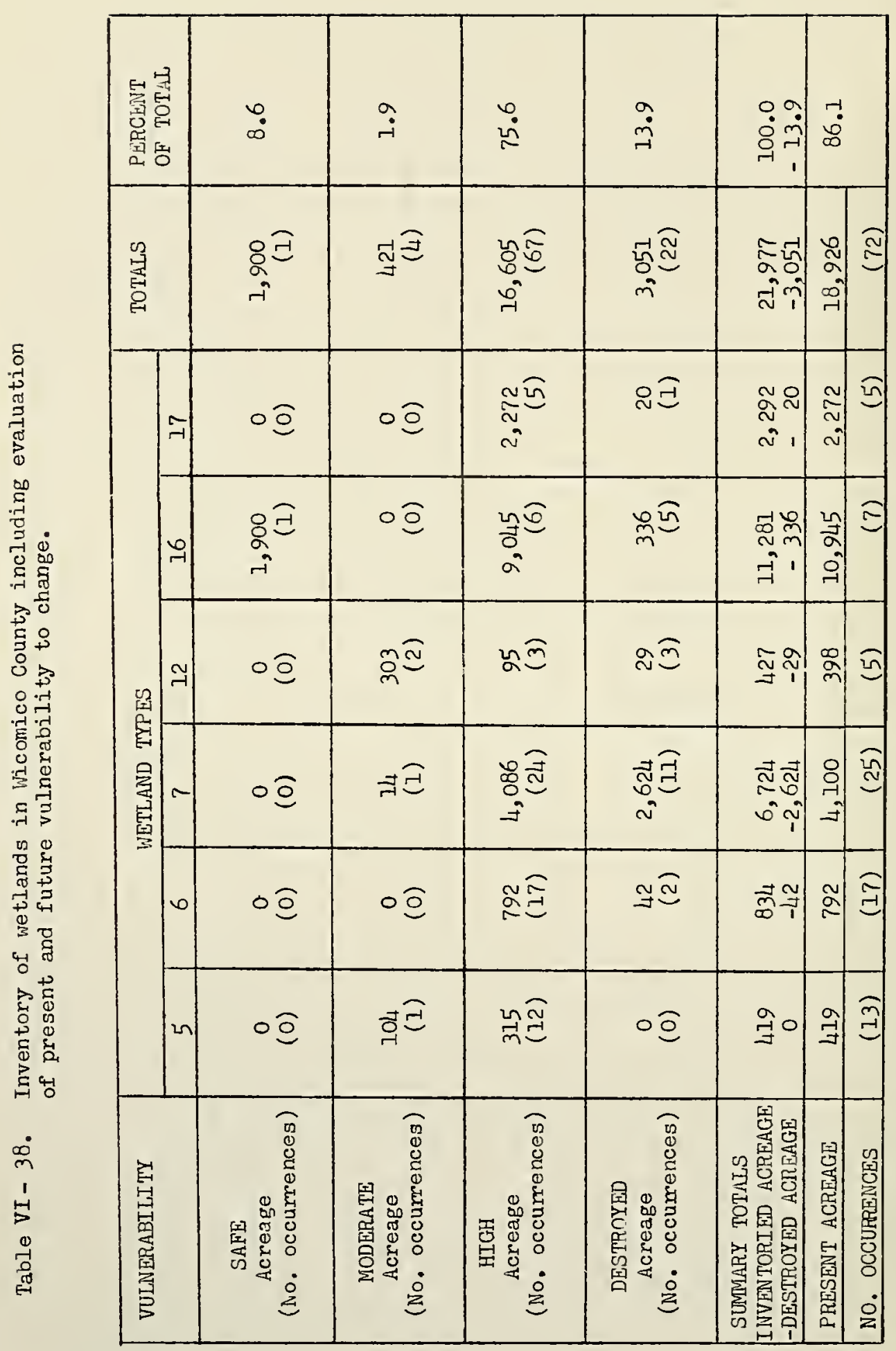




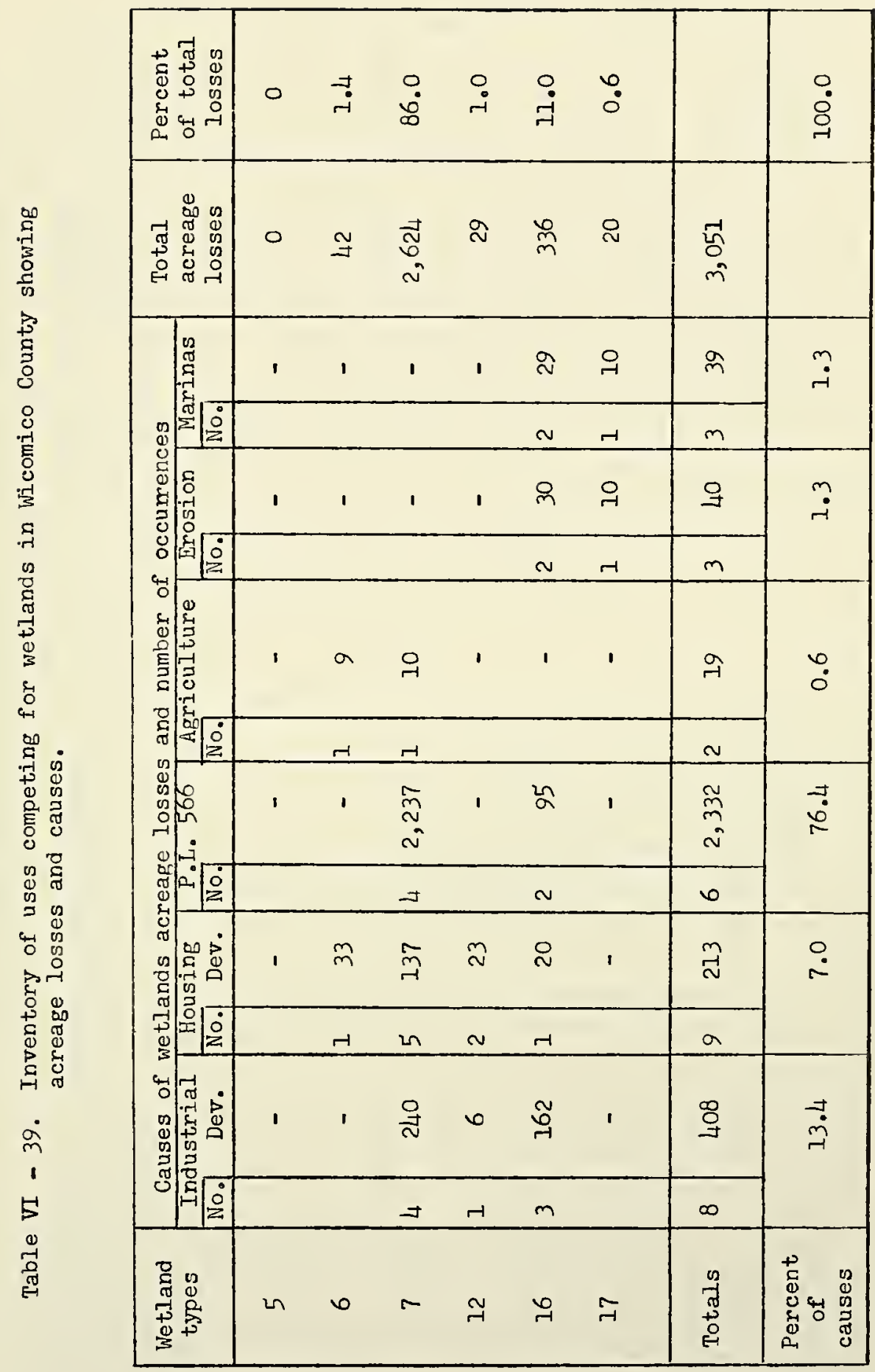




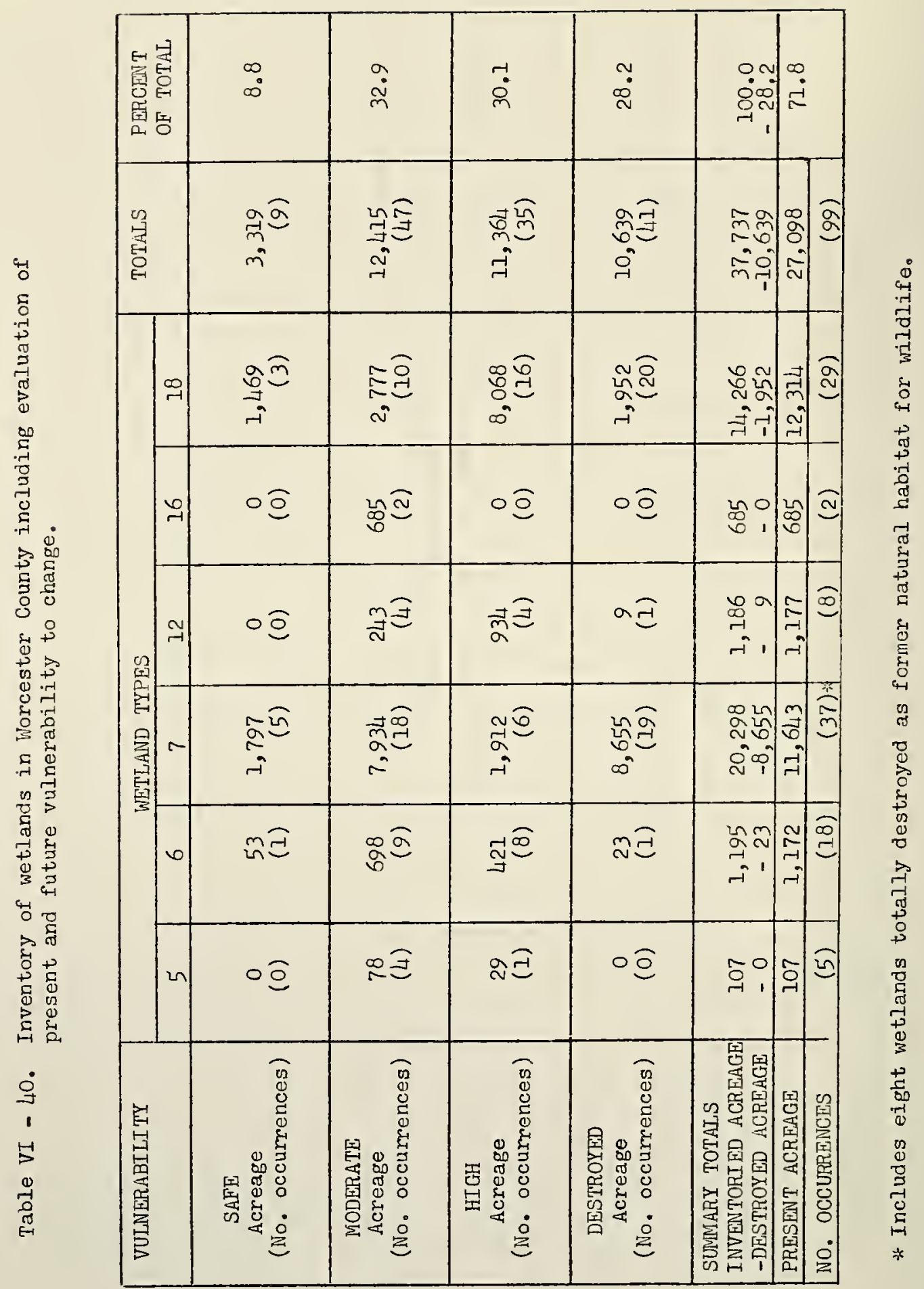




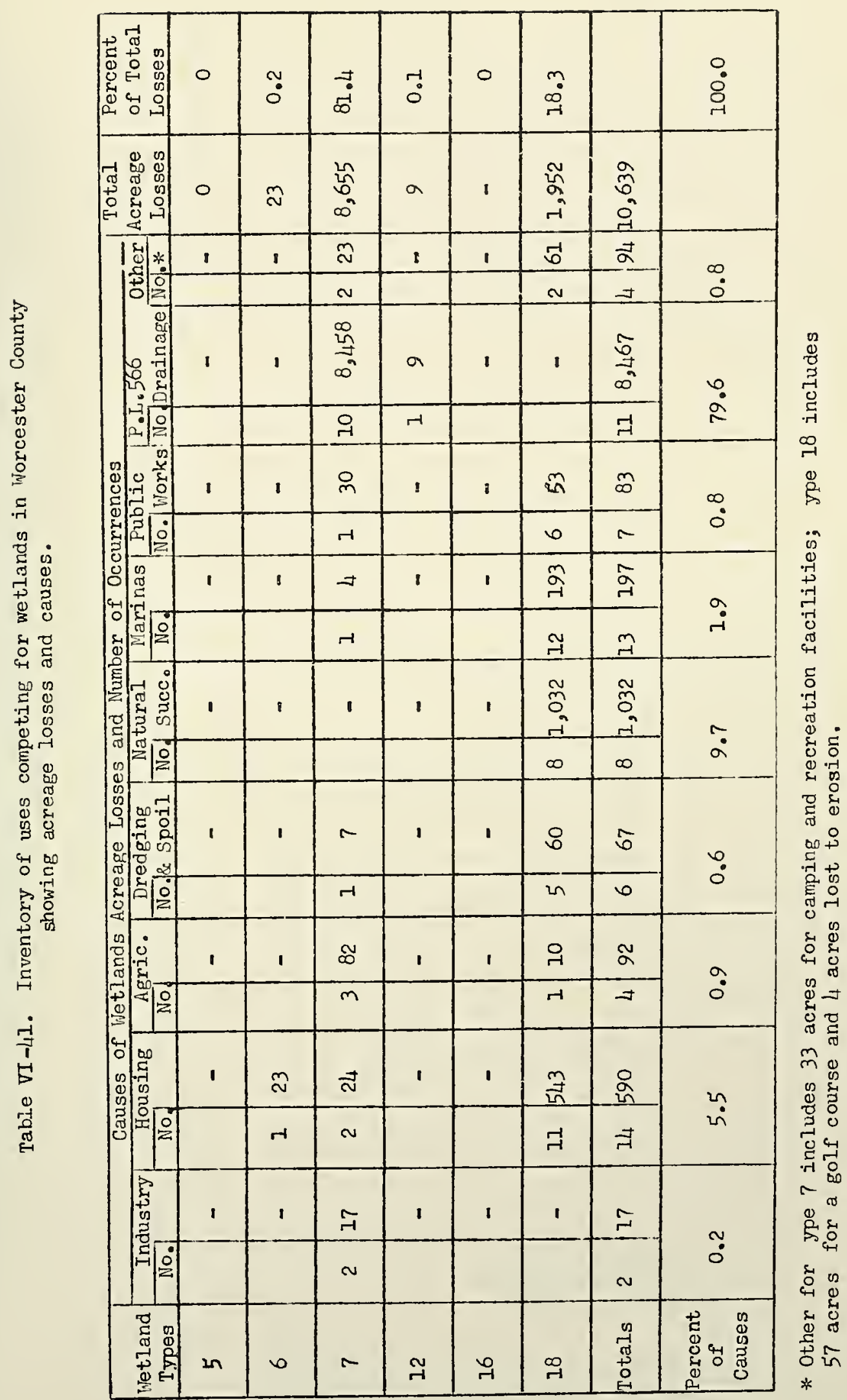





\section{APPENDIX B}

\section{Wetlands Information Retrieval System}





\section{APPENDIX B}

\section{WETLANDS INFORMATION RETRIEVAL SYSTEM*}

To assist the Department of State Planning in establishing a wetlands data processing system which would systematize collected data, organize, store and retrieve the programmed information, assistance was solicited from private organizations with competence in operations research, systems analysis, and automatic data programming and processing. From among the responses received the one most attractive on financial and operational bases was the proposal presented by Link Information Sciences (LIS) of General Precision Systems, Inc.

The basic feature of the LIS proposal was an information retrieval system that would permit complete and immediate access to the data collected by the Wetlands Technical Advisory Committee. The information, when encoded, would be stored in machine readable form for State-operated computers and accessed (or retrieved) by use of the proposed retrieval system.

The system developed by LIS for the Department of State Planning and now operational is a program for retrieving stored information. It is not a panacea for resolving all information problems nor does it provide decisions. The system is designed to extract answers from text data, user-specified format data and compiled file data in response to a user's query.

Figure B-1 shows the basic organization and operation of the wetlands information retrieval system. A question or query at (1) is formulated to extract desired information. The question is addressed to the system's programmed information at (2). An important aid to questioning the program is the wetlands thesaurus (3), a dictionary containing all individual or distinct words, abgreviations, and notations that have appeared at one time or another on all the wetlands habitat file data sheets (4) shown in Figures VI-1 and VI-2 (Ch. VI). The reply to a query will be in the format shown in abbreviated form (Figure B-2).

Depending upon the nature of the requested information, the response is programmed to respond and print out in either a special, standard or random request report format (5). Without eleborating further on technical details which are beyond the scope of this appendices, it is perhaps more informative to illustrate briefly what can be produced in terms of user interest.

The system will answer such questions as what is the total acreage (of a specified wetlands habitat) for each county (Figure B-2) and also for the entire State. Some additional sample questions might be-list wetlands over 50 acres of Type 12 (wooded swamp) by county-by the entire State. List wetlands that possess a unique habitat value ranking of 10 (for endangered species such as the bald eagle, Haliaetus leucocephalus, or the Bryant fox squirrel, Sciurus niger cinereus). List wetland units and acreages by county or entire State evaluated to be in the highly vulnerable category (potential acreage losses within 5 years). Obviously, the question and answer combination possibilities of fered the wetlands information retrieval system are, indeed, endless.

With regard to the future utility of the system following completion of the study, it is envisioned that the system will be especially useful in evaluating applications to the Corps of Engineers and Department of Water Resources for permits for tidewater construction and water resources development projects proposed under Public Law 566 administered by the U.S. Soil Conservation Service. The system should also produce helpful insight into ways of developing future and enlarged systems that might combine many additional parameters such as those on water quality to develop an estuarine management data processing system. The complexities and dynamic properties of estuaries, the mix of its inhabitants, and the characteristics or qualities essential to them imply a requirement of large amounts of data. The only possible way of effectively handling all of the necessary data so as to produce meaningful information and insight can be handled only by computers directed by relevant programming.

For more, detailed information on the system refer to the report, Orientation Manual and User's Guide Maryland Wetlands Information Retrievel System, Maryland Department of State Planning Publication No. 157.

*This system is presently under review and re-evaluation. 


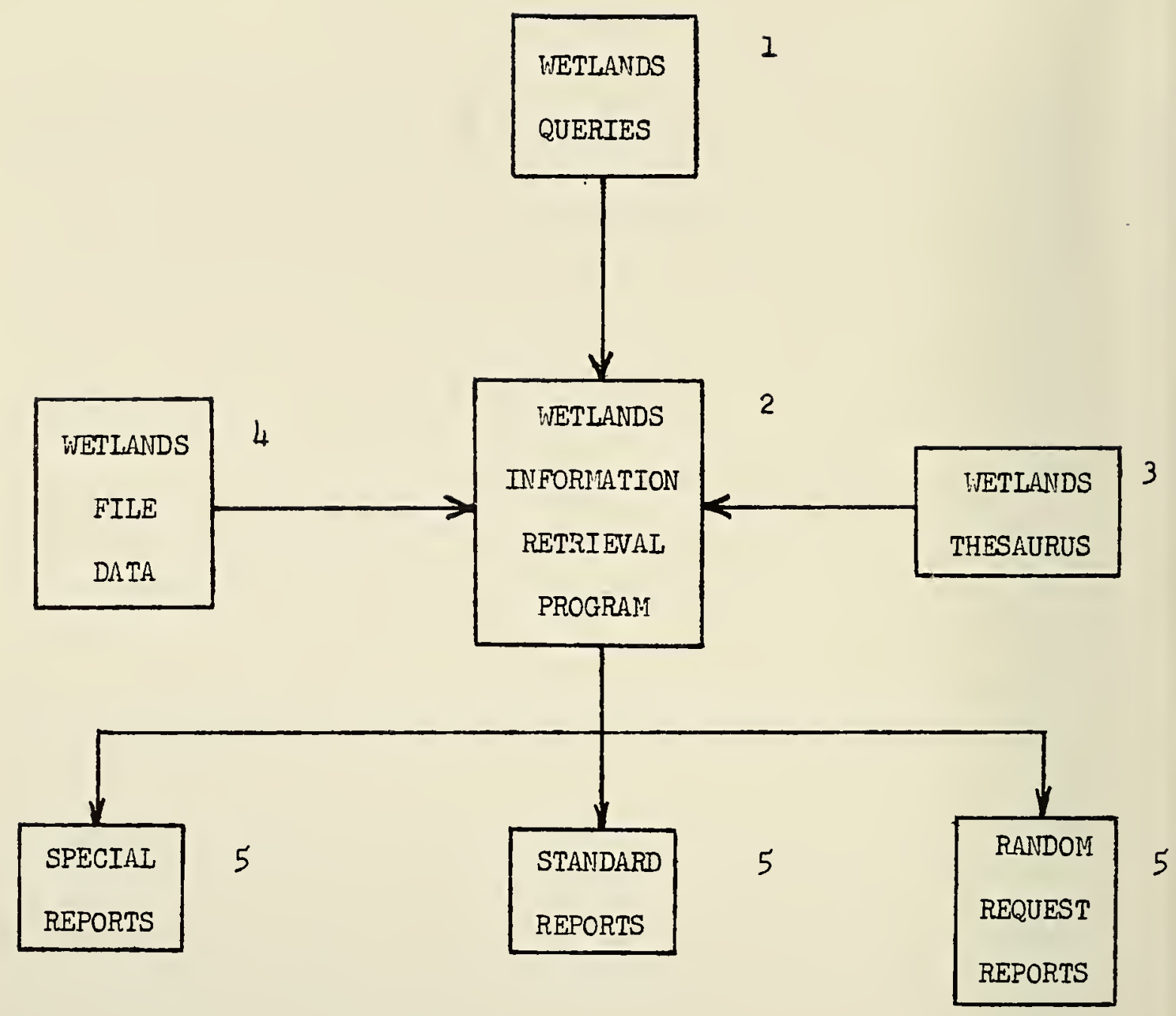

WETLANDS INFORMATION FLOW

Figure B-1. Basic organization and information flow of the wetlands information retrieval system (Courtesy of LIS, I968). 


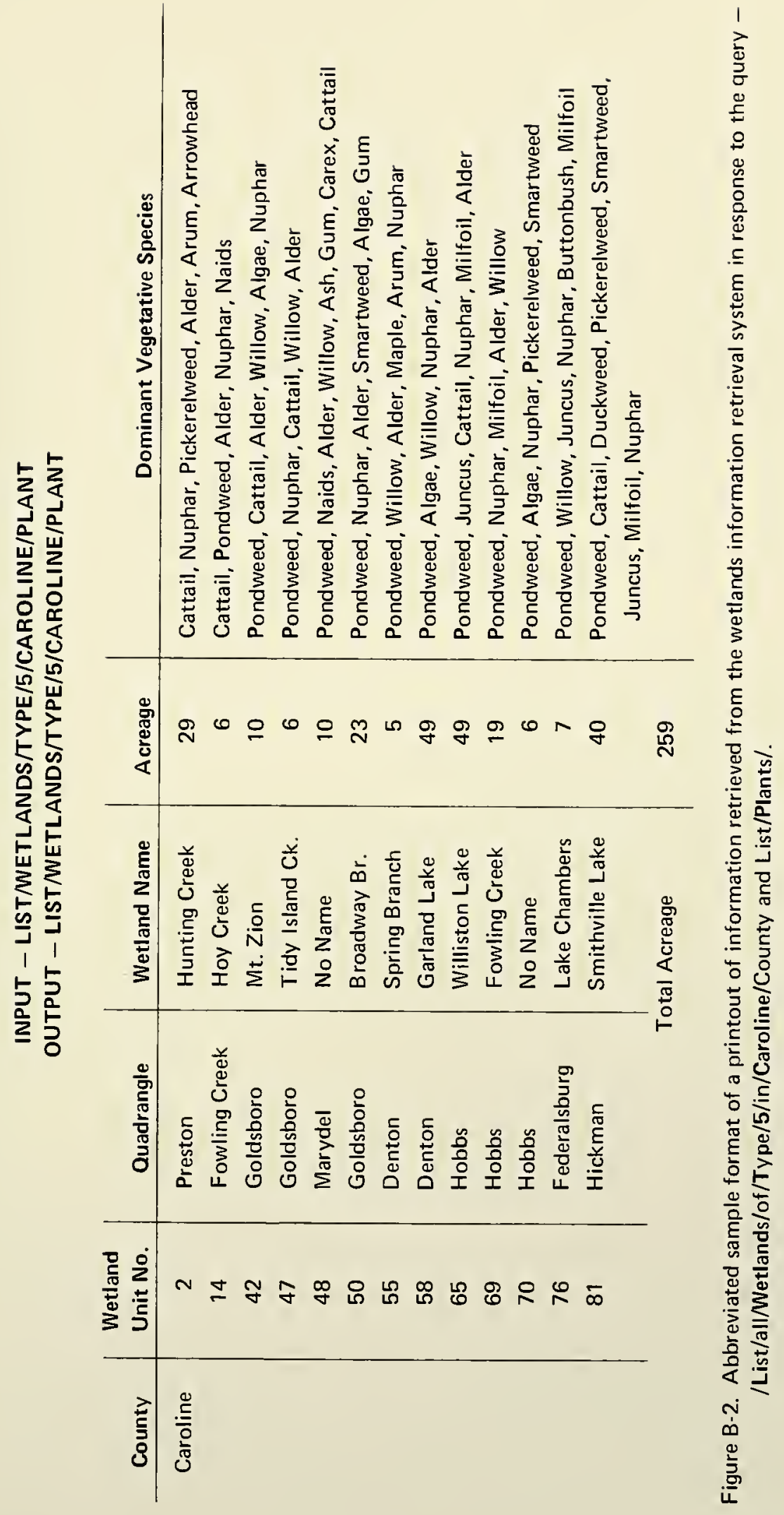



APPENDIX C

House Joint Resolution No. 2 (1967) 



\section{APPENDIX C}

House Bill No. 2-By The Speaker (Legislative Council) - 1967.

\section{HOUSE JOINT RESOLUTION TWO}

House Joint Resolution requesting the State Planning Department, with the cooperation of the Board of Natural Resources and the Department of Economic Development, to prepare a detailed long-term plan for the optimum use of wetlands in the State of Maryland.

WHEREAS, Wetlands are defined as areas on which standing water, seasonal or permanent, has a depth of six feet or less, and where the wet soil retains sufficient mositure to support aquatic or semi-aquatic plant growth; and

WHEREAS, The State of Maryland possesses more that 300,00 acres of coastal and inland marshes, wooded swamps, and other types of wetlands; and

WHEREAS, The wetlands produce the basic micro-organisms and other foods upon which the commerically important finfish, shellfish, and crabs of Chesapeake Bay are dependent; and

WHEREAS, The wetlands have parallel roles as critical habitat for wildlife, particularly migratory waterfowl and furbearers, and as key areas for fish spawning; and

WHEREAS, The wetlands are essential water storage areas for ground-water recharge and flood prevention; and

WHEREAS, Additionally and of emerging significance, the wetlands have vital outdoor recreation, open space, and aesthetic values to the people of our State, and

WHEREAS, The rapid rate of draining, filling, and other altering of Maryland's wetlands is causing serious disturbance to the economic, biologic, hydrologic, and recreational functions of the wetlands; and

WHEREAS, Projected increases in population and industrial activity indicate that accelerated alteration of wetlands soon will be attempted; now therefore, be it

Resolved by the General Assembly of Maryland, That the State Planning Department, in cooperation with the Board of Natural Resources and the Department of Economic Development, is hereby requested to prepare a detailed long-term plan for the optimum use of all Maryland wetlands, such plan to be based so far as is possible upon the results of economic, biologic, hydrologic, and recreational research previously completed or underway in Maryland and in other states or nations having comparable wetland types and functions; and be it further

Resolved, That the preparation of this plan be scheduled for completion by October 31 , 1967, for transmittal to the Legislative Council prior to consideration by the General Assembly; and be it further

Resolved, That the Board of Public Works is hereby requested to appropriate from the Emergency Fund the sum of Fifty Thousand Dollars $(\$ 50,000)$ for preparation of the plan; and be it further

Resolved, That the Governor is hereby requested to direct the heads of relevant State agencies to coordinate all State wetlands development projects through the Board of Natural Resources and that the Governor is hereby requested to urge the chief executives of the State's political subdivisions to coordinate all local wetlands development projects through the Board of Natural Resoruces; and be it further

Resolved, That the State Planning Department is hereby requested to advise the planning and zoning agencies of the State's political subdivisions as to the General Assembly's concern for proper wetlands management and the need for adequate provision for wetlands conservation in local zoning ordinances; and be it further

Resolved, That copies of this Resolution are sent to the Governor of Maryland, the State Comptroller and the State Treasurer, comprising the Board of Public Works, and the Director of the State Planning Department, the Chairman of the Board of Natural Resources and each of the State conservation agencies represented on the Board, and the Director of the Department of Economic Development. 



\section{APPENDIX D}

State Planning Department Advisory Letter on Wetlands to Local Governments and List of Addressees 



\section{APPENDIX D \\ State Planning Department Advisory Letter on Wetlands to Local Governments June 20, 1967, and List of Addressees}

At the recent regular session of the General Assembly, there was adopted HJR 2 requesting the State Planning Department, with the cooperation of the Board of Natural Resources and the Department of Economic Development, to prepare a detailed long-term plan for the optimum use of wetlands in the State of Maryland. The Resolution requested that the plan be completed by October $31,1967$.

The Resolution defines wetlands as areas on which standing water, seasonal of permanent, has a depth of six feet or less, and where the wet soil retains sufficient moisture to support aquatic or semiaquatic plant growth. It states that the rapid rate of draining, filling, and other altering of Maryland's wetlands is causing serious disturbance to the economic, biologic, and hydrologic functions of the wetlands, and anticipates accelerated alteration of the wetlands due to projected increases in population and industrial activity.

The Resolution requests this Department to advise the planning and zoning agencies of the State's political subdivisions as to the General Assembly's concern for proper wetlands management and the need for adequate provision for wetlands conservation and local zoning ordinances.

We are, at this point, embarking on the preparation of the required detailed long-term plan, and as suggested by the terms of the Resolution, we are soliciting your assistance. Initially, we ask your help on the following:

1. Please provide us with a map of your county on which are delineated the wetlands areas as defined above.

2. Does a local zoning law apply to wetlands areas in your county? If so, provide us with copies of such zoning ordinances. What problems have you encountered in the application of your zoning laws as applicable to wetlands?

3. Are there any ongoing encroachments on wetlands areas as defined, or are there any anticipated encroachments, whether formalized by zoning applications or not?

Due to the time limit set by the General Assembly for the preparation of this development plan, your prompt assistance will be most appreciated.

Sincerely yours,

James J. O'Donnell

Director 
Copies of this letter were sent to the following 22 representative of their respective county planning and zoning commissions:

Albert S. Paye, Acting Director

Allegany County Planning and Zoning

Commission

Marion J. McCoy, Planning and Zoning Officer

Anne Arundel County Office of Planning and Zoning

George E. Gavrelis, Director

Baltimore County Office of Planning and Zoning

Clarence R. Bowen, Zoning Inspector

Calvert County Planning and Zoning

Commission

Elias W. Nuttle, Chairman

Carolina County Planning Commission

George A. Grier, Director

Carroll County Planning and Zoning

Commission

C.Y. Vaughan, Zoning Inspector

Cecil County Planning Commission

William E. Highby, Chairman

Charles County Planning Commission

Edgar S. Gore, Executive Secretary

Dorchester County Planning Commission

Robert W. Wirgau, Director

Frederick County Planning Commission Commission

J. Lee Hanlon, Executive Secretary

Harford County Planning and Zoning

Commission

Thomas G. Harris, Jr., Director

Howard County Planning Commission
Leon W. LeCompte, Inspector

Kent County Planning Commission

John S. Hewins, Director of Planning

Maryland-National Capital Park and

Planning Commission

Montgomery County Office and

Prince George's County Office

Mrs. Edward W. Green, Zoning Admin.

Queen Anne's County Planning and

Zoning Commission

Richard A. Bevan, Chairman

Somerset County Planning and Zoning Commission

Leila R. Rogers, Secretary

St. Mary's County Planning and

Zoning Commission

Gladys S. Block, Executive Secretary

Talbot County Planning and Zoning

Commission

Wayne K. Gladden, Planning Director

Washington County Planning and

Zoning Commission

Philip L. Tallon, Director of

Planning

Wicomico County Planning and Zoning

Commission

Edmund R. Cueman, Planning Director Worcester County Planning and

Zoning Commission 


\section{APPENDIX E}

Maryland Wetlands Act(s) of 1970 



\section{APPENDIX E - MARYLAND WETLANDS ACT(S)}

Chapter 241 (H. B. 285) - Laws of Maryland 1970.

AN ACT to add new Sections 718 through 731, inclusive, to Article 66C of the Annotated Code of Maryland, (1967 Replacement Volume), title "Natural Resources," to follow immediately after Section 717 thereof, and to be under the new subtitle "Wetlands"; and to repeal Section 485 of Article 27 of the Annotated Code of Maryland (1967 Replacement Volume), title and subtitle, "Crimes and Punishments," subheading "Rivers, Harbors, etc."; and to repeal Sections 45, 46 and 47 of Article 54 of the Annotated Code of Maryland (1968 Replacement Volume), title "Hall of Records," subtitle "Land Patents," to provide a State policy for the preservation of wetlands in the State; to regulate the filling and dredging of wetlands; to authorize the Secretary of Natural Resources with the advice and consent of the Maryland Agricultural Commission to promulgate rules and regulations; to authorize the Secretary of Natural Resources to prohibit certain activites on specified wetlands; to provide for an inventory of private wetlands; to provide certain protections to riparian owners; and generally dealing with both State and private wetlands; and to repeal sections generally dealing with the removal of sand and gravel, ownership of accretions, improvements on lands bounding navigable waters, and the liability of riparian owners, with the general context of said sections to be incorporated into the new Sections 718 through 731 , inclusive.

SECTION 1. Be it enacted by the General Assembly of Maryland, That Sections 718 through 731 , inclusive, be and they are hereby added to Article 66C of the Annotated Code of Maryland (1967 Replacement Volume), title "Natural Resources," to follow immediately after Section 717 thereof, to be under the new subtitle "Wetlands," and all to read as follows:

\section{Wetlands}

In General

718.

It is declared that in many areas of the State much of the wetlands have been lost or despoiled by unregulated dredging, dumping, filling, and like activities, and that the remaining wetlands of this State are in jeopardy of being lost or despoiled by these and other activities; that such loss or despoliation will adversely affect, if not entirely eliminate, the value of such wetlands as sources of nutrients to finfish, crustacea and shellfish of significant economic value; that such loss or despolitation will in most cases disturb the natural ability of tidal wetlands to reduce flood damage and adversely affect the public health and welfare; that such loss or despoliation will substantially reduce the capacity of such wetlands to absorb silt and will thus result in the increased silting of channels and harbor areas to the detriment of free navigation. Therefore, it is declared to be the public policy of this State, taking into account varying ecological, economic, developmental, recreational and aesthetic values, to preserve the wetlands and to prevent the despoliation and destruction there of.

719.

(a) "State wetlands" means all land under the navigable waters of the State below the mean high tide, which is affected by the regular rise and fall of the tide. Such wetlands, which have been transferred by the State by a valid grant, lease or patent or a grant confirmed by Article 5 of the Declaration of Rights of the Constitution of Maryland, shall be considered "private wetland" to the extent of the interest so transferred.

(b) "Private wetlands" means all lands not considered "State wetlands" bordering on or lying beneath tidal waters, which are subject to regular or periodic tidal action and which support aquatic growth. These include wetlands, which have been transferred by the State by a valid grant, lease or patent or a grant confirmed by Article 5 of the Declaration of Rights of the Constitution of Maryland, to the extent of the interest so transferred.

(c) "Dredging" means the removal or displacement by any means of soil, sand, gravel, shells or other material, whether of intrinsic value or not, from State or private wetlands affected by the regular ebb and flow of the tide. 
(d) "Filling" means either the displacement of navigable waters by the deposition into wetlands affected by the regular ebb and flow of the tide of soil, sand, gravel, shells or other material; or the artificial alteration of navigable water levels by physical structures, drainage ditches or otherwise.

(e) "Person" means any natural person, partnership, joint stock company, unincorporated association or society, or the State and any agency thereof, or municipal or political subdivisions or other corporation of any character whatsoever.

(f) "Regular or periodic tidal action" means the rise and fall of the sea that is produced by the attraction of the sun and the moon uninfluenced by winds or other circumstances.

\section{State Wetlands}

720.

The owner of land bounding on navigable waters shall be entitled to all natural accretions to said land and to make improvements into the waters in front of said land for the purposes of preserving his access to navigable water or for protecting his shore against erosion. After an improvement has been constructed, it shall become the property of the owner of the land to which it is attached. None of the rights covered under this subheading shall exclude the owner from developing other uses as approved by the Board od Public Works.

721.

It shall be unlawful for any person to dredge or fill on State wetlands, except to the extent that he has been issued a license to do so by the Board of Public Works. The provisons of this section shall not apply to the dredging of seafood products by licensed operators, the harvesting of seaweed, mosquito control and abatement as approved by the State entomologist, the improvement of wildife habitat or agricultural drainage ditches as approved by an appropriate agency. In order to aid the Board of Public Works in the determination of whether a license to dredge or fill State wetlands should be issued, the Secretary of Natural Resources, after consultation with interested federal, state and local agencies and appropriate agricultural agencies, and after taking of such evidence and holding of such hearings as the Secretary thinks advisable, shall submit a report indicating whether the license should be granted and, if so, the terms, conditions and consideration which should be required. The Board of Public Works after a hearing in the local subdivision affected shall then decide if issuance of the license is in the best interests of the State, taking into account the varying ecological, economic, developmental, recreational and aesthetic values each application presents, and if it so decides, shall issue a license for such consideration, and according to such terms and conditions as it deems advisable. All licenses shall be in writing. Any person violating the provisions of this section shall be deemed guilty of a misdemeanor, and upon conviction, fined not less than five hundred dollars $(\$ 500.00)$ nor more than one thousand dollars $(\$ 1,000)$. Any person who knowingly violates the provisions of this subheading shall be liable to the State for the restoration of the affected wetland to its condition prior to such violation insofar as that is possible. The appropriate court shall specify a reasonable time for completion of the restoration. The provision of this section shall not apply to any operations for dredging and filling being conducted as of July 1, 1970, as authorized under the terms of an appropriate permit or license granted under the provisions of existing State and Federal law.

\section{Private Wetlands}

722.

The Secretary of Natural Resources, with the advice and consent of the Maryland Agricultural Commission and in consultation with the appropriate agencies within the affected political subdivision, may from time to time, for the purpose of promoting the public safety, health and welfare, and protecting public and private property, wildlife and marine fisheries, promulgate rules and regulations governing dredging, filling, removing or otherwise altering or polluting private wetlands. The Agricultural Commission, within sixty days of receiving any proposed rules and regulations from the Secretary, shall convey its decision concerning the adoption or rejection 
of such rules and regulations to the Secretary; and if this is not done, such rule or regulation shall be considered approved by the Commission. Such rules and regulations may vary as to specific tracts of wetlands because of the character of such wetlands.

723.

Notwithstanding any rule or regulation promulgated by the Secretary of Natural Resources for the protection of private wetlands, the following uses shall be lawful on those lands included in the Secretary's inventory of private wetlands:

(1) Conservation of soil, vegetation, water, fish, shellfish, and wildlife.

(2) Trapping, hunting, fishing, and shellfishing where otherwise legally permitted.

(3) Exercise of riparian rights to make improvements to lands bounding on navigable waters to preserve to such navigable waters or to protect the shore against erosion.

724.

The Secretary shall promptly make an inventory of all private wetlands within the State. The boundaries of such wetlands shall be shown on suitable reproductions or aerial photographs to a scale of one inch equals two hundred feet with such accuracy that they will represent a class D survey. Such maps shall be prepared to cover entire subdivisions of the State as determined by the Secretary. Upon completion of the private wetlands boundary maps for each subdivision and adoption of proposed rules and regulations governing activities on such wetlands as provided by Section 722 , the Secretary shall hold a public hearing in the county of the affected wetlands. The Secretary shall give notice of such hearing to each owner as shown in tax records of all lands designation as wetland as shown on such maps, by registered mail not less than thirty days prior to the date set for such hearing. The notice shall include the proposed rules and regulations. The Secretary shall also cause notice of such hearing to be published at least once not more than thirty days and not fewer than ten days before the date set for such hearing in a newspaper or newspapers published within and having a general circulation in the county or counties where such wetlands are located. After considering the testimony given at such hearing and any other facts which may be deemed pertinent and after considering the rights of affected property owners and the purposes of this subheading, the Secretary shall establish by order the bounds of each of such wetlands and the rules and regulations applicable thereto. A copy of the order, together with a copy of the map depicting such boundary lines, shall be filed among the land records in all counties affected after final appeal of such, if any, has been completed. The Secretary shall give notice of such order to each owner of record of all lands designated as such wetlands by mailing a copy of such order to such owner by registered mail. The Secretary shall also cause a copy of such order to be published in a newspaper or newspapers published within and having a general circulation in the county or counties where such wetlands are located.

725.

Any person having a recorded interest in land affected by any such rules and regulations, may appeal the rules and regulations and the designation of his land within the inventory to the Board of Review of the Department of Natural Resources as provided by Section 237 of Article 41 of the Annotated Code. This proceeding shall be held in the county in which the land is located, and the Board shall view the land in question. If such person is dissatisfied with the decision of the Board, he may, within thirty days after receiving notice thereof, petition the circuit court in the county in which the land is located to determine whether such rules or regulations so restrict the use of his property as to deprive him of the practical uses thereof and are therefore an unreasonable exercise of the police power, because the order constitutes the equivalent of a taking without compensation. The court in a jury trial at the election of either party shall hear the case de novo without the right of removal and the appeal shall not be subject to the provisions of the Administrative Procedure Act. In weighing the appropriate exercise of the police power, the court shall consider the importance of the land to marine life, shellfish, wildlife, prevention of siltation, floods and other natural disasters, the public health and welfare, and the public policy set forth in this subheading. If the court find the ruling to be an unreasonable exercise of the police power, as aforesaid, the 
court shall enter a finding that such ruling shall not apply to the land of the petitioner; provide, d, however, that such finding shall not affect any other land than that of the petitioner. The Secretary shall cause a copy of such finding to be recorded forthwith in the land records. The decision of the Circuit Court may be appealed by either party to the Court of Appeals.

\section{6.}

Any person proposing to conduct an activity upon any wetland which is not permitted by rules and regulations adopted under the provisions of Section 722 shall file an application for a permit with the Secretary, in such form and with such information as the Secretary may prescribe. Such application shall include a detailed description of the proposed work and a map showing the area of wetland directly affected, with the location of the proposed work thereon, together with the names of the owners of record of adjacent land and known claimants of water rights in or adjacent to the wetland of whom the applicant has notice. The Secretary shall cause a copy of such application to be mailed to the chief administrative of ficer in the cunty or counties where the proposed work or any part thereof is located. No sooner than thirty days and not later than sixty days after receipt of such application, the Secretary or his duly designated hearing officer shall hold a public hearing in the county where the land is located on such application. The Secretary shall cause notice of such hearing to be published at least once not more than thirty days and not fewer than ten days before the date set for the hearing in a newspaper published within and having a general circulation in each county where the proposed work, or any part thereof, is located. All applications and maps and documents relating thereto shall be open for public inspection at the offices of the Secretary, and the chief administrative of ficer in the county. At such hearing any person or persons may appear and be heard. No person may make such an application within eighteen months of the denial of a prior application for the same type permit or the final determination of any appeal of such denial.

727.

In granting, denying or limiting any permit, the Secretary or his duly designated hearing officer shall consider the effect of the proposed work with reference to the public health and welfare, marine fisheries, shell-fisheries, wildlife, economic benefits, the protection of life and property from flood, hurricane and other natural disasters, and the public policy set forth in this subtitle. In granting a permit the Secretary may limit or impose conditions or limitations designed to carry out the public policy set forth in this subtitle.

The Secretary may require a bond in an amount and with surety and conditions satisfactory to it securing to the State compliance with the conditions and limitations set forth in the permit. The Secretary may suspend or revoke a permit if the Secretary finds that the applicant has not complied with any of the conditions or limitations set forth in the permit or has exceeded the scope of the work as set forth in the application. The Secretary shall state upon his record, his findings and reasons for all actions taken pursuant to this section. The Secretary shall cause notice of his order in issuance, denial, revocation or suspension of a permit to be published in a newspaper published within and having a general circulation in the county or counties wherein the wetland lies. An appeal of the order may be taken to the Board of Review of the Department of Natural Resources as provided by Section 237 of Article 41 of the Annotated Code by the applicant or the county or municipal government in which the land is located. This proceeding shall be in the county where the land is located and the Board shall view the affected land.

728.

Any party to the appeal to the Board of Review may take an appeal within thirty days after the decision of the Board of Review to the circuit court in the county in which the land is located. The court in a jury trial at the election of either party shall hear the case de novo without the right of removal, and the appeal shall not be subject to the Administrative Procedure Act. If the court finds that the action appealed from is an unreasonable exercise of the police power, it may set aside or modify the order. 
729.

The court may order the State to pay court costs due because of any appeal made pursuant to Section 725 or 728 , if it finds that the financial situation of the person so appealing warrants such action.

730.

Any person who violates the rules and regulations validly promulgated by the Secretary or any provisions of this subheading shall be punished by a fine of not more than one hundred dollars $(\$ 100.00)$ or imprisonment for not more than one (1) month, or by both such fine and imprisonment. Any person who knowingly violates the said rules and regulations or any provision of this subheading shall be liable to the State for the restoration of the affected wetland to its condition prior to such violation insofar as that is possible. The appropriate court shall specify a reasonable time for completion of restoration. The Circuit Court for the county or the Superior Court of Baltimore City shall have jurisdiction in equity to restrain a violation of this subheading at the suit of the Department of Natural Resources of the State of Maryland, or of any duly authorized agency or officer thereof.

\section{Riparian Rights}

731.

It is the intent of this subtitle that no riparian owner shall be in any way deprived of any rights, privileges or enjoyment of such riparian ownership that he had prior to July 1, 1970, except as specifically provided by the provisions of this subtitle, and that the provisions of this subtitle not be construed to transfer the title or ownership of any lands or interest therein.

SEC. 2. And be it further enacted, That Section 485 of Article 27 of the Annotated Code of Maryland (1967 Replacement Volume), title and subtitle "Crimes and Punishments," subheading "Rivers, Harbors, etc." be and it is hereby repealed, and that Sections 45, 46 and 47 of Article 54 of the Annotated Code of Maryland (1968 Replacement Volume), title "Hall of Records," subtitle "Land Patents," be and they are hereby repealed.

SEC. 3. And be it further enacted, That the provisions of this Act shall in no way affect the provisions of Sections 15A and 15B of the Code of Public Local Laws of Worcester County and the provisions of these sections shall remain in effect notwithstanding any provision of this Act.

SEC. 4. And be it further enacted, That if any provision of this Act or the application thereof to any person or circumstances is held invalid for any reason, the invalidity shall not affect the other provisions or any other application of this Act which can be given effect without the invalid provisions or application, and to this end all the provisions of this Act are declared to be severable.

SEC. 5. And be it further enacted, That this Act shall take effect July 1, 1970. 
Chapter 242 (H. B. 286) - Laws of Maryland 1970.

AN ACT to add new Section 15A to Article 78A of the Annotated Code of Maryland (1969 Replacement Volume), title "Public Works," subtitle "Board of Public Works," to follow immediately after Section 15 thereof, pertaining to conveyances by the Board of Public Works of title to lands owned by the State due to their relationship to the waters of the State.

SECTION 1. Be it enacted by the General Assembly of Maryland, That new Section 15A be and it is hereby added to Article 78A of the Annotated Code of Maryland (1969 Replacement Volume), title "Public Works," subtitle "Board of Public Works," to follow immediately after Section 15 thereof, and to read as follows:

$15 \mathrm{~A}$.

(a) The Board of Public Works shall not convey a title to land owned by the State due to its relationship to the waters of the State to any person other than the riparian owner or proprietor of the land abutting the land being conveyed. The Board may only make such a conveyance after seeking the advice of the Department of Natural Resources, appropriate agricultural agencies, including the Maryland Agricultural Commission and the Agricultural Stabilization and Conservation Committee and the Soil Conservation District Committee of the county in which the land is located, and other interested Federal and State agencies. Prior to such a conveyance, there must be a public hearing, with proper notice, in the county in which the land is located, after which a written decision must be rendered by the Board justifying its action, taking into account the best interests of the State with respect to the varying ecological, economic, developmental, agricultural, recreational and aesthetic values of the area under consideration. This document shall be maintained in the permanent records of the Board and be open to public scrutiny.

(b) The provisions of this section shall not affect the title to interests conveyed by the State prior to July 1 , 1970 , by a valid grant, lease or patent or a grant confirmed by Article 5 of the Declaration of Rights of the Maryland Constitution. In addition thereto, the provisions of this section shall not prohibit the approval of the conveyance of any such land for which application for conveyance was made and approved by a majority of the Board of Public Works prior to July 1, 1970.

(c) The provisions of this section shall not deprive any riparian owner or proprietor of any riparian rights, privilege or enjoyment that he had prior to July 1, 1970.

(d) The provisions of this section shall not affect the provisions of Section 15A and 15B of the Code of the Public Local Laws of Worcester County.

SEC. 2. And be it further enacted, That this Act shall take effect July 1, 1970. 


\section{APPENDIX F}

Proposed Order Establishing Private Wetland Boundaries in Calvert County, Maryland, and Proposed Rules 



\section{APPENDIX F \\ STATE OF MARYLAND \\ DEPARTMENT OF NATURAL RESOURCES \\ PROPOSED ORDER ESTABLISHING PRIVATE WETLAND \\ BOUNDARIES IN CALVERT COUNTY, MARYLAND, AND \\ PROPOSED RULES AND REGULATIONS}

The Secretary of Natural Resources, acting pursuant to Sections 718 through 731 of Article 66C of the Annotated Code of Maryland (1967 Replacement Volume), for the purpose of promoting the public safety, health and welfare and protecting public and private property, wild life and marine fisheries, hereby adopts this order establishing the boundary lines of private wetlands in Calvert County, Maryland, as delineated on maps entitled "Private Wetland Boundary Map of Calvert County, Maryland," dated and numbered through inclusive, which maps are recorded herewith and incorporated herein, together with the rules and regulations governing dredging, filling, removing, altering or polluting said private wetlands in Calvert County.

\section{Section I: Definitions}

For the purposes of this Order and the Rules and Regulations thereto:

A. "State wetlands" means all lands under the navigable waters of the State below the mean high tide, which is affected by the regular rise and fall of the tide.

B. "Private wetlands" means all lands bordering on or lying beneath tidal waters, which are subject to regular or periodic tidal action and which support aquatic growth; and all State lands, which have been transferred by the State by a valid grant, lease or patent or a grant confirmed by Article 5 of the Declaration of Rights of the Constitution of Maryland, to the extent of the interest so transferred.

C. "Dredging" means the removal or displacement by any means of soil, sand, gravel, shells or other material, whether of intrinsic value or not, from State or private wetlands affected by the regular ebb and flow of the tide.

D. "Filling" means either the displacement of navigable waters by the deposition into wetlands affected by the regular ebb and flow of the tide of soil, sand, gravel, shells or other material; or the artificial alteration of navigable water levels by physical structures, drainage ditches or otherwise.

E. "Person" means any natural person, partnership, joint stock company, unincorporated association or society, or the State and any agency thereof, or municipal or political subdivisions or other corporation of any character whatsoever.

F. "Regular or periodic tidal action" means the rise and fall of the sea that is produced by the attraction of the sun and the moon uninfluenced by winds or other circumstances.

\section{Section II: General Conditions}

This Order and the Rules and Regulations issued pursuant thereto does not grant any property rights; it does not authorize any person to trespass or insure the property of another; it does not excuse any person from complying with other applicable Federal, State and local laws, regulations or ordinances.

\section{Section III: Authorized Uses of Private Wetlands}

The following uses are permitted on the private wetlands delineated under this Order, if otherwise permitted by law:

\section{A. Projects or Activites Requiring Approval of Other State Agencies or Officials}

(1)The construction or maintenance of agricultural drainage ditches as approved by the Maryland Agricultural Commission or its designee; 
(2)Alterations or modifications for mosquito control purposes as approved by the State entomologist.

\section{B. Recurring Activities}

(1)Trapping, hunting, fishing, shellfishing;

(2)The cultivation and harvesting of shellfish, including such reasonable excavation as normally is necessary in conducting such activities;

(3)The cultivation and haryesting of agricultural or horticultural products, including grazing and haying.

\section{Permanent Alteration or Modification}

(1)The construction and maintenance of walkways, foot bridges, duckblinds, docks, boathouses, boat shelters and other similar structures, provided that said structures are so constructed on pilings as to permit the reasonable unobstructed flow of the tide and preserve the natural contour of the private wetland;

(2) Alterations or modifications which are customary and normal to the conservation of soil, vegetation, water, fish, shellfish, and wildlife;

(3)Making improvements necessary to preserve access to navigable waters or to protect private wetlands against erosion; provided that any improvement authorized under this section (3) involving either the dredging or filling of State wetlands shall not proceed unless a license for filling or dredging such wetland is issued by the Board of Public Works under the provisions of Article 66C, Section 721 of the Annotated Code of Maryland;

(4)The excavation of channels or ditches for the use by the owner of the private wetland for the passage of row boats, skiffs, canoes, or other hand propelled water craft;

(5)The installation and maintenance of underground utilities, provided that the surface of the wetland is is restored substantially to its original condition.

\section{Section IV: Uses and Activities prohibited on Private Wetlands Without a Permit}

Except where otherwise authorized in Section $11 \mathrm{l}$ above or subsequent to a permit issued pursuant to Section VI herein:

A. No person shall fill, place, dump or discharge on the wetlands encompassed in this order any soil, loam, peat, sand, gravel, soil, or other mineral substance;

B. No person shall drain, excavate or dredge the wetlands encompassed by the Order, or remove therefrom loam, peat, sand, gravel, soil, or other mineral substance;

C. No person shall perform any act or use the wetlands encompassed in this Order in a manner which would destroy the natural vegetation, substantially alter existing patterns of tidal flow, or otherwise alter or permit the alteration of the natural and beneficial character of such wetland.

Section V: Notification of Intent to Dredge, Fill, Remove, or Otherwise Alter State or Private Wetlands.

Except for the activities authorized under Section $111 \mathrm{~A}$ and $111 \mathrm{~B}$ above, no person shall dredge, fill, remove or otherwise alter any wetlands in County without first informing the Secretary of such intention. Notification of any such proposed activity shall be made by registered mail, in such form and containing such information as the Secretary shall prescribe. Such a notification form shall be provided, together with a copy of this Order and the Rules and Regulations issued pursuant thereto, to each property owner and other affected parties in the area encompassed by this Order.

Within ten (10) working days after receipt of the Notification of Intent to Dredge, Fill, Remove, or Otherwise Alter State or Private Wetlands, the Secretary shall inform any person filing such Notification by registered mail whether the proposed activities may proceed or whether they shall require a private wetlands permit from the Department of Natural Resources, and in the case of activities affecting State wetlands, whether an application for a license from the Board of Public Works is required. 
In cases where a permit or license is not required, the proposed activities specified in the Notification, may proceed upon notification by the Secretary.

\section{Section VI: Permits}

Under the provisions of Section 726 of Article 66C of the Annotated Code of Maryland, the Secretary of Natural Resources shall require the filing of a permit application from any person proposing to conduct an activity on private wetland not permitted in Section 111 above, and encompassed by this Order. The permit shall contain such information and be in such form as the Secretary may prescribe. The need to file such a permit shall be determined, by the Secretary, from the Notification of Intent to Dredge, Fill, Remove, or Otherwise Alter State or Private Wetlands described in Section V above.

Following the procedures set forth in Section 726 of Article $66 \mathrm{C}$, a permit may be issued after consultation with the chief administrative officer of

County, and due notice and public hearing in said county, if the Secretary or his designee finds that the proposed activity on private wetlands is consistent with the intent and purposes of the laws of Maryland for the protection and preservation of wetlands.

In granting a permit, the Secretary or his designee may impose reasonable conditions or limitations designed to carry out the purposes of the public policy set forth in Article $66 \mathrm{C}$, Section 718 et. seq. of the Annotated Code of Maryland.

Permit applications shall be forwarded by the Secretary in all cases where he determines they are required.

\section{Section VII: State Wetlands}

Under the provisions of Section 721 of Article $66 \mathrm{C}$ of the Annotated Code, no person shall dredge or fill State wetlands, except to the extent that he has been issued a license to do so by the Board of Public Works. No such license is required for the following activities:

A. Dredging of seafood products, by licensed operators:

B. Harvesting of Seaweed;

C. Mosquito control and abatement as approved by the State Entomologist;

D. Improvement of wildlife habitat as approved by the Fish and Wildlife Administration;

E. Agriculture drainage ditches as approved by the Soil Conservation Committee.

In assisting the Board of Public Works to determine whether a license to dredge or fill should be issued, the Secretary of Natural Resources, after consultation with federal, state and local agencies, shall hold a public hearing on the proposal. In cases of proposed activities affecting both private and state wetlands, the Secretary will conduct a single hearing covering activities on both private and state wetlands.

On the basis of the record and upon such independent investigation he deems necessary, the Secretary will prepare a report to the Board od Public Works recommending whether or not the license should be issued. Upon receipt of such report, the Board of Public Works will decide whether the license is consistent with the public policy of the State on the preservation and protection of wetlands. Any license issued by the Board of Public Works may contain such terms and conditions that the Board of Public Works deems advisable.

\section{Section VIII: Appeal of Order and Rules and Regulations}

Any person aggrieved by this Order and the Rules and Regulations issued pursuant thereto who has a recorded interest in any portion of the land so affected, within fifteen (15) days of receipt of notice thereof, may appeal the Order and the Rules and Regulations issued pursuant thereto to the Secretary or his designees by making known the basis of his complaint, together with the a request that the Órder and/or the Rules and Regulations issued pursuant thereto be reviewed. If a satisfactory resolution of the complaint has not occurred within thirty (30) days thereafter, any complainant shall have thirty (30) additional days thereafter to seek further review by the Board of Review of the Department of Natural Resources, by setting forth the nature of the complaint in writing, together with a full description of the pertinent facts and circumstances in the case. Such complaint shall be filed with , who shall promptly acknowledge the receipt thereof. Subject to 
such extension of time as the parties may agree upon, a decision shall be rendered in writing and a copy thereof sent to the complainant within thirty (30) days of the filing of the complaint.

Any person aggrieved by a decision of the Board may, within thirty (30) days after receiving notice thereof, petition the circuit court of Calvert County to determine whether the Rules and Regulations issued pursuant to this Order so restrict the use of this property as to constitute a taking without compensation.

\section{Section IX: Penalties}

Under the provisions of Section 730 of Article $66 \mathrm{C}$ of the Annotated Code of Maryland, any person violating the Rules and Regulations validly promulgated by the Secretary shall be punished by a fine of not more than one hundred dollars (\$100.00) or imprisonment for not more than one (1) month, or both. Any person knowingly violating such Rules and Regulations may also become liable to the State for restoring any affected wetlands to its conditions prior to such violation.

A list of the assessed owners of land affected by this Order is attached hereto and incorporated herein.

Wit ness my hand and seal this day of 19 


\section{APPENDIX G}

The Federal "Water Bank Act" - Public Law 91-559 



\author{
Public Law 91-559 \\ 91 st Congress, H. R. 15770 \\ December 19,1970
}

\title{
An Art
}

To provide for conserving surface waters; to preserve and inprove habitat for migratory waterfowl and other wildlife resources; to reduce runoff, soil and wind erosion. and contribute to flood control; and for other purposes.

Be it enacted by the Senate and House of Representatices of the United States of America in Congress assembled, That this Act may be cited as the "Water Bank Act".

SEc. 2. The Congress finds that it is in the public interest to preserve, restore, and improve the wetlands of the Nation, and thereby to conserve surface waters, to preserve and improve habitat for migratory waterfowl and othel wildlife resources, to reduce runoff, soil and wind
erosion, and contribute to flood control, to contribute to improved water quality and reduce stream sedimentation, to contribute to improved subsurface moisture, to reduce acres of new land coming into production and to retire lands now in agricultural production, to enhance the liatural beauty of the landscape, and to promote comprehensive and total water management planning. The Secretary of Agriculture (hereinafter in this Act referred to as the "Secretary") is authorized and directed to formulate and carry cut a continuous program to prevent. the serious loss of wetlands, and to preserve, restore, and improve such lands, which program shall begin on July 1, 1971.

SEc. 3. In effectuating the water bank program authorized by this Act, the Secretary shall have authority to enter into agreements with landowners and operators in important migratory waterfowl nesting and breeding areas for the conservation of water on specified farm, ranch, or other wetlands identified in a conservation plan developed in cooperation with the Soil and Water Conservation District in which the lands are located, under such rules and regulations as the Secretary may prescribe. These agreements shall be entered into for a period of ten years, with provision for renewal for additional periods of ten years each. The Secretary shall reexamine the payment rates at the beginning of any such ten-year renewal period in the light of the then current land and crop values and make needed adjustments in rates for any such renewal period. As used in this Act, the term "wetlands" means the inland fresh areas (types 1 through 5) describet in Circular 39, Wetlands of the United States, published by the United States Department of the Interior (including artificially developed inland fresh areas which meet the description of inland fresh areas, types 1 through 5, contained in such Circular 39). No agreement shall be entered into under this Act concerning land with respect to which the ownership or control has changed in the two-year period preceding the first year of the agreement period unless the new ownership was acquired by will or succession as a result of the death of the previous owner, or unless the new ownership was acquired prior to July 1, 1971, under other circumstances which the Secretary determines, and specifies by regulation, will give adequate assurance that such land was not acquired for the purpose of placing it in the program, except that this sentence shall not be construed to prohibit the continuation of an agreement by a new owner or operator after an agreement has once been entered into under this Act. A person who has operated the land to be covered by an agreement under this Act for as long as two years preceding the date of the agreement and who controls the land for the agreement period shall not be required to own the land as a condition of eligibility for entering into the agreement. Nothing in this section shall prevent an owner or operator from placing land in the program if the land was acquired by the owner or operator to replace eligible land from which he was displaced because of its acquisition by any Federal, State, or other agency having the right of eminent domain.

Conservation egreements.

"Wetlands." 
84 STAT. 1470 Pub. Law 91-559 - 2 - December 19, 1970

Safeguards. The Secretary shall provide adequate safeguards to protect the interests of tenants and sharecroppers, including provision for sharing, on a fair and equitable basis, in payments or compensation under this program. No provision of this Act shall prevent an owner or operator who is participating in the program under this Act from participating in other Federal or State programs designed to conserve or protect wetlands.

SEc. 4 . In the agreement between the Secretaly and an owner or

Agreement provisions.

Annue 1 peyments. operator, the owner or operator shall agree-

(1) to place in the program for the period of the agreement eligible wetland areas he designates, which areas may include wetlands covered by a Federal or State government easement which permits agricultural use, together with such adjacent areas as determined desirable by the Secretary;

(2) not to drain, burn, fill, or otherwise destroy the wetland character of such areas, nor to use such areas for agricultural purposes, as determined by the Secretary;

(3) to effectuate the wetland conservation and development plan for his land in accordance with the terms of the agreement, unless any requirement thereof is waived or modified by the Secretary pursuant to section 7 of this Act;

(4) to forfeit all rights to further payments or grants under the agreement and refund to the United States all payments or grants received thereunder upon his violation of the agreement at any stage during the time he has control of the land subject to the agreement if the Secretary determines that such violation is of such a mature as to warrant termination of the agreement, or to make refunds or accept such payment adjustments as the Secretary may deem appropriate if he determines that the violation by the owner or operator does not warrant termination of the agreement;

(5) upon transfer of his right and interest in the lands subject to the agreement during the agreement period, to forfeit all rights to further payments or grants under the agreement and refund to the United States all payments or grants received thereunder during the year of the transfer unless the transferee of any such land agrees with the Secretary to assume all obligations of the agreement;

(6) not to adopt any practice specified by the Secretary in the agreement as a practice which would tend to defeat the purposes of the agreement; and

(7) to such additional provisions as the Secretary determines are desirable and includes in the agreement to effectuate the purposes of the program or to facilitate its administration.

SEC. 5. In return for the agreement of the owner or operntor, the Secretary shall (1) make an annual payment to the owner or operator for the period of the agreement at such rate or rates as the Secretary determines to be fair and reasonable in consideration of the obligations undertaken by the owner or operator; and (2) bear such part of the average cost of establishing and maintaining conservation and development practices on the wetlands and adjacent areas for the purposes of this Act as the Secretary determines to be appropriate. In making his determination, the Secletary shall consider, among other things, 
the rate of compensation necessary to ellcourage owluers or operators of wetlands to participate in the water bank proglam. The rate or rates of anmual payments as determined hereunder shall be increased, by an amount determined by the Secretary to be appropriate, in relation to the benefit to the general public of the use of the wetland areas, together with designated adjacent areas, if the owner or operator agrees to permit, without other compensation, access to such acreage by the general public, during the agreement period, for hunting, trapping, fishing, and hiking, subject to applicable State and Federal regulations.

SEc. 6. Aliy agreement may be renewed or extended at the end of the agreement period for an additional period of tell years by mutual agreement of the Secretary and the owner or operator, subject to any rate redetermination by the Secretary. If during the agreement period the owner or operator sells or otherwise divests himself of the ownership or right of occupancy of such land, the new owner or operator may contimue such agreement under the same terms or conditions, or enter into a new agreement in accordance with the provisions of this Act, including the provisions for renewal and adjustment of payment rates, or he may choose not to participate in such program.

SEc. 7. The Secretary may terminate any agreement by mutual agreement with the owner or operator if the Secretary determines that such termination would be in the public interest, and may agree to such modification of agreements as he may determine to be desirable to carry ont the purposes of the program or facilitate its administration.

SEc. 8. In carrying out the program, the Secretary may utilize the services of local, county, and State committees established under section 8 of the Soil Conservation and Domestic Allotment Act, as amended. The Secretary is authorized to utilize the facilities and services of the Commodity Credit Corporation in discharging his functions and responsibilities under this program.

SEc. 9. The Secretary may, without regard to the civil service laws, appoint an Advisory Board to advise and consult on matters relating to his functions under this Act as he deems appropriate. The Board shall consist of persons chosen from members of oryanizations such as wildlife organizations, land-grant colleges, farm organizations, State game and fish departments, soil and water conservation district associations, water management organizations, and representatives of the general public. Members of such an Advisory Board who are not regular full-time employees of the United States shall be entitled to reimbursement on an actual expense basis for attendance at Advisory Board meetings.

SEc. 10. The Secretary shall consult with the Secretary of the Interior and take appropriate measures to insure that the program carried out pursuant to this Act is in harmony with wetlands programs administered by the Secretary of the Interior. He shall also, insofar as practicable, consult with and utilize the technical and related services of appropriate local, State, Federal, and private conservation agencies to assure coordination of the program with programs of such agencies and a solid technical foundation for the program.

SEc. 11. There are hereby authorized to be appropriated without fiscal year limitation, such sums as may be necessary to carry out the

Agreement renewal.

Temination.

Servioes and facilities, utilization. 49 Stat. 1149. 16 USC 590h.

Advisory

Board.

Congruity of programs.

Appropriation. 
Pub. Law 91-559 - $4-\quad$ December 19, 1970

progran anthorized by this Act. In carying ont the program, the Secretary shall not enter into agreements with owners and operators whichl wonld requine payments to owners or operators in any calendar vear und(r such agreenents in excess of $\$ 10,00(1), 000)$.

Swo. 12. The Secretary shall prescribe such regulations as he determine's necessialy and desirable to rarry ont the provisions of this Art. Approved December 19, 1970.

\section{LEGISLATIVE HISTORY:}

HOUSE REPORT No. 91-1307 (Comm. on Merohant Marine and Fisheries). SENATE REPORT No. $91-1393$ (Comm on Agrioulture and Forestry). CONGRESSIONAL RECORD, Vol. 116 (1970):

Oot. 5, considered and passed House.

Deo. 7, oonsidered and passed Senate. 


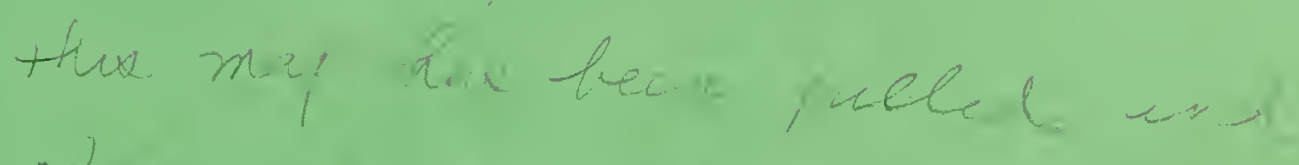

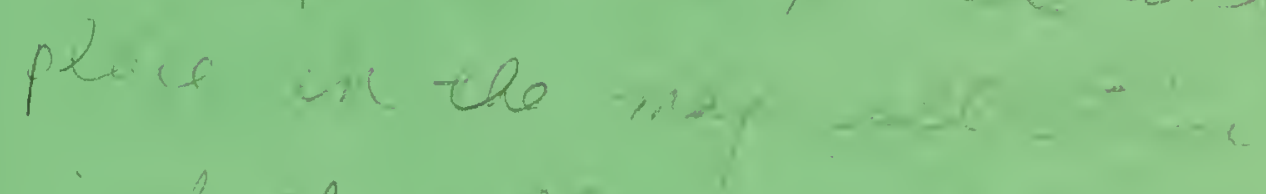
with the folla in Cherapease v? 21 



MARYLAND E RAR BOOK RUOM

UnIVERSITY OF MARYLAND LUBRARU

COlleGE PARK. MD. 

